UNIVERSIDADE DE SÃO PAULO

FACULDADE DE ECONOMIA, ADMINISTRAÇÃO E CONTABILIDADE DEPARTAMENTO DE CONTABILIDADE E ATUÁRIA

PROGRAMA DE PÓS-GRADUAÇÃo EM CONTROLADORIA E CONTABILIDADE

MENSURAÇÃO CONTÁBIL DOS CRÉDITOS DE CARBONO NO BRASIL, CHINA E ÍNDIA

Valdiva Rossato de Souza

Orientador: Prof. Dr. Eliseu Martins

Coorientadora: Prof ${ }^{a}$. Dr ${ }^{a}$. Maisa de Souza Ribeiro

SÃO PAULO

2015 
Prof. Dr. Marco Antonio Zago

Reitor da Universidade de São Paulo

Prof. Dr. Adalberto Américo Fischmann

Diretor da Faculdade de Economia, Administração e Contabilidade

Prof. Dr. Gerlando Augusto Sampaio Franco de Lima

Chefe do Departamento de Contabilidade e Atuária

Prof. Dr. Andson Braga de Aguiar

Coordenador do Programa de Pós-Graduação em Controladoria e Contabilidade 
VALDIVA ROSSATO DE SOUZA

\section{MENSURAÇÃO CONTÁBIL DOS CRÉDITOS DE CARBONO NO BRASIL, CHINA E ÍNDIA}

Tese apresentada ao Programa de Pós-Graduação em Controladoria e Contabilidade do Departamento de Contabilidade e Atuária da Faculdade de Economia, Administração e Contabilidade da Universidade de São Paulo como requisito para obtenção do título de Doutora em Ciências.

Orientador: Prof. Dr. Eliseu Martins

Coorientadora: Prof ${ }^{\text {a }}$ Dr ${ }^{\text {a }}$. Maisa de Souza Ribeiro

Versão Corrigida

(Versão original disponível na Faculdade de Economia, Administração e Contabilidade)

\section{SÃO PAULO}


Auorizo a reprodução e divulgação total ou parcial deste trabalho, por qualquer meio convencional ou eletrônico, para fins de estudo e pesquisa, desde que citada a fonte.

FICHA CATALOGRÁFICA

Elaborada pela Seção de Processamento Técnico do SBD/FEA/USP

Souza, Valdiva Rossato de

Mensuração contábil dos créditos de carbono no Brasil, China e Índia /

Valdiva Rossato de Souza. -- São Paulo, 2015.

$219 \mathrm{p}$.

Tese (Doutorado) - Universidade de São Paulo, 2015.

Orientador: Eliseu Martins.

1. Países em desenvolvimento - Brasil - China - Índia 2. Mecanismo de desenvolvimento limpo (MDL) 3. Créditos de carbono 4. Mensuração e reconhecimento contábil 5. Valor justo I. Universidade de São Paulo. II. Título.

$$
\text { CDD - } 338.91724
$$


Edison Antonio de Souza, por seu companheirismo e apoio incondicionais.

Felipe e Fernanda Rossato de Souza, na esperança de que sigam o caminho dos pais.

Maria Rosa Rossato, cujas orações e incentivos conduziram ao caminho da vitória.

Anacleto Luiz Rossato (In memoriam), sempre presente.

Viviane Rossato, pela atenção dispensada, sempre que necessário. 


\section{AGRADECIMENTOS}

Cursar Doutorado na FEA sempre representou um grande objetivo que almejava alcançar desde a conclusão do mestrado, nessa mesma instituição. Porém, tal conquista não teria sido possível sem a participação de diversas instituições engajadas para sua realização, bem como de pessoas que não mediram esforços para que o mesmo fosse alcançado, às quais externo agradecimentos:

\section{Instituições Envolvidas com a realização $\underline{\text { do }} \underline{\text { curso: }}$}

Universidade de São Paulo - USP

Faculdade de Economia, Administração e Contabilidade - FEA

Departamento de Contabilidade e Atuária

Universidade do Estado de Mato Grosso - UNEMAT

Departamento de Ciências Contábeis - Campus de Sinop-MT

Universidade Federal de Mato Grosso - UFMT

Departamento de Ciências Contábeis - Campus de Cuiabá-MT

\section{Instituições Envolvidas $\underline{\text { com a realização }} \underline{\text { da pesquisa: }}$}

Universidade de São Paulo - USP

Fundação Getúlio Vargas São Paulo - FGV-SP

Instituto de Ensino e Pesquisa - Insper-SP

Bolsa de Valores de São Paulo - BM\&FBovespa

\section{Pessoas que contribuíram para sua realização:}

Professores do Departamento de Contabilidade e Atuária - FEA/USP-SP, especialmente meu Orientador, Professor Dr. Eliseu Martins e, minha Coorientadora, Professora Dr ${ }^{\mathrm{a}}$. Maisa de Souza Ribeiro, do Departamento de Contabilidade - FEA/USP-RP, pela confiança e incentivo depositados.

Turma 2011 do Programa de Pós-Graduação em Controladoria e Contabilidade da FEA, de maneira especial os colegas Dr. Janilson Antonio da Silva Suzart, Dr. Robson Zuccolotto e Doutoranda Bianca Quirantes Checon, por tamanha amizade e carinho dispensados. 
Podemos utilizar as dádivas da natureza como quisermos, mas em nossos registros os débitos são sempre iguais aos créditos.

Mahatma Gandhi

Hoje, nós temos o conhecimento para conseguir estimar os débitos e entender o que fizemos para o planeta chegar a esta situação.

Rajendra Pachauri 


\section{RESUMO}

SOUZA, Valdiva Rossato de. Mensuração Contábil dos Créditos de Carbono no Brasil, China e Índia. 2015, 219 p. Tese de Doutorado - Faculdade de Economia, Administração e Contabilidade - Departamento de Contabilidade e Atuária - Universidade de São Paulo. São Paulo.

A presente pesquisa teve como objetivo geral propor um modelo de mensuração contábil ao valor justo das Reduções Certificadas de Emissões (RCEs) geradas nos processos produtivos das empresas brasileiras, chinesas e indianas, com vistas a possibilitar o reconhecimento desses ativos oriundos da implementação de projetos de Mecanismos de Desenvolvimento Limpo (MDLs), durante o período de 2005 a 2012. Consideraram-se os estímulos oferecidos com as diretrizes do Protocolo de Quioto e a representatividade de implementações de projetos de MDLs da China, da Índia e do Brasil, para apresentar, com base em pesquisas descritiva, analítica e quantitativa, uma proposta de mensuração contábil das RCEs, capaz de evidenciar os fluxos futuros de seus benefícios econômicos, partindo-se do modelo de Ratnatunga, Jones e Balachandran (2011). Para tanto, trabalhou-se com a hipótese de que se as RCEs fossem mensuradas ao valor justo e reconhecidas enquanto ativo intangível, então seriam evidenciados os impactos patrimoniais dos fluxos de caixa futuros. Descreveu-se a teoria da mensuração contábil como suporte ao valor justo; discutiu-se os padrões contábeis existentes nos países mencionados e as principais características que envolvem as adoções das International Financial Reporting Standards (IFRSs) em cada um deles, com foco na mensuração contábil ao valor justo, aceita pelo International Accounting Standards Board (IASB). As orientações contábeis internacionais emanadas para contabilização das RCEs foram apresentadas para analisar o cenário atual de desenvolvimento do tratamento contábil atribuível ao ativo em questão. Assim, detectou-se que a mensuração das RCEs tem sido pouco discutida. Sugeriu-se que com a efetivação do registro dos projetos de MDLs junto ao Conselho Executivo da United Nations Framework Conference on Climate Change (UNFCCC), as RCEs passem a ser reconhecidas ao valor justo e como ativos intangíveis desenvolvidos internamente por parte das entidades hospedeiras dos projetos de MDLs, em contrapartida ao Patrimônio Líquido (PL), até o momento de sua realização. A base para mensuração do valor justo proposta foi os valores de mercados ativos. Em função do lapso temporal que estarão gerando benefícios econômicos, realizou-se projeção financeira sobre as quantidades potenciais constantes estimadas de Reduções Esperadas (REs) para todo o período de desenvolvimento das atividades dos projetos, utilizando-se uma taxa Euribor para desconto de seus valores futuros ao presente. Com isso, os valores justos das REs de 31 projetos de MDLs brasileiros, 379 chineses e 318 indianos, foram projetados sobre o valor do PL de 15 empresas brasileiras, 56 chinesas e 183 indianas componentes da amostra da pesquisa, com apoio do teste estatístico não-paramétrico Wilcoxon. Os resultados da pesquisa forneceram indícios de que a mensuração ao valor justo das RCEs, e seu reconhecimento enquanto ativo intangível, poderia ter representado um impacto positivo no grupo de contas patrimoniais das empresas participantes da pesquisa. Assim, a aplicabilidade empírica do Modelo de Mensuração Contábil ao Valor Justo das RCEs, embasado em discussões teóricas já existentes, possibilitou a realização de avaliações desse ativo enquanto item patrimonial capaz de gerar efeitos econômicos positivos no patrimônio das entidades localizadas em países em desenvolvimento, durante a primeira fase do Protocolo de Quioto.

Palavras-Chave: Países em desenvolvimento - Brasil - China - Índia. Mecanismo de desenvolvimento limpo (MDL). Créditos de carbono. Mensuração e reconhecimento contábil. Valor justo. 


\begin{abstract}
SOUZA, Valdiva Rossato de. Accounting measurement of carbon credits in Brazil, China and India. 2015, 219 p. Tese de Doutorado - Faculdade de Economia, Administração e Contabilidade - Departamento de Contabilidade e Atuária - Universidade de São Paulo. São Paulo.
\end{abstract}

This research aimed to propose a model of accounting measurement at fair value of Certified Emission Reductions (CER) generated in the production processes of Brazilian, Chinese and Indian companies with a view to enable to recognition of assets arising from the implementation of projects Clean Development Mechanisms (CDM) during the period from 2005 to 2012. It was considered the incentives offered to the guidelines of the Kyoto Protocol and the representativeness of CDM projects implementation of China, India and Brazil, to present, based on descriptive, analytical and quantitative research, a proposal for accounting measurement of CER, able to enhance the future flows of its economic benefits, based on the Ratnatunga, Jones and Balachandran (2011) model. Therefore, it worked with the hypothesis that the CER were measured at fair value and recognized as an intangible asset, then the equity impacts of future cash flows would be highlighted. It was described the theory of accounting measurement as support at fair value. It was discussed existing accounting standards in those countries and the main characteristics that involve the adoption of International Financial Reporting Standards (IFRS) in each of them, focusing on accounting measurement at fair value, accepted by the International Accounting Standards Board (IASB). The international accounting guidelines issued for accounting of CER were presented to analyze the current scenario of development of the accounting treatment attributable to the asset. Thus, it was found that the measurement of CERs has been little discussed. It was suggested that with the realization of the registration of CDM projects with the Executive Council of the United Nations Framework Conference on Climate Change (UNFCCC), CER start to be recognized at fair value as intangible assets developed internally by the host entities of CDM projects, in contrast to Equity, until the moment of its realization. The basis for measuring fair value proposition was the values of active markets. Depending on the time gap that will generate economic benefits, a financial projection on potential constants estimated quantities of Expected Reductions (ER) for the whole period of development of project activities was carried out, using a Euribor rate to discount their future values to the present. With that, the fair values of ER from 31 Brazilian CDM projects, 379 Chinese and 318 Indians were simulated on the value of equity of 15 Brazilian companies, 56 Chinese and 183 Indian components of the survey sample, with test support statistical non-parametric Wilcoxon. The survey results provided evidence that the fair value measurement of CER, and its recognition as an intangible asset, could have represented a positive impact on the group balance sheet accounts of the participating research companies. Thereby, the empirical applicability of the Accounting Measurement Model to the Fair Value of CER grounded in existing theoretical discussions, made it possible to carry out assessments of this asset as a heritage item capable of generating positive economic effects on equity of entities located in developing countries, during the first stage of the Kyoto Protocol.

Keywords: Developing countries - Brazil - China - India. Clean Development Mechanism (CDM). Carbon credits. Measurement and accounting recognition. Fair value. 


\section{SUMÁRIO}

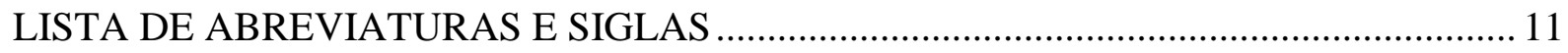

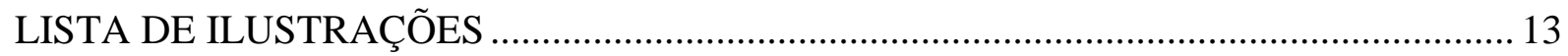

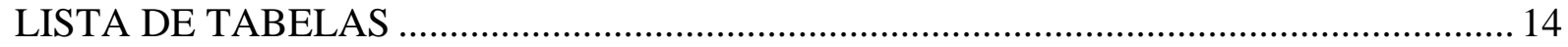

1 INTRODUÇÃ

1.1 Tema e Contextualização do Problema …................................................................. 20

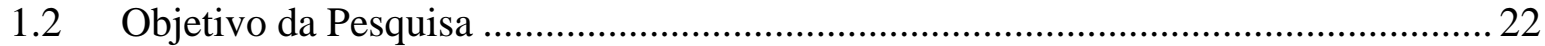

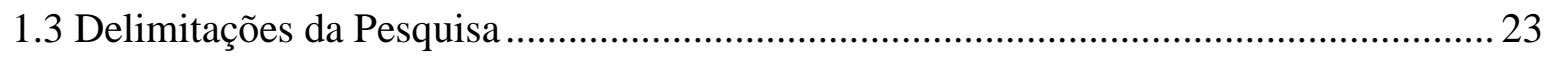

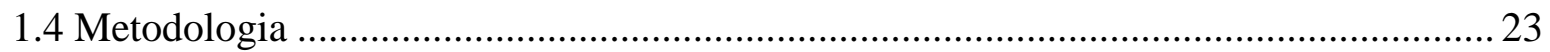

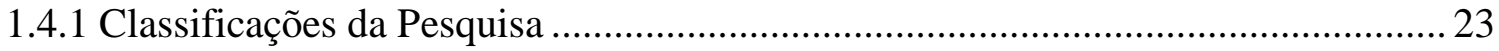

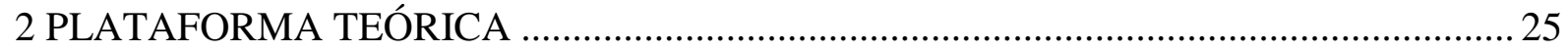

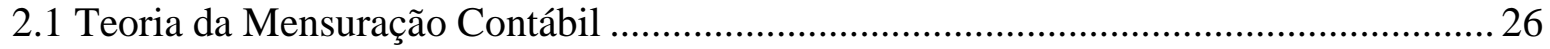

2.1.1 Mensuração Contábil ao Valor Justo adotada pelo IASB ........................................ 38

2.1.1.1 Adoção das IFRSs no Brasil, China e Índia .......................................................... 43

2.1.1.1.1 Adoção das IFRSs no Brasil............................................................................ 43

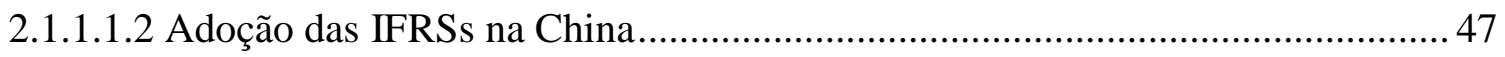

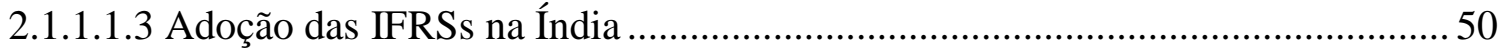

2.2 O Mercado de Carbono e a Regulação Contábil Internacional ......................................54

2.2.1 Tratamento Contábil dos Créditos de Carbono no Brasil, China e Índia ................ 59

3 PROPOSTA DE MENSURAÇÃO CONTÁBIL DOS CRÉDITOS DE CARBONO ..........67

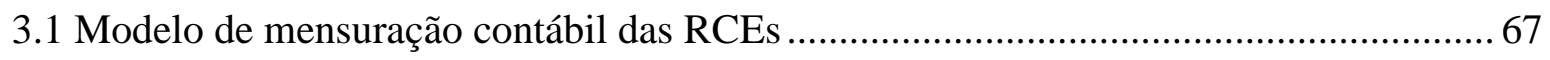

3.2 População, Coleta dos Dados e Seleção da Amostra ..................................................... 74

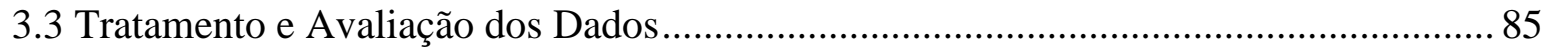

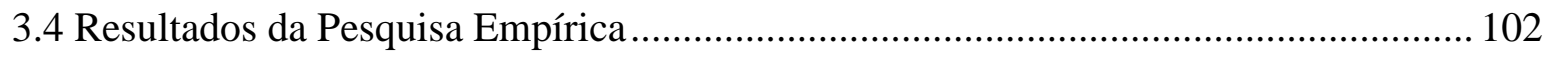

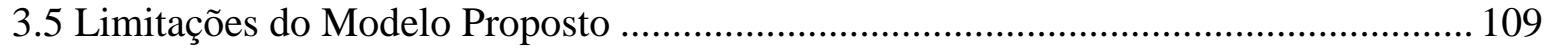

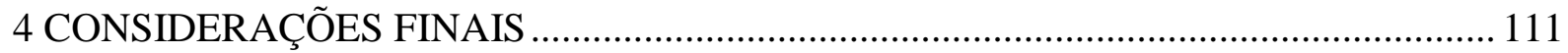


A - Amostra de Empresas com Projetos de MDLs - Brasil

B - Amostra de Empresas com Projetos de MDLs - China 135

C - Amostra de Empresas com Projetos de MDLs - Índia 162

D - Mensuração de RCEs de Projetos de MDLs - Brasil . 187

E - Mensuração de RCEs de Projetos de MDLs - China 189 F - Mensuração de RCEs de Projetos de MDLs - Índia ... 206 


\section{LISTA DE ABREVIATURAS E SIGLAS}

AND

ANEEL

ANS

ANTT

AS

ASB

ASBE

BACEN

BM\&FBovespa

BSE

CASC

CCX

$\mathrm{CDM}$

CER

CERUPT

$\mathrm{CFC}$

CIMGC

$\mathrm{CMN}$

$\mathrm{CO}_{2}$

$\mathrm{CPC}$

CQNUMC

CSRC

CVM

DCP

DFPs

ECEA

EOD

ERUPT

ET

ETS

EURIBOR
Autoridade Nacional Designada

Agência Nacional de Energia Elétrica

Agência Nacional de Saúde Suplementar

Agência Nacional de Transportes Terrestres

Accounting Standards

Accounting Standards Board

Accounting Standards for Business Enterprises

Banco Central do Brasil

Bolsa de Valores de São Paulo

Bombay Stock Exchange

Chinese Accounting Standards Committee

Chicago Climate Exchange

Clean Development Mechanism

Certified Emission Reductions

Certified Emission Reduction Unit Procurement Tender

Conselho Federal de Contabilidade

Comissão Interministerial de Mudança Global do Clima

Conselho Monetário Nacional

Dióxido de Carbono

Comitê de Pronunciamentos Contábeis

Convenção-Quadro das Nações Unidas sobre Mudança do Clima

China Securities Regulatory Commission

Comissão de Valores Mobiliários

Documento de Concepção do Projeto

Demonstrações Financeiras Padronizadas

Environmental Capability Enhancing Asset

Entidade Operacional Designada

Emission Reduction Unit Procurement Tender

Emission Trade

Emissions Trading Scheme

Euro InterBank Offered Rate 
FASB

FDI

FIPECAFI

GAAP

GEE

IAS

IASB

IASC

ICAI

ICE

IFRIC

IFRS

Ind AS

IRDA

JI

MCA

MCT

MDL

MoEF

MOF

NDRC

NSE

ONU

PL

PNMC

RBI

RCEs

RCs

REs

SEBI

SHSE

SUSEP

SZSE

UNFCCC
Financial Accounting Standards Board

Foreign Direct Investment

Fundação Instituto de Pesquisas Contábeis, Atuariais e Financeiras

Generally Accepted Accounting Principles

Gases de Efeito Estufa

International Accounting Standards

International Accounting Standards Board

International Accounting Standards Committee

Institute of Chartered Accountants of India

Intercontinental Exchange, Inc.

International Financial Reporting Interpretations Committee

International Financial Reporting Standards

Indian Accounting Standards

Insurance Regulatory and Development Authority

Joint Implementation

Ministry of Corporate Affairs

Ministério da Ciência e Tecnologia

Mecanismo de Desenvolvimento Limpo

Ministry of Environment \& Forests

Ministry of Finance of China

National Development and Reform Comission

National Stock Exchange

Organização das Nações Unidas

Patrimônio Líquido

Política Nacional sobre Mudança do Clima

Reserve Bank of India

Reduções Certificadas de Emissões

Reduções Certificadas

Reduções Esperadas

Securities and Exchange Board of India

Shanghai Stock Exchange

Superintendência de Seguros Privados

Shenzhen Stock Exchange

United Nations Framework Conference on Climate Change 


\section{LISTA DE ILUSTRAÇÕES}

Quadro 1 - Tratamento Contábil dos Créditos de Carbono no Brasil, China e Índia 59

Quadro 2 - Contratos com liquidez em bolsas de valores do mercado europeu ......... 77 


\section{LISTA DE TABELAS}

Tabela 1 - Evolução do Mercado de Carbono (valores em bilhões de dólares) ........ $\quad 55$

Tabela 2 - Taxas de juros Euribor .................................................................. 76

Tabela 3 - Valores da tonelada de créditos de carbono (em euro) ............................ 77

Tabela 4 - Frequência dos projetos da amostra por ano - Brasil ............................. 79

Tabela 5 - $\quad$ Frequência dos projetos da amostra por ano - China ............................. 79

Tabela 6 - $\quad$ Frequência dos projetos da amostra por ano - Índia ............................. 80

Tabela 7 - Frequência das características qualitativas dos projetos da amostra Brasil

Tabela 8 - Frequência das características qualitativas dos projetos da amostra China.

Tabela 9 - Frequência das características qualitativas dos projetos da amostra Índia.

Tabela 10 - Variáveis para análise estatística dos dados - Brasil ............................ 87

Tabela 11 - Variáveis para análise estatística dos dados - China ............................ 88

Tabela 12 - Variáveis para análise estatística dos dados - Índia ............................. 92

Tabela 13 - Teste de Normalidade - Brasil ......................................................... 102

Tabela 14 - Teste de Normalidade - China ......................................................... 102

Tabela 15 - Teste de Normalidade - Índia ........................................................ 103

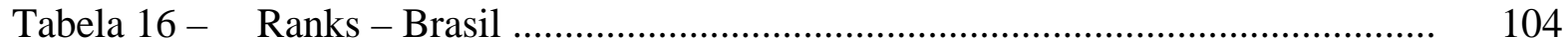

Tabela 17 - Estatísticas dos Testes de Wilcoxon - Brasil ....................................... 104

Tabela 18 - Ranks - China _.......................................................................... 105

Tabela 19 - Estatísticas dos Testes de Wilcoxon - China ....................................... 105

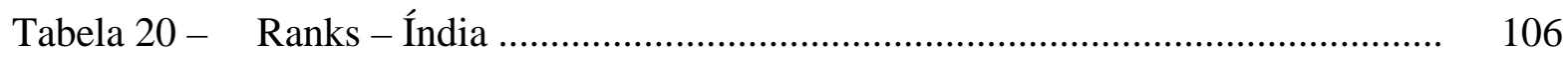

Tabela 21 - Estatísticas dos Testes de Wilcoxon - Índia ........................................ 106 


\section{INTRODUÇÃO}

Com o objetivo de incentivar adequações dos processos produtivos empresariais em prol da redução de impactos ambientais, alguns países implementaram formas de compensações financeiras às entidades, as quais poderiam ser obtidas a partir da comprovação de reduções voluntárias de emissões de gases do efeito estufa (GEEs) na atmosfera (Rocha, 2003; Souza, Andrade, Alvarez, \& Santos, 2013).

Posteriormente, no Protocolo de Quioto, foram regulamentados três tipos de mecanismos, com vistas à redução de emissão dos gases de efeito estufa na atmosfera, quais sejam: o Comércio Internacional de Emissões (Emission Trade-ET); a Implementação Conjunta (Joint Implementation-JI) e o Mecanismo de Desenvolvimento Limpo - MDL (Clean Development Mechanism-CDM), sendo o último o que trata dos acordos entre países desenvolvidos e em desenvolvimento. Tais mecanismos estão contidos, respectivamente, nos artigos 17, 6 e 12 do referido Protocolo (MCT, 1997).

Para possibilitar a atribuição de diferentes compromissos a diferentes países, no Protocolo de Quioto se estabeleceu dois grandes grupos de países (Partes), os desenvolvidos e/ou industrializados, listados no Anexo $\mathrm{I}^{1}$, - que assumiram compromissos de redução de emissões de GEEs na atmosfera - e, os não listados no Anexo I (Não-Anexo I²), os países em desenvolvimento, - sem compromissos de redução de emissões de GEEs -, a exemplo de Brasil, China e Índia, que serão o foco de estudo desta Tese (MCT, 1997).

Dessa forma, visando impulsionar a implementação de práticas de sustentabilidade nos países em desenvolvimento, as diretrizes do Protocolo de Quioto ofereceram estímulos para que as estruturas patrimoniais empresariais destes países recebessem investimentos provenientes de países desenvolvidos, para reduzir as emissões de GEEs a partir da implementação de MDLs. Desta forma, um país, constante no Anexo I, que possua compromisso de reduções de

\footnotetext{
${ }^{1}$ O Anexo I é integrado pelas Partes signatárias da Convenção-Quadro das Nações Unidas sobre Mudança do Clima (CQNUMC, do original em inglês: United Nations Framework Conference on Climate ChangeUNFCCC) pertencentes em 1990 à Organização para Cooperação e Desenvolvimento Econômico (OCDE, do original em inglês: Organization for Economic Co-operation and Development-OECD) e pelos países industrializados da antiga União Soviética e do Leste Europeu.

${ }^{2}$ Não-Anexo I é composto por todas as Partes signatárias da CQNUMC não listadas no Anexo I.
} 
emissões (REs), pode adquirir Reduções Certificadas de Emissões $^{3}$ (RCEs) geradas em países em desenvolvimento (os Não-Anexo I), para cumprimento de suas metas de redução, assumidas no âmbito do Protocolo de Quioto (MCT, 1997).

A implementação de projetos MDLs pode ser realizada, basicamente, de duas formas: (i) com investimentos realizados pela própria companhia, a partir da melhoria e aperfeiçoamento do seu processo operacional e, consequentemente, a redução de seus impactos ambientais situação essa em que a geração de RCEs pode se caracterizar como um objetivo secundário; e (ii) a partir de empreendimentos financiados diretamente por entidades localizadas em países desenvolvidos (Anexo I), possuidores de metas de reduções de emissões de GEEs a serem atingidas.

Tais projetos devem ser capazes de propiciar, a longo prazo, contribuições reais para o desenvolvimento sustentável dos países em desenvolvimento, além de gerar garantias de benefícios reais e mensuráveis em prol da mitigação da mudança climática em níveis globais. Nos dois casos, as RCEs obtidas, após as compensações financeiras, são utilizadas para atingir parte das metas dos países do anexo I. O Protocolo estabelece que tais metas não podem ser cumpridas, apenas, com RCEs geradas por terceiros, a própria atividade da companhia deve contribuir com uma parcela da redução de GEEs.

Os projetos de MDLs devem ser aprovados por uma Autoridade Nacional Designada (AND), que fica responsável pelo aceite de projetos instalados no seu território nacional, cuja função se caracteriza pela emissão de documentos atestando (i) a ratificação do respectivo país ao Protocolo de Quioto; (ii) a participação voluntária do país nas atividades de projetos de MDLs; e (iii) a contribuição dos projetos MDLs ao desenvolvimento sustentável do país (UNFCCC, 2012a).

Deve-se ressaltar que o Protocolo de Quioto deixou a cargo de cada país a definição de indicadores necessários para que os projetos de MDL contribuam, efetivamente, para o alcance do seu desenvolvimento sustentável (MCT, 1997).

Para tanto, o Brasil dispõe da Comissão Interministerial de Mudança Global do Clima CIMGC (Interministerial Comission on Global Climate Change) para aprovação de seus

\footnotetext{
${ }^{3}$ As Reduções Certificadas de Emissões (RCEs) são popularmente conhecidas como Créditos de Carbono.
} 
projetos de MDLs. O governo chinês possui a Comissão de Reforma e Desenvolvimento Nacional da República Popular da China (National Development and Reform Comission of the People's Republic of China - NDRC), para essa finalidade. A Índia, por sua vez, aprova os projetos por meio do Ministério do Meio Ambiente e Florestas (Ministry of Environment \& Forests Government of India - MoEF) (UNFCCC, 2012a).

Os governos do Brasil ${ }^{4}$, da China $^{5}$ e da Índia ${ }^{6}$, por intermédio de suas ANDs, mantêm bancos de dados disponíveis a consultas públicas acerca de todos os projetos de MDLs aprovados junto aos referidos países, ano a ano, a partir de 2004, em diversos escopos setoriais. Tais projetos também estão disponíveis junto ao sítio eletrônico da Convenção-Quadro das Nações Unidas sobre Mudança do Clima (CQNUMC, do original em inglês: United Nations Framework Conference on Climate Change - $\left.\mathrm{UNFCCC}^{7}\right)$.

Em pesquisas desenvolvidas junto ao sítio eletrônico da UNFCCC, foi possível verificar que, até a data de 31 de dezembro de 2012, já haviam sido solicitados registros de 7.510 atividades de projetos de MDLs, dos quais: (i) 5.511 já haviam sido registrados; (ii) 546 estavam em fase de solicitação de registro; (iii) 1.407 se encontravam pendentes de publicação; (iv) para 44 haviam sido solicitadas revisões; (v) para 02 haviam sido solicitadas correções. (UNFCCC, 2013a). Desse total, 7.167 projetos tiveram seus registros finalizados pelo referido órgão, até a data de 01 de setembro de 2014, ocasião em que foram encerradas as buscas para possibilitar o fechamento desta Tese. (UNFCCC, 2014). Portanto, constatou-se a existência de uma defasagem temporal entre a solicitação e a finalização dos registros por parte daquele órgão, que pode ter ocorrido em função do volume de solicitações de registros de MDLs no ano de 2012.

Dentre o montante de 7.167 projetos de MDLs que já haviam tido seus registros finalizados pela UNFCCC, pertinente ao período de 2004 a 2012, a China se encontrava em primeiro lugar, com 3.682 projetos $(51,37 \%)$, em segundo a Índia, com 1.371 projetos $(19,13 \%)$ e, em terceiro o Brasil, com 300 projetos (4,19\%). Os demais projetos (1.814 ou 25,31\%), tiveram

\footnotetext{
${ }^{4}$ Recuperado de http://www.mct.gov.br/index.php/content/view/47952.html

${ }^{5}$ Recuperado de http://cdm.ccchina.gov.cn/english/item_new.asp?ColumnId=68

${ }^{6}$ Recuperado de http://www.cdmindia.gov.in/approved_projects.php

${ }^{7}$ Recuperado de http://cdm.unfccc.int/Projects/projsearch.html
} 
seus registros formalizados por parte dos demais países em desenvolvimento que assinaram o Protocolo de Quioto. (UNFCCC, 2014).

Essas informações evidenciam que, do total de projetos de MDLs, pertinentes ao período de estudo que tiveram seus registros finalizados até a data de 01 de setembro de 2014 junto à UNFCCC, 5.353, ou seja, 74,69\%, foram implementados na China, na Índia e no Brasil. Assim, esses países têm se firmado enquanto os maiores hospedeiros de projetos MDLs dentre os países em desenvolvimento, constantes no quadro Não-Anexo I do Protocolo de Quioto (UNFCCC, 2014).

Tais constatações vêm ao encontro das observações emanadas por Lopez, Tin, Iyadomi, Santos e McIntosh (2009, p. 436), que alertaram em seus estudos para o fato de que, sendo o MDL um mecanismo de mercado, "os investimentos tendem a fluir onde as atividades de MDL proporcionam maiores retornos com limitados riscos econômicos e políticos, isto é, externos aos países menos desenvolvidos" ${ }^{8}$. Com isso, os países em desenvolvimento emergentes $^{9}$ têm sido os que vêm se apresentando com maiores propensões à implementação de projetos MDL no âmbito do Protocolo de Quioto.

Nesse contexto, Newell (2009, p. 426) explica que as diretrizes adotadas por estes países, "servem como significantes para o restante do mundo em desenvolvimento sobre a conveniência de engajamento com os mercados de carbono e com a possibilidade de reduções de emissões. Em outras palavras, o que acontece nesses países tem repercussões globais ${ }^{10}$.

Portanto, o grande número de projetos de MDLs implementados no Brasil, na China e na Índia que, em sua maioria, representa investimentos realizados nas estruturas patrimoniais de empresas situadas nesses países, pode ocasionar impactos econômicos positivos no patrimônio das entidades, principalmente em longo prazo, com a comercialização das RCEs

\footnotetext{
8 ... investments have tended to flow where CDM activities provide higher returns with limited economic and political risks, that is, outside of least developed countries (LDCs).

9 A partir dos anos de 1990, as grandes nações em desenvolvimento passaram a ser denominadas pelos consultores de investimentos e pela academia como mercados emergentes. Em 2001, Jim O'Neill, da consultoria Goldman Sachs de Nova York, criou o conceito de potências emergentes, que na atualidade é representado pelo acrônimo BRICS (Brasil, Rússia, Índia, China e África do Sul). (Visentini, P., Adam, G., Vieira, M., Silva, A., \& Pereira, A., 2013, p. 8-9).

${ }^{10}$... serve as signifiers to the rest of the developing world about the desirability of engagement with carbon markets and the possibility of reducing emissions. In other words, what happens in these countries has global repercussions.
} 
junto aos países desenvolvidos, além de cumprir com seu objetivo principal, o de proporcionar redução dos impactos ambientais e melhoria na sustentabilidade dessas nações.

Deve-se ressaltar que os investimentos realizados nos processos produtivos das entidades, sejam por parte da própria companhia, sejam por meio de recursos externos, se caracterizam, basicamente, pela substituição de ativos operacionais e, por meio de procedimentos que tragam maior eficiência e, menores impactos socioambientais. Dessa forma, tais investimentos devem ser tratados pela contabilidade, conforme sua natureza e utilidade, como ativos operacionais, se for o caso (Perez, Ribeiro, Cunha, \& Rezende, 2008).

Foram estabelecidas, por meio da Decisão 17/CP.7 (MCT, 2001), algumas etapas que devem ser observadas por parte das entidades que visam à implementação de projetos de MDLs, tais sejam: (i) elaboração do Documento de Concepção do Projeto (DCP); (ii) validação por uma Entidade Operacional Designada (EOD) e aprovação por parte da Autoridade Nacional Designada (AND); (iii) registro no Conselho Executivo; (iv) monitoramento; (v) verificação e certificação por meio de uma Entidade Operacional Designada (EOD) e; (vi) emissão de Reduções Certificadas de Emissões (RCEs). Pesquisas detalhadas sobre essas etapas foram desenvolvidas por diversos autores no Brasil (Ribeiro, 2005; Sister, 2007; Limiro, 2008; Sabbag, 2008).

Em linhas gerais, as entidades empresariais envolvidas com os Projetos de MDLs são as responsáveis pela elaboração dos DCPs que, em seguida, os submetem para validação junto a uma EOD e aprovação por parte da AND. A realização dessas etapas garante que os projetos de MDLs atendam às normas nacionais a eles aplicáveis, ficando aptos a seguirem para registro junto ao Conselho Executivo do MDL, na Organização das Nações Unidas (ONU).

Já na fase de elaboração dos DCPs, devem ser especificadas as 'Estimativas de Redução de Emissões (REs) dos Projetos', ano a ano, para a totalidade do período de desenvolvimento de suas atividades. Com a formalização do registro junto ao Conselho Executivo, as REs passam a ser reconhecidas por parte da UNFCCC, às quais "se referem à expectativa de redução de GEEs sobre projetos em fase de implantação e de reduções certificadas (RCs) em empreendimentos já implementados, mas que ainda não realizaram a remoção ou redução de emissões" (Ribeiro, 2005). 
Durante o desenvolvimento das atividades dos projetos de MDLs, o monitoramento deve ser realizado pela entidade que os elaborou, em conformidade com as metodologias contidas nos DCPs, para verificar, ano a ano, a quantidade real de REs de GEEs que foram alcançadas. Os relatos dos monitoramentos devem ser submetidos a uma EOD para verificação/certificação das RCEs, que serão emitidas, posteriormente, por parte do Conselho Executivo do MDL, junto a ONU. Nesse processo, é possível que ocorram oscilações, para mais ou para menos, entre a quantidade estimada de REs nos DCPs e o montante real de RCEs emitidas.

Normalmente, o alvo de comercialização são os certificados de emissões já reduzidas, contudo, negociações antecipadas podem ser realizadas, dependendo do interesse das partes envolvidas. Segundo Sabbag (2008, p. 55), após a efetivação do registro junto ao Conselho Executivo, os investidores passam a "ter segurança jurídica de que os projetos cumprem as normas nacionais e internacionais aplicáveis ao MDL e de que provavelmente serão gerados os créditos de carbono", basicamente, em conformidade com as REs constantes nos DCPs. Na realidade, a segurança jurídica a que o autor se refere é a de cumprimento das exigências contratuais.

Assim, com a efetivação do registro dos projetos de MDLs junto ao Conselho Executivo, a contabilidade pode ter subsídios que possibilitam a identificação, mensuração e comunicação das informações econômicas provenientes do reconhecimento das REs por parte da UNFCCC, de maneira a propiciar informações relevantes aos seus usuários, com base em avaliações passíveis de serem realizadas ao valor justo das RCEs, que já possuem mercados ativos para sua comercialização junto aos países constantes do Anexo I do Protocolo de Quioto.

\subsection{Tema e Contextualização do Problema}

Em se tratando de mensuração contábil das RCEs, as discussões acadêmicas têm se apresentado, até então, de forma bastante tímida e, as poucas discussões existentes, têm se mantido em consonância com as orientações legais emitidas pelas normas internacionais de contabilidade para os diferentes grupos de ativos em que as RCEs possam vir a ser 
reconhecidas (Ferreira, Bufoni, Marques, \& Muniz, 2007; Xiaozhu \& Yunyun, 2011; Zhang, 2011; Wang, 2011; Tang, 2011; Agrawal, 2006; Bothra, 2010; ICAI, 2012).

Dessa forma, a predominância das orientações contábeis existentes no Brasil, China e Índia, tanto em termos legais, quanto no meio acadêmico, pertinente ao tratamento contábil passível de ser atribuído às RCEs, está voltada à mensuração de valores cujo fato gerador tenha ocorrido em períodos passados ou presente, sem vislumbrar projeções temporais, que sejam capazes de espelhar a possibilidade de geração de benefícios econômicos futuros advindos com a sua comercialização.

Isso tem ocorrido, em grande parte, pelo fato de que, até o momento, a utilização do valor justo aceita por parte do IASB pode ser empregada para realizar mensurações de apenas alguns itens patrimoniais. No caso de ativos gerados internamente nos processos produtivos empresariais, a valoração deve ser realizada ao custo. Tal limitação tem impossibilitado a mensuração e reconhecimento a valores justos de ativos gerados nos processos produtivos empresariais por parte das entidades.

Diante do exposto e almejando evoluir com as discussões já existentes, esta Tese se caracterizará pela análise teórica e empírica pertinente à mensuração contábil das RCEs ao valor justo, com a utilização da técnica de ajuste a valor presente, no momento em que sua existência passa a ser reconhecida por parte da UNFCCC, em decorrência da efetivação do registro dos projetos de MDLs, enquadrados no âmbito do Protocolo de Quioto.

Dessa forma, buscar-se-á verificar se a mensuração contábil das RCE's ao valor justo, visando propiciar seu reconhecimento enquanto ativo intangível, com possibilidades de representar benefícios econômicos futuros, em contrapartida ao patrimônio líquido, teria causado impacto no patrimônio de empresas brasileiras, chinesas e indianas, durante a primeira fase do Protocolo de Quioto, tendo em vista a implementação de projetos de MDLs em seus processos produtivos.

Para tanto, esta pesquisa parte da hipótese de que: se as RCEs fossem mensuradas ao valor justo e reconhecidas enquanto ativo intangível, então seriam evidenciados os impactos patrimoniais dos fluxos de caixa futuros esperados com a implementação de projetos de 
MDLs nos processos produtivos das empresas localizadas nos países em desenvolvimento, a exemplo do Brasil, China e Índia.

Nesse contexto, a questão que se apresenta gira em torno da mensuração contábil ao valor justo, dos valores pertinentes as RCEs advindas com a implementação de projetos de MDLs nos processos produtivos de empresas brasileiras, chinesas e indianas, que estão sendo negociadas com entidades de países desenvolvidos, em longo prazo.

Assim, a questão que motiva esta pesquisa é: a mensuração e reconhecimento contábil ao valor justo das RCEs geradas a partir da implementação de projetos de MDLs nos processos produtivos empresariais, teria causado impactos econômicos no patrimônio de empresas brasileiras, chinesas e indianas, durante o período de 2005 a 2012 ?

\subsection{Objetivo da Pesquisa}

O objetivo geral desta Tese consiste em propor um modelo de mensuração contábil ao valor justo das RCEs geradas nos processos produtivos das empresas brasileiras, chinesas e indianas, com vistas a possibilitar o reconhecimento desses ativos oriundos da implementação de projetos MDLs, durante o período de 2005 a 2012.

Para atingir o objetivo geral, os seguintes objetivos específicos foram estabelecidos:

Discutir as bases de mensuração contábil existentes na literatura, passíveis de serem utilizadas para atribuição de valor às RCEs nos países em desenvolvimento.

Identificar os impactos econômicos no patrimônio das empresas brasileiras, chinesas e indianas, causados com o reconhecimento e evidenciação dos fluxos futuros de benefícios econômicos das RCEs, no momento em que sua existência passa a ser aceita por parte da UNFCCC. 


\subsection{Delimitações da Pesquisa}

A presente pesquisa está limitada às empresas brasileiras, chinesas e indianas que disponibilizaram suas Demonstrações Financeiras Padronizadas (DFPs) aos usuários externos por meio das entidades reguladoras de Mercados Mobiliários do Brasil (Comissão de Valores Mobiliários - $\mathrm{CVM}^{11}$ ), da China (China Securities Regulatory Commission $-\operatorname{CSRC}^{12}$ ) e da Índia (Securities and Exchange Board of India - SEBI ${ }^{13}$ ), e que também tenham figurado enquanto "Partes Hospedeiras" de projetos de MDLs registrados junto ao sítio eletrônico da UNFCCC, por meio das ANDs dos referidos países, durante o período de 2005 a 2012.

\subsection{Metodologia}

\subsubsection{Classificações da Pesquisa}

Para atingir os objetivos de realização desta Tese, serão utilizados, enquanto tipos de pesquisas, em um primeiro momento, a pesquisa descritiva e, posteriormente, a pesquisa analítica (Collis \& Hussey, 2005; Cooper \& Schindler, 2011).

A pesquisa descritiva é a que "descreve o comportamento dos fenômenos. É usada para identificar e obter informações sobre as características de um determinado problema ou questão" (Collis \& Hussey, 2005, p. 24). Porém, "um estudo descritivo não explica por que um fato ocorreu ou por que as variáveis interagem de uma determinada forma" (Cooper \& Schindler, 2011, p. 19).

\footnotetext{
${ }^{11}$ Recuperado de http://www.cvm.gov.br/

12 Recuperado de http://www.csrc.gov.cn/

${ }^{13}$ Recuperado de http://www.sebi.gov.in/sebiweb/
} 
Para tanto, será utilizada a pesquisa analítica, que se caracteriza por possibilitar continuidade à pesquisa descritiva e "tem como objetivo entender fenômenos, descobrindo e mensurando relações causais entre eles" (Collis \& Hussey, 2005, p. 24).

No desenvolvimento da primeira fase da pesquisa, utilizar-se-á a estratégia de pesquisa bibliográfica, com amparo em fontes secundárias (Lakatos \& Marconi, 1994; Köche, 2000; Martins, 2002; Martins \& Theóphilo, 2009; Cooper \& Schindler, 2011).

Para a realização da pesquisa analítica, será utilizado o método indutivo para efetivação de análises da prática mercadológica, para possibilitar o alcance de generalizações teóricas para a contabilidade, visando o aprimoramento da ciência (Collis \& Hussey, 2005; Fachin, 2006; Martins \& Theóphilo, 2009; Hendriksen \& Van Breda, 1999; Cooper \& Schindler, 2011).

Assim, será empregada uma abordagem quantitativa de pesquisa, tendo em vista as características avaliativas das variáveis envolvidas com a presente pesquisa, que estarão sendo utilizadas com o propósito de testar teorias (Demo, 2000; Collis \& Hussey, 2005; Fachin, 2006; Martins \& Theóphilo, 2009; Martins, 2010; Cooper \& Schindler, 2011).

Nesse ponto do desenvolvimento da Tese, será utilizada a estratégia de pesquisa ex post facto, que estuda a relação entre variáveis de um fenômeno específico, sem que possa haver a manipulação por parte do pesquisador, pois a constatação de sua manifestação será realizada após os fatos já terem ocorrido e interferido sobre o objeto da pesquisa (Köche, 2000; Martins, 2002; Martins \& Theóphilo, 2009; Cooper \& Schindler, 2011).

Nesse sentido, será utilizada enquanto técnica de coleta de dados e informações, a pesquisa documental, sendo que a natureza das fontes se caracterizará pela utilização de dados primários (Lakatos \& Marconi, 1994; Oliveira et al., 2003; Fachin, 2006; Martins \& Theóphilo, 2009). 


\section{PLATAFORMA TEÓRICA}

A avaliação a valores passados tem se caracterizado, historicamente, enquanto base de mensuração preferencialmente adotada pela contabilidade para sua aplicabilidade junto às entidades empresariais para reconhecimento e evidenciação das demonstrações financeiras. Entretanto, nos últimos tempos, em função de grandes mudanças ocorridas em nível mundial, os usuários externos da informação contábil têm clamado por informações econômicas que propiciem melhor evidenciação dos fatos que cercam a realidade empresarial no presente, com vistas a oferecer subsídios para decisões futuras.

Nesse sentido, serão discutidas, nos tópicos subsequentes, as principais bases de mensuração existentes na literatura e passíveis de serem utilizadas pela contabilidade, com enfoque para a Mensuração Contábil ao Valor Justo, que passa a se caracterizar, sequencialmente, pela possibilidade de atribuição de um enfoque mais econômico aos elementos do patrimônio das organizações.

O Valor Justo está sendo adotado, gradativamente, pelo International Accounting Standards Board (IASB), através das Normas Internacionais de Contabilidade, as International Financial Reporting Standards (IFRSs), enquanto base de mensuração para valoração de alguns itens do ativo e do passivo junto às demonstrações contábeis em diversos países. Assim, o processo de adoção das IFRSs no Brasil, na China e na Índia será discutido enquanto perspectiva para implementação real da proposta de mensuração contábil das RCEs nos países em desenvolvimento, realizada nesse estudo.

Nesse mesmo contexto, serão discutidas a evolução do Mercado de Carbono e as respectivas orientações contábeis internacionais, legais e acadêmicas, pertinentes à contabilização das RCEs no Brasil, na China e na Índia, com vistas a analisar o nível de evolução do processo de Mensuração Contábil das RCEs geradas junto às entidades empresariais neles localizadas.

Com base na literatura que será discutida, apresentar-se-á uma Proposta de Mensuração Contábil das RCEs geradas internamente nos processos produtivos empresariais de entidades 
localizadas no Brasil, na China e na Índia, que têm se destacado enquanto maiores hospedeiros de projetos de MDLs, dentre os países classificados como Não-Anexo I no Protocolo de Quioto.

\subsection{Teoria da Mensuração Contábil}

A contabilidade foi conceituada por Iudícibus (2000, p. 26), como "o método de identificar, mensurar e comunicar informação econômica, financeira, física e social, a fim de permitir decisões e julgamentos adequados por parte dos usuários da informação".

Em conformidade com essa definição, deve-se ter em mente que, para diferentes usuários, diferentes tipos de informações poderão ser relevantes, o que pode levar à necessidade de serem evidenciadas pela empresa, em conjunto com as contábeis, informações integradas, não só as financeiras e econômicas, mas também demais aspectos que sejam considerados importantes, para os diferentes tipos de tomadas de decisões que se fizerem necessários, como é o caso de informações físicas e sociais, mencionadas por Iudícibus (2000).

Apesar disso, Ijiri, (1975, p. 34) já havia salientado que, em vista ao desenvolvimento econômico mundial, "os objetivos mais comumente observados na contabilidade, são os econômicos ${ }^{14 "}$. Assim, um de seus objetivos continua sendo, na atualidade, o de "fornecer informação econômica relevante para que cada usuário possa tomar suas decisões e realizar seus julgamentos com segurança” (Iudícibus, 2000, p. 28).

Com o exposto é possível perceber que a principal função da contabilidade é a de gerar informações quantificáveis aos seus usuários e, para tanto, a "mensuração contábil se caracteriza enquanto função central dos sistemas contábeis ${ }^{15 "}$ (Ijiri, 1975, p. 29).

Na visão de Hendriksen e Van Breda (1999, p. 313), "a escolha de uma base específica de mensuração é influenciada pelos objetivos da mensuração de ativos. Como alguma forma de

\footnotetext{
${ }^{14}$ However, the goals that are most commonly observed in accounting are economic goals.

15 ... accounting measurement, which is the central function of accounting systems.
} 
avaliação é necessária no processo contábil, os objetivos de avaliação são, em grande parte, os mesmos objetivos da contabilidade". Em sendo os objetivos econômicos vislumbrados, deve ser adotada uma base de mensuração que tenha condições de evidenciar informações econômicas, possibilitando julgamentos com mais segurança por parte dos seus usuários.

E, para atinjir os objetivos da contabilidade, Ijiri (1975, p. 36) ressalta que o processo de mensuração contábil deve (i) ocorrer a partir de fatos verificáveis; (ii) ser bem especificado para permitir julgamentos inequívocos; e (iii) possuir algumas regras de mensuração que sejam justificáveis. Ao serem observadas tais características, o processo de mensuração contábil estará primando pelo fornecimento de informações confiáveis aos usuários.

Nessa linha de raciocínio, Ijiri (1975, p. 56), explica que as mensurações normalmente são classificadas como primárias (ocasião em que os objetos são inicialmente quantificados) e secundárias (cujos valores são obtidos matematicamente, transformando-se as mensurações primárias). Nesse sentido, “a mensuração contábil, basicamente gera apenas medidas secundárias. As medidas primárias, que são imputadas em um sistema de mensuração contábil, são essencialmente físicas ${ }^{16}$ ". Para tanto, o autor ressalta que a mensuração contábil se "utiliza da matemática para expressar fenômenos do mundo empírico"17", "de forma a tornar possível a análise de fenômenos com mais profundidade e precisão ${ }^{18 "}$ (Ijiri, 1975, p. 189).

Na visão de Mason e Swanson (1981, p. 12), nessa perspectiva a "mensuração representa o elo entre o mundo empírico e o mundo teórico. Ela permite o uso da matemática no raciocínio científico e facilita a realização de predições e explicações ${ }^{19}$ ", para avaliações de itens patrimoniais, quando se fizerem necessárias ao entendimento econômico do fenômeno que está sendo mensurado.

Nesse mesmo sentido, Most (1982) alertou para o fato de que na contabilidade, o processo de valoração não possui o mesmo significado que nas ciências matemáticas, pois para a realização da mensuração contábil, os objetos são representados por quantidades monetárias,

\footnotetext{
16 ... accounting measurement basically generates only secondary measures. The primary measures which are imputed to an accounting measurement system are essentially physical quantities.

${ }^{17}$ We use mathematics to express phenomena in the empirical world.

18 ... making it possible for us to analyze the phenomena in more depth and with more precision.

19 ... measurement represents the link between the empirical world and the theoretical world. It enables the use of mathematics in scientific reasoning and facilitates the making of predictions and explanations.
} 
que possuem propriedades específicas a serem observadas, em função de oscilações mercadológicas também específicas. Para Most (1982, p. 242), “avaliação em contabilidade é a atribuição de números a objetos de acordo com as regras, onde os números são encontrados dentro de um sistema monetário ${ }^{20}$ ".

Corroborando com tal entendimento, Kam (1986, p. 331) explica que a "mensuração envolve a ligação do sistema formal, o sistema numérico, para alguns aspectos de objetos ou eventos por meio de regras semânticas. Estas regras consistem em operações concebidas para fazer a conexão ${ }^{21} "$ dos eventos que ocorrem na entidade, visando o fornecimento de informações econômicas confiáveis e relevantes ao processo de tomada de decisão, de forma a manter a fidelidade de representação de tais eventos, mesmo com o decorrer do tempo.

No que tange ao conceito de mensuração, Sterling (1970, p. 65-80) enfatizou em seu estudo que podem ser vislumbradas na literatura diversas definições para o termo, alertando para o fato da inexistência de "uma definição única, bem estabelecida de mensuração ${ }^{22 " . ~ P a r a ~ o ~}$ autor, "a mensuração é um processo de comparação ${ }^{23}$ ", que possui como objetivo fundamental "permitir-nos distinguir ou discriminar a relação de algumas propriedades ${ }^{24 \text { " dos }}$ eventos que serão mensurados, de maneira a tornar "a informação mais informativa ${ }^{25}$ ".

Portanto, Sterling (1970, p. 95) salienta que “o objetivo original de realizar a mensuração pode ser de predizer uma condição futura ou retrodizer uma condição passada, mas isso não nega o fato de que a mensuração se refere a uma condição existente ${ }^{26}$ ". Nesse sentido, os fatores temporais devem ser observados pelo processo de mensuração contábil, de forma a tornar as informações mais relevantes aos seus usuários.

Vickrey (1970, p. 732), por sua vez, alertou que uma definição de mensuração que atenda às necessidades que se apresentam à mensuração contábil, pode ser tida como "a atribuição de números para representar elementos ou suas propriedades em um sistema específico sobre as

\footnotetext{
${ }^{20}$ Valuation in accounting is the assignment of numerals to objects according to rules, where the numerals are found within a monetary system.

${ }^{21}$ Measurement involves the linking of the formal system, the number system, to some aspect of objects or events by means of semantical rules. These rules consist of the operations devised to make the connection...

${ }^{22}$ Anyone who expects to find a single, well-established definition of measurement is due for a disappointment.

23 ... measurement is a process of comparison.

$24 . .$. allow us to distinguish or discriminate in respect to some property.

25 The purpose of measurement is to make information more informative.

26 The original purpose of making the measurement may be to predict a future condition or retrodict a past condition, but this does not negate the fact that measurement concerns an existing condition...
} 
bases do isomorfismo ou homomorfismo existentes entre um ou mais sistemas relacionais empíricos (SRE) e um ou mais sistemas relacionais numéricos (SRN) ${ }^{27}$ ”. Na visão do autor, o conceito de mensuração contábil deve se preocupar com atribuições numéricas que representem propriedades específicas de fenômenos empíricos e, também, definições de regras a serem utilizadas em tais atribuições numéricas.

Nesse sentido, Vickrey (1970, p. 738) argumenta que "o processo contábil convencional não é capaz de produzir medidas teóricas consistentes ${ }^{28}$,", necessárias para classificá-lo como uma disciplina de mensuração, da maneira como é requerido pela teoria da mensuração científica.

Conforme o autor (1970, p. 738), as condições necessárias e suficientes para que a contabilidade seja classificada como uma disciplina de mensuração devem ser capazes de identificar grandes propriedades econômicas, que sejam: “(1) predominantemente fenômenos contábeis; (2) mensuráveis em unidades de padrões monetárias; e (3) aceitas por contadores como apropriadas para mensuração contábil ${ }^{29} "$.

Para tanto, Vickrey (1970, p. 741) apresenta seu posicionamento no sentido de assumir que "a mensuração do poder de compra é teoricamente apropriada, a partir do ponto de vista da teoria de mensuração $(. . .)^{30 "}$, para identificar grandes propriedades econômicas, com as características anteriormente elencadas, "mesmo quando mensurado por instrumentos humanos em um mercado imperfeito ${ }^{31}$ ".

Mattessich (1970, p. 30), por sua vez, se posicionou no sentido de que, em termos de mensuração contábil, não é possível tomar decisões de investimentos com base em apenas um modelo de avaliação. Para o autor, duas formas de avaliação devem ser observadas - uma 'objetiva' e outra 'subjetiva'. A avaliação 'objetiva' se faz necessária para que sejam conhecidos os custos de aquisição dos investimentos e, a 'subjetiva' deve levar em conta as

27 ... the assignment of numerals to represent elements or a property of elements in a specified system on the basis of isomorphism or homomorphism existing between one or more empirical relational systems (ERS) and one or more numerical relational systems (NRS).

${ }^{28}$... the conventional accounting process is capable of producing no theoretically sound measures (...)

${ }^{29}$ (1) is possessed by accounting phenomena, (2) is measurable in standard monetary units, and (3) is accepted by accountants as appropriate for accounting measurement.

30 ... the measurement of purchasing power is theoretically sound from the point of view of measurement theory...

31 ... even when measured by human instruments in an imperfect market. 
expectativas futuras de retorno dos investidores, as quais normalmente "são refletidas pelo valor descontado de todos os fluxos de caixa líquidos estimados que podem ser esperados do investimento (ou seja, seu valor presente) $)^{32}$.

De acordo com Mattessich (1970), a utilização da avaliação de ativos apenas pelo seu custo de aquisição, se apresenta enquanto suficiente pura e unicamente para finalidades tributárias. Entretanto, não é suficiente para oferecer informações necessárias ao processo de gestão empresarial e, tão pouco, para os investidores externos, para os quais devem ser consideradas, também, as expectativas futuras líquidas de retorno dos investimentos.

Mattessich (1972, p. 475) diz que a "contabilidade descreve os eventos passados e, ocasionalmente, futuros e, portanto, é uma forma especial de atividade de mensuração, ao menos para os que a identificam com descrição quantitativa ${ }^{33}$ ". Nesse sentido, os fatores temporais que envolvem a perspectiva de geração de recursos devem ser observados com a utilização de bases específicas de mensuração a ser utilizada em casos específicos.

A necessidade de utilização de diferentes bases de mensuração para os diversos itens patrimoniais pode ser identificada na definição adotada por Hendriksen e Van Breda (1999, p. 304), para os quais mensuração em contabilidade, significa "o processo de atribuição de valores monetários significativos a objetos ou eventos associados a uma empresa, e obtidos de modo a permitir agregação (tal como na avaliação total de ativo) ou desagregação, quando exigida em situações específicas".

Nesse mesmo sentido, o IASB também mencionou, no parágrafo 98 do Framework for the Preparation and Presentation of Financial Statements, que "mensuração é o processo que consiste em determinar os valores monetários pelos quais os elementos das demonstrações contábeis devem ser reconhecidos e apresentados no balanço patrimonial e na demonstração

\footnotetext{
$32 \ldots$ are usually reflected in the discounted sum of all estimated future net cash flows to be expected from this asset (i.e., its present value).

${ }^{33}$ Accounting describes past and occasionally future events, and thus is a special kind of measurement activity, at least for those who identify measurement with quantitative description.
} 
do resultado". Para tanto, o documento acrescentou também que "esse processo envolve a

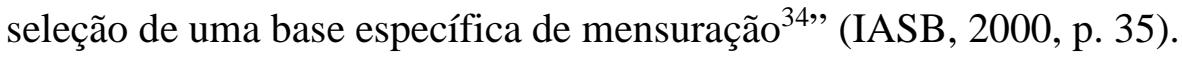

Nessa mesma linha de raciocínio, Bierman Jr. (1963, p. 502) ressaltou que, em sendo "o objetivo da contabilidade o de fornecer informações financeiras úteis, de maneira justa ou razoável $^{35}$ ", a mensuração contábil não, necessariamente, deva ser realizada de forma 'objetiva' para atingir sua finalidade, pois para atender aos diversos princípios contábeis existentes na contabilidade tradicional, vários níveis de subjetividade e inexatidão se fazem necessários. Assim, o autor explicou que a "contabilidade convencional é um aperfeiçoamento em relação à contabilidade objetiva, visto que reconhece a necessidade e permite a utilização de algumas evidências subjetivas, a fim de obter informações mais úteis ${ }^{36 "}$ aos usuários externos.

Kam (1986, p. 97) alertou para o fato de que, "embora a contabilidade convencional muitas vezes seja chamada de contabilidade a custos históricos, o que se entende de fato por este termo é que os ativos não monetários são avaliados pelo custo histórico ${ }^{37}$ ". De acordo com o autor, para avaliação dos itens contábeis, em termos práticos, são utilizados diversos métodos, basicamente da seguinte forma:

Caixa é simplesmente contado,

1. Valor presente: para os itens monetários de longo prazo,

2. Expectativa de caixa: para os itens monetários de curto prazo,

3. Custo histórico: para os ativos não monetários,

4. Preço de mercado: Ao utilizar o menor valor entre custo ou mercado, o ativo pode ser valorizado ao custo de reposição, ou valor realizável líquido ${ }^{38}$. (Kam, 1986, p. 97).

\footnotetext{
34 98. Measurement is the process of determining the monetary amounts at which the elements of financial statements are to be recognised and carried in the balance sheet and statement of profit and loss. This involves the selection of the particular basis of measurement.

35 The goal of the accountant should be to present useful financial information arrived at in a fair or reasonable manner.

${ }^{36}$ Conventional accounting is an improvement over objective accounting since it recognizes the necessity for and allows some use of subjective evidence in order to obtain more useful information.

${ }^{37}$ Although conventional accounting is often called historical cost accounting, we must understand that what is meant by this term is that the nonmonetary assets are valued at historical cost.

${ }^{38}$ Cash is simply counted,

1. Present value. This method is employed for long-term monetary items,

2. Expected cash. For short-term monetary items,

3. Historical cost. For nonmonetary assets,

4. Market price. In using the lower of cost or market method, the asset may be valued at replacement cost or NRV.
} 
Dentre os itens elencados pelo autor, a avaliação a custos históricos atribuída a ativos não monetários é o ponto em que são concentradas as maiores discordâncias em termos de critério de avaliação contábil, enquanto instrumento utilizado para possibilitar a evidenciação de informações úteis aos seus usuários.

Ainda, de acordo com Kam (1986), a utilização de diversos métodos de avaliação pela contabilidade tradicional, baseada fortemente em custos originais, é o que distancia o conhecimento do valor econômico das entidades, para o qual seria necessária a utilização do critério do valor presente para avaliação dos itens patrimoniais.

Nesse contexto, Bierman Jr. (1963, p. 505) já havia sugerido que o processo de mensuração contábil deva evoluir para o aprimoramento de uma visão mais 'subjetiva' de seus conceitos, adotando-se uma postura relacionada à utilização do valor presente dos ativos, em detrimento de seu custo original. Na visão do autor, "quando mensurações justas de valor de mercado estiverem disponíveis, estas seriam utilizadas na apresentação das demonstrações financeiras e, quando os valores de mercado não estiverem disponíveis, então o custo seria utilizado como uma mensuração aproximada do valor ${ }^{39}$ ".

Assim, Bierman Jr. (1963, p. 505) sugere que para a obtenção do valor presente dos ativos sejam utilizadas técnicas de avaliação apropriadas, dentre as quais se encontra o "valor presente líquido dos fluxos de caixa futuros esperados ${ }^{40}$ ". Com isso, a contabilidade passaria a adotar um enfoque mais econômico em seus conceitos de mensuração, com vistas ao fornecimento de informações úteis aos seus usuários.

Compartilhando com essa linha de raciocínio, Most (1982, p. 239), após analisar o conceito de mensuração científica e compará-lo com as diferentes formas de avaliação utilizadas pela contabilidade para elaboração das demonstrações financeiras, ressalta que "em ciência, o melhor método de mensuração é o que produz o menor erro de mensuração ${ }^{41}$ ".

Para tanto, a estrutura básica da contabilidade, traz em seu bojo, diversas bases para mensuração, as quais dizem respeito aos métodos de apuração de valores monetários que

\footnotetext{
${ }^{39}$ Where reasonable measures of market value are available these would be used in the presentation of financial position. Where the market values are not readily available, then cost would be used as an approximate measure of value.

$40 \ldots$ the net present value of expected future cash flows, ...

${ }^{41}$ In science, the best method of measuring is the one which produces the lowest error measurement,...
} 
serão atribuídos aos itens patrimoniais em função de suas propriedades (atributos). Todas as bases de mensuração podem ser empregadas, com vistas ao atendimento dos objetivos de usuários determinados, em função do contexto ao qual a informação será utilizada (Most, 1982; Hendriksen \& Van Breda, 1999; Iudícibus, 2000; Martins, 2001; Glautier \& Underdown, 2001; Riahi-Belkaoui, 2004).

Martins (2001, p. 19), nesse sentido, salienta que, em função do volume e da velocidade em que transformações econômicas e mercadológicas vêm ocorrendo em nível mundial, cada vez mais, as informações fornecidas pelas corporações aos seus usuários, deverão ser "suportadas em diferentes opções de avaliação", que poderão se apresentar de maneira complementar umas às outras. Essa mesma linha de raciocínio já havia sido defendida por diversos autores (Mattessich, 1972; Most, 1982; Kam, 1986, Hendriksen \& Van Breda, 1999; Iudícibus, 2000; Glautier \& Underdown, 2001, Riahi-Belkaoui, 2004, Iudícibus \& Martins, 2007).

Porém, Glautier e Underdown (2001) alertaram, em seus estudos, que a utilização de um ou outro conceito de mensuração contábil gera reflexos no lucro das entidades. Tal reflexo é ocasionado em função da utilização de mensurações correntes a valores de entrada e/ou saída, que foram sintetizadas pelos autores, da seguinte forma:

\begin{abstract}
A distinção entre os valores de entrada e saída leva a dois conceitos diferentes de lucro - lucro realizado e a realizar. Lucro realizado surge apenas no momento da venda, de modo que os bens não vendidos são valorizados pelo custo. Por outro lado, lucro a realizar é baseado no preço corrente de venda dos bens, indicando, assim, a receita que poderia ser obtida caso os ativos sejam vendidos. Como resultado, os ativos não vendidos são valorizados não pelo custo, mas pelo valor de realização ${ }^{42}$. (Glautier \& Underdown, 2001, p. 331).
\end{abstract}

Tal entendimento evidencia que as mensurações correntes realizadas a valores de entrada possuem uma preocupação com o lucro empresarial de determinado período (lucro realizado), enquanto as realizadas a valores de saída se preocupam com o aumento gerado no patrimônio líquido em função da manutenção dos bens na entidade (lucro a realizar).

Nas palavras de Martins (2001),

\footnotetext{
42 The distinction between entry and exit values leads to two different concepts of profit - realized and realizable income. Realized profit arises only upon sale, so that unsold assets are valued at cost. By contrast, realizable profit is based on the current selling price of the assets, thereby indicating the revenue which could be obtained should the assets be sold. As a result, unsold assets are valued not at cost, but at realizable value.
} 
Os valores de entrada são aqueles obtidos nos segmentos de mercado de compra da entidade e refletem a importância associada à obtenção dos recursos. Já os valores de saída, obtidos nos segmentos de vendas, refletem a importância dada pelo mercado aos recursos de que a empresa dispõe (Martins, 2001, p. 27).

Para a realização de mensurações a valores correntes, seja a valores de entrada ou a valores de saída, são utilizados como base os valores de mercado representados pelo montante de desembolso necessário para aquisição de bens e/ou serviços (valores de entrada) e, pela possibilidade de obtenção de recursos em função da entrega de determinados bens e/ou serviços (valores de saída) por parte da entidade.

Assim, a avaliação a valores de entrada se utiliza do custo de aquisição dos bens, apoiada em custos correntes de compra, para avaliar a capacidade econômica institucional em determinado momento do passado, visando suprir a necessidade de informações econômicas por parte dos gestores, acionistas e credores, de forma a realizar um processo avaliativo das ações econômicas empresariais ocorridas no passado, focadas na capacidade de geração de lucro empresarial (rentabilidade) (Most, 1982; Kam, 1986; Riahi-Belkaoui, 2004).

Já a avaliação a valores de saída adota, como base, os valores que a entidade obteria pela venda não forçada de um item em determinado momento, objetivando suprir as necessidades de informações econômicas dos gestores e investidores, pertinentes à capacidade empresarial de obtenção de recursos junto ao mercado, se for necessário. Assim, a utilização de mensuração a valores correntes de saída propicia uma visão econômica da capacidade de geração de fluxo de recursos empresariais no momento presente (liquidez) e possibilita a realização de projeções do fluxo futuro de recebimentos líquidos de caixa, com a utilização da técnica do valor presente (Most, 1982; Kam, 1986; Riahi-Belkaoui, 2004).

Portanto, ao serem realizadas mensurações a valores correntes de saída, utilizando-se da técnica do valor presente para descontar os fluxos de benefícios futuros esperados com um ativo, são obtidas mensurações de valores futuros, transformadas em valores presentes.

Dessa forma, a base de mensuração de valores futuros descontados a valores presentes se baseia em projeções que adota os valores passados e/ou correntes como base para sua realização. Para que tais projeções sejam realizadas, faz-se necessário a utilização de técnicas de avaliação apropriadas a cada circunstância específica. A literatura pertinente à avaliação de empresas (valuation), apresenta, de maneira minuciosa, diversas técnicas de avaliação 
disponíveis no mercado (Capeland, Koller, \& Murrin, 2002; Assaf Neto, 2007; Cunha, 2011).

Porém, em se tratando de mensuração contábil, Most (1982, p. 244) explica que a técnica do valor presente foi utilizada para a definição de 'valor' em contabilidade ${ }^{43}$ e serve de base para a valoração de alguns itens do ativo e do passivo, cujos "futuros recebimentos líquidos podem ser previstos com segurança ${ }^{44 "}$. Entretanto, o autor ressalta que a técnica do valor presente não deve ser utilizada para todos os itens do ativo e do passivo conjuntamente, pois sua aplicabilidade deve ser observada apenas a itens que apresentam propriedades passíveis de aplicação da fórmula do valor presente.

De acordo com Most (1982, p. 243), a fórmula do valor presente representa "a avaliação direta dos futuros recebimentos líquidos de caixa, que, juntamente com uma taxa de desconto positiva, associada a um período esperado ${ }^{45 "}$ possibilita a atribuição de valor ao objeto contábil a ser mensurado a valores futuros, evidenciando o seu valor econômico.

Nesse mesmo sentido, Martins (2001, p. 112), já havia mencionado que "o valor presente... consiste em converter os benefícios e sacrifícios associados a um item patrimonial em quantidades de moeda, respeitando épocas de ocorrência, e transportá-las para a data específica por meio do uso de taxas de juros".

Dessa forma, para a realização do cálculo do valor presente, Riahi-Belkaoui (2004) ressalta que quatro variáveis devem ser conhecidas, tais sejam:

1. os fluxos de caixa esperados que possam resultar do uso ou alienação do ativo;

2. a tempestividade desses fluxos de caixa esperados;

3. o número de anos de vida útil restante do ativo; e

4. a taxa de desconto apropriada ${ }^{46}$ (Riahi-Belkaoui, 2004, p. 485).

\footnotetext{
${ }^{43}$ Existe uma uma diferença conceitual entre os termos 'custo' e 'valor' em contabilidade, pois “custo representa um sacrifício" realizado em determinado momento para adquirir algum item específico, "enquanto valor está associado a benefícios futuros", que são esperados a partir da realização de tal sacrifício. (Kam, 1986, p. 87).

${ }^{44}$ The direct or present value method of valuation is used in accounting where future net cash receipts can be predicted with certainty.

45 ... then present value is the direct valuation of future net cash receipts, which, together with the positive discount rate associated with the waiting period,...

46 1. the expected cash flows that may result from the use or disposal of the asset;

2. the timing of those expected cash flows;

3. the number of years of the asset's remaining life; and

4. the appropriate discount rate.
} 
Para tanto, todas as variáveis necessárias à realização do cálculo devem ser conhecidas com consideráveis níveis de segurança, de maneira a propiciar maior credibilidade possível aos valores mensurados.

Sobre isso, Glautier e Underdown (2001) explicam que:

Valor Presente é um conceito que relaciona o valor de um ativo para a decisão de mantê-lo e auferir vantagem com a sua utilização para a produção de renda. Ele é definido como a soma dos fluxos futuros líquidos de caixa esperados, associados com o uso dos ativos, descontados ao seu valor presente ${ }^{47}$ (Glautier \& Underdown, 2001, p. 301).

Nessa linha de raciocínio, Kam (1986, p. 89-93) enfatizou que, em termos econômicos, “o valor de um ativo deve ser definido em termos de sua capacidade para gerar produtos ou serviços $^{48}$ ". Porém, o autor alertou para o fato da impossibilidade em ser quantificado o verdadeiro valor econômico, sem que sejam realizados ajustes aos valores inicialmente projetados, apesar disso, explica que "muitos teóricos acreditam que o valor presente é a aproximação 'ideal' do verdadeiro valor econômico ${ }^{49}$ ”. Entretanto, deve-se ter em mente que "o método do valor presente resulta em um valor estimado", o qual "é tão confiável quanto as estimativas realizadas ${ }^{50 "}$ para se obtê-lo.

Glautier e Underdown (2001, p. 317) também alertaram para o fato de que, em se tratando de valor presente, a "precisão da mensuração depende do grau de certeza em que as previsões de fluxos de caixa futuros são realizadas 51 ", e, também, "exige que a taxa de desconto selecionada para reduzir o fluxo de caixa futuro ao seu valor presente deve refletir com precisão o valor do dinheiro no tempo ${ }^{52}$ ".

\footnotetext{
${ }^{47}$ Present value is a concept which relates the value of an asset to the decision to hold it and to derive its utility from using it in the production of income. It is defined as the sum of the future expected net cash flows associated with the use of the assets, discounted to their present value.

${ }^{48}[\ldots]$ therefore, the value of an asset must be defined in terms of its capability to generate goods or services.

${ }^{49}$ Many theorists believe that present value is the "ideal" approximation of true economic value.

${ }^{50}$ The present value method results in an estimated value. The value is as reliable as the estimates made.

${ }^{51}$ Accuracy of measurement depends upon the degree of certainty under which the forecasts of expected future cash flows are made.

$52[\ldots .$.$] requires that the discount rate selected for reducing the future cash flows to their present value should$ reflect accurately the time value of money.
} 
Ressaltou Staubus (1985, p. 64) que "a taxa de desconto deve ser selecionada pela observação direta das taxas de juro de mercado, que geralmente incluem uma remuneração para proteção de riscos $^{53}$ ". E, em se tratando de títulos de longo prazo, Hicks (1984, p. 137) explica que tais remunerações aos riscos são atribuídas, principalmente, quanto às "incertezas ao curso futuro das taxas de juro".

Staubus (1985, p. 64) explica que a taxa de desconto a ser utilizada para redução de valores futuros a valores presentes "pode ser observada na data da origem da negociação (taxa antiga) ou pode ser revista à data da mensuração (taxa atual $)^{54}$ ". Dessa forma, os itens patrimoniais mensurados a valor presente no momento das negociações podem ter suas avaliações revistas em situações futuras, ao menos a cada exercício social.

No entanto, Martins (2001, p. 118) explica que, em sendo possível a aplicação da mensuração a valor presente do fluxo futuro de caixa "com valores bastante confiáveis", ela representa uma "forma de avaliação quase insuperável, quando se quer medir o valor econômico de um ativo".

Diante de todo o exposto e, em função do desenvolvimento econômico existente na atualidade, mensurações a valores correntes de saída, com a utilização da técnica do valor presente para realização de projeções de valores futuros, passaram a ser discutidas e aceitas por parte de entidades reguladoras contábeis para elaboração das demonstrações financeiras, às quais, novas nomenclaturas e algumas especificidades foram atribuídas, como é o caso da Mensuração Contábil ao Valor Justo, de forma hierárquica, utilizada pelo IASB e adotada em diversos países, a exemplo de Brasil, China e Índia, que se caracterizam enquanto foco deste estudo.

\footnotetext{
${ }^{53}$ The discount rate is selected by more or less direct observation of market interest rates, so it usually includes a premium to cover uncollectibles.

${ }^{54}$ The discount rate employed may be the rate observed at the date of origin of the claim or obligation (old rate) or it may be revised to the measurement date (current rate).
} 


\subsubsection{Mensuração Contábil ao Valor Justo adotada pelo IASB}

A mensuração a preços correntes de venda (a valores de saída) passou a ser adotada pelo Financial Accounting Standards Board (FASB), para avaliação de alguns itens patrimoniais (ativos e passivos), com a emissão do SFAS 133, em 1998 (Iudícibus \& Martins, 2007, p. 9).

A mensuração a valores correntes de venda é apresentada como 'Valores Justos' pela literatura especializada (Martins, 2001, p. 120), cujo conceito, adotado pelo FASB e, posteriormente, pelo IASB, como 'Valor Justo de Mercado' (fair market value), "não está restrito à avaliação de ativos. Além desses, podemos aplicá-lo também aos passivos registrados (on-balance sheet) ou não (off-balance sheet)".

Nesse sentido, Martins (2001, p. 121) ressalta que "o valor justo de mercado é aquele que receberíamos (ativos) ou pagaríamos (passivo) caso decidíssemos transacionar um item patrimonial (registrado ou não) num mercado eficiente e em condições normais”.

A referência inicialmente utilizada ao termo valor justo, conforme salientado por Hendriksen e Van Breda (1999, p. 309), diz respeito "ao capital total sobre o qual os investidores têm direito de obter um retorno justo". Assim, conforme os mesmos autores, o valor justo "não é uma base específica de avaliação que possa ser aplicada de maneira generalizada às demonstrações financeiras. Na verdade, trata-se de uma combinação de bases de avaliação determinadas... para uma finalidade específica”, que deveria ser utilizada quando da avaliação de valores que estão sendo transacionados no mercado por seus participantes.

A definição mais atualizada de valor justo publicada pelo IASB em maio de 2011 , no parágrafo 9 da International Financial Reporting Standard - IFRS 13 - Fair Value Measurement, especifica que tal valor deve representar "o preço que seria recebido pela venda de um ativo ou que seria pago pela transferência de um passivo em uma transação não forçada entre participantes do mercado na data de mensuração ${ }^{55 "}$ (IASB, 2011a).

\footnotetext{
55 This IFRS defines fair value as the price that would be received to sell an asset or paid to transfer a liability in an orderly transaction between market participants at the measurement date.
} 
A IFRS 13 é uma norma pertinente à mensuração do valor justo, sendo que, com sua publicação, o IASB passa a centralizar os conceitos e procedimentos gerais pertinentes à utilização do valor justo para elaboração e apresentação das demonstrações contábeis, sendo que outros pronunciamentos individuais tratarão, especificamente, da sua respectiva aplicação em determinados itens patrimoniais ${ }^{56}$ (IASB, 2011a).

A utilização de técnicas de avaliação para mensuração de itens patrimoniais, adotadas pelo IASB, tem como objetivo "estimar o preço pelo qual uma transação ordenada para a venda do ativo ou para a transferência do passivo ocorreria entre participantes do mercado na data de mensuração sob condições atuais de mercado ${ }^{57 "}$. Para o atendimento dos objetivos do IASB, fica evidenciado que a mensuração a preços correntes proposta pelo órgão se trata de valores de saída (IASB, 2011a, par. 62).

Para tanto, o IASB determina que sejam utilizadas técnicas condizentes com uma das três abordagens a seguir especificadas, que são amplamente utilizadas pelo mercado, enquanto técnicas para mensuração do valor corrente de saída, tais sejam: “(i) abordagem de mercado, (ii) abordagem de custo e (iii) abordagem de receita" ${ }^{58 "}$ (IASB, 2011a, par. 62).

A abordagem de mercado adota como base para mensuração valores que estão sendo transacionados em mercados ativos, para itens patrimoniais idênticos aos que a entidade deseja negociar em determinado momento. A abordagem de custo, por sua vez, representa os custos de reposição de um ativo, cujos valores estão disponíveis no mercado. A abordagem de receita adota como base a perspectiva de fluxos futuros de caixa para mensuração de um item patrimonial, com a utilização de técnicas de avaliação (a exemplo do valor presente).

Assim, tendo em vista a necessidade de obter maior nível de consistência e comparabilidade nas mensurações realizadas a valor justo e suas respectivas evidenciações, a IFRS 13, em seu

\footnotetext{
${ }^{56}$ A IFRS 13 é a edição aprimorada do Statement of Financial Accounting Standards - SFAS 157 - Fair Value Measurements, emitido pelo FASB em setembro de 2006, vislumbrando a unificação dos fundamentos conceituais pertinentes ao Valor Justo, que até então, encontravam-se desuniformes e espalhados em diversos pronunciamentos. (IASB, 2011b; LUSTOSA, 2010).

${ }^{57} 62$ The objective of using a valuation technique is to estimate the price at which an orderly transaction to sell the asset or to transfer the liability would take place between market participants at the measurement date under current market conditions.

${ }^{58} 62[\ldots]$ Three widely used valuation techniques are the market approach, the cost approach and the income approach.
} 
parágrafo 72 "estabelece uma hierarquia de valor justo que classifica em três níveis... as informações para as técnicas de avaliação utilizadas na mensuração do valor justo". Tal hierarquia atribui "maior prioridade a preços cotados (não ajustados) em mercados ativos para ativos idênticos (informações de Nível 1) e menor prioridade a dados não observáveis

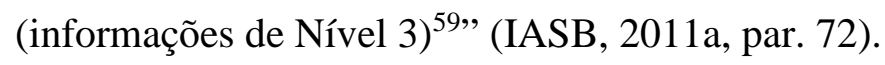

Dessa forma, a mensuração ao valor justo será realizada com base em valores cotados em mercados ativos, para os quais não será necessário o emprego de técnicas de avaliação para precificação dos insumos constantes nos itens patrimoniais. Se possível realizar tal mensuração em mercados ativos, aos quais a entidade tenha acesso na data da mensuração, os itens serão avaliados em Nível 1.

Para os casos em que as informações referentes ao item patrimonial a ser avaliado sejam observáveis, de maneira direta ou indireta no mercado (com exceção aos valores cotados Nível 1), sua mensuração deverá ser considerada em Nível 2, sendo possível a utilização de técnicas de avaliação, a exemplo do valor presente.

Já para os casos em que não estejam disponíveis informações relevantes pertinentes ao item patrimonial a ser avaliado pela entidade, sua mensuração deverá ser classificada em Nível 3 e realizada com utilização de técnicas de avaliação consistentes com as abordagens anteriormente elencadas.

Apesar das diferenciações hierárquicas anteriormente elencadas, a IFRS 13, em seu parágrafo 74, especifica que "a hierarquia de valor justo prioriza as informações (inputs) das técnicas de avaliação e não as técnicas de avaliação utilizadas para mensurar o valor justo ${ }^{60 "}$. Isso significa dizer que a classificação da mensuração a valor justo pode ser realizada tanto no Nível 2 quanto no Nível 3, dependendo da qualidade de informações significativas, disponíveis e utilizadas por parte das entidades para tal finalidade (IASB, 2011a, par. 74).

\footnotetext{
5972 To increase consistency and comparability in fair value measurements and related disclosures, this IFRS establishes a fair value hierarchy that categorises into three levels... the inputs to valuation techniques used to measure fair value. The fair value hierarchy gives the highest priority to quoted prices (unadjusted) in active markets for identical assets or liabilities (Level 1 inputs) and the lowest priority to unobservable inputs (Level 3 inputs).

$6074[\ldots]$ the fair value hierarchy prioritises the inputs to valuation techniques, not the valuation techniques used to measure fair value.
} 
Assim, o IASB prioriza as avaliações a valor justo, realizadas com base em valores cotados em mercados ativos, que não necessitem de aplicações de técnicas de avaliação para sua mensuração. Porém, se tal situação não for possível, a estimativa de valor justo poderá ser realizada com base em informações significativas disponíveis no mercado.

No que tange à utilização da técnica do valor presente para avaliação de itens patrimoniais, entende-se por informações significativas disponíveis no mercado: (i) o preço de mercado do item patrimonial a ser avaliado; (ii) o fluxo de caixa esperado com o item patrimonial; (iii) uma taxa de desconto que reflita com precisão o valor do dinheiro no tempo e; (iv) a quantidade de anos de vida útil do item patrimonial a ser avaliado. Assim, o grau de confiabilidade dessas informações, estará definindo em qual nível hierárquico a estimativa de valor justo poderá ser classificada, se em Nível 2 ou Nível 3.

Portanto, a utilização da técnica do valor presente em mensurações ao valor justo é mencionada pelo IASB enquanto ferramenta que captura diversos elementos, "do ponto de vista dos participantes do mercado, na data da mensuração". Ao ser aplicado enquanto abordagem de receita, o valor presente é definido como "uma ferramenta utilizada para relacionar valores futuros... a um valor presente utilizando uma taxa de desconto ${ }^{61}$ " definida pela entidade (IASB, 2011a, par. B13).

Assim, ao ser utilizada a abordagem de receita, são convertidos "valores futuros... em um valor único atual”, de forma que "a mensuração ao valor justo reflita as expectativas de mercado atuais em relação a esses valores futuros ${ }^{62 "}$ (IASB, 2011a, par. B10).

Dessa forma, a adoção do conceito de valor justo pela contabilidade, através de padrões contábeis aceitos internacionalmente, passa a substituir a utilização já consagrada de mensuração a valores passados, por valor justo (a valores de saída) em alguns casos. Desde então, a contabilidade tem sofrido mudanças consideráveis, em nível global, principalmente

\footnotetext{
${ }^{61}$ B13 Present value (ie an application of the income approach) is a tool used to link future amounts (eg cash flows or values) to a present amount using a discount rate. A fair value measurement of an asset or a liability using a present value technique captures all the following elements from the perspective of market participants at the measurement date.

${ }^{62} \mathrm{~B} 10$ The income approach converts future amounts (eg cash flows or income and expenses) to a single current (ie discounted) amount. When the income approach is used, the fair value measurement reflects current market expectations about those future amounts.
} 
em relação à adoção do conceito de valor justo para mensuração de determinados itens patrimoniais, em atendimento às emanações realizadas pelo IASB (Lhaopadchan, 2010).

Porém, deve-se enfatizar que a utilização do valor justo apenas é aceita pelo IASB para realização de mensurações de alguns itens patrimoniais. No caso de ativos gerados internamente nos processos produtivos empresariais, a valoração deve ser realizada ao custo. Tal limitação tem impossibilitado a mensuração e reconhecimento a valores justos de ativos gerados internamente por parte das entidades.

Complementarmente, Iudícibus e Martins (2007) explicam que a adoção do conceito de valor justo por parte das normas internacionais de contabilidade trouxe a necessidade de ser criado,

... um conjunto de contas dentro do patrimônio líquido que servem para registro das mutações dos elementos ativos e passivos em termos de variações de seus valores justos, para trânsito por resultado apenas posteriormente, quando as condições para o reconhecimento da receita estiverem presentes" (Iudícibus \& Martins, 2007, p. 16).

Para tanto, as alterações que vierem a ocorrer no patrimônio líquido das companhias devem ser evidenciadas de maneira segregada em dois grupos distintos: as que afetam o resultado do período corrente (resultado realizado) e as que não o afetam (resultado não realizado), mas que poderão vir a afetá-lo em períodos futuros (Iudícibus \& Martins, 2007; Ferreira et al., 2007; Iudícibus, Martins, Gelbcke, Santos, \& Fipecafi, 2010; Ernst \& Young \& Fipecafi, 2010).

Assim, gradativamente, as demonstrações financeiras passam a contribuir para com os usuários externos no processo de análise das projeções de fluxos financeiros futuros da companhia e os possíveis impactos que virão a causar no seu patrimônio líquido, à medida que a mensuração ao valor justo passar a ser mais utilizada na avaliação de itens patrimoniais.

Com isso, os conceitos econômicos emanados pela literatura contábil e, mais recentemente, pelo IASB, estão sendo adotados nos países que passaram a implementar Normas Contábeis com base em IFRS, como é o caso do Brasil, através do Comitê de Pronunciamentos Contábeis (CPC); da China, através do Comitê Chinês de Normas Contábeis (Chinese Accounting Standards Committee - CASC) e; da Índia, através do Ministério de Assuntos Corporativos (Ministry of Corporate Affairs - MCA) (Price Waterhouse Coopers, 2012). 


\subsubsection{Adoção das IFRSs no Brasil, China e Índia}

As Normas Internacionais de Contabilidade IFRSs já foram adotadas por mais de uma centena de países ao redor do mundo, dentre os quais Brasil (no ano de 2010), China (em 2007) e Índia (a partir de 2011), que têm se destacado enquanto países em desenvolvimento com elevadas ascensões econômicas, impulsionados pela abertura de mercados de capitais a investidores estrangeiros. Esses países possuem, enquanto característica comum, o fato de terem tornado sua adoção obrigatória às entidades que possuem ações listadas nos mercados de capitais.

Nos tópicos que seguem, serão discutidos os padrões contábeis existentes nos países mencionados, bem como, as respectivas características que envolvem as adoções das IFRSs em cada um deles, com foco direcionado aos níveis de adoção da Mensuração Contábil ao Valor Justo, aceita pelo IASB.

\subsection{Adoção das IFRSs no Brasil}

A contabilidade societária no Brasil vem sendo regida pela Lei das Sociedades por Ações $n^{\circ}$ 6.404, de 1976 e, suas alterações. As sociedades anônimas de capital aberto devem atender às deliberações da Comissão de Valores Mobiliários - CVM, que regulamenta questões contábeis específicas, que, a partir de 1990, tem emitido diversas normas que se apresentam convergentes às emanadas pelo IASB (Lopes, 2006; Iudícibus et al., 2010).

Em relação ao mercado de capitais brasileiro, a Bolsa de Valores de São Paulo (BM\&FBovespa) lançou, em dezembro de 2000, o Novo Mercado, cuja adesão era voluntária. Entretanto, para ser possível a adesão, as companhias deveriam atender diversos requisitos, dentre os quais se destaca a necessidade de serem elaboradas demonstrações financeiras em conformidade com os padrões internacionais de contabilidade (BM\&FBovespa, 2000). 
Mais recentemente, a CVM oficializou iniciativa no sentido de possibilitar a convergência das normas brasileiras de relatórios financeiros aos padrões internacionais. Tal iniciativa culminou na Instrução CVM n 457, de 13 de Julho de 2007 (CVM, 2007a), tornando obrigatório que todas as companhias listadas no órgão passassem a apresentar, a partir de 2010, as suas demonstrações financeiras consolidadas adotando o padrão contábil internacional, de acordo com os pronunciamentos emitidos pelo IASB.

Para justificar tal medida a instrução CVM nº 457/07 (CVM, 2007a), destaca a importância e a necessidade das práticas contábeis brasileiras convergirem com as práticas contábeis internacionais em função de maior transparência e confiabilidade das informações financeiras e de possibilitar às empresas brasileiras o acesso às fontes de financiamento externas a um menor custo.

De acordo com o Ofício-Circular/CVM/SNC/SEP/Nº2/2007 (CVM, 2007b), que colocou em audiência pública a discussão da aderência das normas contábeis adotadas para elaboração dos relatórios financeiros, lemos:

O incentivo à convergência das normas contábeis brasileiras com as normas referenciadas no ambiente internacional está pautado na clara necessidade de comparabilidade das demonstrações financeiras das empresas que se candidatam aos recursos disponíveis no mercado financeiro global e da consequente necessidade de manutenção de um fluxo de informações de qualidade ao longo do tempo (CVM, 2007b, p. 1).

Posteriormente, com a aprovação da Lei n 11.638, em 28 de dezembro de 2007, que alterou e revogou dispositivos da Lei das Sociedades por Ações (6.404/76), as normas internacionais de contabilidade, as IFRSs, passaram a ter sua adoção obrigatória para as entidades que atuam no Brasil (Iudícibus et al., 2010; Martins, Diniz, \& Miranda, 2012).

Entretanto, o Brasil é um país regido por leis de códigos (code-law), e a sua contabilidade, historicamente, vinha se apresentando com fortes influências legais, cujas demonstrações contábeis, anteriormente à convergência às normas internacionais, eram voltadas mais ao atendimento das necessidades legais e regulatórias e com baixos níveis de informações aos investidores (Lopes, 2006; Lopes \& Walker, 2008; Lima, 2011). 
Assim, objetivando o fortalecimento do mercado de capitais brasileiro, de forma desvinculada aos padrões legais nacionais, a Lei $\mathrm{n}^{\circ} 11.941$, de 27 de maio de 2009, foi sancionada para desvincular a Legislação Tributária da Lei das Sociedades por Ações (Iudícibus et al., 2010).

Deve-se ressaltar, também, que a mesma Lei ${ }^{\circ}$ 11.941/2009, regulamentou a adoção da mensuração ao valor justo no Brasil, de forma a não permitir que fossem acarretados impactos nos resultados das companhias, tendo em vista a redação dada à Lei das Sociedades por Ações $\mathrm{n}^{\mathrm{o}} 11.638 / 2007$, artigo $182, \S 3^{\circ}$, onde ficou determinado que:

Serão classificadas como ajustes de avaliação patrimonial, enquanto não computadas no resultado do exercício em obediência ao regime de competência, as contrapartidas de aumentos ou diminuições de valor atribuído a elementos do ativo e do passivo, em decorrência da sua avaliação a preço de mercado $\left(\right.$ Lei ${ }^{\circ} 11.638 / 2007$, Artigo 182, § $3^{\circ}$ ).

Em obediência, existe a previsão legal para que efeitos da utilização do valor justo, em alguns casos, não afetem o resultado, enquanto não forem efetivamente realizados pelas companhias brasileiras, mas seus efeitos econômicos poderão ser vislumbrados nos seus patrimônios.

No Brasil, o Comitê de Pronunciamentos Contábeis (CPC, art. $3^{\circ}$ ) criado pelo Conselho Federal de Contabilidade (CFC), através da Resolução CFC nº 1.055, de 07 de outubro de 2005 (CFC, 2005), tem o objetivo de estudar, preparar e emitir Pronunciamentos Técnicos Contábeis (tidos como CPCs), de forma a "permitir a emissão de normas pela entidade reguladora brasileira, visando à centralização e uniformização do seu processo de produção, levando sempre em conta a convergência da Contabilidade Brasileira aos padrões internacionais".

Após serem emitidos os CPCs, os órgãos reguladores nacionais (p. ex., Comissão de Valores Mobiliários - CVM, Conselho Monetário Nacional - CMN, Superintendência de Seguros Privados - SUSEP, Agência Nacional de Saúde Suplementar - ANS, Agência Nacional de Transportes Terrestres - ANTT, Agência Nacional de Energia Elétrica - ANEEL, Conselho Federal de Contabilidade - CFC) devem emitir suas próprias resoluções, referendando e determinando a utilização dos Pronunciamentos pelas entidades a eles vinculadas (Iudícibus et al., 2010; Costa, Theóphilo, \& Yamamoto, 2012). 
Nesse sentido, tendo em vista a necessidade de serem emitidas resoluções específicas pelos diversos órgãos reguladores nacionais, podem vir a existir diferenças temporais na adoção dos CPCs relativamente aos diversos segmentos empresariais com atuação no Brasil (Martins et al., 2012).

Nesse contexto, um estudo elaborado pela Ernst \& Young Brasil e a Fundação Instituto de Pesquisas Contábeis, Atuariais e Financeiras - Fipecafi (2008, p. 39), com vistas a verificar as diferenças e similaridades entre as Normas Internacionais de Contabilidade (IFRSs) e as Normas e Práticas Contábeis Brasileiras, salientou que um dos principais pontos que merecem a atenção das entidades nacionais diz respeito à adoção do conceito de valor justo (fair value) que passou a ser utilizado pelas companhias brasileiras, em substituição ao custo histórico, para avaliação de alguns itens patrimoniais. Conforme o estudo, a adoção do conceito de valor justo representa "um ponto de dificuldade em países emergentes, de características code-law e que ainda buscam o amadurecimento de seus mercados".

Mais recentemente, o estudo desenvolvido por Souza, Borba e Uhlmann (2011) enfatizou a carência de informações divulgadas por empresas de capital aberto brasileiras, relacionadas à utilização do valor justo em seus ativos, ocasião em que os autores ressaltaram a necessidade de serem realizadas mais pesquisas em torno de sua definição e mensuração.

Mesmo com os diversos desafios que se apresentam e, visando se manter em linha com as normas internacionais de contabilidade, o Comitê de Pronunciamentos Contábeis aprovou e divulgou em dezembro de 2012 o CPC 46 - Mensuração do Valor Justo, tendo a CVM também o aprovado, através da Deliberação $n^{\circ}$ 699/12, contemplando substancialmente a convergência com o texto da IFRS 13 - Fair Value Measurement, emitido pelo IASB, com vigência requerida a partir de 2013 pelas entidades a esse órgão vinculadas. Assim, com a aprovação do CPC 46, a definição, a estrutura para mensuração e as diretrizes para divulgação do valor justo no Brasil ficam centralizadas em um único documento (CPC, 2012). 


\subsection{Adoção das IFRSs na China}

A padronização contábil na China passou por profundas mudanças, a partir de 1978, tendo em vista sua reforma econômica que sofreu fortes alterações, partindo de uma economia socialista fortemente planificada a outra orientada para o mercado, com crescente foco nas exportações para impulsionar seu crescimento econômico. A partir de 1979, as alterações contábeis ocorridas na China passaram a contemplar vários aspectos pertinentes a padrões contábeis internacionalmente aceitos. O ano de 1992 foi o que marcou mudanças profundas nos padrões contábeis chineses, objetivando o desenvolvimento do mercado de capitais naquele país (Ding \& Su, 2008; Peng, Tondkar, Smith, \& Harless, 2008; Peng \& Smith, 2010; Ezzamel, Xiao, \& Pan, 2007; Ramanna, 2013).

A abertura do mercado de capitais na China ocorreu através de uma reforma econômica, que aconteceu, segundo Peng e Smith (2010, p. 17), a partir do ano de 1990, ocasião em que o governo chinês propiciou a participação não-governamental em empresas estatais nas bolsas de valores de Shanghai (Shanghai Stock Exchange - SHSE), em 1990 e Shenzhen (Shenzhen Stock Exchange - SZSE), em 1991. A partir de então, as empresas listadas estavam autorizadas a emitirem dois tipos de ações: 'A' (negociadas basicamente com investidores domésticos - em Yuan Chinês) e; 'B' (negociadas predominantemente para investidores estrangeiros - em dólar norte-americano em SHSE e em dólares de Hong Kong em SZSE).

No ano de 1992, foi criada a Comissão Chinesa de Regulação de Valores Mobiliários (Chinese Securities Regulatory Commission - CSRC), órgão responsável pela regulação do mercado de capitais chinês, devendo fazer com que as normas emitidas pelo Ministério de Finanças da China (Ministry of Finance of China - MOF) fossem cumpridas por todas as empresas listadas (Peng et al., 2008).

Posteriormente, no ano de 1998, também foi criado no país o Comitê Chinês de Normas Contábeis (Chinese Accounting Standards Committee - CASC), órgão vinculado ao MOF, responsável pelo desenvolvimento de padrões contábeis aplicáveis a todas as empresas e negócios na China que, posteriormente, viriam a ser emitidos pelo MOF. Os trabalhos 
desenvolvidos pelo CASC eram embasados em pesquisas realizadas, minutas emitidas e audiências públicas, cujos membros que o compunham eram, dentre outros, profissionais ligados a universidades, empresas de contabilidade, órgãos governamentais e associações profissionais contábeis (Financial Accounting, 2013).

Desde a abertura do mercado de capitais, os órgãos regulamentadores chineses vêm se posicionando no sentido de obterem a credibilidade dos investidores externos às informações contábeis. Nesse sentido, segundo Ezzamel et al. (2007, p. 687), o conservadorismo foi utilizado pelo governo chinês enquanto ferramenta que iria contribuir com o endereçamento de incertezas do mercado e melhoria da confiabilidade das informações contábeis evidenciadas no país. A utilização do conceito de conservadorismo foi sancionada na China em 1992, ocasião em que o "Ministério das Finanças estipulou o conservadorismo como um princípio em Normas Contábeis para Empresas de Negócios (Accounting Standards for Business Enterprises - ASBE), visando reformular o sistema de contabilidade tradicional uniforme $^{63}$ ", existente até então naquele país ${ }^{64}$. Naquela ocasião, o conceito de valor justo não foi incluído nos padrões contábeis chineses, tendo em vista a existência de um mercado de capitais incompatível com a sua implementação (Zhang, Ahmed, Qu, \& Ji, 2012).

Com base em entrevistas realizadas com profissionais contábeis com atuação na China, Ezzamel et al. (2007, p. 693) ressaltaram também que, "não existiam regras contábeis para sociedades anônimas na China antes de 1992 e, portanto, essas empresas tiveram que projetar seus sistemas de contabilidade próprios para acomodar os novos tipos de eventos econômicos ${ }^{65}$ ".

Desde então, a China emitiu quatro conjuntos de ASBEs, respectivamente, nos anos de 1992, 1998, 2001 e 2006, sendo que cada um deles vinha em substituição ao anterior, com o objetivo de ser considerado em maior conformidade com os padrões contábeis internacionais,

\footnotetext{
${ }^{63}$ In 1992, the Ministry of Finance stipulated conservatism as a principle in the Accounting Standards for Business Enterprises (ASBE) designed to overhaul the traditional uniform accounting system.

${ }^{64} \mathrm{O}$ sistema de contabilidade tradicional uniforme vigente até então, fora "orientado para maximizar as receitas do Estado", por apresentar forte direcionamento em prol à maximização dos lucros empresariais, de forma a otimizar a arrecadação de impostos, sendo considerado, também, indispensável para "sustentar e legitimar o planejamento central e para apoiar as aspirações políticas, como a promoção de uma economia pacífica e próspera, enfatizando a vitória da luta de classe e preparação para conflitos internacionais" (Ezzamel et al., 2007, p. 680).

${ }^{65}$ No accounting regulations existed for joint-stock companies in China before 1992 and thus these firms had to design their own accounting systems to accommodate the new types of economic events.
} 
mas mantendo diversas peculiaridades nacionais (Chen, Sun, \& Wang, 2002; Peng et al., 2008; Liu, Yao, Hu, \& Liu, 2011).

A partir do processo de abertura de capital das empresas chinesas, a CSRC passou a determinar que as empresas listadas que emitiam ações para investidores estrangeiros, (ações B) e, também, investidores locais (ações A) fossem obrigadas a reportar dois conjuntos de demonstrações financeiras, no período compreendido entre 1993 e 2007, utilizando o Generally Accepted Accounting Principles (GAAP) chinês e IFRS, identificando claramente os detalhes das diferenças entre os dois conjuntos de demonstrações (Ding \& Su, 2008; Peng et al., 2008; Peng \& Smith, 2010).

O processo de convergência definitivo às normas internacionais de contabilidade teve início em fevereiro de 2006, ocasião em que foi emitido pelo MOF um novo conjunto de regras contábeis chinesas, que entrou em vigor a partir de 01 de janeiro de 2007, tido como 2007GAAP. Nessa ocasião, foi institucionalizada na China, também, a adoção completa das IFRSs, a serem implementadas para todas as empresas listadas. A proposta dos dois órgãos de emissões de normas contábeis (IASB e MOF) era a de implementar a unificação dos dois grupos de regras contábeis naquele país (Peng \& Bewley, 2010).

A partir de então, a China passou a emitir seus padrões de contabilidade nacionais convergentes com as normas IFRSs, significando que "os princípios de reconhecimento, mensuração e relatórios, são os mesmos em IFRS, com a intenção de produzir os mesmos resultados nas demonstrações financeiras de empresas que aplicam as IFRS ou 2007GAAP ${ }^{66}$ ", (Peng \& Bewley, 2010, p. 983).

Entretanto, os estudos desenvolvidos por Peng e Bewley (2010), apontaram uma série de divergências entre os dois grupos normativos, principalmente no que tange à realização da contabilização a valor justo (fair value accounting), ressaltando que:

As principais divergências entre 2007GAAP e IFRS,... estão relacionadas com a mensuração do valor justo inicial e subsequente para certos ativos não-financeiros de longo prazo. Por exemplo, as IFRS exigem uma estimativa do valor de mercado para todos os ativos. No entanto, em 2007GAAP, esta é

\footnotetext{
${ }^{66}[\ldots]$ means that the principles of recognition, measurement, and reporting are the same as those in IFRS, with the intention of producing the same results in financial statements of enterprises applying either IFRS or 2007 GAAP.
} 
opcional para propriedades para investimentos e ativos biológicos, enquanto é proibitiva para os bens do ativo imobilizado e ativos intangíveis ${ }^{67}$ (Peng \& Bewley, 2010, p. 988).

Diante dos esforços empregados por parte dos órgãos regulamentadores chineses no sentido de tornar convergentes os dois grupos de normas contábeis aplicáveis naquele país (IFRS e 2007GAAP), diversas pesquisas empíricas foram realizadas no sentido de verificar se sua aplicabilidade prática, efetivamente, vem ocorrendo (Peng \& Bewley, 2010; Olesen \& Cheng, 2011; Zhang et al., 2012; Ramanna, 2013).

Tais estudos têm detectado basicamente que, em função da opção de escolha por parte das entidades que negociam suas ações com investidores domésticos, quando possível, a maioria das empresas opta pela utilização da mensuração a custos históricos em detrimento do valor justo na preparação de suas demonstrações financeiras, tendo em vista, principalmente, o nível de desenvolvimento desequilibrado em diversos setores econômicos, mercados de capitais imaturos comparativamente aos países desenvolvidos e sistema jurídico com orientações específicas aos diversos segmentos empresariais chineses (Peng \& Bewley, 2010; Olesen \& Cheng, 2011; Zhang et al., 2012; Ramanna, 2013).

Porém, em conformidade com Peng e Bewley (2010), o MOF obteve êxito com a implantação das normas contábeis reconhecidas internacionalmente e, ao mesmo tempo, atendendo às particularidades culturais e legais existentes na China.

\subsection{Adoção das IFRSs na Índia}

A economia indiana se caracterizou, até meados dos anos 80, pelo domínio estatal. Por ocasião de fortes crises financeiras ocorridas nos anos 90, o governo indiano adotou medidas incisivas relacionadas à abertura da economia para ingresso de investidores estrangeiros, em diversos segmentos empresariais. Desde então, os fluxos de investimentos estrangeiros diretos

\footnotetext{
${ }^{67}$ The main divergences between 2007 GAAP and IFRS,..., are related to the initial and subsequent fair value measurement for certain non-financial long-term assets. For example, IFRS requires an estimate of market value for all assets. However, under 2007GAAP, this is optional for investment property and biological assets, while it is prohibited for property, plant, and equipment (PP\&E) and intangible assets.
} 
(foreign direct investment - FDI) passaram a representar um papel cada vez mais importante na economia indiana. Tais fatos trouxeram, consigo, a necessidade de serem adotados sistemas de comunicações financeiras corporativas para a Índia em harmonia com diversos outros países, de forma a se tornar cada vez mais bem sucedida em atrair capital estrangeiro para o país (Haribhakti, 2008; Jain, 2011; Verma \& Brennan, 2011; Ray, 2012a).

O Instituto de Auditores Independentes da Índia (Institute of Chartered Accountants of India - ICAI), organismo membro do Comitê Internacional de Normas Contábeis (International Accounting Standards Committee - IASC) desde junho de 1973, constituiu, em 21 de abril de 1977, o Conselho de Normas Contábeis (Accounting Standards Board - ASB), objetivando harmonizar as políticas e práticas contábeis utilizadas na Índia, composto por diversos segmentos nacionais interessados no processo. Entretanto, apenas a partir dos anos 90, em consonância com as políticas econômicas indianas, seus trabalhos passaram a receber maior relevância (Haribhakti, 2008; Shil, Das \& Pramanik, 2009; Ray, 2012a).

Enquanto órgão formulador de padrões contábeis indianos, o ASB leva em consideração, para tais formulações, fatores legais, institucionais e de práticas de negócios no ambiente econômico indiano, além de observar as orientações constantes nas Normas Internacionais de Contabilidade (International Accounting Standards - IAS). (Haribhakti, 2008; Ray, 2012a). De acordo com Jain (2011), em 2006, o ICAI criou grupos de estudos para oferecer sugestões quanto ao melhor caminho a ser adotado pela Índia, no que concerne à convergência das normas contábeis Indianas para IFRSs.

Tendo em vista o fato de a Índia ser um país membro do IASC, as normas de contabilidade indianas, com vigência anterior à convergência para IFRS, apresentavam-se com fortes influências das IASs, em termos qualitativos. (Shil et al., 2009; Ray, 2012a). Entretanto, ainda existiam variações significativas entre os padrões contábeis indianos e as IASs, dentre as quais, Shil et al. (2009, p. 199-200) destacam: “(a) as Demonstrações Financeiras Consolidadas; (b) Contabilização de Imposto de Renda; (c) Instrumentos Financeiros e (d) Ativos Intangíveis ${ }^{68}$ ". Existiam, também, prescrições contraditórias para casos semelhantes

\footnotetext{
${ }^{68}[\ldots]$ a) Consolidated financial statements, b) Accounting for income taxes, c) Financial Instruments and d) Intangible Assets.
} 
entre "as provisões da Lei de Imposto de Renda de 1961 e das Sociedades Indianas de Responsabilidade Limitada de $1956^{69}$ ".

Nesse mesmo sentido, Gupta e Patro (2010, p. 15) ressaltaram que, "conforme estudo concluído pelo ICAI apenas duas das atuais normas de contabilidade indianas estão em conformidade com as IFRS. Todas as outras normas devem ser alteradas em vários níveis para atingir a referida convergência ${ }^{70}$ ". Conforme os mesmos autores, tais circunstâncias ocorrem tendo em vista o fato de que, na Índia, as normas de contabilidade não são emitidas por uma única entidade, pois diversos reguladores normatizam os diferentes setores da economia. Assim, os padrões contábeis indianos se distanciam das originárias IASs, normalmente, para se enquadrarem ao quadro legal e regulamentar vigente no país (Ramanna, 2013).

De acordo com Ray (2012a), os principais reguladores da Índia são: (i) a Lei das Sociedades de Responsabilidade Limitada (Companies Act); (ii) o Banco Central da Índia (Reserve Bank of India - RBI); (iii) a Comissão de Supervisão do Mercado de Valores Mobiliários da Índia (Securities and Exchange Board of India - SEBI); (iv) Autoridades Regulamentares de Seguros e Desenvolvimento (The Insurance Regulatory and Development Authority - IRDA); (v) o Instituto de Auditores Independentes da Índia (Institute of Chartered Accountants of India - ICAI). Todas essas entidades possuem orientações legais específicas, além de determinações expressas no sentido de que as normas contábeis emitidas pelo ICAI sejam adotadas pelas companhias, em sua totalidade ou de maneira diferenciada.

Assim, Ray (2012a, p. 3) explica que o ICAI realiza alterações nas IASs originais emitidas pelo IASC, com vistas a atender, principalmente, alguns fatores específicos existentes na Índia, tais sejam: "ambiente legal e regulatório vigente no país; alternativas permitidas em IFRS levariam a informações financeiras incomparáveis; ambiente econômico interno do país e; nível de preparação da indústria ${ }^{71}$,"

\footnotetext{
${ }^{69}[\ldots]$ the provisions of the Income Tax Act 1961 and Indian Companies Act 1956.

${ }^{70}$ As per the study done by the ICAI only two of the existing Indian accounting standards are in compliance with IFRS. All other standards will require amendment in varying degree to achieve convergence with IFRS.

${ }^{71}$ Legal and regulatory environment prevailing in the country; Alternatives permitted in IFRS would lead to incomparable financial information; Economic environment within the country; Level of preparedness of industry.
} 
Tendo em vista tais divergências, a Price Waterhouse Coopers (2012) explicou que o órgão governamental da Índia, Ministério de Assuntos Corporativos (Ministry of Corporate Affairs - MCA) anunciou um plano multi-fases de transição para convergência das novas Normas Indianas de Contabilidade (Indian Accounting Standards - "Ind AS") para com as Normas IFRSs, sendo que a Fase I teve início a partir de abril de 2011, visando convergir às normas contábeis IFRS, entretanto, com algumas diferenças aos padrões internacionais.

Conforme Jain (2011), o plano de conversão, dividido em três fases, foi implementado no país da seguinte forma:

Fase I: companhias que faziam parte do Nifty 50 Index, do Sensex $30^{72}$, com ações ou outros valores mobiliários listados em bolsas de valores em outros países que não a Índia, e companhias listadas ou não com patrimônio líquido superior a R \$ 10 bilhões de Rupias Indianas prepararam um Balanço de Abertura em 01 de abril de 2011;

Fase II: empresas listadas ou não, com patrimônio líquido superior a R \$ 5 bilhões de Rupias Indianas, que tenham se mantido alheias às especificações da Primeira Fase prepararam um Balanço de Abertura em 01 de abril de 2013;

Fase III: as demais empresas indianas não abrangidas nas fases anteriores prepararam um Balanço de Abertura em 01 de abril de 2014.

Com isso, a Índia busca permitir que sejam consideradas as condições econômicas locais e as particularidades do ambiente de negócios no período da convergência para as normas IFRSs, com vistas a proteger os interesses das empresas indianas (Ray, 2012a).

Durante a realização de seus estudos, Jain (2011) e Ray (2012a) realizaram comentários sobre um elenco de benefícios e desafios que serão enfrentados pelas partes interessadas ao processo de conversão das normas contábeis na Índia. Dentre eles, merece destaque a possibilidade de utilização do valor justo como base de mensuração trazida pelas normas IFRS, cuja aplicação, até então, era proibida naquele país.

\footnotetext{
${ }^{72}$ Os indices Nifty 50 e Sensex 30 pertencem à Bolsa Nacional de Valores (National Stock Exchange - NSE) e à Bolsa de Valores de Bombay (Bombay Stock Exchange - BSE) respectivamente, ambas sediadas na Índia. (Price Waterhouse Coopers, 2012).
} 
Entretanto, Jain (2011) ressalta que a adoção de normas de contabilidade convergentes com as normas em IFRSs na Índia se apresenta como um processo inevitável para o país que busca o desenvolvimento do mercado de capitais. Por outro lado, Ray (2012a) chama a atenção para o fato de que a abordagem baseada em mensuração ao valor justo adotada por algumas IFRSs merece especial atenção em mercados que não possuem altos níveis de desenvolvimento econômico, como é o caso da Índia.

Nesse mesmo sentido, Swamynathan e Sindhu (2011, p. 82), elencam a adoção da mensuração a valor justo nas demonstrações contábeis como uma das grandes alterações provocadas nos padrões contábeis indianos, pois "o GAAP Indiano exige que as demonstrações financeiras sejam preparadas com base no custo histórico, exceto para os ativos fixos que podem ser reavaliados ${ }^{73}$,"

Diversos outros estudos foram desenvolvidos na Índia, especialmente com enfoque a convergência do GAAP Indiano para IFRSs (Tripathi \& Gupta, 2011; Ray, 2011; Ray, 2012b; Ray, 2012c). Entretanto, devido ao estágio embrionário em que tal procedimento se encontra, e, por consequência, a carência de dados contábeis disponíveis, os estudos estão sendo realizados, basicamente, em torno dos benefícios e desafios que contornam o processo de convergência naquele país.

\subsection{O Mercado de Carbono e a Regulação Contábil Internacional}

Nesse ponto do estudo, serão abordados comentários sobre as orientações contábeis internacionais legais e acadêmicas já emitidas para contabilização das reduções de emissões, que são transações com RCEs realizadas entre países desenvolvidos e estados americanos, mesmo antes da vigência do Protocolo de Quito.

As negociações de redução de emissões de GEEs movimentam o Mercado de Carbono já há algum tempo. Os mercados de carbono do Reino Unido (ETS -Emissions Trading Scheme);

\footnotetext{
${ }^{73}$ Indian GAAP requires financial statements to be prepared on historical cost except for fixed assets which could be selectively revalued.
} 
da Holanda (CERUPT - Certified Emission Reduction Unit Procurement Tender e, ERUPT Emission Reduction Unit Procurement Tender) e dos Estados Unidos (CCX - Chicago Climate Exchange) merecem destaque enquanto iniciativas voluntárias de atuação nesse mercado. (Rocha, 2003; Ribeiro, 2005). Entretanto, com o advento do Protocolo de Quioto, as negociações tiveram grande impulso, com normas mais específicas, propostas pela CQNUMC (Rocha, 2003; Ribeiro, 2005; Lohmann, 2009; Mol, 2012).

Este mercado é formado, predominantemente, por entidades empresariais. No âmbito do Protocolo de Quioto, o núcleo do mercado de carbono, em nível mundial, tem se formado entre o Programa de Comércio de Emissões (Emissions Trading Scheme - ETS) da União Europeia e as perspectivas de transformar as RCEs geradas com a implementação de projetos MDLs em valores monetários, através do ETS (Mackenzie, 2009; Cook, 2009; Ascui \& Lovell, 2011; Mol, 2012).

Em âmbito mundial, os valores negociados nos mercados de carbono, no período de 2005 a 2010, foram divulgados pelo Banco Mundial, em conformidade com a Tabela 1.

Tabela 1 - Evolução do Mercado de Carbono (valores em bilhões de dólares)

\begin{tabular}{c|c|c|c|c|c|c}
\hline & $\begin{array}{c}\text { Subsídios } \\
\text { ETS UE }\end{array}$ & $\begin{array}{c}\text { Outros } \\
\text { Subsídios }\end{array}$ & $\begin{array}{c}\text { MDL } \\
\text { Primário }\end{array}$ & $\begin{array}{c}\text { MDL } \\
\text { Secundário }\end{array}$ & $\begin{array}{c}\text { Outras } \\
\text { Compensações }\end{array}$ & Total \\
\hline 2005 & 7,9 & 0,1 & 2,6 & 0,2 & 0,3 & 11,1 \\
\hline 2006 & 24,4 & 0,3 & 5,8 & 0,4 & 0,3 & 31,2 \\
\hline 2007 & 49,1 & 0,3 & 7,4 & 5,5 & 0,8 & 63,1 \\
\hline 2008 & 100,5 & 1,0 & 6,5 & 26,3 & 0,8 & 135,1 \\
\hline 2009 & 118,5 & 4,3 & 2,7 & 17,5 & 0,7 & 143,7 \\
\hline 2010 & 119,8 & 1,1 & 1,5 & 18,3 & 1,2 & 141,9 \\
\hline
\end{tabular}

Fonte: Adaptado de World Bank (2011, p. 9).

A Tabela 1 demonstra que houve elevado crescimento nos mercados mundiais de carbono desde que passou a vigorar o Protocolo de Quioto, em 2005. A partir de então, o ano de 2009 consta como o período em que as maiores negociações foram registradas, apresentando-se com leves declínios em 2010, com um montante de aproximadamente 142 bilhões de dólares negociados. As negociações com origens em projetos MDLs se mantiveram, durante todo o período analisado, em segunda colocação em nível de relevância no mercado de carbono, sendo precedidas apenas pelas negociações originárias de subsídios ETSs, da União Europeia.

De acordo com informações divulgadas pelo Banco Mundial (World Bank, 2012), essa 
mesma tendência se manteve, também, para o ano de 2011, ocasião em que se registrou um crescimento no volume de negociações, resultando em um montante de aproximadamente 176 bilhões de dólares negociados no mercado de carbono, evidenciando a relevância deste mercado em nível mundial.

Na visão de Ascui e Lovell (2011), a crescente evolução de implementações de projetos de MDLs, que possuem como uma de suas finalidades a emissão de RCEs por parte dos países em desenvolvimento para comercialização junto aos países desenvolvidos que possuem metas de reduções de emissões a serem atingidas, tem provocado uma ascensão no mercado de carbono em âmbito global, com o aparecimento de implicações em prol da necessidade de uma convergência global na contabilidade financeira de carbono.

Ratnatunga, Jones e Balachandran (2011) também se posicionaram no sentido de que, aparentemente,

...parece estar havendo um consenso na profissão contábil acerca da contabilização das permissões de emissões de que, uma vez emitidas, compradas ou criadas, uma empresa deve reconhecê-las como um novo ativo no balanço patrimonial (...). Ao ocorrerem efetivamente emissões reais, um passivo deverá ser reconhecido e mudanças nos preços de mercados das permissões (ou seja, os ganhos ou perdas de subsídios) deverão ser reconhecidas na demonstração de resultados ${ }^{74}$. (Ratnatunga et al., 2011, p. 130).

Com isso, Ratnatunga et al. (2011) explicaram que as atenções da literatura contábil estão voltadas até então, essencialmente, à melhor forma de reconhecimento de valores correntes de ativos e passivos no balanço patrimonial, bem como, seus resultados líquidos dentro de um exercício social, das permissões de emissões e créditos de carbono que estão sendo distribuídas em forma de subsídios governamentais e/ou negociados no mercado. Por outro lado, existe pouca discussão acerca da capacidade de geração de fluxos financeiros futuros por parte dos ativos das companhias que geram RCEs internamente, os quais requerem um tratamento contábil diferenciado aos discutidos até então pelos órgãos regulamentadores.

Nessa mesma linha de raciocínio, Dhar (2012), também ressaltou que, em termos contábeis, dois tipos de questões devem ser discutidas pela profissão contábil, uma referente às implicações financeiras do comércio de emissões para as entidades de países desenvolvidos e

\footnotetext{
74 ... which seems to show some consensus within the accounting profession that once carbon credit permits are issued, purchased or created, a company should recognize them as a new asset on the balance sheet (akin to inventory). As actual emissions occur, a liability should be recognized and changes in the market price of permits (i.e., gains and losses on allowances) should be recognized in the income statement.
} 
outra referente às implicações financeiras pertinentes aos projetos de MDLs em entidades situadas em países em desenvolvimento, pois possuem características contábeis distintas.

Assim, diante do panorama existente em torno das negociações no mercado de carbono, o IASB, conjuntamente com o FASB, retomou as discussões em torno do projeto de comércio de emissões em maio de 2008. Porém, naquela ocasião, nenhuma decisão foi tomada pelo Conselho de Administração. O novo projeto procurava abordar a contabilização de todos os direitos e obrigações decorrentes dos programas de comércio de emissões, além de contemplar discussões sobre a contabilização das atividades realizadas por empreendimentos que objetivem o recebimento de direitos comercializáveis em períodos futuros, como é o caso das RCEs, no âmbito do MDL (IASB, 2008; Ascui \& Lovell, 2011; IASB, 2013).

Tais discussões foram retomadas posteriormente, com base na necessidade de que seja apresentada, por parte do IASB, uma abordagem capaz de viabilizar o reconhecimento contábil dos créditos de carbono, tanto nos países desenvolvidos quanto nos países em desenvolvimento. Assim, um projeto de pesquisa foi preparado por uma equipe da Fundação IFRS para nortear as discussões daquele órgão a partir de setembro de 2014 (IASB, 2014).

O projeto de pesquisa voltado ao Programa de Comércio de Emissões (Project Emissions Trading Schemes - research project) apresentou (i) informações básicas sobre as características dos programas de comércio de emissões voltadas aos países desenvolvidos (cap and $\operatorname{trade}^{75}$ ) e aos países em desenvolvimento (baseline and credit) e; (ii) discussões acerca das questões contábeis relacionadas ao reconhecimento inicial dos créditos de carbono, em ambos os modelos de comércio de emissões mencionados (IASB, 2014).

Tal documento adotou a IAS 38 - Intangible Assets (ativos intangíveis) para direcionar as discussões pertinentes ao tratamento contábil passível de ser atribuído aos créditos de carbono, tanto nos países desenvolvidos quanto nos países em desenvolvimento (IASB,

\footnotetext{
75 Um programa de 'cap and trade' é uma abordagem baseada no mercado em que "licenças de emissão" ou "créditos" são utilizados para fornecer incentivos às empresas para reduzir as emissões através da atribuição de um valor monetário à poluição... A fase 'cap' do programa inicia quando um governo ou órgão regulador estabelece uma meta de toda a economia para o nível máximo de emissões específicas permitidas pelas empresas em um período de tempo determinado... O aspecto 'trade' do programa ocorre quando as emissões efetivas de uma empresa são maiores ou menores do que o montante coberto por seus subsídios estatais. (Fornaro, Winkelman, \& Glodstein, 2009, p. 1).
} 
2014).

Assim, o que se espera é que, as novas discussões a serem mantidas pelo IASB deixem de ser "focadas apenas na posição financeira na data do balanço", conforme vinham ocorrendo até então, para abranger também "as implicações de expectativas de eventos futuros", que devem ser consideradas "na medida em que elas lançam luz sobre a existência de ativos e passivos nessa data ${ }^{76 "}$ (Cook, 2009, p. 465).

Deve-se ressaltar que o IASB, enquanto órgão que emite Normas Internacionais de Contabilidade, iniciou discussões através do International Financial Reporting Interpretations Committee - IFRIC, com vistas a regulamentar a forma de contabilização para tais produtos, já a partir da fase preparatória para o lançamento do ETS europeu, que culminou, em dezembro de 2003, com o IFRIC 3 - Emission rights, direcionado ao atendimento das condições governamentais impostas à União Europeia (Ribeiro, 2005; Mackenzie, 2009; Cook, 2009; Braun, 2009).

O IFRIC 3 foi desenvolvido, exclusivamente, para as negociações de permissões de emissões $^{77}$ da Europa e dos Estados Unidos, visto que nos países em desenvolvimento tais títulos não são distribuídos pelos órgãos governamentais e, também, não são adquiridos pelas companhias, por não possuírem as metas de redução de emissões que foram impostas aos países desenvolvidos pelo Protocolo de Quioto. Tais especificidades fazem com que não sejam gerados passivos relacionados às obrigações de permissões de emissões por parte das entidades sediadas nos países em desenvolvimento.

Ao expor as razões pelas quais o IASB retirou de pauta a discussão sobre a implementação do IFRIC 3, Cook (2009) explicou que a principal fragilidade das soluções emanadas pelo referido documento é que foram ignoradas as negociações orientadas para o mercado de 'limite' e 'negociação' (cap and trade) que viriam a ocorrer no futuro, tendo seu foco principal sido atribuído às Concessões Governamentais alocadas pelo governo.

\footnotetext{
76 The Framework necessarily focuses on the financial position at the reporting date. However, the implications of expected future events are taken into account to the extent that they throw light on the existence of assets and liabilities at that date.

77 Trata-se de títulos que dão direito à emissão de uma quantidade específica de gases em determinado período, que são distribuídos, anualmente, pelo Governo dos países do Anexo I, às empresas. (Ribeiro, 2005).
} 
Dessa forma, diante da ausência de uma orientação padrão definida em nível internacional, até então, estão sendo considerados diferentes tratamentos contábeis por parte das empresas, que possuem o desafio de decidir qual método é mais apropriado e aceitável, cujos reflexos diferenciados estão sendo dirigidos ao mercado. Com isso, as empresas possuem, também, a responsabilidade de explicar ao mercado tais tratamentos, de forma que o seu desempenho sócio econômico ambiental seja compreendido por parte dos usuários externos (Deloitte, 2007; Bebbington \& Gonzáález, 2008; Fornaro et al., 2009; Pahuja, 2012).

\subsubsection{Tratamento Contábil dos Créditos de Carbono no Brasil, China e Índia}

Os ensinamentos pertinentes ao tratamento contábil atribuído às RCEs no Brasil, na China e na Índia, estão sintetizados no Quadro 1:

\begin{tabular}{|l|l|l|}
\hline \multicolumn{1}{|c|}{ Autor(es) } & País & \multicolumn{1}{c|}{ Tratamento Contábil atribuído às RCEs } \\
\hline Ribeiro (2005) & Brasil & $\begin{array}{l}\text { Os créditos de carbono apresentam todas as características para } \\
\text { enquadramento como Ativos. } \\
\text { O valor presente deveria ser utilizado para mensuração das RCEs, tendo em } \\
\text { vista os benefícios esperados em longos períodos futuros. } \\
\text { As negociações realizadas pelas companhias na fase de aprovação dos } \\
\text { projetos de MDLs podem ser consideradas Instrumentos Financeiros - } \\
\text { Derivativos que proporcionarão proteção às RCEs contra risco de } \\
\text { oscilações de preços, aos agentes econômicos, quando estiverem gerando as } \\
\text { reduçôes de emissões previstas. }\end{array}$ \\
\hline Bito (2006) & Brasil & $\begin{array}{l}\text { Apenas os custos necessários à obtenção dos créditos de carbono são de } \\
\text { natureza intangível. }\end{array}$ \\
\hline $\begin{array}{l}\text { Ferreira, Bufoni, } \\
\text { Marques e Muniz } \\
\text { (2007); Bufoni e } \\
\text { Ferreira (2010) }\end{array}$ & Brasil & $\begin{array}{l}\text { O título resultante do sequestro de carbono caracteriza-se enquanto produto } \\
\text { (estoques), devendo ser registrado de forma segregada aos demais estoques } \\
\text { das entidades que implementaram e aprovaram projetos de MDLs. } \\
\text { O valor realizável líquido deve ser utilizado para mensuração das RCEs, } \\
\text { confrontando-se os custos separáveis com os preços correntes de saída } \\
\text { (valor justo), por ocasião da emissão dos certificados. } \\
\text { O reconhecimento da receita com RCEs deve ser realizado apenas no } \\
\text { momento da venda do produto, tendo em vista as incertezas pertinentes aos } \\
\text { fluxos de caixa a serem recebidos. }\end{array}$ \\
\hline $\begin{array}{l}\text { Perez, Ribeiro, Cunha } \\
\text { e Rezende (2008) }\end{array}$ & Brasil & $\begin{array}{l}\text { Apenas os gastos necessários à obtenção dos créditos de carbono são de } \\
\text { natureza intangível. } \\
\text { Legalmente no Brasil, primeiro registro das transações com créditos de }\end{array}$ \\
\hline
\end{tabular}




\begin{tabular}{|c|c|c|}
\hline & & $\begin{array}{l}\text { carbono ocorrerá, apenas, no momento da venda, em contrapartida a uma } \\
\text { disponibilidade financeira. }\end{array}$ \\
\hline CVM (2009) & Brasil & $\begin{array}{l}\text { As RCEs não são passíveis de caracterização enquanto valores mobiliários, } \\
\text { não estando sujeitas ao regime legal estabelecido para tais instrumentos. } \\
\text { As RCEs não estão sujeitas à legislação específica do mercado de valores } \\
\text { mobiliários brasileiro. }\end{array}$ \\
\hline $\begin{array}{l}\text { Santos, Beuren e } \\
\text { Haussmann (2011) }\end{array}$ & Brasil & $\begin{array}{l}\text { O reconhecimento dos créditos de carbono deve ocorrer no momento da sua } \\
\text { emissão por parte da UNFCCC. } \\
\text { Em sendo as RCEs desenvolvidas com o intuito de permanência, devem ser } \\
\text { consideradas como ativos intangíveis por parte das entidades. }\end{array}$ \\
\hline China (2005) & China & $\begin{array}{l}\text { Na China, as RCEs são 'ativos estatais' e, por ocasião da sua venda, as } \\
\text { companhias deverão observar o artigo } 24 \text { das "Medidas para Operação e } \\
\text { Gestão de Projetos de MDL na China" (Measures for Operation and } \\
\text { Management of CDM Projects in China), que especifica percentuais de } \\
\text { retorno ao Estado, que variam de } 2 \% \text { a } 65 \% \text { dos valores negociados. } \\
\text { Na China, as companhias apenas terão a propriedade das RCEs para } \\
\text { reconhecimento em suas contas contábeis, após terem sido firmados } \\
\text { contratos de comercialização com compradores estrangeiros, ocasião em } \\
\text { que será possível realizar seu reconhecimento contábil, com mensuração ao } \\
\text { custo do contrato firmado entre as partes envolvidas na negociação. Até } \\
\text { então, não deverão ser contabilizadas. Porém, os respectivos custos para } \\
\text { implementação dos projetos de MDL, deverão ser suportados pelas } \\
\text { companhias. }\end{array}$ \\
\hline $\begin{array}{l}\text { Xiaozhu e Yunyun } \\
\text { (2011) }\end{array}$ & China & $\begin{array}{l}\text { Existe certo consenso na literatura chinesa de que as RCEs atendem as } \\
\text { características de ativo, pois está em conformidade com a sua definição. } \\
\text { As RCEs poderiam ser reconhecidas como ativos financeiros, se } \\
\text { possuíssem um mercado ativo de livre negociação com mecanismos } \\
\text { específicos de definições de preços. } \\
\text { Isso possibilitaria sua mensuração ao valor justo, cujas oscilações poderiam } \\
\text { ser registradas, ano a ano, no patrimônio das companhias. } \\
\text { Os custos iniciais incorridos com a implementação de projetos de MDLs } \\
\text { devem ser reconhecidos como ativos intangíveis. }\end{array}$ \\
\hline $\begin{array}{l}\text { Wang, Gao, Wen, } \\
\text { MacGill e Huang } \\
\text { (2009); Xiaozhu e } \\
\text { Yunyun (2011); } \\
\text { Wang (2011); Guan e } \\
\text { Zhang (2012); Qi e } \\
\text { Hao (2012) }\end{array}$ & China & $\begin{array}{l}\text { Até o ano de 2012, não havia sido formado um mercado de negociações em } \\
\text { âmbito nacional na China, não sendo possível vislumbrar um mercado } \\
\text { perfeito de negociações financeiras de títulos de carbono, por consequência, } \\
\text { as RCEs não possuíam liquidez como os demais instrumentos financeiros } \\
\text { no país, o que impossibilitaria, ao menos temporariamente, seu } \\
\text { reconhecimento como ativos financeiros. }\end{array}$ \\
\hline Zhang (2011) & China & $\begin{array}{l}\text { As RCEs são ativos intangíveis pois são consistentes com a definição de } \\
\text { ativos não monetários, sem identificação física, pertencentes ou controlados } \\
\text { pela empresa. } \\
\text { A mensuração inicial deve ser realizada pelo custo do desenvolvimento do } \\
\text { projeto e, as subsequentes, ao valor justo, cujas oscilações devem ser } \\
\text { reconhecidas no resultado, a cada período contábil. }\end{array}$ \\
\hline Wang (2011) & China & $\begin{array}{l}\text { Existe certo consenso na literatura chinesa de que as RCEs atendem as } \\
\text { características de ativo, pois está em conformidade com a sua definição. } \\
\text { A mensuração inicial deve ser realizada pelo custo do contrato firmado } \\
\text { entre as partes que negociaram RCEs e, as subsequentes, ao valor justo, que } \\
\text { poderá ser obtido de maneira contínua no mercado financeiro. }\end{array}$ \\
\hline Tang (2011) & China & $\begin{array}{l}\text { As RCEs devam ser reconhecidas como estoques pela contabilidade, pois } \\
\text { possuem a venda como objetivo final da implementação de um projeto de }\end{array}$ \\
\hline
\end{tabular}




\begin{tabular}{|c|c|c|}
\hline & & $\begin{array}{l}\text { MDL, os quais fazem parte do núcleo original das atividades diárias das } \\
\text { companhias. } \\
\text { A mensuração inicial e as subsequentes devem ser realizadas pelo menor } \\
\text { valor entre o custo dos contratos firmados entre as partes e o valor } \\
\text { realizável líquido na mesma ocasião. }\end{array}$ \\
\hline $\begin{array}{l}\text { Zhang (2011) } \\
\text { Tang (2011) }\end{array}$ & China & $\begin{array}{l}\text { As RCEs são consideradas ativos estatais, devendo ser tratadas como de } \\
\text { propriedade do Estado. Após a celebração de contratos de negociação, } \\
\text { passam a ser ativos das companhias, que participaram da implementação } \\
\text { dos projetos de MDL. } \\
\text { O valor da receita advindo com a comercialização das RCEs, deve ser } \\
\text { dividido entre o Estado e a Empresa, cujos percentuais são definidos } \\
\text { previamente pelo Governo da China. }\end{array}$ \\
\hline Agrawal (2006) & Índia & $\begin{array}{l}\text { As RCEs são consideradas bens, uma vez que possuem todos os seus } \\
\text { atributos. A classificação de bens adotada pelo autor, diz respeito a bens } \\
\text { tangíveis e, também bens intangíveis. } \\
\text { Entende que as RCEs atendem às características de ativos intangíveis } \\
\text { constantes na Norma Contábil-26 - Ativos Intangíveis (Accounting } \\
\text { Standard-26-Intangible Assets). }\end{array}$ \\
\hline Bothra (2010) & Índia & $\begin{array}{l}\text { As RCEs devem ser registradas como ativos intangíveis, pois satisfazem as } \\
\text { características definidas pela Norma Contábil-26 - Ativos Intangíveis } \\
\text { (Accounting Standard-26 - Intangible Assets). } \\
\text { Uma vez que as RCEs são aprovadas pelo Conselho, deveriam ser } \\
\text { registradas como ativos intangíveis conforme a Norma Contábil-26. }\end{array}$ \\
\hline ICAI (2012) & Índia & $\begin{array}{l}\text { As RCEs geradas pelas companhias são ativos, com reconhecimento após } \\
\text { sua emissão pela UNFCCC. Na fase em que as RCEs estão em formação, o } \\
\text { tratamento deve ser como ativos contingentes, conforme com a Norma } \\
\text { Contábil-29 - Provisões, Passivos Contingentes e Ativos Contingentes } \\
\text { (Accounting Standard-29- Provisions, Contingent Liabilities and } \\
\text { Contingent Assets). } \\
\text { As RCEs são consideradas ativos intangíveis em conformidade com sua } \\
\text { característica 'não física'. Porém, por serem mantidas para venda, devem } \\
\text { ser classificadas em estoques, conforme a Norma Contábil-2 (Accounting } \\
\text { Standard-2 - Valuation of Inventories). } \\
\text { Os gastos nominais (taxas de consultoria e os gastos administrativos pagos } \\
\text { à UNFCCC) devem ser classificados em estoques pelas companhias. } \\
\text { Os gastos com pesquisa e desenvolvimento de projetos que resultarão em } \\
\text { RCEs, devem ser classificados como ativos intangíveis. } \\
\text { A mensuração das RCEs deve atender aos mesmos critérios dos estoques } \\
\text { das companhias, ou seja, pelo custo ou valor realizável líquido, dos dois o } \\
\text { menor. }\end{array}$ \\
\hline $\begin{array}{l}\text { Ray e Ray (2012); } \\
\text { Dutta e Dasgupta } \\
(2012)\end{array}$ & Índia & $\begin{array}{l}\text { As RCEs se caracterizam enquanto bens das companhias. Porém, não } \\
\text { podem ser incluídos nos 'estoques', por não estarem disponíveis para } \\
\text { comercialização no curso normal dos negócios. }\end{array}$ \\
\hline
\end{tabular}

Quadro 1 - Tratamento Contábil dos Créditos de Carbono no Brasil, China e Índia.

Fonte: Dados da pesquisa (2015).

Enquanto síntese das discussões analisadas nas literaturas brasileira, chinesa e indiana, em prol ao tratamento contábil passível de ser atribuído às RCEs e aos gastos realizados pelas 
companhias dos respectivos países para implementação de projetos de MDLs em seus processos produtivos, é possível inferir-se acerca de algumas carecterísticas, conforme segue.

Não existem, até o momento de desenvolvimento desta Tese, orientações pertinentes ao reconhecimento e mensuração contábil das RCEs por parte dos órgãos regulamentadores internacionais, fato este que pode estar contribuindo para o baixo índice de evidenciação segregada nas demonstrações contábeis tradicionais, de informações pertinentes ao fluxo financeiro dos projetos de MDLs que estão sendo implementados nos países em desenvolvimento (IASB, 2013; IASB, 2014).

Dentre os três países pesquisados, o Brasil é o que possui menores níveis de orientações legais pertinentes ao assunto (CVM, 2009), cujas discussões têm girado basicamente em torno do meio acadêmico do país (Ribeiro, 2005; Bito, 2006; Ribeiro, 2007; Ferreira et al., 2007; Perez et al., 2008; Bufoni e Ferreira, 2010; Rocha, Silva Júnior, Andrade, \& Ramos, 2010; Santos et al., 2011).

Na China, a influência estatal junto à implementação de projetos de MDLs nos processos produtivos empresariais tem guiado as discussões acadêmicas no sentido de atribuir tratamento contábil direcionado às exigências governamentais locais, onde estão especificados os critérios necessários para possibilitar as negociações de RCEs por parte das companhias localizadas naquele país (China, 2005; Zhang, 2011; Tang, 2011; Wang, 2011).

Por outro lado, os órgãos regulamentadores locais da Índia emitiram suas notas de orientações sobre a contabilização de RCEs, onde os conceitos tradicionais da contabilidade podem ser fortemente identificados (ICAI, 2012). Em contrapartida, a literatura acadêmica naquele país tem se apresentado de forma escassa nos periódicos científicos internacionais, de maneira que a predominância sobre o assunto gira em torno das orientações legais existentes (Agrawal, 2006; Bothra, 2010; Ray \& Ray, 2012; Dutta \& Dasgupta, 2012).

O ponto de maior consenso entre as orientações legais e as pesquisas científicas existentes no Brasil, na China e na Índia gira em torno do fato de que as RCEs possuem todas as características existentes nas definições de ativo e, como tal, devem ser reconhecidas e mensuradas nas demonstrações financeiras. Por outro lado, não foi vislumbrado consenso acerca de em qual grupo do ativo as RCEs devem ser classificadas, cujos entendimentos, nos 
países pesquisados, giram basicamente em torno de classificá-las como instrumentos financeiros, estoques (produtos) e/ou ativos intangíveis. Porém, todas as classificações de grupos de ativos possíveis para seu reconhecimento, discutidas no meio acadêmico, esbarram na inviabilidade prática em realizá-lo, tendo em vista as orientações contábeis emitidas pelas Normas Internacionais de Contabilidade, que foram adotadas nos respectivos países.

No que tange às orientações pertinentes às bases de mensurações que poderiam ser adotadas para valoração das RCEs, também não se vislumbrou consenso nos países em análise. No entanto, verificou-se que tanto no Brasil, quanto na China e na Índia, a tendência da maioria das orientações pertinentes ao assunto em questão gira no mesmo sentido que as orientações legais emitidas pelas normas internacionais de contabilidade, tais sejam: a) Instrumentos financeiro: mensuração ao valor justo; b) Estoques: mensuração ao custo ou valor realizável líquido; c) Ativos intangíveis: mensuração inicial ao custo e as subsequentes ao valor justo. Assim, a mensuração das RCEs, efetivamente, tem sido pouco discutida enquanto ativo que possui capacidade de geração de benefícios econômicos futuros, pois a predominância das deliberações contábeis existentes nos países em análise tem girado em torno da mensuração dos valores despendidos ou recebidos em períodos passados ou presente, sem vislumbrar projeções futuras, condizentes com as características das RCEs.

Nesse contexto, o tratamento contábil passível de ser atribuído por parte das companhias situadas em países em desenvolvimento, até então, tem deixado de evidenciar informações pertinentes ao fluxo econômico dos investimentos realizados nos processos produtivos empresariais com a implementação de projetos de MDLs, que já se encontram aprovados junto à UNFCCC, e possuem capacidade de oferecer benefícios econômicos futuros para as companhias, por períodos que giram em torno de 10 a 20 anos, com características condizentes às contidas na IAS 38 - Intangible Assets (IASB, 1998).

No que concerne às discussões em torno de reconhecimento das RCEs enquanto ativo intangível, a literatura existente nos países em questão tem se fixado, basicamente, sobre os dispêndios com a implementação dos projetos de MDLs, pois as RCEs são desenvolvidas internamente por parte das companhias localizadas no Brasil, na China e na Índia, que possuem impedimentos legais quanto ao reconhecimento de ativos intangíveis, cujos custos 
de aquisição não são claramente definidos (Bito, 2006; Perez et al., Santos et al., 2011; Xiaozhu \& Yunyun, 2011; Zhang, 2011; Agrawal, 2006; ICAI, 2012).

Em termos legais, a IAS 38 (IASB, 1998, par. 24) esclarece que o reconhecimento do ativo intangível por parte das entidades empresariais deverá ser realizado apenas se o seu custo puder ser mensurado com confiabilidade, pois "um ativo intangível deve ser reconhecido inicialmente ao custo ${ }^{78}$ " para que possa ser evidenciado nas demonstrações contábeis.

Vale ressaltar, nessa ocasião, que as especificações pertinentes à utilização do conceito de valor justo, aceitas por parte do IASB, para mensuração de alguns itens patrimoniais, foram centralizadas com a publicação da IFRS 13, conforme já mencionado anteriormente. Porém, a IFRS 13 especifica em seu parágrafo 5 que tal norma "é aplicável quando outra requerer ou permitir mensurações do valor justo ou divulgações sobre mensurações do valor justo ${ }^{79}$ ". (IASB, 2011a, par. 5). A IAS 38 (IASB, 1998) ratificou tal entendimento, o que significa que os ativos intangíveis devam ser mensurados em conformidade com essa norma.

Além disso, para o caso específico das RCEs, Perez et al., (2008, p. 63) explicaram que, em termos legais, "as RCEs não podem ser contabilizadas como ativos, já que foram desenvolvidas internamente e não têm o reconhecimento das autoridades competentes como títulos e valores mobiliários". Conforme os autores, isso ocorre, pois, cada país deve emitir regulamentação interna para o efetivo registro das RCEs, pois o Protocolo de Quioto não possui força de lei.

Nesse sentido, as limitações legais existentes, tanto por parte das normas IFRS quanto por parte dos órgãos regulamentadores nacionais, têm impossibilitado a mensuração e reconhecimento a valores justos das RCEs enquanto ativos gerados internamente pelas entidades empresariais, cujos títulos já vêm sendo negociados nos mercados de carbono, mesmo antes da aprovação e registro dos projetos de MDLs junto à UNFCCC.

O entendimento mantido por parte dos órgãos regulamentadores tem feito com que os ativos intangíveis desenvolvidos internamente nas entidades, que não possuem regulamentação nacional, como é o caso das RCEs, não possam ser mensurados e reconhecidos pela

\footnotetext{
7824 An intangible asset shall be measured initially at cost.

795 This IFRS applies when another IFRS requires or permits fair value measurements or disclosures about fair value measurements...
} 
contabilidade, que tem registrado apenas os valores despendidos para a implementação dos projetos de MDLs que, sabe-se, não representam de maneira adequada os fluxos de caixa futuros que as companhias irão obter.

Para que um ativo possa representar, de fato, os fluxos de caixa futuros, como é o caso das RCEs, faz-se necessário empregar a técnica do valor presente, com base em seus valores de mercado. Tal assertiva vem ao encontro dos ensinamentos de Hendriksen e Van Breda (1999, p. 391) que, ao discorrerem sobre a mensuração de ativos intangíveis, enfatizaram que "em princípio, a medida mais informativa é o valor presente de seus benefícios projetados".

Ribeiro (2005), por sua vez, ressaltou que, de fato, o uso da técnica do valor presente seria bastante adequado no caso da mensuração dos créditos de carbono, tendo em vista que seus benefícios esperados deverão ocorrer por diversos anos subsequentes.

Nessa mesma linha de raciocínio, Bothra (2010, p. 5), a exemplo de outros autores, considera que a permissibilidade para reconhecimento de intangíveis deveria ser mais ampla, de maneira a autorizar o reconhecimento dos itens patrimoniais desenvolvidos internamente por parte das companhias. No entendimento do autor, "uma vez que as RCE são aprovadas pelo Conselho, estas deveriam ser registradas como ativos intangíveis... pois satisfazem suas características, conforme definidas pela norma ${ }^{80}$ ".

Por isso, entende-se que, com a efetivação do registro dos projetos de MDLs junto ao Conselho Executivo, as RCEs são passíveis de serem reconhecidas enquanto ativos intangíveis desenvolvidos internamente por parte das entidades hospedeiras dos projetos de MDLs, cuja mensuração deverá ser realizada com apoio da técnica do valor presente sobre seus valores de mercado, para todo o período de desenvolvimento das atividades dos projetos. Tal metodologia estará evidenciando, de fato, o verdadeiro valor econômico das RCEs.

Diante de todo o exposto, esta Tese apresenta uma proposta de mensuração contábil das RCEs que pode ser efetivada no momento do registro dos projetos de MDLs junto ao Conselho Executivo da UNFCCC. Para tanto, a técnica do valor presente sobre seus valores de mercado

\footnotetext{
${ }^{80}$ However, once the CER are approved by the Board, these should be recorded as intangible assets... as they meet te criteria of 'Intangible Assets' as defined in the Standard,...
} 
será utilizada, adotando-se como base as 'Estimativas de Redução de Emissões (REs) dos Projetos', ano a ano, para a totalidade do período de desenvolvimento de suas atividades, de forma a possibilitar a evidenciação da capacidade de geração de benefícios econômicos futuros das RCEs, nas entidades empresariais brasileiras, chinesas e indianas. 


\section{PROPOSTA DE MENSURAÇÃO CONTÁBIL DOS CRÉDITOS DE CARBONO}

Nessa seção serão explanadas as etapas desenvolvidas com a realização da pesquisa empírica, que se norteou pela necessidade de realizar análises sobre fenômenos reais.

\subsection{Modelo de mensuração contábil das RCEs}

Com vistas a suprir a lacuna existente na literatura contábil em prol do tratamento que deve ser atribuído para a mensuração das RCEs geradas nos processos produtivos de entidades situadas em países em desenvolvimento, Ratnatunga et al. (2011, p. 133) apresentaram um modelo de cálculo, a partir do qual seria possível realizar a "valoração da capacidade de geração de créditos de carbono pelas organizações ${ }^{81}$ ", ao valor justo, o qual passaram a chamar de Capacidade Ambiental de Melhorar Ativos (Environmental Capability Enhancing Asset - ECEA), definida pelos autores como "a capacidade intangível total de uma entidade para produzir créditos de carbono ${ }^{82}$ ", sob a justificativa de que, "em um ambiente de gerenciamento de emissões de carbono, se uma organização registra o valor do tangível, deve registrar também o valor do intangível relacionado ${ }^{83 "}$.

Ou seja, ao serem reconhecidos os ativos pertinentes ao processo operacional das entidades, sua respectiva possibilidade de geração de créditos de carbono deveria também ser reconhecida, uma vez que a implementação dos projetos de MDL seja registrada junto ao Conselho Executivo da ONU, de maneira a possibilitar a evidenciação dos fluxos futuros de benefícios econômicos desses ativos, aos quais Ratnatunga et al. (2011) atribuem a

\footnotetext{
81 ... for valuing an organization's capability of producing carbon credits.

82 ... the total intangible capacity of an entity to produce carbon credits.

83 ... in a carbon emissions management environment, if an organization records the value of the tangible, it should record the value of the related intangible as well.
} 
denominação de "reconhecimento de intangíveis desenvolvidos internamente" por parte das entidades localizadas em países em desenvolvimento.

O modelo proposto por Ratnatunga et al. (2011) utilizou, como base para sua aplicação, os potenciais de sequestro de carbono em atividades florestais, que envolvem projetos que contabilizam a possibilidade de geração de benefícios futuros, durante o seu respectivo crescimento e maturação, possuindo, como principal característica, fortes oscilações temporais, causadas tanto pelo sequestro como pela emissão de $\mathrm{CO}_{2}$ na atmosfera, em longo prazo. Entretanto, os autores ressaltam que tal modelo pode ser aplicado a demais projetos que proporcionem alguma forma de compensação e, também, a projetos pertinentes a reduções de emissões de GEEs que sejam variáveis ao longo do tempo, com as devidas alterações necessárias para cada tipo de projeto, tendo em vista as características específicas dos ativos envolvidos.

Nesse sentido, para possibilitar a aplicação do modelo proposto, Ratnatunga et al. (2011) esclarecem que a Contabilização de Emissões e Sequestros de Carbono (Carbon Emission and Sequestration - CES Accounting), que deverá ser realizada por outras áreas de conhecimento, impreterivelmente deve se apresentar de maneira robusta e confiável, para atrair a confiança dos participantes do mercado de comércio de carbono.

Ressalta-se, também, que, ao serem mensuradas, reconhecidas, e evidenciadas nas demonstrações financeiras as RCEs enquanto itens pertencentes aos ativos intangíveis, tal robustez e confiabilidade referentes ao montante de estimativas de reduções de emissões em toneladas, constantes nos projetos de MDLs devem ser suficientes para transmitir confiabilidade aos usuários das informações contábeis, indistintamente, além dos já mencionados participantes do mercado de comércio de carbono.

A primeira etapa de cálculos do modelo proposto por Ratnatunga et al. (2011, p. 132), deve ser realizada conforme a equação 1 , a seguir apresentada:

$\mathrm{X}=$ Sequestro de $\mathrm{Y}$ toneladas de emissões de $\mathrm{CO}_{2}=\$$ Equação 1

Onde: $\mathrm{X}$ - representa o ativo operacional;

$\mathrm{Y}$ - representa a capacidade de sequestro de carbono, em toneladas;

$\$$ - representa o preço da tonelada de carbono, cotado no mercado. 
De posse das informações geradas a partir da equação 1, a segunda etapa de cálculos do modelo proposto por Ratnatunga et al. (2011, p. 134), deve ser realizada conforme a equação 2, como segue:

$\frac{\mathrm{ds}}{\mathrm{dt}}=r \cdot E \cdot\left(\frac{M-s}{M}\right)-\delta \mathrm{S}$.

Equação 2

A equação 2 indica que a alteração no valor econômico (dS/dt) da Capacidade Ambiental de Melhorar Ativos (ECEA) no tempo " $\mathrm{t}$ " é uma função dos seguintes fatores:

$\mathrm{E}=$ os custos/despesas incorridos para apoiar o ECEA;

$\mathrm{r}=\mathrm{o}$ valor crescente - constante de sequestro de carbono (definido como o valor ECEA gerado em cada valor monetário gasto no momento $S=0$ );

$\mathrm{M}=\mathrm{o}$ valor máximo da capacidade de sequestro ECEA, baseado na contagem física de sequestro de carbono (em melhores condições de crescimento);

$\mathrm{S}$ - o valor corrente da capacidade de sequestro ECEA (sobre as condições atuais de crescimento);

$\delta$ - o valor em decomposição - emissão constante de carbono (definida como a fração do valor ECEA perdida por unidade de tempo quando $\mathrm{E}=0$ ).

As variações positivas da equação no valor ECEA ocorrerão quando $\mathrm{r}$, E, e os potenciais valores inexplorados do ECEA (M-S) são mais elevados, e o valor em decomposição (emissões constantes) $(\delta)$ é inferior.

Apesar da aplicação direcionada a projetos voltados às atividades florestais, os autores ressaltaram que para projetos em condições futuras constantes de reduções de emissões, em que seja possível calcular os valores justos dos ECEAs, a aplicação apenas da Equação 1 do seu modelo seria suficiente. Assim, em se conhecendo os valores constantes de redução de emissões, os preços do carbono no mercado em cada ano das reduções obtidas, e, sendo possível assumir como base uma determinada taxa de desconto, os valores presentes dos fluxos futuros de caixa seriam os próprios ECEAs. Posteriormente, quaisquer alterações que venham a ocorrer entre o 'real' e o 'reconhecido', deverá ser ajustado pelas companhias, ano a ano (Ratnatunga et al., 2011). 
Tais percepções vêm ao encontro das discussões apresentadas por Hendriksen e Van Breda (1999, p. 176) ao explanarem sobre a relação existente entre valores presentes e valores de mercado. Eles explicam que, "em situações nas quais os títulos das empresas são negociados, o mercado estabelece um preço ao qual os investidores e credores podem vender e comprar seus direitos sobre os fluxos de caixa esperados". Nesse sentido, "o preço de um ativo é, a qualquer momento, igual ao valor presente dos fluxos de caixa esperados”. Isso significa dizer que, para a fixação do valor do ativo no mercado, seus participantes levam em consideração o potencial de fluxos de caixa futuros esperados desse ativo, para então realizar sua comercialização.

Os projetos de MDLs implementados em entidades situadas nos países em desenvolvimento, passam a gerar RCEs após possuírem suas aprovações junto à AND de cada país, com a respectiva efetivação de seu registro junto à UNFCCC. Nessa ocasião, as RCEs passam a representar um potencial de benefícios futuros para a entidade que implementou os projetos e, como tal, poderiam ser mensuradas e reconhecidas na contabilidade, ao valor justo.

Para viabilizar a aprovação dos projetos de MDLs junto à AND, seus proponentes devem especificar, dentre outros fatores, os potenciais estimados de redução de emissões de GEEs da atmosfera ${ }^{84}$, juntamente com o respectivo período ao qual estarão propensos à obtenção de RCEs, que podem compreender um máximo de 10 anos para projetos de períodos fixos e/ou, 7 anos para projetos de períodos renováveis, cuja renovação pode ocorrer por duas vezes, abrangendo assim, um período de 21 anos de propensão à obtenção de RCEs (MCT, 2011a).

Os projetos de MDLs aprovados e registrados junto à plataforma da UNFCCC, implementados no Brasil, na China e na Índia, durante o período compreendido entre 2005 e 2012, possuem, em sua maioria, estimativas constantes de redução de emissões para todos os períodos subsequentes à sua aprovação, bem como, para os períodos em que sua renovação poderá vir a ocorrer, em sendo o caso.

Assim, aplicando-se apenas a Equação 1, do modelo proposto por Ratnatunga et al. (2011), será possível realizar a mensuração das RCEs enquanto ativo intangível das entidades situadas nos países em questão, com a utilização da técnica do valor presente, tida pela literatura como

\footnotetext{
${ }^{84}$ No momento da implementação dos projetos de MDLs, os proponentes devem apresentar uma quantidade estimada de reduções de emissões que, ao serem certificadas posteriormente, poderão sofrer alterações entre a quantidade estimada e a quantidade real de RCEs a serem emitidas posteriormente pela UNFCCC.
} 
uma das mais apropriadas para atingir os objetivos econômicos de mensuração contábil (Bierman Jr., 1963; Sterling, 1970; Vickrey, 1970; Mattessich, 1970; Mattessich, 1972; Most, 1982; Kam, 1986; Hendriksen \& Van Breda, 1999; Iudícibus, 2000; Martins, 2001; Glautier \& Underdown, 2001; Riahi-Belkaoui, 2004; Ribeiro, 2005).

Dessa forma, as variáveis pertinentes à quantidade estimada de RCEs e o respectivo período em que serão geradas, podem ser obtidas junto aos projetos de MDLs implementados nos países em análise. Vale ressaltar que, quando da emissão das RCEs posteriormente, ajustes deverão ser realizados para adaptar as quantidades previstas de REs às suas quantidades reais de RCEs a serem emitidas pela UNFCCC, ano a ano.

Por outro lado, deve-se enfatizar que no Brasil, na China e na Índia não existem mercados ativos formalizados para venda de RCEs, até porque sua comercialização deve ser realizada junto a entidades localizadas em países desenvolvidos, que possuem a necessidade de adquirílas para que, em sendo o caso, contribuam para a complementação de suas metas de reduções de emissões impostas com a adesão do respectivo país ao Protocolo de Quioto.

Assim, em não existindo mercados ativos formalizados para venda de RCEs junto ao Brasil, China e Índia, os valores justos das RCEs podem ser obtidos junto aos mercados de carbono europeu e norte americano, onde, efetivamente, estão sendo negociadas, com valores definidos por mercados ativos formalizados já consolidados naquelas localidades.

De posse (i) das estimativas de redução de emissões (REs) dos projetos, (ii) do período em que serão geradas e, (iii) dos valores justos das RCEs, é possível obter-se os benefícios econômicos futuros estimados com a implementação de projetos de MDLs que, ao serem efetivados seus registros junto ao Conselho Executivo da UNFCCC, possuem condições de serem caracterizadas enquanto ativos intangíveis das entidades que as desenvolveram.

Porém, para que seja possível realizar seu reconhecimento, os benefícios futuros devem ser reduzidos a valores presentes, de maneira a espelhar, no presente, sua capacidade futura de geração de benefícios. Para tanto, deve ser utilizada uma taxa de descontos a ser definida pela entidade, que seja capaz de refletir com o maior nível de confiabilidade possível o valor do dinheiro no tempo, além de atrair elevados níveis de confiabilidade do mercado. Tais 
características são vislumbradas nas Taxas de Juros Euribor, por exemplo, por se basearem na média das taxas de juros praticadas em empréstimos interbancários em euros, utilizada por grande número de bancos no mercado europeu, onde as RCEs também possuem mercado ativo.

Com o exposto, percebe-se que as características que cercam as RCEs geradas internamente por entidades situadas nos países em desenvolvimento possibilitam a utilização da técnica do valor presente, adotando-se como base valores justos, para realização de sua mensuração. Essa é uma forma de viabilizar seu reconhecimento enquanto ativo intangível nas demonstrações contábeis dessas entidades, com vistas a evidenciar informações pertinentes ao fluxo financeiro dos projetos de MDLs, implementados nos países em desenvolvimento.

Deve-se ressaltar que, na China, as RCEs somente podem ser consideradas ativos das companhias se, e somente se, os projetos de MDLs que as originarão, possuírem contratos firmados com investidores de países do Anexo I do Protocolo de Quioto, cuja informação está disponibilizada junto ao sítio eletrônico da UNFCCC para consulta pública, projeto a projeto.

Mediante isso, entende-se que a mensuração contábil das RCEs deve levar em consideração as características específicas pertinentes ao item patrimonial, de maneira a possibilitar seu reconhecimento e evidenciação aos usuários externos, da seguinte forma.

As RCEs se caracterizam enquanto ativo intangível no momento em que os projetos de MDLs são aprovados pelo órgão governamental competente (ou seja, registrados junto ao Conselho Executivo da UNFCCC). A partir desse ponto, possuem a capacidade de gerar benefícios econômicos futuros que influenciarão o fluxo financeiro das entidades advindos com a melhoria do desenvolvimento sustentável dos países Não-Anexo I que ratificaram o Protocolo de Quioto, em um momento passado, com vistas a gerar garantias reais e mensuráveis em prol da mitigação da mudança climática em níveis globais.

Por possuírem características de ativo intangível desenvolvido internamente nos processos produtivos empresariais de entidades localizadas nos países Não-Anexo I do Protocolo de Quioto, as RCEs não possuem quaisquer custos de aquisição nessas localidades, fato este que leva à necessidade de serem utilizados valores correntes de mercado (a valores de saída) para sua mensuração ao valor justo. Tais valores podem ser obtidos junto a segmentos de 
mercados de vendas consolidados, situados nos países desenvolvidos, onde os contratos para sua comercialização já estão sendo firmados, com valores que oscilam em conformidade com a demanda gerada por investidores globais.

Tendo em vista o longo período ao qual estarão gerando benefícios futuros, a mensuração inicial das RCEs deve ser reduzida ao seu valor presente, adotando-se como base os valores de mercados ativos no momento de registro dos projetos, com projeção financeira sobre as quantidades potenciais constantes estimadas de redução de GEEs na atmosfera, para todo o período de sua aprovação junto ao órgão governamental competente, utilizando-se uma taxa para o desconto como, por exemplo, a taxa Euribor. Tais ativos intangíveis deverão ter seu reconhecimento registrado em contrapartida ao patrimônio líquido da companhia hospedeira dos projetos de MDLs (lucros a realizar), até o momento de sua realização.

No caso específico das RCEs, cuja mensuração inicial tenha sido realizada com base em quantidades estimadas de redução de GEEs na atmosfera, constantes nos projetos de MDLs, serão necessárias mensurações subsequentes, com vistas a realizar ajustes anuais, por ocasião da emissão real de RCEs por parte das entidades governamentais competentes às empresas hospedeiras dos projetos. Assim, à medida em que ocorrerem as emissões reais de RCEs, reduz-se a quantidade que foi inicialmente registrada, implicando em mensurações subsequentes do ativo com o respectivo ajuste do valor registrado no patrimônio líquido.

Dessa forma, as mensurações subsequentes das RCEs devem ser reduzidas ao seu valor presente, adotando-se, também, como base, os valores de mercados ativos no momento de sua emissão por parte das autoridades governamentais competentes, com projeção financeira sobre as quantidades reais de RCEs emitidas ao final de cada período, cujas variações deverão ser registradas, a cada exercício social, também no patrimônio das companhias. $\mathrm{O}$ valor contábil deverá ser determinado sobre a quantidade real de RCEs, de acordo com os preços de carbono disponíveis no mercado e, em sendo verificada perda por impairment, essa deve ser reconhecida no patrimônio das companhias.

Destaca-se que o horizonte temporal para o cálculo do valor presente compreenderá desde o momento da aprovação dos projetos de MDLs até a última data de redução estimada de GEEs da atmosfera, prevista nos referidos projetos. Do mesmo modo que a definição da 
taxa de desconto, a identificação precisa do horizonte temporal é essencial para o correto cálculo do valor presente das mensurações das RCEs.

Dessa forma, o valor contábil das RCEs, registrado no patrimônio líquido das companhias, deverá ser transferido para lucros acumulados apenas no momento da efetivação de sua realização (entrega) junto aos investidores dos países do Anexo I do Protocolo de Quioto. Nesse momento, também deverão ser transferidos os custos e despesas incorridos com seu desenvolvimento, além de serem reconhecidos os gastos com sua comercialização, os quais devem ser deduzidos das receitas obtidas com a venda das RCEs.

\subsection{População, Coleta dos Dados e Seleção da Amostra}

Em função do objetivo da pesquisa, sua população se caracteriza por empresas brasileiras, chinesas e indianas que evidenciaram suas informações financeiras aos usuários externos através das entidades reguladoras de Mercados Mobiliários do Brasil, da China e da Índia, e que também tenham implementado projetos de MDLs durante o período de 2005 a 2012, figurando no Status "Registrado" junto ao sítio eletrônico da UNFCCC.

A obtenção dos dados quantitativos a serem utilizados para testar a hipótese estatística a ser proposta no estudo tem como origem as informações pertinentes às empresas e aos projetos de MDLs que compuseram a amostra, a partir dos quais foram obtidas: (i) as informações financeiras pertinentes ao Patrimônio Líquido (PL) das empresas que possuem suas ações listadas nos mercados de capitais do Brasil, da China e da Índia e, (ii) as 'Estimativas de Redução de Emissões (REs) dos Projetos’ de MDLs, disponíveis junto ao sítio eletrônico da UNFCCC.

A coleta de dados pertinente às informações financeiras das empresas que as disponibilizaram através das entidades reguladoras dos mercados mobiliários dos países em estudo, foi realizada através da Base de Dados Eletrônicos e Financeiros da Thomson Reuters Eikon, na data de 30 de julho de 2013. Dessa forma, na data de realização da coleta, foram obtidas informações financeiras, convertidas em euro, referentes ao Patrimônio Líquido (PL) 
de 380 empresas brasileiras, 2.584 empresas chinesas e, 4.219 empresas indianas, referentes ao período em análise.

Já a coleta de dados pertinente aos projetos de MDLs que figuravam junto ao sítio eletrônico da UNFCCC no Status "Registrado" realizou-se através da Base de Dados Econômicos e Financeiros da Bloomberg, na data de 29 de julho de 2013, ocasião em que se encontravam disponíveis para análise um montante de $289^{85}$ projetos registrados pela AND brasileira, 3.651 projetos registrados pela AND chinesa e, 1.296 projetos registrados pela AND indiana, referentes ao período de 2005 a 2012.

Porém, fez-se necessário realizar novas buscas diretamente ao sítio eletrônico da UNFCCC para complementação de informações indispensáveis à realização da pesquisa, tendo em vista o fato de não constarem, em sua totalidade, as descrições pertinentes aos nomes das entidades receptoras de cada país (parte hospedeira), junto a Base de Dados Econômicos e Financeiros da Bloomberg, na data já mencionada, cuja informação caracterizava-se por ser o único vínculo existente entre a base de dados dos projetos de MDLs (Bloomberg) e a base de dados com informações financeiras (Thomson Reuters Eikon). Tais buscas foram realizadas durante o período de outubro de 2013 a maio de 2014.

Posteriormente, em 01 de setembro de 2014, foram realizadas novas buscas junto ao sítio eletrônico da UNFCCC, com vistas a atualizar as informações pertinentes aos projetos de MDLs registrados pelo órgão durante o período de 2005 a 2012, ocasião em que se verificou no Status "Registrado", a existência de 299 projetos registrados pela AND brasileira, 3.682 projetos registrados pela AND chinesa e, 1.371 projetos registrados pela AND indiana, referentes ao período em questão.

Dessa forma, a presente pesquisa foi desenvolvida adotando-se como base os projetos de MDLs localizados no Status "Registrado" junto ao sítio eletrônico da UNFCCC, referentes ao período de 2005 a 2012, cujos registros foram finalizados pelo referido órgão até a data de 01 de setembro de 2014, onde constavam: 299 projetos registrados pela AND do Brasil, 3.682

\footnotetext{
${ }^{85}$ No ano de 2004, em 18 de novembro, havia sido efetivado o registro de apenas 01 projeto pela AND brasileira, intitulado "Brazil NovaGerar Landfill Gas to Energy Project". (UNFCCC, 2014). Tal projeto fora eliminado da pesquisa, devido à sua delimitação temporal definida entre 2005 e 2012, primeira fase do Protocolo de Quioto.
} 
projetos registrados pela AND da China e, 1.371 projetos registrados pela AND da Índia, perfazendo um total de $\mathbf{5 . 3 5 3}$ projetos, ou seja, $\mathbf{7 4 , 6 9 \%}$ do total implementado junto a todos os países em desenvolvimento, que ratificaram o Protocolo de Quioto.

Fez-se necessário, também, a obtenção de informações qualitativas pertinentes a diversas características dos projetos de MDLs registrados pelas ANDs do Brasil, China e Índia, que figuram no Status 'Aprovados' junto ao sítio eletrônico da UNFCCC, de forma a viabilizar o atendimento das necessidades de tratamento e avaliação dos dados da pesquisa. Para tanto, foram coletadas informações existentes nos projetos de MDLs, dentre as quais se destacam: (i) país hospedeiro; (ii) número de registro do projeto (referência); (iii) ano de registro; (iv) participante autorizado (entidade receptora - parte hospedeira); (v) nome do projeto; (vi) existência ou não de país(es) investidor(es) (Anexo-I); (vii) tipo de empreendimento; (viii) projeto renovável ou não renovável; (ix) escopo setorial (código e nome); (x) projeto de larga ou pequena escala ${ }^{86}$.

Para possibilitar a aplicação da mensuração ao valor justo das 'Estimativas de Redução de Emissões dos Projetos' aprovadas pelas empresas que compõem a pesquisa, foi obtido junto à Base de Dados Econômicos e Financeiros da Bloomberg, na data de 29 de julho de 2013, a taxa de Juros EURIBOR - Euro InterBank Offered Rate ${ }^{87}$, (taxas médias anuais), para realização do ajuste a valor presente dos fluxos futuros de benefícios econômicos das estimativas de RCEs. As taxas a serem utilizadas estão elencadas na Tabela 2.

Tabela 2 - Taxas de Juros Euribor

\begin{tabular}{c|c}
\hline Período & Euribor - Middle Rate \\
\hline 2005 & 2,335 \\
\hline 2006 & 3,440 \\
\hline 2007 & 4,448 \\
\hline 2008 & 4,825 \\
\hline 2009 & 1,610 \\
\hline 2010 & 1,352 \\
\hline 2011 & 2,008 \\
\hline 2012 & 1,108 \\
\hline
\end{tabular}

Fonte: Dados da pesquisa (2015).

${ }^{86}$ Os projetos de pequena escala possuem critérios específicos para elegibilidade, utilizam um documento de concepção de projeto diferente, com metodologias simplificadas para validação, tornando um ciclo do projeto mais ágil e com menores custos de transação. Os projetos de larga escala possuem metodologias de linhas de base diferenciadas, com maiores capacidades de redução de GEEs da atmosfera (MCT, 2014).

${ }^{87}$ A Euribor - Euro InterBank Offered Rate, são taxas que se baseiam na média das taxas de juros praticadas em empréstimos interbancários por um grupo representativo de bancos nos empréstimos mútuos realizados em euros. Há taxas para 8 diferentes períodos de tempo, que variam de uma semana a 12 meses. A Euribor é utilizada por outros bancos para fixarem as suas próprias taxas de juros. (Recuperado de http://pt.globalrates.com/). 
Para a mesma finalidade, também foram coletadas informações junto à Base de Dados Econômicos e Financeiros da Bloomberg, na data de 05 de dezembro de 2013, referentes às séries históricas de preços de Créditos de Carbono, a partir de contratos que possuíram liquidez em bolsas de valores do mercado europeu, durante o período de 2005 a 2012. Enquanto resultado da pesquisa, foram obtidos os dados constantes no Quadro 2.

\begin{tabular}{|l|l|l|l|c|}
\hline \multicolumn{1}{|c|}{ Código } & \multicolumn{1}{c|}{ Contrato } & \multicolumn{1}{c|}{ Bolsa } & Localização & \multicolumn{1}{c|}{ Período } \\
\hline UJLA Comdty & $\begin{array}{l}\text { Carbon, European Mid 3rd } \\
\text { Period }\end{array}$ & European Energy Exchange & Europa & 2011 a 2012 \\
\hline CARA Comdty & ICE CER Future Contracts & ICE Futures Europe & Europa & 2008 a 2012 \\
\hline IEEA Comdty & ICE ERU Futures & ICE Futures Europe & Europa & 2010 a 2012 \\
\hline MOA Comdty & Emissions - EUA & ICE Futures Europe & Europa & $\mathbf{2 0 0 5}$ a 2012 \\
\hline FUAA Comdty & EUA Futures & NASDAQ OMX Commodit & Europa & 2010 a 2012 \\
\hline FTCA Comdty & In Delivery Month EUA & NYMEX Emissions & Europa & 2009 a 2012 \\
\hline
\end{tabular}

Quadro 2 - Contratos com liquidez em bolsas de valores do mercado europeu.

Fonte: Dados da pesquisa (2015).

Com os resultados obtidos, percebe-se que apenas a Intercontinental Exchange, Inc. (ICE) ICE Futures Europe apresentou a série histórica de valores de créditos de carbono de todo o período que abrange a pesquisa (2005 a 2012). Assim, foram adotados os valores pertinentes ao último dia útil de cada ano, enquanto base para mensuração ao valor justo das 'Estimativas de Redução de Emissões dos Projetos' de MDLs aprovados pelas ANDs do Brasil, da China e da Índia, conforme Tabela 3.

Tabela 3 - Valores da tonelada de créditos de carbono (em euro)

\begin{tabular}{c|c|c|c}
\hline Data & Bolsa & Código & $\begin{array}{c}\text { Valor da tonelada de } \\
\text { Crédito de Carbono (€) }\end{array}$ \\
\hline 30.12 .2005 & ICE Futures Europe & MOA Comdty & 21,10 \\
\hline 29.12 .2006 & ICE Futures Europe & MOA Comdty & 6,45 \\
\hline 31.12 .2007 & ICE Futures Europe & MOA Comdty & 0,02 \\
\hline 31.12 .2008 & ICE Futures Europe & MOA Comdty & 15,45 \\
\hline 31.12 .2009 & ICE Futures Europe & MOA Comdty & 12,31 \\
\hline 31.12 .2010 & ICE Futures Europe & MOA Comdty & 14,02 \\
\hline 30.12 .2011 & ICE Futures Europe & MOA Comdty & 7,03 \\
\hline 31.12 .2012 & ICE Futures Europe & MOA Comdty & 6,48 \\
\hline
\end{tabular}

Fonte: Dados da pesquisa (2015).

De posse de todas as informações anteriormente elencadas, procedeu-se a organização dos dados, para viabilizar a seleção da amostra da pesquisa, de forma segregada para Brasil, China e Índia, da seguinte forma. 
Inicialmente, foram organizadas as bases de dados com as informações qualitativas anteriormente elencadas, que continham as especificidades dos projetos de MDLs registrados pelas ANDs do Brasil, da China e da Índia, de maneira a possibilitar, a partir do nome da entidade receptora de cada país (parte hospedeira), a verificação de sua existência ou não junto à base de dados financeiros das empresas brasileiras, chinesas e indianas. As informações quantitativas pertinentes às 'estimativas de redução de emissões dos projetos' de MDLs e 'período de vigência' ( $1^{\text {a }}$ fase e duração geral dos projetos), também estavam contidas nessas bases de dados.

Em sequência, foram adotadas as bases de dados anteriormente organizadas para, a partir do nome de sua 'entidade receptora' (parte hospedeira), verificar a existência ou não da razão social da mesma companhia junto à base de dados financeiros da Thomson Reuters Eikon. Os nomes localizados eram transferidos, juntamente com os respectivos valores de Patrimônio Líquido (PL), pertinentes aos períodos de aprovação dos projetos de MDLs junto à UNFCCC, para uma nova base de dados, para compor a amostra da pesquisa do Brasil, da China e da Índia. Todos os projetos 'registrados' pelas companhias dos três países foram selecionados, de maneira a abranger a totalidade de projetos registrados por uma determinada companhia durante o período envolvido na pesquisa.

Posteriormente, foram excluídos os projetos cujas companhias não disponibilizaram seus valores de Patrimônio Líquido (PL) nos respectivos períodos contábeis de aprovação de seus projetos de MDLs e, também, os projetos que foram renovados durante o período da pesquisa, pois, por ocasião do primeiro registro, considerou-se todo o período de duração do projeto, para os renováveis. Também foram excluídos os projetos registrados pela AND chinesa, que não possuíam país(es) investidor(es) figurando junto ao sítio eletrônico da UNFCCC, até a data de 01 de setembro de 2014, cujas RCEs, segundo a legislação chinesa, ao serem emitidas, serão retidas pelo Estado, por se caracterizarem enquanto 'ativos estatais', até o momento de sua comercialização por parte das 'entidades receptoras' dos projetos de MDLs.

Após a realização dessas etapas, a amostra resultante para tratamento e avaliação de dados ficou composta por: 31 projetos de MDLs pertinentes a 15 empresas brasileiras, 379 projetos de MDLs pertencentes a 56 empresas chinesas e, 318 projetos de MDLs referentes a 183 empresas indianas. Tais informações estão elencadas, de maneira detalhada, respectivamente, nos Apêndices A, B e C. 
Com o exposto, percebeu-se que resultaram para tratamento e avaliação dos dados da pesquisa, maior incidência de projetos de MDLs implementados por uma mesma companhia na China, cuja média foi de aproximadamente sete (07) projetos por companhia, seguida do Brasil e da Índia, que apresentaram uma média em torno de dois (02) projetos por companhia, implementados em cada país que fizeram parte da amostra da pesquisa.

As frequências pertinentes aos períodos em que ocorreram os registros dos projetos de MDLs junto à UNFCCC, que resultaram para tratamento e avaliação dos dados da pesquisa, ficaram representadas, conforme as Tabelas 4, 5 e 6 para o Brasil, China e Índia, respectivamente elencados em sequência.

Tabela 4 - Frequência dos projetos da amostra por ano - Brasil

\begin{tabular}{c|c|c|c}
\hline País & Ano & Frequência & Porcentagem \\
\hline Brasil & 2006 & 06 & $19,35 \%$ \\
\hline Brasil & 2007 & 01 & $3,23 \%$ \\
\hline Brasil & 2008 & 04 & $12,90 \%$ \\
\hline Brasil & 2009 & 03 & $9,68 \%$ \\
\hline Brasil & 2010 & 03 & $9,68 \%$ \\
\hline Brasil & 2011 & 01 & $3,23 \%$ \\
\hline Brasil & 2012 & 13 & $41,94 \%$ \\
\hline \multicolumn{2}{l}{ Total de projetos } & $\mathbf{3 1}$ & $\mathbf{1 0 0 \%}$ \\
\hline
\end{tabular}

Fonte: Dados da pesquisa (2015).

Conforme pôde-se observar na Tabela 4, a frequência de projetos de MDLs registrados por parte da AND brasileira foi mais acentuada no ano de 2012, período em que ficaram concentrados $41,94 \%$ dos projetos que restaram para tratamento e avaliação dos dados da pesquisa. Por outro lado, no ano de 2005, não se verificou a existência de projetos na amostra.

Tabela 5 - Frequência dos projetos da amostra por ano - China

\begin{tabular}{c|c|c|c}
\hline País & Ano & Frequência & Porcentagem \\
\hline China & 2006 & 01 & $0,26 \%$ \\
\hline China & 2007 & 11 & $2,90 \%$ \\
\hline China & 2008 & 29 & $7,65 \%$ \\
\hline China & 2009 & 31 & $8,18 \%$ \\
\hline China & 2010 & 109 & $28,76 \%$ \\
\hline China & 2011 & 107 & $28,23 \%$ \\
\hline China & 2012 & 91 & $24,01 \%$ \\
\hline \multicolumn{2}{r}{ Total de projetos } & $\mathbf{3 7 9}$ & $\mathbf{1 0 0 \%}$
\end{tabular}

Fonte: Dados da pesquisa (2015).

Em observação a Tabela 5, verificou-se que a frequência de projetos de MDLs registrados por parte da AND chinesa foi mais acentuada nos anos de 2010 e 2011, períodos em que ficaram 
concentrados, respectivamente, $28,76 \%$ e $28,23 \%$ dos projetos que restaram para tratamento e avaliação dos dados da pesquisa. Por outro lado, no ano de 2005, também não se verificou a existência de projetos na amostra.

Tabela 6 - Frequência dos projetos da amostra por ano - Índia

\begin{tabular}{c|c|c|c}
\hline País & Ano & Frequência & Porcentagem \\
\hline Índia & 2005 & 04 & $1,26 \%$ \\
\hline Índia & 2006 & 44 & $13,84 \%$ \\
\hline Índia & 2007 & 63 & $19,81 \%$ \\
\hline Índia & 2008 & 25 & $7,86 \%$ \\
\hline Índia & 2009 & 32 & $10,06 \%$ \\
\hline Índia & 2010 & 23 & $7,23 \%$ \\
\hline Índia & 2011 & 42 & $13,21 \%$ \\
\hline Índia & 2012 & 85 & $26,73 \%$ \\
\hline \multicolumn{2}{l}{ Total de projetos } & $\mathbf{3 1 8}$ & $\mathbf{1 0 0 \%}$ \\
\hline
\end{tabular}

Fonte: Dados da pesquisa (2015).

Em análise a Tabela 6, observou-se que a frequência de projetos de MDLs registrados por parte da AND indiana foi mais acentuada no ano de 2012, período em que ficaram concentrados $26,73 \%$ dos projetos que restaram para tratamento e avaliação dos dados da pesquisa. Por outro lado, no ano de 2005 verificou-se a menor concentração, com apenas $1,26 \%$ de projetos na amostra.

Foram verificadas, também, as frequências referentes às informações qualitativas pertinentes às seguintes características dos projetos de MDLs que figuraram no Status 'Aprovados' junto ao sítio eletrônico da UNFCCC: (i) existência ou não de país(es) investidor(es); (ii) tipo de empreendimento; (iii) projeto renovável ou não renovável; (iv) escopo setorial; e (v) projeto de larga ou pequena escala. Tais informações ficaram sintetizadas conforme as Tabelas 7, 8 e 9 para o Brasil, China e Índia, respectivamente elencados em sequência.

A Tabela 7 foi elaborado adotando-se por base as informações pertinentes aos projetos registrados por parte da AND brasileira, que resultaram para tratamento e avaliação dos dados da pesquisa, constantes no Apêndice A desta Tese.

Tabela 7 - Frequência das características qualitativas dos projetos da amostra - Brasil

\begin{tabular}{c|l|l|c|c}
\hline País & Variáveis & Descrição & Frequência & Porcentagem \\
\hline \multirow{4}{*}{ Brasil } & \multirow{2}{*}{ País investidor } & Possui países investidores & 08 & $25,81 \%$ \\
\cline { 3 - 5 } & & Não possui países investidores & 23 & $74,19 \%$ \\
\cline { 3 - 5 } & \multirow{3}{*}{ Tipo de empreendimento } & Produção energética & 21 & $67,74 \%$ \\
\cline { 3 - 5 } & & Tratamento de águas & 05 & $16,13 \%$ \\
\cline { 3 - 5 } & & Atividades de reflorestamentos & 02 & $6,45 \%$ \\
\cline { 3 - 5 } & & Transformação industrial & 02 & $6,45 \%$ \\
\hline
\end{tabular}




\begin{tabular}{|c|c|c|c|c|}
\hline & & Tratamento de resíduos florestais & 01 & $3,23 \%$ \\
\hline & \multirow{6}{*}{ Escopo Setorial } & Indústrias energéticas & 21 & $67,75 \%$ \\
\hline & & Tratamento e eliminação de resíduos & 05 & $16,13 \%$ \\
\hline & & Florestamento e reflorestamento & 02 & $6,46 \%$ \\
\hline & & Agricultura & 01 & $3,22 \%$ \\
\hline & & Indústrias químicas & 01 & $3,22 \%$ \\
\hline & & Transformação industrial & 01 & $3,22 \%$ \\
\hline & \multirow{2}{*}{ Renovabilidade } & Projetos renováveis & 25 & $80,65 \%$ \\
\hline & & Projetos não renováveis & 06 & $19,35 \%$ \\
\hline & \multirow{2}{*}{ Escala } & Pequena escala & 08 & $25,81 \%$ \\
\hline & & Larga escala & 23 & $74,19 \%$ \\
\hline \multicolumn{3}{|c|}{ Total de projetos } & 31 & $100 \%$ \\
\hline
\end{tabular}

Fonte: Dados da pesquisa (2015).

Em observação a Tabela 7, foi possível verificar que, dentre os 31 projetos de empresas brasileiras que compuseram a amostra, em apenas 25,81\% vislumbrou-se a existência de países investidores do Anexo I do Protocolo de Quioto, enquanto que na maioria dos projetos $(74,19 \%)$, não se verificou a participação de investidores estrangeiros, o que leva a crer que sua implementação foi realizada, em grande parte, apenas com participação financeira nacional.

No Brasil, tais projetos foram implementados predominantemente na 'produção energética', cujo tipo de empreendimento abrangeu $67,74 \%$ projetos da amostra. Os demais projetos foram desenvolvidos em empreendimentos de: 'tratamento de águas' (16,13\%); 'atividades de reflorestamentos' (6,45\%); 'transformação industrial' $(6,45 \%)$ e; 'tratamento de resíduos florestais' $(3,23 \%)$ dos projetos registrados pela AND brasileira.

O escopo setorial desses projetos corrobora com tais informações, pois se verificou a incidência de $67,75 \%$ dos projetos registrados por 'indústrias energéticas'; $16,13 \%$ dos projetos registrados para 'tratamento e eliminação de resíduos'; 6,46\% dos projetos registrados em 'florestamento e reflorestamento'; 3,22\% dos projetos registrados para a 'agricultura'; 3,22\% dos projetos registrados por 'indústrias químicas' e; 3,22\% dos projetos registrados para 'transformação industrial'. Porém, foi possível perceber a atribuição de mais de um 'escopo setorial' para alguns projetos registrados junto ao sítio eletrônico da UNFCCC pela AND brasileira (Apêndice A), fato este que causou uma pequena oscilação em relação à classificação dos 'tipos de empreendimentos' anteriormente mencionada. 
Foi possível observar também que, dentre os 31 projetos brasileiros participantes da amostra, a maioria deles (25 ou 80,65\%), foi registrada como 'projetos renováveis' e, apenas 06 (ou $19,35 \%$ ) foram registrados enquanto 'projetos não renováveis'. Dentre os 25 projetos renováveis, 23 deles possuem períodos de duração de 7 anos, 01 possui período de 10 anos de duração e, 01 possui 17 anos de duração do desenvolvimento de suas atividades, cujas renovações poderão perfazer até 30 anos de desenvolvimento de atividades. Já dentre os 06 projetos não renováveis, 05 se apresentaram com 10 anos de duração e, 01 com 30 anos de duração para o desenvolvimento de suas atividades.

Já os projetos de 'larga escala', por sua vez, predominaram em termos de registros realizados pela AND brasileira, tendo permanecido $74,19 \%$ dos projetos nessa escala. Os $25,81 \%$ dos projetos restantes foram registrados em 'pequena escala'.

A Tabela 8 foi elaborado adotando-se por base as informações pertinentes aos projetos registrados por parte da AND chinesa, que resultaram para tratamento e avaliação dos dados da pesquisa, constantes no Apêndice B desta Tese.

Tabela 8 - Frequência das características qualitativas dos projetos da amostra - China

\begin{tabular}{|c|c|c|c|c|}
\hline País & Variáveis & Descrição & Frequência & Porcentagem \\
\hline \multirow{15}{*}{ China } & \multirow{2}{*}{ País investidor } & Possui países investidores & 379 & $100 \%$ \\
\hline & & Não possui países investidores & 00 & $0,00 \%$ \\
\hline & \multirow{4}{*}{ Tipo de empreendimento } & Produção energética & 362 & $95,51 \%$ \\
\hline & & Transformação industrial & 12 & $3,17 \%$ \\
\hline & & Produção mineral & 04 & $1,06 \%$ \\
\hline & & Distribuição energética & 01 & $0,26 \%$ \\
\hline & \multirow{5}{*}{ Escopo Setorial } & Indústrias energéticas & 361 & $95,25 \%$ \\
\hline & & Indústrias químicas & 10 & $2,64 \%$ \\
\hline & & Mineração/produção mineral & 04 & $1,05 \%$ \\
\hline & & Transformação industrial & 02 & $0,53 \%$ \\
\hline & & Emissões fugitivas & 02 & $0,53 \%$ \\
\hline & \multirow{2}{*}{ Renovabilidade } & Projetos renováveis & 348 & $91,82 \%$ \\
\hline & & Projetos não renováveis & 31 & $8,18 \%$ \\
\hline & \multirow{2}{*}{ Escala } & Pequena escala & 16 & $4,22 \%$ \\
\hline & & Larga escala & 363 & $95,78 \%$ \\
\hline \multicolumn{3}{|c|}{ Total de projetos } & 379 & $100 \%$ \\
\hline
\end{tabular}

Fonte: Dados da pesquisa (2015).

Ao observar a Tabela 8 , foi possível confirmar que a totalidade dos 379 projetos de empresas chinesas que compõem a amostra, possuem países investidores do Anexo I do Protocolo de Quioto, condição essa estabelecida por parte das Autoridades Governamentais daquele país 
para que as RCEs a serem geradas se caracterizem em ativos das empresas hospedeiras dos projetos.

Porém, a título de comparabilidade com os demais países, vale mencionar que foram excluídos da amostra chinesa, apenas 23 projetos de MDLs por não possuírem país(es) investidor(es) figurando junto ao sítio eletrônico da UNFCCC, até o encerramento da coleta de dados para a realização desta pesquisa. Tal informação permite inferir que na China, a maioria dos projetos de MDLs possuem participação financeira de investidores dos países do Anexo I do Protocolo de Quioto.

Na China, tais projetos foram implementados predominantemente na 'produção energética', cujo tipo de empreendimento abrangeu 95,51\% dos projetos da amostra. Os demais projetos foram desenvolvidos em empreendimentos de: 'transformação industrial' (3,17\%); 'produção mineral' $(1,06 \%)$ e; 'distribuição energética' $(0,26 \%)$ dos projetos registrados pela AND chinesa.

O escopo setorial desses projetos corrobora com tais informações, pois se verificou a incidência de 95,25\% dos projetos registrados por 'indústrias energéticas'; 2,64\% dos projetos registrados por 'indústrias químicas'; $1,05 \%$ dos projetos registrados para a 'mineração/produção mineral'; $0,53 \%$ dos projetos registrados para a 'transformação industrial' e; $0,53 \%$ dos projetos registrados para 'emissões fugitivas'. Porém, foi possível perceber a atribuição de mais de um 'escopo setorial' para alguns projetos registrados junto ao sítio eletrônico da UNFCCC pela AND chinesa (Apêndice B), fato este que causou uma pequena oscilação em relação à classificação dos 'tipos de empreendimentos' anteriormente mencionada.

Foi possível observar também que, dentre os 379 projetos chineses participantes da amostra, a maioria deles (348 ou 91,82\%), foi registrada como 'projetos renováveis' e, apenas 31 (ou $8,18 \%$ ) foram registrados enquanto 'projetos não renováveis'. A totalidade dos 348 projetos renováveis, possuem períodos de duração de 7 anos. Já dentre os 31 projetos não renováveis, 30 se apresentaram com 10 anos de duração e, apenas 01 com 7 anos de duração para o desenvolvimento de suas atividades. 
Já os projetos de 'larga escala', por sua vez, predominaram em termos de registros realizados pela AND chinesa, tendo permanecido $95,78 \%$ dos projetos nessa escala. Os $4,22 \%$ dos projetos restantes tiveram seus registros formalizados em 'pequena escala'.

Por fim, a Tabela 9 foi elaborado adotando-se por base as informações pertinentes aos projetos registrados por parte da AND indiana, que resultaram para tratamento e avaliação dos dados da pesquisa, constantes no Apêndice $\mathbf{C}$ desta Tese.

Tabela 9 - Frequência das características qualitativas dos projetos da amostra - Índia

\begin{tabular}{|c|c|c|c|c|}
\hline País & Variáveis & Descrição & Frequência & Porcentagem \\
\hline \multirow{21}{*}{ Índia } & \multirow{2}{*}{ País investidor } & Possui países investidores & 183 & $57,55 \%$ \\
\hline & & Não possui países investidores & 135 & $42,45 \%$ \\
\hline & \multirow{6}{*}{ Tipo de empreendimento } & Produção energética & 258 & $81,13 \%$ \\
\hline & & Transformação industrial & 45 & $14,15 \%$ \\
\hline & & Eficiência energética & 07 & $2,20 \%$ \\
\hline & & Tratamento de águas & 04 & $1,26 \%$ \\
\hline & & Atividades de reflorestamentos & 02 & $0,63 \%$ \\
\hline & & Transporte & 02 & $0,63 \%$ \\
\hline & \multirow{9}{*}{ Escopo Setorial } & Indústrias energéticas & 251 & $78,94 \%$ \\
\hline & & Transformação industrial & 29 & $9,12 \%$ \\
\hline & & Demanda energética & 11 & $3,46 \%$ \\
\hline & & Indústrias químicas & 08 & $2,51 \%$ \\
\hline & & Emissões fugitivas & 08 & $2,51 \%$ \\
\hline & & Tratamento e eliminação de resíduos & 05 & $1,57 \%$ \\
\hline & & Distribuição energética & 02 & $0,63 \%$ \\
\hline & & Transporte & 02 & $0,63 \%$ \\
\hline & & Florestamento e reflorestamento & 02 & $0,63 \%$ \\
\hline & \multirow{2}{*}{ Renovabilidade } & Projetos renováveis & 61 & $19,18 \%$ \\
\hline & & Projetos não renováveis & 257 & $80,82 \%$ \\
\hline & \multirow{2}{*}{ Escala } & Pequena escala & 183 & $57,55 \%$ \\
\hline & & Larga escala & 135 & $42,45 \%$ \\
\hline \multicolumn{3}{|c|}{ Total de projetos } & 318 & $100 \%$ \\
\hline
\end{tabular}

Fonte: Dados da pesquisa (2015).

Em verificação a Tabela 9, foi possível perceber que, dentre os 318 projetos de empresas indianas que compuseram a amostra, em sua maioria (57,55\%), verificou-se a existência de países investidores do Anexo I do Protocolo de Quioto, enquanto que em 42,45\% dos projetos não se verificou a participação de investidores estrangeiros.

Na Índia, tais projetos foram implementados predominantemente na 'produção energética', cujo tipo de empreendimento abrangeu $81,13 \%$ dos projetos da amostra. Os demais projetos foram desenvolvidos em empreendimentos de: 'transformação industrial' (14,15\%); 'eficiência energética' (2,20\%); 'tratamento de águas' (1,26\%); 'atividades de reflorestamentos' $(0,63 \%)$ e; 'transporte' $(0,63 \%)$ dos projetos registrados pela AND indiana. 
O escopo setorial desses projetos corrobora com tais informações, pois se verificou a incidência de 78,94\% dos projetos registrados por 'indústrias energéticas'; 9,12\% dos projetos registrados para a 'transformação industrial'; 3,46\% dos projetos registrados pela 'demanda energética'; 2,51\% dos projetos registrados por 'indústrias químicas'; 2,51\% dos projetos registrados para 'emissões fugitivas'; 1,57\% dos projetos registrados para 'tratamento e eliminação de resíduos'; 0,63\% dos projetos registrados pela 'distribuição energética'; 0,63\% dos projetos registrados para o 'transporte' e; $0,63 \%$ dos projetos registrados em 'florestamento e reflorestamento'. Porém, foi possível perceber a atribuição de mais de um 'escopo setorial' para alguns projetos registrados junto ao sítio eletrônico da UNFCCC pela AND indiana (Apêndice $C$ ), fato este que causou uma pequena oscilação em relação à classificação dos 'tipos de empreendimentos' anteriormente especificada.

Foi possível observar também que, dentre os 318 projetos indianos participantes da amostra, a maioria deles (257 ou 80,82\%), foi registrada como 'projetos não renováveis' e, apenas 61 (ou 19,18\%) foram registrados enquanto 'projetos renováveis'. A totalidade dos 61 projetos renováveis, possuem períodos de duração de 7 anos. Já dentre os 257 projetos não renováveis, 255 se apresentaram com 10 anos de duração e, apenas 02 com 30 anos de duração para o desenvolvimento de suas atividades.

Já os projetos de 'pequena escala', por sua vez, apresentaram-se em maior número em termos de registros realizados pela AND indiana, tendo permanecido $57,55 \%$ dos projetos nessa escala. Os $42,45 \%$ dos projetos restantes foram registrados em 'pequena escala'.

\subsection{Tratamento e Avaliação dos Dados}

A metodologia utilizada para o tratamento e avaliação dos dados da pesquisa em questão, no que concerne às variáveis quantitativas, girou em torno da verificação da existência ou não de diferenças médias estatisticamente significativas, no grupo de contas patrimoniais (Patrimônio Líquido) das empresas que compõem a sua amostra. Para tanto, foi verificada a situação real do Patrimônio Líquido (PL original), comparativamente à projeção da 
mensuração contábil das RCEs ao valor justo no mesmo grupo de contas patrimoniais, para o período da primeira fase de aprovação dos projetos (PL projetado $1^{\mathrm{a}}$ fase) e, também, para o período geral de existência/aprovação dos projetos (PL projetado geral), caso sejam renováveis.

Para a projeção da mensuração ao valor justo das RCEs, adotou-se como base o modelo de cálculo proposto por Ratnatunga et al. (2011, p. 132), realizada conforme a equação 1 dos mesmos autores, que foi adaptada para essa pesquisa, a seguir apresentada:

$\mathrm{X}=$ Sequestro de $\mathrm{Y}$ toneladas de emissões de $\mathrm{CO}_{2}=\$$

Equação 1

Onde: $\mathrm{X}$ - representa o ativo intangível;

$\mathrm{Y}$ - representa a capacidade de sequestro de carbono, em toneladas;

$\$$ - representa o preço da tonelada de carbono, cotado no mercado.

Assim, adotando-se como base os projetos selecionados para tratamento e avaliação dos dados (conforme Apêndices A, B e C), a partir das informações de estimativas anuais de redução de emissões dos projetos de MDLs (estimativa anual de Redução de Emissões REs), foram realizadas multiplicações para se obter a 'estimativa total de RE ( $1^{\mathrm{a}}$ fase)', projeto a projeto, de maneira a obter-se os 'períodos de vigência ( $1^{\mathrm{a}}$ fase)'. Procedeu-se da mesma forma para a obtenção da 'estimativa total de RE (geral)' e os respectivos 'períodos de vigência - total geral', visando abranger a previsão total de desenvolvimento das atividades dos projetos renováveis.

Também, foram adicionados à mesma base de dados, o 'valor da tonelada de RCEs', que, ao ser multiplicado pela 'estimativa total de RE ( $1^{\mathrm{a}}$ fase $)$ ', se obteve o 'valor total de REs ( $1^{\mathrm{a}}$ fase)' e, ao ser muliplicado pela 'estimativa total de RE (geral)', se obteve o "valor total de REs (geral)'.

As taxas de juros adotadas como base para realização da pesquisa (EURIBOR - Middle Rate), também foram adicionadas a essa mesma base de dados, ano a ano, em conformidade com os respectivos períodos de registro dos projetos e o valor do Patrimônio Líquido (PL) das companhias lá existentes, de maneira a possibilitar a realização do cálculo do valor presente, individualmente, projeto a projeto.

Assim, foi possível obter-se o 'valor presente ( $1^{\text {a }}$ fase $)$ ', com a utilização das variáveis: 'taxa 
de juros', 'período de vigência ( $1^{\text {a }}$ fase)' e, 'valor total de REs ( $1^{\text {a }}$ fase)'. E, também, o 'valor presente (geral)', com a utilização das variáveis: 'taxa de juros', 'período de vigência (geral)' e, 'valor total de REs (geral)'. Tais cálculos estão elencados nos Apêndices D, E e F, de forma segregada para Brasil, China e Índia, respectivamente.

Em seguida, o 'valor presente ( $1^{\text {a }}$ fase $)$ ' foi somado ao 'PL original' para obtenção da variável 'PL projetado ( $1^{\text {a }}$ fase)' e, o 'valor presente (geral)' foi somado ao 'PL original' para obtenção da variável 'PL projetado (geral)'. Dessa forma, as variáveis testadas estatisticamente foram: 'PL original', 'PL projetado ( $1^{\mathrm{a}}$ fase)' e, 'PL projetado (geral)'.

Porém, para possibilitar a realização de apenas uma mensuração por ano, para cada companhia, independentemente da quantidade de projetos por ela registrados naquele período, procedeu-se a soma de todas as variáveis 'valor presente ( $1^{\text {a }}$ fase)' e 'valor presente (geral)' de uma mesma companhia em um ano específico, para todos os períodos de realização da pesquisa, de maneira que os projetos registrados nos anos de 2005 a 2012 passaram a ser representados por apenas uma variável para cada ano, em determinada companhia. A variável 'PL original' foi considerada apenas uma vez ao ano, evitando-se duplicidades de cálculos.

Com a realização dessas etapas, foram obtidas as variáveis para tratamento e avaliação estatística dos dados, tendo permanecido: 20 observações para o Brasil, pertinentes a 15 empresas brasileiras; 102 observações para a China, pertencentes a 56 empresas chinesas e; 255 observações para a Índia, referentes a 183 empresas indianas; conforme visualização das Tabelas 10, 11 e 12, respectivamente elencadas a seguir:

Tabela 10 - Variáveis para análise estatística dos dados - Brasil

\begin{tabular}{c|c|l|c|c|c}
\hline $\begin{array}{c}\text { País } \\
\text { hospedeiro }\end{array}$ & $\begin{array}{c}\text { Ano de } \\
\text { aprovação }\end{array}$ & $\begin{array}{l}\text { Participante autorizado } \\
\text { (empresa brasileira) }\end{array}$ & \multicolumn{1}{c|}{$\begin{array}{c}\text { Patrimônio } \\
\text { PL original }\end{array}$} & $\begin{array}{c}\text { PL projetado } \\
\text { (1 } \text { fase) }\end{array}$ & $\begin{array}{c}\text { PL projetado } \\
\text { (geral) }\end{array}$ \\
\hline Brasil & 2009 & AES Tietê S.A. & $154.564 .764,04$ & $155.230 .057,08$ & $156.539 .448,97$ \\
\hline Brasil & 2011 & AES Tietê S.A. & $889.539 .570,13$ & $907.850 .156,35$ & $907.850 .156,35$ \\
\hline Brasil & 2006 & BRF S. A. & $747.641 .429,68$ & $748.757 .957,67$ & $748.757 .957,67$ \\
\hline Brasil & 2009 & BRF S. A. & $1.268 .083 .397,48$ & $1.273 .940 .927,07$ & $1.273 .940 .927,07$ \\
\hline Brasil & 2012 & $\begin{array}{l}\text { Brookfield Energia } \\
\text { Renovável S.A. }\end{array}$ & $1.246 .310 .735,14$ & $1.248 .945 .528,80$ & $1.255 .074 .745,24$ \\
\hline Brasil & 2008 & Celulose Irani S.A. & $38.784 .998,52$ & $43.104 .960,68$ & $45.485 .279,30$ \\
\hline Brasil & 2012 & $\begin{array}{l}\text { Companhia de } \\
\text { Saneamento de Minas }\end{array}$ & $1.872 .345 .901,64$ & $1.872 .506 .229,99$ & $1.872 .742 .846,82$ \\
\hline
\end{tabular}




\begin{tabular}{c|c|l|r|r|r}
\hline & & Gerais - COPASA MG & & & \\
\hline Brasil & 2006 & $\begin{array}{l}\text { Cosan S.A. Indústria e } \\
\text { Comércio }\end{array}$ & $514.538 .162,42$ & $515.203 .551,28$ & $515.830 .941,40$ \\
\hline Brasil & 2006 & $\begin{array}{l}\text { CPFL Geração de Energia } \\
\text { S.A. }\end{array}$ & $1.740 .947 .372,99$ & $1.741 .745 .739,85$ & $1.742 .519 .146,42$ \\
\hline Brasil & 2012 & $\begin{array}{l}\text { CPFL Energias } \\
\text { Renováveis S.A. }\end{array}$ & $2.918 .685 .513,24$ & $2.930 .236 .146,97$ & $2.941 .349 .232,27$ \\
\hline Brasil & 2010 & $\begin{array}{l}\text { Desenvix Energias } \\
\text { Renováveis S.A. }\end{array}$ & $264.132 .997,26$ & $265.510 .179,75$ & $268.466 .821,31$ \\
\hline Brasil & 2008 & $\begin{array}{l}\text { EDP Energias do Brasil } \\
\text { S.A. }\end{array}$ & $1.503 .921 .593,87$ & $1.513 .284 .387,61$ & $1.516 .578 .901,64$ \\
\hline Brasil & 2010 & JBS S.A. & $6.688 .425 .261,39$ & $6.694 .892 .462,50$ & $6.697 .299 .300,87$ \\
\hline Brasil & 2006 & Klabin S.A. & $814.803 .857,71$ & $815.458 .634,20$ & $815.458 .634,20$ \\
\hline Brasil & 2007 & $\begin{array}{l}\text { Petrobras - Petróleo } \\
\text { Brasileiro S.A. }\end{array}$ & $34.642 .464 .296,44$ & $34.642 .464 .428,27$ & $34.642 .464 .512,13$ \\
\hline Brasil & 2009 & $\begin{array}{l}\text { Petrobras - Petróleo } \\
\text { Brasileiro S.A. }\end{array}$ & $42.684 .267 .156,91$ & $42.688 .687 .495,15$ & $42.696 .109 .601,08$ \\
\hline Brasil & 2012 & Renova Energia S.A. & $267.154 .317,58$ & $279.094 .874,56$ & $296.717 .064,40$ \\
\hline Brasil & 2006 & Tractebel Energia S.A. & $981.963 .660,93$ & $992.101 .911,67$ & $992.101 .911,67$ \\
\hline Brasil & 2012 & Tractebel Energia S.A. & $2.249 .977 .037,60$ & $2.259 .592 .161,58$ & $2.273 .782 .415,88$ \\
\hline Brasil & 2012 & Vale S.A. & $59.283 .880 .361,60$ & $59.284 .854 .614,41$ & $59.285 .496 .013,62$ \\
\hline TOTAIS & & & $\mathbf{1 6 0 . 7 7 2 . 4 3 2 . 3 8 6 , 5 4}$ & $\mathbf{1 6 0 . 8 7 3 . 4 6 2 . 4 0 5 , 4 4}$ & $\mathbf{1 6 0 . 9 4 4 . 5 6 5 . 8 5 8 , 3 3}$ \\
\hline Fonf Da & & &
\end{tabular}

Fonte: Dados da pesquisa (2015).

Tabela 11 - Variáveis para análise estatística dos dados - China

\begin{tabular}{|c|c|c|c|c|c|}
\hline $\begin{array}{c}\text { País } \\
\text { hospedeiro }\end{array}$ & $\begin{array}{c}\text { Ano de } \\
\text { aprovação }\end{array}$ & $\begin{array}{c}\text { Participante autorizado } \\
\text { (empresa chinesa) }\end{array}$ & $\begin{array}{l}\text { Patrimônio } \\
\text { PL original }\end{array}$ & $\begin{array}{c}\text { PL projetado } \\
\left(1^{\mathbf{a}} \text { fase }\right)\end{array}$ & $\begin{array}{c}\text { PL projetado } \\
\text { (geral) }\end{array}$ \\
\hline China & 2007 & Anhui Conch Cement Co., Ltd. & $685.150 .502,32$ & $685.157 .608,83$ & $685.157 .608,83$ \\
\hline China & 2008 & Anyang Iron \& Steel Co. Ltd. & $701.036 .894,84$ & $712.100 .102,21$ & $712.100 .102,21$ \\
\hline China & 2010 & Anyang Iron \& Steel Co., Ltd. & $1.068 .537 .712,47$ & $1.091 .916 .815,87$ & $1.091 .916 .815,87$ \\
\hline China & 2008 & $\begin{array}{l}\text { Beijing BBMG Group Co., } \\
\text { Ltd. }\end{array}$ & 805.092.161,94 & $810.873 .833,27$ & $813.933 .697,31$ \\
\hline China & 2008 & $\begin{array}{l}\text { China Datang Corporation } \\
\text { Renewable Power Co., Ltd. }\end{array}$ & $116.773 .106,10$ & 176.061.482,12 & 208.645.379,49 \\
\hline China & 2009 & $\begin{array}{l}\text { China Datang Corporation } \\
\text { Renewable Power Co., Ltd. }\end{array}$ & $297.963 .696,78$ & $375.534 .368,24$ & $488.200 .523,94$ \\
\hline China & 2010 & $\begin{array}{l}\text { China Datang Corporation } \\
\text { Renewable Power Co., Ltd. }\end{array}$ & $393.267 .427,73$ & $653.475 .695,08$ & $1.086 .470 .250,88$ \\
\hline China & 2011 & $\begin{array}{l}\text { China Datang Corporation } \\
\text { Renewable Power Co., Ltd. }\end{array}$ & $942.575 .244,16$ & $1.001 .843 .778,75$ & $1.075 .084 .819,06$ \\
\hline China & 2012 & $\begin{array}{l}\text { China Datang Corporation } \\
\text { Renewable Power Co., Ltd. }\end{array}$ & $1.112 .366 .813,42$ & $1.177 .570 .734,12$ & 1.268.717.686,22 \\
\hline China & 2007 & $\begin{array}{l}\text { China Longyuan Power Group } \\
\text { Co., Ltd. }\end{array}$ & $190.846 .563,42$ & $190.874 .585,33$ & $190.892 .239,99$ \\
\hline China & 2008 & $\begin{array}{l}\text { China Longyuan Power Group } \\
\text { Co., Ltd. }\end{array}$ & $268.318 .288,23$ & $304.297 .002,87$ & $324.064 .863,77$ \\
\hline China & 2009 & $\begin{array}{l}\text { China Longyuan Power Group } \\
\text { Co., Ltd. }\end{array}$ & $408.604 .654,28$ & $521.585 .266,35$ & $681.562 .795,28$ \\
\hline China & 2010 & $\begin{array}{l}\text { China Longyuan Power Group } \\
\text { Co., Ltd. }\end{array}$ & $2.235 .803 .561,06$ & $2.581 .428 .215,52$ & $3.072 .553 .924,21$ \\
\hline China & 2011 & $\begin{array}{l}\text { China Longyuan Power Group } \\
\text { Co., Ltd. }\end{array}$ & $2.632 .775 .386,47$ & $2.835 .448 .104,38$ & 3.082.379.508,65 \\
\hline China & 2012 & $\begin{array}{l}\text { China Longyuan Power Group } \\
\text { Co., Ltd. }\end{array}$ & $3.119 .766 .707,49$ & 3.158.457.071,76 & $3.217 .584 .066,18$ \\
\hline
\end{tabular}




\begin{tabular}{|c|c|c|c|c|c|}
\hline China & 2008 & $\begin{array}{l}\text { Chongqing Iron \& Steel Co., } \\
\text { Ltd. }\end{array}$ & $595.188 .488,19$ & $625.741 .996,63$ & $642.577 .117,46$ \\
\hline China & 2008 & $\begin{array}{l}\text { Chongqing Water Group Co., } \\
\text { Ltd. }\end{array}$ & $584.247 .776,01$ & $595.354 .728,21$ & $601.343 .147,93$ \\
\hline China & 2010 & $\begin{array}{l}\text { Chongqing Water Group Co., } \\
\text { Ltd. }\end{array}$ & 729.383.129,11 & $780.196 .124,64$ & $889.285 .381,32$ \\
\hline China & 2012 & $\begin{array}{l}\text { Chongqing Water Group Co., } \\
\text { Ltd. }\end{array}$ & 1.418.238.609,51 & $1.422 .609 .551,79$ & $1.432 .777 .502,21$ \\
\hline China & 2008 & $\begin{array}{l}\text { Datang International Power } \\
\text { Generation Co., Ltd. }\end{array}$ & 2.752.278.022,29 & 2.759.448.150,12 & 2.763.242.834,23 \\
\hline China & 2010 & \begin{tabular}{|l} 
Datang International Power \\
Generation Co., Ltd. \\
\end{tabular} & 2.661.900.224,97 & $2.743 .443 .525,58$ & $2.860 .190 .661,72$ \\
\hline China & 2011 & $\begin{array}{l}\text { Datang International Power } \\
\text { Generation Co., Ltd. }\end{array}$ & $3.476 .907 .910,88$ & $3.485 .745 .160,38$ & $3.496 .406 .538,55$ \\
\hline China & 2012 & $\begin{array}{l}\text { Datang International Power } \\
\text { Generation Co., Ltd. } \\
\end{array}$ & 4.747.277.337,31 & 4.751.741.629,49 & 4.758.330.149,98 \\
\hline China & 2010 & Fujian Cement Inc. & $149.029 .463,32$ & $154.511 .551,28$ & $154.511 .551,28$ \\
\hline China & 2007 & $\begin{array}{l}\text { Gansu Qilianshan Cement } \\
\text { Group Co., Ltd. }\end{array}$ & $85.195 .876,49$ & $85.199 .446,76$ & $85.199 .446,76$ \\
\hline China & 2010 & $\begin{array}{l}\text { GD Power Development Co., } \\
\text { Ltd. }\end{array}$ & 1.601.127.046,86 & $1.612 .208 .738,40$ & $1.627 .717 .014,70$ \\
\hline China & 2010 & \begin{tabular}{|l|} 
Guangdong Baolihua New \\
Energy Stock Co., Ltd.
\end{tabular} & $303.547 .515,44$ & $311.527 .955,66$ & $322.696 .184,95$ \\
\hline China & 2010 & $\begin{array}{l}\text { Guangdong Electric Power } \\
\text { Development Co., Ltd. }\end{array}$ & $946.584 .170,98$ & $952.762 .106,59$ & $961.941 .373,38$ \\
\hline China & 2007 & $\begin{array}{l}\text { Guangdong Shaoneng Group } \\
\text { Co., Ltd. }\end{array}$ & $235.950 .914,28$ & $235.956 .851,95$ & $235.960 .266,96$ \\
\hline China & 2012 & $\begin{array}{l}\text { Guangdong Shaoneng Group } \\
\text { Co., Ltd. }\end{array}$ & $368.251 .603,74$ & $376.236 .862,77$ & $388.021 .719,27$ \\
\hline China & 2011 & $\begin{array}{l}\text { Guangxi Guiguan Electric } \\
\text { Power Co., Ltd }\end{array}$ & $342.188 .591,97$ & $351.947 .001,10$ & $369.006 .264,95$ \\
\hline China & 2009 & $\begin{array}{l}\text { Guangzhou Zhujiang Brewery } \\
\text { Group Co., Ltd. }\end{array}$ & $287.729 .525,25$ & $290.486 .553,84$ & $292.928 .801,32$ \\
\hline China & 2011 & \begin{tabular}{|l|} 
Guodian Technology \& \\
Environment Group Co., Ltd.
\end{tabular} & $696.481 .622,92$ & 706.080.925,00 & $717.661 .653,79$ \\
\hline China & 2011 & $\begin{array}{l}\text { Henan Yinge Industrial } \\
\text { Investment Co. Ltd. }\end{array}$ & $230.941 .710,35$ & $235.206 .729,70$ & $235.206 .729,70$ \\
\hline China & 2011 & Huadian Energy Co., Ltd. & $383.299 .700,99$ & $496.892 .944,60$ & $496.892 .944,60$ \\
\hline China & 2007 & $\begin{array}{l}\text { Huadian Power International } \\
\text { Co., Ltd. }\end{array}$ & $1.299 .752 .822,53$ & $1.299 .780 .055,93$ & $1.299 .797 .259,20$ \\
\hline China & 2008 & $\begin{array}{l}\text { Huadian Power International } \\
\text { Co., Ltd. }\end{array}$ & $1.342 .413 .521,87$ & $1.358 .188 .658,48$ & $1.366 .861 .946,65$ \\
\hline China & 2009 & $\begin{array}{l}\text { Huadian Power International } \\
\text { Co., Ltd. } \\
\end{array}$ & $1.161 .713 .183,74$ & $1.174 .637 .005,68$ & $1.193 .442 .425,54$ \\
\hline China & 2010 & $\begin{array}{l}\text { Huadian Power International } \\
\text { Co., Ltd. }\end{array}$ & $1.601 .298 .664,16$ & $1.754 .831 .285,17$ & $1.987 .041 .865,04$ \\
\hline China & 2011 & $\begin{array}{l}\text { Huadian Power International } \\
\text { Co., Ltd. } \\
\end{array}$ & $1.801 .599 .629,01$ & $1.831 .031 .974,84$ & 1.859.944.203,46 \\
\hline China & 2012 & $\begin{array}{l}\text { Huadian Power International } \\
\text { Co., Ltd. } \\
\end{array}$ & 1.971.017.395,72 & 2.007.158.547,57 & $2.060 .496 .615,48$ \\
\hline China & 2007 & $\begin{array}{l}\text { Huaneng Power International, } \\
\text { Inc. }\end{array}$ & 4.059.678.300,07 & 4.059.698.924,37 & 4.059.711.766,51 \\
\hline China & 2010 & $\begin{array}{l}\text { Huaneng Power International, } \\
\text { Inc. }\end{array}$ & 4.187.372.219,25 & 4.197.656.956,65 & $4.212 .049 .935,27$ \\
\hline China & 2011 & $\begin{array}{l}\text { Huaneng Power International, } \\
\text { Inc. }\end{array}$ & $5.982 .904 .664,56$ & $5.998 .724 .727,14$ & $6.020 .721 .942,83$ \\
\hline China & 2012 & $\begin{array}{l}\text { Huaneng Power International, } \\
\text { Inc. }\end{array}$ & 6.128.751.104,55 & 6.157.718.927,36 & $6.200 .890 .509,14$ \\
\hline China & 2009 & \begin{tabular}{|l|} 
Huaneng Renewables \\
Corporation Ltd.
\end{tabular} & $176.535 .437,82$ & $187.128 .730,71$ & $201.127 .167,02$ \\
\hline China & 2010 & Huaneng Renewables & & & \\
\hline
\end{tabular}




\begin{tabular}{|c|c|c|c|c|c|}
\hline & & Corporation Ltd. & $263.726 .584,26$ & $567.437 .311,30$ & $1.001 .412 .274,17$ \\
\hline China & 2011 & \begin{tabular}{|l|} 
Huaneng Renewables \\
Corporation Ltd. \\
\end{tabular} & $597.697 .629,01$ & 723.315.390,36 & $874.862 .368,78$ \\
\hline China & 2012 & $\begin{array}{l}\text { Huaneng Renewables } \\
\text { Corporation Ltd. }\end{array}$ & 1.386.873.568,13 & 1.551.893.394,26 & 1.794.759.015,42 \\
\hline China & 2009 & Huaxin Cement Co., Ltd. & $428.894 .818,67$ & $440.449 .966,79$ & $440.449 .966,79$ \\
\hline China & 2010 & Huaxin Cement Co., Ltd. & $465.024 .797,17$ & $485.476 .655,35$ & $485.476 .655,35$ \\
\hline China & 2012 & Huayi Electric Co., Ltd. & $225.443 .377,16$ & $229.375 .159,17$ & $235.552 .498,49$ \\
\hline China & 2010 & Hubei Energy Group Co., Ltd. & $93.554 .093,96$ & $96.391 .182,81$ & $100.606 .570,77$ \\
\hline China & 2011 & Hubei Energy Group Co., Ltd. & $968.285 .745,40$ & $971.744 .739,66$ & $975.917 .717,45$ \\
\hline China & 2012 & Hubei Energy Group Co., Ltd. & 1.117.663.753,43 & $1.123 .884 .812,68$ & 1.138.356.617,14 \\
\hline China & 2012 & $\begin{array}{l}\text { Hubei Sanxia New Building } \\
\text { Materials Co., Ltd. }\end{array}$ & $94.370 .125,22$ & $96.927 .032,70$ & $96.927 .032,70$ \\
\hline China & 2012 & Hunan Valin Steel Co., Ltd. & 1.624.041.557,11 & 1.631.294.631,01 & 1.631.294.631,01 \\
\hline China & 2010 & $\begin{array}{l}\text { Inner Mongolia MengDian } \\
\text { HuaNeng Thermal Power Co., } \\
\text { Ltd. }\end{array}$ & $348.434 .883,39$ & $360.305 .399,62$ & $380.826 .551,54$ \\
\hline China & 2011 & $\begin{array}{l}\text { Inner Mongolia MengDian } \\
\text { HuaNeng Thermal Power Co., } \\
\text { Ltd. }\end{array}$ & $461.263 .268,89$ & $467.179 .516,63$ & $474.316 .958,51$ \\
\hline China & 2012 & $\begin{array}{l}\text { Inner Mongolia MengDian } \\
\text { HuaNeng Thermal Power Co., } \\
\text { Ltd. }\end{array}$ & $578.283 .818,96$ & $582.382 .144,24$ & $588.430 .561,11$ \\
\hline China & 2011 & Jilin Yatai (Group) Co., Ltd. & $822.754 .355,52$ & $829.254 .947,34$ & $829.254 .947,34$ \\
\hline China & 2012 & Jilin Yatai (Group) Co., Ltd. & $957.043 .066,16$ & $964.057 .948,07$ & $964.057 .948,07$ \\
\hline China & 2008 & $\begin{array}{l}\text { Liuzhou Chemical Industry } \\
\text { Co., Ltd. }\end{array}$ & $120.874 .988,29$ & $191.005 .456,10$ & $228.120 .969,05$ \\
\hline China & 2008 & $\begin{array}{l}\text { Maanshan Iron \& Steel Co., } \\
\text { Ltd. }\end{array}$ & 2.154.599.775,26 & $2.171 .618 .847,92$ & 2.171.618.847,92 \\
\hline China & 2009 & $\begin{array}{l}\text { Maanshan Iron \& Steel Co., } \\
\text { Ltd. }\end{array}$ & 2.742.108.940,32 & $2.760 .631 .656,83$ & $2.760 .631 .656,83$ \\
\hline China & 2009 & Nanjing Iron \& Steel Co., Ltd. & $460.049 .253,82$ & 471.138.204,54 & 471.138.204,54 \\
\hline China & 2007 & PetroChina Company Ltd. & $52.609 .451 .817,88$ & $52.610 .485 .947,55$ & 52.611.138.737,76 \\
\hline China & 2008 & PetroChina Company Ltd. & $63.429 .815 .525,80$ & $63.452 .523 .535,65$ & 63.464.977.051,04 \\
\hline China & 2011 & PetroChina Company Ltd. & $106.221 .779 .698,24$ & $106.237 .054 .104,11$ & 106.257.587.810,74 \\
\hline China & 2009 & $\begin{array}{l}\text { Shaanxi Xinghua Chemistry } \\
\text { Co., Ltd. } \\
\end{array}$ & $100.179 .352,20$ & $144.510 .337,67$ & $206.524 .657,23$ \\
\hline China & 2012 & $\begin{array}{l}\text { Shaanxi Xinghua Chemistry } \\
\text { Co., Ltd. }\end{array}$ & $149.839 .199,31$ & $158.745 .275,55$ & $175.924 .090,02$ \\
\hline China & 2008 & $\begin{array}{l}\text { Shanxi Taigang Stainless Steel } \\
\text { Co., Ltd. }\end{array}$ & $1.583 .176 .982,86$ & $1.593 .113 .230,26$ & $1.593 .113 .230,26$ \\
\hline China & 2008 & \begin{tabular}{|l|} 
Shanxi Zhangze Electric \\
Power Co., Ltd. \\
\end{tabular} & $325.973 .312,11$ & $344.168 .663,34$ & $354.147 .348,75$ \\
\hline China & 2010 & Shenergy Company Ltd. & $2.002 .738 .741,52$ & $2.030 .055 .749,46$ & $2.068 .284 .543,82$ \\
\hline China & 2011 & $\begin{array}{l}\text { Shenzhen Energy Group Co., } \\
\text { Ltd. }\end{array}$ & 1.558.473.108,87 & 1.627.136.666,80 & 1.714.556.453,24 \\
\hline China & 2012 & $\begin{array}{l}\text { Shenzhen Energy Group Co., } \\
\text { Ltd. }\end{array}$ & 1.775.233.895,53 & 1.777.268.948,61 & $1.780 .272 .333,77$ \\
\hline China & 2008 & Sichuan Chemical Co., Ltd. & $156.810 .375,50$ & $185.785 .763,73$ & 201.751.333,21 \\
\hline China & 2009 & Sichuan Lutianhua Co., Ltd. & & & \\
\hline
\end{tabular}




\begin{tabular}{|c|c|c|c|c|c|}
\hline & & & $255.055 .204,55$ & $280.469 .799,23$ & $316.022 .106,02$ \\
\hline China & 2009 & $\begin{array}{l}\text { Sichuan Minjiang Hydropower } \\
\text { Co., Ltd. }\end{array}$ & $58.429 .406,23$ & $61.879 .390,61$ & $68.669 .453,51$ \\
\hline China & 2010 & Sinohydro Group Ltd. & $1.001 .721 .158,19$ & 1.017.161.307,14 & $1.038 .769 .027,89$ \\
\hline China & 2011 & Sinohydro Group Ltd. & 1.219.983.284,01 & $1.238 .830 .405,44$ & $1.262 .706 .904,29$ \\
\hline China & 2009 & $\begin{array}{l}\text { Tangshan Jidong Cement Co., } \\
\text { Ltd. }\end{array}$ & $624.757 .988,19$ & $631.793 .865,04$ & $631.793 .865,04$ \\
\hline China & 2009 & Wuhan Iron and Steel Co., Ltd. & $2.916 .627 .782,23$ & $2.918 .384 .075,76$ & $2.918 .384 .075,76$ \\
\hline China & 2010 & Wuhan Iron and Steel Co., Ltd. & $2.784 .303 .075,05$ & $3.116 .660 .143,17$ & $3.116 .660 .143,17$ \\
\hline China & 2012 & Wuhan Iron and Steel Co., Ltd. & 4.395.018.290,94 & 4.409.108.647,46 & $4.409 .108 .647,46$ \\
\hline China & 2010 & $\begin{array}{l}\text { Wuhan Kaidi Electric Power } \\
\text { Co., Ltd. }\end{array}$ & $171.232 .209,27$ & $226.724 .641,50$ & $304.383 .541,23$ \\
\hline China & 2011 & $\begin{array}{l}\text { Wuhan Kaidi Electric Power } \\
\text { Co., Ltd. } \\
\end{array}$ & $222.049 .945,07$ & $271.042 .373,15$ & $330.147 .505,75$ \\
\hline China & 2012 & $\begin{array}{l}\text { Wuhan Kaidi Electric Power } \\
\text { Co., Ltd. }\end{array}$ & $308.493 .149,80$ & $309.576 .311,02$ & $311.665 .606,59$ \\
\hline China & 2010 & $\begin{array}{l}\text { Xinjiang Goldwind Science \& } \\
\text { Technology Co., Ltd. }\end{array}$ & $530.988 .219,49$ & $541.441 .531,31$ & $556.070 .421,46$ \\
\hline China & 2011 & $\begin{array}{l}\text { Xinjiang Goldwind Science \& } \\
\text { Technology Co., Ltd. }\end{array}$ & 1.503.211.178,30 & $1.507 .713 .188,68$ & 1.513.144.475,32 \\
\hline China & 2009 & $\begin{array}{l}\text { Xinjiang Urban Construction } \\
\text { Group. Co., Ltd. }\end{array}$ & $101.327 .776,47$ & $102.565 .665,36$ & $103.998 .046,39$ \\
\hline China & 2011 & \begin{tabular}{|l|} 
Xishan Xishan Coal and \\
Electricity Power Co., Ltd.
\end{tabular} & $1.430 .306 .449,49$ & $1.444 .920 .910,28$ & 1.444.920.910,28 \\
\hline China & 2007 & \begin{tabular}{|l|} 
Yangquan Coal Industry \\
(Group) Co., Ltd. \\
\end{tabular} & $302.521 .326,83$ & $302.841 .453,43$ & $303.043 .676,61$ \\
\hline China & 2008 & Yunnan Yuntianhua Co., Ltd. & $310.943 .440,40$ & $322.108 .170,43$ & $328.259 .987,00$ \\
\hline China & 2011 & Yunnan Yuntianhua Co., Ltd. & $523.091 .800,67$ & $532.934 .773,59$ & $532.934 .773,59$ \\
\hline China & 2012 & Zhejiang Guangsha Co., Ltd. & $281.915 .340,97$ & $292.679 .680,78$ & $314.636 .475,78$ \\
\hline China & 2011 & $\begin{array}{l}\text { Zhejiang Jingxing Paper Joint } \\
\text { Stock Co., Ltd. } \\
\end{array}$ & $207.887 .084,47$ & $211.377 .850,65$ & $211.377 .850,65$ \\
\hline China & 2006 & Zhejiang Juhua Co., Ltd. & $169.502 .594,93$ & $375.799 .580,55$ & $554.958 .737,30$ \\
\hline China & 2007 & Zhejiang Juhua Co., Ltd. & $169.094 .945,69$ & $169.591 .468,14$ & $169.904 .895,95$ \\
\hline China & 2008 & $\begin{array}{l}\text { Zhejiang Southeast Electric } \\
\text { Power Co., Ltd. }\end{array}$ & 1.071.267.534,41 & 1.144.136.578,13 & $1.184 .287 .749,60$ \\
\hline China & 2008 & \begin{tabular}{|l|} 
Zhengzhou Coal Industry \& \\
Electric Power Co., Ltd.
\end{tabular} & 138.291.693,98 & $175.135 .521,15$ & $175.135 .521,15$ \\
\hline China & 2012 & Zijin Mining Group Co., Ltd. & $3.060 .823 .661,38$ & $3.061 .749 .097,80$ & $3.063 .372 .885,78$ \\
\hline TOTAIS & & & 336.870.969.855,85 & 340.819.718.043,02 & 345.029.894.069,55 \\
\hline
\end{tabular}

Fonte: Dados da pesquisa (2015). 
Tabela 12 - Variáveis para análise estatística dos dados - Índia

\begin{tabular}{|c|c|c|c|c|c|}
\hline \begin{tabular}{c|c} 
País \\
hospedeiro
\end{tabular} & \begin{tabular}{|c|} 
Ano de \\
aprovação
\end{tabular} & $\begin{array}{l}\text { Participante autorizado } \\
\text { (empresa indiana) }\end{array}$ & $\begin{array}{l}\text { Patrimônio } \\
\text { PL original }\end{array}$ & $\begin{array}{l}\text { PL projetado } \\
\left(1^{\text {a }} \text { fase }\right)\end{array}$ & $\begin{array}{l}\text { PL projetado } \\
\text { (geral) }\end{array}$ \\
\hline Índia & 2012 & $\begin{array}{l}\text { A2Z Maintenance \& } \\
\text { Engineering Services Limited }\end{array}$ & $163.420 .253,79$ & $175.517 .203,34$ & 175.517.203,34 \\
\hline Índia & 2009 & ACC Limited & $712.348 .300,30$ & $714.774 .352,57$ & $714.774 .352,57$ \\
\hline Índia & 2012 & ACC Limited & $1.012 .362 .542,20$ & $1.013 .052 .799,85$ & 1.013.052.799,85 \\
\hline Índia & 2012 & Adani Enterprises Limited & $2.872 .762 .431,21$ & $2.875 .375 .094,69$ & $2.880 .414 .627,24$ \\
\hline Índia & 2009 & Adani Power Limited & $339.061 .537,83$ & $532.079 .225,69$ & $532.079 .225,69$ \\
\hline Índia & 2010 & Adani Power Limited & $951.153 .461,83$ & $1.097 .395 .225,00$ & $1.097 .395 .225,00$ \\
\hline Índia & 2008 & Alembic Limited & $53.697 .323,78$ & $54.562 .339,10$ & $54.562 .339,10$ \\
\hline Índia & 2007 & $\begin{array}{l}\text { Amarjothi Spinning Mills } \\
\text { Limited }\end{array}$ & 4.379.101,44 & $4.381 .608,82$ & $4.383 .170,08$ \\
\hline Índia & 2012 & $\begin{array}{l}\text { Amarjothi Spinning Mills } \\
\text { Limited }\end{array}$ & $6.707 .236,05$ & 7.084.037,07 & 7.640.129,99 \\
\hline Índia & 2005 & Ambuja Cements Limited & 456.174.741,34 & $460.519 .445,98$ & $460.519 .445,98$ \\
\hline Índia & 2007 & $\begin{array}{l}\text { Andhra Pradesh Paper Mills } \\
\text { Limited }\end{array}$ & $66.554 .847,78$ & $66.555 .220,15$ & $66.555 .220,15$ \\
\hline Índia & 2008 & $\begin{array}{l}\text { Andhra Pradesh Paper Mills } \\
\text { Limited } \\
\end{array}$ & $65.505 .011,13$ & $68.798 .415,41$ & $68.798 .415,41$ \\
\hline Índia & 2011 & Anik Industries Limited & $34.104 .378,41$ & $34.647 .209,21$ & $35.226 .041,40$ \\
\hline Índia & 2009 & $\begin{array}{l}\text { Ansal Properties and } \\
\text { Infrastructure Limited } \\
\end{array}$ & $178.613 .048,77$ & $180.889 .892,68$ & $180.889 .892,68$ \\
\hline Índia & 2006 & Apollo Tyres Limited & $117.557 .195,63$ & $118.634 .723,09$ & 118.634.723,09 \\
\hline Índia & 2006 & Ashok Leyland Limited & $261.903 .206,11$ & $263.581 .394,20$ & $265.163 .745,05$ \\
\hline Índia & 2010 & Ashok Leyland Limited & $603.936 .278,00$ & $606.459 .985,06$ & $606.459 .985,06$ \\
\hline Índia & 2012 & Asian Electronics Limited & $2.057 .899,62$ & $4.270 .752,00$ & $4.270 .752,00$ \\
\hline Índia & 2012 & Asian Star Company Limited & $62.771 .591,27$ & $63.572 .064,95$ & $63.572 .064,95$ \\
\hline Índia & 2011 & $\begin{array}{l}\text { Associated Stone Industries } \\
\text { (Kotah) Limited }\end{array}$ & $23.675 .783,33$ & $24.188 .590,64$ & $24.188 .590,64$ \\
\hline Índia & 2007 & $\begin{array}{l}\text { Bannari Amman Spinning Mills } \\
\text { Limited }\end{array}$ & $28.480 .682,47$ & $28.569 .560,38$ & $28.569 .560,38$ \\
\hline Índia & 2011 & $\begin{array}{l}\text { Bannari Amman Spinning Mills } \\
\text { Limited }\end{array}$ & $32.823 .561,19$ & $34.052 .650,65$ & $34.052 .650,65$ \\
\hline Índia & 2012 & $\begin{array}{l}\text { Bannari Amman Spinning Mills } \\
\text { Limited }\end{array}$ & $28.204 .214,72$ & $29.138 .178,06$ & $29.138 .178,06$ \\
\hline Índia & 2007 & Bannari Amman Sugars Limited & $75.291 .912,87$ & $75.294 .406,83$ & $75.294 .406,83$ \\
\hline Índia & 2008 & Bannari Amman Sugars Limited & 73.641.106,08 & $80.600 .385,28$ & $80.600 .385,28$ \\
\hline Índia & 2010 & Bannari Amman Sugars Limited & $112.671 .634,20$ & $122.525 .344,69$ & $122.525 .344,69$ \\
\hline Índia & 2007 & BF Utilities Limited & $112.041 .433,34$ & $112.043 .764,08$ & $112.045 .215,36$ \\
\hline Índia & 2012 & Bhagyanagar India Limited & $31.906 .445,49$ & $33.225 .787,70$ & $33.225 .787,70$ \\
\hline Índia & 2007 & Bharat Electronics Limited & 461.445.101,06 & $461.445 .794,79$ & 461.445.794,79 \\
\hline Índia & 2011 & Bharat Electronics Limited & $811.027 .471,04$ & $811.387 .629,00$ & $811.387 .629,00$ \\
\hline Índia & 2007 & Bharat Forge Limited & $257.489 .809,83$ & $257.490 .659,87$ & 257.491.189,16 \\
\hline
\end{tabular}




\begin{tabular}{|c|c|c|c|c|c|}
\hline Índia & 2009 & $\begin{array}{l}\text { Bharat Petroleum Corporation } \\
\text { Limited }\end{array}$ & $1.976 .106 .592,49$ & 1.977.131.639,19 & 1.977.131.639,19 \\
\hline Índia & 2012 & Bhushan Steel Limited & $1.172 .660 .940,20$ & $1.172 .902 .440,41$ & $1.172 .902 .440,41$ \\
\hline Índia & 2006 & Birla Corporation Limited & $71.326 .135,06$ & $72.662 .638,88$ & $72.662 .638,88$ \\
\hline Índia & 2011 & C. Mahendra Exports Limited & $109.314 .700,90$ & $110.560 .962,69$ & $110.560 .962,69$ \\
\hline Índia & 2012 & C. Mahendra Exports Limited & $127.136 .217,80$ & $128.306 .933,93$ & $130.034 .707,75$ \\
\hline Índia & 2012 & CEAT Limited & $99.878 .846,07$ & $100.783 .964,04$ & $100.783 .964,04$ \\
\hline Índia & 2006 & $\begin{array}{l}\text { Century Textiles and Industries } \\
\text { Limited }\end{array}$ & $157.553 .232,00$ & $164.593 .470,56$ & $164.593 .470,56$ \\
\hline Índia & 2006 & CESC Limited & $684.805 .570,68$ & $684.982 .222,82$ & $684.982 .222,82$ \\
\hline Índia & 2007 & CESC Limited & $659.395 .529,90$ & $659.399 .655,81$ & $659.399 .655,81$ \\
\hline Índia & 2008 & CESC Limited & $713.558 .158,43$ & $713.948 .374,95$ & $713.948 .374,95$ \\
\hline Índia & 2010 & $\begin{array}{l}\text { Chennai Petroleum Corporation } \\
\text { Limited }\end{array}$ & $569.914 .694,51$ & $574.105 .264,23$ & $574.105 .264,23$ \\
\hline Índia & 2009 & Claris Lifesciences Limited & $77.451 .054,94$ & $84.617 .148,08$ & $84.617 .148,08$ \\
\hline Índia & 2008 & $\begin{array}{l}\text { Dalmia Bharat Sugar and } \\
\text { Industries Limited }\end{array}$ & $184.270 .959,93$ & $188.773 .013,11$ & $188.773 .013,11$ \\
\hline Índia & 2011 & Dalmia Bharat Limited & $495.635 .989,38$ & $499.518 .549,79$ & $499.518 .549,79$ \\
\hline Índia & 2006 & $\begin{array}{l}\text { DCM Shriram Consolidated } \\
\text { Limited }\end{array}$ & $97.446 .068,58$ & $99.303 .744,51$ & $99.303 .744,51$ \\
\hline Índia & 2007 & \begin{tabular}{|l} 
DCM Shriram Consolidated \\
Limited
\end{tabular} & $95.759 .573,21$ & $95.766 .955,02$ & $95.766 .955,02$ \\
\hline Índia & 2012 & D C W Limited & $62.868 .063,38$ & $64.806 .101,16$ & $64.806 .101,16$ \\
\hline Índia & 2009 & $\begin{array}{l}\text { Deepak Fertilisers \& } \\
\text { Petrochemicals Corporation } \\
\text { Limited }\end{array}$ & $120.285 .287,42$ & $121.787 .129,30$ & $121.787 .129,30$ \\
\hline Índia & 2010 & $\begin{array}{l}\text { Deepak Fertilisers \& } \\
\text { Petrochemicals Corporation } \\
\text { Limited }\end{array}$ & $152.099 .668,01$ & 195.457.587,74 & $195.457 .587,74$ \\
\hline Índia & 2012 & \begin{tabular}{|l|} 
Deepak Fertilisers \& \\
Petrochemicals Corporation \\
Limited \\
\end{tabular} & $178.860 .536,93$ & 193.955.896,52 & 193.955.896,52 \\
\hline Índia & 2008 & Deepak Spinners Limited & $8.509 .067,26$ & $11.071 .804,12$ & $11.071 .804,12$ \\
\hline Índia & 2009 & DLF Limited & $3.585 .735 .807,33$ & $3.611 .721 .996,14$ & $3.646 .061 .272,23$ \\
\hline Índia & 2011 & DLF Limited & $4.160 .889 .019,92$ & $4.166 .952 .600,12$ & $4.174 .267 .785,87$ \\
\hline Índia & 2007 & $\begin{array}{l}\text { Dwarikesh Sugar Industries } \\
\text { Limited }\end{array}$ & $27.752 .069,10$ & $27.757 .412,41$ & $27.757 .412,41$ \\
\hline Índia & 2008 & $\begin{array}{l}\text { Dwarikesh Sugar Industries } \\
\text { Limited }\end{array}$ & $21.130 .360,29$ & $27.014 .181,16$ & $27.014 .181,16$ \\
\hline Índia & 2010 & $\begin{array}{l}\text { Dwarikesh Sugar Industries } \\
\text { Limited }\end{array}$ & $24.359 .968,49$ & $25.200 .428,59$ & 26.717.064,39 \\
\hline Índia & 2007 & E.I.D. Parry India Limited & $160.961 .809,46$ & $160.973 .020,92$ & $160.973 .020,92$ \\
\hline Índia & 2006 & Electro Steel Castings Limited & $141.047 .978,48$ & $144.652 .767,53$ & $144.652 .767,53$ \\
\hline Índia & 2012 & Electrotherm India Limited & $2.745 .649,25$ & $4.845 .209,53$ & $4.845 .209,53$ \\
\hline Índia & 2012 & EMCO Limited & $75.500 .278,62$ & $76.661 .620,15$ & $77.266 .117,82$ \\
\hline
\end{tabular}




\begin{tabular}{|c|c|c|c|c|c|}
\hline Índia & 2008 & Empee Distilleries Limited & $38.106 .677,25$ & $40.250 .367,01$ & $41.384 .883,11$ \\
\hline Índia & 2010 & $\begin{array}{l}\text { Energy Development Company } \\
\text { Limited }\end{array}$ & $20.105 .476,22$ & $23.427 .801,47$ & $23.427 .801,47$ \\
\hline Índia & 2007 & Essar Oil Limited & $517.665 .139,46$ & $517.682 .712,96$ & $517.682 .712,96$ \\
\hline Índia & 2010 & Ester Industries Limited & $29.245 .579,53$ & $30.415 .059,03$ & $32.525 .420,35$ \\
\hline Índia & 2011 & Gayatri Projects Limited & $74.965 .436,80$ & 75.901.674,61 & $75.901 .674,61$ \\
\hline Índia & 2011 & GeeCee Ventures Limited & $40.081 .620,87$ & $40.558 .412,39$ & $40.558 .412,39$ \\
\hline Índia & 2011 & $\begin{array}{l}\text { Gillanders Arbuthnot \& Co. } \\
\text { Limited }\end{array}$ & $33.313 .011,97$ & $35.332 .432,04$ & $35.332 .432,04$ \\
\hline Índia & 2006 & $\begin{array}{l}\text { Godawari Power and Ispat } \\
\text { Limited }\end{array}$ & $18.630 .717,43$ & $19.450 .648,27$ & $19.450 .648,27$ \\
\hline Índia & 2007 & $\begin{array}{l}\text { Godawari Power and Ispat } \\
\text { Limited }\end{array}$ & $35.854 .264,66$ & $35.860 .816,32$ & $35.860 .816,32$ \\
\hline Índia & 2008 & $\begin{array}{l}\text { Godawari Power And Ispat } \\
\text { Limited }\end{array}$ & $62.065 .454,33$ & $77.489 .519,37$ & $77.489 .519,37$ \\
\hline Índia & 2006 & Godrej Industries Limited & $78.619 .802,61$ & $79.376 .219,62$ & $79.376 .219,62$ \\
\hline Índia & 2011 & $\begin{array}{l}\text { Gokul Refoils and Solvent } \\
\text { Limited }\end{array}$ & $71.522 .666,48$ & $72.072 .872,59$ & $72.072 .872,59$ \\
\hline Índia & 2006 & Graphite India Limited & $88.356 .195,17$ & $88.484 .234,63$ & $88.484 .234,63$ \\
\hline Índia & 2006 & Grasim Industries Limited & $897.005 .218,44$ & $899.393 .632,63$ & $899.393 .632,63$ \\
\hline Índia & 2007 & Grasim Industries Limited & $1.147 .611 .208,70$ & $1.147 .613 .170,44$ & 1.147.613.170,44 \\
\hline Índia & 2011 & Grasim Industries Limited & $2.302 .823 .438,26$ & $2.304 .062 .900,26$ & $2.304 .062 .900,26$ \\
\hline Índia & 2007 & Greenply Industries Limited & $18.798 .897,90$ & $18.801 .159,65$ & $18.801 .159,65$ \\
\hline Índia & 2006 & $\begin{array}{l}\text { Gujarat Alkalies \& Chemicals } \\
\text { Limited }\end{array}$ & $134.075 .428,85$ & $138.649 .804,06$ & $138.649 .804,06$ \\
\hline Índia & 2007 & $\begin{array}{l}\text { Gujarat Alkalies \& Chemicals } \\
\text { Limited }\end{array}$ & $153.560 .435,30$ & $153.562 .193,58$ & $153.562 .193,58$ \\
\hline Índia & 2012 & $\begin{array}{l}\text { Gujarat Alkalies \& Chemicals } \\
\text { Limited }\end{array}$ & $236.984 .693,22$ & $243.403 .688,87$ & $243.403 .688,87$ \\
\hline Índia & 2005 & $\begin{array}{l}\text { Gujarat Fluorochemicals } \\
\text { Limited }\end{array}$ & $70.559 .273,41$ & $573.089 .016,15$ & $573.089 .016,15$ \\
\hline Índia & 2008 & $\begin{array}{l}\text { Gujarat Fluorochemicals } \\
\text { Limited }\end{array}$ & $176.313 .134,88$ & $180.327 .100,05$ & $182.528 .436,82$ \\
\hline Índia & 2012 & $\begin{array}{l}\text { Gujarat Fluorochemicals } \\
\text { Limited }\end{array}$ & $400.634 .961,86$ & 401.382.013,04 & $402.484 .530,93$ \\
\hline Índia & 2010 & Gujarat Gas Company Limited & $116.781 .231,15$ & $118.767 .050,77$ & $118.767 .050,77$ \\
\hline Índia & 2008 & Gujarat Hotels Limited & $1.543 .238,81$ & $2.033 .372,36$ & $2.033 .372,36$ \\
\hline Índia & 2011 & $\begin{array}{l}\text { Gujarat Mineral Development } \\
\text { Corporation Limited }\end{array}$ & $263.850 .102,15$ & $265.546 .330,66$ & $267.592 .683,84$ \\
\hline Índia & 2012 & $\begin{array}{l}\text { Gujarat Mineral Development } \\
\text { Corporation Limited }\end{array}$ & $301.530 .929,04$ & $305.913 .975,14$ & $305.913 .975,14$ \\
\hline Índia & 2009 & $\begin{array}{l}\text { Gujarat Narmada Valley } \\
\text { Fertilizer Company Limited }\end{array}$ & $299.004 .020,73$ & $333.939 .656,04$ & $333.939 .656,04$ \\
\hline Índia & 2012 & Gujarat NRE Coke Limited & $230.915 .455,43$ & $236.247 .787,17$ & $236.247 .787,17$ \\
\hline Índia & 2009 & $\begin{array}{l}\text { Gujarat State Fertilizers \& } \\
\text { Chemicals Limited }\end{array}$ & $286.735 .082,28$ & $286.825 .950,38$ & $286.825 .950,38$ \\
\hline Índia & 2010 & $\begin{array}{l}\text { Gujarat State Fertilisers \& } \\
\text { Chemicals Limited }\end{array}$ & $352.956 .734,62$ & $354.986 .193,24$ & $354.986 .193,24$ \\
\hline Índia & 2012 & $\begin{array}{l}\text { Gujarat State Fertilisers \& } \\
\text { Chemicals Limited }\end{array}$ & $518.363 .358,46$ & $524.668 .945,94$ & $524.668 .945,94$ \\
\hline Índia & 2012 & Gujarat State Petronet Limited & & & \\
\hline
\end{tabular}




\begin{tabular}{|c|c|c|c|c|c|}
\hline & & & $377.480 .668,91$ & $382.919 .966,50$ & $382.919 .966,50$ \\
\hline Índia & 2007 & Hindustan Zinc Limited & 1.318.227.615,69 & $1.318 .234 .295,35$ & $1.318 .234 .295,35$ \\
\hline Índia & 2009 & Hindustan Zinc Limited & $2.131 .443 .135,21$ & $2.148 .638 .964,48$ & 2.171.362.278,51 \\
\hline Índia & 2012 & Hindustan Zinc Limited & $3.962 .248 .674,13$ & $3.972 .638 .018,61$ & $3.987 .970 .887,99$ \\
\hline Índia & 2011 & I.C.S.A. India Limited & $133.545 .325,29$ & $134.849 .730,97$ & $134.849 .730,97$ \\
\hline Índia & 2007 & India Cements Limited & $373.679 .261,51$ & $373.685 .930,56$ & $373.685 .930,56$ \\
\hline Índia & 2010 & India Glycols Limited & $63.446 .857,85$ & $76.950 .063,51$ & $76.950 .063,51$ \\
\hline Índia & 2007 & Indian Acrylics Limited & $21.779 .793,77$ & $21.785 .936,82$ & $21.785 .936,82$ \\
\hline Índia & 2007 & Indian Sucrose Limited & $5.796 .889,29$ & 5.798.264,72 & $5.798 .264,72$ \\
\hline Índia & 2006 & Indowind Energy Limited & $9.739 .990,71$ & $10.253 .659,22$ & $10.737 .993,37$ \\
\hline Índia & 2011 & Indowind Energy Limited & $22.359 .027,31$ & $24.032 .263,22$ & $26.050 .877,82$ \\
\hline Índia & 2006 & ITC Limited & $1.709 .883 .400,71$ & $1.711 .436 .477,02$ & $1.711 .436 .477,02$ \\
\hline Índia & 2007 & ITC Limited & $1.840 .108 .215,84$ & $1.840 .123 .858,91$ & $1.840 .123 .858,91$ \\
\hline Índia & 2009 & ITC Limited & $2.082 .539 .350,76$ & 2.095.756.977,73 & 2.095.756.977,73 \\
\hline Índia & 2010 & ITC Limited & $2.380 .069 .137,73$ & $2.383 .301 .442,93$ & $2.387 .824 .893,35$ \\
\hline Índia & 2011 & ITC Limited & $2.601 .264 .812,58$ & $2.605 .566 .539,23$ & $2.605 .566 .539,23$ \\
\hline Índia & 2006 & Jai Balaji Industries Limited & $11.996 .344,77$ & $14.129 .737,85$ & $14.129 .737,85$ \\
\hline Índia & 2012 & Jain Irrigation Systems Limited & $258.487 .315,91$ & $261.458 .718,37$ & 262.531.391,91 \\
\hline Índia & 2006 & Jaiprakash Associates Limited & 483.180.674,69 & $485.034 .487,36$ & $485.034 .487,36$ \\
\hline Índia & 2010 & \begin{tabular}{|l|} 
Jayaswal Neco Industries \\
Limited \\
\end{tabular} & $97.576 .956,21$ & $102.121 .663,76$ & $102.121 .663,76$ \\
\hline Índia & 2007 & Jindal Saw Limited & $165.556 .262,08$ & $165.565 .333,70$ & $165.565 .333,70$ \\
\hline Índia & 2008 & Jindal Stainless Limited & $290.194 .239,79$ & $297.445 .650,93$ & $297.445 .650,93$ \\
\hline Índia & 2006 & Jindal Steel \& Power Limited & $353.020 .184,70$ & $370.848 .345,48$ & $370.848 .345,48$ \\
\hline Índia & 2012 & Jindal Steel \& Power Limited & 2.669.543.092,93 & 2.671.775.214,25 & $2.671 .775 .214,25$ \\
\hline Índia & 2009 & Jocil Limited & $13.159 .030,83$ & $15.810 .879,31$ & 19.315.146,83 \\
\hline Índia & 2007 & JSW Energy Limited & $193.593 .519,49$ & $193.698 .558,97$ & $193.698 .558,97$ \\
\hline Índia & 2012 & JSW Energy Limited & $840.179 .917,16$ & $890.367 .156,04$ & $890.367 .156,04$ \\
\hline Índia & 2007 & JSW Steel Limited & $978.045 .642,26$ & $978.144 .955,70$ & $978.144 .955,70$ \\
\hline Índia & 2007 & K M Sugar Mills Limited & $7.308 .809,89$ & $7.316 .511,12$ & 7.316.511,12 \\
\hline Índia & 2011 & K.P.R. Mill Limited & $94.233 .225,80$ & $96.797 .492,83$ & $96.797 .492,83$ \\
\hline Índia & 2009 & K.S. Oils Limited & $135.768 .793,86$ & $137.517 .952,25$ & $137.517 .952,25$ \\
\hline Índia & 2010 & K.S. Oils Limited & $237.422 .362,36$ & $238.567 .721,52$ & $240.170 .594,71$ \\
\hline
\end{tabular}




\begin{tabular}{|c|c|c|c|c|c|}
\hline Índia & 2011 & K.S. Oils Limited & $172.121 .073,50$ & $174.392 .027,89$ & $174.392 .027,89$ \\
\hline Índia & 2012 & K.S. Oils Limited & $172.121 .073,50$ & $172.711 .446,06$ & $172.711 .446,06$ \\
\hline Índia & 2006 & Kalyani Steels Limited & $68.211 .413,60$ & $71.106 .926,60$ & $71.106 .926,60$ \\
\hline Índia & 2012 & Kamdhenu Ispat Limited & $11.771 .668,14$ & $12.251 .645,37$ & $12.960 .008,47$ \\
\hline Índia & 2008 & $\begin{array}{l}\text { KCP Sugar and Industries } \\
\text { Corporation Limited }\end{array}$ & $24.921 .198,19$ & $26.837 .078,36$ & $26.837 .078,36$ \\
\hline Índia & 2006 & Kesoram Industries Limited & $77.145 .808,67$ & $77.356 .678,26$ & $77.356 .678,26$ \\
\hline Índia & 2009 & Kilburn Chemicals Limited & $5.640 .161,26$ & $6.185 .789,55$ & $6.185 .789,55$ \\
\hline Índia & 2012 & Kilburn Chemicals Limited & 9.293.320,82 & $9.477 .014,21$ & $9.477 .014,21$ \\
\hline Índia & 2008 & KRBL Limited & $56.756 .069,14$ & $58.470 .957,90$ & $58.470 .957,90$ \\
\hline Índia & 2009 & KRBL Limited & $62.711 .328,57$ & $64.772 .544,38$ & $64.772 .544,38$ \\
\hline Índia & 2012 & KRBL Limited & $105.708 .267,03$ & $106.233 .868,07$ & $106.233 .868,07$ \\
\hline Índia & 2007 & Lanco Infratech Limited & $261.065 .260,22$ & $261.070 .637,44$ & $261.070 .637,44$ \\
\hline Índia & 2008 & Lanco Infratech Limited & $288.387 .159,00$ & $290.169 .251,29$ & $291.112 .397,28$ \\
\hline Índia & 2012 & Lanco Infratech Limited & $693.663 .330,33$ & $694.621 .689,08$ & $696.470 .254,77$ \\
\hline Índia & 2012 & M and B Switchgears Limited & $15.705 .924,13$ & $16.099 .438,27$ & $16.858 .482,58$ \\
\hline Índia & 2012 & Madras Cements Limited & $302.222 .270,70$ & $311.293 .067,57$ & $311.293 .067,57$ \\
\hline Índia & 2010 & Magma Fincorp Limited & $77.100 .964,77$ & $77.953 .641,39$ & $77.953 .641,39$ \\
\hline Índia & 2011 & Magma Fincorp Limited & $115.609 .230,66$ & $116.863 .444,73$ & $116.863 .444,73$ \\
\hline Índia & 2008 & Mahalaxmi Rubtech Limited & $1.292 .075,35$ & $4.000 .557,02$ & $5.433 .980,88$ \\
\hline Índia & 2012 & Mahalaxmi Rubtech Limited & $5.943 .680,19$ & $6.803 .701,87$ & $6.803 .701,87$ \\
\hline Índia & 2008 & Malu Paper Mills Limited & $6.833 .464,67$ & $13.930 .081,57$ & $13.930 .081,57$ \\
\hline Índia & 2011 & Man Industries India Limited & $78.212 .187,82$ & $78.910 .375,63$ & 78.910.375,63 \\
\hline Índia & 2011 & Mangalam Cement Limited & $62.372 .474,30$ & $63.694 .686,19$ & $63.694 .686,19$ \\
\hline Índia & 2011 & $\begin{array}{l}\text { Mangalam Timber Products } \\
\text { Limited }\end{array}$ & $3.022 .764,19$ & $20.097 .776,42$ & $20.097 .776,42$ \\
\hline Índia & 2011 & Maruti Suzuki India Limited & $2.261 .017 .185,00$ & $2.262 .342 .623,91$ & 2.262.342.623,91 \\
\hline Índia & 2012 & Maruti Suzuki India Limited & $2.310 .392 .698,96$ & $2.312 .784 .543,56$ & 2.312.784.543,56 \\
\hline Índia & 2007 & Mawana Sugars Limited & $33.158 .703,11$ & $33.181 .195,78$ & $33.181 .195,78$ \\
\hline Índia & 2008 & Mawana Sugars Limited & $42.227 .765,90$ & $43.823 .352,19$ & $43.823 .352,19$ \\
\hline Índia & 2009 & MMTC Limited & 205.265.551,91 & $207.566 .319,53$ & $207.566 .319,53$ \\
\hline Índia & 2006 & $\begin{array}{l}\text { Monnet Ispat and Energy } \\
\text { Limited }\end{array}$ & $76.028 .367,26$ & $81.472 .941,67$ & $81.472 .941,67$ \\
\hline Índia & 2007 & MSP Steel \& Power Limited & $14.379 .577,61$ & $14.387 .226,42$ & $14.387 .226,42$ \\
\hline Índia & 2011 & Mukand Limited & $337.792 .535,33$ & $341.917 .410,02$ & $341.917 .410,02$ \\
\hline Índia & 2011 & Nagarjuna Agrichem Limited & $32.022 .363,32$ & $32.698 .480,65$ & $32.698 .480,65$ \\
\hline
\end{tabular}




\begin{tabular}{|c|c|c|c|c|c|}
\hline Índia & 2007 & $\begin{array}{l}\text { Nahar Industrial Enterprises } \\
\text { Limited }\end{array}$ & $93.743 .255,63$ & $93.749 .056,60$ & $93.749 .056,60$ \\
\hline Índia & 2005 & Nahar Spinning Mills Limited & $101.549 .627,86$ & $105.279 .571,12$ & $105.279 .571,12$ \\
\hline Índia & 2011 & Nakoda Limited & 44.612.004,08 & $45.395 .823,05$ & $45.395 .823,05$ \\
\hline Índia & 2008 & Nava Bharat Ventures Limited & $130.303 .218,97$ & $131.521 .919,08$ & $132.166 .898,09$ \\
\hline Índia & 2007 & $\begin{array}{l}\text { Navin Fluorine International } \\
\text { Limited }\end{array}$ & $33.467 .508,50$ & $33.830 .185,57$ & $33.830 .185,57$ \\
\hline Índia & 2009 & NHPC Limited & $2.908 .646 .923,05$ & $2.935 .980 .187,71$ & $2.996 .032 .724,28$ \\
\hline Índia & 2012 & NMDC Limited & $3.597 .452 .930,05$ & $3.598 .830 .833,59$ & $3.598 .830 .833,59$ \\
\hline Índia & 2012 & NTPC Limited & $10.966 .835 .484,25$ & $10.967 .117 .423,64$ & $10.967 .661 .252,84$ \\
\hline Índia & 2006 & OCL India Limited & $41.773 .792,51$ & $44.298 .708,54$ & $44.298 .708,54$ \\
\hline Índia & 2007 & $\begin{array}{l}\text { Oil and Natural gas Corporation } \\
\text { Limited }\end{array}$ & $11.530 .481 .678,17$ & 11.530.496.026,96 & 11.530.496.026,96 \\
\hline Índia & 2008 & $\begin{array}{l}\text { Oil and Natural Gas } \\
\text { Corporation Limited }\end{array}$ & $12.283 .149 .204,47$ & $12.283 .997 .245,46$ & $12.283 .997 .245,46$ \\
\hline Índia & 2009 & $\begin{array}{l}\text { Oil and Natural Gas } \\
\text { Corporation Limited }\end{array}$ & $13.690 .966 .442,82$ & $13.691 .390 .668,82$ & $13.691 .390 .668,82$ \\
\hline Índia & 2010 & $\begin{array}{l}\text { Oil and Natural Gas } \\
\text { Corporation Limited }\end{array}$ & $16.693 .155 .465,97$ & $16.700 .816 .981,60$ & 16.711.538.891,78 \\
\hline Índia & 2012 & $\begin{array}{l}\text { Oil and Natural gas Corporation } \\
\text { Limited }\end{array}$ & $20.110 .878 .803,40$ & 20.208.340.327,19 & 20.208.424.710,58 \\
\hline Índia & 2009 & Oil India Limited & $1.385 .229 .088,59$ & $1.390 .798 .904,19$ & $1.390 .798 .904,19$ \\
\hline Índia & 2012 & Orient Abrasives Limited & $19.416 .452,10$ & 19.757.349,31 & $20.260 .454,44$ \\
\hline Índia & 2012 & $\begin{array}{l}\text { Orient Green Power Company } \\
\text { Limited }\end{array}$ & 175.214.309,06 & $182.133 .357,60$ & $188.700 .509,55$ \\
\hline Índia & 2008 & Oudh Sugar Mills Limited & $16.818 .615,54$ & $17.837 .465,01$ & $18.398 .855,65$ \\
\hline Índia & 2008 & Patspin India Limited & $7.969 .496,83$ & $9.220 .870,86$ & $9.220 .870,86$ \\
\hline Índia & 2006 & Phillips Carbon Black Limited & $17.467 .939,76$ & $19.570 .702,71$ & $19.570 .702,71$ \\
\hline Índia & 2006 & Polyplex Corporation Limited & $63.406 .660,27$ & $66.518 .653,77$ & $66.518 .653,77$ \\
\hline Índia & 2011 & Polyplex Corporation Limited & $253.816 .671,37$ & $255.172 .421,17$ & $255.172 .421,17$ \\
\hline Índia & 2009 & $\begin{array}{l}\text { Rai Saheb Rekhchand Mohota } \\
\text { Spinning \& Weaving Mills } \\
\text { Limited }\end{array}$ & 4.925.636,32 & $7.280 .756,91$ & $7.280 .756,91$ \\
\hline Índia & 2008 & Rama Paper Mills Limited & $5.912 .353,69$ & $7.828 .431,45$ & $8.842 .487,26$ \\
\hline Índia & 2009 & $\begin{array}{l}\text { Rashtriya Chemicals and } \\
\text { Fertilizers Limited }\end{array}$ & 248.227.308,33 & $352.195 .565,35$ & $497.636 .065,88$ \\
\hline Índia & 2009 & $\begin{array}{l}\text { Ratnamani Metals and Tubes } \\
\text { Limited }\end{array}$ & $42.784 .739,62$ & 45.298.826,91 & 45.298.826,91 \\
\hline Índia & 2006 & REI Agro Limited & $60.435 .067,87$ & $60.929 .427,12$ & $60.929 .427,12$ \\
\hline Índia & 2010 & REI Agro Limited & $148.408 .261,57$ & $150.321 .758,13$ & $150.321 .758,13$ \\
\hline Índia & 2011 & REI Agro Limited & $373.104 .379,38$ & $374.089 .541,05$ & $374.089 .541,05$ \\
\hline Índia & 2012 & REI Agro Limited & $403.467 .120,22$ & $406.358 .100,10$ & 406.358.100,10 \\
\hline Índia & 2011 & Relaxo Footwears Limited & $21.272 .520,28$ & $21.864 .447,09$ & $21.864 .447,09$ \\
\hline
\end{tabular}




\begin{tabular}{|c|c|c|c|c|c|}
\hline Índia & 2006 & Reliance Industries Limited & $9.461 .840 .258,24$ & $9.465 .003 .072,01$ & $9.465 .003 .072,01$ \\
\hline Índia & 2007 & Reliance Industries Limited & $11.790 .686 .735,53$ & $11.790 .689 .027,32$ & $11.790 .689 .027,32$ \\
\hline Índia & 2011 & Reliance Industries Limited & $24.349 .096 .767,97$ & $24.351 .834 .767,06$ & $24.352 .295 .250,41$ \\
\hline Índia & 2012 & \begin{tabular}{|l|} 
Riddhi Siddhi Gluco Biols \\
Limited
\end{tabular} & $148.907 .385,23$ & $152.653 .395,43$ & $152.653 .395,43$ \\
\hline Índia & 2010 & Ruchi Infrastructure Limited & $33.149 .398,06$ & $35.605 .072,40$ & $35.605 .072,40$ \\
\hline Índia & 2011 & Ruchi Soya Industries Limited & $349.124 .262,73$ & $353.133 .080,11$ & $353.133 .080,11$ \\
\hline Índia & 2012 & Ruchi Soya Industries Limited & $327.809 .046,25$ & $333.017 .058,49$ & $333.017 .058,49$ \\
\hline Índia & 2012 & $\begin{array}{l}\text { Rural Electrification } \\
\text { Corporation Limited }\end{array}$ & 2.182.359.695,91 & $2.185 .844 .182,45$ & $2.185 .844 .182,45$ \\
\hline Índia & 2012 & Sadbhav Engineering Limited & $172.940 .318,70$ & $173.790 .756,05$ & $175.045 .853,99$ \\
\hline Índia & 2011 & Sanwaria Agro Oils Limited & $34.434 .683,68$ & $35.192 .513,65$ & $35.192 .513,65$ \\
\hline Índia & 2011 & $\begin{array}{l}\text { Savita Oil Technologies } \\
\text { Limited } \\
\end{array}$ & $62.441 .385,01$ & $63.321 .207,68$ & $63.321 .207,68$ \\
\hline Índia & 2012 & $\begin{array}{l}\text { SEL Manufacturing Company } \\
\text { Limited }\end{array}$ & $161.299 .942,24$ & $164.679 .029,98$ & $164.679 .029,98$ \\
\hline Índia & 2007 & Sesa Goa Limited & $278.109 .651,93$ & $278.124 .194,08$ & $278.124 .194,08$ \\
\hline Índia & 2010 & Shilpa Medicare Limited & $16.671 .415,78$ & $20.984 .812,12$ & $20.984 .812,12$ \\
\hline Índia & 2007 & $\begin{array}{l}\text { Shree Bhawani Paper Mills } \\
\text { Limited }\end{array}$ & $5.059 .900,94$ & $5.061 .712,02$ & $5.061 .712,02$ \\
\hline Índia & 2006 & Shree Cements Limited & $65.081 .709,84$ & $73.134 .260,36$ & $73.134 .260,36$ \\
\hline Índia & 2007 & Shreyans Industries Limited & $4.817 .913,79$ & $4.819 .541,74$ & $4.819 .541,74$ \\
\hline Índia & 2011 & Shreyans Industries Limited & $10.445 .305,89$ & $11.498 .811,13$ & $11.498 .811,13$ \\
\hline Índia & 2012 & Shriram EPC & $107.669 .797,72$ & $109.035 .360,25$ & $111.050 .693,54$ \\
\hline Índia & 2007 & Simbhaoli Sugar Mills Limited & $17.525 .798,52$ & $17.531 .581,63$ & $17.531 .581,63$ \\
\hline Índia & 2009 & Sintex Industries limited & $253.102 .544,45$ & $255.738 .558,68$ & $255.738 .558,68$ \\
\hline Índia & 2011 & SPML Infra Limited & $69.368 .234,47$ & $71.108 .575,35$ & $71.108 .575,35$ \\
\hline Índia & 2012 & SPML Infra Limited & $73.146 .848,19$ & $75.790 .581,99$ & $75.790 .581,99$ \\
\hline Índia & 2009 & Sree Sakthi Paper Mills Limited & $5.243 .298,63$ & $5.654 .933,21$ & $5.654 .933,21$ \\
\hline Índia & 2005 & SRF Limited & $79.629 .245,42$ & 721.789.557,34 & $721.789 .557,34$ \\
\hline Índia & 2009 & SRF Limited & $144.780 .602,50$ & 148.441.138,78 & $148.441 .138,78$ \\
\hline Índia & 2012 & Srinivasa Hatcheries Limited & $13.442 .846,25$ & $13.668 .809,28$ & 14.002.291,51 \\
\hline Índia & 2009 & Sterlite Industries India Limited & 3.802.381.324,22 & 3.804.278.641,69 & 3.804.278.641,69 \\
\hline Índia & 2012 & Suashish Diamonds Limited & $107.725 .945,67$ & $107.899 .714,39$ & $107.899 .714,39$ \\
\hline Índia & 2009 & Surana Corporation Limited & $20.287 .736,91$ & $21.515 .400,57$ & $21.515 .400,57$ \\
\hline Índia & 2012 & Surana Industries Limited & $114.378 .203,23$ & $115.933 .415,87$ & $115.933 .415,87$ \\
\hline Índia & 2007 & $\begin{array}{l}\text { Suryachakra Power Corporation } \\
\text { Limited }\end{array}$ & $11.012 .981,77$ & $11.029 .007,04$ & $11.029 .007,04$ \\
\hline Índia & 2007 & Suzlon Energy Limited & $607.271 .764,74$ & $607.276 .572,21$ & $607.276 .572,21$ \\
\hline
\end{tabular}




\begin{tabular}{|c|c|c|c|c|c|}
\hline Índia & 2012 & Swan Energy Limited & $27.706 .965,65$ & $29.238 .730,54$ & $29.238 .730,54$ \\
\hline Índia & 2006 & $\begin{array}{l}\text { Tamil Nadu Newsprint \& } \\
\text { Papers Limited }\end{array}$ & $96.887 .588,92$ & $98.536 .832,80$ & $98.536 .832,80$ \\
\hline Índia & 2011 & $\begin{array}{l}\text { Tamil Nadu Newsprint \& } \\
\text { Papers Limited }\end{array}$ & $144.709 .397,87$ & $152.352 .353,11$ & $152.352 .353,11$ \\
\hline Índia & 2007 & $\begin{array}{l}\text { Tamil Nadu Newsprint \& } \\
\text { Papers Limited } \\
\end{array}$ & $99.639 .819,22$ & $99.641 .686,99$ & $99.641 .686,99$ \\
\hline Índia & 2012 & $\begin{array}{l}\text { Tamil Nadu Newsprint \& } \\
\text { Papers Limited } \\
\end{array}$ & $143.077 .389,42$ & $144.730 .223,63$ & $144.730 .223,63$ \\
\hline Índia & 2006 & Tata Chemicals Limited & $411.521 .573,09$ & $411.853 .905,39$ & 411.853.905,39 \\
\hline Índia & 2007 & Tata Chemicals Limited & $444.502 .094,72$ & $444.503 .919,79$ & $444.503 .919,79$ \\
\hline Índia & 2007 & Tata Motors Limited & $1.334 .579 .593,35$ & 1.334.583.791,09 & 1.334.583.791,09 \\
\hline Índia & 2010 & Tata Power Company Limited & $2.026 .077 .248,33$ & $2.036 .254 .206,13$ & $2.036 .254 .206,13$ \\
\hline Índia & 2012 & Tata Power Company Limited & $1.829 .133 .234,61$ & $1.840 .504 .290,58$ & $1.840 .504 .290,58$ \\
\hline Índia & 2006 & Tata Sponge Iron Limited & 27.273.551,23 & $28.734 .323,24$ & $28.734 .323,24$ \\
\hline Índia & 2009 & Tata Steel Limited & 4.114.301.424,98 & $4.120 .682 .233,09$ & 4.120.682.233,09 \\
\hline Índia & 2010 & $\begin{array}{l}\text { Techno Electric \& Engineering } \\
\text { Company Limited }\end{array}$ & $76.158 .083,84$ & $83.312 .625,51$ & $93.325 .050,83$ \\
\hline Índia & 2007 & Torrent Power Limited & $467.586 .434,44$ & 467.999.271,90 & 467.999.271,90 \\
\hline Índia & 2012 & Torrent Power Limited & $849.088 .662,88$ & $922.832 .823,00$ & $922.832 .823,00$ \\
\hline Índia & 2006 & $\begin{array}{l}\text { Transport Corporation of India } \\
\text { Limited }\end{array}$ & $30.044 .811,14$ & $30.311 .789,96$ & $30.311 .789,96$ \\
\hline Índia & 2006 & $\begin{array}{l}\text { Triveni Engineering and } \\
\text { Industries Limited }\end{array}$ & $102.423 .785,76$ & $106.354 .652,31$ & 106.354.652,31 \\
\hline Índia & 2007 & $\begin{array}{l}\text { Triveni Engineering and } \\
\text { Industries Limited }\end{array}$ & $124.874 .305,50$ & $124.885 .540,89$ & $124.885 .540,89$ \\
\hline Índia & 2012 & $\begin{array}{l}\text { Ultramarine \& Pigments } \\
\text { Limited }\end{array}$ & $12.068 .928,10$ & $12.217 .372,51$ & $12.436 .450,68$ \\
\hline Índia & 2007 & UltraTech Cement Limited & $305.609 .665,11$ & $305.611 .848,69$ & $305.611 .848,69$ \\
\hline Índia & 2006 & United Phosphorus Limited & $236.872 .214,28$ & $239.437 .740,53$ & $239.437 .740,53$ \\
\hline Índia & 2012 & United Spirits Limited & $687.136 .067,46$ & $687.507 .807,15$ & $687.507 .807,15$ \\
\hline Índia & 2007 & $\begin{array}{l}\text { Upper Ganges Sugar \& } \\
\text { Industries Limited }\end{array}$ & $28.161 .271,32$ & $28.171 .589,72$ & $28.171 .589,72$ \\
\hline Índia & 2006 & Usha Martin Limited & $113.147 .173,70$ & $115.646 .334,67$ & $115.646 .334,67$ \\
\hline Índia & 2012 & $\begin{array}{l}\text { Ushdev International Pvt } \\
\text { Limited } \\
\end{array}$ & $76.372 .507,32$ & $77.288 .201,42$ & 78.639.606,99 \\
\hline Índia & 2012 & Varun Industries Limited & 44.787.068,23 & 45.297.521,10 & 45.297.521,10 \\
\hline Índia & 2012 & Videocon Industries Limited & $1.134 .907 .431,94$ & $1.135 .626 .054,02$ & 1.137.012.194,79 \\
\hline Índia & 2007 & Vikash Metal \& Power Limited & $12.832 .042,06$ & $12.837 .733,52$ & $12.841 .326,22$ \\
\hline Índia & 2006 & $\begin{array}{l}\text { Vishal Exports Overseas } \\
\text { Limited } \\
\end{array}$ & $37.479 .123,07$ & $38.853 .339,67$ & $38.853 .339,67$ \\
\hline Índia & 2008 & Welspun India Limited & $83.072 .548,25$ & $86.460 .757,98$ & $86.460 .757,98$ \\
\hline Índia & 2007 & West Coast Paper Mills Limited & $40.128 .662,29$ & $40.133 .281,97$ & $40.133 .281,97$ \\
\hline Índia & 2007 & Yash Papers Limited & & & \\
\hline
\end{tabular}




\begin{tabular}{c|c|r|r|r|r}
\hline & & & $6.540 .186,14$ & $6.543 .636,46$ & $6.545 .620,89$ \\
\hline Índia & 2012 & ZF Steering Gear India Limited & $29.748 .636,73$ & $30.553 .593,87$ & $31.210 .660,08$ \\
\hline TOTAIS & & & $\mathbf{2 3 4 . 4 5 4 . 8 8 9 . 1 0 5 , 4 7}$ & $\mathbf{2 3 6 . 9 7 8 . 6 9 6 . 2 6 6 , 2 7}$ & $\mathbf{2 3 7 . 3 4 1 . 3 3 9 . 9 4 3 , 2 2}$ \\
\hline
\end{tabular}

Fonte: Dados da pesquisa (2015).

Para tratamento e avaliação estatística das variáveis quantitativas ('PL original', 'PL projetado ( $1^{\text {a }}$ fase)' e, 'PL projetado (geral)'), utilizou-se, inicialmente, os testes nãoparamétricos de Shapiro-Wilk e de Kolmogorov-Smirnov, cujo “objetivo é determinar se uma amostra é proveniente de uma população com distribuição normal" (Fávero, Belfiore, Silva, \& Chan, 2009, p. 112).

O teste de Shapiro-Wilk foi utilizado para testar se a distribuição da variável é ou não normal em amostras pequenas (menores que 30 observações) e o teste de Kolmogorov-Smirnov foi utilizado para a mesma finalidade, para amostras grandes (maiores que 30 observações) (Maroco, 2007; Hair Jr., Black, Babin, Anderson, \& Tatham, 2009; Fávero et al., 2009).

A utilização de ambos os testes se fez necessária, pois, de acordo com Fávero et al. (2009, p. 112), o teste de Kolmogorov-Smirnov "é um teste de aderência que compara a distribuição de frequência acumulada de um conjunto de valores observados da amostra com uma distribuição esperada ou teórica”. Porém, Maroco (2007, p. 136) ressalta que os programas estatísticos (a exemplo do SPSS) fornecem tal resultado a partir do teste de Shapiro-Wilk "sempre que a dimensão da amostra seja menor ou igual a 50".

Com a realização dos testes mencionados, verificou-se que os dados de todas as variáveis não se distribuem normalmente. Assim, em sequência, foi aplicado o teste não-paramétrico de Wilcoxon, que é utilizado, segundo Maroco (2007, p. 214), "quando se pretende comparar a medida de tendência central da população sob estudo com um determinado valor teórico". Para tanto, Fávero et al. (2009, p. 158) ressaltam que "se a variável for ordinal ou até mesmo contínua, porém não apresentar distribuição normal, deve-se utilizar o teste de Wilcoxon”.

Deve-se ressaltar também que, pelo fato de terem sido utilizadas amostras emparelhadas para tratamento e avaliação estatística dos dados, com o propósito de realizar comparações entre duas médias populacionais formadas pelos mesmos indivíduos, optou-se por não atribuir qualquer procedimento para o tratamento de possíveis outliers existentes na amostra da pesquisa, visto que o mesmo indivíduo afeta, da mesma maneira, as duas amostras utilizadas. 
Nesse sentido, Fávero et al. (2009, p. 56) explicam que:

\begin{abstract}
É importante ressaltar que o tratamento de outliers é desejado quando o pesquisador tem por interesse investigar o comportamento da variável em questão sem a influência de observações com valores discrepantes. Por outro lado, se a intenção for justamente a de analisar o comportamento dessas observações discrepantes..., talvez a eliminação dessas observações ou a substituição de seus valores não sejam boas soluções.
\end{abstract}

Assim, adotou-se enquanto valores originais as situações reais do Patrimônio Líquido ('PL original'), comparativamente aos valores projetados no mesmo grupo de contas 'PL projetado ( $1^{\text {a }}$ fase)' e, 'PL projetado (geral)', das companhias, enquanto variáveis contínuas que foram analisadas estatisticamente.

O tratamento e avaliação dos dados quantitativos coletados foram realizados com a utilização do sistema estatístico SPSS 22 (IBM SPSS Statistics 22), necessário à aplicação de testes estatísticos que forneceram evidências para a verificação das hipóteses estatísticas da pesquisa, tais sejam:

$\mathrm{H}_{0}$ - A mensuração ao valor justo das RCEs enquanto ativos, no momento da aprovação dos projetos de MDLs, não causa impacto estatisticamente significativo no patrimônio das empresas brasileiras, chinesas e indianas.

$\mathrm{H}_{1}$ - A mensuração ao valor justo das RCEs enquanto ativos, no momento da aprovação dos projetos de MDLs, causa impacto estatisticamente significativo no patrimônio das empresas brasileiras, chinesas e indianas.

A utilização das ferramentas estatísticas anteriormente elencadas propicia ao pesquisador a obtenção de informações sobre a direção das diferenças para cada par de variáveis que, no caso da pesquisa em questão, gira em torno da verificação de existência ou não de diferenças estatisticamente significativas, com a realização da mensuração ao valor justo das RCEs no grupo de contas patrimoniais (Patrimônio Líquido) das empresas que compõem a amostra da pesquisa. 


\subsection{Resultados da Pesquisa Empírica}

Inicialmente, testou-se a normalidade das variáveis com o apoio do SPSS, aplicando-se os testes não-paramétricos de Shapiro-Wilk para amostra pequena (Brasil) e KolmogorovSmirnov para amostras maiores (China e Índia), com um nível de significância de 5\%. A hipótese nula $\left(\mathrm{H}_{0}\right)$ afirma que a amostra provém de uma distribuição normal, e a hipótese alternativa $\left(\mathrm{H}_{1}\right)$ afirma que a amostra não provém de uma distribuição normal. (Maroco, 2007; Fávero et al., 2009). Os resultados dos testes são apresentados nas Tabelas 13, 14 e 15, respectivamente para Brasil, China e Índia, na sequência:

Tabela 13 - Teste de Normalidade - Brasil

\begin{tabular}{l|c|c|c}
\hline \multirow{2}{*}{ Variáveis } & \multicolumn{3}{|c}{ Shapiro-Wilk } \\
\cline { 2 - 4 } & Estatística & $\begin{array}{c}\text { Graus de } \\
\text { Liberdade }\end{array}$ & Significância \\
\hline Patrimônio Original & 0,521 & 20 & 0,000 \\
\hline Patrimônio Projetado 1 & 0,521 & 20 & 0,000 \\
\hline Patrimônio Projetado 2 & 0,521 & 20 & 0,000 \\
\hline
\end{tabular}

Fonte: Dados da pesquisa (2015).

De posse dos resultados obtidos para o Brasil, pode-se inferir que as três variáveis (Patrimônio Original; Patrimônio Projetado 1 e Patrimônio Projetado 2) não atendem ao pressuposto da normalidade, pois a significância do resultado estatístico ficou abaixo do nível de significância estabelecido no teste, o que nos leva a rejeitar a hipótese nula, cujas probabilidades foram inferiores a 0,001 para todas as variáveis.

Tabela 14 - Teste de Normalidade - China

\begin{tabular}{l|c|c|c}
\hline \multirow{2}{*}{ Variáveis } & \multicolumn{3}{|c}{ Kolmogorov-Smirnov } \\
\cline { 2 - 4 } & Estatística & $\begin{array}{c}\text { Graus de } \\
\text { Liberdade }\end{array}$ & Significância \\
\hline Patrimônio Original & 0,408 & 102 & 0,000 \\
\hline Patrimônio Projetado 1 & 0,409 & 102 & 0,000 \\
\hline Patrimônio Projetado 2 & 0,410 & 102 & 0,000 \\
\hline
\end{tabular}

Fonte: Dados da pesquisa (2015).

Da mesma forma, com os resultados obtidos para a China, pode-se concluir que as três variáveis (Patrimônio Original; Patrimônio Projetado 1 e Patrimônio Projetado 2) também não atendem ao pressuposto da normalidade, pois a significância do resultado estatístico ficou 
abaixo do nível de significância estabelecido no teste, o que nos leva a rejeitar a hipótese nula, cujas probabilidades foram inferiores a 0,001 para todas as variáveis.

Tabela 15 - Teste de Normalidade - Índia

\begin{tabular}{l|c|c|c}
\hline \multirow{2}{*}{ Variáveis } & \multicolumn{3}{|c}{ Kolmogorov-Smirnov } \\
\cline { 2 - 4 } & Estatística & $\begin{array}{c}\text { Graus de } \\
\text { Liberdade }\end{array}$ & Significância \\
\hline Patrimônio Original & 0,374 & 255 & 0,000 \\
\hline Patrimônio Projetado 1 & 0,373 & 255 & 0,000 \\
\hline Patrimônio Projetado 2 & 0,373 & 255 & 0,000 \\
\hline
\end{tabular}

Fonte: Dados da pesquisa (2015).

Igualmente, com os resultados obtidos para a Índia, compreendeu-se que as três variáveis (Patrimônio Original; Patrimônio Projetado 1 e Patrimônio Projetado 2) também não atendem ao pressuposto da normalidade, pois a significância do resultado estatístico ficou abaixo do nível de significância estabelecido no teste, o que nos leva a rejeitar a hipótese nula, cujas probabilidades foram inferiores a 0,001 para todas as variáveis.

Tendo em vista que para a aplicação dos testes paramétricos é necessário que todas as variáveis atendam ao pressuposto da normalidade, recorreu-se ao teste não-paramétrico Wilcoxon, para comparar duas médias populacionais, a partir de amostras emparelhadas. (Fávero et al., 2009). O teste de média é capaz de explicar se a direção das diferenças para cada par de variáveis é estatisticamente idêntica ou não. Assim foram comparadas as médias das variáveis 'Patrimônio Original' com 'Patrimônio Projetado 1" e também 'Patrimônio Original' com 'Patrimônio Projetado 2', com um nível de significância de 5\%. A hipótese nula $\left(\mathrm{H}_{0}\right)$ afirma não haver diferença entre os grupos e a hipótese alternativa $\left(\mathrm{H}_{1}\right)$ afirma haver diferenças. (Maroco, 2007; Fávero et al., 2009). Os resultados dos testes são apresentados nas Tabelas 16 e 17 para o Brasil, 18 e 19 para a China e, 20 e 21 para a Índia, a seguir: 
Tabela 16 - Ranks - Brasil

\begin{tabular}{l|l|r|r|r}
\hline \multicolumn{1}{c|}{ Variáveis } & \multicolumn{1}{|c|}{$\mathrm{N}$} & Rank Médio & \multicolumn{1}{c}{ Soma de Ranks } \\
\hline \multirow{4}{*}{$\begin{array}{l}\text { Patrimônio Projetado 1 } \\
\text { Patrimônio Original }\end{array}$} & Ranks Negativos & $0^{\mathrm{a}}$ & 0,00 & 0,00 \\
\cline { 2 - 5 } & Ranks Positivos & $20^{\mathrm{b}}$ & 10,50 & 210,00 \\
\cline { 2 - 5 } & Empates & $0^{\mathrm{c}}$ & & \\
\cline { 2 - 5 } & Total & 20 & & \\
\hline \multirow{3}{*}{$\begin{array}{l}\text { Patrimônio Projetado 2 } \\
\text { Patrimônio Original }\end{array}$} & Ranks Negativos & $0^{\mathrm{d}}$ & 0,00 & 0,00 \\
\cline { 2 - 5 } & Ranks Positivos & $20^{\mathrm{e}}$ & 10,50 & 210,00 \\
\cline { 2 - 5 } & Empates & $0^{\mathrm{f}}$ & & \\
\cline { 2 - 5 } & Total & 20 & & \\
\hline
\end{tabular}

a. Patrimônio Projetado (1) < Patrimônio Original

b. Patrimônio Projetado (1) > Patrimônio Original

c. Patrimônio Projetado (1) = Patrimônio Original

d. Patrimônio Projetado (2) < Patrimônio Original

e. Patrimônio Projetado (2) > Patrimônio Original

f. Patrimônio Projetado (2) = Patrimônio Original

Fonte: Dados da pesquisa (2015).

Tabela 17 - Estatísticas dos Testes de Wilcoxon ${ }^{\mathrm{a}}$ - Brasil

\begin{tabular}{r|r|r}
\hline & $\begin{array}{l}\text { Patrimônio Projetado 1 } \\
\text { Patrimônio Original }\end{array}$ & $\begin{array}{l}\text { Patrimônio Projetado 2 - } \\
\text { Patrimônio Original }\end{array}$ \\
\hline $\mathrm{Z}$ & $-3,920^{\mathrm{b}}$ & $-3,920^{\mathrm{b}}$ \\
\hline $\begin{array}{r}\text { Significância assintótica. } \\
\text { (Bicaudal) }\end{array}$ & 0,000 & 0,000 \\
\hline
\end{tabular}

a. Testes de sinais de Wilcoxon.

b. Baseados em ranks negativos.

Fonte: Dados da pesquisa (2015).

De posse dos resultados obtidos com a aplicação dos testes nas empresas brasileiras, percebese que os pares de variáveis 'Patrimônio Original' e 'Patrimônio Projetado 1', assim como, 'Patrimônio Original' e 'Patrimônio Projetado 2', possuem variações estatisticamente significativas entre si, conforme Tabela 16. Os resultados expostos na Tabela 17 corroboram com essa afirmação, pois a significância do resultado estatístico ficou abaixo do nível de significância estabelecido no teste, o que nos leva a rejeitar a hipótese nula, cujas probabilidades foram inferiores a 0,001 para os dois pares de variáveis das empresas brasileiras. 
Tabela 18 - Ranks - China

\begin{tabular}{l|l|r|r|r}
\hline \multicolumn{1}{c|}{ Variáveis } & \multicolumn{1}{|c|}{$\mathrm{N}$} & Rank Médio & Soma de Ranks \\
\hline \multirow{4}{*}{$\begin{array}{l}\text { Patrimônio Projetado 1 } \\
\text { Patrimônio Original }\end{array}$} & Ranks Negativos & $0^{\mathrm{a}}$ & 0,00 & 0,00 \\
\cline { 2 - 5 } & Ranks Positivos & $102^{\mathrm{b}}$ & 51,50 & 5253,00 \\
\cline { 2 - 5 } & Empates & $0^{\mathrm{c}}$ & & \\
\cline { 2 - 5 } & Total & 102 & & \\
\hline \multirow{3}{*}{$\begin{array}{l}\text { Patrimônio Projetado 2 } \\
\text { Patrimônio Original }\end{array}$} & Ranks Negativos & $0^{\mathrm{d}}$ & 0,00 & 0,00 \\
\cline { 2 - 5 } & Ranks Positivos & $102^{\mathrm{e}}$ & 51,50 & 5253,00 \\
\cline { 2 - 5 } & Empates & $0^{\mathrm{f}}$ & & \\
\cline { 2 - 5 } & Total & 102 & & \\
\hline
\end{tabular}

a. Patrimônio Projetado (1) < Patrimônio Original

b. Patrimônio Projetado (1) > Patrimônio Original

c. Patrimônio Projetado $(1)=$ Patrimônio Original

d. Patrimônio Projetado (2) < Patrimônio Original

e. Patrimônio Projetado (2) > Patrimônio Original

f. Patrimônio Projetado (2) = Patrimônio Original

Fonte: Dados da pesquisa (2015).

Tabela 19 - Estatísticas dos Testes de Wilcoxon ${ }^{\mathrm{a}}$ - China

\begin{tabular}{r|r|r}
\hline & $\begin{array}{l}\text { Patrimônio Projetado 1 - } \\
\text { Patrimônio Original }\end{array}$ & $\begin{array}{l}\text { Patrimônio Projetado 2 } \\
\text { Patrimônio Original }\end{array}$ \\
\hline $\mathrm{Z}$ & $-8,768^{\mathrm{b}}$ & $-8,768^{\mathrm{b}}$ \\
\hline $\begin{array}{r}\text { Significância assintótica. } \\
\text { (Bicaudal) }\end{array}$ & 0,000 & 0,000 \\
\hline
\end{tabular}

a. Testes de sinais de Wilcoxon.

b. Baseados em ranks negativos.

Fonte: Dados da pesquisa (2015).

Da mesma forma, os resultados obtidos a partir da aplicação dos testes às empresas chinesas, evidenciam que os pares de variáveis 'Patrimônio Original' e 'Patrimônio Projetado 1', assim como, 'Patrimônio Original' e 'Patrimônio Projetado 2', possuem variações estatisticamente significativas entre si, conforme Tabela 18. Os resultados expostos na Tabela 19 apoiam essa afirmação, pois a significância do resultado estatístico ficou abaixo do nível de significância estabelecido no teste, o que nos leva a rejeitar a hipótese nula, cujas probabilidades foram inferiores a 0,001 para os dois pares de variáveis das empresas chinesas. 
Tabela 20 - Ranks - Índia

\begin{tabular}{l|l|r|r|r}
\hline \multicolumn{1}{c|}{ Variáveis } & \multicolumn{1}{|c|}{$\mathrm{N}$} & Rank Médio & Soma de Ranks \\
\hline \multirow{3}{*}{$\begin{array}{c}\text { Patrimônio Projetado 1 } \\
\text { Patrimônio Original }\end{array}$} & Ranks Negativos & $0^{\mathrm{a}}$ & 0,00 & 0,00 \\
\cline { 2 - 5 } & Ranks Positivos & $255^{\mathrm{b}}$ & 128,00 & 32640,00 \\
\cline { 2 - 5 } & Empates & $0^{\mathrm{c}}$ & & \\
\cline { 2 - 5 } & Total & 255 & & 0,00 \\
\hline \multirow{3}{*}{$\begin{array}{l}\text { Patrimônio Projetado 2 }- \\
\text { Patrimônio Original }\end{array}$} & Ranks Negativos & $0^{\mathrm{d}}$ & 0,00 & 32640,00 \\
\cline { 2 - 5 } & Ranks Positivos & $255^{\mathrm{e}}$ & 128,00 & \\
\cline { 2 - 5 } & Empates & $0^{\mathrm{f}}$ & & \\
\cline { 2 - 5 } & Total & 255 & & \\
\hline
\end{tabular}

a. Patrimônio Projetado (1) < Patrimônio Original

b. Patrimônio Projetado (1) > Patrimônio Original

c. Patrimônio Projetado $(1)=$ Patrimônio Original

d. Patrimônio Projetado (2) < Patrimônio Original

e. Patrimônio Projetado (2) > Patrimônio Original

f. Patrimônio Projetado (2) = Patrimônio Original

Fonte: Dados da pesquisa (2015).

Tabela 21 - Estatísticas dos Testes de Wilcoxon ${ }^{\mathrm{a}}$ - Índia

\begin{tabular}{r|r|r}
\hline $\mathrm{Z}$ & $\begin{array}{l}\text { Patrimônio Projetado 1 - } \\
\text { Patrimônio Original }\end{array}$ & $\begin{array}{l}\text { Patrimônio Projetado 2 - } \\
\text { Patrimônio Original }\end{array}$ \\
\hline Significância assintótica. & $-13,843^{\mathrm{b}}$ & $-13,843^{\mathrm{b}}$ \\
(Bicaudal) & 0,000 & 0,000 \\
\hline
\end{tabular}

a. Testes de sinais de Wilcoxon.

b. Baseados em ranks negativos.

Fonte: Dados da pesquisa (2015).

Igualmente, os resultados obtidos a partir da aplicação dos testes às empresas indianas, demonstram que os pares de variáveis 'Patrimônio Original' e 'Patrimônio Projetado 1', assim como, 'Patrimônio Original' e 'Patrimônio Projetado 2', possuem variações estatisticamente significativas entre si, conforme Tabela 20. Os resultados expostos na Tabela 21 confirmam essa afirmação, pois a significância do resultado estatístico ficou abaixo do nível de significância estabelecido no teste, o que nos leva a rejeitar a hipótese nula, cujas probabilidades foram inferiores a 0,001 para os dois pares de variáveis das empresas indianas.

Tais resultados nos fornecem indícios de que a mensuração ao valor justo das RCEs, e seu reconhecimento enquanto ativo intangível, para respectiva evidenciação nas demonstrações contábeis, pode representar um impacto positivo no grupo de contas patrimoniais das empresas brasileiras, chinesas e indianas que evidenciaram suas informações financeiras aos usuários externos através das entidades reguladoras de mercados mobiliários de seus respectivos países e que, também, implementaram projetos de MDLs em seus processos produtivos durante o período de 2005 a 2012. 
Assim, a utilização da técnica do valor presente, apontada por parte da literatura como uma das mais apropriadas para atingir os objetivos econômicos da mensuração contábil, de fato, teria possibilitado, com base nos valores de mercado das RCEs, conhecer o valor presente dos fluxos de caixa esperados com a comercialização desse ativo já no momento de registro dos projetos de MDLs junto ao Conselho Executivo.

Dessa forma, teria sido possível realizar o reconhecimento das RCEs enquanto ativo intangível, desenvolvido junto ao processo produtivo empresarial de entidades localizadas no Brasil, na China e na Índia, possibilitando, assim, a evidenciação dos efeitos patrimoniais dos fluxos de caixa futuros esperados com a implementação de projetos de MDLs junto às demonstrações financeiras das entidades que compuseram a amostra da pesquisa, durante todo o período de sua realização.

Porém, na atualidade, em conformidade com as normas internacionais de contabilidade, que foram adotadas por parte do Brasil, da China e da Índia, os ativos intangíveis desenvolvidos internamente nos processos produtivos empresariais devem ser reconhecidos ao seu custo que, sabe-se, não representam, de fato, seu valor econômico, pois, os custos envolvidos no processo burocrático da obtenção das RCEs podem estar muito aquém do valor de mercado dos títulos em si (IASB, 2011c).

Conforme ficou demonstrado com o desenvolvimento da presente pesquisa, todas as variáveis necessárias à realização da mensuração contábil das RCEs a valores justos estão disponíveis no mercado com elevado grau de confiabilidade e transparência, de forma a possibilitar a realização da valoração econômica desse ativo, em detrimento de seu custo. Com a adoção de tal metodologia, corrobora-se com os ensinamentos de Bierman Jr. (1963) no sentido de que, em tais informações estando disponíveis, a mensuração ao valor justo deve ser priorizada para avaliações de itens patrimoniais.

O nível de subjetividade existente no processo de mensuração contábil das RCEs a valores justos, indiscutivelmente, é compensado pelo nível de qualidade da informação econômica prestada aos usuários externos, pois, em conformidade com os ensinamentos de Mattessich (1970) e Most (1982), levam em conta as expectativas futuras de retorno dos investidores, possibilitando-lhes a realização de julgamentos com maior segurança. 
Assim, sendo considerados seus objetivos econômicos, a ciência contábil deve ser capaz de fornecer informações econômicas relevantes para que os usuários possam tomar suas decisões e realizar seus julgamentos com maiores níveis de segurança, conforme já havia sido preconizado por parte da literatura contábil (Bierman Jr., 1963; Ijiri, 1975; Hendriksen \& Van Breda, 1999; Iudícibus, 2000).

Com a aplicabilidade do modelo de mensuração apresentado nesta Tese, voltado para a valoração da capacidade intangível total de uma entidade gerar créditos de carbono, os objetivos econômicos que envolvem o processo de implementação de projetos de MDLs passam a ser mensurados e divulgados pela contabilidade, possibilitando, dessa forma, análises mais precisas para o processo de tomada de decisões e julgamentos por parte dos usuários externos (Ratnatunga et al., 2011; Ijiri, 1975; Iudícibus, 2000).

A mensuração a valor justo, nesse caso, representa o elo entre o mundo empírico e o mundo teórico, pois permite o entendimento das características do fenômeno que está sendo mensurado, de maneira a possibilitar a realização de avaliações das RCEs enquanto item patrimonial capaz de gerar efeitos econômicos positivos no patrimônio das entidades localizadas em países em desenvolvimento (Mason \& Swanson, 1981).

Com isso, a aplicabilidade das pesquisas empíricas desenvolvidas nesta Tese possibilita, às entidades empresariais localizadas nos países em desenvolvimento, evidenciarem, com elevados níveis de credibilidade, os fluxos de caixa futuros esperados com a comercialização das RCEs, por meio do emprego de mensurações a valores correntes de saída, com a utilização da técnica do valor presente para projeções futuras descontadas a valores atuais, evidenciando o aumento gerado no patrimônio líquido das companhias, com seus lucros que serão realizados no futuro (Glautier \& Underdown, 2001).

Considerando a hipótese de mensuração das RCEs a valores justos, com a utilização da técnica do valor presente, todas as informações necessárias a tal finalidade estão disponíveis no mercado com elevado grau de confiabilidade, de maneira a viabilizar a estimativa de valor justo desse ativo, com classificação hierárquica compatível ao Nível 2, definido na IFRS 13. Vale ressaltar também que, os conceitos existentes na literatura contábil há longa data, passaram a ser contemplados com a emissão da IFRS 13, recentemente emitida. 
Com a adoção de tal metodologia, as informações pertinentes à implementação dos projetos de MDLs e a sua capacidade futura de geração de RCEs, ultrapassam o foco até então atribuído à posição financeira das entidades na data em que as demonstrações contábeis estão sendo elaboradas, para evidenciar as expectativas de eventos futuros, que devem ser consideradas na medida em que lançam luz sobre a existência de ativos e passivos nessa data, e que, sabe-se, irão afetar a situação patrimonial das companhias em diversos períodos futuros (Cook, 2009).

Com o modelo de valoração contábil apresentado nesta Tese, o PL das companhias estará evidenciando o aumento da riqueza advindo através de operações realizadas no presente e, também, com a manutenção dos bens na entidade, que serão realizados no futuro. Tais informações possuem a capacidade de viabilizar a realização de análises da tendência dos empreendimentos (Iudícibus, 2000).

\subsection{Limitações do Modelo Proposto}

No modelo de mensuração contábil das RCEs proposto nesta Tese, algumas limitações devem ser observadas, destacando-se:

Suas discussões limitaram-se ao mercado regulado de carbono, deixando de abordar aspectos específicos do mercado de carbono voluntário.

Para validação do modelo, adotou-se a taxa de juros Euribor para descontar a valores presentes os fluxos de benefícios futuros esperados, que inclui em sua configuração uma remuneração para proteção de riscos, não tendo sido observada a existência de taxas de riscos do mercado específico de comercialização das RCEs.

Por inacessibilidade, não foram observados também os custos e despesas incorridos com o desenvolvimento dos projetos de MDLs e os gastos com a comercialização das RCEs, que possam ter sido suportados por parte das companhias hospedeiras dos projetos. O 
conhecimento e utilização de tais valores possibilitaria a projeção dos fluxos líquidos de caixa futuros esperados com a implementação dos projetos de MDLs.

A projeção do valor justo mensurado das REs foi realizada apenas no "Patrimônio Líquido" das entidades envolvidas com a pesquisa, deixando de ser efetivada nas contas de "Ativo Intangível", de forma a serem evitadas possíveis duplicidades, para o caso de já haverem registros contábeis pertinentes a tais rubricas na respectiva classificação contábil do ativo. 


\section{CONSIDERAÇÕES FINAIS}

O Protocolo de Quioto, que entrou em vigor no ano de 2005, propiciou aos países em desenvolvimento uma participação concreta no mercado de carbono, a partir da implementação de projetos de MDLs que possuem como objetivo principal contribuir para a redução da emissão de GEEs na atmosfera.

Adotando-se como base o objetivo principal dos projetos de MDLs, entende-se que a evidenciação financeira dos impactos econômicos positivos ocasionados no patrimônio das entidades, principalmente em longo prazo, com a comercialização das RCEs junto aos países desenvolvidos, é de vital importância para dimensionar se, de fato, seus objetivos principais estão sendo atingidos e em quais proporções por parte de cada entidade, bem como o potencial de benefícios futuros que a empresa tem a sua disposição.

A comercialização de RCEs, originárias com a implementação de projetos de MDLs, se apresenta enquanto única possibilidade de os países em desenvolvimento ingressarem no mercado de carbono e, dessa forma, ampliarem suas conecções com os países desenvolvidos, com vistas à obtenção de recursos financeiros, que representam melhorias econômicas nas estruturas patrimoniais de entidades localizadas nos países em desenvolvimento, as quais devem ser mensuradas pela contabilidade, para propiciar análises econômicos de seus benefícios.

Em se tratando de métodos de mensuração contábil disponíveis para tal finalidade, as discussões teóricas existentes na literatura têm se apresentado no sentido de enfatizar que, para sua realização, as características dos itens patrimoniais devem ser observadas para possibilitar a escolha de um dentre os diversos métodos existentes, os quais se classificam, basicamente, em função dos aspectos temporais em que se localizam as perspectivas de geração de benefícios econômicos do item a ser mensurado.

No que concerne ao fornecimento de informações econômicas por parte da contabilidade, o método de mensuração contábil que melhor evidencia a capacidade de geração de benefícios 
futuros dos itens patrimoniais é o que leva em conta o conceito de 'valor', em detrimento do conceito de 'custo' que, historicamente vem sendo mais utilizado na prática contábil por possuir fortes características de verificabilidade e objetividade.

Porém, o atual estágio de desenvolvimento econômico, principalmente dos países emergentes, com a abertura dos mercados de capitais a investidores estrangeiros, tem clamado por informações contábeis que tragam, em seu bojo, a capacidade de evidenciar os aspectos econômicos dos itens patrimoniais com a utilização de projeções que sejam capazes de acompanhar as necessidades informacionais dos gestores, acionistas e credores.

Nesse contexto, a base de mensuração a valores futuros descontados a valores presentes, que utiliza valores passados e correntes para realização de projeções, tem se apresentado enquanto ferramenta capaz de medir o valor econômico de itens patrimoniais. Para tanto, a utilização da técnica do valor presente é tida pela literatura contábil como a mais apropriada para realização de avaliações que possuam capacidade de evidenciação de informações econômicas, em conformidade com as características específicas de cada ativo.

Para propiciar a utilização da técnica do valor presente, visando o fornecimento de informações econômicas, os valores praticados no mercado para comercialização de itens patrimoniais devem ser verificados e, nesse contexto, as demais variáveis que envolvem o seu cálculo devem ser adotadas pelas entidades com o maior nível de confiabilidade possível. Nesse sentido, a adoção de uma taxa de desconto apropriada a ser utilizada e o horizonte temporal compreendido para geração de benefícios econômicos futuros dos ativos é essencial para uma estimativa precisa de mensurações a valor presente.

O IASB, enquanto órgão responsável pela emanação de Normas Internacionais de Contabilidade, as IFRSs, tem procurado acompanhar, mesmo que de maneira muito tímida, as necessidades econômicas que têm surgido em prol à mensuração de itens patrimoniais que levem em consideração os valores praticados no mercado.

Porém, deve-se ressaltar que a mensuração a valores justos, aceita pelo IASB, tem sido desconsiderada, até então, para realização de avaliações de ativos intangíveis que vêm sendo avaliados através dos seus custos de aquisição. Com isso, a técnica do valor presente deixa de ser utilizada na mensuração de ativos intangíveis desenvolvidos internamente nas entidades, 
com probabilidade de geração de benefícios econômicos futuros que abranjam vasto horizonte temporal, a exemplo das RCEs geradas internamente nos processos produtivos de entidades localizadas nos países em desenvolvimento, a partir da implementação de projetos de MDLs.

Em termos quantitativos, Brasil, China e Índia foram responsáveis por 74,69\% de todos os projetos de MDLs implementados nos países em desenvolvimento durante a primeira fase do Protocolo de Quioto, ou seja, de 2005 a 2012. Dentro desse mesmo lapso temporal, os referidos países também apresentaram grandes evoluções em seus padrões contábeis com a adoção das Normas Internacionais de Contabilidade IFRSs, demonstrando, assim, uma elevada preocupação por parte dos órgãos regulamentadores desses países, quanto ao seu posicionamento no sentido de obterem a credibilidade dos investidores estrangeiros no que concerne ao tratamento que é atribuído às informações contábeis por parte das entidades empresariais nesses locais.

Em se tratando da mensuração contábil ao valor justo adotada pelo IASB, o Brasil manteve uma postura de adotá-la em conformidade às normas IFRSs, implementando a sua utilização da maneira como definida através do órgão normatizador internacional para instrumentos financeiros, propriedade para investimentos e ativos biológicos. Da mesma forma a China passou a emitir padrões contábeis nacionais convergentes com as normas IFRSs, com finalidade de propiciar uma implementação unificada entre essas e o GAAP local. A Índia, por sua vez, anunciou um plano multi-fases de transição para convergência das novas Normas Indianas de Contabilidade para com as normas IFRSs.

Em se tratando de regulamentação contábil internacional voltada aos títulos de carbono, muito pouco fora realizado pelo IASB até então. Porém, a partir de 2008, diante do crescimento de negociações em torno do mercado de carbono, o órgão passou a discutir um projeto que seja capaz de abordar a contabilização dos créditos de carbono comercializáveis, tanto por parte dos países desenvolvidos como por parte dos países em desenvolvimento.

Tais discussões têm se apresentado mais abrangentes que as realizadas com o IFRIC 3 que, tendo em vista o atual estágio de desenvolvimento do mercado de carbono, naquela ocasião, direcionou suas discussões apenas às permissões de emissões existentes nos países pertencentes ao Anexo I do Protocolo de Quioto, as quais não se enquadravam às 
características das reduções de emissões geradas com a implementação de projetos de MDLs nos países em desenvolvimento (os Não-Anexo I).

Em termos nacionais, os órgãos regulamentadores do Brasil, da China e da Índia também envidaram poucos esforços em prol ao tratamento contábil que deve ser dispendido às RCEs. No Brasil, percebeu-se apenas uma manifestação da CVM para afirmar que as RCEs não poderiam ser tratadas como derivativos. Na China, vislumbrou-se que a participação estatal na implementação de projetos de MDLs, nos processos produtivos empresariais, direcionou as discussões contábeis locais ao atendimento dos critérios estabelecidos pelo Estado para possibilitar as negociações de RCEs por parte das companhias. Na Índia, observou-se a existência de notas de orientações emitidas pelo Estado sobre a contabilização de RCEs, onde os conceitos tradicionais da contabilidade foram fortemente identificados.

Em se tratando de literatura acadêmica, os três países em estudo possuem discussões científicas que giram em torno, basicamente, da classificação contábil que deve ser utilizada para possibilitar o reconhecimento das RCEs, de forma a evidenciá-las nas demonstrações financeiras das entidades. Nesse sentido, o único ponto em consenso vislumbrado na literatura é a sua classificação enquanto ativo das entidades, não existindo concordância acerca de que grupo do ativo as RCEs devem ser classificadas. Porém, todas as classificações de grupos de ativos possíveis para seu reconhecimento, discutidas no meio acadêmico, esbarram na inviabilidade prática em realizá-lo, tendo em vista as orientações contábeis emanadas pelo IASB, que foram adotadas nos respectivos países, e a carência de regulamentação nacional em cada um deles.

Essa mesma falta de consenso pode ser vislumbrada ao verificar as orientações acadêmicas pertinentes às bases de mensurações que poderiam ser adotadas para valoração das RCEs nos três países em referência. Porém, verificou-se que, tanto no Brasil, quanto na China e na Índia, existe uma tendência em atribuir bases de mensurações contábeis às RCEs em conformidade com as orientações legais emitidas por parte das normas internacionais de contabilidade, tais sejam: a) Instrumentos financeiros: mensuração ao valor justo; b) Estoques: mensuração ao custo ou valor realizável líquido; c) Ativos intangíveis: mensuração inicial ao custo e as subsequentes ao valor justo. 
Diante da carência de orientações legais por parte dos órgãos regulamentadores, e, da falta de concordância no meio acadêmico, a mensuração das RCEs, efetivamente, tem sido pouco discutida enquanto ativo que possui capacidade de geração de benefícios econômicos futuros, pois, em sua maioria, a classe contábil tem discutido o tratamento que lhes deve ser atribuído, adotando como base para sua mensuração os valores despendidos e/ou recebidos em períodos passados ou presente, sem vislumbrar projeções futuras condizentes com as características das RCEs.

As constatações, anteriormente elencadas, confirmam a hipótese de pesquisa desta Tese, de que se as RCEs fossem mensuradas ao valor justo e reconhecidas enquanto ativo intangível, então seriam evidenciados os impactos patrimoniais dos fluxos de caixa futuros esperados com a implementação de projetos de MDLs nos processos produtivos das empresas brasileiras, chinesas e indianas.

A proposta de mensuração contábil das RCEs desenvolvida nesta Tese, adotou como ponto de partida, a teoria da mensuração contábil e analisou as características do ativo em questão para verificar, junto às empresas brasileiras, chinesas e indianas que evidenciaram suas informações financeiras aos usuários externos e que, também implementaram projetos de MDLs durante o período de 2005 a 2012, a incidência de impacto em seus PLs, em caso tal mensuração tivesse sido realizada por parte das companhias que participaram da pesquisa.

Nesse sentido, a mensuração ao valor presente, no momento de aprovação dos projetos de MDLs junto ao órgão governamental competente (registro junto ao Conselho Excutivo), foi utilizada para mensurar, a partir dos valores de mercado das RCEs e do potencial estimado de REs de GEEs na atmosfera, juntamente ao respectivo período ao qual estarão propensos à obtenção de RCEs, e adoção da taxa Euribor de descontos, o valor dos ativos intangíveis RCEs, de maneira a propiciar seu reconhecimento em contrapartida ao PL das companhias listadas nos mercados de valores mobiliários do Brasil, da China e da Índia.

Com a aplicabilidade da proposta em questão, o reflexo do resultado econômico deverá ser evidenciado no PL, de forma segregada, enquanto item patrimonial não realizado no período corrente, mas que, sabe-se, virá a impactá-lo em períodos futuros. Com isso, os objetivos econômicos pertinentes à implementação dos projetos de MDLs nas estruturas patrimoniais 
dessas entidades, tidos como secundários, passam a ser contemplados pela contabilidade, adicionalmente aos já conhecidos benefícios socioambientais gerados em prol ao desenvolvimento sustentável dessas nações.

Sendo considerada a possibilidade de mensuração das RCEs a valores justos, a IFRS 13 oferece condições para realizar sua classificação hierárquica compatível ao Nível 2, lá definido, tendo em vista o fato de que todas as informações necessárias à tal finalidade estão disponíveis no mercado, de maneira a viabilizar a estimativa de valor justo desse ativo.

Vale ressaltar que, ao se tratar de negociação de mercado, em que são conhecidos os valores e os períodos respectivos que envolvem o fluxo futuro de caixa e o tempo necessário para realização de tais valores, a confiabilidade da taxa de descontos a ser utilizada para reduzir o fluxo futuro de caixa a valores presentes é altamente relevante. Dessa forma, a taxa de juros Euribor foi adotada para realização desta pesquisa, pela sua capacidade de refletir com o maior nível de precisão possível o valor do dinheiro no tempo, além de atrair elevados níveis de confiabilidade do mercado.

Com a aplicabilidade empírica do "Modelo de Mensuração Contábil das RCEs" desenvolvido nesta Tese, foi possível realizar análises da prática mercadológica existente, possibilitando a validação dos conceitos teóricos existentes na literatura contábil, de maneira a propiciar o aprimoramento da ciência contábil. Tal característica é que diferencia a presente pesquisa da simulação desenvolvida por Ratnatunga et al. (2011).

Assim, de posse dos resultados obtidos com o tratamento e avaliação dos dados da pesquisa, é possível inferir que a realização da mensuração contábil dos ativos intangíveis RCEs, ao valor justo, em contrapartida ao grupo de contas patrimoniais das empresas brasileiras, chinesas e indianas, durante o período de 2005 a 2012, teria representado um impacto estatisticamente positivo no valor do PL dessas companhias.

Com o desenvolvimento da pesquisa em questão, foi possível alcançar seu objetivo geral, pois foi proposto um modelo de mensuração contábil ao valor justo das RCEs geradas nos processos produtivos das empresas brasileiras, chinesas e indianas, para possibilitar o reconhecimento desses ativos oriundos da implementação de projetos MDLs, durante o período de 2005 a 2012. 
Seus objetivos específicos também foram atingidos, pois foram identificados impactos econômicos positivos no patrimônio das empresas brasileiras, chinesas e indianas, causados pelo reconhecimento e evidenciação dos fluxos futuros de benefícios econômicos das RCEs, no momento em que sua existência passa a ser aceita por parte da UNFCCC.

Com os achados da pesquisa é possível inferir que a utilização da técnica do valor presente, com base em valores justos disponíveis em mercados ativos, possibilita a mensuração das RCEs já no momento de registro dos projetos de MDLs junto ao Conselho Executivo, de maneira a propiciar a evidenciação dos fluxos futuros de caixa esperados com a sua comercialização, em períodos futuros.

Tais achados também nos possibilitam inferir que, apesar de as RCEs terem surgido há pouco tempo, a teoria contábil, há longa data, tem alertado para a necessidade de serem mensurados os ativos desenvolvidos internamente pelas empresas capacitadas em gerar efeitos econômicos que impactam positivamente o grupo de contas patrimoniais. Porém, uma nova postura deve ser adotada pela classe contábil com finalidade de rever antigos conceitos (a exemplo da mensuração a valores futuros descontados a valores presentes) para avaliação de novos ativos (a exemplo das RCEs) que, conforme restou demonstrado nesta Tese, tem encontrado dificuldades para tratamento condizente com suas características, principalmente quando observados os aspectos legais aplicados por parte dos órgãos regulamentadores da contabilidade.

O novo enfoque adotado por parte do IASB, possibilitando a utilização de valores justos para mensuração contábil de alguns itens patrimoniais, já foi um grande passo nesse sentido. Porém, o órgão carece ainda de novas evoluções para possibilitar a mensuração contábil das RCEs enquanto ativo, propiciando discussões voltadas ao reconhecimento contábil de ativos intangíveis desenvolvidos internamente por parte das companhias, de forma a possibilitar sua avaliação a valores justos com apoio da técnica do valor presente para redução de seus valores futuros.

Enquanto limitações para realização da pesquisa, elenca-se, inicialmente, dificuldades para obtenção dos dados, como a divergência de nomenclatura de 'razões sociais' das companhias registradas junto às entidades reguladoras de Mercados Mobiliários do Brasil, da China e da 
Índia, e o nome da 'parte hospedeira' dos projetos de MDLs registrados junto ao sítio eletrônico da UNFCCC, fato este que pode ter ocasionado uma diferença negativa entre os projetos que, de fato, foram aprovados pelas companhias e os que foram utilizados enquanto amostra da pesquisa para mensuração das RCEs. Tal limitação, se superada, ratificará os resultados da pesquisa.

Posteriormente, deve-se mencionar as dificuldades em serem obtidas as séries históricas de preços de Créditos de Carbono durante todo o período de abrangência da pesquisa, pois foi possível obter apenas uma série histórica de todo o período, existente junto à Base de Dados Econômicos e Financeiros da Bloomberg. Ressalta-se que a indisponibilidade de tal informação junto ao meio acadêmico pode inviabilizar o desenvolvimento de novas pesquisas.

Para o desenvolvimento de pesquisas futuras, sugere-se a realização de novas mensurações de RCEs a valores justos, com a utilização de séries históricas de preços de Créditos de Carbono de outros mercados, e adoção de outras taxas de desconto para reduzir o fluxo de caixa futuro das RCEs ao seu valor presente, de maneira a possibilitar a comparabilidade entre os resultados obtidos com a presente pesquisa.

Posteriormente, novas discussões podem ser lançadas em prol do aprimoramento do tratamento contábil desses ativos, adotando-se como base a presente proposta de mensuração e reconhecimento contábil ao valor justo das RCEs.

Vale enfatizar que o objetivo principal desta Tese consistiu em discutir a mensuração para possibilitar o reconhecimento das RCEs enquanto ativo intangível. E, para tanto, o aprofundamento dos estudos aqui desenvolvido foi direcionado à proposta de um "Modelo de Mensuração Contábil das RCEs”.

Diante da validação dos resultados obtidos com o desenvolvimento da pesquisa empírica, entende-se que novas discussões voltadas ao reconhecimento contábil das RCEs devem ser realizadas de maneira mais aprofundada, adotando-se como base para as discussões o “Modelo de Mensuração Contábil das RCEs” proposto nesta Tese. 


\section{REFERÊNCIAS}

Agrawal, S. K. (2006). Accounting and Taxation Aspects of Carbon Trading. Accounting and Auditing. The Chartered Accountant, October, p. 509-513.

Ascui, F., \& Lovell, H. (2011). As frames collide: making sense of carbon accounting. Accounting, Auditing \& Accountability Journal, 24(8) 978-999.

Assaf Neto, A. (2007). Finanças Corporativas e Valor (3a ed.). São Paulo: Atlas.

Bebbington, J., \& Gonzáález, C. L. (2008). Carbon Trading: Accounting and Reporting Issues. European Accounting Review, 17(4), 697-717.

Bierman Jr., H. (1963). Measurement and accounting. The Accounting Review, july, 501-507.

Bito, N. S. (2006). Tratamento contábil dos projetos de mecanismo de desenvolvimento limpo - MDL no Brasil: um estudo exploratório. Dissertação de mestrado. Centro Universitário Álvares Penteado - Programa de Mestrado em Ciências Contábeis-UNIFECAP, São Paulo, SP, Brasil.

Bolsa de Valores de São Paulo - BM\&Fbovespa. (2000). Novo Mercado. Recuperado em 15 de janeiro de 2013, de http://www.bmfbovespa.com.br/empresas/download/Folder_NovoMercado.pdf

Bolsa de Valores de São Paulo - BM\&FBovespa. (2012). Bolsa de Valores, Mercadorias e Futuros - BM\&FBovespa S.A. Índices. Recuperado em 18 de maio de 2012, de http://www.bmfbovespa.com.br/indices/BuscarIndices.aspx?idioma=pt-br

Bombay Stock Exchange - BSE. (2012). Indices. Recuperado em 18 de maio de 2012, de http://www.bseindia.com/

Bothra, N. (2010). Carbon Credits - Unravelling Regulatory, Taxation \& Accounting Issues. Recuperado em 20 de março de 2013, de http://india-financing.com/staff-publicationsenergy-trading-carbon-credits-innovative-instruments.html

Braun, B. (2009). The evolution of emissions trading in the European Union - The role of policy networks, knowledge and policy entrepreneurs. Accounting, Organizations and Society. 34, 469-487.

Bufoni, A. L., \& Ferreira, A. C. S. (2010). Um debate sobre a contabilização de reduções certificadas de emissões. In 10 Congresso USP de Controladoria e Contabilidade, Ensaio Teórico, (pp. 1-14). São Paulo. 
Capeland, T., Koller, T., \& Murrin, J. (2002). Avaliação de Empresas - Valuation: calculando e gerenciando o valor das empresas. (3a ed.). São Paulo: Pearson Makron Books.

Chen, S., Sun, Z., \& Wang, Y. (2002). Evidence from China on whether a harmonized accounting standard harmonizes accounting practices. Accounting Horizons, 16, $183-$ 197.

China Securities Regulatory Commission - CSRC. (2013). Annual Reports. Recuperado em 23 de maio de 2013, de http://www.csrc.gov.cn/

China. (2005). Department of Climate change, National Development and Reform Commission. Clean Development Mechanisms in China. Domestic Policy \& Regulation. In Measures for Operation and Management of Clean Development Mechanism Projects in China. Recuperado em 20 de junho de 2013, de http://cdmen.ccchina.gov.cn/Detail.aspx ?newsId=5628\&TId=37

China. (2012). National Development and Reform Commission of the People's Republic of China. Clean Development Mechanisms in China. In CDM Project Database. Recuperado em 23 de abril de 2012, de http://cdm.ccchina.gov.cn/english/item_new.asp?ColumnId=68

Collis, J., Hussey, R. (2005). Pesquisa em Administração: um guia prático para alunos de graduação e pós graduação (2a ed., L. Simonini, trad., M. Levacov, rev. técnica). São Paulo: Bookman.

Comissão de Valores Mobiliários - CVM. (2002). Demonstrações Financeiras Padronizadas (DFPs). Recuperado em 18 de maio de 2012, de http://www.cvm.gov.br/

Comissão de Valores Mobiliários - CVM. (2007a). Instrução CVM no 457, de 13 de julho de 2007. Recuperada em 10 de janeiro de 2013, de http://www.cvm.gov.br/port/snc/inst457.pdf

Comissão de Valores Mobiliários - CVM. (2007b). OfícioCircular/CVM/SNC/SEP/No2/2007, de 18 de maio de 2007. Recuperado em 10 de janeiro de 2013, de http://www.cvm.gov.br/port/atos/oficios/OFICIO-CIRCULAR-CVMSNC-SEP-02_2007.pdf

Comissão de Valores Mobiliários - CVM. (2009). Processo Administrativo CVM n ${ }^{\circ}$ RJ 2009/6346, de 07 de julho de 2009. Recuperada em 26 de fevereiro de 2013, de www.cvm.gov.br/port/infos/carbono\%20-\%20Voto\%2007.07.09.doc

Comissão de Valores Mobiliários - CVM. (2012). Deliberação CVM $n^{o}$ 669, de 20 de dezembrode 2012. Recuperada em 18 de janeiro de 2013, de http://www.cvm.gov.br/asp/cvmwww/atos/Atos_Redir.asp?Tipo=D\&File=ldelildeli699.d oc 
Comitê de Pronunciamentos Contábeis - CPC. (2012). CPC 46 - Mensuração do Valor Justo.

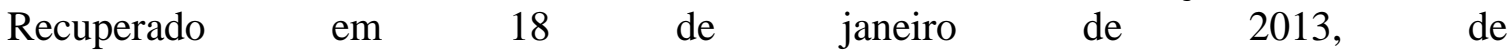
http://www.cpc.org.br/pdf/CPC\%2046\%20_final.pdf

Conselho Federal de Contabildade - CFC. (CFC, 2005). Resolução CFC $n^{o} 1055$, de 07 de outubro de 2005. Recuperada em 11 de janeiro de 2013, de http://www.crcsp.org.br/portal_novo/legislacao_contabil/resolucoes/Res1055.htm

Cook, A. (2009). Emission rights: From costless activity to market operations. Accounting, Organizations and Society. 34, 456-468.

Cooper, D. R., Schindler, P. S. (2011). Métodos de Pesquisa em Administração (10a ed., I. D. Abreu, trad., F. C. T. Bacellar, rev. técnica). Porto Alegre: Bookman.

Costa, J. A., Theóphilo, C. R., \& Yamamoto, M. M. (2012). A aderência dos Pronunciamentos Contábeis do CPC às Normas Internacionais de Contabilidade. Contabilidade, Gestão e Governança, 15(2), 110-126.

Cunha, M. F. (2011). Avaliação de empresas no Brasil pelo Fluxo de Caixa Descontado: evidências empíricas sob o ponto de vista do desempenho econômico-financeiro. Tese de Doutorado, Universidade de São Paulo - Faculdade de Economia, Administração e Contabilidade-FEA/USP, São Paulo, SP, Brasil.

Deloitte. (2007). Accounting for Emission Rights. Recuperado em 28 de janeiro de 2013, de http://www.deloitte.com/assets/DcomAustralia/Local\%20Assets/Documents/Deloitte_Accounting_Emissionright_Feb07.pdf

Demo, p. (2000). Metodologia do conhecimento científico. São Paulo: Atlas.

Dhar, S. (2012). Carbon Emissions Trading in India: A Study on Accounting and Disclosure Practice. Accounting. The Chartered Accountant, December, p. 937-943.

Ding, Y., \& Su, X. (2008). Implementation of IFRS in a regulated market. Journal of Accounting and Public Policy, 27(6), 474-479.

Dutta, S., \& Dasgupta, R. (2012). Carbon Accounting Challenges in India - Some Practical Issues. The Management Accountant, 47(1), January, p. 91-94 e 108.

Ernst \& Young Brasil, \& Fipecafi. (2008). Estudo sobre as diferenças e similaridades entre as Normas Internacionais de Contabilidade - IFRS e as Normas e Práticas Contábeis Brasileiras - Fair Value Measurements. Recuperado em 17 de janeiro de 2013, de http://www.cvm.gov.br/port/snc/Estudo\%20sobre\%20as\%20pr\%C3\%A1ticas\%20cont\% C3\%A1beis\%20brasileiras\%20e\%20as\%20normas\%20internacionais\%20de\%20contabil idade\%20(IFRS).asp 
Ernst \& Young, \& Fipecafi. (2010). Manual de normas internacionais de contabilidade: IFRS versus normas brasileiras (2a ed.). São Paulo: Atlas.

Euro InterBank Offered Rate - EURIBOR. (2014). In: EURIBOR - current EURIBOR interest rates. Recuperado em 08 de outubro de 2014, de http://www.globalrates.com/interest-rates/euribor/euribor.aspx

Ezzamel, M., Xiao, J. Z., \& Pan, A. (2007). Political ideology and accounting regulation in China. Accounting, Organizations and Society, 32(7-8), 669-700.

Fachin, O. (2006). Fundamentos de Metodologia. (5a ed.). São Paulo: Saraiva.

Fávero, L. P., Belfiore, P., Silva, F. L., \& Chan, B. L. (2009). Análise de dados: modelagem multivariada para tomada de decisões. Rio de Janeiro: Elsevier.

Ferreira, A. C. S., Bufoni, A. L., Marques, J. A. V. C., \& Muniz, N. P. (2007). Protocolo de Kyoto: uma abordagem contábil. In IX Encontro Nacional sobre Gestão Empresarial e Meio Ambiente (ENGEMA), (pp. 1-16). Curitiba-PR.

Financial Accounting. (2013). Accounting Regulation and Enforcement in China. Recuperado em 19 de abril de 2013, de http://www.wadsworthantheneum.org/39-accountingregulation-and-enforcement-in-china.html

Fornaro, J. M., Winkelman, K. A., \& Glodstein, D. (2009, Julho). Accounting for Emissions. $\begin{array}{llllll}\text { Recuperado em } 24 \text { de janeiro de } & \end{array}$ http://www.journalofaccountancy.com/Issues/2009/Jul/20081312

Glautier, M. W. E., Underdown, B. (2001). Accounting theory and practice. (Seventh Edition). London: Pearson Education.

Guan, L., \& Zhang, W. (2012). Research on the Investment and Financing Mechanism for Development of Low-Carbon Economy. Business and Management Research, 1(3), 4850 .

Gupta, V. K., \& Patro, A. (2010). New Regulatory Framework for Financial Reporting in India. Review of Business and Technology Research, 3(1), 12-17.

Hair Jr., J. F., Black, W. C., Babin, B. J., Anderson, R. E., \& Tatham, R. L. (2009). Análise Multivariada de Dados (6a ed., A. S. Sant'Anna, trad., M. A. Gouvêa, rev. técnica.). Porto Alegre: Bookman.

Haribhakti, S. (2008). Financial accounting standards: Convergence of Indian standards with the global standards. International Journal of Disclosure and Governance, 5(3), 272-283.

Hendriksen, E. S., \& Van Breda, M. F. (1999). Teoria da Contabilidade (5a ed., A. Z. Sanvicente, trad.). São Paulo: Atlas. 
Hicks, J. R. (1984). Valor e capital: estudo sobre alguns princípios fundamentais da teoria econômica. (D. A. Azevedo, trad.). São Paulo: Abril Cultural.

Ijiri, Y. (1975). Theory of Accounting Measurement. Flórida: American Accounting Association.

India. (2012). Ministry of Environment \& Forests Government of India. National CDM Authority. In Approved Projects. Recuperado em 23 de abril de 2012, de http://www.cdmindia.gov.in/approved_projects.php

India. (2013a). Ministry of Environment \& Forests Government of India. National CDM Authority. In Approval Process. Recuperado em 25 de junho de 2013, de http://www.cdmindia.gov.in/approval_process.php

Institute of Chartered Accountants of India - ICAI. (2012). Guidance Note on Accounting for Self-generated Certified Emission Reductions (CERs). Recuperado em 15 de março de 2013, de http://www.icai.org/post.html?post_id=1399

International Accounting Standards Board - IASB. (1998). International Accounting Standard - IAS 38 - Intangible Assets. Recuperado em 10 de novembro de 2014, de http://eifrs.ifrs.org/eifrs/PdfAlone?id=12033\&sidebarOption=UnaccompaniedIas

International Accounting Standards Board - IASB. (2000). Framework for the Preparation and Presentation of Financial Statements. Recuperado em 20 de outubro de 2012, de http://220.227.161.86/238acc_bodies_framework_ppfs.pdf.

International Accounting Standards Board - IASB. (2008). Information for Observers. Recuperado em 23 de janeiro de 2013, de http://www.ifrs.org/Current-Projects/IASBProjects/Emission-Trading-Schemes/Meeting-

Summaries/Documents/ETS0805b03obs.pdf

International Accounting Standards Board - IASB. (2011a). IFRS 13 - Fair Value Measurement. Recuperado em 23 de outubro de 2012, de http://eifrs.ifrs.org/eifrs/bnstandards/en/2012/ifrs13.pdf.

International Accounting Standards Board - IASB. (2011b). Project Summary and Feedback Statement: IFRS 13 Fair Value Measurement. Recuperado em 23 de outubro de 2012, de http://www.ifrs.org/Current-Projects/IASB-Projects/Fair-Value-Measurement/IFRS-13Fair-Value-

Measurement/Documents/FairValueMeasurementFeedbackstatement_May2011.pdf.

International Accounting Standards Board - IASB. (2011c). International Accounting Standard 38 (IAS38): Intangible Assets. Recuperado em 25 de outubro de 2014, de http://eifrs.ifrs.org/eifrs/bnstandards/en/2014/ias38.pdf 
International Accounting Standards Board - IASB. (2013). Projects Work plan for IFRSs Emissions Trading Schemes - Project history. Recuperado em 23 de janeiro de 2013, de http://www.ifrs.org/Current-Projects/IASB-Projects/Emission-Trading-

Schemes/Pages/Project-history.aspx

International Accounting Standards Board - IASB. (2014). Project Emissions Trading Schemes - research project. Recuperado em 28 de outubro de 2014, de http://www.ifrs.org/Pages/default.aspx

Iudícibus, S. (2000). Teoria da Contabilidade (6a ed.). São Paulo: Atlas.

Iudícibus, S. D., \& Martins, E. (2007). Uma investigação e uma proposição sobre o conceito e o uso do valor justo. Revista Contabilidade \& Finanças, 18(spe), 9-18.

Iudícibus, S., Martins, E., Gelbcke, E. R., Santos, A., \& Fipecafi. (2010). Manual de contabilidade societária: aplicável a todas as sociedades - de acordo com as Normas Internacionais e do CPC. São Paulo: Atlas.

Jain, P. (2011). IFRS Implementation in India: Opportunities and Challenges. World Journal of 's, 1(1), 125-136.

Kam, V. (1986). Accounting theory. New York: John Wiley \& Sons.

Köche, J. C. (2000). Fundamentos de metodologia científica: teoria da ciência e prática da pesquisa (17a ed.). Petrópolis, RJ: Vozes.

Lakatos, E. M., \& Marconi, M. A. (1994). Fundamentos de Metodologia Científica (3a ed. rev. ampl.). São Paulo: Atlas.

Lei das Sociedades por Ações no 6.404 (1976, 15 de dezembro). Recuperada em 14 de janeiro de 2013, de http://www.planalto.gov.br/ccivil_03/leis/L6404compilada.htm

Lei de Política Nacional sobre Mudança do Clima $\mathrm{n}^{\circ} 12.187$ (2009, 29 de dezembro). Recuperada em 30 de abril de 2011, de http://www.planalto.gov.br/ccivil_03/_ato20072010/2009/lei/112187.htm

Lei $\mathrm{n}^{\circ} 11.638$ (2007, 28 de dezembro). Recuperada em 22 de fevereiro de 2013, de http://www.planalto.gov.br/ccivil_03/_ato2007-2010/2007/lei/111638.htm

Lei $\mathrm{n}^{\mathrm{o}} 11.941$ (2009, 27 de maio). Recuperada em 22 de fevereiro de 2013, de http://www.planalto.gov.br/ccivil_03/_ato2007-2010/2009/lei/111941.htm

Lhaopadchan, S. (2010). Fair value accounting and intangible assets: Goodwill impairment and managerial choice. Journal of Financial Regulation and Compliance, 18(2), 120-130. 
Lima, V. S. (2011). Incentivos no nível da firma e consequências econômicas da convergência ao IFRS no Brasil. Dissertação de Mestrado, Universidade de São Paulo Faculdade de Economia, Administração e Contabilidade-FEA/USP, São Paulo, SP, Brasil.

Limiro, D. (2008). Créditos de Carbono: Protocolo de Kyoto e Projetos de MDL. Curitiba: Juruá.

Liu, C., Yao, L. J., Hu, N., \& Liu, L. (2011).The Impact of IFRS on Accounting Quality in a Regulated Market: An Empirical Study of China. Journal of Accounting, Auditing \& Finance, 26(4), 659-676.

Lohmann, L. (2009). Toward a different debate in environmental accounting: The cases of carbon and cost-benefit. Accounting, Organizations and Society, 34, 499-534.

Lopes, A. B. (2006). Financial Accounting in Brazil: An Empirical Examination. Latin American Business Review, 6(4), 45-68.

Lopes, A. B., \& Walker, M. (2008). Firm-Level Incentives and the Informativeness of Accounting Reports: an Experiment in Brazil. Working Paper, p. 1-60.

Lopez, T., Tin, P., Iyadomi, K., Santos, S., \& McIntosh, B. (2009). Clean Development Mechanism and Least Developed Countries: Changing the Rules for Greater Participation. The Journal of Environment \& Development, 18(4), 436-452.

Lustosa, P. R. B. (2010). A (In?) Justiça do Valor Justo: SFAS 157, Irving Fisher e Gecon. In 10 Congresso USP de Controladoria e Contabilidade (pp. 1-16). São Paulo.

Mackenzie, D. (2009). Making things the same: Gases, emission rights and the politics of carbon markets. Accounting, Organizations and Society. 34, 440-455.

Maroco, J. (2007). Análise estatística com utilização do SPSS (3a ed., rev. aum.). Lisboa: Edições Sílabo.

Martins, E. (Org.). (2001). Avaliação de Empresas: da Mensuração Contábil à Econômica. São Paulo: Atlas.

Martins, E., Diniz, J. A., \& Miranda, G. J. (2012). Análise avançada das demonstrações contábeis: uma abordagem crítica. São Paulo: Atlas.

Martins, G. A. (2002). Manual para elaboração de monografias e dissertações (3a ed.). São Paulo: Atlas.

Martins, G. A. (2010). Estatística geral e aplicada (3a ed.). São Paulo: Atlas. 
Martins, G. A., Theóphilo, C. R. (2009). Metodologia da Investigação Científica para Ciências Sociais Aplicadas (2a ed.). São Paulo: Atlas.

Mason, R. O., Swanson, E. B. (1981). Measurement for management decision. California: Addison-Wesley Publishing Company.

Mattessich, R. (1970). On the perennial misunderstanding of asset measurement by means of "present values". Cost and Management, march-april, 29-31.

Mattessich, R. (1972). Methodological preconditions and problems of a general theory of accounting. The Accounting Review, july, 469-487.

Ministério da Ciência e Tecnologia - MCT. (1997). Protocolo de Quioto. Recuperado em 01 de junho de 2011, de http://www.mct.gov.br/upd_blob/0012/12425.pdf.

Ministério da Ciência e Tecnologia - MCT. (2001). Decisão 17/CP.7. Modalidades e procedimentos para um mecanismo de desenvolvimento limpo, conforme definido no Artigo 12 do Protocolo de Quioto. Recuperado em 10 de outubro de 2014, de http://www.mct.gov.br/index.php/content/view/19448.html.

Ministério da Ciência e Tecnologia - MCT. (2011a). Status atual das atividades de projeto no âmbito do Mecanismo de Desenvolvimento Limpo (MDL) no Brasil e no mundo: Última compilação do site da CQNUMC: 30 de junho de 2011. In Mudanças Climáticas. $\begin{array}{llllll}\text { Recuperado em } 01 \text { de agosto de } & \text { 2011, }\end{array}$ http://www.mct.gov.br/index.php/content/view/42954.html

Ministério da Ciência e Tecnologia - MCT. (2011b). Atividades de Projetos MDL aprovados nos termos da Resolução no 1 . In Atividades de Projetos MDL. Recuperado em 07 de junho de 2011, de http://www.mct.gov.br/index.php/content/view/47952.html

Ministério da Ciência e Tecnologia - MCT. (2014). Metodologias de pequena escala. Recuperado em 09 de novembro de 2014, de http://www.mct.gov.br/index.php/content/view/51507.html

Most, K. S. (1982). Accounting Theory. Second Edition. Columbus, Ohio: Grid Publishing, Inc.

National Stock Exchange - NSE. (2012). Indices. Recuperado em 18 de maio de 2012, de http://www.nseindia.com/products/content/equities/indices/indices.htm

Newell, P. (2009). Varieties of CDM Governance: Some Reflections. The Journal of Environment \& Development, 18(4) 425-435.

Olesen, K., Cheng, F. (2011). Convergence of Accounting Standards does not always lead to Convergence of Accounting Practices: The Case of China. Asian Journal of Business and Accounting, 4(1), 23-58. 
Oliveira, A. B. S. (Coord.), Cecconello, A. R., Barbosa, C. F., Célice, E. S., Kounrouzan, M. C., \& Di Giorgi, W. A. B. (2003). Métodos e técnicas de pesquisa em contabilidade. São Paulo: Savaira.

Pahuja, S. (2012). Accounting for the Carbon: Need for an International Accounting Standard. Social Responsibility Review, 1, 27-34.

Peng, S., \& Bewley, K. (2010). Adaptability to fair value accounting in an emerging economy: A case study of China's IFRS convergence. Accounting, Auditing \& Accountability Journal, 23(8), 982-1011.

Peng, S., \& Smith, J. van der L. (2010). Chinese GAAP and IFRS: An analysis of the convergence process. Journal of International Accounting, Auditing and Taxation, 19(1), $16-34$.

Peng, S., Tondkar, R. H., Smith, J. van der L., \& Harless, D. W. (2008). Does Convergence of Accounting Standards Lead to the Convergence of Accounting Practices? The International Journal of Accounting, 43(4), 448-468.

Perez, R. A., Ribeiro, M. S., Cunha, J. V. A., \& Rezende, J. R. (2008). Reflexos contábeis e socioambientais dos créditos de carbono brasileiros. Revista de Educação e Pesquisa em Contabilidade, 2(2), 56-83.

Price Waterhouse Coopers. (2012). IFRS adoption by country. Recuperado em 23 de maio de 2012, de http://www.pwc.com/us/en/issues/ifrsreporting/assets/ifrs_country_adoption.pdf.

Qi, P., \& Hao, X. (2012). Analysis on Status of Developing Low Carbon Economy and Selection of Evaluation Index in China. Global Journal of Management and Business Research, 12(20), 65-73.

Ramanna, K. (2013). The international politics of IFRS harmonization. Accounting, Economics and Law: a Convivium, 3(2), 1-46.

Ratnatunga, J., Jones, S., \& Balachandran, K. R. (2011). The valuation and reporting of organizational capability in carbon emissions management. Accounting Horizons, 25(1), 127-147.

Ray, S. (2011). Emergence of International Financial Reporting Standard in India's Accounting Scenario. Research Journal of Finance and Accounting, 2(12), 47-66.

Ray, S. (2012a). Applicability of International Financial Reporting Standards in India: Some Key Issues and Challenges. Journal of Expert Systems, 1(1), 1-15. 
Ray, S. (2012b). Indian GAAP and Its Convergence to IFRS: Empirical Evidence from India. Advances in Applied Economics and Finance, 2(1), 257-276.

Ray, S. (2012c). Relevance of Fair Value Accounting: An Appraisal. Advances in Information Technology and Management, 1(4), 146-152.

Ray, S., \& Ray, A. (2012). Some Aspects of Carbon Trading: Issues and Challenges with reference to India. Advances in Applied Economics and Finance, 1(2), 95-106.

Riahi-Belkaoui, A. (2004). Accounting theory (5a ed.). South-Western: Cengage Learning.

Ribeiro, M. S. (2005). O tratamento contábil dos créditos de carbono. Tese de livre docência. Universidade de São Paulo - Faculdade de Economia, Administração e Contabilidade de Ribeirão Preto-FEARP/USP, Ribeirão Preto, SP, Brasil.

Ribeiro, M. S. (2007). Os créditos de carbono e seus efeitos contábeis. In I Congresso ANPCONT (pp. 1-17). Gramado-RS.

Rocha, A., Silva Júnior, A. C., Andrade, J. C. S., \& Ramos, E. (2010). Análise dos aspectos contábeis no reconhecimento dos créditos de carbono em projetos de MDL no Brasil. In Congresso Brasileiro de Custos, (pp. 1-15). Belo Horizonte.

Rocha, M. T. (2003). Aquecimento global e o mercado de carbono: uma aplicação do modelo Cert. Tese de Doutorado, Universidade de São Paulo - Escola Superior de Agricultura Luiz de Queiroz-ESALQ/USP, Piracicaba, SP, Brasil.

Sabbag, B. K. (2007). O Protocolo de Quioto e seus Créditos de Carbono: Manual Jurídico Brasileiro de Mecanismo de Desenvolvimento Limpo. São Paulo: LTr.

Santos, V., Beuren, I. M., \& Haussmann, D. C. S. (2011). Tratamento Contábil nas Operações com Créditos de Carbono em Empresas Brasileiras. RIC - Revista de Informação Contábil, 5(1), 36-67.

Securities and Exchange Board of India - SEBI. (2013). Annual Reports. Recuperado em 23 de maio de 2013, de http://www.sebi.gov.in/

Shanghai Stock Exchange - SHSE. (2012). List of SSE Indices. Recuperado em 18 de maio de 2012, de http://english.sse.com.cn/information/indices/list/

Shenzhen Stock Exchange - SZSE. (2012). Indices. Recuperado em 18 de maio de 2012, de http://www.szse.cn/main/en/marketdata/Indiceslist/

Shil, N. C., Das, B., \& Pramanik, A. K. (2009). Harmonization of Accounting Standards through Internationalization. International Business Research, 2(2), 194-201.

Sister, G. (2007). Mercado de Carbono e Protocolo de Quioto. Rio de Janeiro: Elsevier. 
Souza, A. L. R., Andrade, J. C. S., Alvarez, G., \& Santos, N. (2013). Financiamento de Carbono no Mundo e no Brasil: um estudo sobre financiadores, fundos de investimentos e índices de sustentabilidade ambiental em prol de uma economia de baixo carbono. Revista de Gestão Ambiental e Sustentabilidade - GeAS, 2(2), 177-207.

Souza, M., Borba, J., \& Uhlmann, V. (2011). Valor justo: uma verificação das informações divulgadas por empresas de capital aberto brasileiras. Revista de Contabilidade do Mestrado em Ciências Contábeis da UERJ, 16(3), 99-114.

Staubus, G. J. (1985). An induced theory of accounting measurement. The Accounting Review, LX(1), January, 53-75.

Sterling, R. R. (1970). Theory of the measurement of enterprise income. Lawrence: University of Kansas Press.

Swamynathan, S., \& Sindhu, D. (2011). Convergence to IFRS - An Indian Perspective. International Journal of Research in Computer Application and Management, 1(10), 8185.

Tang, X. (2011). Accounting Theory of Carbon Emissions Trading in China under Lowcarbon Economy. In ICMREE - International Conference on Materials for Renewable Energy \& Environment, (pp. 1202-1204), 2011, Shanghai-China.

Tripathi, R., \& Gupta, S. (2011). International Financial Reporting Standard: Away to global consistency. Australian Journal of Business and Management Research, 1(1), 38-51.

United Nations Framework Conference On Climate Change - UNFCCC. (2012a). In Project Cycle Search. Recuperado em 21 de maio de 2012, de http://cdm.unfccc.int/Projects/projsearch.html

United Nations Framework Conference On Climate Change - UNFCCC. (2013a). In Project activities. Recuperado em 26 de maio de 2013, de http://cdm.unfccc.int/Statistics/Public/archives/201212/index.html

United Nations Framework Conference On Climate Change - UNFCCC. (2013b). In Distribution of registered projects by Host Party. Recuperado em 26 de maio de 2013, de http://cdm.unfccc.int/Statistics/Public/archives/201212/index.html

United Nations Framework Conference On Climate Change - UNFCCC. (2014). In Project Cycle Search. Recuperado em 01 de setembro de 2014, de http://cdm.unfccc.int/Projects/projsearch.html

Universidade de São Paulo. Sistema Integrado de Bibliotecas da USP. (2009). Diretrizes para apresentação de dissertações e teses da USP: documento eletrônico e impresso. Parte II 
(APA). Funaro, V. M. B. O. (Coord.). (2a ed. rev. ampl.). São Paulo. Sistema Integrado de Bibliotecas da USP. - SIBi-USP.

Universidade de São Paulo. Sistema Integrado de Bibliotecas da USP. (2009). Diretrizes para apresentação de dissertações e teses da USP: documento eletrônico e impresso. Parte I $(A B N T)$. Funaro, V. M. B. O. (Coord.). (2a ed. rev. ampl.). São Paulo. Sistema Integrado de Bibliotecas da USP. - SIBi-USP.

Verma, R., \& Brennan, L. (2011) The investment development path theory: evidence from India. International Journal of Emerging Markets, 6(1), 74-89.

Vickrey, D. W. (1970). Is accounting a measurement discipline? The Accounting Review, october, 731-742.

Visentini, P., Adam, G., Vieira, M., Silva, A., \& Pereira, A. (2013). BRICS: As potências emergentes. Petrópolis, RJ: Vozes.

Wang, L. (2011). The Current Situation and Accounting Risk Prevention of Clean Development Mechanism in China. In $2^{\text {nd }}$ AIMSEC - International Conference on Artificial Intelligence, Management Science and Electronic Commerce, (pp. 3431-3434), 2011, Zhengzhou-China.

Wang, Q., Gao, H., Wen, F., MacGill, I., \& Huang, J. (2009). From command and control regulations to a business proposition: Creating a Chinese market for emissions trading. International Journal of Energy Sector Management, 3(1), 62-82.

World Bank. (2011). State and Trends of the Carbon Market 2011. World Bank, Washington, DC. Recuperado em 08 de fevereiro de 2013, de: http://siteresources.worldbank.org/INTCARBONFINANCE/Resources/State_and_Trends _Updated_June_2011.pdf

World Bank. (2012). State and Trends of the Carbon Market 2012. World Bank, Washington, DC. Recuperado em 14 de maio de 2014, de: http://siteresources.worldbank.org/INTCARBONFINANCE/Resources/State_and_Trends _2012_Web_Optimized_19035_Cvr\&Txt_LR.pdf

Xiaozhu, D.; \& Yunyun, Z. (2011). Accounting recognition and measurement of Carbon emissions permit in China. In ICIII - International Conference on Information Management, Innovation Management and Industrial Engineering, (pp. 405-409), 2011, Shenzhen-China.

Zhang, G., Ahmed, K.; Qu, X. \& Ji, X. (2012). Economic consequences of the adoption of Fair Value Accounting in China. Financial Markets \& Corporate Governance Conference (pp. 1-31).

Zhang, J. (2011). Accounting recognition and measurement on carbon emissions under Lowcarbon economy. In BMEI - International Conference on Business Management and Electronic Information, (pp. 910-912), 2011, Guangzhou-China. 
APÊNDICES 
APÊNDICE A - Amostra de Empresas com Projetos de MDLs - Brasil

\begin{tabular}{|c|c|c|c|c|c|c|c|c|c|c|}
\hline $\begin{array}{c}\text { País } \\
\text { hospedeiro }\end{array}$ & $\begin{array}{c}\text { Referência } \\
\text { UNFCCC }\end{array}$ & $\begin{array}{l}\text { Ano de } \\
\text { registro }\end{array}$ & $\begin{array}{l}\begin{array}{l}\text { Participante autorizado } \\
\text { (empresa brasileira) }\end{array} \\
\end{array}$ & Nome do projeto - UNFCCC & $\begin{array}{c}\text { País(es) } \\
\text { investidor(es) }\end{array}$ & $\begin{array}{l}\text { Tipo de } \\
\text { empreendimento }\end{array}$ & $\begin{array}{c}\text { Renovável } \\
\text { ou não }\end{array}$ & $\begin{array}{l}\text { Escopo } \\
\text { setorial }\end{array}$ & Escopo setorial (descrição) & $\begin{array}{c}\text { Escala } \\
(\mathbf{P} / \mathbf{L})\end{array}$ \\
\hline Brasil & 2570 & 2009 & AES Tietê S.A. & $\begin{array}{l}\text { Jaguari Mirim River } \\
\text { Hydroelectric Plants }\end{array}$ & NÃO & Produção energética - águas & SIM & 1 & $\begin{array}{l}\text { Indústrias energéticas (fontes } \\
\text { renováveis - / não-renováveis) }\end{array}$ & Pequena \\
\hline Brasil & 3887 & 2011 & AES Tietê S.A. & $\begin{array}{l}\text { AES Tietê } \\
\text { Afforestation/Reforestation } \\
\text { Project in the State of São Paulo, } \\
\text { Brazil }\end{array}$ & SIM & $\begin{array}{l}\text { Atividades de reflorestamentos } \\
\text { - pastagens }\end{array}$ & NÃO & 14 & $\begin{array}{l}\text { Florestamento e } \\
\text { reflorestamento }\end{array}$ & Larga \\
\hline Brasil & 47 & 2006 & BRF S. A. & $\begin{array}{l}\text { GHG capture and combustion } \\
\text { from swine manure management } \\
\text { systems at Faxinal dos Guedes } \\
\text { and Toledo }\end{array}$ & SIM & $\begin{array}{l}\text { Tratamento de águas - dejetos } \\
\text { suínos }\end{array}$ & NÃO & 13 e 15 & $\begin{array}{l}\text { Tratamento e eliminação de } \\
\text { resíduos / Agricultura }\end{array}$ & Larga \\
\hline Brasil & 2249 & 2009 & BRF S. A. & $\begin{array}{l}\text { Perdigão Sustainable Swine } \\
\text { Production } 01 \text { - Methane } \\
\text { capture and combustion }\end{array}$ & NÃO & $\begin{array}{l}\text { Tratamento de águas - dejetos } \\
\text { suínos }\end{array}$ & NÃO & 15 & Agricultura & Pequena \\
\hline Brasil & 7483 & 2012 & $\begin{array}{l}\text { Brookfield Energia Renovável } \\
\text { S.A. }\end{array}$ & $\begin{array}{l}\text { Pezzi Small Hydro Power Plant } \\
\text { - Project Activity }\end{array}$ & NÃO & Produção energética - águas & SIM & 1 & $\begin{array}{l}\text { Indústrias energéticas (fontes } \\
\text { renováveis - / não-renováveis) }\end{array}$ & Larga \\
\hline Brasil & 7612 & 2012 & $\begin{array}{l}\text { Brookfield Energia Renovável } \\
\text { S.A. }\end{array}$ & $\begin{array}{l}\text { SHPP Serra Cavalinhos I- } \\
\text { Project Activity }\end{array}$ & NÃO & Produção energética - águas & SIM & 1 & $\begin{array}{l}\text { Indústrias energéticas (fontes } \\
\text { renováveis - / não-renováveis) }\end{array}$ & Larga \\
\hline Brasil & 1410 & 2008 & Celulose Irani S.A. & $\begin{array}{l}\text { Irani Wastewater Methane } \\
\text { Avoidance Project }\end{array}$ & SIM & $\begin{array}{l}\text { Tratamento de águas - celulose } \\
\text { e papel }\end{array}$ & SIM & 13 & $\begin{array}{l}\text { Tratamento e eliminação de } \\
\text { resíduos }\end{array}$ & Pequena \\
\hline Brasil & 7635 & 2012 & $\begin{array}{l}\text { Companhia de Saneamento de } \\
\text { Minas Gerais - COPASA MG }\end{array}$ & $\begin{array}{l}\text { COPASA MG Small } \\
\text { Thermoelectric Plant at ETE } \\
\text { Arrudas Project }\end{array}$ & NÃO & $\begin{array}{l}\text { Produção energética - águas de } \\
\text { esgotos }\end{array}$ & SIM & 1 & $\begin{array}{l}\text { Indústrias energéticas (fontes } \\
\text { renováveis - / não-renováveis) }\end{array}$ & Pequena \\
\hline Brasil & 213 & 2006 & Cosan S.A. Indústria e Comércio & $\begin{array}{l}\text { Serra Bagasse Cogeneration } \\
\text { Project (SBCP) - Crediting } \\
\text { Period Renewal Request }\end{array}$ & SIM & Produção energética - bagaço & SIM & 1 & $\begin{array}{l}\text { Indústrias energéticas (fontes } \\
\text { renováveis - / não-renováveis) }\end{array}$ & Larga \\
\hline Brasil & 179 & 2006 & Cosan S.A. Indústria e Comércio & $\begin{array}{l}\text { Nova America Bagasse } \\
\text { Cogeneration Project NABCP }\end{array}$ & SIM & Produção energética - bagaço & SIM & 1 & $\begin{array}{l}\text { Indústrias energéticas (fontes } \\
\text { renováveis - / não-renováveis) }\end{array}$ & Larga \\
\hline Brasil & 489 & 2006 & CPFL Geração de Energia S.A. & $\begin{array}{l}\text { Repowering Small Hydro Plants } \\
\text { (SHP) in the State of São Paulo, } \\
\text { Brazil - Crediting Period } \\
\text { Renewal Request }\end{array}$ & SIM & Produção energética - águas & SIM & 1 & $\begin{array}{l}\text { Indústrias energéticas (fontes } \\
\text { renováveis - / não-renováveis) }\end{array}$ & Larga \\
\hline Brasil & 6350 & 2012 & CPFL Energias Renováveis S.A. & $\begin{array}{l}\text { Electricity generation from } \\
\text { renewable sources - Windfarms } \\
\text { Macacos, Juremas, Pedra Preta } \\
\text { and Costa Branca }\end{array}$ & NÃO & $\begin{array}{l}\text { Produção energética - } \\
\text { geradores eólicos }\end{array}$ & SIM & 1 & $\begin{array}{l}\text { Indústrias energéticas (fontes } \\
\text { renováveis - / não-renováveis) }\end{array}$ & Larga \\
\hline Brasil & 5495 & 2012 & CPFL Geração de Energia S.A. & $\begin{array}{l}\text { Electricity generation from } \\
\text { renewable sources - Windfarms } \\
\text { Santa Clara I, Santa Clara II, }\end{array}$ & NÃO & $\begin{array}{l}\text { Produção energética - } \\
\text { geradores eólicos }\end{array}$ & SIM & 1 & $\begin{array}{l}\text { Indústrias energéticas (fontes } \\
\text { renováveis - / não-renováveis) }\end{array}$ & Larga \\
\hline
\end{tabular}




\begin{tabular}{|c|c|c|c|c|c|c|c|c|c|c|}
\hline & & & & $\begin{array}{l}\text { Santa Clara III, Santa Clara IV, } \\
\text { Santa Clara V, Santa Clara VI } \\
\text { and Eurus VI }\end{array}$ & & & & & & \\
\hline Brasil & 2500 & 2010 & $\begin{array}{l}\text { Desenvix Energias Renováveis } \\
\text { S.A. }\end{array}$ & $\begin{array}{l}\text { CDM Project of Moinho and } \\
\text { Barracão Small Hydropower } \\
\text { Plant }\end{array}$ & NÃO & Produção energética - águas & SIM & 1 & $\begin{array}{l}\text { Indústrias energéticas (fontes } \\
\text { renováveis - / não-renováveis) }\end{array}$ & Larga \\
\hline Brasil & 1232 & 2008 & EDP Energias do Brasil S.A. & $\begin{array}{l}\text { UHE Mascarenhas Power } \\
\text { Upgrading Project }\end{array}$ & NÃO & Produção energética - águas & SIM & 1 & $\begin{array}{l}\text { Indústrias energéticas (fontes } \\
\text { renováveis - / não-renováveis) }\end{array}$ & Larga \\
\hline Brasil & 1317 & 2008 & EDP Energias do Brasil S.A. & $\begin{array}{l}\text { Paraiso Small Hydropower Plant } \\
\text { PCH Paraiso }\end{array}$ & NÃO & Produção energética - águas & NÃO & 1 & $\begin{array}{l}\text { Indústrias energéticas (fontes } \\
\text { renováveis - / não-renováveis) }\end{array}$ & Larga \\
\hline Brasil & 1342 & 2008 & EDP Energias do Brasil S.A. & Sao Joao Hydro Power Plant & NÃO & Produção energética - águas & SIM & 1 & $\begin{array}{l}\text { Indústrias energéticas (fontes } \\
\text { renováveis - / não-renováveis) }\end{array}$ & Larga \\
\hline Brasil & 2609 & 2010 & JBS S.A. & $\begin{array}{l}\text { Project JBS S/A - } \\
\text { Slaughterhouse Wastewater } \\
\text { Aerobic Treatment - Barra do } \\
\text { Garças Unit }\end{array}$ & NÃO & $\begin{array}{l}\text { Tratamento de águas - dejetos } \\
\text { bovinos }\end{array}$ & SIM & 13 & $\begin{array}{l}\text { Tratamento e eliminação de } \\
\text { resíduos }\end{array}$ & Pequena \\
\hline Brasil & 2610 & 2010 & JBS S.A. & $\begin{array}{l}\text { Project JBS S/A - } \\
\text { Slaughterhouse Wastewater } \\
\text { Aerobic Treatment - Vilhena } \\
\text { Unit }\end{array}$ & NÃO & $\begin{array}{l}\text { Tratamento de águas - dejetos } \\
\text { bovinos }\end{array}$ & SIM & 13 & $\begin{array}{l}\text { Tratamento e eliminação de } \\
\text { resíduos }\end{array}$ & Pequena \\
\hline Brasil & 429 & 2006 & Klabin S.A. & $\begin{array}{l}\text { Fuel oil to natural gas switching } \\
\text { at Klabin Piracicaba boilers }\end{array}$ & SIM & $\begin{array}{l}\text { Transformação industrial - } \\
\text { combustíveis industriais }\end{array}$ & NÃO & 4 & Transformação industrial & Larga \\
\hline Brasil & 843 & 2007 & $\begin{array}{l}\text { Petrobras - Petróleo Brasileiro } \\
\text { S.A. }\end{array}$ & $\begin{array}{l}\text { Petrobras Wind Power Project } \\
\text { for Oil Pumping at Macau, } \\
\text { Brazil }\end{array}$ & NÃO & $\begin{array}{l}\text { Produção energética - } \\
\text { geradores eólicos }\end{array}$ & SIM & 1 & $\begin{array}{l}\text { Indústrias energéticas (fontes } \\
\text { renováveis - / não-renováveis) }\end{array}$ & Pequena \\
\hline Brasil & 1731 & 2009 & $\begin{array}{l}\text { Petrobras - Petróleo Brasileiro } \\
\text { S.A. }\end{array}$ & $\begin{array}{l}\text { Petrobras FAFEN-BA Nitrous } \\
\text { Oxide Abatement Project }\end{array}$ & NÃO & $\begin{array}{l}\text { Transformação industrial - } \\
\text { incineração de fluxos de } \\
\text { resíduos N2O }\end{array}$ & SIM & 5 & Indústrias químicas & Larga \\
\hline Brasil & 7597 & 2012 & Renova Energia S.A. & $\begin{array}{l}\text { Renova Area 6-8 Wind Power } \\
\text { Project }\end{array}$ & NÃO & Produção energética - águas & SIM & 1 & $\begin{array}{l}\text { Indústrias energéticas (fontes } \\
\text { renováveis - / não-renováveis) }\end{array}$ & Larga \\
\hline Brasil & 7769 & 2012 & Renova Energia S.A. & Renova 2010 Wind Parks & NÃO & Produção energética - águas & SIM & 1 & $\begin{array}{l}\text { Indústrias energéticas (fontes } \\
\text { renováveis - / não-renováveis) }\end{array}$ & Larga \\
\hline Brasil & 268 & 2006 & Tractebel Energia S.A. & $\begin{array}{l}\text { Lages Methane Avoidance } \\
\text { Project }\end{array}$ & SIM & $\begin{array}{l}\text { Tratamento de resíduos } \\
\text { florestais - madeireiras }\end{array}$ & NÃO & 13 e 15 & $\begin{array}{l}\text { Tratamento e eliminação de } \\
\text { resíduos / Agricultura }\end{array}$ & Pequena \\
\hline Brasil & 7027 & 2012 & Tractebel Energia S.A. & $\begin{array}{l}\text { Porto do Delta Wind Power } \\
\text { Plant CDM Project }\end{array}$ & NÃO & $\begin{array}{l}\text { Produção energética - } \\
\text { geradores eólicos }\end{array}$ & SIM & 1 & $\begin{array}{l}\text { Indústrias energéticas (fontes } \\
\text { renováveis - / não-renováveis) }\end{array}$ & Larga \\
\hline
\end{tabular}




\begin{tabular}{|c|c|c|c|c|c|c|c|c|c|c|}
\hline Brasil & 7017 & 2012 & Tractebel Energia S.A. & $\begin{array}{l}\text { Fleixeiras I Wind Power Plant } \\
\text { CDM Project }\end{array}$ & NÃO & $\begin{array}{l}\text { Produção energética - } \\
\text { geradores eólicos }\end{array}$ & SIM & 1 & $\begin{array}{l}\text { Indústrias energéticas (fontes } \\
\text { renováveis - / não-renováveis) }\end{array}$ & Larga \\
\hline Brasil & 7021 & 2012 & Tractebel Energia S.A. & $\begin{array}{l}\text { Guajiru Wind Power Plant CDM } \\
\text { Project }\end{array}$ & NÃO & $\begin{array}{l}\text { Produção energética - } \\
\text { geradores eólicos }\end{array}$ & SIM & 1 & $\begin{array}{l}\text { Indústrias energéticas (fontes } \\
\text { renováveis - / não-renováveis) }\end{array}$ & Larga \\
\hline Brasil & 7026 & 2012 & Tractebel Energia S.A. & $\begin{array}{l}\text { Mundaú Wind Power Plant } \\
\text { CDM Project }\end{array}$ & NÃO & Produção energética - águas & SIM & 1 & $\begin{array}{l}\text { Indústrias energéticas (fontes } \\
\text { renováveis - / não-renováveis) }\end{array}$ & Larga \\
\hline Brasil & 7023 & 2012 & Tractebel Energia S.A. & $\begin{array}{l}\text { Trairi Wind Power Plant CDM } \\
\text { Project }\end{array}$ & NÃO & $\begin{array}{l}\text { Produção energética - } \\
\text { geradores eólicos }\end{array}$ & SIM & 1 & $\begin{array}{l}\text { Indústrias energéticas (fontes } \\
\text { renováveis - / não-renováveis) }\end{array}$ & Larga \\
\hline Brasil & 7258 & 2012 & Vale S.A. & $\begin{array}{l}\text { Vale Florestar. Reforestation of } \\
\text { degraded tropical land in } \\
\text { Brazilian Amazon }\end{array}$ & NÃO & $\begin{array}{l}\text { Atividades de reflorestamentos } \\
\text { - florestas }\end{array}$ & SIM & 14 & $\begin{array}{l}\text { Florestamento e } \\
\text { reflorestamento }\end{array}$ & Larga \\
\hline
\end{tabular}

Fonte: Dados da pesquisa (2015). 
APÊNDICE B - Amostra de Empresas com Projetos de MDLs - China

\begin{tabular}{|c|c|c|c|c|c|c|c|c|c|c|}
\hline $\begin{array}{c}\text { País } \\
\text { hospedeiro }\end{array}$ & $\begin{array}{l}\text { Referência } \\
\text { UNFCCC } \\
\end{array}$ & $\begin{array}{l}\text { Ano de } \\
\text { registro }\end{array}$ & \begin{tabular}{|l}
$\begin{array}{l}\text { Participante autorizado } \\
\text { (empresa chinesa) }\end{array}$ \\
\end{tabular} & Nome do projeto - UNFCCC & $\begin{array}{c}\text { Pais(es) } \\
\text { investidor(es) }\end{array}$ & \begin{tabular}{|l|}
$\begin{array}{l}\text { Tipo de } \\
\text { empreendimento }\end{array}$ \\
\end{tabular} & $\begin{array}{c}\text { Renovável } \\
\text { ou não }\end{array}$ & $\begin{array}{l}\text { Escopo } \\
\text { setorial }\end{array}$ & Escopo Setorial (nome) & $\begin{array}{c}\begin{array}{c}\text { Escala } \\
(\mathbf{S} / \mathbf{L})\end{array} \\
\end{array}$ \\
\hline China & 898 & 2007 & $\begin{array}{l}\text { Anhui Conch Cement Co., } \\
\text { Ltd. }\end{array}$ & $\begin{array}{l}\text { Ningguo Cement Plant 9100KW } \\
\text { Waste Heat Recovery and } \\
\text { Utilisation for Power Generation } \\
\text { Project of Anhui Conch Cement } \\
\text { Co. Ltd }\end{array}$ & SIM & $\begin{array}{l}\text { Produção energética - } \\
\text { utilização de calor na produção } \\
\text { de cimento }\end{array}$ & NÃO & $1 \mathrm{e} 4$ & $\begin{array}{l}\text { Indústrias energéticas (fontes } \\
\text { renováveis - / não-renováveis) } \\
\text { / Transformação Industrial }\end{array}$ & Larga \\
\hline China & 1709 & 2008 & Anyang Iron \& Steel Co. Ltd. & $\begin{array}{l}\text { Angang Sinter Machine Waste } \\
\text { Heat Recovery and Generation } \\
\text { Project }\end{array}$ & SIM & $\begin{array}{l}\text { Produção energética - } \\
\text { utilização de calor na produção } \\
\text { de ferro e aço }\end{array}$ & NÃO & 1 & $\begin{array}{l}\text { Indústrias energéticas (fontes } \\
\text { renováveis - / não-renováveis) }\end{array}$ & Larga \\
\hline China & 2703 & 2010 & Anyang Iron \& Steel Co., Ltd. & $\begin{array}{l}\text { Angang Coke Dry Quenching } \\
\text { Project }\end{array}$ & SIM & $\begin{array}{l}\text { Produção energética - } \\
\text { utilização de calor na produção } \\
\text { de ferro e aço }\end{array}$ & NÃO & $1 \mathrm{e} 4$ & $\begin{array}{l}\text { Indústrias energéticas (fontes } \\
\text { renováveis - / não-renováveis) } \\
\text { / Transformaçãa Industrial }\end{array}$ & Larga \\
\hline China & 1402 & 2008 & $\begin{array}{l}\text { Beijing BBMG Group Co., } \\
\text { Ltd. }\end{array}$ & $\begin{array}{l}\text { BBMG Cement WHR for } 10.5 \\
\text { MW power generation project in } \\
\text { Beijing }\end{array}$ & SIM & $\begin{array}{l}\text { Produção energética - } \\
\text { utilização de calor na produção } \\
\text { de cimento }\end{array}$ & SIM & 1 & $\begin{array}{l}\text { Indústrias energéticas (fontes } \\
\text { renováveis - / não-renováveis) }\end{array}$ & Larga \\
\hline China & 1628 & 2008 & $\begin{array}{l}\text { China Datang Corporation } \\
\text { Renewable Power Co., Ltd. }\end{array}$ & $\begin{array}{l}\text { Inner Mongolia Dali Phase IV } \\
\text { 49.5MW Wind Power Project }\end{array}$ & SIM & $\begin{array}{l}\text { Produção energética - } \\
\text { geradores eólicos }\end{array}$ & SIM & 1 & $\begin{array}{l}\text { Indústrias energéticas (fontes } \\
\text { renováveis - / não-renováveis) }\end{array}$ & Larga \\
\hline China & 1629 & 2008 & $\begin{array}{l}\text { China Datang Corporation } \\
\text { Renewable Power Co., Ltd. }\end{array}$ & $\begin{array}{l}\text { Inner Mongolia Dali Phase V } \\
\text { 49.5MW Wind Power Project }\end{array}$ & SIM & $\begin{array}{l}\text { Produção energética - } \\
\text { geradores eólicos }\end{array}$ & SIM & 1 & $\begin{array}{l}\text { Indústrias energéticas (fontes } \\
\text { renováveis - / não-renováveis) }\end{array}$ & Larga \\
\hline China & 1830 & 2008 & $\begin{array}{l}\text { China Datang Corporation } \\
\text { Renewable Power Co., Ltd. }\end{array}$ & $\begin{array}{l}\text { Inner Mongolia Chifeng Bolike } \\
\text { 50MW Wind Power Project }\end{array}$ & SIM & $\begin{array}{l}\text { Produção energética - } \\
\text { geradores eólicos }\end{array}$ & SIM & 1 & $\begin{array}{l}\text { Indústrias energéticas (fontes } \\
\text { renováveis - / não-renováveis) }\end{array}$ & Larga \\
\hline China & 1869 & 2008 & $\begin{array}{l}\text { China Datang Corporation } \\
\text { Renewable Power Co., Ltd. }\end{array}$ & $\begin{array}{l}\text { Inner Mongolia Chifeng } \\
\text { Dongshan Phase II 50MW Wind } \\
\text { Power Project }\end{array}$ & SIM & $\begin{array}{l}\text { Produção energética - } \\
\text { geradores eólicos }\end{array}$ & SIM & 1 & $\begin{array}{l}\text { Indústrias energéticas (fontes } \\
\text { renováveis - / não-renováveis) }\end{array}$ & Larga \\
\hline China & 2032 & 2008 & $\begin{array}{l}\text { China Datang Corporation } \\
\text { Renewable Power Co., Ltd. }\end{array}$ & $\begin{array}{l}\text { Heilongjiang Dajiazishan } \\
\text { 49.5MW Wind Power Project }\end{array}$ & SIM & $\begin{array}{l}\text { Produção energética - } \\
\text { geradores eólicos }\end{array}$ & SIM & 1 & $\begin{array}{l}\text { Indústrias energéticas (fontes } \\
\text { renováveis - / não-renováveis) }\end{array}$ & Larga \\
\hline China & 2049 & 2008 & $\begin{array}{l}\text { China Datang Corporation } \\
\text { Renewable Power Co., Ltd. }\end{array}$ & $\begin{array}{l}\text { Heilongjiang Beiantun 49.5MW } \\
\text { Wind Power Project }\end{array}$ & SIM & $\begin{array}{l}\text { Produção energética - } \\
\text { geradores eólicos }\end{array}$ & SIM & 1 & $\begin{array}{l}\text { Indústrias energéticas (fontes } \\
\text { renováveis - / não-renováveis) }\end{array}$ & Larga \\
\hline China & 2886 & 2009 & $\begin{array}{l}\text { China Datang Corporation } \\
\text { Renewable Power Co., Ltd. }\end{array}$ & $\begin{array}{l}\text { Inner Mongolia Tongliao } \\
\text { Huolinhe Wind Power Project }\end{array}$ & SIM & $\begin{array}{l}\text { Produção energética - } \\
\text { geradores eólicos }\end{array}$ & SIM & 1 & $\begin{array}{l}\text { Indústrias energéticas (fontes } \\
\text { renováveis - / não-renováveis) }\end{array}$ & Larga \\
\hline China & 2440 & 2009 & $\begin{array}{l}\text { China Datang Corporation } \\
\text { Renewable Power Co., Ltd. }\end{array}$ & $\begin{array}{l}\text { Anhui Anqing 30MW Biomass } \\
\text { Power Generation Project }\end{array}$ & SIM & $\begin{array}{l}\text { Produção energética - outros } \\
\text { resíduos agrícolas }\end{array}$ & SIM & 1 & $\begin{array}{l}\text { Indústrias energéticas (fontes } \\
\text { renováveis - / não-renováveis) }\end{array}$ & Larga \\
\hline
\end{tabular}




\begin{tabular}{|c|c|c|c|c|c|c|c|c|c|c|}
\hline China & 1833 & 2009 & $\begin{array}{l}\text { China Datang Corporation } \\
\text { Renewable Power Co., Ltd. }\end{array}$ & $\begin{array}{l}\text { Inner Mongolia Duolun } \\
\text { Daxishan 30.6MW Wind Power } \\
\text { Project }\end{array}$ & SIM & $\begin{array}{l}\text { Produção energética - } \\
\text { geradores eólicos }\end{array}$ & SIM & 1 & $\begin{array}{l}\text { Indústrias energéticas (fontes } \\
\text { renováveis - / não-renováveis) }\end{array}$ & Larga \\
\hline China & 2530 & 2009 & $\begin{array}{l}\text { China Datang Corporation } \\
\text { Renewable Power Co., Ltd. }\end{array}$ & $\begin{array}{l}\text { Shandong Laizhou phase I Wind } \\
\text { Power Project }\end{array}$ & SIM & \begin{tabular}{|l}
$\begin{array}{l}\text { Produção energética - } \\
\text { geradores eólicos }\end{array}$ \\
\end{tabular} & SIM & 1 & $\begin{array}{l}\text { Indústrias energéticas (fontes } \\
\text { renováveis - / não-renováveis) }\end{array}$ & Larga \\
\hline China & 1815 & 2009 & $\begin{array}{l}\text { China Datang Corporation } \\
\text { Renewable Power Co., Ltd. }\end{array}$ & $\begin{array}{l}\text { Inner Mongolia Huitengliang } \\
\text { Phase II Wind Power Project }\end{array}$ & SIM & $\begin{array}{l}\text { Produção energética - } \\
\text { geradores eólicos }\end{array}$ & SIM & 1 & $\begin{array}{l}\text { Indústrias energéticas (fontes } \\
\text { renováveis - / não-renováveis) }\end{array}$ & Larga \\
\hline China & 2215 & 2009 & $\begin{array}{l}\text { China Datang Corporation } \\
\text { Renewable Power Co., Ltd. }\end{array}$ & $\begin{array}{l}\text { Henan Sanmenxia 25.5MW } \\
\text { Wind Power Project }\end{array}$ & SIM & $\begin{array}{l}\text { Produção energética - } \\
\text { geradores eólicos }\end{array}$ & SIM & 1 & $\begin{array}{l}\text { Indústrias energéticas (fontes } \\
\text { renováveis - / não-renováveis) }\end{array}$ & Larga \\
\hline China & 2568 & 2009 & $\begin{array}{l}\text { China Datang Corporation } \\
\text { Renewable Power Co.. Ltd. }\end{array}$ & $\begin{array}{l}\text { Shanghai Dong Hai Bridge } \\
\text { Offshore Wind Farm Project }\end{array}$ & SIM & $\begin{array}{l}\text { Produção energética - } \\
\text { geradores eólicos }\end{array}$ & SIM & 1 & $\begin{array}{l}\text { Indústrias energéticas (fontes } \\
\text { renováveis - / não-renováveis) }\end{array}$ & Larga \\
\hline China & 2441 & 2009 & $\begin{array}{l}\text { China Datang Corporation } \\
\text { Renewable Power Co., Ltd. }\end{array}$ & $\begin{array}{l}\text { Shanxi Wulushan 1st phase } \\
\text { Wind Power Project }\end{array}$ & SIM & $\begin{array}{l}\text { Produção energética - } \\
\text { geradores eólicos }\end{array}$ & SIM & 1 & $\begin{array}{l}\text { Indústrias energéticas (fontes } \\
\text { renováveis - / não-renováveis) }\end{array}$ & Larga \\
\hline China & 2615 & 2010 & $\begin{array}{l}\text { China Datang Corporation } \\
\text { Renewable Power Co., Ltd. }\end{array}$ & $\begin{array}{l}\text { Inner Mongolia Chifeng } \\
\text { Saihanba Tashanzi Wind Power } \\
\text { Project }\end{array}$ & SIM & $\begin{array}{l}\text { Produção energética - } \\
\text { geradores eólicos }\end{array}$ & SIM & 1 & $\begin{array}{l}\text { Indústrias energéticas (fontes } \\
\text { renováveis - / não-renováveis) }\end{array}$ & Larga \\
\hline China & 2617 & 2010 & $\begin{array}{l}\text { China Datang Corporation } \\
\text { Renewable Power Co., Ltd. }\end{array}$ & $\begin{array}{l}\text { Inner Mongolia Chifeng } \\
\text { Saihanba Qingmachang Wind } \\
\text { Power Project }\end{array}$ & SIM & $\begin{array}{l}\text { Produção energética - } \\
\text { geradores eólicos }\end{array}$ & SIM & 1 & $\begin{array}{l}\text { Indústrias energéticas (fontes } \\
\text { renováveis - / não-renováveis) }\end{array}$ & Larga \\
\hline China & 3116 & 2010 & $\begin{array}{l}\text { China Datang Corporation } \\
\text { Renewable Power Co., Ltd. }\end{array}$ & $\begin{array}{l}\text { Inner Mongolia Chifeng } \\
\text { Daguangdingzishan Wind Power } \\
\text { Project }\end{array}$ & SIM & $\begin{array}{l}\text { Produção energética - } \\
\text { geradores eólicos }\end{array}$ & SIM & 1 & $\begin{array}{l}\text { Indústrias energéticas (fontes } \\
\text { renováveis - / não-renováveis) }\end{array}$ & Larga \\
\hline China & 3126 & 2010 & $\begin{array}{l}\text { China Datang Corporation } \\
\text { Renewable Power Co., Ltd. }\end{array}$ & $\begin{array}{l}\text { Inner Mongolia Chifeng } \\
\text { Daheishan Wind Power Project }\end{array}$ & SIM & $\begin{array}{l}\text { Produção energética - } \\
\text { geradores eólicos }\end{array}$ & SIM & 1 & $\begin{array}{l}\text { Indústrias energéticas (fontes } \\
\text { renováveis - / não-renováveis) }\end{array}$ & Larga \\
\hline China & 3105 & 2010 & $\begin{array}{l}\text { China Datang Corporation } \\
\text { Renewable Power Co., Ltd. }\end{array}$ & $\begin{array}{l}\text { Datang Chifeng Bolike II Wind } \\
\text { Power Project }\end{array}$ & SIM & $\begin{array}{l}\text { Produção energética - } \\
\text { geradores eólicos }\end{array}$ & SIM & 1 & $\begin{array}{l}\text { Indústrias energéticas (fontes } \\
\text { renováveis - / não-renováveis) }\end{array}$ & Larga \\
\hline China & 3903 & 2010 & $\begin{array}{l}\text { China Datang Corporation } \\
\text { Renewable Power Co., Ltd. }\end{array}$ & $\begin{array}{l}\text { Daode 49.5MW Wind Power } \\
\text { Project }\end{array}$ & SIM & $\begin{array}{l}\text { Produção energética - } \\
\text { geradores eólicos }\end{array}$ & SIM & 1 & $\begin{array}{l}\text { Indústrias energéticas (fontes } \\
\text { renováveis - / não-renováveis) }\end{array}$ & Larga \\
\hline China & 3828 & 2010 & $\begin{array}{l}\text { China Datang Corporation } \\
\text { Renewable Power Co., Ltd. }\end{array}$ & $\begin{array}{l}\text { Inner Mongolia Chifeng } \\
\text { Toudaogou Wind Power Project }\end{array}$ & SIM & $\begin{array}{l}\text { Produção energética - } \\
\text { geradores eólicos }\end{array}$ & SIM & 1 & $\begin{array}{l}\text { Indústrias energéticas (fontes } \\
\text { renováveis - / não-renováveis) }\end{array}$ & Larga \\
\hline China & 3607 & 2010 & $\begin{array}{l}\text { China Datang Corporation } \\
\text { Renewable Power Co., Ltd. }\end{array}$ & $\begin{array}{l}\text { Inner Mongolia Tongliao } \\
\text { Zhalute Qi Dangxiaogou Wind } \\
\text { Power Project }\end{array}$ & SIM & $\begin{array}{l}\text { Produção energética - } \\
\text { geradores eólicos }\end{array}$ & SIM & 1 & $\begin{array}{l}\text { Indústrias energéticas (fontes } \\
\text { renováveis - / não-renováveis) }\end{array}$ & Larga \\
\hline China & 3469 & 2010 & $\begin{array}{l}\text { China Datang Corporation } \\
\text { Renewable Power Co., Ltd. }\end{array}$ & $\begin{array}{l}\text { Datang Chifeng Danianzi Wind } \\
\text { Power Project }\end{array}$ & SIM & $\begin{array}{l}\text { Produção energética - } \\
\text { geradores eólicos }\end{array}$ & SIM & 1 & $\begin{array}{l}\text { Indústrias energéticas (fontes } \\
\text { renováveis - / não-renováveis) }\end{array}$ & Larga \\
\hline China & 2892 & 2010 & $\begin{array}{l}\text { China Datang Corporation } \\
\text { Renewable Power Co., Ltd. }\end{array}$ & $\begin{array}{l}\text { Xiangtan Shuangma Landfill } \\
\text { Gas Recovery and Utilization }\end{array}$ & SIM & Produção energétia - resíduos & NÃO & 1 e 13 & \begin{tabular}{|l} 
Indústrias energéticas (fontes \\
renováveis - / não-renováveis)
\end{tabular} & Pequena \\
\hline
\end{tabular}




\begin{tabular}{|c|c|c|c|c|c|c|c|c|c|c|}
\hline & & & & Project in Hunan Province & & sólidos urbanos & & & $\begin{array}{l}\text { / Tratamento e eliminação de } \\
\text { resíduos }\end{array}$ & \\
\hline China & 2766 & 2010 & $\begin{array}{l}\text { China Datang Corporation } \\
\text { Renewable Power Co., Ltd. }\end{array}$ & $\begin{array}{l}\text { Gansu Jingtai 45MW Wind } \\
\text { Power Project }\end{array}$ & SIM & \begin{tabular}{|l}
$\begin{array}{l}\text { Produção energética - } \\
\text { geradores eólicos }\end{array}$ \\
\end{tabular} & SIM & 1 & $\begin{array}{l}\text { Indústrias energéticas (fontes } \\
\text { renováveis - / não-renováveis) }\end{array}$ & Larga \\
\hline China & 3512 & 2010 & $\begin{array}{l}\text { China Datang Corporation } \\
\text { Renewable Power Co., Ltd. }\end{array}$ & $\begin{array}{l}\text { Gansu Datang Changma Wind } \\
\text { Power Project }\end{array}$ & SIM & $\begin{array}{l}\text { Produção energética - } \\
\text { geradores eólicos }\end{array}$ & SIM & 1 & $\begin{array}{l}\text { Indústrias energéticas (fontes } \\
\text { renováveis - / não-renováveis) }\end{array}$ & Larga \\
\hline China & 2680 & 2010 & $\begin{array}{l}\text { China Datang Corporation } \\
\text { Renewable Power Co., Ltd. }\end{array}$ & $\begin{array}{l}\text { Gansu Yumen Diwopu Wind } \\
\text { Power Project }\end{array}$ & SIM & $\begin{array}{l}\text { Produção energética - } \\
\text { geradores eólicos }\end{array}$ & SIM & 1 & $\begin{array}{l}\text { Indústrias energéticas (fontes } \\
\text { renováveis - / não-renováveis) }\end{array}$ & Larga \\
\hline China & 3804 & 2010 & $\begin{array}{l}\text { China Datang Corporation } \\
\text { Renewable Power Co.. Ltd. }\end{array}$ & $\begin{array}{l}\text { Shaanxi Hanjiang Shuhe } \\
\text { Hydropower Station }\end{array}$ & SIM & Produção energética - águas & SIM & 1 & $\begin{array}{l}\text { Indústrias energéticas (fontes } \\
\text { renováveis - / não-renováveis) }\end{array}$ & Larga \\
\hline China & 3060 & 2010 & $\begin{array}{l}\text { China Datang Corporation } \\
\text { Renewable Power Co., Ltd. }\end{array}$ & $\begin{array}{l}\text { Shanxi Wulushan 2nd phase } \\
\text { Wind Power Project }\end{array}$ & SIM & $\begin{array}{l}\begin{array}{l}\text { Produção energética - } \\
\text { geradores eólicos }\end{array} \\
\end{array}$ & SIM & 1 & $\begin{array}{l}\text { Indústrias energéticas (fontes } \\
\text { renováveis - / não-renováveis) }\end{array}$ & Larga \\
\hline China & 2227 & 2010 & $\begin{array}{l}\text { China Datang Corporation } \\
\text { Renewable Power Co., Ltd. }\end{array}$ & $\begin{array}{l}\text { Inner Mongolia Xinghe } \\
\text { Hangtian Wind Farm Project }\end{array}$ & SIM & $\begin{array}{l}\text { Produção energética - } \\
\text { geradores eólicos }\end{array}$ & SIM & 1 & $\begin{array}{l}\text { Indústrias energéticas (fontes } \\
\text { renováveis - / não-renováveis) }\end{array}$ & Larga \\
\hline China & 4067 & 2011 & $\begin{array}{l}\text { China Datang Corporation } \\
\text { Renewable Power Co., Ltd. }\end{array}$ & $\begin{array}{l}\text { Dalian Tuchengzi Wind Power } \\
\text { Project } 30 \mathrm{MW}\end{array}$ & SIM & $\begin{array}{l}\text { Produção energética - } \\
\text { geradores eólicos }\end{array}$ & SIM & 1 & $\begin{array}{l}\text { Indústrias energéticas (fontes } \\
\text { renováveis - / não-renováveis) }\end{array}$ & Larga \\
\hline China & 3573 & 2011 & $\begin{array}{l}\text { China Datang Corporation } \\
\text { Renewable Power Co., Ltd. }\end{array}$ & $\begin{array}{l}\text { Inner Mongolia Chifeng } \\
\text { Chaganhada Wind Power } \\
\text { Project }\end{array}$ & SIM & $\begin{array}{l}\text { Produção energética - } \\
\text { geradores eólicos }\end{array}$ & SIM & 1 & $\begin{array}{l}\text { Indústrias energéticas (fontes } \\
\text { renováveis - / não-renováveis) }\end{array}$ & Larga \\
\hline China & 4341 & 2011 & $\begin{array}{l}\text { China Datang Corporation } \\
\text { Renewable Power Co., Ltd. }\end{array}$ & $\begin{array}{l}\text { Inner Mongolia Chifeng } \\
\text { Yikesong Wind Power Project }\end{array}$ & SIM & $\begin{array}{l}\text { Produção energética - } \\
\text { geradores eólicos }\end{array}$ & SIM & 1 & $\begin{array}{l}\text { Indústrias energéticas (fontes } \\
\text { renováveis - / não-renováveis) }\end{array}$ & Larga \\
\hline China & 4093 & 2011 & $\begin{array}{l}\text { China Datang Corporation } \\
\text { Renewable Power Co., Ltd. }\end{array}$ & $\begin{array}{l}\text { Datang Duolun Daxishan phase } \\
\text { III Wind Farm project }\end{array}$ & SIM & $\begin{array}{l}\text { Produção energética - } \\
\text { geradores eólicos }\end{array}$ & SIM & 1 & $\begin{array}{l}\text { Indústrias energéticas (fontes } \\
\text { renováveis - / não-renováveis) }\end{array}$ & Larga \\
\hline China & 4112 & 2011 & $\begin{array}{l}\text { China Datang Corporation } \\
\text { Renewable Power Co., Ltd. }\end{array}$ & $\begin{array}{l}\text { Datang Duolun Daxishan Farm } \\
\text { II }\end{array}$ & SIM & $\begin{array}{l}\text { Produção energética - } \\
\text { geradores eólicos }\end{array}$ & SIM & 1 & $\begin{array}{l}\text { Indústrias energéticas (fontes } \\
\text { renováveis - / não-renováveis) }\end{array}$ & Larga \\
\hline China & 3608 & 2011 & $\begin{array}{l}\text { China Datang Corporation } \\
\text { Renewable Power Co., Ltd. }\end{array}$ & $\begin{array}{l}\text { Inner Mongolia Tongliao } \\
\text { Zhalute Qi Beishala Wind Power } \\
\text { Project }\end{array}$ & SIM & $\begin{array}{l}\text { Produção energética - } \\
\text { geradores eólicos }\end{array}$ & SIM & 1 & $\begin{array}{l}\text { Indústrias energéticas (fontes } \\
\text { renováveis - / não-renováveis) }\end{array}$ & Larga \\
\hline China & 4738 & 2011 & $\begin{array}{l}\text { China Datang Corporation } \\
\text { Renewable Power Co., Ltd. }\end{array}$ & \begin{tabular}{|l|} 
Inner Mongolia Tongliao \\
Zhalute Qi Phase II North Wind \\
Power Project
\end{tabular} & SIM & $\begin{array}{l}\text { Produção energética - } \\
\text { geradores eólicos }\end{array}$ & SIM & 1 & $\begin{array}{l}\text { Indústrias energéticas (fontes } \\
\text { renováveis - / não-renováveis) }\end{array}$ & Larga \\
\hline China & 4912 & 2011 & $\begin{array}{l}\text { China Datang Corporation } \\
\text { Renewable Power Co., Ltd. }\end{array}$ & $\begin{array}{l}\text { Yunnan Luopingshan Phase I } \\
\text { Wind Power Project }\end{array}$ & SIM & Produção energética - & SIM & 1 & Indústrias energéticas (fontes & Larga \\
\hline
\end{tabular}




\begin{tabular}{|c|c|c|c|c|c|c|c|c|c|c|}
\hline & & & & & & geradores eólicos & & & renováveis - / não-renováveis) & \\
\hline China & 4781 & 2011 & $\begin{array}{l}\text { China Datang Corporation } \\
\text { Renewable Power Co., Ltd. }\end{array}$ & $\begin{array}{l}\text { Inner Mongolia Urad Houqi } \\
\text { Wuliii Wind Power Project }\end{array}$ & SIM & $\begin{array}{l}\text { Produção energética - } \\
\text { geradores eólicos }\end{array}$ & SIM & 1 & $\begin{array}{l}\text { Indústrias energéticas (fontes } \\
\text { renováveis - / não-renováveis) }\end{array}$ & Larga \\
\hline China & 4059 & 2011 & $\begin{array}{l}\text { China Datang Corporation } \\
\text { Renewable Power Co., Ltd. }\end{array}$ & $\begin{array}{l}\text { Liaoning Changtu Manjing } \\
\text { Wind Power Project }\end{array}$ & SIM & $\begin{array}{l}\text { Produção energética - } \\
\text { geradores eólicos }\end{array}$ & SIM & 1 & $\begin{array}{l}\text { Indústrias energéticas (fontes } \\
\text { renováveis - / não-renováveis) }\end{array}$ & Larga \\
\hline China & 4821 & 2011 & $\begin{array}{l}\text { China Datang Corporation } \\
\text { Renewable Power Co., Ltd. }\end{array}$ & $\begin{array}{l}\text { Yunnan Mangli Hydropower } \\
\text { Project }\end{array}$ & SIM & Produção energética - águas & SIM & 1 & $\begin{array}{l}\text { Indústrias energéticas (fontes } \\
\text { renováveis - / não-renováveis) }\end{array}$ & Larga \\
\hline China & 5132 & 2011 & $\begin{array}{l}\text { China Datang Corporation } \\
\text { Renewable Power Co., Ltd. }\end{array}$ & $\begin{array}{l}\text { Datang Wendeng Wind Power } \\
\text { Project }\end{array}$ & SIM & $\begin{array}{l}\text { Produção energética - } \\
\text { geradores eólicos }\end{array}$ & SIM & 1 & $\begin{array}{l}\text { Indústrias energéticas (fontes } \\
\text { renováveis - / não-renováveis) }\end{array}$ & Larga \\
\hline China & 4440 & 2011 & $\begin{array}{l}\text { China Datang Corporation } \\
\text { Renewable Power Co., Ltd. }\end{array}$ & $\begin{array}{l}\text { Inner Mongolia Tongliao } \\
\text { Zhalute Qi Phase I North Wind } \\
\text { Power Project }\end{array}$ & SIM & $\begin{array}{l}\text { Produção energética - } \\
\text { geradores eólicos }\end{array}$ & SIM & 1 & $\begin{array}{l}\text { Indústrias energéticas (fontes } \\
\text { renováveis - / não-renováveis) }\end{array}$ & Larga \\
\hline China & 5443 & 2012 & $\begin{array}{l}\text { China Datang Corporation } \\
\text { Renewable Power Co., Ltd. }\end{array}$ & $\begin{array}{l}\text { Heilongjiang Hailin Weihushan } \\
\text { Wind Power Project }\end{array}$ & SIM & $\begin{array}{l}\text { Produção energética - } \\
\text { geradores eólicos }\end{array}$ & SIM & 1 & $\begin{array}{l}\text { Indústrias energéticas (fontes } \\
\text { renováveis - / não-renováveis) }\end{array}$ & Larga \\
\hline China & 6678 & 2012 & $\begin{array}{l}\text { China Datang Corporation } \\
\text { Renewable Power Co., Ltd. }\end{array}$ & $\begin{array}{l}\text { Inner Mongolia Wuliji Phase II } \\
\text { Wind Power Project }\end{array}$ & SIM & $\begin{array}{l}\text { Produção energética - } \\
\text { geradores eólicos }\end{array}$ & SIM & 1 & $\begin{array}{l}\text { Indústrias energéticas (fontes } \\
\text { renováveis - / não-renováveis) }\end{array}$ & Larga \\
\hline China & 7091 & 2012 & $\begin{array}{l}\text { China Datang Corporation } \\
\text { Renewable Power Co., Ltd. }\end{array}$ & $\begin{array}{l}\text { Datang Tuquan Laoyeling Wind } \\
\text { Farm Phase II Project }\end{array}$ & SIM & $\begin{array}{l}\text { Produção energética - } \\
\text { geradores eólicos }\end{array}$ & SIM & 1 & $\begin{array}{l}\text { Indústrias energéticas (fontes } \\
\text { renováveis - / não-renováveis) }\end{array}$ & Larga \\
\hline China & 5681 & 2012 & $\begin{array}{l}\text { China Datang Corporation } \\
\text { Renewable Power Co., Ltd. }\end{array}$ & $\begin{array}{l}\text { Heilongjiang Huachuan } \\
\text { Sujiadian Wind Power Project }\end{array}$ & SIM & $\begin{array}{l}\text { Produção energética - } \\
\text { geradores eólicos }\end{array}$ & SIM & 1 & $\begin{array}{l}\text { Indústrias energéticas (fontes } \\
\text { renováveis - / não-renováveis) }\end{array}$ & Larga \\
\hline China & 6158 & 2012 & $\begin{array}{l}\text { China Datang Corporation } \\
\text { Renewable Power Co., Ltd. }\end{array}$ & $\begin{array}{l}\text { Gansu Jingtai Xingquan } \\
\text { Localization Wind Power } \\
\text { Project }\end{array}$ & SIM & $\begin{array}{l}\text { Produção energética - } \\
\text { geradores eólicos }\end{array}$ & SIM & 1 & $\begin{array}{l}\text { Indústrias energéticas (fontes } \\
\text { renováveis - / não-renováveis) }\end{array}$ & Larga \\
\hline China & 6561 & 2012 & $\begin{array}{l}\text { China Datang Corporation } \\
\text { Renewable Power Co., Ltd. }\end{array}$ & $\begin{array}{l}\text { Heilongjiang Jixian Taiyangshan } \\
\text { Wind Power Project }\end{array}$ & SIM & $\begin{array}{l}\text { Produção energética - } \\
\text { geradores eólicos }\end{array}$ & SIM & 1 & $\begin{array}{l}\text { Indústrias energéticas (fontes } \\
\text { renováveis - / não-renováveis) }\end{array}$ & Larga \\
\hline China & 5199 & 2012 & $\begin{array}{l}\text { China Datang Corporation } \\
\text { Renewable Power Co., Ltd. }\end{array}$ & $\begin{array}{l}\text { Datang Qingyuan Phase II Wind } \\
\text { Power Project }\end{array}$ & SIM & $\begin{array}{l}\text { Produção energética - } \\
\text { geradores eólicos }\end{array}$ & SIM & 1 & $\begin{array}{l}\text { Indústrias energéticas (fontes } \\
\text { renováveis - / não-renováveis) }\end{array}$ & Larga \\
\hline China & 5733 & 2012 & $\begin{array}{l}\text { China Datang Corporation } \\
\text { Renewable Power Co., Ltd. }\end{array}$ & $\begin{array}{l}\text { Datang Anzishan Wind Power } \\
\text { Project }\end{array}$ & SIM & $\begin{array}{l}\text { Produção energética - } \\
\text { geradores eólicos }\end{array}$ & SIM & 1 & $\begin{array}{l}\text { Indústrias energéticas (fontes } \\
\text { renováveis - / não-renováveis) }\end{array}$ & Larga \\
\hline China & 5978 & 2012 & $\begin{array}{l}\text { China Datang Corporation } \\
\text { Renewable Power Co., Ltd. }\end{array}$ & $\begin{array}{l}\text { Shanxi Hunyuan Mimazongliang } \\
\text { Phase I Wind Power Project }\end{array}$ & SIM & $\begin{array}{l}\text { Produção energética - } \\
\text { geradores eólicos }\end{array}$ & SIM & 1 & $\begin{array}{l}\text { Indústrias energéticas (fontes } \\
\text { renováveis - / não-renováveis) }\end{array}$ & Larga \\
\hline China & 6415 & 2012 & $\begin{array}{l}\text { China Datang Corporation } \\
\text { Renewable Power Co., Ltd. }\end{array}$ & $\begin{array}{l}\text { Inner Mongolia Chifeng } \\
\text { Yangshugou Wind Power } \\
\text { Project }\end{array}$ & SIM & $\begin{array}{l}\text { Produção energética - } \\
\text { geradores eólicos }\end{array}$ & SIM & 1 & $\begin{array}{l}\text { Indústrias energéticas (fontes } \\
\text { renováveis - / não-renováveis) }\end{array}$ & Larga \\
\hline
\end{tabular}




\begin{tabular}{|c|c|c|c|c|c|c|c|c|c|c|}
\hline China & 6670 & 2012 & $\begin{array}{l}\text { China Datang Corporation } \\
\text { Renewable Power Co., Ltd. }\end{array}$ & $\begin{array}{l}\text { Inner Mongolia Chifeng } \\
\text { Changhangou Wind Power } \\
\text { Project }\end{array}$ & SIM & $\begin{array}{l}\text { Produção energética - } \\
\text { geradores eólicos }\end{array}$ & SIM & 1 & $\begin{array}{l}\text { Indústrias energéticas (fontes } \\
\text { renováveis - / não-renováveis) }\end{array}$ & Larga \\
\hline China & 5688 & 2012 & $\begin{array}{l}\text { China Datang Corporation } \\
\text { Renewable Power Co., Ltd. }\end{array}$ & $\begin{array}{l}\text { Heilongjiang Yilan Fuqiang } \\
\text { Wind Power Project }\end{array}$ & SIM & $\begin{array}{l}\text { Produção energética - } \\
\text { geradores eólicos }\end{array}$ & SIM & 1 & $\begin{array}{l}\text { Indústrias energéticas (fontes } \\
\text { renováveis - / não-renováveis) }\end{array}$ & Larga \\
\hline China & 5856 & 2012 & $\begin{array}{l}\text { China Datang Corporation } \\
\text { Renewable Power Co., Ltd. }\end{array}$ & $\begin{array}{l}\text { Heilongjiang Yilan Chenguang } \\
\text { Wind Power Project }\end{array}$ & SIM & $\begin{array}{l}\text { Produção energética - } \\
\text { geradores eólicos }\end{array}$ & SIM & 1 & $\begin{array}{l}\text { Indústrias energéticas (fontes } \\
\text { renováveis - / não-renováveis) }\end{array}$ & Larga \\
\hline China & 7710 & 2012 & $\begin{array}{l}\text { China Datang Corporation } \\
\text { Renewable Power Co., Ltd. }\end{array}$ & $\begin{array}{l}\text { Heilongjiang Wuerguli Wind } \\
\text { Power Project }\end{array}$ & SIM & $\begin{array}{l}\begin{array}{l}\text { Produção energética - } \\
\text { geradores eólicos }\end{array} \\
\end{array}$ & NÃO & 1 & $\begin{array}{l}\text { Indústrias energéticas (fontes } \\
\text { renováveis - / não-renováveis) }\end{array}$ & Larga \\
\hline China & 5875 & 2012 & $\begin{array}{l}\text { China Datang Corporation } \\
\text { Renewable Power Co., Ltd. }\end{array}$ & $\begin{array}{l}\text { Shanxi Wulushan 3rd phase } \\
\text { Wind Power Project }\end{array}$ & SIM & $\begin{array}{l}\text { Produção energética - } \\
\text { geradores eólicos }\end{array}$ & SIM & 1 & $\begin{array}{l}\text { Indústrias energéticas (fontes } \\
\text { renováveis - / não-renováveis) }\end{array}$ & Larga \\
\hline China & 1172 & 2007 & $\begin{array}{l}\text { China Longyuan Power Group } \\
\text { Co., Ltd. }\end{array}$ & $\begin{array}{l}\text { Fujian Nanridao } 16.15 \mathrm{MW} \\
\text { Wind Power Project }\end{array}$ & SIM & $\begin{array}{l}\text { Produção energética - } \\
\text { geradores eólicos }\end{array}$ & SIM & 1 & $\begin{array}{l}\text { Indústrias energéticas (fontes } \\
\text { renováveis - / não-renováveis) }\end{array}$ & Larga \\
\hline China & 1177 & 2007 & $\begin{array}{l}\text { China Longyuan Power Group } \\
\text { Co.. Ltd. }\end{array}$ & $\begin{array}{l}\text { Fujian Pingtan Changiiang'ao } \\
\text { 100 MW Wind Power Project }\end{array}$ & SIM & $\begin{array}{l}\text { Produção energética - } \\
\text { geradores eólicos }\end{array}$ & SIM & 1 & $\begin{array}{l}\text { Indústrias energéticas (fontes } \\
\text { renováveis - / não-renováveis) }\end{array}$ & Larga \\
\hline China & 1487 & 2008 & $\begin{array}{l}\text { China Longyuan Power Group } \\
\text { Co., Ltd. }\end{array}$ & $\begin{array}{l}\text { Inner Mongolia Wudaogou } \\
\text { 50.25MW Wind Power Project }\end{array}$ & SIM & $\begin{array}{l}\text { Produção energética - } \\
\text { geradores eólicos }\end{array}$ & SIM & 1 & $\begin{array}{l}\text { Indústrias energéticas (fontes } \\
\text { renováveis - / não-renováveis) }\end{array}$ & Larga \\
\hline China & 1488 & 2008 & $\begin{array}{l}\text { China Longyuan Power Group } \\
\text { Co., Ltd. }\end{array}$ & $\begin{array}{l}\text { Inner Mongolia Sunjiaying } \\
\text { 50.25MW Wind Power Project }\end{array}$ & SIM & $\begin{array}{l}\text { Produção energética - } \\
\text { geradores eólicos }\end{array}$ & SIM & 1 & $\begin{array}{l}\text { Indústrias energéticas (fontes } \\
\text { renováveis - / não-renováveis) }\end{array}$ & Larga \\
\hline China & 2056 & 2008 & $\begin{array}{l}\text { China Longyuan Power Group } \\
\text { Co., Ltd. }\end{array}$ & $\begin{array}{l}\text { Heilongjiang Huanan } \\
\text { Hengdaishan East Wind Power } \\
\text { Project }\end{array}$ & SIM & $\begin{array}{l}\text { Produção energética - } \\
\text { geradores eólicos }\end{array}$ & SIM & 1 & $\begin{array}{l}\text { Indústrias energéticas (fontes } \\
\text { renováveis - / não-renováveis) }\end{array}$ & Larga \\
\hline China & 2067 & 2008 & $\begin{array}{l}\text { China Longyuan Power Group } \\
\text { Co., Ltd. }\end{array}$ & $\begin{array}{l}\text { Hebei Shirenshan Wind Power } \\
\text { Project }\end{array}$ & SIM & $\begin{array}{l}\text { Produção energética - } \\
\text { geradores eólicos }\end{array}$ & SIM & 1 & $\begin{array}{l}\text { Indústrias energéticas (fontes } \\
\text { renováveis - / não-renováveis) }\end{array}$ & Larga \\
\hline China & 1892 & 2009 & $\begin{array}{l}\text { China Longyuan Power Group } \\
\text { Co., Ltd. }\end{array}$ & $\begin{array}{l}\text { Jiangsu Longyuan Donghai } \\
\text { Biomass Power Project }\end{array}$ & SIM & $\begin{array}{l}\text { Produção energética - outros } \\
\text { resíduos agrícolas }\end{array}$ & SIM & 1 & $\begin{array}{l}\text { Indústrias energéticas (fontes } \\
\text { renováveis - / não-renováveis) }\end{array}$ & Larga \\
\hline China & 2140 & 2009 & $\begin{array}{l}\text { China Longyuan Power Group } \\
\text { Co., Ltd. }\end{array}$ & $\begin{array}{l}\text { Hebei Chongli Qingsanying } \\
\text { 49.3MW Wind Farm Project }\end{array}$ & SIM & $\begin{array}{l}\text { Produção energética - } \\
\text { geradores eólicos }\end{array}$ & SIM & 1 & $\begin{array}{l}\text { Indústrias energéticas (fontes } \\
\text { renováveis - / não-renováveis) }\end{array}$ & Larga \\
\hline China & 2870 & 2009 & $\begin{array}{l}\text { China Longyuan Power Group } \\
\text { Co., Ltd. }\end{array}$ & $\begin{array}{l}\text { Hebei Weichang Longyuan } \\
\text { Construction Investment } \\
\text { Shanwanzi Wind Power Project }\end{array}$ & SIM & $\begin{array}{l}\text { Produção energética - } \\
\text { geradores eólicos }\end{array}$ & SIM & 1 & $\begin{array}{l}\text { Indústrias energéticas (fontes } \\
\text { renováveis - / não-renováveis) }\end{array}$ & Larga \\
\hline China & 2200 & 2009 & $\begin{array}{l}\text { China Longyuan Power Group } \\
\text { Co., Ltd. }\end{array}$ & $\begin{array}{l}\text { Heilongjiang Huanan } \\
\text { Hengdaishan West Wind Power }\end{array}$ & SIM & Produção energética - & SIM & 1 & Indústrias energéticas (fontes & Larga \\
\hline
\end{tabular}




\begin{tabular}{|c|c|c|c|c|c|c|c|c|c|c|}
\hline & & & & Project & & geradores eólicos & & & renováveis - / não-renováveis) & \\
\hline China & 2153 & 2009 & $\begin{array}{l}\text { China Longyuan Power Group } \\
\text { Co., Ltd. }\end{array}$ & $\begin{array}{l}\text { Inner Mongolia Baotou Bayin } \\
\text { Wind Power Project }\end{array}$ & SIM & $\begin{array}{l}\text { Produção energética - } \\
\text { geradores eólicos }\end{array}$ & SIM & 1 & $\begin{array}{l}\text { Indústrias energéticas (fontes } \\
\text { renováveis - / não-renováveis) }\end{array}$ & Larga \\
\hline China & 1621 & 2009 & $\begin{array}{l}\text { China Longyuan Power Group } \\
\text { Co., Ltd. }\end{array}$ & $\begin{array}{l}\text { Inner Mongolia Bayannaoer } \\
\text { Chuanjingsumu 49.3MW Wind } \\
\text { Power Project }\end{array}$ & SIM & $\begin{array}{l}\text { Produção energética - } \\
\text { geradores eólicos }\end{array}$ & SIM & 1 & $\begin{array}{l}\text { Indústrias energéticas (fontes } \\
\text { renováveis - / não-renováveis) }\end{array}$ & Larga \\
\hline China & 2857 & 2009 & $\begin{array}{l}\text { China Longyuan Power Group } \\
\text { Co., Ltd. }\end{array}$ & $\begin{array}{l}\text { Jiangsu Qidong Dongyuan Wind } \\
\text { Power Project }\end{array}$ & SIM & $\begin{array}{l}\text { Produção energética - } \\
\text { geradores eólicos }\end{array}$ & SIM & 1 & $\begin{array}{l}\text { Indústrias energéticas (fontes } \\
\text { renováveis - / não-renováveis) }\end{array}$ & Larga \\
\hline China & 2035 & 2009 & $\begin{array}{l}\text { China Longyuan Power Group } \\
\text { Co., Ltd. }\end{array}$ & $\begin{array}{l}\text { Heilongjiang Yilan Maanshan } \\
\text { Wind Power Project }\end{array}$ & SIM & $\begin{array}{l}\text { Produção energética - } \\
\text { geradores eólicos }\end{array}$ & SIM & 1 & $\begin{array}{l}\text { Indústrias energéticas (fontes } \\
\text { renováveis - / não-renováveis) }\end{array}$ & Larga \\
\hline China & 2449 & 2009 & $\begin{array}{l}\text { China Longyuan Power Group } \\
\text { Co., Ltd. }\end{array}$ & $\begin{array}{l}\text { Zhejiang Wenling Donghaitang } \\
\text { Wind Power Project }\end{array}$ & SIM & $\begin{array}{l}\text { Produção energética - } \\
\text { geradores eólicos }\end{array}$ & SIM & 1 & $\begin{array}{l}\text { Indústrias energéticas (fontes } \\
\text { renováveis - / não-renováveis) }\end{array}$ & Larga \\
\hline China & 3519 & 2010 & $\begin{array}{l}\text { China Longyuan Power Group } \\
\text { Co., Ltd. }\end{array}$ & $\begin{array}{l}\text { Inner Mongolia Wudaogou III } \\
\text { Wind Power Project }\end{array}$ & SIM & $\begin{array}{l}\text { Produção energética - } \\
\text { geradores eólicos }\end{array}$ & SIM & 1 & $\begin{array}{l}\text { Indústrias energéticas (fontes } \\
\text { renováveis - / não-renováveis) }\end{array}$ & Larga \\
\hline China & 3325 & 2010 & $\begin{array}{l}\text { China Longyuan Power Group } \\
\text { Co., Ltd. }\end{array}$ & $\begin{array}{l}\text { Inner Mongolia Wengniute } \\
\text { Banner Wudaogou Wind Power } \\
\text { Project (II) }\end{array}$ & SIM & $\begin{array}{l}\text { Produção energética - } \\
\text { geradores eólicos }\end{array}$ & SIM & 1 & $\begin{array}{l}\text { Indústrias energéticas (fontes } \\
\text { renováveis - / não-renováveis) }\end{array}$ & Larga \\
\hline China & 3439 & 2010 & $\begin{array}{l}\text { China Longyuan Power Group } \\
\text { Co., Ltd. }\end{array}$ & $\begin{array}{l}\text { Inner Mongolia Chifeng } \\
\text { Gaofeng Wind Power Project }\end{array}$ & SIM & $\begin{array}{l}\text { Produção energética - } \\
\text { geradores eólicos }\end{array}$ & SIM & 1 & $\begin{array}{l}\text { Indústrias energéticas (fontes } \\
\text { renováveis - / não-renováveis) }\end{array}$ & Larga \\
\hline China & 3777 & 2010 & $\begin{array}{l}\text { China Longyuan Power Group } \\
\text { Co., Ltd. }\end{array}$ & $\begin{array}{l}\text { Chifeng Sunjiaying Wind Power } \\
\text { Project }\end{array}$ & SIM & $\begin{array}{l}\text { Produção energética - } \\
\text { geradores eólicos }\end{array}$ & SIM & 1 & $\begin{array}{l}\text { Indústrias energéticas (fontes } \\
\text { renováveis - / não-renováveis) }\end{array}$ & Larga \\
\hline China & 3003 & 2010 & $\begin{array}{l}\text { China Longyuan Power Group } \\
\text { Co., Ltd. }\end{array}$ & $\begin{array}{l}\text { Xinjiang Alashankou Phase I } \\
\text { Wind Power Project }\end{array}$ & SIM & $\begin{array}{l}\text { Produção energética - } \\
\text { geradores eólicos }\end{array}$ & SIM & 1 & $\begin{array}{l}\text { Indústrias energéticas (fontes } \\
\text { renováveis - / não-renováveis) }\end{array}$ & Larga \\
\hline China & 2604 & 2010 & $\begin{array}{l}\text { China Longyuan Power Group } \\
\text { Co., Ltd. }\end{array}$ & $\begin{array}{l}\text { Hainan Danzhou Eman Wind } \\
\text { Power Project }\end{array}$ & SIM & $\begin{array}{l}\text { Produção energética - } \\
\text { geradores eólicos }\end{array}$ & SIM & 1 & $\begin{array}{l}\text { Indústrias energéticas (fontes } \\
\text { renováveis - / não-renováveis) }\end{array}$ & Larga \\
\hline China & 3093 & 2010 & $\begin{array}{l}\text { China Longyuan Power Group } \\
\text { Co., Ltd. }\end{array}$ & $\begin{array}{l}\text { Hebei Weichang Zhangjiawan } \\
\text { Wind Power Project }\end{array}$ & SIM & $\begin{array}{l}\text { Produção energética - } \\
\text { geradores eólicos }\end{array}$ & SIM & 1 & $\begin{array}{l}\text { Indústrias energéticas (fontes } \\
\text { renováveis - / não-renováveis) }\end{array}$ & Larga \\
\hline China & 2951 & 2010 & $\begin{array}{l}\text { China Longyuan Power Group } \\
\text { Co., Ltd. }\end{array}$ & $\begin{array}{l}\text { Inner Mongolia Bayannaoer } \\
\text { Chuanjingsumu (IV) Wind } \\
\text { Power Project }\end{array}$ & SIM & $\begin{array}{l}\text { Produção energética - } \\
\text { geradores eólicos }\end{array}$ & SIM & 1 & $\begin{array}{l}\text { Indústrias energéticas (fontes } \\
\text { renováveis - / não-renováveis) }\end{array}$ & Larga \\
\hline China & 3134 & 2010 & $\begin{array}{l}\text { China Longyuan Power Group } \\
\text { Co., Ltd. }\end{array}$ & $\begin{array}{l}\text { Inner Mongolia Saiwusu I Wind } \\
\text { Power Project }\end{array}$ & SIM & $\begin{array}{l}\text { Produção energética - } \\
\text { geradores eólicos }\end{array}$ & SIM & 1 & $\begin{array}{l}\text { Indústrias energéticas (fontes } \\
\text { renováveis - / não-renováveis) }\end{array}$ & Larga \\
\hline China & 3447 & 2010 & $\begin{array}{l}\text { China Longyuan Power Group } \\
\text { Co., Ltd. }\end{array}$ & $\begin{array}{l}\text { Inner Mongolia Bayannaoer } \\
\text { Chuanjingsumu ( III ) Wind } \\
\text { Power Project }\end{array}$ & SIM & $\begin{array}{l}\text { Produção energética - } \\
\text { geradores eólicos }\end{array}$ & SIM & 1 & $\begin{array}{l}\text { Indústrias energéticas (fontes } \\
\text { renováveis - / não-renováveis) }\end{array}$ & Larga \\
\hline
\end{tabular}




\begin{tabular}{|c|c|c|c|c|c|c|c|c|c|c|}
\hline China & 3679 & 2010 & $\begin{array}{l}\text { China Longyuan Power Group } \\
\text { Co., Ltd. }\end{array}$ & $\begin{array}{l}\text { Inner Mongolia Saiwusu II Wind } \\
\text { Power Project }\end{array}$ & SIM & $\begin{array}{l}\text { Produção energética - } \\
\text { geradores eólicos }\end{array}$ & SIM & 1 & \begin{tabular}{|l} 
Indústrias energéticas (fontes \\
renováveis - / não-renováveis)
\end{tabular} & Larga \\
\hline China & 3122 & 2010 & $\begin{array}{l}\text { China Longyuan Power Group } \\
\text { Co., Ltd. }\end{array}$ & $\begin{array}{l}\text { Jilin Longyuan Changling } \\
\text { Shuanglong Phase I Wind Power } \\
\text { Project }\end{array}$ & SIM & $\begin{array}{l}\text { Produção energética - } \\
\text { geradores eólicos }\end{array}$ & SIM & 1 & $\begin{array}{l}\text { Indústrias energéticas (fontes } \\
\text { renováveis - / não-renováveis) }\end{array}$ & Larga \\
\hline China & 3153 & 2010 & $\begin{array}{l}\text { China Longyuan Power Group } \\
\text { Co., Ltd. }\end{array}$ & $\begin{array}{l}\text { Tongliao Naiman Banner } \\
\text { Baxiantong Haritang Wind } \\
\text { Power Project }\end{array}$ & SIM & $\begin{array}{l}\text { Produção energética - } \\
\text { geradores eólicos }\end{array}$ & SIM & 1 & $\begin{array}{l}\text { Indústrias energéticas (fontes } \\
\text { renováveis - / não-renováveis) }\end{array}$ & Larga \\
\hline China & 3799 & 2010 & $\begin{array}{l}\text { China Longyuan Power Group } \\
\text { Co., Ltd. }\end{array}$ & $\begin{array}{l}\text { Fujian Putian Nanri Phase III } \\
\text { Wind Power Project }\end{array}$ & SIM & $\begin{array}{l}\text { Produção energética - } \\
\text { geradores eólicos }\end{array}$ & SIM & 1 & $\begin{array}{l}\text { Indústrias energéticas (fontes } \\
\text { renováveis - / não-renováveis) }\end{array}$ & Larga \\
\hline China & 3736 & 2010 & $\begin{array}{l}\text { China Longyuan Power Group } \\
\text { Co., Ltd. }\end{array}$ & $\begin{array}{l}\text { Jiangsu Rudong (II) Expansion } \\
\text { Wind Power Project }\end{array}$ & SIM & $\begin{array}{l}\text { Produção energética - } \\
\text { geradores eólicos }\end{array}$ & SIM & 1 & $\begin{array}{l}\text { Indústrias energéticas (fontes } \\
\text { renováveis - / não-renováveis) }\end{array}$ & Larga \\
\hline China & 3258 & 2010 & $\begin{array}{l}\text { China Longyuan Power Group } \\
\text { Co., Ltd. }\end{array}$ & $\begin{array}{l}\text { Tongliao Kezuozhong Banner } \\
\text { Dailiji Aorimu Wind Power } \\
\text { Project }\end{array}$ & SIM & $\begin{array}{l}\text { Produção energética - } \\
\text { geradores eólicos }\end{array}$ & SIM & 1 & $\begin{array}{l}\text { Indústrias energéticas (fontes } \\
\text { renováveis - / não-renováveis) }\end{array}$ & Larga \\
\hline China & 3704 & 2010 & $\begin{array}{l}\text { China Longyuan Power Group } \\
\text { Co., Ltd. }\end{array}$ & $\begin{array}{l}\text { Hebei Shangyi Longyuan Wind } \\
\text { Power Project }\end{array}$ & SIM & $\begin{array}{l}\text { Produção energética - } \\
\text { geradores eólicos }\end{array}$ & SIM & 1 & $\begin{array}{l}\text { Indústrias energéticas (fontes } \\
\text { renováveis - / não-renováveis) }\end{array}$ & Larga \\
\hline China & 3800 & 2010 & $\begin{array}{l}\text { China Longyuan Power Group } \\
\text { Co., Ltd. }\end{array}$ & $\begin{array}{l}\text { Hebei Shiren II Wind Power } \\
\text { Project }\end{array}$ & SIM & $\begin{array}{l}\text { Produção energética - } \\
\text { geradores eólicos }\end{array}$ & SIM & 1 & $\begin{array}{l}\text { Indústrias energéticas (fontes } \\
\text { renováveis - / não-renováveis) }\end{array}$ & Larga \\
\hline China & 4001 & 2010 & $\begin{array}{l}\text { China Longyuan Power Group } \\
\text { Co., Ltd. }\end{array}$ & $\begin{array}{l}\text { Xinjiang Alashankou Wind } \\
\text { Power Project }\end{array}$ & SIM & $\begin{array}{l}\text { Produção energética - } \\
\text { geradores eólicos }\end{array}$ & SIM & 1 & $\begin{array}{l}\text { Indústrias energéticas (fontes } \\
\text { renováveis - / não-renováveis) }\end{array}$ & Larga \\
\hline China & 3758 & 2010 & $\begin{array}{l}\text { China Longyuan Power Group } \\
\text { Co., Ltd. }\end{array}$ & $\begin{array}{l}\text { Hebei Weichang Guangfayong } \\
\text { Wind power project }\end{array}$ & SIM & $\begin{array}{l}\text { Produção energética - } \\
\text { geradores eólicos }\end{array}$ & SIM & 1 & $\begin{array}{l}\text { Indústrias energéticas (fontes } \\
\text { renováveis - / não-renováveis) }\end{array}$ & Larga \\
\hline China & 3743 & 2010 & $\begin{array}{l}\text { China Longyuan Power Group } \\
\text { Co., Ltd. }\end{array}$ & $\begin{array}{l}\text { Hebei Weichang Zhuzixia Wind } \\
\text { Power Project }\end{array}$ & SIM & $\begin{array}{l}\text { Produção energética - } \\
\text { geradores eólicos }\end{array}$ & SIM & 1 & $\begin{array}{l}\text { Indústrias energéticas (fontes } \\
\text { renováveis - / não-renováveis) }\end{array}$ & Larga \\
\hline China & 3470 & 2010 & $\begin{array}{l}\text { China Longyuan Power Group } \\
\text { Co., Ltd. }\end{array}$ & $\begin{array}{l}\text { Liaoning Faku Ciensi Wind } \\
\text { Power Project }\end{array}$ & SIM & $\begin{array}{l}\text { Produção energética - } \\
\text { geradores eólicos }\end{array}$ & SIM & 1 & $\begin{array}{l}\text { Indústrias energéticas (fontes } \\
\text { renováveis - / não-renováveis) }\end{array}$ & Larga \\
\hline China & 2864 & 2010 & $\begin{array}{l}\text { China Longyuan Power Group } \\
\text { Co., Ltd. }\end{array}$ & $\begin{array}{l}\text { Liaoning Kangping Furaoshan } \\
\text { Wind Power Project }\end{array}$ & SIM & $\begin{array}{l}\text { Produção energética - } \\
\text { geradores eólicos }\end{array}$ & SIM & 1 & $\begin{array}{l}\text { Indústrias energéticas (fontes } \\
\text { renováveis - / não-renováveis) }\end{array}$ & Larga \\
\hline China & 1924 & 2010 & $\begin{array}{l}\text { China Longyuan Power Group } \\
\text { Co., Ltd. }\end{array}$ & $\begin{array}{l}\text { Liaoning Faku Heping Wind } \\
\text { Power Project }\end{array}$ & SIM & $\begin{array}{l}\text { Produção energética - } \\
\text { geradores eólicos }\end{array}$ & SIM & 1 & $\begin{array}{l}\text { Indústrias energéticas (fontes } \\
\text { renováveis - / não-renováveis) }\end{array}$ & Larga \\
\hline China & 1965 & 2010 & $\begin{array}{l}\text { China Longyuan Power Group } \\
\text { Co., Ltd. }\end{array}$ & $\begin{array}{l}\text { Liaoning Faku Wanghaisi East } \\
\text { Wind Power Project }\end{array}$ & SIM & Produção energética - & SIM & 1 & Indústrias energéticas (fontes & Larga \\
\hline
\end{tabular}




\begin{tabular}{|c|c|c|c|c|c|c|c|c|c|c|}
\hline & & & & & & geradores eólicos & & & renováveis - / não-renováveis) & \\
\hline China & 2123 & 2010 & $\begin{array}{l}\text { China Longyuan Power Group } \\
\text { Co., Ltd. }\end{array}$ & $\begin{array}{l}\text { Liaoning Faku Baijiagou Wind } \\
\text { Power Project }\end{array}$ & SIM & $\begin{array}{l}\text { Produção energética - } \\
\text { geradores eólicos }\end{array}$ & SIM & 1 & $\begin{array}{l}\text { Indústrias energéticas (fontes } \\
\text { renováveis - / não-renováveis) }\end{array}$ & Larga \\
\hline China & 2854 & 2010 & $\begin{array}{l}\text { China Longyuan Power Group } \\
\text { Co., Ltd. }\end{array}$ & $\begin{array}{l}\text { Shenyang Faku Wanghaisi Wind } \\
\text { Power Project }\end{array}$ & SIM & $\begin{array}{l}\text { Produção energética - } \\
\text { geradores eólicos }\end{array}$ & SIM & 1 & $\begin{array}{l}\text { Indústrias energéticas (fontes } \\
\text { renováveis - / não-renováveis) }\end{array}$ & Larga \\
\hline China & 2817 & 2010 & $\begin{array}{l}\text { China Longyuan Power Group } \\
\text { Co., Ltd. }\end{array}$ & $\begin{array}{l}\text { Liaoning Changtu Shihu Wind } \\
\text { Power Project }\end{array}$ & SIM & $\begin{array}{l}\text { Produção energética - } \\
\text { geradores eólicos }\end{array}$ & SIM & 1 & $\begin{array}{l}\text { Indústrias energéticas (fontes } \\
\text { renováveis - / não-renováveis) }\end{array}$ & Larga \\
\hline China & 3806 & 2010 & $\begin{array}{l}\text { China Longyuan Power Group } \\
\text { Co., Ltd. }\end{array}$ & $\begin{array}{l}\text { Liaoning Changtu Quantou } \\
\text { Wind Power Project }\end{array}$ & SIM & $\begin{array}{l}\text { Produção energética - } \\
\text { geradores eólicos }\end{array}$ & SIM & 1 & $\begin{array}{l}\text { Indústrias energéticas (fontes } \\
\text { renováveis - / não-renováveis) }\end{array}$ & Larga \\
\hline China & 3652 & 2010 & $\begin{array}{l}\text { China Longyuan Power Group } \\
\text { Co., Ltd. }\end{array}$ & $\begin{array}{l}\text { Yunnan Luliang Yangmeishan } \\
\text { Zijia Wind Power Project }\end{array}$ & SIM & $\begin{array}{l}\text { Produção energética - } \\
\text { geradores eólicos }\end{array}$ & SIM & 1 & $\begin{array}{l}\text { Indústrias energéticas (fontes } \\
\text { renováveis - / não-renováveis) }\end{array}$ & Larga \\
\hline China & 3792 & 2010 & $\begin{array}{l}\text { China Longyuan Power Group } \\
\text { Co., Ltd. }\end{array}$ & $\begin{array}{l}\text { Zhejiang Cangnan Huangdiping } \\
\text { Wind Power Project }\end{array}$ & SIM & $\begin{array}{l}\text { Produção energética - } \\
\text { geradores eólicos }\end{array}$ & SIM & 1 & $\begin{array}{l}\text { Indústrias energéticas (fontes } \\
\text { renováveis - / não-renováveis) }\end{array}$ & Larga \\
\hline China & 3835 & 2010 & $\begin{array}{l}\text { China Longyuan Power Group } \\
\text { Co., Ltd. }\end{array}$ & $\begin{array}{l}\text { Zhejiang Zhoushan Cengang } \\
\text { Wind Power Project }\end{array}$ & SIM & $\begin{array}{l}\text { Produção energética - } \\
\text { geradores eólicos }\end{array}$ & SIM & 1 & $\begin{array}{l}\text { Indústrias energéticas (fontes } \\
\text { renováveis - / não-renováveis) }\end{array}$ & Larga \\
\hline China & 3253 & 2010 & $\begin{array}{l}\text { China Longyuan Power Group } \\
\text { Co., Ltd. }\end{array}$ & $\begin{array}{l}\text { Gansu Guazhou Xiangyang } \\
\text { Phase II Wind Power Project }\end{array}$ & SIM & $\begin{array}{l}\text { Produção energética - } \\
\text { geradores eólicos }\end{array}$ & SIM & 1 & $\begin{array}{l}\text { Indústrias energéticas (fontes } \\
\text { renováveis - / não-renováveis) }\end{array}$ & Larga \\
\hline China & 4123 & 2011 & $\begin{array}{l}\text { China Longyuan Power Group } \\
\text { Co., Ltd. }\end{array}$ & $\begin{array}{l}\text { Hebei Chongli County } \\
\text { Qingsanying Second Phase } 49.3 \\
\text { MW Wind Power Project }\end{array}$ & SIM & $\begin{array}{l}\text { Produção energética - } \\
\text { geradores eólicos }\end{array}$ & SIM & 1 & $\begin{array}{l}\text { Indústrias energéticas (fontes } \\
\text { renováveis - / não-renováveis) }\end{array}$ & Larga \\
\hline China & 4462 & 2011 & $\begin{array}{l}\text { China Longyuan Power Group } \\
\text { Co., Ltd. }\end{array}$ & $\begin{array}{l}\text { Gansu Guazhou } 300 \text { MW Wind } \\
\text { Power Project }\end{array}$ & SIM & $\begin{array}{l}\text { Produção energética - } \\
\text { geradores eólicos }\end{array}$ & SIM & 1 & $\begin{array}{l}\text { Indústrias energéticas (fontes } \\
\text { renováveis - / não-renováveis) }\end{array}$ & Larga \\
\hline China & 5427 & 2011 & $\begin{array}{l}\text { China Longyuan Power Group } \\
\text { Co., Ltd. }\end{array}$ & $\begin{array}{l}\text { Gansu Anxi Xiangyang Wind } \\
\text { Power Project }\end{array}$ & SIM & $\begin{array}{l}\text { Produção energética - } \\
\text { geradores eólicos }\end{array}$ & SIM & 1 & $\begin{array}{l}\text { Indústrias energéticas (fontes } \\
\text { renováveis - / não-renováveis) }\end{array}$ & Larga \\
\hline China & 5246 & 2011 & $\begin{array}{l}\text { China Longyuan Power Group } \\
\text { Co., Ltd. }\end{array}$ & $\begin{array}{l}\text { Guodian Xinjiang Alashankou } \\
\text { Phase II Wind Power Project }\end{array}$ & SIM & $\begin{array}{l}\text { Produção energética - } \\
\text { geradores eólicos }\end{array}$ & SIM & 1 & $\begin{array}{l}\text { Indústrias energéticas (fontes } \\
\text { renováveis - / não-renováveis) }\end{array}$ & Larga \\
\hline China & 5235 & 2011 & $\begin{array}{l}\text { China Longyuan Power Group } \\
\text { Co., Ltd. }\end{array}$ & $\begin{array}{l}\text { Hainan Danzhou Eman Phase II } \\
\text { Wind Power Project }\end{array}$ & SIM & $\begin{array}{l}\text { Produção energética - } \\
\text { geradores eólicos }\end{array}$ & SIM & 1 & $\begin{array}{l}\text { Indústrias energéticas (fontes } \\
\text { renováveis - / não-renováveis) }\end{array}$ & Larga \\
\hline China & 5171 & 2011 & $\begin{array}{l}\text { China Longyuan Power Group } \\
\text { Co., Ltd. }\end{array}$ & $\begin{array}{l}\text { Heilongjiang Huanan Yimashan } \\
\text { Wind Power Project }\end{array}$ & SIM & $\begin{array}{l}\text { Produção energética - } \\
\text { geradores eólicos }\end{array}$ & SIM & 1 & $\begin{array}{l}\text { Indústrias energéticas (fontes } \\
\text { renováveis - / não-renováveis) }\end{array}$ & Larga \\
\hline China & 4203 & 2011 & $\begin{array}{l}\text { China Longyuan Power Group } \\
\text { Co., Ltd. }\end{array}$ & $\begin{array}{l}\text { Inner Mongolia Bayannaoer } \\
\text { Chuanjingsumu Wind Power } \\
\text { Project }\end{array}$ & SIM & $\begin{array}{l}\text { Produção energética - } \\
\text { geradores eólicos }\end{array}$ & SIM & 1 & $\begin{array}{l}\text { Indústrias energéticas (fontes } \\
\text { renováveis - / não-renováveis) }\end{array}$ & Larga \\
\hline
\end{tabular}




\begin{tabular}{|c|c|c|c|c|c|c|c|c|c|c|}
\hline China & 4689 & 2011 & $\begin{array}{l}\text { China Longyuan Power Group } \\
\text { Co., Ltd. }\end{array}$ & $\begin{array}{l}\text { Inner Mongolia Wulatezhongqi } \\
\text { Chuanjing Phase V Wind Power } \\
\text { Project }\end{array}$ & SIM & $\begin{array}{l}\text { Produção energética - } \\
\text { geradores eólicos }\end{array}$ & SIM & 1 & \begin{tabular}{|l|} 
Indústrias energéticas (fontes \\
renováveis - / não-renováveis)
\end{tabular} & Larga \\
\hline China & 5122 & 2011 & $\begin{array}{l}\text { China Longyuan Power Group } \\
\text { Co., Ltd. }\end{array}$ & $\begin{array}{l}\text { Jilin Longyuan Changling } \\
\text { Shuanglong Phase II Wind } \\
\text { Power Project }\end{array}$ & SIM & $\begin{array}{l}\text { Produção energética - } \\
\text { geradores eólicos }\end{array}$ & SIM & 1 & $\begin{array}{l}\text { Indústrias energéticas (fontes } \\
\text { renováveis - / não-renováveis) }\end{array}$ & Larga \\
\hline China & 4854 & 2011 & $\begin{array}{l}\text { China Longyuan Power Group } \\
\text { Co., Ltd. }\end{array}$ & $\begin{array}{l}\text { Inner Mongolia Keyouqianqi } \\
\text { Chaersen Wind Power Project }\end{array}$ & SIM & $\begin{array}{l}\text { Produção energética - } \\
\text { geradores eólicos }\end{array}$ & SIM & 1 & $\begin{array}{l}\text { Indústrias energéticas (fontes } \\
\text { renováveis - / não-renováveis) }\end{array}$ & Larga \\
\hline China & 4035 & 2011 & $\begin{array}{l}\text { China Longyuan Power Group } \\
\text { Co., Ltd. }\end{array}$ & $\begin{array}{l}\text { Inner Mongolia Kezuohouqi } \\
\text { Xihailasitai Wind Power Project }\end{array}$ & SIM & $\begin{array}{l}\text { Produção energética - } \\
\text { geradores eólicos }\end{array}$ & SIM & 1 & $\begin{array}{l}\text { Indústrias energéticas (fontes } \\
\text { renováveis - / não-renováveis) }\end{array}$ & Larga \\
\hline China & 4038 & 2011 & $\begin{array}{l}\text { China Longyuan Power Group } \\
\text { Co., Ltd. }\end{array}$ & $\begin{array}{l}\text { Inner Mongolia Kezuohouqi } \\
\text { Baiyintala Wind Power Project }\end{array}$ & SIM & $\begin{array}{l}\text { Produção energética - } \\
\text { geradores eólicos }\end{array}$ & SIM & 1 & $\begin{array}{l}\text { Indústrias energéticas (fontes } \\
\text { renováveis - / não-renováveis) }\end{array}$ & Larga \\
\hline China & 5157 & 2011 & $\begin{array}{l}\text { China Longyuan Power Group } \\
\text { Co., Ltd. }\end{array}$ & $\begin{array}{l}\text { Inner Mongolia Tongliao } \\
\text { Kezuohouqi Xin'aili Wind } \\
\text { Power Project }\end{array}$ & SIM & $\begin{array}{l}\text { Produção energética - } \\
\text { geradores eólicos }\end{array}$ & SIM & 1 & $\begin{array}{l}\text { Indústrias energéticas (fontes } \\
\text { renováveis - / não-renováveis) }\end{array}$ & Larga \\
\hline China & 4004 & 2011 & $\begin{array}{l}\text { China Longyuan Power Group } \\
\text { Co., Ltd. }\end{array}$ & $\begin{array}{l}\text { Inner Mongolia Tongliao } \\
\text { Naiman Banner Baxiantong } \\
\text { Chagantala Wind Power Project }\end{array}$ & SIM & $\begin{array}{l}\text { Produção energética - } \\
\text { geradores eólicos }\end{array}$ & SIM & 1 & $\begin{array}{l}\text { Indústrias energéticas (fontes } \\
\text { renováveis - / não-renováveis) }\end{array}$ & Larga \\
\hline China & 5214 & 2011 & $\begin{array}{l}\text { China Longyuan Power Group } \\
\text { Co., Ltd. }\end{array}$ & $\begin{array}{l}\text { Jiangsu Nantong Rudong Wind } \\
\text { Power Project }\end{array}$ & SIM & $\begin{array}{l}\text { Produção energética - } \\
\text { geradores eólicos }\end{array}$ & SIM & 1 & $\begin{array}{l}\text { Indústrias energéticas (fontes } \\
\text { renováveis - / não-renováveis) }\end{array}$ & Larga \\
\hline China & 4797 & 2011 & $\begin{array}{l}\text { China Longyuan Power Group } \\
\text { Co., Ltd. }\end{array}$ & $\begin{array}{l}\text { Inner Mongolia Jiulong Wind } \\
\text { Power Project }\end{array}$ & SIM & $\begin{array}{l}\text { Produção energética - } \\
\text { geradores eólicos }\end{array}$ & SIM & 1 & $\begin{array}{l}\text { Indústrias energéticas (fontes } \\
\text { renováveis - / não-renováveis) }\end{array}$ & Larga \\
\hline China & 4172 & 2011 & $\begin{array}{l}\text { China Longyuan Power Group } \\
\text { Co., Ltd. }\end{array}$ & $\begin{array}{l}\text { Inner Mongolia Wengniute } \\
\text { Wudaogou Xigouli Wind Power } \\
\text { Project }\end{array}$ & SIM & $\begin{array}{l}\text { Produção energética - } \\
\text { geradores eólicos }\end{array}$ & SIM & 1 & $\begin{array}{l}\text { Indústrias energéticas (fontes } \\
\text { renováveis - / não-renováveis) }\end{array}$ & Larga \\
\hline China & 4178 & 2011 & $\begin{array}{l}\text { China Longyuan Power Group } \\
\text { Co., Ltd. }\end{array}$ & $\begin{array}{l}\text { Inner Mongolia Chifeng } \\
\text { Songshan Laoshuiquan Wind } \\
\text { Power Project }\end{array}$ & SIM & $\begin{array}{l}\text { Produção energética - } \\
\text { geradores eólicos }\end{array}$ & SIM & 1 & $\begin{array}{l}\text { Indústrias energéticas (fontes } \\
\text { renováveis - / não-renováveis) }\end{array}$ & Larga \\
\hline China & 4180 & 2011 & $\begin{array}{l}\text { China Longyuan Power Group } \\
\text { Co., Ltd. }\end{array}$ & $\begin{array}{l}\text { Inner Mongolia Wengniute } \\
\text { Sunjiaying Shangchang Wind } \\
\text { Power Project }\end{array}$ & SIM & $\begin{array}{l}\text { Produção energética - } \\
\text { geradores eólicos }\end{array}$ & SIM & 1 & $\begin{array}{l}\text { Indústrias energéticas (fontes } \\
\text { renováveis - / não-renováveis) }\end{array}$ & Larga \\
\hline China & 4381 & 2011 & $\begin{array}{l}\text { China Longyuan Power Group } \\
\text { Co., Ltd. }\end{array}$ & $\begin{array}{l}\text { Inner Mongolia Wengniute } \\
\text { Xiyangshugou Wind Power } \\
\text { Project }\end{array}$ & SIM & $\begin{array}{l}\text { Produção energética - } \\
\text { geradores eólicos }\end{array}$ & SIM & 1 & $\begin{array}{l}\text { Indústrias energéticas (fontes } \\
\text { renováveis - / não-renováveis) }\end{array}$ & Larga \\
\hline China & 3803 & 2011 & $\begin{array}{l}\text { China Longyuan Power Group } \\
\text { Co., Ltd. }\end{array}$ & $\begin{array}{l}\text { Hebei Zhangbei Baimiaotan } \\
\text { Wind Power Project Phase I }\end{array}$ & SIM & $\begin{array}{l}\text { Produção energética - } \\
\text { geradores eólicos }\end{array}$ & SIM & 1 & $\begin{array}{l}\text { Indústrias energéticas (fontes } \\
\text { renováveis - / não-renováveis) }\end{array}$ & Larga \\
\hline China & 5388 & 2011 & $\begin{array}{l}\text { China Longyuan Power Group } \\
\text { Co., Ltd. }\end{array}$ & $\begin{array}{l}\text { Hebei Zhangbei Baimiaotan } \\
\text { Wind Power Project Phase II }\end{array}$ & SIM & Produção energética - & SIM & 1 & Indústrias energéticas (fontes & Larga \\
\hline
\end{tabular}




\begin{tabular}{|c|c|c|c|c|c|c|c|c|c|c|}
\hline & & & & & & geradores eólicos & & & renováveis - / não-renováveis) & \\
\hline China & 4573 & 2011 & $\begin{array}{l}\text { China Longyuan Power Group } \\
\text { Co., Ltd. }\end{array}$ & $\begin{array}{l}\text { Xinjiang Alashankou Phase II } \\
\text { Wind Power Project }\end{array}$ & SIM & $\begin{array}{l}\text { Produção energética - } \\
\text { geradores eólicos }\end{array}$ & SIM & 1 & $\begin{array}{l}\text { Indústrias energéticas (fontes } \\
\text { renováveis - / não-renováveis) }\end{array}$ & Larga \\
\hline China & 3972 & 2011 & $\begin{array}{l}\text { China Longyuan Power Group } \\
\text { Co., Ltd. }\end{array}$ & $\begin{array}{l}\text { Hebei Weichang Dishuihu Wind } \\
\text { power project }\end{array}$ & SIM & $\begin{array}{l}\text { Produção energética - } \\
\text { geradores eólicos }\end{array}$ & SIM & 1 & $\begin{array}{l}\text { Indústrias energéticas (fontes } \\
\text { renováveis - / não-renováveis) }\end{array}$ & Larga \\
\hline China & 4104 & 2011 & $\begin{array}{l}\text { China Longyuan Power Group } \\
\text { Co., Ltd. }\end{array}$ & $\begin{array}{l}\text { Liaoning Kangping Dongsheng } \\
\text { Wind Power Project }\end{array}$ & SIM & $\begin{array}{l}\text { Produção energética - } \\
\text { geradores eólicos }\end{array}$ & SIM & 1 & $\begin{array}{l}\text { Indústrias energéticas (fontes } \\
\text { renováveis - / não-renováveis) }\end{array}$ & Larga \\
\hline China & 4195 & 2011 & $\begin{array}{l}\text { China Longyuan Power Group } \\
\text { Co., Ltd. }\end{array}$ & $\begin{array}{l}\text { Liaoning Kangping Zhangqiang } \\
\text { Wind Power Project }\end{array}$ & SIM & $\begin{array}{l}\text { Produção energética - } \\
\text { geradores eólicos }\end{array}$ & SIM & 1 & $\begin{array}{l}\text { Indústrias energéticas (fontes } \\
\text { renováveis - / não-renováveis) }\end{array}$ & Larga \\
\hline China & 4784 & 2011 & $\begin{array}{l}\text { China Longyuan Power Group } \\
\text { Co., Ltd. }\end{array}$ & $\begin{array}{l}\text { Liaoning Kangping Aoliyingzi } \\
\text { Wind Power Project }\end{array}$ & SIM & $\begin{array}{l}\text { Produção energética - } \\
\text { geradores eólicos }\end{array}$ & SIM & 1 & $\begin{array}{l}\text { Indústrias energéticas (fontes } \\
\text { renováveis - / não-renováveis) }\end{array}$ & Larga \\
\hline China & 5009 & 2011 & $\begin{array}{l}\text { China Longyuan Power Group } \\
\text { Co., Ltd. }\end{array}$ & $\begin{array}{l}\text { Liaoning Kangping Zhangjiayao } \\
\text { Wind Power Project }\end{array}$ & SIM & $\begin{array}{l}\text { Produção energética - } \\
\text { geradores eólicos }\end{array}$ & SIM & 1 & $\begin{array}{l}\text { Indústrias energéticas (fontes } \\
\text { renováveis - / não-renováveis) }\end{array}$ & Larga \\
\hline China & 4842 & 2011 & $\begin{array}{l}\text { China Longyuan Power Group } \\
\text { Co., Ltd. }\end{array}$ & $\begin{array}{l}\text { Liaoning Faku Ma'anshan North } \\
\text { Wind Power Project }\end{array}$ & SIM & $\begin{array}{l}\text { Produção energética - } \\
\text { geradores eólicos }\end{array}$ & SIM & 1 & $\begin{array}{l}\text { Indústrias energéticas (fontes } \\
\text { renováveis - / não-renováveis) }\end{array}$ & Larga \\
\hline China & 4909 & 2011 & $\begin{array}{l}\text { China Longyuan Power Group } \\
\text { Co., Ltd. }\end{array}$ & $\begin{array}{l}\text { Liaoning Faku Ma'anshan Wind } \\
\text { Power Project }\end{array}$ & SIM & $\begin{array}{l}\text { Produção energética - } \\
\text { geradores eólicos }\end{array}$ & SIM & 1 & $\begin{array}{l}\text { Indústrias energéticas (fontes } \\
\text { renováveis - / não-renováveis) }\end{array}$ & Larga \\
\hline China & 4987 & 2011 & $\begin{array}{l}\text { China Longyuan Power Group } \\
\text { Co., Ltd. }\end{array}$ & $\begin{array}{l}\text { Liaoning Faku Yemaotai Wind } \\
\text { Power Project }\end{array}$ & SIM & $\begin{array}{l}\text { Produção energética - } \\
\text { geradores eólicos }\end{array}$ & SIM & 1 & $\begin{array}{l}\text { Indústrias energéticas (fontes } \\
\text { renováveis - / não-renováveis) }\end{array}$ & Larga \\
\hline China & 5147 & 2011 & $\begin{array}{l}\text { China Longyuan Power Group } \\
\text { Co., Ltd. }\end{array}$ & $\begin{array}{l}\text { Liaoning Faku Woniushi Wind } \\
\text { Power Project }\end{array}$ & SIM & $\begin{array}{l}\text { Produção energética - } \\
\text { geradores eólicos }\end{array}$ & SIM & 1 & $\begin{array}{l}\text { Indústrias energéticas (fontes } \\
\text { renováveis - / não-renováveis) }\end{array}$ & Larga \\
\hline China & 5587 & 2011 & $\begin{array}{l}\text { China Longyuan Power Group } \\
\text { Co., Ltd. }\end{array}$ & $\begin{array}{l}\text { Liaoning Kangping Fangjia } \\
\text { Wind Power Project }\end{array}$ & SIM & $\begin{array}{l}\text { Produção energética - } \\
\text { geradores eólicos }\end{array}$ & SIM & 1 & $\begin{array}{l}\text { Indústrias energéticas (fontes } \\
\text { renováveis - / não-renováveis) }\end{array}$ & Larga \\
\hline China & 5491 & 2011 & $\begin{array}{l}\text { China Longyuan Power Group } \\
\text { Co., Ltd. }\end{array}$ & $\begin{array}{l}\text { Heilongjiang Bianfushan Wind } \\
\text { Power Project }\end{array}$ & SIM & $\begin{array}{l}\text { Produção energética - } \\
\text { geradores eólicos }\end{array}$ & SIM & 1 & $\begin{array}{l}\text { Indústrias energéticas (fontes } \\
\text { renováveis - / não-renováveis) }\end{array}$ & Larga \\
\hline China & 5178 & 2011 & $\begin{array}{l}\text { China Longyuan Power Group } \\
\text { Co., Ltd. }\end{array}$ & $\begin{array}{l}\text { Heilongjiang Yilan Yunling } \\
\text { Wind Power Project }\end{array}$ & SIM & $\begin{array}{l}\text { Produção energética - } \\
\text { geradores eólicos }\end{array}$ & SIM & 1 & $\begin{array}{l}\text { Indústrias energéticas (fontes } \\
\text { renováveis - / não-renováveis) }\end{array}$ & Larga \\
\hline China & 5382 & 2011 & $\begin{array}{l}\text { China Longyuan Power Group } \\
\text { Co., Ltd. }\end{array}$ & $\begin{array}{l}\text { Heilongjiang Yilan } \\
\text { Hezuolinchang Wind Power } \\
\text { Project }\end{array}$ & SIM & $\begin{array}{l}\text { Produção energética - } \\
\text { geradores eólicos }\end{array}$ & SIM & 1 & $\begin{array}{l}\text { Indústrias energéticas (fontes } \\
\text { renováveis - / não-renováveis) }\end{array}$ & Larga \\
\hline China & 4812 & 2011 & $\begin{array}{l}\text { China Longyuan Power Group } \\
\text { Co., Ltd. }\end{array}$ & $\begin{array}{l}\text { Yunnan Luliang Yangmeishan } \\
\text { Daluwan Wind Power Project }\end{array}$ & SIM & $\begin{array}{l}\text { Produção energética - } \\
\text { geradores eólicos }\end{array}$ & SIM & 1 & $\begin{array}{l}\text { Indústrias energéticas (fontes } \\
\text { renováveis - / não-renováveis) }\end{array}$ & Larga \\
\hline
\end{tabular}




\begin{tabular}{|c|c|c|c|c|c|c|c|c|c|c|}
\hline China & 4980 & 2011 & $\begin{array}{l}\text { China Longyuan Power Group } \\
\text { Co., Ltd. }\end{array}$ & $\begin{array}{l}\text { Yunnan Luliang Damogu Wind } \\
\text { Power Project }\end{array}$ & SIM & $\begin{array}{l}\text { Produção energética - } \\
\text { geradores eólicos }\end{array}$ & SIM & 1 & $\begin{array}{l}\text { Indústrias energéticas (fontes } \\
\text { renováveis - / não-renováveis) }\end{array}$ & Larga \\
\hline China & 5711 & 2012 & $\begin{array}{l}\text { China Longyuan Power Group } \\
\text { Co., Ltd. }\end{array}$ & $\begin{array}{l}\text { Heilongjiang Wangyunfeng } \\
\text { Wind Power Project }\end{array}$ & SIM & $\begin{array}{l}\begin{array}{l}\text { Produção energética - } \\
\text { geradores eólicos }\end{array} \\
\end{array}$ & SIM & 1 & $\begin{array}{l}\text { Indústrias energéticas (fontes } \\
\text { renováveis - / não-renováveis) }\end{array}$ & Larga \\
\hline China & 6265 & 2012 & $\begin{array}{l}\text { China Longyuan Power Group } \\
\text { Co., Ltd. }\end{array}$ & $\begin{array}{l}\text { Heilongjiang Huangtuanling } \\
\text { Wind Power Project }\end{array}$ & SIM & $\begin{array}{l}\begin{array}{l}\text { Produção energética - } \\
\text { geradores eólicos }\end{array} \\
\end{array}$ & SIM & 1 & $\begin{array}{l}\text { Indústrias energéticas (fontes } \\
\text { renováveis - / não-renováveis) }\end{array}$ & Larga \\
\hline China & 7129 & 2012 & $\begin{array}{l}\text { China Longyuan Power Group } \\
\text { Co., Ltd. }\end{array}$ & $\begin{array}{l}\text { Heilongjiang Huanan } \\
\text { Changshoushan } 49.5 \mathrm{MW} \text { Wind } \\
\text { Power Project }\end{array}$ & SIM & $\begin{array}{l}\text { Produção energética - } \\
\text { geradores eólicos }\end{array}$ & SIM & 1 & $\begin{array}{l}\text { Indústrias energéticas (fontes } \\
\text { renováveis - / não-renováveis) }\end{array}$ & Larga \\
\hline China & 5834 & 2012 & $\begin{array}{l}\text { China Longyuan Power Group } \\
\text { Co., Ltd. }\end{array}$ & $\begin{array}{l}\text { Heilongjiang Huanan } \\
\text { Hengdaishan East (II) Wind } \\
\text { Power Project }\end{array}$ & SIM & $\begin{array}{l}\text { Produção energética - } \\
\text { geradores eólicos }\end{array}$ & SIM & 1 & $\begin{array}{l}\text { Indústrias energéticas (fontes } \\
\text { renováveis - / não-renováveis) }\end{array}$ & Larga \\
\hline China & 7425 & 2012 & $\begin{array}{l}\text { China Longyuan Power Group } \\
\text { Co., Ltd. }\end{array}$ & $\begin{array}{l}\text { Fujian Putian Nanridao Phase IV } \\
\text { Wind Power Project }\end{array}$ & SIM & $\begin{array}{l}\begin{array}{l}\text { Produção energética - } \\
\text { geradores eólicos }\end{array} \\
\end{array}$ & SIM & 1 & $\begin{array}{l}\text { Indústrias energéticas (fontes } \\
\text { renováveis - / não-renováveis) }\end{array}$ & Larga \\
\hline China & 7189 & 2012 & $\begin{array}{l}\text { China Longyuan Power Group } \\
\text { Co., Ltd. }\end{array}$ & $\begin{array}{l}\text { Hebei Shangyi Longyuan } \\
\text { Qilinshan Phase II Wind Power } \\
\text { Project }\end{array}$ & SIM & $\begin{array}{l}\text { Produção energética - } \\
\text { geradores eólicos }\end{array}$ & SIM & 1 & $\begin{array}{l}\text { Indústrias energéticas (fontes } \\
\text { renováveis - / não-renováveis) }\end{array}$ & Larga \\
\hline China & 6926 & 2012 & $\begin{array}{l}\text { China Longyuan Power Group } \\
\text { Co., Ltd. }\end{array}$ & $\begin{array}{l}\text { Liaoning Longyuan Kangping } \\
\text { Shajintai Wind Power Project }\end{array}$ & SIM & $\begin{array}{l}\text { Produção energética - } \\
\text { geradores eólicos }\end{array}$ & SIM & 1 & $\begin{array}{l}\text { Indústrias energéticas (fontes } \\
\text { renováveis - / não-renováveis) }\end{array}$ & Larga \\
\hline China & 6906 & 2012 & $\begin{array}{l}\text { China Longyuan Power Group } \\
\text { Co., Ltd. }\end{array}$ & $\begin{array}{l}\text { Liaoning Longyuan Kangping } \\
\text { Xiguan Wind Power Project }\end{array}$ & SIM & $\begin{array}{l}\text { Produção energética - } \\
\text { geradores eólicos }\end{array}$ & SIM & 1 & $\begin{array}{l}\text { Indústrias energéticas (fontes } \\
\text { renováveis - / não-renováveis) }\end{array}$ & Larga \\
\hline China & 6094 & 2012 & $\begin{array}{l}\text { China Longyuan Power Group } \\
\text { Co., Ltd. }\end{array}$ & $\begin{array}{l}\text { Heilongjiang Yilan } \\
\text { Hezuolinchang Phase II Wind } \\
\text { Power Project }\end{array}$ & SIM & $\begin{array}{l}\text { Produção energética - } \\
\text { geradores eólicos }\end{array}$ & SIM & 1 & $\begin{array}{l}\text { Indústrias energéticas (fontes } \\
\text { renováveis - / não-renováveis) }\end{array}$ & Larga \\
\hline China & 1689 & 2008 & $\begin{array}{l}\text { Chongqing Iron \& Steel Co., } \\
\text { Ltd. }\end{array}$ & $\begin{array}{l}\text { Chongqing Iron \& Steel Co. Ltd. } \\
\text { Waste Gas to Electricity Project }\end{array}$ & SIM & $\begin{array}{l}\text { Produção energética - } \\
\text { utilização de calor na produção } \\
\text { de ferro e aço }\end{array}$ & SIM & 1 & $\begin{array}{l}\text { Indústrias energéticas (fontes } \\
\text { renováveis - / não-renováveis) }\end{array}$ & Larga \\
\hline China & 1499 & 2008 & $\begin{array}{l}\text { Chongqing Water Group Co., } \\
\text { Ltd. }\end{array}$ & $\begin{array}{l}\text { Chongqing Menkantan } \\
\text { Hydroelectric Project }\end{array}$ & SIM & Produção energética - águas & SIM & 1 & $\begin{array}{l}\text { Indústrias energéticas (fontes } \\
\text { renováveis - / não-renováveis) }\end{array}$ & Larga \\
\hline China & 1537 & 2008 & $\begin{array}{l}\text { Chongqing Water Group Co., } \\
\text { Ltd. }\end{array}$ & $\begin{array}{l}\text { Jielong Cascade Small-Scale } \\
\text { Hydropower Project }\end{array}$ & SIM & Produção energética - águas & SIM & 1 & $\begin{array}{l}\text { Indústrias energéticas (fontes } \\
\text { renováveis - / não-renováveis) }\end{array}$ & Pequena \\
\hline China & 1539 & 2008 & $\begin{array}{l}\text { Chongqing Water Group Co., } \\
\text { Ltd. }\end{array}$ & $\begin{array}{l}\text { Liyutang small Hydropower } \\
\text { project }\end{array}$ & SIM & Produção energética - águas & SIM & 1 & $\begin{array}{l}\text { Indústrias energéticas (fontes } \\
\text { renováveis - / não-renováveis) }\end{array}$ & Pequena \\
\hline
\end{tabular}




\begin{tabular}{|c|c|c|c|c|c|c|c|c|c|c|}
\hline China & 2847 & 2010 & $\begin{array}{l}\text { Chongqing Water Group Co., } \\
\text { Ltd. }\end{array}$ & $\begin{array}{l}\text { Chongqing Zhongliang } \\
\text { Hydroelectric Project }\end{array}$ & SIM & Produção energética - águas & SIM & 1 & $\begin{array}{l}\text { Indústrias energéticas (fontes } \\
\text { renováveis - / não-renováveis) }\end{array}$ & Larga \\
\hline China & 2960 & 2010 & $\begin{array}{l}\text { Chongqing Water Group Co., } \\
\text { Ltd. }\end{array}$ & $\begin{array}{l}\text { Chongqing Jinjiaba } \\
\text { HydroElectric Project }\end{array}$ & SIM & Produção energética - águas & SIM & 1 & $\begin{array}{l}\text { Indústrias energéticas (fontes } \\
\text { renováveis - / não-renováveis) }\end{array}$ & Larga \\
\hline China & 3968 & 2010 & $\begin{array}{l}\text { Chongqing Water Group Co., } \\
\text { Ltd. }\end{array}$ & Beiping Hydro Electric Project & SIM & Produção energética - águas & SIM & 1 & $\begin{array}{l}\text { Indústrias energéticas (fontes } \\
\text { renováveis - / não-renováveis) }\end{array}$ & Larga \\
\hline China & 7648 & 2012 & $\begin{array}{l}\text { Chongqing Water Group Co., } \\
\text { Ltd. }\end{array}$ & $\begin{array}{l}\text { Wushan Houxihe Hydropower } \\
\text { Station Project }\end{array}$ & SIM & Produção energética - águas & SIM & 1 & $\begin{array}{l}\text { Indústrias energéticas (fontes } \\
\text { renováveis - / não-renováveis) }\end{array}$ & Larga \\
\hline China & 1327 & 2008 & $\begin{array}{l}\text { Datang International Power } \\
\text { Generation Co., Ltd. }\end{array}$ & $\begin{array}{l}\text { Inner Mongolia Zhuozi 40MW } \\
\text { Wind Power Project }\end{array}$ & SIM & $\begin{array}{l}\text { Produção energética - } \\
\text { geradores eólicos }\end{array}$ & SIM & 1 & $\begin{array}{l}\text { Indústrias energéticas (fontes } \\
\text { renováveis - / não-renováveis) }\end{array}$ & Larga \\
\hline China & 2223 & 2010 & $\begin{array}{l}\text { Datang International Power } \\
\text { Generation Co., Ltd. }\end{array}$ & $\begin{array}{l}\text { Liaoning Faku 1st phase Wind } \\
\text { Power Project }\end{array}$ & SIM & \begin{tabular}{|l}
$\begin{array}{l}\text { Produção energética - } \\
\text { geradores eólicos }\end{array}$ \\
\end{tabular} & SIM & 1 & $\begin{array}{l}\text { Indústrias energéticas (fontes } \\
\text { renováveis - / não-renováveis) }\end{array}$ & Larga \\
\hline China & 2462 & 2010 & $\begin{array}{l}\text { Datang International Power } \\
\text { Generation Co., Ltd. }\end{array}$ & $\begin{array}{l}\text { Hebei Fengning Luotuogou 1st } \\
\text { Phase Wind Power Project }\end{array}$ & SIM & $\begin{array}{l}\text { Produção energética - } \\
\text { geradores eólicos }\end{array}$ & SIM & 1 & $\begin{array}{l}\text { Indústrias energéticas (fontes } \\
\text { renováveis - / não-renováveis) }\end{array}$ & Larga \\
\hline China & 2584 & 2010 & $\begin{array}{l}\text { Datang International Power } \\
\text { Generation Co., Ltd. }\end{array}$ & $\begin{array}{l}\text { Shandong Dongying 1st phase } \\
\text { Wind Power Project }\end{array}$ & SIM & $\begin{array}{l}\text { Produção energética - } \\
\text { geradores eólicos }\end{array}$ & SIM & 1 & $\begin{array}{l}\text { Indústrias energéticas (fontes } \\
\text { renováveis - / não-renováveis) }\end{array}$ & Larga \\
\hline China & 3092 & 2010 & $\begin{array}{l}\text { Datang International Power } \\
\text { Generation Co., Ltd. }\end{array}$ & $\begin{array}{l}\text { Inner Mongolia Chayouhouqi } \\
\text { Hongmu } 48 \text { MW Wind Power } \\
\text { Project }\end{array}$ & SIM & $\begin{array}{l}\text { Produção energética - } \\
\text { geradores eólicos }\end{array}$ & SIM & 1 & $\begin{array}{l}\text { Indústrias energéticas (fontes } \\
\text { renováveis - / não-renováveis) }\end{array}$ & Larga \\
\hline China & 4193 & 2010 & $\begin{array}{l}\text { Datang International Power } \\
\text { Generation Co., Ltd. }\end{array}$ & $\begin{array}{l}\text { Hebei Fengning Dahexi Wind } \\
\text { Power Project }\end{array}$ & SIM & $\begin{array}{l}\text { Produção energética - } \\
\text { geradores eólicos }\end{array}$ & SIM & 1 & $\begin{array}{l}\text { Indústrias energéticas (fontes } \\
\text { renováveis - / não-renováveis) }\end{array}$ & Larga \\
\hline China & 3840 & 2010 & $\begin{array}{l}\text { Datang International Power } \\
\text { Generation Co., Ltd. }\end{array}$ & $\begin{array}{l}\text { Chongqing Siyanping 49.3MW } \\
\text { Wind Power Project }\end{array}$ & SIM & $\begin{array}{l}\text { Produção energética - } \\
\text { geradores eólicos }\end{array}$ & SIM & 1 & $\begin{array}{l}\text { Indústrias energéticas (fontes } \\
\text { renováveis - / não-renováveis) }\end{array}$ & Larga \\
\hline China & 3251 & 2010 & $\begin{array}{l}\text { Datang International Power } \\
\text { Generation Co., Ltd. }\end{array}$ & $\begin{array}{l}\text { Inner Mongolia Zhuozi III Wind } \\
\text { Power Project }\end{array}$ & SIM & $\begin{array}{l}\text { Produção energética - } \\
\text { geradores eólicos }\end{array}$ & SIM & 1 & $\begin{array}{l}\text { Indústrias energéticas (fontes } \\
\text { renováveis - / não-renováveis) }\end{array}$ & Larga \\
\hline China & 3688 & 2010 & $\begin{array}{l}\text { Datang International Power } \\
\text { Generation Co., Ltd. }\end{array}$ & $\begin{array}{l}\text { Inner Mongolia Zhuozi II Wind } \\
\text { Power Project }\end{array}$ & SIM & $\begin{array}{l}\text { Produção energética - } \\
\text { geradores eólicos }\end{array}$ & SIM & 1 & $\begin{array}{l}\text { Indústrias energéticas (fontes } \\
\text { renováveis - / não-renováveis) }\end{array}$ & Larga \\
\hline China & 4182 & 2011 & $\begin{array}{l}\text { Datang International Power } \\
\text { Generation Co., Ltd. }\end{array}$ & $\begin{array}{l}\text { Hebei Fengning Batou Wind } \\
\text { Power Project }\end{array}$ & SIM & $\begin{array}{l}\text { Produção energética - } \\
\text { geradores eólicos }\end{array}$ & SIM & 1 & $\begin{array}{l}\text { Indústrias energéticas (fontes } \\
\text { renováveis - / não-renováveis) }\end{array}$ & Larga \\
\hline China & 5064 & 2011 & $\begin{array}{l}\text { Datang International Power } \\
\text { Generation Co., Ltd. }\end{array}$ & $\begin{array}{l}\text { Hebei Xiqiaoliang Farm Phase I } \\
\text { Project }\end{array}$ & SIM & $\begin{array}{l}\text { Produção energética - } \\
\text { geradores eólicos }\end{array}$ & SIM & 1 & $\begin{array}{l}\text { Indústrias energéticas (fontes } \\
\text { renováveis - / não-renováveis) }\end{array}$ & Larga \\
\hline China & 5706 & 2012 & $\begin{array}{l}\text { Datang International Power } \\
\text { Generation Co., Ltd. }\end{array}$ & $\begin{array}{l}\text { Inner Mongolia Datang } \\
\text { International Zhuozi Phase IV }\end{array}$ & SIM & Produção energética - & SIM & 1 & Indústrias energéticas (fontes & Larga \\
\hline
\end{tabular}




\begin{tabular}{|c|c|c|c|c|c|c|c|c|c|c|}
\hline & & & & Wind Farm Project & & geradores eólicos & & & renováveis - / não-renováveis) & \\
\hline China & 2763 & 2010 & Fujian Cement Inc. & $\begin{array}{l}\text { Fujian Cement } 4 \# \text { and } 5 \# \text { kilns } \\
\text { Waste Heat Recovery for Power } \\
\text { Generation Project }\end{array}$ & SIM & $\begin{array}{l}\text { Produção energética - } \\
\text { utilização de calor na produção } \\
\text { de cimento }\end{array}$ & NÃO & $1 \mathrm{e} 4$ & \begin{tabular}{|l} 
Indústrias energéticas (fontes \\
renováveis - / não-renováveis) \\
/ Transformação Industrial
\end{tabular} & Larga \\
\hline China & 1046 & 2007 & $\begin{array}{l}\text { Gansu Qilianshan Cement } \\
\text { Group Co., Ltd. }\end{array}$ & $\begin{array}{l}\text { Gansu Qilianshan Cement } \\
\text { 6000kW Waste Heat Recovery } \\
\text { Project }\end{array}$ & SIM & $\begin{array}{l}\text { Produção energética - } \\
\text { utilização de calor na produção } \\
\text { de cimento }\end{array}$ & NÃO & 1 & $\begin{array}{l}\text { Indústrias energéticas (fontes } \\
\text { renováveis - / não-renováveis) }\end{array}$ & Larga \\
\hline China & 2963 & 2010 & $\begin{array}{l}\text { GD Power Development Co., } \\
\text { Ltd. }\end{array}$ & $\begin{array}{l}\text { Guodian Liaocheng Biomass } \\
\text { Power Project }\end{array}$ & SIM & $\begin{array}{l}\text { Produção energética - outros } \\
\text { resíduos agrícolas }\end{array}$ & SIM & 1 & $\begin{array}{l}\text { Indústrias energéticas (fontes } \\
\text { renováveis - / não-renováveis) }\end{array}$ & Larga \\
\hline China & 3727 & 2010 & $\begin{array}{l}\text { Guangdong Baolihua New } \\
\text { Energy Stock Co., Ltd. }\end{array}$ & $\begin{array}{l}\text { Guangdong Jiahu Wind Farm } \\
\text { Project }\end{array}$ & SIM & $\begin{array}{l}\text { Produção energética - } \\
\text { geradores eólicos }\end{array}$ & SIM & 1 & $\begin{array}{l}\text { Indústrias energéticas (fontes } \\
\text { renováveis - / não-renováveis) }\end{array}$ & Larga \\
\hline China & 3299 & 2010 & $\begin{array}{l}\text { Guangdong Electric Power } \\
\text { Development Co., Ltd. }\end{array}$ & \begin{tabular}{|l} 
LinCang Yun County, \\
XinTangFang Hydropower \\
Station Project
\end{tabular} & SIM & Produção energética - águas & SIM & 1 & \begin{tabular}{|l} 
Indústrias energéticas (fontes \\
renováveis - / não-renováveis)
\end{tabular} & Larga \\
\hline China & 1376 & 2007 & $\begin{array}{l}\text { Guangdong Shaoneng Group } \\
\text { Co., Ltd. }\end{array}$ & $\begin{array}{l}\text { China Shangbao Small } \\
\text { Hydropower Project }\end{array}$ & SIM & Produção energética - águas & SIM & 1 & $\begin{array}{l}\text { Indústrias energéticas (fontes } \\
\text { renováveis - / não-renováveis) }\end{array}$ & Pequena \\
\hline China & 8454 & 2012 & $\begin{array}{l}\text { Guangdong Shaoneng Group } \\
\text { Co., Ltd. }\end{array}$ & $\begin{array}{l}\text { Shaoguan City Shaoneng } \\
\text { Biomass Power Generation } \\
\text { Project }\end{array}$ & SIM & $\begin{array}{l}\text { Produção energética - outros } \\
\text { resíduos agrícolas }\end{array}$ & SIM & 1 & $\begin{array}{l}\text { Indústrias energéticas (fontes } \\
\text { renováveis - / não-renováveis) }\end{array}$ & Larga \\
\hline China & 4276 & 2011 & $\begin{array}{l}\text { Guangxi Guiguan Electric } \\
\text { Power Co., Ltd }\end{array}$ & $\begin{array}{l}\text { Guangxi Dahua Hydropower } \\
\text { Project }\end{array}$ & SIM & Produção energética - águas & SIM & 1 & $\begin{array}{l}\text { Indústrias energéticas (fontes } \\
\text { renováveis - / não-renováveis) }\end{array}$ & Larga \\
\hline China & 2946 & 2009 & $\begin{array}{l}\text { Guangzhou Zhujiang Brewery } \\
\text { Group Co., Ltd. }\end{array}$ & $\begin{array}{l}\text { Guangzhou Zhujiang Beer } \\
\text { Methane Recovery Project }\end{array}$ & SIM & $\begin{array}{l}\text { Produção energética - } \\
\text { tratamento de águas industriais }\end{array}$ & SIM & 1 e 13 & $\begin{array}{l}\text { Indústrias energéticas (fontes } \\
\text { renováveis - / não-renováveis) } \\
\text { / Tratamento e eliminação de } \\
\text { resíduos }\end{array}$ & Pequena \\
\hline China & 5453 & 2011 & $\begin{array}{l}\text { Guodian Technology \& } \\
\text { Environment Group Co., Ltd. }\end{array}$ & $\begin{array}{l}\text { Inner Mongolia Chifeng } \\
\text { Songshanqu Sandaogou Wind } \\
\text { Farm Project }\end{array}$ & SIM & $\begin{array}{l}\text { Produção energética - } \\
\text { geradores eólicos }\end{array}$ & SIM & 1 & $\begin{array}{l}\text { Indústrias energéticas (fontes } \\
\text { renováveis - / não-renováveis) }\end{array}$ & Larga \\
\hline China & 4553 & 2011 & $\begin{array}{l}\text { Guodian Technology \& } \\
\text { Environment Group Co., Ltd. }\end{array}$ & $\begin{array}{l}\text { Inner Mongolia Chifeng } \\
\text { Dayuying Wind Farm Project }\end{array}$ & SIM & $\begin{array}{l}\text { Produção energética - } \\
\text { geradores eólicos }\end{array}$ & SIM & 1 & $\begin{array}{l}\text { Indústrias energéticas (fontes } \\
\text { renováveis - / não-renováveis) }\end{array}$ & Larga \\
\hline China & 4114 & 2011 & $\begin{array}{l}\text { Henan Yinge Industrial } \\
\text { Investment Co. Ltd. }\end{array}$ & $\begin{array}{l}\text { Henan Yinge Industrial } \\
\text { Investment Corporation } \\
\text { Wastewater Treatment and } \\
\text { Methane Recovery Project }\end{array}$ & SIM & $\begin{array}{l}\text { Produção energética - } \\
\text { tratamento de águas industriais }\end{array}$ & NÃO & 1 e 13 & $\begin{array}{l}\text { Indústrias energéticas (fontes } \\
\text { renováveis - / não-renováveis) } \\
\text { / Tratamento e eliminação de } \\
\text { resíduos }\end{array}$ & Pequena \\
\hline
\end{tabular}




\begin{tabular}{|c|c|c|c|c|c|c|c|c|c|c|}
\hline China & 4221 & 2011 & Huadian Energy Co., Ltd. & $\begin{array}{l}\text { Primary Heating Network in } \\
\text { Hulan and Songbei Districts of } \\
\text { Harbin City }\end{array}$ & SIM & $\begin{array}{l}\text { Distribuição energética - novos } \\
\text { sistemas }\end{array}$ & NÃO & 1 & \begin{tabular}{|l} 
Indústrias energéticas (fontes \\
renováveis - / não-renováveis)
\end{tabular} & Larga \\
\hline China & 823 & 2007 & $\begin{array}{l}\text { Huadian Power International } \\
\text { Co., Ltd. }\end{array}$ & $\begin{array}{l}\text { Huadian Inner Mongolia } \\
\text { Huitengxile 100.25MW Wind } \\
\text { Farm Project }\end{array}$ & SIM & $\begin{array}{l}\text { Produção energética - } \\
\text { geradores eólicos }\end{array}$ & SIM & 1 & $\begin{array}{l}\text { Indústrias energéticas (fontes } \\
\text { renováveis - / não-renováveis) }\end{array}$ & Larga \\
\hline China & 1592 & 2008 & $\begin{array}{l}\text { Huadian Power International } \\
\text { Co., Ltd. }\end{array}$ & \begin{tabular}{|l} 
Huadian Ningxia Ningdong \\
Yangiaayao 45MW Wind-farm \\
Project
\end{tabular} & SIM & $\begin{array}{l}\text { Produção energética - } \\
\text { geradores eólicos }\end{array}$ & SIM & 1 & $\begin{array}{l}\text { Indústrias energéticas (fontes } \\
\text { renováveis - / não-renováveis) }\end{array}$ & Larga \\
\hline China & 1480 & 2008 & $\begin{array}{l}\text { Huadian Power International } \\
\text { Co., Ltd. }\end{array}$ & $\begin{array}{l}\text { Xinjiang Xiaocaohu Wind } \\
\text { Power Project }\end{array}$ & SIM & $\begin{array}{l}\text { Produção energética - } \\
\text { geradores eólicos }\end{array}$ & SIM & 1 & $\begin{array}{l}\text { Indústrias energéticas (fontes } \\
\text { renováveis - / não-renováveis) }\end{array}$ & Larga \\
\hline China & 1992 & 2009 & $\begin{array}{l}\text { Huadian Power International } \\
\text { Co., Ltd. }\end{array}$ & $\begin{array}{l}\text { Expansion Project of Huadian } \\
\text { Inner Mongolia Huitengxile } \\
\text { Wind Farm }\end{array}$ & SIM & $\begin{array}{l}\text { Produção energética - } \\
\text { geradores eólicos }\end{array}$ & SIM & 1 & $\begin{array}{l}\text { Indústrias energéticas (fontes } \\
\text { renováveis - / não-renováveis) }\end{array}$ & Larga \\
\hline China & 2413 & 2009 & $\begin{array}{l}\text { Huadian Power International } \\
\text { Co., Ltd. }\end{array}$ & $\begin{array}{l}\text { Xinjiang Huadian Xiaocaohu the } \\
\text { 2nd phase of No.1 Wind Farm } \\
\text { project }\end{array}$ & SIM & $\begin{array}{l}\text { Produção energética - } \\
\text { geradores eólicos }\end{array}$ & SIM & 1 & $\begin{array}{l}\text { Indústrias energéticas (fontes } \\
\text { renováveis - / não-renováveis) }\end{array}$ & Larga \\
\hline China & 2831 & 2010 & $\begin{array}{l}\text { Huadian Power International } \\
\text { Co., Ltd. }\end{array}$ & $\begin{array}{l}\text { Huadian Laizhou Wind Farm } \\
\text { Project }\end{array}$ & SIM & $\begin{array}{l}\text { Produção energética - } \\
\text { geradores eólicos }\end{array}$ & SIM & 1 & $\begin{array}{l}\text { Indústrias energéticas (fontes } \\
\text { renováveis - / não-renováveis) }\end{array}$ & Larga \\
\hline China & 3750 & 2010 & $\begin{array}{l}\text { Huadian Power International } \\
\text { Co.. Ltd. }\end{array}$ & $\begin{array}{l}\text { Huadian Kailu Yihetala Phase } \\
\text { Two 49.5 MW Wind Farm } \\
\text { Project in China }\end{array}$ & SIM & $\begin{array}{l}\text { Produção energética - } \\
\text { geradores eólicos }\end{array}$ & SIM & 1 & $\begin{array}{l}\text { Indústrias energéticas (fontes } \\
\text { renováveis - / não-renováveis) }\end{array}$ & Larga \\
\hline China & 3091 & 2010 & $\begin{array}{l}\text { Huadian Power International } \\
\text { Co., Ltd. }\end{array}$ & $\begin{array}{l}\text { Huadian Tongliao Beiqinghe } \\
300 \text { MW Wind Farm Project }\end{array}$ & SIM & $\begin{array}{l}\text { Produção energética - } \\
\text { geradores eólicos }\end{array}$ & SIM & 1 & $\begin{array}{l}\text { Indústrias energéticas (fontes } \\
\text { renováveis - / não-renováveis) }\end{array}$ & Larga \\
\hline China & 3104 & 2010 & $\begin{array}{l}\text { Huadian Power International } \\
\text { Co., Ltd. }\end{array}$ & $\begin{array}{l}\text { Huadian Kailu Yihetala Phase } \\
\text { one 49.5 MW Wind Farm } \\
\text { Project }\end{array}$ & SIM & $\begin{array}{l}\text { Produção energética - } \\
\text { geradores eólicos }\end{array}$ & SIM & 1 & $\begin{array}{l}\text { Indústrias energéticas (fontes } \\
\text { renováveis - / não-renováveis) }\end{array}$ & Larga \\
\hline China & 4232 & 2010 & $\begin{array}{l}\text { Huadian Power International } \\
\text { Co., Ltd. }\end{array}$ & $\begin{array}{l}\text { Huadian Da'an Fengshuishan } \\
\text { Phase I Wind Farm Project }\end{array}$ & SIM & $\begin{array}{l}\text { Produção energética - } \\
\text { geradores eólicos }\end{array}$ & SIM & 1 & $\begin{array}{l}\text { Indústrias energéticas (fontes } \\
\text { renováveis - / não-renováveis) }\end{array}$ & Larga \\
\hline China & 2887 & 2010 & $\begin{array}{l}\text { Huadian Power International } \\
\text { Co., Ltd. }\end{array}$ & $\begin{array}{l}\text { The 2nd 45MW Wind-farm } \\
\text { project of Huadian Ningxia } \\
\text { Ningdong Yangjiayao }\end{array}$ & SIM & $\begin{array}{l}\text { Produção energética - } \\
\text { geradores eólicos }\end{array}$ & SIM & 1 & $\begin{array}{l}\text { Indústrias energéticas (fontes } \\
\text { renováveis - / não-renováveis) }\end{array}$ & Larga \\
\hline China & 3539 & 2010 & $\begin{array}{l}\text { Huadian Power International } \\
\text { Co., Ltd. }\end{array}$ & $\begin{array}{l}\text { Huadian Kulun 201MW Wind } \\
\text { Farm Project }\end{array}$ & SIM & $\begin{array}{l}\text { Produção energética - } \\
\text { geradores eólicos }\end{array}$ & SIM & 1 & $\begin{array}{l}\text { Indústrias energéticas (fontes } \\
\text { renováveis - / não-renováveis) }\end{array}$ & Larga \\
\hline China & 4418 & 2011 & $\begin{array}{l}\text { Huadian Power International } \\
\text { Co., Ltd. }\end{array}$ & $\begin{array}{l}\text { Huadian Hebei Guyuan } \\
\text { 100.5MW Wind Farm Project }\end{array}$ & SIM & $\begin{array}{l}\text { Produção energética - } \\
\text { geradores eólicos }\end{array}$ & SIM & 1 & $\begin{array}{l}\text { Indústrias energéticas (fontes } \\
\text { renováveis - / não-renováveis) }\end{array}$ & Larga \\
\hline China & 4783 & 2011 & $\begin{array}{l}\text { Huadian Power International } \\
\text { Co., Ltd. }\end{array}$ & $\begin{array}{l}\text { Huadian Fuqing Niutouwei } \\
\text { Wind Power Project }\end{array}$ & SIM & $\begin{array}{l}\text { Produção energética - } \\
\text { geradores eólicos }\end{array}$ & SIM & 1 & $\begin{array}{l}\text { Indústrias energéticas (fontes } \\
\text { renováveis - / não-renováveis) }\end{array}$ & Larga \\
\hline China & 4808 & 2011 & $\begin{array}{l}\text { Huadian Power International } \\
\text { Co., Ltd. }\end{array}$ & $\begin{array}{l}\text { Huadian Kezuozhongqi Wind } \\
\text { Power Phase I Project }\end{array}$ & SIM & Produção energética - & SIM & 1 & Indústrias energéticas (fontes & Larga \\
\hline
\end{tabular}




\begin{tabular}{|c|c|c|c|c|c|c|c|c|c|c|}
\hline & & & & & & geradores eólicos & & & renováveis - / não-renováveis) & \\
\hline China & 4914 & 2011 & $\begin{array}{l}\text { Huadian Power International } \\
\text { Co., Ltd. }\end{array}$ & $\begin{array}{l}\text { Huadian Ningxia Ningdong } \\
\text { Yangjiayao Wind Farm } \\
\text { Expansion Project }\end{array}$ & SIM & $\begin{array}{l}\text { Produção energética - } \\
\text { geradores eólicos }\end{array}$ & SIM & 1 & $\begin{array}{l}\text { Indústrias energéticas (fontes } \\
\text { renováveis - / não-renováveis) }\end{array}$ & Pequena \\
\hline China & 5102 & 2011 & $\begin{array}{l}\text { Huadian Power International } \\
\text { Co., Ltd. }\end{array}$ & $\begin{array}{l}\text { Huadian Ningxia Ningdong } \\
\text { Yangjiayao Phase III Wind Farm } \\
\text { Project }\end{array}$ & SIM & $\begin{array}{l}\text { Produção energética - } \\
\text { geradores eólicos }\end{array}$ & NÃO & 1 & $\begin{array}{l}\text { Indústrias energéticas (fontes } \\
\text { renováveis - / não-renováveis) }\end{array}$ & Larga \\
\hline China & 3965 & 2011 & $\begin{array}{l}\text { Huadian Power International } \\
\text { Co., Ltd. }\end{array}$ & $\begin{array}{l}\text { Anhui Suzhou Biomass Power } \\
\text { Generation Project }\end{array}$ & SIM & $\begin{array}{l}\text { Produção energética - outros } \\
\text { resíduos agrícolas }\end{array}$ & SIM & 1 & $\begin{array}{l}\text { Indústrias energéticas (fontes } \\
\text { renováveis - / não-renováveis) }\end{array}$ & Larga \\
\hline China & 6744 & 2012 & $\begin{array}{l}\text { Huadian Power International } \\
\text { Co., Ltd. }\end{array}$ & $\begin{array}{l}\text { Huadian Laizhou Jincheng First } \\
\text { Phase } 48 \text { MW Wind Power } \\
\text { Project }\end{array}$ & SIM & $\begin{array}{l}\text { Produção energética - } \\
\text { geradores eólicos }\end{array}$ & SIM & 1 & $\begin{array}{l}\text { Indústrias energéticas (fontes } \\
\text { renováveis - / não-renováveis) }\end{array}$ & Larga \\
\hline China & 7239 & 2012 & $\begin{array}{l}\text { Huadian Power International } \\
\text { Co., Ltd. }\end{array}$ & $\begin{array}{l}\text { Huadian Guyuan Phase III } \\
\text { 49.5MW Wind Farm Project }\end{array}$ & SIM & $\begin{array}{l}\text { Produção energética - } \\
\text { geradores eólicos }\end{array}$ & SIM & 1 & $\begin{array}{l}\text { Indústrias energéticas (fontes } \\
\text { renováveis - / não-renováveis) }\end{array}$ & Larga \\
\hline China & 8332 & 2012 & $\begin{array}{l}\text { Huadian Power International } \\
\text { Co., Ltd. }\end{array}$ & $\begin{array}{l}\text { Huadian Guyuan Phase II } \\
\text { 100.5MW Wind Farm Project }\end{array}$ & SIM & $\begin{array}{l}\text { Produção energética - } \\
\text { geradores eólicos }\end{array}$ & SIM & 1 & $\begin{array}{l}\text { Indústrias energéticas (fontes } \\
\text { renováveis - / não-renováveis) }\end{array}$ & Larga \\
\hline China & 6345 & 2012 & $\begin{array}{l}\text { Huadian Power International } \\
\text { Co., Ltd. }\end{array}$ & $\begin{array}{l}\text { Huadian Da'an Fengshuishan } \\
\text { Phase II Wind Farm Project }\end{array}$ & SIM & $\begin{array}{l}\text { Produção energética - } \\
\text { geradores eólicos }\end{array}$ & SIM & 1 & $\begin{array}{l}\text { Indústrias energéticas (fontes } \\
\text { renováveis - / não-renováveis) }\end{array}$ & Larga \\
\hline China & 8334 & 2012 & $\begin{array}{l}\text { Huadian Power International } \\
\text { Co., Ltd. }\end{array}$ & $\begin{array}{l}\text { Huadian Da'an Fengshuishan } \\
\text { Phase III Wind Farm Project }\end{array}$ & SIM & $\begin{array}{l}\text { Produção energética - } \\
\text { geradores eólicos }\end{array}$ & SIM & 1 & $\begin{array}{l}\text { Indústrias energéticas (fontes } \\
\text { renováveis - / não-renováveis) }\end{array}$ & Larga \\
\hline China & 6060 & 2012 & $\begin{array}{l}\text { Huadian Power International } \\
\text { Co., Ltd. }\end{array}$ & $\begin{array}{l}\text { Huadian Ningxia Ningdong } \\
\text { Phase } 4 \text { 49.5MW Wind Farm } \\
\text { Project }\end{array}$ & SIM & $\begin{array}{l}\text { Produção energética - } \\
\text { geradores eólicos }\end{array}$ & SIM & 1 & $\begin{array}{l}\text { Indústrias energéticas (fontes } \\
\text { renováveis - / não-renováveis) }\end{array}$ & Larga \\
\hline China & 7264 & 2012 & $\begin{array}{l}\text { Huadian Power International } \\
\text { Co., Ltd. }\end{array}$ & $\begin{array}{l}\text { Huadian Ningxia Ningdong } \\
\text { Phase V Wind Farm Project }\end{array}$ & SIM & $\begin{array}{l}\text { Produção energética - } \\
\text { geradores eólicos }\end{array}$ & SIM & 1 & $\begin{array}{l}\text { Indústrias energéticas (fontes } \\
\text { renováveis - / não-renováveis) }\end{array}$ & Larga \\
\hline China & 7784 & 2012 & $\begin{array}{l}\text { Huadian Power International } \\
\text { Co., Ltd. }\end{array}$ & $\begin{array}{l}\text { Huadian Ningxia Ningdong } \\
\text { Phase VI Wind Farm Project }\end{array}$ & SIM & $\begin{array}{l}\text { Produção energética - } \\
\text { geradores eólicos }\end{array}$ & SIM & 1 & $\begin{array}{l}\text { Indústrias energéticas (fontes } \\
\text { renováveis - / não-renováveis) }\end{array}$ & Larga \\
\hline China & 905 & 2007 & $\begin{array}{l}\text { Huaneng Power International, } \\
\text { Inc. }\end{array}$ & $\begin{array}{l}\text { Jiangsu Qidong } 91.5 \mathrm{MW} \text { Wind } \\
\text { Power Project }\end{array}$ & SIM & $\begin{array}{l}\text { Produção energética - } \\
\text { geradores eólicos }\end{array}$ & SIM & 1 & $\begin{array}{l}\text { Indústrias energéticas (fontes } \\
\text { renováveis - / não-renováveis) }\end{array}$ & Larga \\
\hline China & 2853 & 2010 & $\begin{array}{l}\text { Huaneng Power International, } \\
\text { Inc. }\end{array}$ & $\begin{array}{l}\text { Huade Daditaihong 49.5MW } \\
\text { Wind Power Project }\end{array}$ & SIM & $\begin{array}{l}\text { Produção energética - } \\
\text { geradores eólicos }\end{array}$ & SIM & 1 & $\begin{array}{l}\text { Indústrias energéticas (fontes } \\
\text { renováveis - / não-renováveis) }\end{array}$ & Larga \\
\hline China & 4736 & 2011 & $\begin{array}{l}\text { Huaneng Power International, } \\
\text { Inc. }\end{array}$ & $\begin{array}{l}\text { Huaneng Gansu Guazhou } \\
\text { Ganhekou No.2 Wind Farm }\end{array}$ & SIM & $\begin{array}{l}\text { Produção energética - } \\
\text { geradores eólicos }\end{array}$ & SIM & 1 & $\begin{array}{l}\text { Indústrias energéticas (fontes } \\
\text { renováveis - / não-renováveis) }\end{array}$ & Larga \\
\hline
\end{tabular}




\begin{tabular}{|c|c|c|c|c|c|c|c|c|c|c|}
\hline China & 6479 & 2012 & $\begin{array}{l}\text { Huaneng Power International, } \\
\text { Inc. }\end{array}$ & $\begin{array}{l}\text { Huaneng Gansu Qiaowan Sanbei } \\
\text { Wind Farm Project }\end{array}$ & SIM & $\begin{array}{l}\text { Produção energética - } \\
\text { geradores eólicos }\end{array}$ & SIM & 1 & $\begin{array}{l}\text { Indústrias energéticas (fontes } \\
\text { renováveis - / não-renováveis) }\end{array}$ & Larga \\
\hline China & 6528 & 2012 & $\begin{array}{l}\text { Huaneng Power International, } \\
\text { Inc. }\end{array}$ & $\begin{array}{l}\text { Gansu Guazhou Qiaowan } \\
\text { Second Phase Wind Farm } \\
\text { Project }\end{array}$ & SIM & $\begin{array}{l}\text { Produção energética - } \\
\text { geradores eólicos }\end{array}$ & SIM & 1 & $\begin{array}{l}\text { Indústrias energéticas (fontes } \\
\text { renováveis - / não-renováveis) }\end{array}$ & Larga \\
\hline China & 4151 & 2012 & $\begin{array}{l}\text { Huaneng Power International, } \\
\text { Inc. }\end{array}$ & $\begin{array}{l}\text { Huaneng International Huade } \\
\text { Daditaihong Wind Power Farm } \\
\text { Phase II 49.5 MW Project }\end{array}$ & SIM & $\begin{array}{l}\text { Produção energética - } \\
\text { geradores eólicos }\end{array}$ & SIM & 1 & $\begin{array}{l}\text { Indústrias energéticas (fontes } \\
\text { renováveis - / não-renováveis) }\end{array}$ & Larga \\
\hline China & 2599 & 2009 & $\begin{array}{l}\text { Huaneng Renewables } \\
\text { Corporation Ltd. }\end{array}$ & $\begin{array}{l}\text { Huaneng Tongliao Baolongshan } \\
\text { Phase II Wind Farm Project }\end{array}$ & SIM & $\begin{array}{l}\text { Produção energética - } \\
\text { geradores eólicos }\end{array}$ & SIM & 1 & $\begin{array}{l}\text { Indústrias energéticas (fontes } \\
\text { renováveis - / não-renováveis) }\end{array}$ & Larga \\
\hline China & 2598 & 2010 & $\begin{array}{l}\text { Huaneng Renewables } \\
\text { Corporation Ltd. }\end{array}$ & $\begin{array}{l}\text { Huaneng Jilin Tongyu Phase II } \\
\text { Wind Farm Project }\end{array}$ & SIM & $\begin{array}{l}\text { Produção energética - } \\
\text { geradores eólicos }\end{array}$ & SIM & 1 & $\begin{array}{l}\text { Indústrias energéticas (fontes } \\
\text { renováveis - / não-renováveis) }\end{array}$ & Larga \\
\hline China & 3078 & 2010 & $\begin{array}{l}\text { Huaneng Renewables } \\
\text { Corporation Ltd. }\end{array}$ & $\begin{array}{l}\text { Huaneng Jilin Taobei Phase II } \\
\text { Wind Farm Project }\end{array}$ & SIM & $\begin{array}{l}\text { Produção energética - } \\
\text { geradores eólicos }\end{array}$ & SIM & 1 & $\begin{array}{l}\text { Indústrias energéticas (fontes } \\
\text { renováveis - / não-renováveis) }\end{array}$ & Larga \\
\hline China & 3353 & 2010 & $\begin{array}{l}\text { Huaneng Renewables } \\
\text { Corporation Ltd. }\end{array}$ & $\begin{array}{l}\text { Huaneng Changyi Phase I Wind } \\
\text { Farm Project }\end{array}$ & SIM & $\begin{array}{l}\text { Produção energética - } \\
\text { geradores eólicos }\end{array}$ & SIM & 1 & $\begin{array}{l}\text { Indústrias energéticas (fontes } \\
\text { renováveis - / não-renováveis) }\end{array}$ & Larga \\
\hline China & 3128 & 2010 & $\begin{array}{l}\text { Huaneng Renewables } \\
\text { Corporation Ltd. }\end{array}$ & $\begin{array}{l}\text { Yunnan Dali Dafengba 48MW } \\
\text { Wind Power Project }\end{array}$ & SIM & $\begin{array}{l}\text { Produção energética - } \\
\text { geradores eólicos }\end{array}$ & SIM & 1 & $\begin{array}{l}\text { Indústrias energéticas (fontes } \\
\text { renováveis - / não-renováveis) }\end{array}$ & Larga \\
\hline China & 2911 & 2010 & $\begin{array}{l}\text { Huaneng Renewables } \\
\text { Corporation Ltd. }\end{array}$ & $\begin{array}{l}\text { Huaneng Damao Maoming } \\
\text { Phase I Wind Farm Project }\end{array}$ & SIM & $\begin{array}{l}\text { Produção energética - } \\
\text { geradores eólicos }\end{array}$ & SIM & 1 & $\begin{array}{l}\text { Indústrias energéticas (fontes } \\
\text { renováveis - / não-renováveis) }\end{array}$ & Larga \\
\hline China & 2918 & 2010 & $\begin{array}{l}\text { Huaneng Renewables } \\
\text { Corporation Ltd. }\end{array}$ & $\begin{array}{l}\text { Huaneng Liaoning Fuxin Phase } \\
\text { II Wind Farm Project }\end{array}$ & SIM & $\begin{array}{l}\text { Produção energética - } \\
\text { geradores eólicos }\end{array}$ & SIM & 1 & $\begin{array}{l}\text { Indústrias energéticas (fontes } \\
\text { renováveis - / não-renováveis) }\end{array}$ & Larga \\
\hline China & 3080 & 2010 & $\begin{array}{l}\text { Huaneng Renewables } \\
\text { Corporation Ltd. }\end{array}$ & $\begin{array}{l}\text { Huaneng Inner Mongolia } \\
\text { Keyouzhongqi Gaoliban Wind } \\
\text { Farm Project }\end{array}$ & SIM & $\begin{array}{l}\text { Produção energética - } \\
\text { geradores eólicos }\end{array}$ & SIM & 1 & $\begin{array}{l}\text { Indústrias energéticas (fontes } \\
\text { renováveis - / não-renováveis) }\end{array}$ & Larga \\
\hline China & 3274 & 2010 & $\begin{array}{l}\text { Huaneng Renewables } \\
\text { Corporation Ltd. }\end{array}$ & $\begin{array}{l}\text { Huaneng Hailar Xiaoliang Phase } \\
\text { I Wind Farm Project }\end{array}$ & SIM & $\begin{array}{l}\text { Produção energética - } \\
\text { geradores eólicos }\end{array}$ & SIM & 1 & $\begin{array}{l}\text { Indústrias energéticas (fontes } \\
\text { renováveis - / não-renováveis) }\end{array}$ & Larga \\
\hline China & 3344 & 2010 & $\begin{array}{l}\text { Huaneng Renewables } \\
\text { Corporation Ltd. }\end{array}$ & $\begin{array}{l}\text { Liaoning Fuxin Gaoshanzi } \\
\text { 100.5MW Wind Power Project }\end{array}$ & SIM & $\begin{array}{l}\text { Produção energética - } \\
\text { geradores eólicos }\end{array}$ & SIM & 1 & $\begin{array}{l}\text { Indústrias energéticas (fontes } \\
\text { renováveis - / não-renováveis) }\end{array}$ & Larga \\
\hline China & 3534 & 2010 & $\begin{array}{l}\text { Huaneng Renewables } \\
\text { Corporation Ltd. }\end{array}$ & $\begin{array}{l}\text { Inner Mongolia Tongliao } \\
\text { Baolongshan 49.5MW Wind } \\
\text { Power Project }\end{array}$ & SIM & $\begin{array}{l}\text { Produção energética - } \\
\text { geradores eólicos }\end{array}$ & SIM & 1 & $\begin{array}{l}\text { Indústrias energéticas (fontes } \\
\text { renováveis - / não-renováveis) }\end{array}$ & Larga \\
\hline China & 3579 & 2010 & $\begin{array}{l}\text { Huaneng Renewables } \\
\text { Corporation Ltd. }\end{array}$ & $\begin{array}{l}\text { Huaneng Xinjiang Hami } \\
\text { Santanghu Phase I Wind Farm } \\
\text { Project }\end{array}$ & SIM & $\begin{array}{l}\text { Produção energética - } \\
\text { geradores eólicos }\end{array}$ & SIM & 1 & $\begin{array}{l}\text { Indústrias energéticas (fontes } \\
\text { renováveis - / não-renováveis) }\end{array}$ & Larga \\
\hline China & 3596 & 2010 & $\begin{array}{l}\text { Huaneng Renewables } \\
\text { Corporation Ltd. }\end{array}$ & $\begin{array}{l}\text { Huaneng Wuchuan Lihanliang } \\
\text { Phase I Wind Farm Project }\end{array}$ & SIM & Produção energética - & SIM & 1 & Indústrias energéticas (fontes & Larga \\
\hline
\end{tabular}




\begin{tabular}{|c|c|c|c|c|c|c|c|c|c|c|}
\hline & & & & & & geradores eólicos & & & renováveis - / não-renováveis) & \\
\hline China & 3603 & 2010 & $\begin{array}{l}\text { Huaneng Renewables } \\
\text { Corporation Ltd. }\end{array}$ & $\begin{array}{l}\text { Huaneng Binhai Wind Farm } \\
\text { Project }\end{array}$ & SIM & $\begin{array}{l}\text { Produção energética - } \\
\text { geradores eólicos }\end{array}$ & SIM & 1 & $\begin{array}{l}\text { Indústrias energéticas (fontes } \\
\text { renováveis - / não-renováveis) }\end{array}$ & Larga \\
\hline China & 3718 & 2010 & $\begin{array}{l}\text { Huaneng Renewables } \\
\text { Corporation Ltd. }\end{array}$ & $\begin{array}{l}\text { Shandong Huaneng Hekou } \\
\text { Phase I Wind Farm Project }\end{array}$ & SIM & $\begin{array}{l}\text { Produção energética - } \\
\text { geradores eólicos }\end{array}$ & SIM & 1 & $\begin{array}{l}\text { Indústrias energéticas (fontes } \\
\text { renováveis - / não-renováveis) }\end{array}$ & Larga \\
\hline China & 3784 & 2010 & $\begin{array}{l}\text { Huaneng Renewables } \\
\text { Corporation Ltd. }\end{array}$ & $\begin{array}{l}\text { Huaneng Shanxi Ningwu } \\
\text { Dongmafang Phase I Wind Farm } \\
\text { Project }\end{array}$ & SIM & $\begin{array}{l}\text { Produção energética - } \\
\text { geradores eólicos }\end{array}$ & SIM & 1 & $\begin{array}{l}\text { Indústrias energéticas (fontes } \\
\text { renováveis - / não-renováveis) }\end{array}$ & Larga \\
\hline China & 3867 & 2010 & $\begin{array}{l}\text { Huaneng Renewables } \\
\text { Corporation Ltd. }\end{array}$ & $\begin{array}{l}\text { Huaneng Fuxin Phase III Wind } \\
\text { Farm Project }\end{array}$ & SIM & $\begin{array}{l}\text { Produção energética - } \\
\text { geradores eólicos }\end{array}$ & SIM & 1 & $\begin{array}{l}\text { Indústrias energéticas (fontes } \\
\text { renováveis - / não-renováveis) }\end{array}$ & Larga \\
\hline China & 3891 & 2010 & $\begin{array}{l}\text { Huaneng Renewables } \\
\text { Corporation Ltd. }\end{array}$ & $\begin{array}{l}\text { Huaneng Wuchuan Lihanliang } \\
\text { Phase II Wind Farm Project }\end{array}$ & SIM & $\begin{array}{l}\text { Produção energética - } \\
\text { geradores eólicos }\end{array}$ & SIM & 1 & $\begin{array}{l}\text { Indústrias energéticas (fontes } \\
\text { renováveis - / não-renováveis) }\end{array}$ & Larga \\
\hline China & 3391 & 2010 & $\begin{array}{l}\text { Huaneng Renewables } \\
\text { Corporation Ltd. }\end{array}$ & $\begin{array}{l}\text { Shandong Huaneng Shouguang } \\
\text { 49.5MW Wind Farm Project }\end{array}$ & SIM & $\begin{array}{l}\text { Produção energética - } \\
\text { geradores eólicos }\end{array}$ & SIM & 1 & $\begin{array}{l}\text { Indústrias energéticas (fontes } \\
\text { renováveis - / não-renováveis) }\end{array}$ & Larga \\
\hline China & 3084 & 2010 & $\begin{array}{l}\text { Huaneng Renewables } \\
\text { Corporation Ltd. }\end{array}$ & $\begin{array}{l}\text { Huaneng Tongliao Baolongshan } \\
\text { Phase III Wind Farm Project }\end{array}$ & SIM & $\begin{array}{l}\text { Produção energética - } \\
\text { geradores eólicos }\end{array}$ & SIM & 1 & $\begin{array}{l}\text { Indústrias energéticas (fontes } \\
\text { renováveis - / não-renováveis) }\end{array}$ & Larga \\
\hline China & 3124 & 2010 & $\begin{array}{l}\text { Huaneng Renewables } \\
\text { Corporation Ltd. }\end{array}$ & $\begin{array}{l}\text { Huaneng Tongliao Zhurihe } \\
\text { Phase I Wind Farm Project }\end{array}$ & SIM & $\begin{array}{l}\text { Produção energética - } \\
\text { geradores eólicos }\end{array}$ & SIM & 1 & $\begin{array}{l}\text { Indústrias energéticas (fontes } \\
\text { renováveis - / não-renováveis) }\end{array}$ & Larga \\
\hline China & 4241 & 2010 & $\begin{array}{l}\text { Huaneng Renewables } \\
\text { Corporation Ltd. }\end{array}$ & $\begin{array}{l}\text { Huaneng Tongliao Zhurihe } \\
\text { Phase II Wind Farm Project }\end{array}$ & SIM & $\begin{array}{l}\text { Produção energética - } \\
\text { geradores eólicos }\end{array}$ & SIM & 1 & $\begin{array}{l}\text { Indústrias energéticas (fontes } \\
\text { renováveis - / não-renováveis) }\end{array}$ & Larga \\
\hline China & 4255 & 2010 & $\begin{array}{l}\text { Huaneng Renewables } \\
\text { Corporation Ltd. }\end{array}$ & $\begin{array}{l}\text { Huaneng Tongliao Kezuo Zhong } \\
\text { Qi Nanhari Wind Farm Project }\end{array}$ & SIM & $\begin{array}{l}\text { Produção energética - } \\
\text { geradores eólicos }\end{array}$ & SIM & 1 & $\begin{array}{l}\text { Indústrias energéticas (fontes } \\
\text { renováveis - / não-renováveis) }\end{array}$ & Larga \\
\hline China & 4034 & 2011 & $\begin{array}{l}\text { Huaneng Renewables } \\
\text { Corporation Ltd. }\end{array}$ & $\begin{array}{l}\text { Huaneng Eryuan Ma'anshan } \\
\text { Wind Farm Project }\end{array}$ & SIM & $\begin{array}{l}\text { Produção energética - } \\
\text { geradores eólicos }\end{array}$ & SIM & 1 & $\begin{array}{l}\text { Indústrias energéticas (fontes } \\
\text { renováveis - / não-renováveis) }\end{array}$ & Larga \\
\hline China & 4204 & 2011 & $\begin{array}{l}\text { Huaneng Renewables } \\
\text { Corporation Ltd. }\end{array}$ & $\begin{array}{l}\text { Huaneng Weichang Yudaokou } \\
\text { Phase I Wind Farm Project }\end{array}$ & SIM & $\begin{array}{l}\text { Produção energética - } \\
\text { geradores eólicos }\end{array}$ & SIM & 1 & $\begin{array}{l}\text { Indústrias energéticas (fontes } \\
\text { renováveis - / não-renováveis) }\end{array}$ & Larga \\
\hline China & 4320 & 2011 & $\begin{array}{l}\text { Huaneng Renewables } \\
\text { Corporation Ltd. }\end{array}$ & $\begin{array}{l}\text { Huaneng Fuxin Zhangbei Wind } \\
\text { Farm Project }\end{array}$ & SIM & $\begin{array}{l}\text { Produção energética - } \\
\text { geradores eólicos }\end{array}$ & SIM & 1 & $\begin{array}{l}\text { Indústrias energéticas (fontes } \\
\text { renováveis - / não-renováveis) }\end{array}$ & Larga \\
\hline China & 4400 & 2011 & $\begin{array}{l}\text { Huaneng Renewables } \\
\text { Corporation Ltd. }\end{array}$ & $\begin{array}{l}\text { Huaneng Guizhou Jiucaiping } \\
\text { Phase I Wind Farm Project }\end{array}$ & SIM & $\begin{array}{l}\text { Produção energética - } \\
\text { geradores eólicos }\end{array}$ & SIM & 1 & $\begin{array}{l}\text { Indústrias energéticas (fontes } \\
\text { renováveis - / não-renováveis) }\end{array}$ & Larga \\
\hline
\end{tabular}




\begin{tabular}{|c|c|c|c|c|c|c|c|c|c|c|}
\hline China & 4699 & 2011 & $\begin{array}{l}\text { Huaneng Renewables } \\
\text { Corporation Ltd. }\end{array}$ & $\begin{array}{l}\text { Huaneng Shandong Rongcheng } \\
\text { Chudao Wind Power Project }\end{array}$ & SIM & $\begin{array}{l}\text { Produção energética - } \\
\text { geradores eólicos }\end{array}$ & SIM & 1 & $\begin{array}{l}\text { Indústrias energéticas (fontes } \\
\text { renováveis - / não-renováveis) }\end{array}$ & Larga \\
\hline China & 4830 & 2011 & $\begin{array}{l}\text { Huaneng Renewables } \\
\text { Corporation Ltd. }\end{array}$ & $\begin{array}{l}\text { Huaneng Shandong Hekou } \\
\text { Phase III Wind Farm Project }\end{array}$ & SIM & $\begin{array}{l}\text { Produção energética - } \\
\text { geradores eólicos }\end{array}$ & SIM & 1 & $\begin{array}{l}\text { Indústrias energéticas (fontes } \\
\text { renováveis - / não-renováveis) }\end{array}$ & Larga \\
\hline China & 4871 & 2011 & $\begin{array}{l}\text { Huaneng Renewables } \\
\text { Corporation Ltd. }\end{array}$ & $\begin{array}{l}\text { Huaneng Shandong Hekou } \\
\text { Phase IV Wind Farm Project }\end{array}$ & SIM & $\begin{array}{l}\text { Produção energética - } \\
\text { geradores eólicos }\end{array}$ & SIM & 1 & $\begin{array}{l}\text { Indústrias energéticas (fontes } \\
\text { renováveis - / não-renováveis) }\end{array}$ & Larga \\
\hline China & 4880 & 2011 & $\begin{array}{l}\text { Huaneng Renewables } \\
\text { Corporation Ltd. }\end{array}$ & $\begin{array}{l}\text { Huaneng Tongyu Xinhua 1A } \\
\text { Wind Farm Project }\end{array}$ & SIM & $\begin{array}{l}\text { Produção energética - } \\
\text { geradores eólicos }\end{array}$ & SIM & 1 & $\begin{array}{l}\text { Indústrias energéticas (fontes } \\
\text { renováveis - / não-renováveis) }\end{array}$ & Larga \\
\hline China & 4917 & 2011 & $\begin{array}{l}\text { Huaneng Renewables } \\
\text { Corporation Ltd. }\end{array}$ & $\begin{array}{l}\text { Huaneng Tongyu Xinhua 1B } \\
\text { Wind Farm Project }\end{array}$ & SIM & $\begin{array}{l}\text { Produção energética - } \\
\text { geradores eólicos }\end{array}$ & SIM & 1 & $\begin{array}{l}\text { Indústrias energéticas (fontes } \\
\text { renováveis - / não-renováveis) }\end{array}$ & Larga \\
\hline China & 4928 & 2011 & $\begin{array}{l}\text { Huaneng Renewables } \\
\text { Corporation Ltd. }\end{array}$ & $\begin{array}{l}\text { Huaneng Changyi Phase II Wind } \\
\text { Farm Project }\end{array}$ & SIM & $\begin{array}{l}\text { Produção energética - } \\
\text { geradores eólicos }\end{array}$ & SIM & 1 & $\begin{array}{l}\text { Indústrias energéticas (fontes } \\
\text { renováveis - / não-renováveis) }\end{array}$ & Larga \\
\hline China & 4932 & 2011 & $\begin{array}{l}\text { Huaneng Renewables } \\
\text { Corporation Ltd. }\end{array}$ & $\begin{array}{l}\text { Huaneng Tongyu Xinhua 1C } \\
\text { Wind Farm Project }\end{array}$ & SIM & $\begin{array}{l}\text { Produção energética - } \\
\text { geradores eólicos }\end{array}$ & SIM & 1 & $\begin{array}{l}\text { Indústrias energéticas (fontes } \\
\text { renováveis - / não-renováveis) }\end{array}$ & Larga \\
\hline China & 5081 & 2011 & $\begin{array}{l}\text { Huaneng Renewables } \\
\text { Corporation Ltd. }\end{array}$ & $\begin{array}{l}\text { Huaneng Shandong Hekou } \\
\text { Phase II Wind Farm Project }\end{array}$ & SIM & $\begin{array}{l}\text { Produção energética - } \\
\text { geradores eólicos }\end{array}$ & SIM & 1 & $\begin{array}{l}\text { Indústrias energéticas (fontes } \\
\text { renováveis - / não-renováveis) }\end{array}$ & Larga \\
\hline China & 5180 & 2011 & $\begin{array}{l}\text { Huaneng Renewables } \\
\text { Corporation Ltd. }\end{array}$ & $\begin{array}{l}\text { Huaneng Jilin Taobei Phase III } \\
\text { Wind Farm Project }\end{array}$ & SIM & $\begin{array}{l}\text { Produção energética - } \\
\text { geradores eólicos }\end{array}$ & SIM & 1 & $\begin{array}{l}\text { Indústrias energéticas (fontes } \\
\text { renováveis - / não-renováveis) }\end{array}$ & Larga \\
\hline China & 5252 & 2011 & $\begin{array}{l}\text { Huaneng Renewables } \\
\text { Corporation Ltd. }\end{array}$ & $\begin{array}{l}\text { Huaneng Shandong Shouguang } \\
\text { Phase II Wind Power Project }\end{array}$ & SIM & $\begin{array}{l}\text { Produção energética - } \\
\text { geradores eólicos }\end{array}$ & SIM & 1 & $\begin{array}{l}\text { Indústrias energéticas (fontes } \\
\text { renováveis - / não-renováveis) }\end{array}$ & Larga \\
\hline China & 5269 & 2011 & $\begin{array}{l}\text { Huaneng Renewables } \\
\text { Corporation Ltd. }\end{array}$ & $\begin{array}{l}\text { Huaneng Shandong Shouguang } \\
\text { Phase III Wind Power Project }\end{array}$ & SIM & $\begin{array}{l}\text { Produção energética - } \\
\text { geradores eólicos }\end{array}$ & SIM & 1 & $\begin{array}{l}\text { Indústrias energéticas (fontes } \\
\text { renováveis - / não-renováveis) }\end{array}$ & Larga \\
\hline China & 4126 & 2011 & $\begin{array}{l}\text { Huaneng Renewables } \\
\text { Corporation Ltd. }\end{array}$ & \begin{tabular}{|l} 
Huaneng Tongliao \\
Kezuozhongqi Xibaiyin Wind \\
Farm Project \\
\end{tabular} & SIM & $\begin{array}{l}\text { Produção energética - } \\
\text { geradores eólicos }\end{array}$ & SIM & 1 & $\begin{array}{l}\text { Indústrias energéticas (fontes } \\
\text { renováveis - / não-renováveis) }\end{array}$ & Larga \\
\hline China & 4326 & 2011 & $\begin{array}{l}\text { Huaneng Renewables } \\
\text { Corporation Ltd. }\end{array}$ & $\begin{array}{l}\text { Huaneng Tongliao } \\
\text { Kezuozhongqi Dongbaiyin Wind } \\
\text { Farm Project }\end{array}$ & SIM & $\begin{array}{l}\text { Produção energética - } \\
\text { geradores eólicos }\end{array}$ & SIM & 1 & $\begin{array}{l}\text { Indústrias energéticas (fontes } \\
\text { renováveis - / não-renováveis) }\end{array}$ & Larga \\
\hline China & 4900 & 2011 & $\begin{array}{l}\text { Huaneng Renewables } \\
\text { Corporation Ltd. }\end{array}$ & \begin{tabular}{|l|} 
Huaneng Tongliao \\
Kezuozhongqi Haorigetu Wind \\
Farm Project \\
\end{tabular} & SIM & $\begin{array}{l}\text { Produção energética - } \\
\text { geradores eólicos }\end{array}$ & SIM & 1 & $\begin{array}{l}\text { Indústrias energéticas (fontes } \\
\text { renováveis - / não-renováveis) }\end{array}$ & Larga \\
\hline China & 4047 & 2011 & $\begin{array}{l}\text { Huaneng Renewables } \\
\text { Corporation Ltd. }\end{array}$ & $\begin{array}{l}\text { Huaneng Tuokexun Baiyanghe } \\
\text { First Stage 49.5MW wind farm } \\
\text { project }\end{array}$ & SIM & $\begin{array}{l}\text { Produção energética - } \\
\text { geradores eólicos }\end{array}$ & SIM & 1 & $\begin{array}{l}\text { Indústrias energéticas (fontes } \\
\text { renováveis - / não-renováveis) }\end{array}$ & Larga \\
\hline China & 4648 & 2011 & $\begin{array}{l}\text { Huaneng Renewables } \\
\text { Corporation Ltd. }\end{array}$ & $\begin{array}{l}\text { Huaneng Xinjiang Hami } \\
\text { Santanghu Phase II Wind Farm }\end{array}$ & SIM & Produção energética - & SIM & 1 & Indústrias energéticas (fontes & Larga \\
\hline
\end{tabular}




\begin{tabular}{|c|c|c|c|c|c|c|c|c|c|c|}
\hline & & & & Project & & geradores eólicos & & & renováveis - / não-renováveis) & \\
\hline China & 6438 & 2012 & $\begin{array}{l}\text { Huaneng Renewables } \\
\text { Corporation Ltd. }\end{array}$ & $\begin{array}{l}\text { Huaneng Zhanjiang Nansan } \\
\text { (Haifeng) Wind Power Project }\end{array}$ & SIM & $\begin{array}{l}\text { Produção energética - } \\
\text { geradores eólicos }\end{array}$ & SIM & 1 & $\begin{array}{l}\text { Indústrias energéticas (fontes } \\
\text { renováveis - / não-renováveis) }\end{array}$ & Larga \\
\hline China & 6752 & 2012 & $\begin{array}{l}\text { Huaneng Renewables } \\
\text { Corporation Ltd. }\end{array}$ & $\begin{array}{l}\text { Huaneng Shandong Yishui } \\
\text { Mazhan Phase I Wind Power } \\
\text { Project }\end{array}$ & SIM & $\begin{array}{l}\text { Produção energética - } \\
\text { geradores eólicos }\end{array}$ & SIM & 1 & $\begin{array}{l}\text { Indústrias energéticas (fontes } \\
\text { renováveis - / não-renováveis) }\end{array}$ & Larga \\
\hline China & 7298 & 2012 & $\begin{array}{l}\text { Huaneng Renewables } \\
\text { Corporation Ltd. }\end{array}$ & $\begin{array}{l}\text { Huaneng Yumen Qiaowan NO.3 } \\
\text { North Phase I } 48 \text { MW Wind } \\
\text { Power Project }\end{array}$ & SIM & $\begin{array}{l}\text { Produção energética - } \\
\text { geradores eólicos }\end{array}$ & SIM & 1 & $\begin{array}{l}\text { Indústrias energéticas (fontes } \\
\text { renováveis - / não-renováveis) }\end{array}$ & Larga \\
\hline China & 7453 & 2012 & $\begin{array}{l}\text { Huaneng Renewables } \\
\text { Corporation Ltd. }\end{array}$ & $\begin{array}{l}\text { Huaneng Dongying Hekou } \\
\text { Phase VI Wind Farm Project }\end{array}$ & SIM & $\begin{array}{l}\text { Produção energética - } \\
\text { geradores eólicos }\end{array}$ & SIM & 1 & $\begin{array}{l}\text { Indústrias energéticas (fontes } \\
\text { renováveis - / não-renováveis) }\end{array}$ & Larga \\
\hline China & 7517 & 2012 & $\begin{array}{l}\text { Huaneng Renewables } \\
\text { Corporation Ltd. }\end{array}$ & $\begin{array}{l}\text { Huaneng Fanshi Shanglangjian } \\
\text { (Shahe Phase I) } 49.5 \text { MW Wind } \\
\text { Power Project }\end{array}$ & SIM & $\begin{array}{l}\text { Produção energética - } \\
\text { geradores eólicos }\end{array}$ & NÃO & 1 & $\begin{array}{l}\text { Indústrias energéticas (fontes } \\
\text { renováveis - / não-renováveis) }\end{array}$ & Larga \\
\hline China & 7556 & 2012 & $\begin{array}{l}\text { Huaneng Renewables } \\
\text { Corporation Ltd. }\end{array}$ & $\begin{array}{l}\text { Huaneng Dongying Hekou } \\
\text { Phase V Wind Farm Project }\end{array}$ & SIM & $\begin{array}{l}\text { Produção energética - } \\
\text { geradores eólicos }\end{array}$ & SIM & 1 & $\begin{array}{l}\text { Indústrias energéticas (fontes } \\
\text { renováveis - / não-renováveis) }\end{array}$ & Larga \\
\hline China & 7749 & 2012 & $\begin{array}{l}\text { Huaneng Renewables } \\
\text { Corporation Ltd. }\end{array}$ & $\begin{array}{l}\text { Huaneng Haiyang Guocheng } \\
\text { Phase I Wind Farm Project }\end{array}$ & SIM & $\begin{array}{l}\text { Produção energética - } \\
\text { geradores eólicos }\end{array}$ & SIM & 1 & $\begin{array}{l}\text { Indústrias energéticas (fontes } \\
\text { renováveis - / não-renováveis) }\end{array}$ & Larga \\
\hline China & 7993 & 2012 & $\begin{array}{l}\text { Huaneng Renewables } \\
\text { Corporation Ltd. }\end{array}$ & $\begin{array}{l}\text { Huaneng Shenchi } \\
\text { Taipingzhuang 49.5MW Wind } \\
\text { Power Project }\end{array}$ & SIM & $\begin{array}{l}\text { Produção energética - } \\
\text { geradores eólicos }\end{array}$ & SIM & 1 & $\begin{array}{l}\text { Indústrias energéticas (fontes } \\
\text { renováveis - / não-renováveis) }\end{array}$ & Larga \\
\hline China & 8026 & 2012 & $\begin{array}{l}\text { Huaneng Renewables } \\
\text { Corporation Ltd. }\end{array}$ & $\begin{array}{l}\text { Huaneng Hebei Huailai } 49.5 \mathrm{MW} \\
\text { Wind Farm Project }\end{array}$ & SIM & $\begin{array}{l}\text { Produção energética - } \\
\text { geradores eólicos }\end{array}$ & SIM & 1 & $\begin{array}{l}\text { Indústrias energéticas (fontes } \\
\text { renováveis - / não-renováveis) }\end{array}$ & Larga \\
\hline China & 8302 & 2012 & $\begin{array}{l}\text { Huaneng Renewables } \\
\text { Corporation Ltd. }\end{array}$ & $\begin{array}{l}\text { Huaneng Wutai Eling } 49.5 \mathrm{MW} \\
\text { Wind Power Project }\end{array}$ & SIM & $\begin{array}{l}\text { Produção energética - } \\
\text { geradores eólicos }\end{array}$ & SIM & 1 & $\begin{array}{l}\text { Indústrias energéticas (fontes } \\
\text { renováveis - / não-renováveis) }\end{array}$ & Larga \\
\hline China & 8318 & 2012 & $\begin{array}{l}\text { Huaneng Renewables } \\
\text { Corporation Ltd. }\end{array}$ & $\begin{array}{l}\text { Huaneng Ningxia Qingtongxia } \\
\text { solar PV Power Plant }\end{array}$ & SIM & $\begin{array}{l}\text { Produção energética - } \\
\text { geradores solares }\end{array}$ & SIM & 1 & $\begin{array}{l}\text { Indústrias energéticas (fontes } \\
\text { renováveis - / não-renováveis) }\end{array}$ & Larga \\
\hline China & 8600 & 2012 & $\begin{array}{l}\text { Huaneng Renewables } \\
\text { Corporation Ltd. }\end{array}$ & $\begin{array}{l}\text { Huaneng Fanshi Xiaozhuang } \\
\text { (Shahe Phase II) 49.5MW Wind } \\
\text { Power Project }\end{array}$ & SIM & $\begin{array}{l}\text { Produção energética - } \\
\text { geradores eólicos }\end{array}$ & SIM & 1 & $\begin{array}{l}\text { Indústrias energéticas (fontes } \\
\text { renováveis - / não-renováveis) }\end{array}$ & Larga \\
\hline China & 8626 & 2012 & $\begin{array}{l}\text { Huaneng Renewables } \\
\text { Corporation Ltd. }\end{array}$ & $\begin{array}{l}\text { Huaneng Wulatehou Qi Wuliji } \\
\text { Wind Farm Phase I 49.5MW } \\
\text { Project }\end{array}$ & SIM & $\begin{array}{l}\text { Produção energética - } \\
\text { geradores eólicos }\end{array}$ & SIM & 1 & $\begin{array}{l}\text { Indústrias energéticas (fontes } \\
\text { renováveis - / não-renováveis) }\end{array}$ & Larga \\
\hline China & 8682 & 2012 & $\begin{array}{l}\text { Huaneng Renewables } \\
\text { Corporation Ltd. }\end{array}$ & $\begin{array}{l}\text { Huaneng Dingbian Langergou } \\
\text { Wind Farm Project }\end{array}$ & SIM & $\begin{array}{l}\text { Produção energética - } \\
\text { geradores eólicos }\end{array}$ & SIM & 1 & $\begin{array}{l}\text { Indústrias energéticas (fontes } \\
\text { renováveis - / não-renováveis) }\end{array}$ & Pequena \\
\hline
\end{tabular}




\begin{tabular}{|c|c|c|c|c|c|c|c|c|c|c|}
\hline China & 8765 & 2012 & $\begin{array}{l}\text { Huaneng Renewables } \\
\text { Corporation Ltd. }\end{array}$ & $\begin{array}{l}\text { Huaneng Gansu Jinchang } \\
\text { 20MWp Gridconnected Solar } \\
\text { PV Power Generation Project }\end{array}$ & SIM & $\begin{array}{l}\text { Produção energética - } \\
\text { geradores solares }\end{array}$ & SIM & 1 & $\begin{array}{l}\text { Indústrias energéticas (fontes } \\
\text { renováveis - / não-renováveis) }\end{array}$ & Larga \\
\hline China & 6329 & 2012 & $\begin{array}{l}\text { Huaneng Renewables } \\
\text { Corporation Ltd. }\end{array}$ & $\begin{array}{l}\text { Huaneng Yunnan Eryuan } \\
\text { Huangcaopo Wind Farm Project }\end{array}$ & SIM & $\begin{array}{l}\text { Produção energética - } \\
\text { geradores eólicos }\end{array}$ & SIM & 1 & $\begin{array}{l}\text { Indústrias energéticas (fontes } \\
\text { renováveis - / não-renováveis) }\end{array}$ & Larga \\
\hline China & 6748 & 2012 & $\begin{array}{l}\text { Huaneng Renewables } \\
\text { Corporation Ltd. }\end{array}$ & $\begin{array}{l}\text { Huaneng Yunnan Eryuan } \\
\text { Ganhaizi Wind Farm Project }\end{array}$ & SIM & $\begin{array}{l}\text { Produção energética - } \\
\text { geradores eólicos }\end{array}$ & SIM & 1 & $\begin{array}{l}\text { Indústrias energéticas (fontes } \\
\text { renováveis - / não-renováveis) }\end{array}$ & Larga \\
\hline China & 6788 & 2012 & $\begin{array}{l}\text { Huaneng Renewables } \\
\text { Corporation Ltd. }\end{array}$ & $\begin{array}{l}\text { Huaneng Yunnan Eryuan } \\
\text { Dalongtan Wind Farm Project }\end{array}$ & SIM & $\begin{array}{l}\text { Produção energética - } \\
\text { geradores eólicos }\end{array}$ & SIM & 1 & $\begin{array}{l}\text { Indústrias energéticas (fontes } \\
\text { renováveis - / não-renováveis) }\end{array}$ & Larga \\
\hline China & 7979 & 2012 & $\begin{array}{l}\text { Huaneng Renewables } \\
\text { Corporation Ltd. }\end{array}$ & $\begin{array}{l}\text { Huaneng Yunnan Eryuan } \\
\text { Guanyinshan Wind Farm Project }\end{array}$ & SIM & $\begin{array}{l}\text { Produção energética - } \\
\text { geradores eólicos }\end{array}$ & SIM & 1 & $\begin{array}{l}\text { Indústrias energéticas (fontes } \\
\text { renováveis - / não-renováveis) }\end{array}$ & Larga \\
\hline China & 4926 & 2012 & $\begin{array}{l}\text { Huaneng Renewables } \\
\text { Corporation Ltd. }\end{array}$ & $\begin{array}{l}\text { Huaneng Shanghai Chongming } \\
\text { Qianwei Wind Farm Project }\end{array}$ & SIM & $\begin{array}{l}\text { Produção energética - } \\
\text { geradores eólicos }\end{array}$ & SIM & 1 & $\begin{array}{l}\text { Indústrias energéticas (fontes } \\
\text { renováveis - / não-renováveis) }\end{array}$ & Larga \\
\hline China & 5055 & 2012 & $\begin{array}{l}\text { Huaneng Renewables } \\
\text { Corporation Ltd. }\end{array}$ & $\begin{array}{l}\text { Huaneng Tongyu Xinhua 1D } \\
\text { Wind Farm Project }\end{array}$ & SIM & $\begin{array}{l}\text { Produção energética - } \\
\text { geradores eólicos }\end{array}$ & SIM & 1 & $\begin{array}{l}\text { Indústrias energéticas (fontes } \\
\text { renováveis - / não-renováveis) }\end{array}$ & Larga \\
\hline China & 5094 & 2012 & $\begin{array}{l}\text { Huaneng Renewables } \\
\text { Corporation Ltd. }\end{array}$ & $\begin{array}{l}\text { Huaneng Tongyu Xinhua 1E } \\
\text { Wind Farm Project }\end{array}$ & SIM & $\begin{array}{l}\text { Produção energética - } \\
\text { geradores eólicos }\end{array}$ & SIM & 1 & $\begin{array}{l}\text { Indústrias energéticas (fontes } \\
\text { renováveis - / não-renováveis) }\end{array}$ & Larga \\
\hline China & 5277 & 2012 & $\begin{array}{l}\text { Huaneng Renewables } \\
\text { Corporation Ltd. }\end{array}$ & $\begin{array}{l}\text { Huaneng Tongyu Xinhua 1F } \\
\text { Wind Farm Project }\end{array}$ & SIM & $\begin{array}{l}\text { Produção energética - } \\
\text { geradores eólicos }\end{array}$ & SIM & 1 & $\begin{array}{l}\text { Indústrias energéticas (fontes } \\
\text { renováveis - / não-renováveis) }\end{array}$ & Larga \\
\hline China & 5782 & 2012 & $\begin{array}{l}\text { Huaneng Renewables } \\
\text { Corporation Ltd. }\end{array}$ & $\begin{array}{l}\text { Huaneng Erwenkeqi Yiminsumu } \\
\text { Wind Farm Project }\end{array}$ & SIM & $\begin{array}{l}\text { Produção energética - } \\
\text { geradores eólicos }\end{array}$ & SIM & 1 & $\begin{array}{l}\text { Indústrias energéticas (fontes } \\
\text { renováveis - / não-renováveis) }\end{array}$ & Larga \\
\hline China & 5818 & 2012 & $\begin{array}{l}\text { Huaneng Renewables } \\
\text { Corporation Ltd. }\end{array}$ & $\begin{array}{l}\text { Huaneng Erwenkeqi Huihe } \\
\text { Wind Farm Project }\end{array}$ & SIM & $\begin{array}{l}\text { Produção energética - } \\
\text { geradores eólicos }\end{array}$ & SIM & 1 & $\begin{array}{l}\text { Indústrias energéticas (fontes } \\
\text { renováveis - / não-renováveis) }\end{array}$ & Larga \\
\hline China & 6288 & 2012 & $\begin{array}{l}\text { Huaneng Renewables } \\
\text { Corporation Ltd. }\end{array}$ & $\begin{array}{l}\text { Huaneng Inner Mongolia } \\
\text { Manzhouli Donghu Wind Farm } \\
\text { Project }\end{array}$ & SIM & $\begin{array}{l}\text { Produção energética - } \\
\text { geradores eólicos }\end{array}$ & SIM & 1 & $\begin{array}{l}\text { Indústrias energéticas (fontes } \\
\text { renováveis - / não-renováveis) }\end{array}$ & Larga \\
\hline China & 6451 & 2012 & $\begin{array}{l}\text { Huaneng Renewables } \\
\text { Corporation Ltd. }\end{array}$ & $\begin{array}{l}\text { Huaneng Inner Mongolia } \\
\text { Chenbaerhuqi Daliang Wind } \\
\text { Farm Project }\end{array}$ & SIM & $\begin{array}{l}\text { Produção energética - } \\
\text { geradores eólicos }\end{array}$ & SIM & 1 & $\begin{array}{l}\text { Indústrias energéticas (fontes } \\
\text { renováveis - / não-renováveis) }\end{array}$ & Larga \\
\hline China & 8083 & 2012 & $\begin{array}{l}\text { Huaneng Renewables } \\
\text { Corporation Ltd. }\end{array}$ & $\begin{array}{l}\text { Huaneng Jimo Fengcheng Phase } \\
\text { I Wind Farm Project }\end{array}$ & SIM & $\begin{array}{l}\text { Produção energética - } \\
\text { geradores eólicos }\end{array}$ & SIM & 1 & $\begin{array}{l}\text { Indústrias energéticas (fontes } \\
\text { renováveis - / não-renováveis) }\end{array}$ & Larga \\
\hline China & 8398 & 2012 & $\begin{array}{l}\text { Huaneng Renewables } \\
\text { Corporation Ltd. }\end{array}$ & $\begin{array}{l}\text { Huaneng Guangdong Raoping } \\
\text { Suocheng Wind Farm Project }\end{array}$ & SIM & $\begin{array}{l}\text { Produção energética - } \\
\text { geradores eólicos }\end{array}$ & SIM & 1 & $\begin{array}{l}\text { Indústrias energéticas (fontes } \\
\text { renováveis - / não-renováveis) }\end{array}$ & Larga \\
\hline China & 8691 & 2012 & $\begin{array}{l}\text { Huaneng Renewables } \\
\text { Corporation Ltd. }\end{array}$ & $\begin{array}{l}\text { Huaneng Guangdong Raoping } \\
\text { Dacheng Wind Farm Project }\end{array}$ & SIM & Produção energética - & SIM & 1 & Indústrias energéticas (fontes & Larga \\
\hline
\end{tabular}




\begin{tabular}{|c|c|c|c|c|c|c|c|c|c|c|}
\hline & & & & & & geradores eólicos & & & renováveis - / não-renováveis) & \\
\hline China & 8842 & 2012 & $\begin{array}{l}\text { Huaneng Renewables } \\
\text { Corporation Ltd. }\end{array}$ & $\begin{array}{l}\text { Huaneng Lijin Phase I Wind } \\
\text { Farm Project }\end{array}$ & SIM & $\begin{array}{l}\text { Produção energética - } \\
\text { geradores eólicos }\end{array}$ & SIM & 1 & $\begin{array}{l}\text { Indústrias energéticas (fontes } \\
\text { renováveis - / não-renováveis) }\end{array}$ & Larga \\
\hline China & 6427 & 2012 & $\begin{array}{l}\text { Huaneng Renewables } \\
\text { Corporation Ltd. }\end{array}$ & $\begin{array}{l}\text { Huaneng Tongliao Baolongshan } \\
\text { Phase IV Wind Farm Project }\end{array}$ & SIM & $\begin{array}{l}\text { Produção energética - } \\
\text { geradores eólicos }\end{array}$ & SIM & 1 & $\begin{array}{l}\text { Indústrias energéticas (fontes } \\
\text { renováveis - / não-renováveis) }\end{array}$ & Larga \\
\hline China & 6454 & 2012 & $\begin{array}{l}\text { Huaneng Renewables } \\
\text { Corporation Ltd. }\end{array}$ & $\begin{array}{l}\text { Huaneng Tongliao Kailu Jianhua } \\
\text { Wind Farm Project }\end{array}$ & SIM & $\begin{array}{l}\text { Produção energética - } \\
\text { geradores eólicos }\end{array}$ & SIM & 1 & $\begin{array}{l}\text { Indústrias energéticas (fontes } \\
\text { renováveis - / não-renováveis) }\end{array}$ & Larga \\
\hline China & 6593 & 2012 & $\begin{array}{l}\text { Huaneng Renewables } \\
\text { Corporation Ltd. }\end{array}$ & $\begin{array}{l}\text { Huaneng Tongliao } \\
\text { Kezuozhongqi Dagula Wind } \\
\text { Farm Project }\end{array}$ & SIM & $\begin{array}{l}\text { Produção energética - } \\
\text { geradores eólicos }\end{array}$ & SIM & 1 & $\begin{array}{l}\text { Indústrias energéticas (fontes } \\
\text { renováveis - / não-renováveis) }\end{array}$ & Larga \\
\hline China & 6758 & 2012 & $\begin{array}{l}\text { Huaneng Renewables } \\
\text { Corporation Ltd. }\end{array}$ & $\begin{array}{l}\text { Huaneng Tongliao Nugusitai } \\
\text { Jingguan Wind Farm Project }\end{array}$ & SIM & $\begin{array}{l}\text { Produção energética - } \\
\text { geradores eólicos }\end{array}$ & SIM & 1 & $\begin{array}{l}\text { Indústrias energéticas (fontes } \\
\text { renováveis - / não-renováveis) }\end{array}$ & Larga \\
\hline China & 6759 & 2012 & $\begin{array}{l}\text { Huaneng Renewables } \\
\text { Corporation Ltd. }\end{array}$ & $\begin{array}{l}\text { Huaneng Tongliao Kezuohouqi } \\
\text { Halunhuduga Wind Farm } \\
\text { Project }\end{array}$ & SIM & $\begin{array}{l}\text { Produção energética - } \\
\text { geradores eólicos }\end{array}$ & SIM & 1 & $\begin{array}{l}\text { Indústrias energéticas (fontes } \\
\text { renováveis - / não-renováveis) }\end{array}$ & Larga \\
\hline China & 5789 & 2012 & $\begin{array}{l}\text { Huaneng Renewables } \\
\text { Corporation Ltd. }\end{array}$ & $\begin{array}{l}\text { Huaneng Tuokexun Baiyanghe } \\
\text { Third Stage 49.5MW Wind } \\
\text { Farm }\end{array}$ & SIM & $\begin{array}{l}\text { Produção energética - } \\
\text { geradores eólicos }\end{array}$ & SIM & 1 & $\begin{array}{l}\text { Indústrias energéticas (fontes } \\
\text { renováveis - / não-renováveis) }\end{array}$ & Larga \\
\hline China & 8550 & 2012 & $\begin{array}{l}\text { Huaneng Renewables } \\
\text { Corporation Ltd. }\end{array}$ & $\begin{array}{l}\text { Huaneng Xinjiang Balikun } \\
\text { Santanghu Second Wind Farm } \\
\text { Phase I 49.5MW Project }\end{array}$ & SIM & $\begin{array}{l}\text { Produção energética - } \\
\text { geradores eólicos }\end{array}$ & SIM & 1 & $\begin{array}{l}\text { Indústrias energéticas (fontes } \\
\text { renováveis - / não-renováveis) }\end{array}$ & Larga \\
\hline China & 2521 & 2009 & Huaxin Cement Co., Ltd. & $\begin{array}{l}\text { Wuxue Huaxin Cement 18MW } \\
\text { Waste Heat Recovery as Power } \\
\text { Project }\end{array}$ & SIM & $\begin{array}{l}\text { Produção energética - } \\
\text { utilização de calor na produção } \\
\text { de cimento }\end{array}$ & NÃO & 1 e 4 & $\begin{array}{l}\text { Indústrias energéticas (fontes } \\
\text { renováveis - / não-renováveis) } \\
\text { / Transformação Industrial }\end{array}$ & Larga \\
\hline China & 2907 & 2010 & Huaxin Cement Co., Ltd. & $\begin{array}{l}\text { Chibi Huaxin Cement } 7.5 \mathrm{MW} \\
\text { Waste Heat Recovery as Power } \\
\text { Project }\end{array}$ & SIM & $\begin{array}{l}\text { Produção energética - } \\
\text { utilização de calor na produção } \\
\text { de cimento }\end{array}$ & NÃO & 4 & Transformação industrial & Pequena \\
\hline China & 2522 & 2010 & Huaxin Cement Co., Ltd. & $\begin{array}{l}\text { Yangxin Huaxin Cement } 18 \mathrm{MW} \\
\text { Waste Heat Recovery as Power } \\
\text { Project }\end{array}$ & SIM & $\begin{array}{l}\text { Produção energética - } \\
\text { utilização de calor na produção } \\
\text { de cimento }\end{array}$ & NÃO & 1 e 4 & \begin{tabular}{|l} 
Indústrias energéticas (fontes \\
renováveis - / não-renováveis) \\
/ Transformação Industrial
\end{tabular} & Larga \\
\hline China & 7499 & 2012 & Huayi Electric Co., Ltd. & $\begin{array}{l}\text { Inner Mongolia Huade Sansheng } \\
\text { 49.5 MW Wind Farm Phase I } \\
\text { Project }\end{array}$ & SIM & $\begin{array}{l}\text { Produção energética - } \\
\text { geradores eólicos }\end{array}$ & SIM & 1 & $\begin{array}{l}\text { Indústrias energéticas (fontes } \\
\text { renováveis - / não-renováveis) }\end{array}$ & Larga \\
\hline China & 2781 & 2010 & Hubei Energy Group Co., Ltd. & $\begin{array}{l}\text { Hubei Jiugongshan Wind Farm } \\
\text { CDM Project }\end{array}$ & SIM & $\begin{array}{l}\text { Produção energética - } \\
\text { geradores eólicos }\end{array}$ & SIM & 1 & $\begin{array}{l}\text { Indústrias energéticas (fontes } \\
\text { renováveis - / não-renováveis) }\end{array}$ & Pequena \\
\hline
\end{tabular}




\begin{tabular}{|c|c|c|c|c|c|c|c|c|c|c|}
\hline China & 5204 & 2011 & Hubei Energy Group Co., Ltd. & $\begin{array}{l}\text { Hubei Lichuan Qiyueshan Wind } \\
\text { Power Project }\end{array}$ & SIM & $\begin{array}{l}\text { Produção energética - } \\
\text { geradores eólicos }\end{array}$ & SIM & 1 & $\begin{array}{l}\text { Indústrias energéticas (fontes } \\
\text { renováveis - / não-renováveis) }\end{array}$ & Larga \\
\hline China & 6836 & 2012 & Hubei Energy Group Co., Ltd. & $\begin{array}{l}\text { Hubei Fang County Sanliping } \\
\text { Hydropower Project }\end{array}$ & SIM & Produção energética - águas & SIM & 1 & \begin{tabular}{|l|} 
Indústrias energéticas (fontes \\
renováveis - / não-renováveis)
\end{tabular} & Larga \\
\hline China & 7905 & 2012 & $\begin{array}{l}\text { Hubei Sanxia New Building } \\
\text { Materials Co., Ltd. }\end{array}$ & $\begin{array}{l}\text { Hubei Sanxia New Building } \\
\text { Materials Co., Ltd. 9MW Glass } \\
\text { WHR Power Generation Project }\end{array}$ & SIM & $\begin{array}{l}\text { Produção energética - } \\
\text { utilização de calor na produção } \\
\text { de vidro }\end{array}$ & NÃO & 4 & Transformação industrial & Pequena \\
\hline China & 7233 & 2012 & Hunan Valin Steel Co., Ltd. & $\begin{array}{l}\text { CDQ Waste Heat Recovery } \\
\text { Project of Hunan VALIN } \\
\text { Xiangtan Iron \& Steel Co., Ltd. }\end{array}$ & SIM & $\begin{array}{l}\text { Produção energética - } \\
\text { utilização de calor na produção } \\
\text { de ferro e aço }\end{array}$ & NÃO & 1 e 4 & $\begin{array}{l}\text { Indústrias energéticas (fontes } \\
\text { renováveis - / não-renováveis) } \\
\text { / Transformação Industrial }\end{array}$ & Larga \\
\hline China & 2593 & 2010 & $\begin{array}{l}\text { Inner Mongolia MengDian } \\
\text { HuaNeng Thermal Power Co., } \\
\text { Ltd. }\end{array}$ & $\begin{array}{l}\text { Inner Mongolia Keyouqianqi } \\
\text { Wind Farm Project } \\
\end{array}$ & SIM & $\begin{array}{l}\text { Produção energética - } \\
\text { geradores eólicos }\end{array}$ & SIM & 1 & $\begin{array}{l}\text { Indústrias energéticas (fontes } \\
\text { renováveis - / não-renováveis) }\end{array}$ & Larga \\
\hline China & 4020 & 2011 & $\begin{array}{l}\text { Inner Mongolia MengDian } \\
\text { HuaNeng Thermal Power Co., } \\
\text { Ltd. }\end{array}$ & \begin{tabular}{|l|} 
Inner Mongolia Zhalute Qi \\
Wulijimuren Phase I Wind Farm \\
Project
\end{tabular} & SIM & $\begin{array}{l}\text { Produção energética - } \\
\text { geradores eólicos }\end{array}$ & SIM & 1 & \begin{tabular}{|l|} 
Indústrias energéticas (fontes \\
renováveis - / não-renováveis)
\end{tabular} & Larga \\
\hline China & 8800 & 2012 & $\begin{array}{l}\text { Inner Mongolia MengDian } \\
\text { HuaNeng Thermal Power Co., } \\
\text { Ltd. }\end{array}$ & $\begin{array}{l}\text { Inner Mongolia Baotou Huiquan } \\
\text { Baiyunebo Wind Farm Project }\end{array}$ & SIM & $\begin{array}{l}\text { Produção energética - } \\
\text { geradores eólicos }\end{array}$ & SIM & 1 & $\begin{array}{l}\text { Indústrias energéticas (fontes } \\
\text { renováveis - / não-renováveis) }\end{array}$ & Larga \\
\hline China & 3994 & 2011 & Jilin Yatai (Group) Co., Ltd. & $\begin{array}{l}\text { Waste Heat Recovery and Power } \\
\text { Generation Project in Jilin Yatai } \\
\text { Group Mingcheng Cemennt Co., } \\
\text { Ltd. }\end{array}$ & SIM & $\begin{array}{l}\text { Produção energética - } \\
\text { utilização de calor na produção } \\
\text { de cimento }\end{array}$ & NÃO & 1 e 4 & $\begin{array}{l}\text { Indústrias energéticas (fontes } \\
\text { renováveis - / não-renováveis) } \\
\text { / Transformação Industrial }\end{array}$ & Larga \\
\hline China & 3992 & 2012 & Jilin Yatai (Group) Co., Ltd. & $\begin{array}{l}\text { Shuangyang Waste Heat } \\
\text { Recovery and Power Generation } \\
\text { Project in Jilin Yatai Cement } \\
\text { Co., Ltd. } \\
\end{array}$ & SIM & $\begin{array}{l}\text { Produção energética - } \\
\text { utilização de calor na produção } \\
\text { de cimento }\end{array}$ & NÃO & 1 e 4 & $\begin{array}{l}\text { Indústrias energéticas (fontes } \\
\text { renováveis - / não-renováveis) } \\
\text { / Transformação Industrial }\end{array}$ & Larga \\
\hline China & 1481 & 2008 & $\begin{array}{l}\text { Liuzhou Chemical Industry } \\
\text { Co., Ltd. }\end{array}$ & $\begin{array}{l}\text { Liuzhou Chemical Industry Co., } \\
\text { LTD N2O Abatement Project }\end{array}$ & SIM & $\begin{array}{l}\text { Transformação industrial - } \\
\text { incineraça de fluxos de } \\
\text { resíduos N2O }\end{array}$ & SIM & 5 & Indústrias químicas & Larga \\
\hline China & 1729 & 2008 & $\begin{array}{l}\text { Maanshan Iron \& Steel Co., } \\
\text { Ltd. }\end{array}$ & $\begin{array}{l}\text { Ma Steel (old plant) CDQ and } \\
\text { waste heat utilization project }\end{array}$ & SIM & $\begin{array}{l}\text { Produção energética - gases } \\
\text { industriais }\end{array}$ & NÃO & 1 & $\begin{array}{l}\text { Indústrias energéticas (fontes } \\
\text { renováveis - / não-renováveis) }\end{array}$ & Larga \\
\hline China & 1726 & 2009 & $\begin{array}{l}\text { Maanshan Iron \& Steel Co., } \\
\text { Ltd. }\end{array}$ & $\begin{array}{l}\text { Ma Steel (new plant) CDQ and } \\
\text { waste heat utilization project }\end{array}$ & SIM & $\begin{array}{l}\text { Produção energética - gases } \\
\text { industriais }\end{array}$ & NÃO & 1 & $\begin{array}{l}\text { Indústrias energéticas (fontes } \\
\text { renováveis - / não-renováveis) }\end{array}$ & Larga \\
\hline China & 2469 & 2009 & Nanjing Iron \& Steel Co., Ltd. & $\begin{array}{l}\text { NISCO Converter Gas Recovery } \\
\text { and Utilization for Power } \\
\text { Generation Project }\end{array}$ & SIM & $\begin{array}{l}\text { Produção energética - } \\
\text { utilização de calor na produção } \\
\text { de ferro e aço }\end{array}$ & NÃO & 1 e 4 & \begin{tabular}{|l|} 
Indústrias energéticas (fontes \\
renováveis - / não-renováveis) \\
/ Transformação Industrial
\end{tabular} & Larga \\
\hline China & 1238 & 2007 & PetroChina Company Ltd. & $\begin{array}{l}\mathrm{N} 2 \mathrm{O} \text { decomposition project of } \\
\text { PetroChina Company Limited }\end{array}$ & SIM & $\begin{array}{l}\text { Transformação industrial - } \\
\text { incineração de fluxos de }\end{array}$ & SIM & 5 & Indústrias químicas & Larga \\
\hline
\end{tabular}




\begin{tabular}{|c|c|c|c|c|c|c|c|c|c|c|}
\hline & & & & $\begin{array}{l}\text { Liaoyang Petrochemical } \\
\text { Company }\end{array}$ & & resíduos $\mathrm{N} 2 \mathrm{O}$ & & & & \\
\hline China & 1368 & 2008 & PetroChina Company Ltd. & $\begin{array}{l}\text { Qinghai Ge-ermu Gas Turbine } \\
\text { Power Plant Project }\end{array}$ & SIM & $\begin{array}{l}\text { Produção energética - gases } \\
\text { naturais }\end{array}$ & SIM & 1 & $\begin{array}{l}\text { Indústrias energéticas (fontes } \\
\text { renováveis - / não-renováveis) }\end{array}$ & Larga \\
\hline China & 5361 & 2011 & PetroChina Company Ltd. & $\begin{array}{l}\text { N2O abatement project of Nitric } \\
\text { Acid Plant of PetroChina } \\
\text { Company Limited Liaoyang } \\
\text { Petrochemical Company }\end{array}$ & SIM & $\begin{array}{l}\text { Transformação industrial - } \\
\text { incineração de fluxos de } \\
\text { resíduos N2O }\end{array}$ & SIM & 5 & Indústrias químicas & Larga \\
\hline China & 5362 & 2011 & PetroChina Company Ltd. & $\begin{array}{l}\mathrm{N} 2 \mathrm{O} \text { abatement project of Nylon } \\
\text { Plant of PetroChina Company } \\
\text { Limited Liaoyang Petrochemical } \\
\text { Company }\end{array}$ & SIM & $\begin{array}{l}\text { Transformação industrial - } \\
\text { incineração de fluxos de } \\
\text { resíduos N2O }\end{array}$ & SIM & 5 & Indústrias químicas & Larga \\
\hline China & 2309 & 2009 & $\begin{array}{l}\text { Shaanxi Xinghua Chemistry } \\
\text { Co., Ltd. }\end{array}$ & $\begin{array}{l}\text { Shaanxi Xinghua N2O } \\
\text { Abatement Project }\end{array}$ & SIM & $\begin{array}{l}\text { Transformação industrial - } \\
\text { incineração de fluxos de } \\
\text { resíduos } \mathrm{N} 2 \mathrm{O}\end{array}$ & SIM & 5 & Indústrias químicas & Larga \\
\hline China & 7673 & 2012 & $\begin{array}{l}\text { Shaanxi Xinghua Chemistry } \\
\text { Co., Ltd. }\end{array}$ & $\begin{array}{l}\text { Shaanxi Xinghua Chemistry Co., } \\
\text { Ltd. Nitric Acid Line } 5 \text { Project }\end{array}$ & SIM & $\begin{array}{l}\text { Transformação industrial - } \\
\text { incineração de fluxos de } \\
\text { resíduos N2O }\end{array}$ & SIM & 5 & Indústrias químicas & Larga \\
\hline China & 1711 & 2008 & $\begin{array}{l}\text { Shanxi Taigang Stainless Steel } \\
\text { Co., Ltd. }\end{array}$ & $\begin{array}{l}\text { Shanxi Taigang Stainless Steel } \\
\text { Co., Ltd. Waste Saturated Steam } \\
\text { Recovery and Generation } \\
\text { Project }\end{array}$ & SIM & $\begin{array}{l}\text { Produção energética - } \\
\text { utilização de calor na produção } \\
\text { de ferro e aço }\end{array}$ & NÃO & 1 & $\begin{array}{l}\text { Indústrias energéticas (fontes } \\
\text { renováveis - / não-renováveis) }\end{array}$ & Larga \\
\hline China & 1823 & 2008 & $\begin{array}{l}\text { Shanxi Zhangze Electric } \\
\text { Power Co., Ltd. }\end{array}$ & $\begin{array}{l}\text { Inner Mongolia Bayin'aobao } \\
\text { 49.5MW Wind Farm Project } \\
\text { (Phase I) }\end{array}$ & SIM & $\begin{array}{l}\text { Produção energética - } \\
\text { geradores eólicos }\end{array}$ & SIM & 1 & $\begin{array}{l}\text { Indústrias energéticas (fontes } \\
\text { renováveis - / não-renováveis) }\end{array}$ & Larga \\
\hline China & 2027 & 2008 & $\begin{array}{l}\text { Shanxi Zhangze Electric } \\
\text { Power Co., Ltd. }\end{array}$ & $\begin{array}{l}\text { Inner Mongolia Bayinhanggai } \\
\text { 49.5MW Wind Farm Project }\end{array}$ & SIM & $\begin{array}{l}\text { Produção energética - } \\
\text { geradores eólicos }\end{array}$ & SIM & 1 & $\begin{array}{l}\text { Indústrias energéticas (fontes } \\
\text { renováveis - / não-renováveis) }\end{array}$ & Larga \\
\hline China & 3288 & 2010 & Shenergy Company Ltd. & $\begin{array}{l}\text { Shanghai Waigaoqiao coal-fired } \\
\text { power project using a less GHG } \\
\text { intensive technology }\end{array}$ & SIM & $\begin{array}{l}\text { Produção energética - } \\
\text { eficiência energética na } \\
\text { produção de carvão }\end{array}$ & SIM & 1 & $\begin{array}{l}\text { Indústrias energéticas (fontes } \\
\text { renováveis - / não-renováveis) }\end{array}$ & Larga \\
\hline China & 3477 & 2011 & $\begin{array}{l}\text { Shenzhen Energy Group Co., } \\
\text { Ltd. }\end{array}$ & $\begin{array}{l}\text { Shenzhen Dongbu LNG Power } \\
\text { Generation Project }\end{array}$ & SIM & $\begin{array}{l}\text { Produção energética - gases } \\
\text { naturais }\end{array}$ & SIM & 1 & $\begin{array}{l}\text { Indústrias energéticas (fontes } \\
\text { renováveis - / não-renováveis) }\end{array}$ & Larga \\
\hline China & 5233 & 2011 & $\begin{array}{l}\text { Shenzhen Energy Group Co., } \\
\text { Ltd. }\end{array}$ & $\begin{array}{l}\text { Shenzhen Energy Yihetala No.2 } \\
\text { Wind Farm Project }\end{array}$ & SIM & $\begin{array}{l}\text { Produção energética - } \\
\text { geradores eólicos }\end{array}$ & SIM & 1 & $\begin{array}{l}\text { Indústrias energéticas (fontes } \\
\text { renováveis - / não-renováveis) }\end{array}$ & Larga \\
\hline China & 5736 & 2012 & $\begin{array}{l}\text { Shenzhen Energy Group Co., } \\
\text { Ltd. }\end{array}$ & $\begin{array}{l}\text { Manzhouli Shennengyuan } \\
\text { Windfarm Project }\end{array}$ & SIM & $\begin{array}{l}\text { Produção energética - } \\
\text { geradores eólicos }\end{array}$ & SIM & 1 & $\begin{array}{l}\text { Indústrias energéticas (fontes } \\
\text { renováveis - / não-renováveis) }\end{array}$ & Larga \\
\hline
\end{tabular}




\begin{tabular}{|c|c|c|c|c|c|c|c|c|c|c|}
\hline China & 1781 & 2008 & Sichuan Chemical Co., Ltd. & $\begin{array}{l}\text { Chuanhua N2O Abatement } \\
\text { Project }\end{array}$ & SIM & $\begin{array}{l}\text { Transformação industrial - } \\
\text { incineração de fluxos de } \\
\text { resíduos N2O }\end{array}$ & SIM & 5 & Indústrias químicas & Larga \\
\hline China & 2321 & 2009 & Sichuan Lutianhua Co., Ltd. & $\begin{array}{l}\text { Sichuan Lutianhua } \mathrm{N} 2 \mathrm{O} \\
\text { Abatement Project at nitric acid } \\
\text { plant Line } 2\end{array}$ & SIM & $\begin{array}{l}\text { Transformação industrial - } \\
\text { incineração de fluxos de } \\
\text { resíduos } \mathrm{N} 2 \mathrm{O}\end{array}$ & SIM & 5 & Indústrias químicas & Larga \\
\hline China & 2323 & 2009 & Sichuan Lutianhua Co., Ltd. & $\begin{array}{l}\text { Sichuan Lutianhua } \mathrm{N} 2 \mathrm{O} \\
\text { Abatement Project at nitric acid } \\
\text { plant Line } 1\end{array}$ & SIM & $\begin{array}{l}\text { Transformação industrial - } \\
\text { incineração de fluxos de } \\
\text { resíduos N2O }\end{array}$ & SIM & 5 & Indústrias químicas & Larga \\
\hline China & 2071 & 2009 & $\begin{array}{l}\text { Sichuan Minjiang Hydropower } \\
\text { Co., Ltd. }\end{array}$ & $\begin{array}{l}\text { Sichuan provincial Longchi \& } \\
\text { Caoyuan } 9 \text { MW Small-scale } \\
\text { Hydro Power Bundle Project }\end{array}$ & SIM & Produção energética - águas & SIM & 1 & \begin{tabular}{|l|} 
Indústrias energéticas (fontes \\
renováveis - / não-renováveis)
\end{tabular} & Pequena \\
\hline China & 3058 & 2010 & Sinohydro Group Ltd. & $\begin{array}{l}\text { Yunnan Dali Zhemoshan Wind } \\
\text { Power Project }\end{array}$ & SIM & $\begin{array}{l}\text { Produção energética - } \\
\text { geradores eólicos }\end{array}$ & SIM & 1 & $\begin{array}{l}\text { Indústrias energéticas (fontes } \\
\text { renováveis - / não-renováveis) }\end{array}$ & Larga \\
\hline China & 3917 & 2010 & Sinohydro Group Ltd. & $\begin{array}{l}\text { Jilin Changling Wind Farm } \\
\text { Phase II Project }\end{array}$ & SIM & $\begin{array}{l}\text { Produção energética - } \\
\text { geradores eólicos }\end{array}$ & SIM & 1 & \begin{tabular}{|l|} 
Indústrias energéticas (fontes \\
renováveis - / não-renováveis)
\end{tabular} & Larga \\
\hline China & 4849 & 2011 & Sinohydro Group Ltd. & $\begin{array}{l}\text { Yunnan Dali Zhemoshan Wind } \\
\text { Farm Phase II Project }\end{array}$ & SIM & $\begin{array}{l}\begin{array}{l}\text { Produção energética - } \\
\text { geradores eólicos }\end{array} \\
\end{array}$ & SIM & 1 & \begin{tabular}{|l|} 
Indústrias energéticas (fontes \\
renováveis - / não-renováveis)
\end{tabular} & Pequena \\
\hline China & 3306 & 2011 & Sinohydro Group Ltd. & $\begin{array}{l}\text { Gansu Guazhou Ganhekou } \\
\text { Fourth Wind Farm Power } \\
\text { Generation Project }\end{array}$ & SIM & $\begin{array}{l}\text { Produção energética - } \\
\text { geradores eólicos }\end{array}$ & SIM & 1 & $\begin{array}{l}\text { Indústrias energéticas (fontes } \\
\text { renováveis - / não-renováveis) }\end{array}$ & Larga \\
\hline China & 2701 & 2009 & $\begin{array}{l}\text { Tangshan Jidong Cement Co., } \\
\text { Ltd. }\end{array}$ & $\begin{array}{l}\text { Tangshan Jidong Cement Guye } \\
\text { District 12MW Cement Waste } \\
\text { Heat Recovery Project }\end{array}$ & SIM & $\begin{array}{l}\text { Produção energética - } \\
\text { utilização de calor na produção } \\
\text { de cimento }\end{array}$ & NÃO & 1 e 4 & \begin{tabular}{|l|} 
Indústrias energéticas (fontes \\
renováveis - / não-renováveis) \\
/ Transformação Industrial
\end{tabular} & Larga \\
\hline China & 1695 & 2009 & $\begin{array}{l}\text { Wuhan Iron and Steel Co., } \\
\text { Ltd. }\end{array}$ & $\begin{array}{l}\text { Coke Dry Quenching (CDQ) } \\
\text { Waste Heat Recovery for Power } \\
\text { Generation Project of Wugang } \\
\text { No. } 9 \text { and } 10 \text { Coke Ovens } \\
\end{array}$ & SIM & $\begin{array}{l}\text { Produção energética - gases } \\
\text { industriais }\end{array}$ & NÃO & 1 & $\begin{array}{l}\text { Indústrias energéticas (fontes } \\
\text { renováveis - / não-renováveis) }\end{array}$ & Larga \\
\hline China & 3166 & 2010 & $\begin{array}{l}\text { Wuhan Iron and Steel Co., } \\
\text { Ltd. }\end{array}$ & $\begin{array}{l}\text { Wugang Gas-Steam Combined } \\
\text { Cycle Power Plant (CCPP) } \\
\text { Project }\end{array}$ & SIM & $\begin{array}{l}\text { Produção energética - } \\
\text { utilização de calor na produção } \\
\text { de ferro e aço }\end{array}$ & NÃO & $1 \mathrm{e} 4$ & $\begin{array}{l}\text { Indústrias energéticas (fontes } \\
\text { renováveis - / não-renováveis) } \\
\text { / Transformação Industrial }\end{array}$ & Larga \\
\hline China & 3328 & 2010 & $\begin{array}{l}\text { Wuhan Iron and Steel Co., } \\
\text { Ltd. }\end{array}$ & $\begin{array}{l}\text { Wugang Waste Gas Recovery } \\
\text { and Power Generation Project }\end{array}$ & SIM & $\begin{array}{l}\text { Produção energética - } \\
\text { utilização de calor na produção } \\
\text { de ferro e aço }\end{array}$ & NÃO & 1 e 4 & \begin{tabular}{|l} 
Indústrias energéticas (fontes \\
renováveis - / não-renováveis) \\
/ Transformação Industrial
\end{tabular} & Larga \\
\hline China & 6774 & 2012 & $\begin{array}{l}\text { Wuhan Iron and Steel Co., } \\
\text { Ltd. }\end{array}$ & $\begin{array}{l}\text { WISCO 1234\# Coke Dry } \\
\text { Quenching (CDQ) Waste Heat } \\
\text { Recovery for Cogeneration } \\
\text { Project in Hubei Province }\end{array}$ & SIM & $\begin{array}{l}\text { Produção energética - gases } \\
\text { industriais }\end{array}$ & NÃO & $1 \mathrm{e} 4$ & $\begin{array}{l}\text { Indústrias energéticas (fontes } \\
\text { renováveis - / não-renováveis) } \\
\text { / Transformação Industrial }\end{array}$ & Larga \\
\hline
\end{tabular}




\begin{tabular}{|c|c|c|c|c|c|c|c|c|c|c|}
\hline China & 3044 & 2010 & $\begin{array}{l}\text { Wuhan Kaidi Electric Power } \\
\text { Co., Ltd. }\end{array}$ & $\begin{array}{l}\text { Jianli Kaidi Biomass Power } \\
\text { Project }\end{array}$ & SIM & $\begin{array}{l}\text { Produção energética - casca de } \\
\text { arroz }\end{array}$ & SIM & 1 & $\begin{array}{l}\text { Indústrias energéticas (fontes } \\
\text { renováveis - / não-renováveis) }\end{array}$ & Larga \\
\hline China & 3055 & 2010 & $\begin{array}{l}\text { Wuhan Kaidi Electric Power } \\
\text { Co., Ltd. }\end{array}$ & $\begin{array}{l}\text { Jingshan Kaidi Biomass Power } \\
\text { Project }\end{array}$ & SIM & $\begin{array}{l}\text { Produção energética - casca de } \\
\text { arroz }\end{array}$ & SIM & 1 & $\begin{array}{l}\text { Indústrias energéticas (fontes } \\
\text { renováveis - / não-renováveis) }\end{array}$ & Larga \\
\hline China & 3072 & 2010 & $\begin{array}{l}\text { Wuhan Kaidi Electric Power } \\
\text { Co., Ltd. }\end{array}$ & $\begin{array}{l}\text { Hunan Yiyang Kaidi Biomass } \\
\text { Power Project }\end{array}$ & SIM & $\begin{array}{l}\text { Produção energética - casca de } \\
\text { arroz }\end{array}$ & SIM & 1 & $\begin{array}{l}\text { Indústrias energéticas (fontes } \\
\text { renováveis - / não-renováveis) }\end{array}$ & Larga \\
\hline China & 3065 & 2010 & $\begin{array}{l}\text { Wuhan Kaidi Electric Power } \\
\text { Co., Ltd. }\end{array}$ & $\begin{array}{l}\text { Hunan Yueyang Kaidi Biomass } \\
\text { Power Project }\end{array}$ & SIM & $\begin{array}{l}\text { Produção energética - outros } \\
\text { resíduos agrícolas }\end{array}$ & SIM & 1 & $\begin{array}{l}\text { Indústrias energéticas (fontes } \\
\text { renováveis - / não-renováveis) }\end{array}$ & Larga \\
\hline China & 4069 & 2011 & $\begin{array}{l}\text { Wuhan Kaidi Electric Power } \\
\text { Co., Ltd. }\end{array}$ & $\begin{array}{l}\text { Fujian Kaisheng Biomass } \\
\text { Residues-fired Cogeneration } \\
\text { Project }\end{array}$ & SIM & $\begin{array}{l}\text { Produção energética - restos de } \\
\text { aves }\end{array}$ & SIM & 1 & $\begin{array}{l}\text { Indústrias energéticas (fontes } \\
\text { renováveis - / não-renováveis) }\end{array}$ & Larga \\
\hline China & 3056 & 2011 & $\begin{array}{l}\text { Wuhan Kaidi Electric Power } \\
\text { Co., Ltd. }\end{array}$ & $\begin{array}{l}\text { Poyang Kaidi Biomass Power } \\
\text { Project }\end{array}$ & SIM & $\begin{array}{l}\text { Produção energética - casca de } \\
\text { arroz }\end{array}$ & SIM & 1 & $\begin{array}{l}\text { Indústrias energéticas (fontes } \\
\text { renováveis - / não-renováveis) }\end{array}$ & Larga \\
\hline China & 3057 & 2011 & $\begin{array}{l}\text { Wuhan Kaidi Electric Power } \\
\text { Co., Ltd. }\end{array}$ & $\begin{array}{l}\text { Qichun Kaidi Biomass Power } \\
\text { Project }\end{array}$ & SIM & $\begin{array}{l}\text { Produção energética - outros } \\
\text { resíduos agrícolas }\end{array}$ & SIM & 1 & $\begin{array}{l}\text { Indústrias energéticas (fontes } \\
\text { renováveis - / não-renováveis) }\end{array}$ & Larga \\
\hline China & 3066 & 2011 & $\begin{array}{l}\text { Wuhan Kaidi Electric Power } \\
\text { Co., Ltd. }\end{array}$ & $\begin{array}{l}\text { Hunan Qidong Kaidi Biomass } \\
\text { Power Project }\end{array}$ & SIM & $\begin{array}{l}\text { Produção energética - casca de } \\
\text { arroz }\end{array}$ & SIM & 1 & $\begin{array}{l}\text { Indústrias energéticas (fontes } \\
\text { renováveis - / não-renováveis) }\end{array}$ & Larga \\
\hline China & 3068 & 2011 & $\begin{array}{l}\text { Wuhan Kaidi Electric Power } \\
\text { Co., Ltd. }\end{array}$ & $\begin{array}{l}\text { Suqian Kaidi Biomass Co- } \\
\text { generation Project }\end{array}$ & SIM & $\begin{array}{l}\text { Produção energética - casca de } \\
\text { arroz }\end{array}$ & SIM & 1 & $\begin{array}{l}\text { Indústrias energéticas (fontes } \\
\text { renováveis - / não-renováveis) }\end{array}$ & Larga \\
\hline China & 3061 & 2011 & $\begin{array}{l}\text { Wuhan Kaidi Electric Power } \\
\text { Co., Ltd. }\end{array}$ & $\begin{array}{l}\text { Tongcheng Kaidi Biomass } \\
\text { Power Project }\end{array}$ & SIM & $\begin{array}{l}\text { Produção energética - casca de } \\
\text { arroz }\end{array}$ & SIM & 1 & $\begin{array}{l}\text { Indústrias energéticas (fontes } \\
\text { renováveis - / não-renováveis) }\end{array}$ & Larga \\
\hline China & 3069 & 2011 & $\begin{array}{l}\text { Wuhan Kaidi Electric Power } \\
\text { Co., Ltd. }\end{array}$ & $\begin{array}{l}\text { Wangjiang Kaidi Biomass } \\
\text { Power Project }\end{array}$ & SIM & $\begin{array}{l}\text { Produção energética - casca de } \\
\text { arroz }\end{array}$ & SIM & 1 & $\begin{array}{l}\text { Indústrias energéticas (fontes } \\
\text { renováveis - / não-renováveis) }\end{array}$ & Larga \\
\hline China & 3071 & 2011 & $\begin{array}{l}\text { Wuhan Kaidi Electric Power } \\
\text { Co., Ltd. }\end{array}$ & $\begin{array}{l}\text { Wanzai Kaidi Biomass Power } \\
\text { Project }\end{array}$ & SIM & $\begin{array}{l}\text { Produção energética - casca de } \\
\text { arroz }\end{array}$ & SIM & 1 & $\begin{array}{l}\text { Indústrias energéticas (fontes } \\
\text { renováveis - / não-renováveis) }\end{array}$ & Larga \\
\hline China & 3064 & 2011 & $\begin{array}{l}\text { Wuhan Kaidi Electric Power } \\
\text { Co., Ltd. }\end{array}$ & $\begin{array}{l}\text { Wuhe Kaidi Biomass Power } \\
\text { Project }\end{array}$ & SIM & $\begin{array}{l}\text { Produção energética - casca de } \\
\text { arroz }\end{array}$ & SIM & 1 & $\begin{array}{l}\text { Indústrias energéticas (fontes } \\
\text { renováveis - / não-renováveis) }\end{array}$ & Larga \\
\hline China & 7869 & 2012 & $\begin{array}{l}\text { Wuhan Kaidi Electric Power } \\
\text { Co., Ltd. }\end{array}$ & $\begin{array}{l}\text { Dunhuang 9MW solar power } \\
\text { project }\end{array}$ & SIM & $\begin{array}{l}\text { Produção energética - } \\
\text { geradores solares }\end{array}$ & SIM & 1 & $\begin{array}{l}\text { Indústrias energéticas (fontes } \\
\text { renováveis - / não-renováveis) }\end{array}$ & Pequena \\
\hline China & 8327 & 2012 & $\begin{array}{l}\text { Wuhan Kaidi Electric Power } \\
\text { Co., Ltd. }\end{array}$ & $\begin{array}{l}\text { CGN Dunhuang Phase II 9MW } \\
\text { Grid-connected PV Power }\end{array}$ & SIM & Produção energética - & SIM & 1 & Indústrias energéticas (fontes & Larga \\
\hline
\end{tabular}




\begin{tabular}{|c|c|c|c|c|c|c|c|c|c|c|}
\hline & & & & Generation Project & & geradores solares & & & renováveis - / não-renováveis) & \\
\hline China & 3282 & 2010 & $\begin{array}{l}\text { Xinjiang Goldwind Science \& } \\
\text { Technology Co., Ltd. }\end{array}$ & $\begin{array}{l}\text { Inner Mongolia Shangdu } \\
\text { Jiqingliang 49.5MW Wind } \\
\text { Power Project }\end{array}$ & SIM & $\begin{array}{l}\text { Produção energética - } \\
\text { geradores eólicos }\end{array}$ & SIM & 1 & $\begin{array}{l}\text { Indústrias energéticas (fontes } \\
\text { renováveis - / não-renováveis) }\end{array}$ & Larga \\
\hline China & 4369 & 2011 & $\begin{array}{l}\text { Xinjiang Goldwind Science \& } \\
\text { Technology Co., Ltd. }\end{array}$ & $\begin{array}{l}\text { Xinjiang Buerjin Tianrun } \\
\text { Windpower Co., Ltd. Wind } \\
\text { Farm 1st Stage Project }\end{array}$ & SIM & $\begin{array}{l}\text { Produção energética - } \\
\text { geradores eólicos }\end{array}$ & SIM & 1 & $\begin{array}{l}\text { Indústrias energéticas (fontes } \\
\text { renováveis - / não-renováveis) }\end{array}$ & Larga \\
\hline China & 2374 & 2009 & $\begin{array}{l}\text { Xinjiang Urban Construction } \\
\text { Group. Co., Ltd. }\end{array}$ & $\begin{array}{l}\text { Municipal Solid Waste (MSW) } \\
\text { Composting Project in Urumqi, } \\
\text { China }\end{array}$ & SIM & $\begin{array}{l}\text { Produção energétia - dejetos } \\
\text { bovinos }\end{array}$ & SIM & 1 e 13 & $\begin{array}{l}\text { Indústrias energéticas (fontes } \\
\text { renováveis - / não-renováveis) } \\
\text { / Tratamento e eliminação de } \\
\text { resíduos }\end{array}$ & Larga \\
\hline China & 5358 & 2011 & $\begin{array}{l}\text { Xishan Xishan Coal and } \\
\text { Electricity Power Co., Ltd. }\end{array}$ & $\begin{array}{l}\text { Duerping Middle Station } \\
\text { Ventilation Air Methane } \\
\text { Destruction Project }\end{array}$ & SIM & $\begin{array}{l}\text { Produção mineral - eficiência } \\
\text { nas emissões fugicidas } \\
\text { (metano) }\end{array}$ & NÃO & 8 e 10 & $\begin{array}{l}\text { Mineração/Produção mineral } \\
\text { / Emissões fugitivas de } \\
\text { combustíveis (sólidos, } \\
\text { petróleo e gás) }\end{array}$ & Larga \\
\hline China & 892 & 2007 & $\begin{array}{l}\text { Yangquan Coal Industry } \\
\text { (Group) Co., Ltd. }\end{array}$ & $\begin{array}{l}\text { Yangquan Coal Mine Methane } \\
\text { (CMM) Utilization for Power } \\
\text { Generation Project, Shanxi } \\
\text { Province, China }\end{array}$ & SIM & $\begin{array}{l}\text { Produção mineral - eficiência } \\
\text { nas emissões fugicidas } \\
\text { (metano) }\end{array}$ & SIM & 8 e 10 & $\begin{array}{l}\text { Mineração/Produção mineral } \\
\text { / Emissões fugitivas de } \\
\text { combustíveis (sólidos, } \\
\text { petróleo e gás) }\end{array}$ & Larga \\
\hline China & 902 & 2007 & $\begin{array}{l}\text { Yangquan Coal Industry } \\
\text { (Group) Co., Ltd. }\end{array}$ & $\begin{array}{l}\text { Yangquan Coal Mine Methane } \\
\text { Advanced Industrial Furnace } \\
\text { Utilisation Project }\end{array}$ & SIM & $\begin{array}{l}\text { Produção mineral - eficiência } \\
\text { nas emissões fugicidas } \\
\text { (metano) }\end{array}$ & SIM & 8 e 10 & $\begin{array}{l}\text { Mineração/Produção mineral } \\
\text { / Emissões fugitivas de } \\
\text { combustíveis (sólidos, } \\
\text { petróleo e gás) }\end{array}$ & Larga \\
\hline China & 1630 & 2008 & Yunnan Yuntianhua Co., Ltd. & $\begin{array}{l}\text { Yuntianhua Shuifu N2O } \\
\text { Abatement Project }\end{array}$ & SIM & $\begin{array}{l}\text { Transformação industrial - } \\
\text { incineração de fluxos de } \\
\text { resíduos N2O }\end{array}$ & SIM & 5 & Indústrias químicas & Larga \\
\hline China & 4662 & 2011 & Yunnan Yuntianhua Co., Ltd. & $\begin{array}{l}\text { Yuntianhua Furui Waste Heat } \\
\text { Recovery and Utilization Project }\end{array}$ & SIM & $\begin{array}{l}\text { Produção energética - } \\
\text { utilização de aquecimento } \\
\text { químico }\end{array}$ & NÃO & $1 \mathrm{e} 4$ & \begin{tabular}{|l} 
Indústrias energéticas (fontes \\
renováveis - / não-renováveis) \\
/ Transformação Industrial
\end{tabular} & Larga \\
\hline China & 5768 & 2012 & Zhejiang Guangsha Co., Ltd. & $\begin{array}{l}\text { Baiyang Hydropower Project in } \\
\text { Songpan, Sichuan }\end{array}$ & SIM & Produção energética - águas & SIM & 1 & $\begin{array}{l}\text { Indústrias energéticas (fontes } \\
\text { renováveis - / não-renováveis) }\end{array}$ & Larga \\
\hline China & 7868 & 2012 & Zhejiang Guangsha Co., Ltd. & $\begin{array}{l}\text { Sichuan Beichuan Kaiping } \\
\text { Hydropower Project }\end{array}$ & SIM & Produção energética - águas & SIM & 1 & \begin{tabular}{|l|} 
Indústrias energéticas (fontes \\
renováveis - / não-renováveis)
\end{tabular} & Larga \\
\hline China & 8333 & 2012 & Zhejiang Guangsha Co., Ltd. & $\begin{array}{l}\text { Sichuan Beichuan Gansongba } \\
\text { Hydropower Project }\end{array}$ & SIM & Produção energética - águas & SIM & 1 & $\begin{array}{l}\text { Indústrias energéticas (fontes } \\
\text { renováveis - / não-renováveis) }\end{array}$ & Larga \\
\hline China & 5042 & 2011 & $\begin{array}{l}\text { Zhejiang Jingxing Paper Joint } \\
\text { Stock Co., Ltd. }\end{array}$ & $\begin{array}{l}\text { Biogas Utilization Project in } \\
\text { Zhejiang Jingxing Paper Joint }\end{array}$ & SIM & Produção energética - & NÃO & 1 e 13 & $\begin{array}{l}\text { Indústrias energéticas (fontes } \\
\text { renováveis - / não-renováveis) }\end{array}$ & Pequena \\
\hline
\end{tabular}




\begin{tabular}{|c|c|c|c|c|c|c|c|c|c|c|}
\hline & & & & Stock Co. Ltd. & & tratamento de águas industriais & & & $\begin{array}{l}\text { / Tratamento e eliminação de } \\
\text { resíduos }\end{array}$ & \\
\hline China & 193 & 2006 & Zhejiang Juhua Co., Ltd. & $\begin{array}{l}\text { HFC23 Decomposition Project } \\
\text { of Zhejiang Juhua Co., Ltd, P. R. } \\
\text { China }\end{array}$ & SIM & $\begin{array}{l}\text { Transformação industrial - } \\
\text { incineração de fluxos de } \\
\text { resíduos HFC } 23\end{array}$ & SIM & 11 & $\begin{array}{l}\text { Emissões fugitivas da } \\
\text { produção e consumo de } \\
\text { hidrocarbonetos halogenados } \\
\text { e hexafluoreto de enxofre }\end{array}$ & Larga \\
\hline China & 868 & 2007 & Zhejiang Juhua Co., Ltd. & $\begin{array}{l}\text { No.2 HFC-23 Decomposition } \\
\text { Project of Zhejiang Juhua Co., } \\
\text { Ltd, P. R. China }\end{array}$ & SIM & $\begin{array}{l}\text { Transformação industrial - } \\
\text { incineração de fluxos de } \\
\text { resíduos HFC } 23\end{array}$ & SIM & 11 & $\begin{array}{l}\text { Emissões fugitivas da } \\
\text { produção e consumo de } \\
\text { hidrocarbonetos halogenados } \\
\text { e hexafluoreto de enxofre }\end{array}$ & Larga \\
\hline China & 1343 & 2008 & $\begin{array}{l}\text { Zhejiang Southeast Electric } \\
\text { Power Co., Ltd. }\end{array}$ & $\begin{array}{l}\text { Xiaoshan Power Plant's NG } \\
\text { Power Generation Project of } \\
\text { Zhejiang Southeast Electric } \\
\text { Power Co., Ltd. }\end{array}$ & SIM & $\begin{array}{l}\text { Produção energética - gases } \\
\text { naturais }\end{array}$ & SIM & 1 & $\begin{array}{l}\text { Indústrias energéticas (fontes } \\
\text { renováveis - / não-renováveis) }\end{array}$ & Larga \\
\hline China & 1603 & 2008 & $\begin{array}{l}\text { Zhengzhou Coal Industry \& } \\
\text { Electric Power Co., Ltd. }\end{array}$ & $\begin{array}{l}\text { Zhengzhou Coal Industry } \\
\text { (Group) Co., Ltd. Coalmine } \\
\text { Methane Utilization Project }\end{array}$ & SIM & $\begin{array}{l}\text { Produção mineral - eficiência } \\
\text { nas emissões fugicidas } \\
\text { (metano) }\end{array}$ & NÃO & 8,1 e 10 & $\begin{array}{l}\text { Mineração/Produção mineral } \\
\text { / Indústrias energéticas } \\
\text { (fontes renováveis - / não- } \\
\text { renováveis) / Emissões } \\
\text { fugitivas de combustíveis } \\
\text { (sólidos, petróleo e gás) }\end{array}$ & Larga \\
\hline China & 4903 & 2012 & Zijin Mining Group Co., Ltd. & $\begin{array}{l}\text { Fujian Shanghang Jiantou } 9.8 \\
\text { MW hydropower Station Project }\end{array}$ & SIM & Produção energética - águas & SIM & 1 & $\begin{array}{l}\text { Indústrias energéticas (fontes } \\
\text { renováveis - / não-renováveis) }\end{array}$ & Pequena \\
\hline
\end{tabular}

Fonte: Dados da pesquisa (2015). 
APÊNDICE C - Amostra de Empresas com Projetos de MDLs - Índia

\begin{tabular}{|c|c|c|c|c|c|c|c|c|c|c|}
\hline $\begin{array}{c}\text { País } \\
\text { hospedeiro }\end{array}$ & $\begin{array}{l}\text { Referência } \\
\text { UNFCCC }\end{array}$ & $\begin{array}{l}\text { Ano de } \\
\text { registro }\end{array}$ & \begin{tabular}{|l|}
$\begin{array}{l}\text { Participante autorizado } \\
\text { (empresa indiana) }\end{array}$ \\
\end{tabular} & Nome do projeto - UNFCCC & $\begin{array}{c}\text { Pais(es) } \\
\text { investidor(es) }\end{array}$ & \begin{tabular}{|l|} 
Tipo de \\
empreendimento
\end{tabular} & \begin{tabular}{|l|}
$\begin{array}{l}\text { Renovável } \\
\text { ou não }\end{array}$ \\
\end{tabular} & $\begin{array}{l}\text { Escopo } \\
\text { setorial }\end{array}$ & Escopo setorial (descrição) & $\begin{array}{c}\text { Escala } \\
(\mathrm{P} / \mathrm{L})\end{array}$ \\
\hline Índia & 5728 & 2012 & $\begin{array}{l}\text { A2Z Maintenance \& } \\
\text { Engineering Services Limited }\end{array}$ & \begin{tabular}{|l|} 
Biomass based Cogeneration \\
unit at Co-operative Sugar mills \\
in Morinda, Punjab, India \\
\end{tabular} & NÃO & Produção energética - bagaço & NÃO & 1 & $\begin{array}{l}\text { Indústrias energéticas (fontes } \\
\text { renováveis - / não-renováveis) }\end{array}$ & Pequena \\
\hline Índia & 5980 & 2012 & $\begin{array}{l}\text { A2Z Maintenance \& } \\
\text { Engineering Services Limited }\end{array}$ & $\begin{array}{l}\text { Biomass based Cogeneration } \\
\text { unit at Co-operative Sugar mills } \\
\text { in Nakodar, Punjab, India }\end{array}$ & NÃO & Produção energética - bagaço & NÃO & 1 & $\begin{array}{l}\text { Indústrias energéticas (fontes } \\
\text { renováveis - / não-renováveis) }\end{array}$ & Pequena \\
\hline Índia & 6072 & 2012 & $\begin{array}{l}\text { A2Z Maintenance \& } \\
\text { Engineering Services Limited }\end{array}$ & $\begin{array}{l}\text { Biomass based Cogeneration } \\
\text { unit at Co-operative Sugar mills } \\
\text { in Fazilka, Punjab, India }\end{array}$ & NÃO & Produção energética - bagaço & NÃO & 1 & $\begin{array}{l}\text { Indústrias energéticas (fontes } \\
\text { renováveis - / não-renováveis) }\end{array}$ & Pequena \\
\hline Índia & 2679 & 2009 & ACC Limited & $\begin{array}{l}9 \mathrm{MW} \text { Wind Power Project in } \\
\text { Tamil Nadu by ACC Limited }\end{array}$ & SIM & $\begin{array}{l}\text { Produção energética - } \\
\text { geradores eólicos }\end{array}$ & NÃO & 1 & $\begin{array}{l}\text { Indústrias energéticas (fontes } \\
\text { renováveis - / não-renováveis) }\end{array}$ & Pequena \\
\hline Índia & 6700 & 2012 & ACC Limited & $\begin{array}{l}\text { 7.5 MW Wind Project by ACC } \\
\text { Limited in Rajasthan }\end{array}$ & NÃO & $\begin{array}{l}\text { Produção energética - } \\
\text { geradores eólicos }\end{array}$ & NÃO & 1 & $\begin{array}{l}\text { Indústrias energéticas (fontes } \\
\text { renováveis - / não-renováveis) }\end{array}$ & Pequena \\
\hline Índia & 5928 & 2012 & Adani Enterprises Limited & $\begin{array}{l}\text { Adani Enterprises Limited Solar } \\
\text { PV Power Project in Gujarat, } \\
\text { India }\end{array}$ & NÃO & $\begin{array}{l}\text { Produção energética - } \\
\text { geradores solares }\end{array}$ & SIM & 1 & $\begin{array}{l}\text { Indústrias energéticas (fontes } \\
\text { renováveis - / não-renováveis) }\end{array}$ & Larga \\
\hline Índia & 2716 & 2009 & Adani Power Limited & $\begin{array}{l}\text { Grid connected energy efficient } \\
\text { power generation }\end{array}$ & SIM & $\begin{array}{l}\text { Transformação industrial - } \\
\text { substituição de combustíveis } \\
\text { fósseis }\end{array}$ & NÃO & 1 & $\begin{array}{l}\text { Indústrias energéticas (fontes } \\
\text { renováveis - / não-renováveis) }\end{array}$ & Larga \\
\hline Índia & 3225 & 2010 & Adani Power Limited & $\begin{array}{l}\text { Energy efficient power } \\
\text { generation in Tirora, India }\end{array}$ & NÃO & $\begin{array}{l}\text { Transformação industrial - } \\
\text { substituição de combustíveis } \\
\text { fósseis }\end{array}$ & NÃO & 1 & $\begin{array}{l}\text { Indústrias energéticas (fontes } \\
\text { renováveis - / não-renováveis) }\end{array}$ & Larga \\
\hline Índia & 1456 & 2008 & Alembic Limited & $\begin{array}{l}5 \mathrm{MW} \text { Wind Power Project of } \\
\text { Alembic Ltd at Bhavnagar, } \\
\text { Gujarat, India }\end{array}$ & SIM & $\begin{array}{l}\text { Produção energética - } \\
\text { geradores eólicos }\end{array}$ & NÃO & 1 & $\begin{array}{l}\text { Indústrias energéticas (fontes } \\
\text { renováveis - / não-renováveis) }\end{array}$ & Pequena \\
\hline Índia & 1047 & 2007 & $\begin{array}{l}\text { Amarjothi Spinning Mills } \\
\text { Limited }\end{array}$ & $\begin{array}{l}\text { 11.2 MW Wind Power project in } \\
\text { Tamilnadu, by Amarjothi Group }\end{array}$ & SIM & $\begin{array}{l}\text { Produção energética - } \\
\text { geradores eólicos }\end{array}$ & SIM & 1 & $\begin{array}{l}\text { Indústrias energéticas (fontes } \\
\text { renováveis - / não-renováveis) }\end{array}$ & Pequena \\
\hline Índia & 9410 & 2012 & $\begin{array}{l}\text { Amarjothi Spinning Mills } \\
\text { Limited }\end{array}$ & $\begin{array}{l}\text { 4.25 MW Wind Power Project in } \\
\text { Tamilnadu by Amarjothi } \\
\text { Spinning Mills Ltd }\end{array}$ & NÃO & $\begin{array}{l}\text { Produção energética - } \\
\text { geradores eólicos }\end{array}$ & SIM & 1 & $\begin{array}{l}\text { Indústrias energéticas (fontes } \\
\text { renováveis - / não-renováveis) }\end{array}$ & Pequena \\
\hline Índia & 109 & 2005 & Ambuja Cements Limited & \begin{tabular}{|l|}
24 MW Biomass Based \\
Renewable Electricity \\
Generation \& Consumption in \\
Ropar, Punjab, India \\
\end{tabular} & SIM & $\begin{array}{l}\text { Produção energética - casca } \\
\text { de arroz }\end{array}$ & NÃO & 1 & $\begin{array}{l}\text { Indústrias energéticas (fontes } \\
\text { renováveis - / não-renováveis) }\end{array}$ & Larga \\
\hline Índia & 932 & 2007 & $\begin{array}{l}\text { Andhra Pradesh Paper Mills } \\
\text { Limited }\end{array}$ & $\begin{array}{l}\text { Energy Efficiency Measures At } \\
\text { Paper Production Plant }\end{array}$ & SIM & $\begin{array}{l}\text { Produção energética - papel e } \\
\text { celulose }\end{array}$ & NÃO & 4 & Transformação industrial & Pequena \\
\hline
\end{tabular}




\begin{tabular}{|c|c|c|c|c|c|c|c|c|c|c|}
\hline Índia & 1403 & 2008 & $\begin{array}{l}\text { Andhra Pradesh Paper Mills } \\
\text { Limited }\end{array}$ & $\begin{array}{l}\text { Steam Optimization in Cooking } \\
\text { Process in Paper Plant }\end{array}$ & NÃO & $\begin{array}{l}\text { Produção energética - papel e } \\
\text { celulose }\end{array}$ & NÃO & 3 & Demanda energética & Larga \\
\hline Índia & 112 & 2011 & Anik Industries Limited & $\begin{array}{l}\text { Nagda Hills Wind Energy } \\
\text { Project (India) - Crediting Period } \\
\text { Renewal Request }\end{array}$ & SIM & \begin{tabular}{|l|} 
Produção energética - \\
geradores eólicos
\end{tabular} & SIM & 1 & $\begin{array}{l}\text { Indústrias energéticas (fontes } \\
\text { renováveis - / não-renováveis) }\end{array}$ & Pequena \\
\hline Índia & 2546 & 2009 & $\begin{array}{l}\text { Ansal Properties and } \\
\text { Infrastructure Limited }\end{array}$ & $\begin{array}{l}12 \mathrm{MW} \text { Grid connected Wind } \\
\text { Power Project, Gujarat State, } \\
\text { India. }\end{array}$ & SIM & $\begin{array}{l}\text { Produção energética - } \\
\text { geradores eólicos }\end{array}$ & NÃO & 1 & $\begin{array}{l}\text { Indústrias energéticas (fontes } \\
\text { renováveis - / não-renováveis) }\end{array}$ & Pequena \\
\hline Índia & 389 & 2006 & Apollo Tyres Limited & $\begin{array}{l}\text { Waste heat recovery project } \\
\text { based on technology up- } \\
\text { gradation at Apollo Tyres, } \\
\text { Vadodara, India } \\
\end{array}$ & SIM & $\begin{array}{l}\text { Produção energética - planta } \\
\text { industrial petroquímica }\end{array}$ & NÃO & 4 & Transformação industrial & Pequena \\
\hline Índia & 471 & 2006 & Ashok Leyland Limited & $\begin{array}{l}56.25 \text { MW Bundled Wind } \\
\text { Energy Project In Tirunelveli \& } \\
\text { Coimbatore Districts }\end{array}$ & SIM & \begin{tabular}{|l} 
Produção energética - \\
geradores eólicos
\end{tabular} & SIM & 1 & $\begin{array}{l}\text { Indústrias energéticas (fontes } \\
\text { renováveis - / não-renováveis) }\end{array}$ & Larga \\
\hline Índia & 2947 & 2010 & Ashok Leyland Limited & $\begin{array}{l}\text { Wind Power Project By AL } \\
\text { Wind Energy In Tamilnadu }\end{array}$ & NÃO & \begin{tabular}{|l} 
Produção energética - \\
geradores eólicos
\end{tabular} & NÃO & 1 & $\begin{array}{l}\text { Indústrias energéticas (fontes } \\
\text { renováveis - / não-renováveis) }\end{array}$ & Pequena \\
\hline Índia & 8415 & 2012 & Asian Electronics Limited & $\begin{array}{l}\text { Bundled Street Lighting Energy } \\
\text { Efficiency Projects implemented } \\
\text { by AEL in India }\end{array}$ & SIM & $\begin{array}{l}\text { Eficiência energética - } \\
\text { localidades urbanas }\end{array}$ & NÃO & 3 & Demanda energética & Pequena \\
\hline Índia & 7770 & 2012 & Asian Star Company Limited & $\begin{array}{l}6 \mathrm{MW} \text { wind power project of } \\
\text { Asian Star Company Limited at } \\
\text { Tamil Nadu, India }\end{array}$ & NÃO & $\begin{array}{l}\text { Produção energética - } \\
\text { geradores eólicos }\end{array}$ & NÃO & 1 & $\begin{array}{l}\text { Indústrias energéticas (fontes } \\
\text { renováveis - / não-renováveis) }\end{array}$ & Pequena \\
\hline Índia & 4343 & 2011 & $\begin{array}{l}\text { Associated Stone Industries } \\
\text { (Kotah) Limited }\end{array}$ & $\begin{array}{l}\text { 4.75 MW Bundled Wind Power } \\
\text { Project by Associated Stone } \\
\text { Industries (Kotah) Ltd }\end{array}$ & NÃO & $\begin{array}{l}\text { Produção energética - } \\
\text { geradores eólicos }\end{array}$ & NÃO & 1 & $\begin{array}{l}\text { Indústrias energéticas (fontes } \\
\text { renováveis - / não-renováveis) }\end{array}$ & Pequena \\
\hline Índia & 991 & 2007 & $\begin{array}{l}\text { Bannari Amman Spinning Mills } \\
\text { Limited }\end{array}$ & $\begin{array}{l}\text { Bundled Wind Power Project } \\
\text { Tamilnadu Spinning Mills } \\
\text { Association }\end{array}$ & SIM & $\begin{array}{l}\text { Produção energética - } \\
\text { geradores eólicos }\end{array}$ & NÃO & 1 & $\begin{array}{l}\text { Indústrias energéticas (fontes } \\
\text { renováveis - / não-renováveis) }\end{array}$ & Larga \\
\hline Índia & 4877 & 2011 & $\begin{array}{l}\text { Bannari Amman Spinning Mills } \\
\text { Limited }\end{array}$ & $\begin{array}{l}\text { Bannari Amman Spinning Mills } \\
\text { Wind Power Project managed by } \\
\text { Enercon (India) Ltd. }\end{array}$ & NÃO & $\begin{array}{l}\text { Produção energética - } \\
\text { geradores eólicos }\end{array}$ & NÃO & 1 & $\begin{array}{l}\text { Indústrias energéticas (fontes } \\
\text { renováveis - / não-renováveis) }\end{array}$ & Pequena \\
\hline Índia & 7968 & 2012 & $\begin{array}{l}\text { Bannari Amman Spinning Mills } \\
\text { Limited }\end{array}$ & $\begin{array}{l}8 \mathrm{MW} \text { bundled wind power } \\
\text { project by Bannari Amman } \\
\text { Spinning Mills Limited in Tamil } \\
\text { Nadu, India }\end{array}$ & NÃO & $\begin{array}{l}\text { Produção energética - } \\
\text { geradores eólicos }\end{array}$ & NÃO & 1 & $\begin{array}{l}\text { Indústrias energéticas (fontes } \\
\text { renováveis - / não-renováveis) }\end{array}$ & Pequena \\
\hline Índia & 1236 & 2007 & Bannari Amman Sugars Limited & $\begin{array}{l}\text { Eco Friendly Electricity Export } \\
\text { to Grid }\end{array}$ & SIM & $\begin{array}{l}\text { Produção energética - } \\
\text { geradores eólicos }\end{array}$ & NÃO & 1 & $\begin{array}{l}\text { Indústrias energéticas (fontes } \\
\text { renováveis - / não-renováveis) }\end{array}$ & Pequena \\
\hline Índia & 1574 & 2008 & Bannari Amman Sugars Limited & $\begin{array}{l}20 \text { MW Bagasse Based Co- } \\
\text { generation Power Project at } \\
\text { Bannari Amman Sugars Limited, } \\
\text { Nanjangud, Karnataka }\end{array}$ & NÃO & Produção energética - bagaço & NÃO & 1 & $\begin{array}{l}\text { Indústrias energéticas (fontes } \\
\text { renováveis - / não-renováveis) }\end{array}$ & Larga \\
\hline
\end{tabular}




\begin{tabular}{|c|c|c|c|c|c|c|c|c|c|c|}
\hline Índia & 3822 & 2010 & Bannari Amman Sugars Limited & $\begin{array}{l}20 \text { MW Bagasse based } \\
\text { Cogeneration power project at } \\
\text { Bannari Amman Sugars Limited, } \\
\text { Sathyamangalam, Tamil Nadu } \\
\text { by Bannari Amman Sugars } \\
\text { Limited }\end{array}$ & NÃO & Produção energética - bagaço & NÃO & 1 & $\begin{array}{l}\text { Indústrias energéticas (fontes } \\
\text { renováveis - / não-renováveis) }\end{array}$ & Larga \\
\hline Índia & 792 & 2007 & BF Utilities Limited & $\begin{array}{l}\text { 14.65 MW Wind Power Project } \\
\text { in Maharashtra by BF Utilities } \\
\text { Ltd. }\end{array}$ & SIM & $\begin{array}{l}\text { Produção energética - } \\
\text { geradores eólicos }\end{array}$ & SIM & 1 & $\begin{array}{l}\text { Indústrias energéticas (fontes } \\
\text { renováveis - / não-renováveis) }\end{array}$ & Pequena \\
\hline Índia & 7558 & 2012 & Bhagyanagar India Limited & $\begin{array}{l}\text { Bundled Wind Project Activity } \\
\text { by M/s Bhagyanagar India } \\
\text { Limited and M/s Surana } \\
\text { Telecom and Power Limited } \\
\end{array}$ & NÃO & $\begin{array}{l}\text { Produção energética - } \\
\text { geradores eólicos }\end{array}$ & NÃO & 1 & $\begin{array}{l}\text { Indústrias energéticas (fontes } \\
\text { renováveis - / não-renováveis) }\end{array}$ & Pequena \\
\hline Índia & 1216 & 2007 & Bharat Electronics Limited & $\begin{array}{l}2.5 \mathrm{MW} \text { BEL grid-connected } \\
\text { wind power project at } \\
\text { Davanagere district, Karnataka, } \\
\text { India }\end{array}$ & NÃO & $\begin{array}{l}\text { Produção energética - } \\
\text { geradores eólicos }\end{array}$ & NÃO & 1 & $\begin{array}{l}\text { Indústrias energéticas (fontes } \\
\text { renováveis - / não-renováveis) }\end{array}$ & Pequena \\
\hline Índia & 4997 & 2011 & Bharat Electronics Limited & $\begin{array}{l}\text { 3.0 MW BEL grid-connected } \\
\text { wind power project at } \\
\text { Somarigudda, Hassan district, } \\
\text { Karnataka, India } \\
\end{array}$ & NÃO & $\begin{array}{l}\text { Produção energética - } \\
\text { geradores eólicos }\end{array}$ & NÃO & 1 & $\begin{array}{l}\text { Indústrias energéticas (fontes } \\
\text { renováveis - / não-renováveis) }\end{array}$ & Pequena \\
\hline Índia & 800 & 2007 & Bharat Forge Limited & $\begin{array}{l}\text { 4.2 MW Wind power project in } \\
\text { Maharashtra, by Bharat Forge } \\
\text { Limited }\end{array}$ & SIM & $\begin{array}{l}\text { Produção energética - } \\
\text { geradores eólicos }\end{array}$ & SIM & 1 & $\begin{array}{l}\text { Indústrias energéticas (fontes } \\
\text { renováveis - / não-renováveis) }\end{array}$ & Pequena \\
\hline Índia & 2036 & 2009 & $\begin{array}{l}\text { Bharat Petroleum Corporation } \\
\text { Limited }\end{array}$ & $\begin{array}{l}\text { Bharat Petroleum Corporation } \\
\text { Limited (BPCL)'s Wind Power } \\
\text { Project, India }\end{array}$ & NÃO & $\begin{array}{l}\text { Produção energética - } \\
\text { geradores eólicos }\end{array}$ & NÃO & 1 & $\begin{array}{l}\text { Indústrias energéticas (fontes } \\
\text { renováveis - / não-renováveis) }\end{array}$ & Pequena \\
\hline Índia & 8801 & 2012 & Bhushan Steel Limited & $\begin{array}{l}\text { CDM Project of Fuel Switch } \\
\text { from Heavy Fuel Oil (HFO) to } \\
\text { Liquefied Natural Gas (LNG) in } \\
\text { Boiler } \\
\end{array}$ & NÃO & $\begin{array}{l}\text { Transformação industrial - } \\
\text { substituição de combustíveis } \\
\text { fósseis }\end{array}$ & NÃO & 1 & $\begin{array}{l}\text { Indústrias energéticas (fontes } \\
\text { renováveis - / não-renováveis) }\end{array}$ & Pequena \\
\hline Índia & 314 & 2006 & Birla Corporation Limited & $\begin{array}{l}\text { Optimal Utilization of Clinker in } \\
\text { PPC manufacturing at Birla } \\
\text { Corporation Limited, Raebareli } \\
\text { Unit }\end{array}$ & SIM & $\begin{array}{l}\text { Transformação industrial - } \\
\text { substituição de clinker na } \\
\text { produção de cimento }\end{array}$ & NÃO & 4 & Transformação industrial & Larga \\
\hline Índia & 568 & 2006 & Birla Corporation Limited & $\begin{array}{l}\text { GHG Emissions Reduction } \\
\text { through Energy Efficiency } \\
\text { Improvements }\end{array}$ & SIM & $\begin{array}{l}\text { Transformação industrial - } \\
\text { substituição de clinker na } \\
\text { produção de cimento }\end{array}$ & NÃO & 4 & Transformação industrial & Pequena \\
\hline Índia & 4543 & 2011 & C. Mahendra Exports Limited & $\begin{array}{l}15 \mathrm{MW} \text { bundled grid connected } \\
\text { renewable energy project in } \\
\text { Maharashtra, India }\end{array}$ & NÃO & $\begin{array}{l}\text { Produção energética - } \\
\text { geradores eólicos }\end{array}$ & NÃO & 1 & $\begin{array}{l}\text { Indústrias energéticas (fontes } \\
\text { renováveis - / não-renováveis) }\end{array}$ & Pequena \\
\hline Índia & 8417 & 2012 & C. Mahendra Exports Limited & $\begin{array}{l}15 \mathrm{MW} \text { bundled grid connected } \\
\text { wind energy project in Gujarat, } \\
\text { India }\end{array}$ & NÃO & $\begin{array}{l}\text { Produção energética - } \\
\text { geradores eólicos }\end{array}$ & SIM & 1 & $\begin{array}{l}\text { Indústrias energéticas (fontes } \\
\text { renováveis - / não-renováveis) }\end{array}$ & Pequena \\
\hline Índia & 8121 & 2012 & CEAT Limited & $\begin{array}{l}\text { Renewable energy use for } \\
\text { process steam generation at tyre } \\
\text { manufacturing units in India }\end{array}$ & NÃO & $\begin{array}{l}\text { Produção energética - } \\
\text { resíduos de madeira }\end{array}$ & NÃO & 1 & $\begin{array}{l}\text { Indústrias energéticas (fontes } \\
\text { renováveis - / não-renováveis) }\end{array}$ & Pequena \\
\hline
\end{tabular}




\begin{tabular}{|c|c|c|c|c|c|c|c|c|c|c|}
\hline Índia & 548 & 2006 & $\begin{array}{l}\text { Century Textiles and Industries } \\
\text { Limited }\end{array}$ & \begin{tabular}{|l|} 
Century Textiles \& Industries \\
Ltd blended cement projects at: $\bullet$ \\
Century cement $\bullet$ Manikgarh \\
cement $\bullet$ Maihar cement
\end{tabular} & SIM & \begin{tabular}{|l} 
Transformação industrial - \\
substituição de clinker na \\
produção de cimento
\end{tabular} & NÃO & 4 & Transformação industrial & Larga \\
\hline Índia & 479 & 2006 & CESC Limited & $\begin{array}{l}\text { Energy Efficiency Measures At } \\
\text { a Thermal Power Generating } \\
\text { Station Of CESC-limited, BBGS }\end{array}$ & SIM & $\begin{array}{l}\text { Transformação industrial - } \\
\text { substituição de combustíveis } \\
\text { fósseis }\end{array}$ & NÃO & 1 & $\begin{array}{l}\text { Indústrias energéticas (fontes } \\
\text { renováveis - / não-renováveis) }\end{array}$ & Pequena \\
\hline Índia & 987 & 2007 & CESC Limited & $\begin{array}{l}\text { Energy Efficiency through } \\
\text { Alteration of fuel oil atomizing } \\
\text { media in coal-fired thermal } \\
\text { power plant }\end{array}$ & SIM & $\begin{array}{l}\text { Transformação industrial - } \\
\text { substituição de combustíveis } \\
\text { fósseis }\end{array}$ & NÃO & 4 & Transformação industrial & Pequena \\
\hline Índia & 1807 & 2008 & CESC Limited & $\begin{array}{l}\text { Energy efficiency improvement } \\
\text { measures in CESC-TGS- } \\
\text { modification of the Furnace } \\
\text { Draft Control System and the } \\
\text { Auxiliary Cooling Water System }\end{array}$ & NÃO & $\begin{array}{l}\text { Transformação industrial - } \\
\text { substituição de combustíveis } \\
\text { fósseis }\end{array}$ & NÃO & 4 & Transformação industrial & Pequena \\
\hline Índia & 3115 & 2010 & $\begin{array}{l}\text { Chennai Petroleum Corporation } \\
\text { Limited }\end{array}$ & $\begin{array}{l}\text { 17.6 MW captive grid connected } \\
\text { electricity generation from wind } \\
\text { energy project by Chennai } \\
\text { Petroleum Corporation Limited. }\end{array}$ & NÃO & $\begin{array}{l}\text { Produção energética - } \\
\text { geradores eólicos }\end{array}$ & NÃO & 1 & $\begin{array}{l}\text { Indústrias energéticas (fontes } \\
\text { renováveis - / não-renováveis) }\end{array}$ & Larga \\
\hline Índia & 1852 & 2009 & Claris Lifesciences Limited & $\begin{array}{l}\text { Abatement of Green House Gas } \\
\text { (GHG) emissions through } \\
\text { biomass residue based } \\
\text { cogeneration at Claris } \\
\text { Lifesciences Limited }\end{array}$ & SIM & $\begin{array}{l}\text { Produção energética - outros } \\
\text { resíduos agrícolas }\end{array}$ & NÃO & 1 & $\begin{array}{l}\text { Indústrias energéticas (fontes } \\
\text { renováveis - / não-renováveis) }\end{array}$ & Pequena \\
\hline Índia & 1003 & 2008 & $\begin{array}{l}\text { Dalmia Bharat Sugar and } \\
\text { Industries Limited }\end{array}$ & Ramgarh Chini Mills RE project & SIM & Produção energética - bagaço & NÃO & 1 & $\begin{array}{l}\text { Indústrias energéticas (fontes } \\
\text { renováveis - / não-renováveis) }\end{array}$ & Larga \\
\hline Índia & 4332 & 2011 & Dalmia Bharat Limited & $\begin{array}{l}\text { Dalmia Chini Mills Jawaharpur } \\
\text { Project }\end{array}$ & NÃO & Produção energética - bagaço & NÃO & 1 & $\begin{array}{l}\text { Indústrias energéticas (fontes } \\
\text { renováveis - / não-renováveis) }\end{array}$ & Larga \\
\hline Índia & 4608 & 2011 & Dalmia Bharat Limited & $\begin{array}{l}\text { Dalmia Chini Mills Nigohi } \\
\text { Project }\end{array}$ & NÃO & Produção energética - bagaço & NÃO & 1 & $\begin{array}{l}\text { Indústrias energéticas (fontes } \\
\text { renováveis - / não-renováveis) }\end{array}$ & Larga \\
\hline Índia & 332 & 2006 & $\begin{array}{l}\text { DCM Shriram Consolidated } \\
\text { Limited }\end{array}$ & $\begin{array}{l}\text { Ajbapur Sugar Complex } \\
\text { Cogeneration Project }\end{array}$ & SIM & Produção energética - bagaço & NÃO & 1 & $\begin{array}{l}\text { Indústrias energéticas (fontes } \\
\text { renováveis - / não-renováveis) }\end{array}$ & Pequena \\
\hline Índia & 982 & 2007 & $\begin{array}{l}\text { DCM Shriram Consolidated } \\
\text { Limited }\end{array}$ & $\begin{array}{l}\text { DSCL Sugar Ajbapur } \\
\text { Cogeneration Project Phase II }\end{array}$ & SIM & Produção energética - bagaço & NÃO & 1 & $\begin{array}{l}\text { Indústrias energéticas (fontes } \\
\text { renováveis - / não-renováveis) }\end{array}$ & Larga \\
\hline Índia & 6522 & 2012 & D C W Limited & $\begin{array}{l}\text { Clean energy generation } \\
\text { from wind energy in the state of } \\
\text { Rajasthan. }\end{array}$ & NÃO & $\begin{array}{l}\text { Produção energética - } \\
\text { geradores eólicos }\end{array}$ & NÃO & 1 & $\begin{array}{l}\text { Indústrias energéticas (fontes } \\
\text { renováveis - / não-renováveis) }\end{array}$ & Larga \\
\hline
\end{tabular}




\begin{tabular}{|c|c|c|c|c|c|c|c|c|c|c|}
\hline Índia & 2540 & 2009 & $\begin{array}{l}\text { Deepak Fertilisers \& } \\
\text { Petrochemicals Corporation } \\
\text { Limited }\end{array}$ & $\begin{array}{l}10 \mathrm{MW} \text { Wind Power Project in } \\
\text { Maharashtra by Deepak } \\
\text { Fertilizers and Petrochemicals } \\
\text { Corporation Limited } \\
\end{array}$ & NÃO & $\begin{array}{l}\text { Produção energética - } \\
\text { geradores eólicos }\end{array}$ & NÃO & 1 & $\begin{array}{l}\text { Indústrias energéticas (fontes } \\
\text { renováveis - / não-renováveis) }\end{array}$ & Pequena \\
\hline Índia & 2943 & 2010 & $\begin{array}{l}\text { Deepak Fertilisers \& } \\
\text { Petrochemicals Corporation } \\
\text { Limited }\end{array}$ & \begin{tabular}{|l|} 
N2O reduction project at the \\
WNA I nitric acid plant of \\
Deepak Fertilisers \& \\
Petrochemicals Corporation Ltd. \\
("Deepak"), India \\
\end{tabular} & SIM & $\begin{array}{l}\text { Transformação industrial - } \\
\text { incineração de fluxos de } \\
\text { resíduos } \mathrm{N} 2 \mathrm{O}\end{array}$ & NÃO & 5 & Indústrias químicas & Larga \\
\hline Índia & 2997 & 2010 & $\begin{array}{l}\text { Deepak Fertilisers \& } \\
\text { Petrochemicals Corporation } \\
\text { Limited }\end{array}$ & $\begin{array}{l}\text { N2O reduction project at the } \\
\text { WNA III nitric acid plant of } \\
\text { Deepak Fertilisers \& } \\
\text { Petrochemicals Corporation Ltd. } \\
\text { ("Deepak"), India }\end{array}$ & SIM & $\begin{array}{l}\text { Transformação industrial - } \\
\text { incineração de fluxos de } \\
\text { resíduos } \mathrm{N} 2 \mathrm{O}\end{array}$ & NÃO & 5 & Indústrias químicas & Larga \\
\hline Índia & 8595 & 2012 & $\begin{array}{l}\text { Deepak Fertilisers \& } \\
\text { Petrochemicals Corporation } \\
\text { Limited }\end{array}$ & $\begin{array}{l}\text { Deepak WNA } 5 \text { N2O Abatement } \\
\text { Project }\end{array}$ & SIM & $\begin{array}{l}\text { Transformação industrial - } \\
\text { incineração de fluxos de } \\
\text { resíduos } \mathrm{N} 2 \mathrm{O}\end{array}$ & NÃO & 5 & Indústrias químicas & Larga \\
\hline Índia & 8729 & 2012 & $\begin{array}{l}\text { Deepak Fertilisers \& } \\
\text { Petrochemicals Corporation } \\
\text { Limited }\end{array}$ & $\begin{array}{l}\text { Deepak WNA } 2 \text { N2O Abatement } \\
\text { Project }\end{array}$ & SIM & $\begin{array}{l}\text { Transformação industrial - } \\
\text { incineração de fluxos de } \\
\text { resíduos N2O }\end{array}$ & NÃO & 5 & Indústrias químicas & Larga \\
\hline Índia & 8731 & 2012 & $\begin{array}{l}\text { Deepak Fertilisers \& } \\
\text { Petrochemicals Corporation } \\
\text { Limited }\end{array}$ & $\begin{array}{l}\text { Deepak WNA } 4 \text { N2O Abatement } \\
\text { Project }\end{array}$ & SIM & $\begin{array}{l}\text { Transformação industrial - } \\
\text { incineração de fluxos de } \\
\text { resíduos } \mathrm{N} 2 \mathrm{O}\end{array}$ & NÃO & 5 & Indústrias químicas & Larga \\
\hline Índia & 1461 & 2008 & Deepak Spinners Limited & $\begin{array}{l}5 \text { MW Biomass based } \\
\text { Cogeneration project" at Solan, } \\
\text { Himachal Pradesh, by M/s } \\
\text { Deepak Spinners Limited }\end{array}$ & NÃO & $\begin{array}{l}\text { Produção energética - casca } \\
\text { de arroz }\end{array}$ & NÃO & 1 & $\begin{array}{l}\text { Indústrias energéticas (fontes } \\
\text { renováveis - / não-renováveis) }\end{array}$ & Pequena \\
\hline Índia & 2347 & 2009 & DLF Limited & $\begin{array}{l}150 \mathrm{MW} \text { grid connected Wind } \\
\text { Power based electricity } \\
\text { generation project in Gujarat, } \\
\text { India }\end{array}$ & SIM & $\begin{array}{l}\text { Produção energética - } \\
\text { geradores eólicos }\end{array}$ & SIM & 1 & $\begin{array}{l}\text { Indústrias energéticas (fontes } \\
\text { renováveis - / não-renováveis) }\end{array}$ & Larga \\
\hline Índia & 2474 & 2009 & DLF Limited & $\begin{array}{l}\text { 25.6 MW grid connected Wind } \\
\text { Power based electricity } \\
\text { generation project in Karnataka, } \\
\text { India. }\end{array}$ & SIM & $\begin{array}{l}\text { Produção energética - } \\
\text { geradores eólicos }\end{array}$ & SIM & 1 & $\begin{array}{l}\text { Indústrias energéticas (fontes } \\
\text { renováveis - / não-renováveis) }\end{array}$ & Larga \\
\hline Índia & 3642 & 2011 & DLF Limited & $\begin{array}{l}\text { Wind Power Based Electricity } \\
\text { Generation Project By DLF } \\
\text { Home Developers Ltd }\end{array}$ & NÃO & $\begin{array}{l}\text { Produção energética - } \\
\text { geradores eólicos }\end{array}$ & SIM & 1 & $\begin{array}{l}\text { Indústrias energéticas (fontes } \\
\text { renováveis - / não-renováveis) }\end{array}$ & Larga \\
\hline Índia & 1257 & 2007 & $\begin{array}{l}\text { Dwarikesh Sugar Industries } \\
\text { Limited }\end{array}$ & $\begin{array}{l}\text { Power capacity expansion } \\
\text { project at Dwarikesh Puram }\end{array}$ & SIM & Produção energética - bagaço & NÃO & 1 & $\begin{array}{l}\text { Indústrias energéticas (fontes } \\
\text { renováveis - / não-renováveis) }\end{array}$ & Larga \\
\hline Índia & 1339 & 2008 & $\begin{array}{l}\text { Dwarikesh Sugar Industries } \\
\text { Limited }\end{array}$ & $\begin{array}{l}\text { Greenfield power project at } \\
\text { Dwarikesh Dham }\end{array}$ & SIM & Produção energética - bagaço & NÃO & 1 & $\begin{array}{l}\text { Indústrias energéticas (fontes } \\
\text { renováveis - / não-renováveis) }\end{array}$ & Larga \\
\hline
\end{tabular}




\begin{tabular}{|c|c|c|c|c|c|c|c|c|c|c|}
\hline Índia & 3191 & 2010 & $\begin{array}{l}\text { Dwarikesh Sugar Industries } \\
\text { Limited }\end{array}$ & $\begin{array}{l}\text { Methane recovery from } \\
\text { wastewater treatment at } \\
\text { Dwarikesh Sugar Industries } \\
\text { Limited (DSIL) } \\
\end{array}$ & SIM & $\begin{array}{l}\text { Tratamento de águas - dejetos } \\
\text { industriais }\end{array}$ & SIM & 13 & $\begin{array}{l}\text { Tratamento e eliminação de } \\
\text { resíduos }\end{array}$ & Pequena \\
\hline Índia & 1139 & 2007 & E.I.D. Parry India Limited & $\begin{array}{l}\text { Bagasse based Cogeneration } \\
\text { Project at Pudukkottai Tamil } \\
\text { Nadu, India }\end{array}$ & SIM & Produção energética - bagaço & NÃO & 1 & $\begin{array}{l}\text { Indústrias energéticas (fontes } \\
\text { renováveis - / não-renováveis) }\end{array}$ & Larga \\
\hline Índia & 556 & 2006 & Electro Steel Castings Limited & $\begin{array}{l}12 \text { MW Captive Power Project } \\
\text { based on Waste Heat Recovery } \\
\text { of Industrial Waste Gases }\end{array}$ & SIM & $\begin{array}{l}\text { Produção energética - gases } \\
\text { industriais }\end{array}$ & NÃO & 1 & $\begin{array}{l}\text { Indústrias energéticas (fontes } \\
\text { renováveis - / não-renováveis) }\end{array}$ & Larga \\
\hline Índia & 6712 & 2012 & Electrotherm India Limited & $\begin{array}{l}\text { Electrotherm Electric Vehicles, } \\
\text { India }\end{array}$ & SIM & Transporte - motocicletas & NÃO & 7 & Transporte & Pequena \\
\hline Índia & 5767 & 2012 & EMCO Limited & $\begin{array}{l}\text { Renewable wind energy } \\
\text { generation in Maharashtra by } \\
\text { EMCO Limited }\end{array}$ & NÃO & $\begin{array}{l}\text { Produção energética - } \\
\text { geradores eólicos }\end{array}$ & NÃO & 1 & $\begin{array}{l}\text { Indústrias energéticas (fontes } \\
\text { renováveis - / não-renováveis) }\end{array}$ & Pequena \\
\hline Índia & 7819 & 2012 & EMCO Limited & $\begin{array}{l}\text { Grid Connected Solar } \\
\text { Photovoltaic Power Project by } \\
\text { M/s EMCO Limited }\end{array}$ & NÃO & $\begin{array}{l}\text { Produção energética - } \\
\text { geradores solares }\end{array}$ & SIM & 1 & $\begin{array}{l}\text { Indústrias energéticas (fontes } \\
\text { renováveis - / não-renováveis) }\end{array}$ & Pequena \\
\hline Índia & 1548 & 2008 & Empee Distilleries Limited & $\begin{array}{l}\text { Empee Distilleries } 10 \mathrm{MW} \\
\text { Woody Biomass-Based Power } \\
\text { Project, Tamil Nadu }\end{array}$ & SIM & $\begin{array}{l}\text { Produção energética - } \\
\text { resíduos florestais }\end{array}$ & SIM & 1 & $\begin{array}{l}\text { Indústrias energéticas (fontes } \\
\text { renováveis - / não-renováveis) }\end{array}$ & Pequena \\
\hline Índia & 3594 & 2010 & $\begin{array}{l}\text { Energy Development Company } \\
\text { Limited }\end{array}$ & $\begin{array}{l}6 \text { MW Harangi Phase-II Hydro } \\
\text { Power Project in Karnataka, } \\
\text { India }\end{array}$ & NÃO & Produção energética - águas & NÃO & 1 & $\begin{array}{l}\text { Indústrias energéticas (fontes } \\
\text { renováveis - / não-renováveis) }\end{array}$ & Pequena \\
\hline Índia & 2937 & 2010 & $\begin{array}{l}\text { Energy Development Company } \\
\text { Limited }\end{array}$ & $\begin{array}{l}\text { 2X3.5 MW Ullunkal Hydro } \\
\text { Power Project In Kerala }\end{array}$ & NÃO & Produção energética - águas & NÃO & 1 & $\begin{array}{l}\text { Indústrias energéticas (fontes } \\
\text { renováveis - / não-renováveis) }\end{array}$ & Pequena \\
\hline Índia & 832 & 2007 & Essar Oil Limited & $\begin{array}{l}\text { GHG emission reduction } \\
\text { through the installation of } \\
\text { energy efficient vacuum creating } \\
\text { system in the vacuum distillation } \\
\text { column of petroleum refinery }\end{array}$ & NÃO & $\begin{array}{l}\text { Produção energética - planta } \\
\text { industrial petroquímica }\end{array}$ & NÃO & 3 & Demanda energética & Larga \\
\hline Índia & 3182 & 2010 & Ester Industries Limited & $\begin{array}{l}\text { Biomass based thermal energy } \\
\text { generation at } \mathrm{M} / \mathrm{s} \text {. Ester } \\
\text { Industries limited, Khatima, } \\
\text { Uttarakhand, India }\end{array}$ & NÃO & $\begin{array}{l}\text { Produção energética - casca } \\
\text { de arroz }\end{array}$ & SIM & 1 & $\begin{array}{l}\text { Indústrias energéticas (fontes } \\
\text { renováveis - / não-renováveis) }\end{array}$ & Pequena \\
\hline Índia & 5384 & 2011 & Gayatri Projects Limited & $\begin{array}{l}\text { Wind Power project by GPL in } \\
\text { Theni. }\end{array}$ & NÃO & $\begin{array}{l}\text { Produção energética - } \\
\text { geradores eólicos }\end{array}$ & NÃO & 1 & $\begin{array}{l}\text { Indústrias energéticas (fontes } \\
\text { renováveis - / não-renováveis) }\end{array}$ & Pequena \\
\hline Índia & 4898 & 2011 & GeeCee Ventures Limited & $\begin{array}{l}5.35 \mathrm{MW} \text { Wind Power Project } \\
\text { by GeeCee Ventures Ltd }\end{array}$ & NÃO & $\begin{array}{l}\text { Produção energética - } \\
\text { geradores eólicos }\end{array}$ & NÃO & 1 & $\begin{array}{l}\text { Indústrias energéticas (fontes } \\
\text { renováveis - / não-renováveis) }\end{array}$ & Pequena \\
\hline Índia & 4886 & 2011 & $\begin{array}{l}\text { Gillanders Arbuthnot \& Co. } \\
\text { Limited }\end{array}$ & $\begin{array}{l}\text { 6.5 MW cogeneration project in } \\
\text { Akbarpur, Punjab. }\end{array}$ & NÃO & $\begin{array}{l}\text { Produção energética - casca } \\
\text { de arroz }\end{array}$ & NÃO & 1 & $\begin{array}{l}\text { Indústrias energéticas (fontes } \\
\text { renováveis - / não-renováveis) }\end{array}$ & Pequena \\
\hline
\end{tabular}




\begin{tabular}{|c|c|c|c|c|c|c|c|c|c|c|}
\hline Índia & 264 & 2006 & $\begin{array}{l}\text { Godawari Power and Ispat } \\
\text { Limited }\end{array}$ & $\begin{array}{l}\text { Waste heat based } 7 \text { MW Captive } \\
\text { Power Project Godawari Power } \\
\text { and Ispat Ltd (GPIL) }\end{array}$ & SIM & $\begin{array}{l}\text { Produção energética - gases } \\
\text { industriais }\end{array}$ & NÃO & 1 & $\begin{array}{l}\text { Indústrias energéticas (fontes } \\
\text { renováveis - / não-renováveis) }\end{array}$ & Larga \\
\hline Índia & 772 & 2007 & $\begin{array}{l}\text { Godawari Power and Ispat } \\
\text { Limited }\end{array}$ & $\begin{array}{l}\text { Waste Heat based } 10 \mathrm{MW} \\
\text { captive power project "GPIL- } \\
\text { WHRB 2" CDM PROJECT } \\
\text { ACTIVITY }\end{array}$ & SIM & $\begin{array}{l}\text { Produção energética - gases } \\
\text { industriais }\end{array}$ & NÃO & 1 & $\begin{array}{l}\text { Indústrias energéticas (fontes } \\
\text { renováveis - / não-renováveis) }\end{array}$ & Larga \\
\hline Índia & 1719 & 2008 & $\begin{array}{l}\text { Godawari Power And Ispat } \\
\text { Limited }\end{array}$ & WHR CDM CPP & SIM & $\begin{array}{l}\text { Produção energética - gases } \\
\text { industriais }\end{array}$ & NÃO & 1 & $\begin{array}{l}\text { Indústrias energéticas (fontes } \\
\text { renováveis - / não-renováveis) }\end{array}$ & Larga \\
\hline Índia & 531 & 2006 & Godrej Industries Limited & $\begin{array}{l}11.25 \mathrm{MW} \text { wind power project } \\
\text { in Dhule, Maharashtra, India }\end{array}$ & SIM & $\begin{array}{l}\text { Produção energética - } \\
\text { geradores eólicos }\end{array}$ & NÃO & 1 & $\begin{array}{l}\text { Indústrias energéticas (fontes } \\
\text { renováveis - / não-renováveis) }\end{array}$ & Pequena \\
\hline Índia & 4062 & 2011 & $\begin{array}{l}\text { Gokul Refoils and Solvent } \\
\text { Limited }\end{array}$ & $\begin{array}{l}5 \mathrm{MW} \text { Wind Power Project by } \\
\text { Gokul Refoils and Solvent } \\
\text { Limited }\end{array}$ & NÃO & $\begin{array}{l}\text { Produção energética - } \\
\text { geradores eólicos }\end{array}$ & NÃO & 1 & \begin{tabular}{|l|} 
Indústrias energéticas (fontes \\
renováveis - / não-renováveis)
\end{tabular} & Pequena \\
\hline Índia & 662 & 2006 & Graphite India Limited & $\begin{array}{l}\text { 1.5 MW Link Canal Mini Hydel } \\
\text { Project }\end{array}$ & SIM & Produção energética - águas & NÃO & 1 & $\begin{array}{l}\text { Indústrias energéticas (fontes } \\
\text { renováveis - / não-renováveis) }\end{array}$ & Pequena \\
\hline Índia & 339 & 2006 & Grasim Industries Limited & $\begin{array}{l}\text { Emission reduction through } \\
\text { partial substitution of fossil fuel } \\
\text { with alternative fuels like } \\
\text { agricultural by-products, tyres } \\
\text { and municipal solid waste } \\
\text { (MSW) in the manufacturing of } \\
\text { portland cement at Grasim } \\
\text { Industries Limited-Cement } \\
\text { division South (GIL-CDS), } \\
\text { Tamilnadu, India. } \\
\end{array}$ & SIM & $\begin{array}{l}\text { Produção energética - outros } \\
\text { resíduos agrícolas }\end{array}$ & NÃO & 4 & Transformação industrial & Larga \\
\hline Índia & 858 & 2007 & Grasim Industries Limited & $\begin{array}{l}\text { Grasim Cement: Energy } \\
\text { efficiency by up-gradation of } \\
\text { clinker cooler in cement } \\
\text { manufacturing }\end{array}$ & NÃO & $\begin{array}{l}\text { Transformação industrial - } \\
\text { substituição de clinker na } \\
\text { produção de cimento }\end{array}$ & NÃO & 4 & Transformação industrial & Pequena \\
\hline Índia & 3602 & 2011 & Grasim Industries Limited & $\begin{array}{l}\text { Energy Efficiency measure at } \\
\text { Grasim, Kotputli. }\end{array}$ & NÃO & $\begin{array}{l}\text { Produção energética - } \\
\text { indústria de cimento }\end{array}$ & NÃO & 4 & Transformação industrial & Pequena \\
\hline Índia & 949 & 2007 & Greenply Industries Limited & $\begin{array}{l}\text { Fuel switch from fossil fuel to } \\
\text { renewable biomass for thermal } \\
\text { energy applications in Rajasthan }\end{array}$ & SIM & $\begin{array}{l}\text { Produção energética - outros } \\
\text { resíduos agrícolas }\end{array}$ & NÃO & 1 & $\begin{array}{l}\text { Indústrias energéticas (fontes } \\
\text { renováveis - / não-renováveis) }\end{array}$ & Pequena \\
\hline Índia & 494 & 2006 & $\begin{array}{l}\text { Gujarat Alkalies \& Chemicals } \\
\text { Limited }\end{array}$ & $\begin{array}{l}\text { Switching of fuel from naphtha } \\
\text { to natural gas in the captive } \\
\text { power plant(CPP) at Dahej } \\
\text { complex of Gujarat Alkalies and } \\
\text { Chemicals Limited } \\
\end{array}$ & SIM & $\begin{array}{l}\text { Transformação industrial - } \\
\text { substituição de combustíveis } \\
\text { fósseis }\end{array}$ & NÃO & 4 & Transformação industrial & Larga \\
\hline Índia & 500 & 2007 & $\begin{array}{l}\text { Gujarat Alkalies \& Chemicals } \\
\text { Limited }\end{array}$ & $\begin{array}{l}\text { Efficient utilisation of waste heat } \\
\text { and natural gas at Dahej } \\
\text { complex of GACL }\end{array}$ & NÃO & $\begin{array}{l}\text { Transformação industrial - } \\
\text { substituição de combustíveis } \\
\text { fósseis }\end{array}$ & NÃO & 4 & Transformação industrial & Pequena \\
\hline
\end{tabular}




\begin{tabular}{|c|c|c|c|c|c|c|c|c|c|c|}
\hline Índia & 940 & 2007 & $\begin{array}{l}\text { Gujarat Alkalies \& Chemicals } \\
\text { Limited }\end{array}$ & $\begin{array}{l}\text { Switching of fuel from Natural } \\
\text { Gas to Hydrogen in CCU-II at } \\
\text { Dahej complex of GACL }\end{array}$ & NÃO & $\begin{array}{l}\text { Transformação industrial - } \\
\text { substituição de combustíveis } \\
\text { fósseis }\end{array}$ & NÃO & 1 & $\begin{array}{l}\text { Indústrias energéticas (fontes } \\
\text { renováveis - / não-renováveis) }\end{array}$ & Pequena \\
\hline Índia & 7092 & 2012 & $\begin{array}{l}\text { Gujarat Alkalies \& Chemicals } \\
\text { Limited }\end{array}$ & $\begin{array}{l}\text { Grid-connected electricity } \\
\text { generation from } 39 \text { MW wind } \\
\text { energy by GACL in Gujarat }\end{array}$ & NÃO & $\begin{array}{l}\text { Produção energética - } \\
\text { geradores eólicos }\end{array}$ & NÃO & 1 & $\begin{array}{l}\text { Indústrias energéticas (fontes } \\
\text { renováveis - / não-renováveis) }\end{array}$ & Larga \\
\hline Índia & 7248 & 2012 & $\begin{array}{l}\text { Gujarat Alkalies \& Chemicals } \\
\text { Limited }\end{array}$ & $\begin{array}{l}\text { Grid-connected electricity } \\
\text { generation from } 21 \mathrm{MW} \text { wind } \\
\text { energy by GACL in Gujarat }\end{array}$ & NÃO & $\begin{array}{l}\text { Produção energética - } \\
\text { geradores eólicos }\end{array}$ & NÃO & 1 & $\begin{array}{l}\text { Indústrias energéticas (fontes } \\
\text { renováveis - / não-renováveis) }\end{array}$ & Larga \\
\hline Índia & 1 & 2005 & Gujarat Fluorochemicals Limited & $\begin{array}{l}\text { Project for GHG emission } \\
\text { reduction by thermal oxidation } \\
\text { of HFC } 23 \text { in Gujarat, India. }\end{array}$ & SIM & $\begin{array}{l}\text { Transformação industrial - } \\
\text { incineração de fluxos de } \\
\text { resíduos HFC } 23\end{array}$ & NÃO & 11 & $\begin{array}{l}\text { Emissões fugitivas da } \\
\text { produção e consumo de } \\
\text { hidrocarbonetos halogenados } \\
\text { e hexafluoreto de enxofre }\end{array}$ & Larga \\
\hline Índia & 1615 & 2008 & Gujarat Fluorochemicals Limited & $\begin{array}{l}\text { Wind power project by GFL in } \\
\text { Gudhepanchgani }\end{array}$ & SIM & $\begin{array}{l}\text { Produção energética - } \\
\text { geradores eólicos }\end{array}$ & SIM & 1 & $\begin{array}{l}\text { Indústrias energéticas (fontes } \\
\text { renováveis - / não-renováveis) }\end{array}$ & Larga \\
\hline Índia & 7724 & 2012 & Gujarat Fluorochemicals Limited & $\begin{array}{l}10.5 \mathrm{MW} \text { wind power project in } \\
\text { Ossiya, Rajasthan by Gujarat } \\
\text { Fluorochemicals Limited (GFL) }\end{array}$ & NÃO & \begin{tabular}{|l|}
$\begin{array}{l}\text { Produção energética - } \\
\text { geradores eólicos }\end{array}$ \\
\end{tabular} & SIM & 1 & $\begin{array}{l}\text { Indústrias energéticas (fontes } \\
\text { renováveis - / não-renováveis) }\end{array}$ & Larga \\
\hline Índia & 2948 & 2010 & Gujarat Gas Company Limited & $\begin{array}{l}\text { Installation of Natural Gas based } \\
\text { package cogeneration systems at } \\
\text { industrial facilities in Gujarat by } \\
\text { Gujarat Gas Company Limited } \\
\text { (GGCL), India. }\end{array}$ & NÃO & $\begin{array}{l}\text { Produção energética - } \\
\text { cogeração de gases naturais }\end{array}$ & NÃO & 1 e 4 & $\begin{array}{l}\text { Indústrias energéticas (fontes } \\
\text { renováveis - / não-renováveis) } \\
\text { / Transformação industrial }\end{array}$ & Larga \\
\hline Índia & 1540 & 2008 & Gujarat Hotels Limited & $\begin{array}{l}\text { Generation of electricity from } \\
\text { 3.2 MW capacity wind mills by } \\
\text { Gujarat JHM at Bhambarwadi, } \\
\text { Maharashtra }\end{array}$ & SIM & $\begin{array}{l}\text { Produção energética - } \\
\text { geradores eólicos }\end{array}$ & NÃO & 1 & $\begin{array}{l}\text { Indústrias energéticas (fontes } \\
\text { renováveis - / não-renováveis) }\end{array}$ & Pequena \\
\hline Índia & 5141 & 2011 & $\begin{array}{l}\text { Gujarat Mineral Development } \\
\text { Corporation Limited }\end{array}$ & $\begin{array}{l}\text { 19.5 MW Wind project by } \\
\text { GMDC }\end{array}$ & NÃO & $\begin{array}{l}\text { Produção energética - } \\
\text { geradores eólicos }\end{array}$ & SIM & 1 & $\begin{array}{l}\text { Indústrias energéticas (fontes } \\
\text { renováveis - / não-renováveis) }\end{array}$ & Larga \\
\hline Índia & 7720 & 2012 & $\begin{array}{l}\text { Gujarat Mineral Development } \\
\text { Corporation Limited }\end{array}$ & $\begin{array}{l}40.5 \mathrm{MW} \text { Wind Power Project } \\
\text { by GMDC }\end{array}$ & NÃO & $\begin{array}{l}\text { Produção energética - } \\
\text { geradores eólicos }\end{array}$ & NÃO & 1 & $\begin{array}{l}\text { Indústrias energéticas (fontes } \\
\text { renováveis - / não-renováveis) }\end{array}$ & Larga \\
\hline Índia & 2550 & 2009 & $\begin{array}{l}\text { Gujarat Narmada Valley } \\
\text { Fertilizer Company Limited }\end{array}$ & $\begin{array}{l}\text { Gujarat Narmada Valley } \\
\text { Fertilizer Company (GNFC) } \\
\text { Nitrous Oxide Abatement } \\
\text { Project }\end{array}$ & NÃO & $\begin{array}{l}\text { Transformação industrial - } \\
\text { incineração de fluxos de } \\
\text { resíduos } \mathrm{N} 2 \mathrm{O}\end{array}$ & NÃO & 5 & Indústrias químicas & Larga \\
\hline Índia & 5087 & 2012 & Gujarat NRE Coke Limited & $\begin{array}{l}\text { GHG abatement project through } \\
\text { wind based energy generation, in } \\
\text { Kutch, Gujarat }\end{array}$ & NÃO & $\begin{array}{l}\text { Produção energética - } \\
\text { geradores eólicos }\end{array}$ & NÃO & 1 & $\begin{array}{l}\text { Indústrias energéticas (fontes } \\
\text { renováveis - / não-renováveis) }\end{array}$ & Larga \\
\hline Índia & 1727 & 2009 & $\begin{array}{l}\text { Gujarat State Fertilizers \& } \\
\text { Chemicals Limited }\end{array}$ & $\begin{array}{l}\text { Fossil Fuel switch over project } \\
\text { activity at Ammonia-IV plant of }\end{array}$ & NÃO & $\begin{array}{l}\text { Transformação industrial - } \\
\text { substituição de combustíveis }\end{array}$ & NÃO & 4 & Transformação industrial & Pequena \\
\hline
\end{tabular}




\begin{tabular}{|c|c|c|c|c|c|c|c|c|c|c|}
\hline & & & & GSFC Ltd, Vadodara, India. & & fósseis & & & & \\
\hline Índia & 3372 & 2010 & $\begin{array}{l}\text { Gujarat State Fertilisers \& } \\
\text { Chemicals Limited }\end{array}$ & $\begin{array}{l}10 \text { MW Wind Power Project at } \\
\text { GSFC Limited }\end{array}$ & NÃO & $\begin{array}{l}\text { Produção energética - } \\
\text { geradores eólicos }\end{array}$ & NÃO & 1 & $\begin{array}{l}\text { Indústrias energéticas (fontes } \\
\text { renováveis - / não-renováveis) }\end{array}$ & Pequena \\
\hline Índia & 6551 & 2012 & $\begin{array}{l}\text { Gujarat State Fertilisers \& } \\
\text { Chemicals Limited }\end{array}$ & $\begin{array}{l}12 \mathrm{MW} \text { Wind Mill Project of } \\
\text { GSFC Ltd }\end{array}$ & NÃO & \begin{tabular}{|l} 
Produção energética - \\
geradores eólicos
\end{tabular} & NÃO & 1 & $\begin{array}{l}\text { Indústrias energéticas (fontes } \\
\text { renováveis - / não-renováveis) }\end{array}$ & Pequena \\
\hline Índia & 8020 & 2012 & $\begin{array}{l}\text { Gujarat State Fertilisers \& } \\
\text { Chemicals Limited }\end{array}$ & $\begin{array}{l}18 \mathrm{MW} \text { Wind Mill Project of } \\
\text { GSFC Ltd }\end{array}$ & NÃO & $\begin{array}{l}\text { Produção energética - } \\
\text { geradores eólicos }\end{array}$ & NÃO & 1 & $\begin{array}{l}\text { Indústrias energéticas (fontes } \\
\text { renováveis - / não-renováveis) }\end{array}$ & Larga \\
\hline Índia & 8172 & 2012 & $\begin{array}{l}\text { Gujarat State Fertilisers \& } \\
\text { Chemicals Limited }\end{array}$ & $\begin{array}{l}33 \text { MW Wind Power Project of } \\
\text { GSFC Ltd. }\end{array}$ & NÃO & $\begin{array}{l}\text { Produção energética - } \\
\text { geradores eólicos }\end{array}$ & NÃO & 1 & $\begin{array}{l}\text { Indústrias energéticas (fontes } \\
\text { renováveis - / não-renováveis) }\end{array}$ & Larga \\
\hline Índia & 7397 & 2012 & Gujarat State Petronet Limited & $\begin{array}{l}\text { Grid Connected wind power } \\
\text { generation project by GSPL in } \\
\text { Gujarat }\end{array}$ & NÃO & $\begin{array}{l}\text { Produção energética - } \\
\text { geradores eólicos }\end{array}$ & NÃO & 1 & $\begin{array}{l}\text { Indústrias energéticas (fontes } \\
\text { renováveis - / não-renováveis) }\end{array}$ & Larga \\
\hline Índia & 855 & 2007 & Hindustan Zinc Limited & $\begin{array}{l}\text { Waste heat recovery based } \\
\text { power plant at Hindustan Zinc } \\
\text { Limited, Chanderia. }\end{array}$ & SIM & $\begin{array}{l}\text { Transformação industrial - } \\
\text { substituição de combustíveis } \\
\text { fósseis }\end{array}$ & NÃO & 1 & $\begin{array}{l}\text { Indústrias energéticas (fontes } \\
\text { renováveis - / não-renováveis) }\end{array}$ & Larga \\
\hline Índia & 1824 & 2009 & Hindustan Zinc Limited & $\begin{array}{l}\text { Wind power project by HZL in } \\
\text { Karnataka. }\end{array}$ & SIM & \begin{tabular}{|l} 
Produção energética - \\
geradores eólicos
\end{tabular} & SIM & 1 & $\begin{array}{l}\text { Indústrias energéticas (fontes } \\
\text { renováveis - / não-renováveis) }\end{array}$ & Larga \\
\hline Índia & 1856 & 2009 & Hindustan Zinc Limited & $\begin{array}{l}\text { Wind power project by HZL in } \\
\text { Gujarat. }\end{array}$ & SIM & \begin{tabular}{|l} 
Produção energética - \\
geradores eólicos
\end{tabular} & SIM & 1 & $\begin{array}{l}\text { Indústrias energéticas (fontes } \\
\text { renováveis - / não-renováveis) }\end{array}$ & Larga \\
\hline Índia & 7873 & 2012 & Hindustan Zinc Limited & $\begin{array}{l}\text { 27.3 MW Wind energy farm at } \\
\text { Mokla Rajasthan by HZL }\end{array}$ & NÃO & \begin{tabular}{|l} 
Produção energética - \\
geradores eólicos
\end{tabular} & SIM & 1 & $\begin{array}{l}\text { Indústrias energéticas (fontes } \\
\text { renováveis - / não-renováveis) }\end{array}$ & Larga \\
\hline Índia & 7895 & 2012 & Hindustan Zinc Limited & $\begin{array}{l}52.50 \text { MW Wind energy farm at } \\
\text { Mokla Rajasthan by HZL }\end{array}$ & NÃO & $\begin{array}{l}\text { Produção energética - } \\
\text { geradores eólicos }\end{array}$ & SIM & 1 & $\begin{array}{l}\text { Indústrias energéticas (fontes } \\
\text { renováveis - / não-renováveis) }\end{array}$ & Larga \\
\hline Índia & 7981 & 2012 & Hindustan Zinc Limited & $\begin{array}{l}25.5 \text { MW Wind Energy Farm at } \\
\text { Nandurbar Maharashtra by HZL }\end{array}$ & NÃO & \begin{tabular}{|l} 
Produção energética - \\
geradores eólicos
\end{tabular} & SIM & 1 & $\begin{array}{l}\text { Indústrias energéticas (fontes } \\
\text { renováveis - / não-renováveis) }\end{array}$ & Larga \\
\hline Índia & 8198 & 2012 & Hindustan Zinc Limited & $\begin{array}{l}21 \mathrm{MW} \text { Wind energy farm at } \\
\text { Palladam, TamilNadu by HZL }\end{array}$ & NÃO & $\begin{array}{l}\text { Produção energética - } \\
\text { geradores eólicos }\end{array}$ & SIM & 1 & $\begin{array}{l}\text { Indústrias energéticas (fontes } \\
\text { renováveis - / não-renováveis) }\end{array}$ & Larga \\
\hline Índia & 8303 & 2012 & Hindustan Zinc Limited & $\begin{array}{l}15 \mathrm{MW} \text { Wind energy farm at } \\
\text { Gopalpura, Karnataka by HZL }\end{array}$ & NÃO & $\begin{array}{l}\text { Produção energética - } \\
\text { geradores eólicos }\end{array}$ & SIM & 1 & $\begin{array}{l}\text { Indústrias energéticas (fontes } \\
\text { renováveis - / não-renováveis) }\end{array}$ & Pequena \\
\hline Índia & 3964 & 2011 & I.C.S.A. India Limited & $\begin{array}{l}\text { Wind power project by ICSA } \\
\text { India Ltd. }\end{array}$ & NÃO & $\begin{array}{l}\text { Produção energética - } \\
\text { geradores eólicos }\end{array}$ & NÃO & 1 & $\begin{array}{l}\text { Indústrias energéticas (fontes } \\
\text { renováveis - / não-renováveis) }\end{array}$ & Pequena \\
\hline Índia & 717 & 2007 & India Cements Limited & India Cements WHR project & SIM & Produção energética - & NÃO & 1 e 4 & $\begin{array}{l}\text { Indústrias energéticas (fontes } \\
\text { renováveis - / não-renováveis) }\end{array}$ & Larga \\
\hline
\end{tabular}




\begin{tabular}{|c|c|c|c|c|c|c|c|c|c|c|}
\hline & & & & & & indústria de cimento & & & / Transformação industrial & \\
\hline Índia & 3763 & 2010 & India Glycols Limited & $\begin{array}{l}\text { Biomass based Cogeneration } \\
\text { Project activity taken up by } \\
\text { India Glycols Limited at } \\
\text { Gorakhpur, U.P. } \\
\end{array}$ & NÃO & $\begin{array}{l}\text { Produção energética - casca } \\
\text { de arroz }\end{array}$ & NÃO & 1 & $\begin{array}{l}\text { Indústrias energéticas (fontes } \\
\text { renováveis - / não-renováveis) }\end{array}$ & Larga \\
\hline Índia & 348 & 2007 & Indian Acrylics Limited & $\begin{array}{l}\text { Cogeneration system based on } \\
\text { biomass (rice-husk) replacing oil } \\
\text { fired boiler for process steam } \\
\text { and generating power for partly } \\
\text { replacement of grid power } \\
\text { supply to the plant at M/s Indian } \\
\text { Acrylics Ltd., District Sangrur, } \\
\text { Punjab, India. }\end{array}$ & SIM & $\begin{array}{l}\text { Produção energética - casca } \\
\text { de arroz }\end{array}$ & NÃO & 1 & $\begin{array}{l}\text { Indústrias energéticas (fontes } \\
\text { renováveis - / não-renováveis) }\end{array}$ & Pequena \\
\hline Índia & 793 & 2007 & Indian Sucrose Limited & $\begin{array}{l}\text { Energy efficiency improvement } \\
\text { project at ISL }\end{array}$ & NÃO & Produção energética - bagaço & NÃO & 1 & $\begin{array}{l}\text { Indústrias energéticas (fontes } \\
\text { renováveis - / não-renováveis) }\end{array}$ & Larga \\
\hline Índia & 277 & 2006 & Indowind Energy Limited & $\begin{array}{l}\text { 12.3 MW wind energy project in } \\
\text { Tamil Nadu, India }\end{array}$ & SIM & $\begin{array}{l}\text { Produção energética - } \\
\text { geradores eólicos }\end{array}$ & SIM & 1 & $\begin{array}{l}\text { Indústrias energéticas (fontes } \\
\text { renováveis - / não-renováveis) }\end{array}$ & Pequena \\
\hline Índia & 4740 & 2011 & Indowind Energy Limited & $\begin{array}{l}18 \mathrm{MW} \text { Wind energy project by } \\
\text { Indowind Energy Ltd }\end{array}$ & NÃO & $\begin{array}{l}\text { Produção energética - } \\
\text { geradores eólicos }\end{array}$ & SIM & 1 & $\begin{array}{l}\text { Indústrias energéticas (fontes } \\
\text { renováveis - / não-renováveis) }\end{array}$ & Larga \\
\hline Índia & 686 & 2006 & ITC Limited & $\begin{array}{l}\text { Improvement in Energy } \\
\text { Consumption of a Hotel }\end{array}$ & SIM & $\begin{array}{l}\text { Eficiência energética - } \\
\text { edifícios }\end{array}$ & NÃO & 1 e 3 & $\begin{array}{l}\text { Indústrias energéticas (fontes } \\
\text { renováveis - / não-renováveis) } \\
\text { / Demanda energética }\end{array}$ & Pequena \\
\hline Índia & 677 & 2006 & ITC Limited & $\begin{array}{l}\text { Optimization of steam } \\
\text { consumption by applying retrofit } \\
\text { measures in blow heat recovery } \\
\text { system }\end{array}$ & SIM & $\begin{array}{l}\text { Produção energética - papel e } \\
\text { celulose }\end{array}$ & NÃO & 3 & Demanda energética & Larga \\
\hline Índia & 745 & 2006 & ITC Limited & $\begin{array}{l}\text { Demand side energy } \\
\text { conservation and reduction } \\
\text { measures at ITC Tribeni Unit }\end{array}$ & SIM & $\begin{array}{l}\text { Produção energética - papel e } \\
\text { celulose }\end{array}$ & NÃO & $1 \mathrm{e} 4$ & $\begin{array}{l}\text { Indústrias energéticas (fontes } \\
\text { renováveis - / não-renováveis) } \\
\text { / Transformação industrial }\end{array}$ & Pequena \\
\hline Índia & 679 & 2007 & ITC Limited & $\begin{array}{l}\text { Optimization of steam } \\
\text { consumption at the evaporator }\end{array}$ & SIM & $\begin{array}{l}\text { Produção energética - papel e } \\
\text { celulose }\end{array}$ & NÃO & 3 & Demanda energética & Larga \\
\hline Índia & 821 & 2007 & ITC Limited & $\begin{array}{l}\text { Efficiency improvement of } \\
\text { Turbine Generator to reduce } \\
\text { fossil fuel consumption in the } \\
\text { Coal fired boiler system } \\
\end{array}$ & SIM & $\begin{array}{l}\text { Transformação industrial - } \\
\text { substituição de combustíveis } \\
\text { fósseis }\end{array}$ & NÃO & 1 & $\begin{array}{l}\text { Indústrias energéticas (fontes } \\
\text { renováveis - / não-renováveis) }\end{array}$ & Pequena \\
\hline Índia & 806 & 2007 & ITC Limited & $\begin{array}{l}\text { Demand side energy efficiency } \\
\text { programmes for specific } \\
\text { technologies at ITC }\end{array}$ & SIM & $\begin{array}{l}\text { Produção energética - papel e } \\
\text { celulose }\end{array}$ & NÃO & $1 \mathrm{e} 4$ & $\begin{array}{l}\text { Indústrias energéticas (fontes } \\
\text { renováveis - / não-renováveis) }\end{array}$ & Pequena \\
\hline
\end{tabular}




\begin{tabular}{|c|c|c|c|c|c|c|c|c|c|c|}
\hline & & & & $\begin{array}{l}\text { Bhadrachalam pulp and paper } \\
\text { making facility in India }\end{array}$ & & & & & / Transformação industrial & \\
\hline Índia & 890 & 2007 & ITC Limited & $\begin{array}{l}\text { Efficient use of industrial } \\
\text { biomass residue for thermal } \\
\text { energy generation }\end{array}$ & SIM & $\begin{array}{l}\text { Produção energética - papel e } \\
\text { celulose }\end{array}$ & NÃO & 1 & $\begin{array}{l}\text { Indústrias energéticas (fontes } \\
\text { renováveis - / não-renováveis) }\end{array}$ & Larga \\
\hline Índia & 2241 & 2009 & ITC Limited & $\begin{array}{l}\text { Reforestation of severely } \\
\text { degraded landmass in } \\
\text { Khammam District of Andhra } \\
\text { Pradesh, India under ITC Social } \\
\text { Forestry Project }\end{array}$ & NÃO & $\begin{array}{l}\text { Atividades de } \\
\text { reflorestamentos - terras } \\
\text { degradadas }\end{array}$ & NÃO & 14 & $\begin{array}{l}\text { Florestamento e } \\
\text { reflorestamento }\end{array}$ & Larga \\
\hline Índia & 3035 & 2010 & ITC Limited & $\begin{array}{l}\text { 14.1 MW grid connected wind } \\
\text { energy project in Tamilnadu by } \\
\text { ITC Limited }\end{array}$ & SIM & $\begin{array}{l}\begin{array}{l}\text { Produção energética - } \\
\text { geradores eólicos }\end{array} \\
\end{array}$ & SIM & 1 & $\begin{array}{l}\text { Indústrias energéticas (fontes } \\
\text { renováveis - / não-renováveis) }\end{array}$ & Pequena \\
\hline Índia & 3890 & 2011 & ITC Limited & $\begin{array}{l}\text { Fuel switch from fossil fuel to } \\
\text { biomass residues for } \\
\text { cogeneration in integrated pulp } \\
\text { and paper unit of ITC PSPD at } \\
\text { Bhadrachalam }\end{array}$ & NÃO & $\begin{array}{l}\text { Produção energética - } \\
\text { resíduos florestais }\end{array}$ & NÃO & $1 \mathrm{e} 4$ & $\begin{array}{l}\text { Indústrias energéticas (fontes } \\
\text { renováveis - / não-renováveis) } \\
\text { / Transformação industrial }\end{array}$ & Larga \\
\hline Índia & 433 & 2006 & Jai Balaji Industries Limited & $\begin{array}{l}\text { JBSL-Waste Heat Recovery } \\
\text { Based Captive Power Project }\end{array}$ & SIM & $\begin{array}{l}\text { Produção energética - gases } \\
\text { industriais }\end{array}$ & NÃO & 1 & $\begin{array}{l}\text { Indústrias energéticas (fontes } \\
\text { renováveis - / não-renováveis) }\end{array}$ & Larga \\
\hline Índia & 7186 & 2012 & Jain Irrigation Systems Limited & $\begin{array}{l}\text { Improvement in Energy } \\
\text { Efficiency through Micro- } \\
\text { Irrigation Systems (MIS) in } \\
\text { cultivation of Banana Crop in } \\
\text { Jalgaon, Dhule Nadurbar and } \\
\text { Nashik districts, Maharastra } \\
\text { State, India }\end{array}$ & NÃO & $\begin{array}{l}\text { Eficiência energética - } \\
\text { substituição de conbustíveis } \\
\text { agrícolas }\end{array}$ & NÃO & 3 & Demanda energética & Pequena \\
\hline Índia & 8079 & 2012 & Jain Irrigation Systems Limited & $\begin{array}{l}\text { 13.2 MW Wind Mill Power } \\
\text { Project in Theni district of Tamil } \\
\text { Nadu, by JISL-India }\end{array}$ & NÃO & $\begin{array}{l}\text { Produção energética - } \\
\text { geradores eólicos }\end{array}$ & NÃO & 1 & $\begin{array}{l}\text { Indústrias energéticas (fontes } \\
\text { renováveis - / não-renováveis) }\end{array}$ & Pequena \\
\hline Índia & 8464 & 2012 & Jain Irrigation Systems Limited & $\begin{array}{l}\text { Solar Photovoltaic Power } \\
\text { Project at Jalgaon, Maharashtra }\end{array}$ & NÃO & $\begin{array}{l}\text { Produção energética - } \\
\text { geradores solares }\end{array}$ & SIM & 1 & $\begin{array}{l}\text { Indústrias energéticas (fontes } \\
\text { renováveis - / não-renováveis) }\end{array}$ & Pequena \\
\hline Índia & 8958 & 2012 & Jain Irrigation Systems Limited & $\begin{array}{l}\text { Fuel Switch Project at Chittoor } \\
\text { by Jain Irrigation Systems } \\
\text { Limited }\end{array}$ & NÃO & $\begin{array}{l}\text { Produção energética - outros } \\
\text { resíduos industriais }\end{array}$ & NÃO & 1 & $\begin{array}{l}\text { Indústrias energéticas (fontes } \\
\text { renováveis - / não-renováveis) }\end{array}$ & Pequena \\
\hline Índia & 510 & 2006 & Jaiprakash Associates Limited & $\begin{array}{l}\text { Methane Avoidance by } \\
\text { Municipal Solid Waste } \\
\text { Processing in the city of } \\
\text { Chandigarh, India }\end{array}$ & NÃO & $\begin{array}{l}\text { Produção energétia - resíduos } \\
\text { sólidos urbanos }\end{array}$ & NÃO & 13 e 15 & $\begin{array}{l}\text { Tratamento e eliminação de } \\
\text { resíduos / Agricultura }\end{array}$ & Pequena \\
\hline Índia & 3683 & 2010 & $\begin{array}{l}\text { Jayaswal Neco Industries } \\
\text { Limited }\end{array}$ & $\begin{array}{l}\text { Energy efficiency improvement } \\
\text { in the Electric Arc Furnace }\end{array}$ & NÃO & $\begin{array}{l}\text { Produção energética - gases } \\
\text { industriais }\end{array}$ & NÃO & 4 & Transformação industrial & Pequena \\
\hline Índia & 1287 & 2007 & Jindal Saw Limited & $\begin{array}{l}\text { Non-recovery type coke oven } \\
\text { exhaust gas heat recovery power } \\
\text { project at Mundra }\end{array}$ & SIM & $\begin{array}{l}\text { Produção energética - gases } \\
\text { industriais }\end{array}$ & NÃO & 1 & $\begin{array}{l}\text { Indústrias energéticas (fontes } \\
\text { renováveis - / não-renováveis) }\end{array}$ & Larga \\
\hline
\end{tabular}




\begin{tabular}{|c|c|c|c|c|c|c|c|c|c|c|}
\hline Índia & 1324 & 2008 & Jindal Stainless Limited & $\begin{array}{l}\text { Power generation from waste } \\
\text { heat of submerged arc furnaces }\end{array}$ & NÃO & $\begin{array}{l}\text { Produção energética - gases } \\
\text { industriais }\end{array}$ & NÃO & 1 & $\begin{array}{l}\text { Indústrias energéticas (fontes } \\
\text { renováveis - / não-renováveis) }\end{array}$ & Larga \\
\hline Índia & 351 & 2006 & Jindal Steel \& Power Limited & $\begin{array}{l}\text { Power generation from waste } \\
\text { heat of non-recovery } \\
\text { type coke ovens at JSPL }\end{array}$ & NÃO & $\begin{array}{l}\text { Produção energética - gases } \\
\text { industriais }\end{array}$ & NÃO & 1 & $\begin{array}{l}\text { Indústrias energéticas (fontes } \\
\text { renováveis - / não-renováveis) }\end{array}$ & Larga \\
\hline Índia & 5864 & 2012 & Jindal Steel \& Power Limited & $\begin{array}{l}\text { Wind Power Project at Satara in } \\
\text { Maharashtra, India }\end{array}$ & NÃO & \begin{tabular}{|l|}
$\begin{array}{l}\text { Produção energética - } \\
\text { geradores eólicos }\end{array}$ \\
\end{tabular} & NÃO & 1 & $\begin{array}{l}\text { Indústrias energéticas (fontes } \\
\text { renováveis - / não-renováveis) }\end{array}$ & Larga \\
\hline Índia & 2562 & 2009 & Jocil Limited & $\begin{array}{l}\text { Bundled Wind Power Project in } \\
\text { Tirunelveli, Tamil Nadu }\end{array}$ & SIM & \begin{tabular}{|l|} 
Produção energética - \\
geradores eólicos
\end{tabular} & SIM & 1 & $\begin{array}{l}\text { Indústrias energéticas (fontes } \\
\text { renováveis - / não-renováveis) }\end{array}$ & Pequena \\
\hline Índia & 350 & 2007 & JSW Energy Limited & $\begin{array}{l}\text { Use of waste gas use for } \\
\text { electricity generation at JSW } \\
\text { Energy Limited }\end{array}$ & SIM & $\begin{array}{l}\text { Produção energética - gases } \\
\text { industriais }\end{array}$ & NÃO & 1 & $\begin{array}{l}\text { Indústrias energéticas (fontes } \\
\text { renováveis - / não-renováveis) }\end{array}$ & Larga \\
\hline Índia & 8009 & 2012 & JSW Energy Limited & $\begin{array}{l}\text { Installation of } 240 \text { MW } \\
\text { Hydroelectric Project at Kutehr } \\
\text { in the Chamba district of } \\
\text { Himachal Pradesh by JSW } \\
\text { Energy }\end{array}$ & NÃO & Produção energética - águas & NÃO & 1 & $\begin{array}{l}\text { Indústrias energéticas (fontes } \\
\text { renováveis - / não-renováveis) }\end{array}$ & Larga \\
\hline Índia & 325 & 2007 & JSW Steel Limited & $\begin{array}{l}\text { Generation of Electricity } \\
\text { through combustion of waste } \\
\text { gases from Blast furnace and } \\
\text { Corex units at JSW Steel } \\
\text { Limited (in JPL unit 1), at } \\
\text { Torangallu in Karnataka, India } \\
\end{array}$ & SIM & $\begin{array}{l}\text { Produção energética - gases } \\
\text { industriais }\end{array}$ & NÃO & 1 & $\begin{array}{l}\text { Indústrias energéticas (fontes } \\
\text { renováveis - / não-renováveis) }\end{array}$ & Larga \\
\hline Índia & 915 & 2007 & K M Sugar Mills Limited & KM RE project & SIM & Produção energética - bagaço & NÃO & 1 & $\begin{array}{l}\text { Indústrias energéticas (fontes } \\
\text { renováveis - / não-renováveis) }\end{array}$ & Larga \\
\hline Índia & 4540 & 2011 & K.P.R. Mill Limited & $\begin{array}{l}\text { 19.8MW grid connected Wind } \\
\text { farm project by K.P.R Mill } \\
\text { Private Limited, Tamil Nadu, } \\
\text { India }\end{array}$ & NÃO & $\begin{array}{l}\text { Produção energética - } \\
\text { geradores eólicos }\end{array}$ & NÃO & 1 & $\begin{array}{l}\text { Indústrias energéticas (fontes } \\
\text { renováveis - / não-renováveis) }\end{array}$ & Larga \\
\hline Índia & 2266 & 2009 & K.S. Oils Limited & $\begin{array}{l}\text { 8.5 MW Wind Energy Project } \\
\text { By KS Oils Ltd }\end{array}$ & SIM & $\begin{array}{l}\text { Produção energética - } \\
\text { geradores eólicos }\end{array}$ & NÃO & 1 & $\begin{array}{l}\text { Indústrias energéticas (fontes } \\
\text { renováveis - / não-renováveis) }\end{array}$ & Pequena \\
\hline Índia & 2958 & 2010 & K.S. Oils Limited & $\begin{array}{l}8 \mathrm{MW} \text { wind power plant by K.S } \\
\text { Oils Limited }\end{array}$ & NÃO & \begin{tabular}{|l|}
$\begin{array}{l}\text { Produção energética - } \\
\text { geradores eólicos }\end{array}$ \\
\end{tabular} & SIM & 1 & $\begin{array}{l}\text { Indústrias energéticas (fontes } \\
\text { renováveis - / não-renováveis) }\end{array}$ & Pequena \\
\hline Índia & 3946 & 2011 & K.S. Oils Limited & $\begin{array}{l}\text { 7.5 MW Wind Power project in } \\
\text { Jodhpur, Rajasthan }\end{array}$ & NÃO & $\begin{array}{l}\text { Produção energética - } \\
\text { geradores eólicos }\end{array}$ & NÃO & 1 & $\begin{array}{l}\text { Indústrias energéticas (fontes } \\
\text { renováveis - / não-renováveis) }\end{array}$ & Pequena \\
\hline Índia & 4578 & 2011 & K.S. Oils Limited & $\begin{array}{l}\text { KS Oils Wind Power Project in } \\
\text { Tamil Nadu }\end{array}$ & NÃO & $\begin{array}{l}\text { Produção energética - } \\
\text { geradores eólicos }\end{array}$ & NÃO & 1 & $\begin{array}{l}\text { Indústrias energéticas (fontes } \\
\text { renováveis - / não-renováveis) }\end{array}$ & Pequena \\
\hline
\end{tabular}




\begin{tabular}{|c|c|c|c|c|c|c|c|c|c|c|}
\hline Índia & 6930 & 2012 & K.S. Oils Limited & $\begin{array}{l}\text { Grid connected wind Power } \\
\text { Project in Jodhpur, Rajasthan }\end{array}$ & NÃO & $\begin{array}{l}\text { Produção energética - } \\
\text { geradores eólicos }\end{array}$ & NÃO & 1 & $\begin{array}{l}\text { Indústrias energéticas (fontes } \\
\text { renováveis - / não-renováveis) }\end{array}$ & Pequena \\
\hline Índia & 427 & 2006 & Kalyani Steels Limited & $\begin{array}{l}\text { Electricity generation at } 8 \mathrm{MW} \\
\text { captive power plant using } \\
\text { enthalpy of flue gases from blast } \\
\text { furnace operations of Kalyani } \\
\text { Steels Limited, in Karnataka } \\
\text { state of India }\end{array}$ & SIM & $\begin{array}{l}\text { Produção energética - gases } \\
\text { industriais }\end{array}$ & NÃO & 1 & $\begin{array}{l}\text { Indústrias energéticas (fontes } \\
\text { renováveis - / não-renováveis) }\end{array}$ & Larga \\
\hline Índia & 7620 & 2012 & Kamdhenu Ispat Limited & $\begin{array}{l}\text { GHG mitigation through wind } \\
\text { energy program in India }\end{array}$ & NÃO & $\begin{array}{l}\text { Produção energética - } \\
\text { geradores eólicos }\end{array}$ & SIM & 1 & $\begin{array}{l}\text { Indústrias energéticas (fontes } \\
\text { renováveis - / não-renováveis) }\end{array}$ & Pequena \\
\hline Índia & 1472 & 2008 & $\begin{array}{l}\text { KCP Sugar and Industries } \\
\text { Corporation Limited }\end{array}$ & $\begin{array}{l}\text { Surplus power generation for } \\
\text { grid at Vayyuru, Andhra Pradesh }\end{array}$ & NÃO & Produção energética - bagaço & NÃO & 1 & $\begin{array}{l}\text { Indústrias energéticas (fontes } \\
\text { renováveis - / não-renováveis) }\end{array}$ & Larga \\
\hline Índia & 1571 & 2008 & $\begin{array}{l}\text { KCP Sugar and Industries } \\
\text { Corporation Limited }\end{array}$ & $\begin{array}{l}\text { Capacity enhancement for } \\
\text { export of surplus power to grid } \\
\text { at Lakshmipuram, Andhra } \\
\text { Pradesh, India }\end{array}$ & NÃO & Produção energética - bagaço & NÃO & 1 & $\begin{array}{l}\text { Indústrias energéticas (fontes } \\
\text { renováveis - / não-renováveis) }\end{array}$ & Larga \\
\hline Índia & 262 & 2006 & Kesoram Industries Limited & $\begin{array}{l}\text { Energy efficiency projects- } \\
\text { Steam system upgradation at the } \\
\text { manufacturing unit of Birla } \\
\text { tyres. }\end{array}$ & NÃO & $\begin{array}{l}\text { Produção energética - planta } \\
\text { industrial petroquímica }\end{array}$ & NÃO & 4 & Transformação industrial & Pequena \\
\hline Índia & 1690 & 2009 & Kilburn Chemicals Limited & $\begin{array}{l}\text { Installation of Wind power } \\
\text { project by Kilburn Chemicals } \\
\text { Ltd }\end{array}$ & NÃO & $\begin{array}{l}\text { Produção energética - } \\
\text { geradores eólicos }\end{array}$ & NÃO & 1 & $\begin{array}{l}\text { Indústrias energéticas (fontes } \\
\text { renováveis - / não-renováveis) }\end{array}$ & Pequena \\
\hline Índia & 9398 & 2012 & Kilburn Chemicals Limited & $\begin{array}{l}1.5 \mathrm{MW} \text { Wind Power CDM } \\
\text { Project by M/s.Kilburn } \\
\text { Chemicals Limited, Tamilnadu, } \\
\text { India (Renewable Energy Wind) }\end{array}$ & NÃO & $\begin{array}{l}\text { Produção energética - } \\
\text { geradores eólicos }\end{array}$ & NÃO & 1 & $\begin{array}{l}\text { Indústrias energéticas (fontes } \\
\text { renováveis - / não-renováveis) }\end{array}$ & Pequena \\
\hline Índia & 1551 & 2008 & KRBL Limited & $\begin{array}{l}\text { Rice husk based Co generation } \\
\text { project at Dujana unit of KRBL } \\
\text { Limited }\end{array}$ & SIM & $\begin{array}{l}\text { Produção energética - casca } \\
\text { de arroz }\end{array}$ & NÃO & 1 & $\begin{array}{l}\text { Indústrias energéticas (fontes } \\
\text { renováveis - / não-renováveis) }\end{array}$ & Pequena \\
\hline Índia & 2894 & 2009 & KRBL Limited & $\begin{array}{l}12.5 \text { MW Small Scale Grid } \\
\text { Connected "Wind Electricity } \\
\text { Generation Project" by KRBL } \\
\text { Ltd., District Dhule, } \\
\text { Maharashtra, India } \\
\end{array}$ & SIM & $\begin{array}{l}\text { Produção energética - } \\
\text { geradores eólicos }\end{array}$ & NÃO & 1 & $\begin{array}{l}\text { Indústrias energéticas (fontes } \\
\text { renováveis - / não-renováveis) }\end{array}$ & Pequena \\
\hline Índia & 9250 & 2012 & KRBL Limited & $\begin{array}{l}\text { Generation of electricity from } \\
4 \times 1.5 \text { MW capacity Wind Mills } \\
\text { by KRBL Ltd. at Ratan Ka Bas } \\
\text { site, Jodhpur district, Rajasthan, } \\
\text { India }\end{array}$ & NÃO & $\begin{array}{l}\text { Produção energética - } \\
\text { geradores eólicos }\end{array}$ & NÃO & 1 & $\begin{array}{l}\text { Indústrias energéticas (fontes } \\
\text { renováveis - / não-renováveis) }\end{array}$ & Pequena \\
\hline Índia & 1308 & 2007 & Lanco Infratech Limited & $\begin{array}{l}3 \mathrm{MW} \text { Wind Power Project at } \\
\text { Chikkasiddavanahalli village, } \\
\text { Chitradurga district, Karnataka } \\
\end{array}$ & NÃO & $\begin{array}{l}\text { Produção energética - } \\
\text { geradores eólicos }\end{array}$ & NÃO & 1 & $\begin{array}{l}\text { Indústrias energéticas (fontes } \\
\text { renováveis - / não-renováveis) }\end{array}$ & Pequena \\
\hline Índia & 960 & 2007 & Lanco Infratech Limited & $\begin{array}{l}2 \text { X } 5 \text { MW Upper khauli \& } \\
\text { Drinidhar small hydroelectric }\end{array}$ & NÃO & Produção energética - águas & NÃO & 1 & Indústrias energéticas (fontes & Pequena \\
\hline
\end{tabular}




\begin{tabular}{|c|c|c|c|c|c|c|c|c|c|c|}
\hline & & & & $\begin{array}{l}\text { project for a grid system, } \\
\text { Himachal Pradesh }\end{array}$ & & & & & renováveis - / não-renováveis) & \\
\hline Índia & 1573 & 2008 & Lanco Infratech Limited & $\begin{array}{l}\text { LITL's Wind Project at Tamil } \\
\text { Nadu }\end{array}$ & NÃO & $\begin{array}{l}\text { Produção energética - } \\
\text { geradores eólicos }\end{array}$ & SIM & 1 & $\begin{array}{l}\text { Indústrias energéticas (fontes } \\
\text { renováveis - / não-renováveis) }\end{array}$ & Pequena \\
\hline Índia & 8689 & 2012 & Lanco Infratech Limited & $\begin{array}{l}\text { Bundled Solar Photovoltic } \\
\text { Power project at Chadiyana, } \\
\text { Patan District in Gujarat }\end{array}$ & NÃO & \begin{tabular}{|l|} 
Produção energética - \\
geradores solares
\end{tabular} & SIM & 1 & $\begin{array}{l}\text { Indústrias energéticas (fontes } \\
\text { renováveis - / não-renováveis) }\end{array}$ & Pequena \\
\hline Índia & 9403 & 2012 & M and B Switchgears Limited & $\begin{array}{l}\text { Solar Power Project by M AND } \\
\text { B Switchgears Limited }\end{array}$ & NÃO & $\begin{array}{l}\text { Produção energética - } \\
\text { geradores solares }\end{array}$ & SIM & 1 & $\begin{array}{l}\text { Indústrias energéticas (fontes } \\
\text { renováveis - / não-renováveis) }\end{array}$ & Pequena \\
\hline Índia & 7647 & 2012 & Madras Cements Limited & $\begin{array}{l}74 \mathrm{MW} \text { wind energy project in } \\
\text { Tamilnadu, India }\end{array}$ & NÃO & $\begin{array}{l}\text { Produção energética - } \\
\text { geradores eólicos }\end{array}$ & NÃO & 1 & $\begin{array}{l}\text { Indústrias energéticas (fontes } \\
\text { renováveis - / não-renováveis) }\end{array}$ & Larga \\
\hline Índia & 3973 & 2010 & Magma Fincorp Limited & $\begin{array}{l}\text { Environmental Friendly Power } \\
\text { Generation }\end{array}$ & NÃO & $\begin{array}{l}\text { Produção energética - } \\
\text { geradores eólicos }\end{array}$ & NÃO & 1 & $\begin{array}{l}\text { Indústrias energéticas (fontes } \\
\text { renováveis - / não-renováveis) }\end{array}$ & Pequena \\
\hline Índia & 4879 & 2011 & Magma Fincorp Limited & $\begin{array}{l}\text { Bundled green power supply to } \\
\text { grid }\end{array}$ & NÃO & \begin{tabular}{|l|} 
Produção energética - \\
geradores eólicos
\end{tabular} & NÃO & 1 & $\begin{array}{l}\text { Indústrias energéticas (fontes } \\
\text { renováveis - / não-renováveis) }\end{array}$ & Pequena \\
\hline Índia & 1579 & 2008 & Mahalaxmi Rubtech Limited & $\begin{array}{l}\text { Renewable biomass based } \\
\text { thermal energy generation at } \\
\text { Mahalaxmi Group of } \\
\text { Companies, Ahmedabad }\end{array}$ & NÃO & $\begin{array}{l}\text { Produção energética - outros } \\
\text { resíduos agrícolas }\end{array}$ & SIM & 1 & $\begin{array}{l}\text { Indústrias energéticas (fontes } \\
\text { renováveis - / não-renováveis) }\end{array}$ & Pequena \\
\hline Índia & 8792 & 2012 & Mahalaxmi Rubtech Limited & $\begin{array}{l}\text { 8.45 MW bundled wind energy } \\
\text { project in Gujarat }\end{array}$ & NÃO & \begin{tabular}{|l|} 
Produção energética - \\
geradores eólicos
\end{tabular} & NÃO & 1 & $\begin{array}{l}\text { Indústrias energéticas (fontes } \\
\text { renováveis - / não-renováveis) }\end{array}$ & Pequena \\
\hline Índia & 1568 & 2008 & Malu Paper Mills Limited & $\begin{array}{l}6 \text { MW Biomass residue based } \\
\text { cogeneration unit by MPML at } \\
\text { Village Heti (Surla), District } \\
\text { Nagpur in Maharashtra, India } \\
\end{array}$ & SIM & $\begin{array}{l}\text { Produção energética - casca } \\
\text { de arroz }\end{array}$ & NÃO & 1 & $\begin{array}{l}\text { Indústrias energéticas (fontes } \\
\text { renováveis - / não-renováveis) }\end{array}$ & Pequena \\
\hline Índia & 5184 & 2011 & Man Industries India Limited & $\begin{array}{l}7 \mathrm{MW} \text { Wind Power Project of } \\
\text { Man Industries at Kutch, Gujarat }\end{array}$ & NÃO & \begin{tabular}{|l|} 
Produção energética - \\
geradores eólicos
\end{tabular} & NÃO & 1 & $\begin{array}{l}\text { Indústrias energéticas (fontes } \\
\text { renováveis - / não-renováveis) }\end{array}$ & Pequena \\
\hline Índia & 4481 & 2011 & Mangalam Cement Limited & $\begin{array}{l}\text { 6.15 MW wind power project in } \\
\text { Rajasthan, India }\end{array}$ & NÃO & \begin{tabular}{|l|} 
Produção energética - \\
geradores eólicos
\end{tabular} & NÃO & 1 & $\begin{array}{l}\text { Indústrias energéticas (fontes } \\
\text { renováveis - / não-renováveis) }\end{array}$ & Pequena \\
\hline Índia & 5576 & 2011 & Mangalam Cement Limited & $\begin{array}{l}7.5 \mathrm{MW} \text { wind power project at } \\
\text { Jaisalmer, India }\end{array}$ & NÃO & \begin{tabular}{|l|} 
Produção energética - \\
geradores eólicos
\end{tabular} & NÃO & 1 & $\begin{array}{l}\text { Indústrias energéticas (fontes } \\
\text { renováveis - / não-renováveis) }\end{array}$ & Pequena \\
\hline Índia & 5016 & 2011 & $\begin{array}{l}\text { Mangalam Timber Products } \\
\text { Limited }\end{array}$ & $\begin{array}{l}\text { Reforestation of degraded land } \\
\text { by MTPL in India }\end{array}$ & NÃO & \begin{tabular}{|l} 
Atividades de \\
reflorestamentos - terras \\
degradadas
\end{tabular} & NÃO & 14 & $\begin{array}{l}\text { Florestamento e } \\
\text { reflorestamento }\end{array}$ & Larga \\
\hline
\end{tabular}




\begin{tabular}{|c|c|c|c|c|c|c|c|c|c|c|}
\hline Índia & 4066 & 2011 & Maruti Suzuki India Limited & $\begin{array}{l}\text { Modal Shift from Road to Train } \\
\text { for transportation of cars }\end{array}$ & NÃO & $\begin{array}{l}\text { Transporte - rodovia para } \\
\text { ferrovia }\end{array}$ & NÃO & 7 & Transporte & Pequena \\
\hline Índia & 6011 & 2012 & Maruti Suzuki India Limited & $\begin{array}{l}\text { Combined cycle electricity } \\
\text { generation activity at Gurgaon, } \\
\text { India }\end{array}$ & NÃO & Produção energética - outros & NÃO & 3 & Demanda energética & Pequena \\
\hline Índia & 803 & 2007 & Mawana Sugars Limited & $\begin{array}{l}\text { Bagasse based Co-generation } \\
\text { Project at Titawi Sugar Complex }\end{array}$ & SIM & Produção energética - bagaço & NÃO & 1 & $\begin{array}{l}\text { Indústrias energéticas (fontes } \\
\text { renováveis - / não-renováveis) }\end{array}$ & Larga \\
\hline Índia & 804 & 2007 & Mawana Sugars Limited & $\begin{array}{l}\text { Bagasse based Co-generation } \\
\text { Project at Nanglamal Sugar } \\
\text { Complex. }\end{array}$ & SIM & Produção energética - bagaço & NÃO & 1 & $\begin{array}{l}\text { Indústrias energéticas (fontes } \\
\text { renováveis - / não-renováveis) }\end{array}$ & Larga \\
\hline Índia & 805 & 2007 & Mawana Sugars Limited & $\begin{array}{l}\text { Bagasse based Co-generation } \\
\text { Project at Mawana Sugar Works }\end{array}$ & SIM & Produção energética - bagaço & NÃO & 1 & $\begin{array}{l}\text { Indústrias energéticas (fontes } \\
\text { renováveis - / não-renováveis) }\end{array}$ & Larga \\
\hline Índia & 813 & 2007 & Mawana Sugars Limited & $\begin{array}{l}\text { Installation of co-generation } \\
\text { project at sugar manufacturing } \\
\text { unit of Mawana Sugars Limited }\end{array}$ & SIM & Produção energética - bagaço & NÃO & 1 & $\begin{array}{l}\text { Indústrias energéticas (fontes } \\
\text { renováveis - / não-renováveis) }\end{array}$ & Larga \\
\hline Índia & 1233 & 2008 & Mawana Sugars Limited & $\begin{array}{l}6 \text { MW bagasse based } \\
\text { cogeneration plant for electricity } \\
\text { generation for grid supply at } \\
\text { Mawana Sugars Limited (MSL) } \\
\text { at Mawana in Uttar Pradesh. } \\
\end{array}$ & SIM & Produção energética - bagaço & NÃO & 1 & $\begin{array}{l}\text { Indústrias energéticas (fontes } \\
\text { renováveis - / não-renováveis) }\end{array}$ & Larga \\
\hline Índia & 1797 & 2009 & MMTC Limited & $\begin{array}{l}15 \mathrm{MW} \text { grid-connected wind } \\
\text { power project by MMTC in } \\
\text { Karnataka }\end{array}$ & NÃO & \begin{tabular}{|l} 
Produção energética - \\
geradores eólicos
\end{tabular} & NÃO & 1 & $\begin{array}{l}\text { Indústrias energéticas (fontes } \\
\text { renováveis - / não-renováveis) }\end{array}$ & Pequena \\
\hline Índia & 394 & 2006 & $\begin{array}{l}\text { Monnet Ispat and Energy } \\
\text { Limited }\end{array}$ & $\begin{array}{l}\text { Waste heat recovery based } \\
\text { captive power project at Monnet }\end{array}$ & SIM & $\begin{array}{l}\text { Produção energética - gases } \\
\text { industriais }\end{array}$ & NÃO & 1 & $\begin{array}{l}\text { Indústrias energéticas (fontes } \\
\text { renováveis - / não-renováveis) }\end{array}$ & Larga \\
\hline Índia & 818 & 2007 & MSP Steel \& Power Limited & $\begin{array}{l}\text { MSPSPL Waste Heat Recovery } \\
\text { Based Captive Power Project }\end{array}$ & SIM & $\begin{array}{l}\text { Produção energética - gases } \\
\text { industriais }\end{array}$ & NÃO & 1 & $\begin{array}{l}\text { Indústrias energéticas (fontes } \\
\text { renováveis - / não-renováveis) }\end{array}$ & Larga \\
\hline Índia & 4249 & 2011 & Mukand Limited & $\begin{array}{l}\text { Power generation by utilizing } \\
\text { Blast Furnace Gas at Mukand } \\
\text { Limited, Ginigera, Karnataka }\end{array}$ & NÃO & $\begin{array}{l}\text { Produção energética - gases } \\
\text { industriais }\end{array}$ & NÃO & $1 \mathrm{e} 4$ & \begin{tabular}{|l} 
Indústrias energéticas (fontes \\
renováveis - / não-renováveis) \\
/ Transformação industrial
\end{tabular} & Larga \\
\hline Índia & 5096 & 2011 & Nagarjuna Agrichem Limited & $\begin{array}{l}\text { Wind Power Project by NACL } \\
\text { in Tamil Nadu }\end{array}$ & NÃO & $\begin{array}{l}\text { Produção energética - } \\
\text { geradores eólicos }\end{array}$ & NÃO & 1 & $\begin{array}{l}\text { Indústrias energéticas (fontes } \\
\text { renováveis - / não-renováveis) }\end{array}$ & Pequena \\
\hline Índia & 1130 & 2007 & $\begin{array}{l}\text { Nahar Industrial Enterprises } \\
\text { Limited }\end{array}$ & $\begin{array}{l}\text { Rice husk based cogeneration } \\
\text { plant }(5 \mathrm{MW}) \text { at Shibzada Ajit } \\
\text { Singh Nagar District, Punjab by } \\
\text { M/s Nahar Industrial Enterprises } \\
\text { limited }\end{array}$ & SIM & $\begin{array}{l}\text { Produção energética - casca } \\
\text { de arroz }\end{array}$ & NÃO & 1 & $\begin{array}{l}\text { Indústrias energéticas (fontes } \\
\text { renováveis - / não-renováveis) }\end{array}$ & Pequena \\
\hline Índia & 117 & 2005 & Nahar Spinning Mills Limited & $\begin{array}{l}\text { 3.5 MW Rice Husk based } \\
\text { Cogeneration Project at Nahar } \\
\text { Spinning Mills Ltd. } \\
\end{array}$ & SIM & $\begin{array}{l}\text { Produção energética - casca } \\
\text { de arroz }\end{array}$ & NÃO & 1 & $\begin{array}{l}\text { Indústrias energéticas (fontes } \\
\text { renováveis - / não-renováveis) }\end{array}$ & Pequena \\
\hline
\end{tabular}




\begin{tabular}{|c|c|c|c|c|c|c|c|c|c|c|}
\hline Índia & 4518 & 2011 & Nakoda Limited & $\begin{array}{l}\text { Electricity generation using } \\
\text { renewable wind energy by } \\
\text { Nakoda Limited }\end{array}$ & NÃO & $\begin{array}{l}\text { Produção energética - } \\
\text { geradores eólicos }\end{array}$ & NÃO & 1 & $\begin{array}{l}\text { Indústrias energéticas (fontes } \\
\text { renováveis - / não-renováveis) }\end{array}$ & Pequena \\
\hline Índia & 1288 & 2008 & Nava Bharat Ventures Limited & Nava Bharat RE Bagasse Project & SIM & Produção energética - bagaço & SIM & 1 & $\begin{array}{l}\text { Indústrias energéticas (fontes } \\
\text { renováveis - / não-renováveis) }\end{array}$ & Pequena \\
\hline Índia & 838 & 2007 & $\begin{array}{l}\text { Navin Fluorine International } \\
\text { Limited }\end{array}$ & \begin{tabular}{|l|} 
GHG emission reduction by \\
thermal oxidation of HFC 23 at \\
Navin Fluorine International \\
Limited (NFIL), Surat, Gujarat, \\
India \\
\end{tabular} & SIM & $\begin{array}{l}\text { Transformação industrial - } \\
\text { incineração de fluxos de } \\
\text { resíduos HFC } 23\end{array}$ & NÃO & 11 & $\begin{array}{l}\text { Emissões fugitivas da } \\
\text { produção e consumo de } \\
\text { hidrocarbonetos halogenados } \\
\text { e hexafluoreto de enxofre }\end{array}$ & Larga \\
\hline Índia & 2023 & 2009 & NHPC Limited & $\begin{array}{l}\text { Nimoo-Bazgo Hydroelectric } \\
\text { Project }\end{array}$ & NÃO & Produção energética - águas & SIM & 1 & $\begin{array}{l}\text { Indústrias energéticas (fontes } \\
\text { renováveis - / não-renováveis) }\end{array}$ & Larga \\
\hline Índia & 2025 & 2009 & NHPC Limited & Chutak Hydroelectric Project & NÃO & Produção energética - águas & SIM & 1 & $\begin{array}{l}\text { Indústrias energéticas (fontes } \\
\text { renováveis - / não-renováveis) }\end{array}$ & Larga \\
\hline Índia & 5558 & 2012 & NMDC Limited & NMDC wind power project & NÃO & $\begin{array}{l}\text { Produção energética - } \\
\text { geradores eólicos }\end{array}$ & NÃO & 1 & \begin{tabular}{|l} 
Indústrias energéticas (fontes \\
renováveis - / não-renováveis)
\end{tabular} & Pequena \\
\hline Índia & 9392 & 2012 & NTPC Limited & $\begin{array}{l}5 \text { MW Solar PV Power Project } \\
\text { at NTPC-Dadri, a Business unit } \\
\text { of NTPC limited }\end{array}$ & NÃO & $\begin{array}{l}\text { Produção energética - } \\
\text { geradores solares }\end{array}$ & SIM & 1 & $\begin{array}{l}\text { Indústrias energéticas (fontes } \\
\text { renováveis - / não-renováveis) }\end{array}$ & Pequena \\
\hline Índia & 473 & 2006 & OCL India Limited & $\begin{array}{l}\text { Optimal utilization of clinker: } \\
\text { Substitution of Clinker by Fly } \\
\text { ash in Portland Pozzolana } \\
\text { Cement blend at OCL, India } \\
\end{array}$ & NÃO & $\begin{array}{l}\text { Transformação industrial - } \\
\text { substituição de clinker na } \\
\text { produção de cimento }\end{array}$ & NÃO & 4 & Transformação industrial & Larga \\
\hline Índia & 579 & 2006 & OCL India Limited & \begin{tabular}{|l|} 
Optimal utilization of clinker: \\
Substitution of Clinker by Slag \\
in Portland Slag Cement at OCL, \\
Rajgangpur, Sundargarh, Orissa. \\
\end{tabular} & NÃO & $\begin{array}{l}\text { Transformação industrial - } \\
\text { substituição de clinker na } \\
\text { produção de cimento }\end{array}$ & NÃO & 4 & Transformação industrial & Larga \\
\hline Índia & 814 & 2007 & $\begin{array}{l}\text { Oil and Natural gas Corporation } \\
\text { Limited }\end{array}$ & $\begin{array}{l}\text { Waste heat recovery from } \\
\text { Process Gas Compressors } \\
\text { (PGCs), Mumbai high south } \\
\text { (offshore platform) and using the } \\
\text { recovered heat to heat process } \\
\text { heating oil }\end{array}$ & SIM & $\begin{array}{l}\text { Produção energética - planta } \\
\text { industrial petroquímica }\end{array}$ & NÃO & 4 & Transformação industrial & Pequena \\
\hline Índia & 847 & 2007 & $\begin{array}{l}\text { Oil and Natural Gas Corporation } \\
\text { Limited }\end{array}$ & $\begin{array}{l}\text { Up-gradation of Gas Turbine } 1 \\
\text { (GT 1) and Gas Turbine } 2 \text { (GT } \\
\text { 2) at co-generation plant of } \\
\text { Hazira Gas Processing Complex } \\
\text { (HGPC) of Oil and Natural Gas } \\
\text { Corporation Limited (ONGC) }\end{array}$ & SIM & $\begin{array}{l}\text { Produção energética - planta } \\
\text { industrial petroquímica }\end{array}$ & NÃO & 4 & Transformação industrial & Pequena \\
\hline Índia & 1220 & 2007 & $\begin{array}{l}\text { Oil and Natural Gas Corporation } \\
\text { Limited }\end{array}$ & $\begin{array}{l}\text { Flare gas recovery project at } \\
\text { Uran plant, Oil and Natural Gas }\end{array}$ & SIM & $\begin{array}{l}\text { Transformação industrial - } \\
\text { substituição de combustíveis }\end{array}$ & NÃO & 10 e 5 & $\begin{array}{l}\text { Emissões fugitivas de } \\
\text { combustíveis (sólidos, }\end{array}$ & Larga \\
\hline
\end{tabular}




\begin{tabular}{|c|c|c|c|c|c|c|c|c|c|c|}
\hline & & & & Corporation (ONGC) Limited & & fósseis & & & $\begin{array}{l}\text { petróleo e gás) / Indústrias } \\
\text { químicas }\end{array}$ & \\
\hline Índia & 1354 & 2008 & $\begin{array}{l}\text { Oil and Natural Gas Corporation } \\
\text { Limited }\end{array}$ & \begin{tabular}{|l} 
Flare gas recovery project at \\
Hazira Gas Processing Complex \\
(HGPC), Hazira plant, Oil and \\
Natural Gas Corporation \\
(ONGC) Limited \\
\end{tabular} & SIM & $\begin{array}{l}\text { Transformação industrial - } \\
\text { substituição de combustíveis } \\
\text { fósseis }\end{array}$ & NÃO & 10 e 5 & $\begin{array}{l}\text { Emissões fugitivas de } \\
\text { combustíveis (sólidos, } \\
\text { petróleo e gás) / Indústrias } \\
\text { químicas }\end{array}$ & Larga \\
\hline Índia & 2648 & 2009 & $\begin{array}{l}\text { Oil and Natural Gas Corporation } \\
\text { Limited }\end{array}$ & $\begin{array}{l}\text { Amine Circulation Pumps } \\
\text { Energy Efficiency at Hazira } \\
\text { works of ONGC }\end{array}$ & SIM & $\begin{array}{l}\text { Produção energética - planta } \\
\text { industrial petroquímica }\end{array}$ & NÃO & 4 & Transformação industrial & Pequena \\
\hline Índia & 2856 & 2010 & $\begin{array}{l}\text { Oil and Natural Gas Corporation } \\
\text { Limited }\end{array}$ & $\begin{array}{l}51 \mathrm{MW} \text { wind power project of } \\
\text { ONGC at Surajbari, Gujarat in } \\
\text { India }\end{array}$ & SIM & $\begin{array}{l}\text { Produção energética - } \\
\text { geradores eólicos }\end{array}$ & SIM & 1 & $\begin{array}{l}\text { Indústrias energéticas (fontes } \\
\text { renováveis - / não-renováveis) }\end{array}$ & Larga \\
\hline Índia & 6888 & 2012 & $\begin{array}{l}\text { Oil and Natural gas Corporation } \\
\text { Limited }\end{array}$ & $\begin{array}{l}\text { Natural gas based combined } \\
\text { cycle power plant in Tripura, } \\
\text { India }\end{array}$ & NÃO & \begin{tabular}{|l|} 
Transformação industrial - \\
substituição de combustíveis \\
fósseis
\end{tabular} & NÃO & 1 & $\begin{array}{l}\text { Indústrias energéticas (fontes } \\
\text { renováveis - / não-renováveis) }\end{array}$ & Larga \\
\hline Índia & 7578 & 2012 & $\begin{array}{l}\text { Oil and Natural gas Corporation } \\
\text { Limited }\end{array}$ & $\begin{array}{l}\text { Energy Efficient Green Building } \\
\text { at Mumbai by ONGC Limited }\end{array}$ & NÃO & $\begin{array}{l}\text { Eficiência energética - } \\
\text { edifícios }\end{array}$ & SIM & 3 & Demanda energética & Pequena \\
\hline Índia & 7634 & 2012 & $\begin{array}{l}\text { Oil and Natural gas Corporation } \\
\text { Limited }\end{array}$ & Green Building at Dehradun & NÃO & $\begin{array}{l}\text { Eficiência energética - } \\
\text { edifícios }\end{array}$ & SIM & 3 & Demanda energética & Pequena \\
\hline Índia & 8286 & 2012 & $\begin{array}{l}\text { Oil and Natural Gas Corporation } \\
\text { Limited }\end{array}$ & $\begin{array}{l}\text { Gas Flaring Reduction at } \\
\text { Neelam \& Heera Asset }\end{array}$ & NÃO & $\begin{array}{l}\text { Transformação industrial - } \\
\text { substituição de combustíveis } \\
\text { fósseis }\end{array}$ & NÃO & 10 & $\begin{array}{l}\text { Emissões fugitivas de } \\
\text { combustíveis (sólidos, } \\
\text { petróleo e gás) }\end{array}$ & Larga \\
\hline Índia & 2126 & 2009 & Oil India Limited & $\begin{array}{l}\text { Oil India Limited (OIL) - } \\
\text { Greenhouse Gas Emission } \\
\text { Reduction through Recovery and } \\
\text { Utilization of Flare Gas }\end{array}$ & NÃO & \begin{tabular}{|l|} 
Transformação industrial - \\
substituição de combustíveis \\
fósseis
\end{tabular} & NÃO & 10 & $\begin{array}{l}\text { Emissões fugitivas de } \\
\text { combustíveis (sólidos, } \\
\text { petróleo e gás) }\end{array}$ & Larga \\
\hline Índia & 5480 & 2012 & Orient Abrasives Limited & $\begin{array}{l}\text { Wind Power Project Activity by } \\
\text { M/s Orient Abrasives Ltd }\end{array}$ & NÃO & $\begin{array}{l}\text { Produção energética - } \\
\text { geradores eólicos }\end{array}$ & SIM & 1 & $\begin{array}{l}\text { Indústrias energéticas (fontes } \\
\text { renováveis - / não-renováveis) }\end{array}$ & Pequena \\
\hline Índia & 8984 & 2012 & $\begin{array}{l}\text { Orient Green Power Company } \\
\text { Limited }\end{array}$ & $\begin{array}{l}8 \text { MW Biomass based Power } \\
\text { Plant at Kishanganj, Baran } \\
\text { District. Rajasthan }\end{array}$ & NÃO & $\begin{array}{l}\text { Produção energética - outros } \\
\text { resíduos agrícolas }\end{array}$ & SIM & 1 & $\begin{array}{l}\text { Indústrias energéticas (fontes } \\
\text { renováveis - / não-renováveis) }\end{array}$ & Pequena \\
\hline Índia & 5313 & 2012 & $\begin{array}{l}\text { Orient Green Power Company } \\
\text { Limited }\end{array}$ & $\begin{array}{l}10 \text { MW Biomass based power } \\
\text { Plant at Pollachi,Coimbatore } \\
\text { district, Tamil Nadu }\end{array}$ & NÃO & $\begin{array}{l}\text { Produção energética - outros } \\
\text { resíduos agrícolas }\end{array}$ & SIM & 1 & $\begin{array}{l}\text { Indústrias energéticas (fontes } \\
\text { renováveis - / não-renováveis) }\end{array}$ & Pequena \\
\hline Índia & 5328 & 2012 & $\begin{array}{l}\text { Orient Green Power Company } \\
\text { Limited }\end{array}$ & $\begin{array}{l}10 \mathrm{MW} \text { Biomass based Power } \\
\text { Plant at Narsimhapur, Madhya } \\
\text { Pradesh }\end{array}$ & NÃO & $\begin{array}{l}\text { Produção energética - outros } \\
\text { resíduos agrícolas }\end{array}$ & NÃO & 1 & $\begin{array}{l}\text { Indústrias energéticas (fontes } \\
\text { renováveis - / não-renováveis) }\end{array}$ & Pequena \\
\hline Índia & 1294 & 2008 & Oudh Sugar Mills Limited & $\begin{array}{l}\text { NSSM - Narkatiaganj Biomass } \\
\text { Power Project }\end{array}$ & SIM & Produção energética - bagaço & SIM & 1 & $\begin{array}{l}\text { Indústrias energéticas (fontes } \\
\text { renováveis - / não-renováveis) }\end{array}$ & Pequena \\
\hline
\end{tabular}




\begin{tabular}{|c|c|c|c|c|c|c|c|c|c|c|}
\hline Índia & 2026 & 2008 & Patspin India Limited & $\begin{array}{l}\text { 5.8 MW Wind Energy } \\
\text { Generation by M/s Patspin India } \\
\text { Limited. }\end{array}$ & SIM & $\begin{array}{l}\text { Produção energética - } \\
\text { geradores eólicos }\end{array}$ & NÃO & 1 & $\begin{array}{l}\text { Indústrias energéticas (fontes } \\
\text { renováveis - / não-renováveis) }\end{array}$ & Pequena \\
\hline Índia & 309 & 2006 & Phillips Carbon Black Limited & $\begin{array}{l}\text { Process Waste Heat utilization } \\
\text { for power generation at Phillips } \\
\text { Carbon Black Limited, Gujarat }\end{array}$ & SIM & $\begin{array}{l}\text { Produção energética - gases } \\
\text { industriais }\end{array}$ & NÃO & 1 & $\begin{array}{l}\text { Indústrias energéticas (fontes } \\
\text { renováveis - / não-renováveis) }\end{array}$ & Larga \\
\hline Índia & 327 & 2006 & Polyplex Corporation Limited & $\begin{array}{l}\text { Lohgarh Chakbhai And Sidhana } \\
\text { Mini Hydroelectric Projects }\end{array}$ & SIM & Produção energética - águas & NÃO & 1 & $\begin{array}{l}\text { Indústrias energéticas (fontes } \\
\text { renováveis - / não-renováveis) }\end{array}$ & Pequena \\
\hline Índia & 329 & 2006 & Polyplex Corporation Limited & $\begin{array}{l}\text { Babanpur Killa And Sahoke } \\
\text { Mini Hydroelectric Projects }\end{array}$ & SIM & Produção energética - águas & NÃO & 1 & $\begin{array}{l}\text { Indústrias energéticas (fontes } \\
\text { renováveis - / não-renováveis) }\end{array}$ & Pequena \\
\hline Índia & 328 & 2006 & Polyplex Corporation Limited & $\begin{array}{l}\text { Dolowal Salar And Bhanubhura } \\
\text { Mini Hydroelectric Project }\end{array}$ & SIM & Produção energética - águas & NÃO & 1 & $\begin{array}{l}\text { Indústrias energéticas (fontes } \\
\text { renováveis - / não-renováveis) }\end{array}$ & Pequena \\
\hline Índia & 4856 & 2011 & Polyplex Corporation Limited & $\begin{array}{l}\text { Abohar Branch Canal Based } \\
\text { Small Hydro Project In Punjab } \\
\text { India }\end{array}$ & NÃO & Produção energética - águas & NÃO & 1 & $\begin{array}{l}\text { Indústrias energéticas (fontes } \\
\text { renováveis - / não-renováveis) }\end{array}$ & Pequena \\
\hline Índia & 2233 & 2009 & $\begin{array}{l}\text { Rai Saheb Rekhchand Mohota } \\
\text { Spinning \& Weaving Mills } \\
\text { Limited }\end{array}$ & $\begin{array}{l}\text { Thermal energy from biomass at } \\
\text { Mohota Mills }\end{array}$ & NÃO & $\begin{array}{l}\text { Produção energética - casca } \\
\text { de arroz }\end{array}$ & NÃO & 1 & $\begin{array}{l}\text { Indústrias energéticas (fontes } \\
\text { renováveis - / não-renováveis) }\end{array}$ & Pequena \\
\hline Índia & 1181 & 2008 & Rama Paper Mills Limited & $\begin{array}{l}\text { 6.0 MW Biomass based } \\
\text { cogeneration power plant of } \\
\text { Rama Paper Mills Limited, } \\
\text { Kiratpur, Uttar Pradesh. }\end{array}$ & SIM & Produção energética - bagaço & SIM & 1 & $\begin{array}{l}\text { Indústrias energéticas (fontes } \\
\text { renováveis - / não-renováveis) }\end{array}$ & Pequena \\
\hline Índia & 2792 & 2009 & $\begin{array}{l}\text { Rashtriya Chemicals and } \\
\text { Fertilizers Limited }\end{array}$ & $\begin{array}{l}\mathrm{N} 2 \mathrm{O} \text { abatement in HP Nitric } \\
\text { Acid plants at Rashtriya } \\
\text { Chemicals \& Fertilizers Limited, } \\
\text { India }\end{array}$ & SIM & $\begin{array}{l}\text { Transformação industrial - } \\
\text { incineração de fluxos de } \\
\text { resíduos } \mathrm{N} 2 \mathrm{O}\end{array}$ & SIM & 5 & Indústrias químicas & Larga \\
\hline Índia & 2801 & 2009 & $\begin{array}{l}\text { Rashtriya Chemicals and } \\
\text { Fertilizers Limited }\end{array}$ & $\begin{array}{l}\text { N2O abatement in MP Nitric } \\
\text { Acid plants at Rashtriya } \\
\text { Chemicals \& Fertilizers Limited, } \\
\text { India }\end{array}$ & SIM & $\begin{array}{l}\text { Transformação industrial - } \\
\text { incineração de fluxos de } \\
\text { resíduos } \mathrm{N} 2 \mathrm{O}\end{array}$ & SIM & 5 & Indústrias químicas & Larga \\
\hline Índia & 2247 & 2009 & $\begin{array}{l}\text { Ratnamani Metals and Tubes } \\
\text { Limited }\end{array}$ & $\begin{array}{l}\text { 13.25 MW Wind Power } \\
\text { Generation by RMTL, in Kutch, } \\
\text { Gujarat }\end{array}$ & SIM & $\begin{array}{l}\text { Produção energética - } \\
\text { geradores eólicos }\end{array}$ & NÃO & 1 & $\begin{array}{l}\text { Indústrias energéticas (fontes } \\
\text { renováveis - / não-renováveis) }\end{array}$ & Pequena \\
\hline Índia & 564 & 2006 & REI Agro Limited & $\begin{array}{l}\text { 7.5 MW wind farm of REI Agro } \\
\text { Ltd. at Soda village in the state } \\
\text { of Rajasthan, India. }\end{array}$ & SIM & $\begin{array}{l}\begin{array}{l}\text { Produção energética - } \\
\text { geradores eólicos }\end{array} \\
\end{array}$ & NÃO & 1 & $\begin{array}{l}\text { Indústrias energéticas (fontes } \\
\text { renováveis - / não-renováveis) }\end{array}$ & Pequena \\
\hline Índia & 3710 & 2010 & REI Agro Limited & $\begin{array}{l}6 \text { MW Wind Power Project in } \\
\text { Tamil Nadu by REI Agro } \\
\text { Limited }\end{array}$ & NÃO & $\begin{array}{l}\text { Produção energética - } \\
\text { geradores eólicos }\end{array}$ & NÃO & 1 & $\begin{array}{l}\text { Indústrias energéticas (fontes } \\
\text { renováveis - / não-renováveis) }\end{array}$ & Pequena \\
\hline Índia & 4475 & 2011 & REI Agro Limited & $\begin{array}{l}\text { 9.9 MW Bundled Wind Power } \\
\text { Project in Maharashtra by REI } \\
\text { Agro Limited }\end{array}$ & NÃO & $\begin{array}{l}\text { Produção energética - } \\
\text { geradores eólicos }\end{array}$ & NÃO & 1 & $\begin{array}{l}\text { Indústrias energéticas (fontes } \\
\text { renováveis - / não-renováveis) }\end{array}$ & Pequena \\
\hline
\end{tabular}




\begin{tabular}{|c|c|c|c|c|c|c|c|c|c|c|}
\hline Índia & 4301 & 2012 & REI Agro Limited & $\begin{array}{l}\text { 20.8 MW Grid connected wind } \\
\text { electricity generation project at } \\
\text { Dhule, Maharashtra }\end{array}$ & NÃO & \begin{tabular}{|l} 
Produção energética - \\
geradores eólicos
\end{tabular} & NÃO & 1 & \begin{tabular}{|l|} 
Indústrias energéticas (fontes \\
renováveis - / não-renováveis)
\end{tabular} & Larga \\
\hline Índia & 8988 & 2012 & REI Agro Limited & $\begin{array}{l}10.2 \mathrm{MW} \text { grid connected wind } \\
\text { energy project in Gujarat, India }\end{array}$ & NÃO & $\begin{array}{l}\text { Produção energética - } \\
\text { geradores eólicos }\end{array}$ & NÃO & 1 & $\begin{array}{l}\text { Indústrias energéticas (fontes } \\
\text { renováveis - / não-renováveis) }\end{array}$ & Pequena \\
\hline Índia & 5228 & 2011 & Relaxo Footwears Limited & $\begin{array}{l}\text { Wind power project by Relaxo } \\
\text { Footwears Limited in Rajasthan }\end{array}$ & NÃO & $\begin{array}{l}\text { Produção energética - } \\
\text { geradores eólicos }\end{array}$ & NÃO & 1 & $\begin{array}{l}\text { Indústrias energéticas (fontes } \\
\text { renováveis - / não-renováveis) }\end{array}$ & Pequena \\
\hline Índia & 261 & 2006 & Reliance Industries Limited & $\begin{array}{l}\text { Energy Efficiency Through } \\
\text { Steam Optimisation Projects At } \\
\text { RIL Hazira }\end{array}$ & NÃO & $\begin{array}{l}\text { Produção energética - planta } \\
\text { industrial petroquímica }\end{array}$ & NÃO & 3 & Demanda energética & Larga \\
\hline Índia & 340 & 2006 & Reliance Industries Limited & $\begin{array}{l}\text { Reduction In Steam } \\
\text { Consumption In Stripper } \\
\text { Reboilers Via Process } \\
\text { Modifications } \\
\end{array}$ & SIM & $\begin{array}{l}\text { Produção energética - planta } \\
\text { industrial petroquímica }\end{array}$ & NÃO & 3 & Demanda energética & Larga \\
\hline Índia & 445 & 2006 & Reliance Industries Limited & $\begin{array}{l}\text { Demand Side Energy } \\
\text { Conservation \& Reduction } \\
\text { Measures At IPCL Gandhar } \\
\text { Complex }\end{array}$ & NÃO & $\begin{array}{l}\text { Produção energética - planta } \\
\text { industrial petroquímica }\end{array}$ & NÃO & 4 & Transformação industrial & Pequena \\
\hline Índia & 946 & 2007 & Reliance Industries Limited & $\begin{array}{l}\text { Improvement In Energy } \\
\text { Efficiency Recron Synthetics } \\
\text { Ltd Allahabad }\end{array}$ & NÃO & $\begin{array}{l}\text { Transformação industrial - } \\
\text { substituição de combustíveis } \\
\text { fósseis }\end{array}$ & NÃO & $1 \mathrm{e} 4$ & \begin{tabular}{|l} 
Indústrias energéticas (fontes \\
renováveis - / não-renováveis) \\
/ Transformação industrial
\end{tabular} & Pequena \\
\hline Índia & 956 & 2007 & Reliance Industries Limited & $\begin{array}{l}\text { Demand Side Energy Efficiency } \\
\text { Projects At RIL-PG }\end{array}$ & NÃO & $\begin{array}{l}\text { Produção energética - planta } \\
\text { industrial petroquímica }\end{array}$ & NÃO & 4 & Transformação industrial & Pequena \\
\hline Índia & 3772 & 2011 & Reliance Industries Limited & $\begin{array}{l}\text { Energy efficiency through heat } \\
\text { recovery at Vadodara } \\
\text { Manufacturing Complex of } \\
\text { IPCL }\end{array}$ & NÃO & $\begin{array}{l}\text { Produção energética - planta } \\
\text { industrial petroquímica }\end{array}$ & NÃO & 4 & Transformação industrial & Pequena \\
\hline Índia & 4239 & 2011 & Reliance Industries Limited & $\begin{array}{l}\text { Biomass based Process Steam } \\
\text { Generation Project }\end{array}$ & SIM & $\begin{array}{l}\text { Produção energética - casca } \\
\text { de arroz }\end{array}$ & NÃO & 1 & $\begin{array}{l}\text { Indústrias energéticas (fontes } \\
\text { renováveis - / não-renováveis) }\end{array}$ & Pequena \\
\hline Índia & 5129 & 2011 & Reliance Industries Limited & Solar Power Generation Project & NÃO & \begin{tabular}{|l} 
Produção energética - \\
geradores solares
\end{tabular} & SIM & 1 & \begin{tabular}{|l|} 
Indústrias energéticas (fontes \\
renováveis - / não-renováveis)
\end{tabular} & Pequena \\
\hline Índia & 9380 & 2012 & $\begin{array}{l}\text { Riddhi Siddhi Gluco Biols } \\
\text { Limited }\end{array}$ & $\begin{array}{l}\text { Wind power project by Riddhi } \\
\text { Siddhi Gluco Biols Limited } \\
\text { (RSGBL) }\end{array}$ & NÃO & $\begin{array}{l}\text { Produção energética - } \\
\text { geradores eólicos }\end{array}$ & NÃO & 1 & $\begin{array}{l}\text { Indústrias energéticas (fontes } \\
\text { renováveis - / não-renováveis) }\end{array}$ & Larga \\
\hline Índia & 3818 & 2010 & Ruchi Infrastructure Limited & $\begin{array}{l}10.8 \text { MW Wind Power Project } \\
\text { by Ruchi Infrastructure Ltd }\end{array}$ & NÃO & $\begin{array}{l}\text { Produção energética - } \\
\text { geradores eólicos }\end{array}$ & NÃO & 1 & $\begin{array}{l}\text { Indústrias energéticas (fontes } \\
\text { renováveis - / não-renováveis) }\end{array}$ & Pequena \\
\hline Índia & 3996 & 2011 & Ruchi Soya Industries Limited & $\begin{array}{l}22.5 \text { MW Wind Power Project } \\
\text { by Ruchi Soya Industries } \\
\text { Limited at Palsodi, District- } \\
\text { Ratlam, Madhya Pradesh }\end{array}$ & NÃO & $\begin{array}{l}\text { Produção energética - } \\
\text { geradores eólicos }\end{array}$ & NÃO & 1 & $\begin{array}{l}\text { Indústrias energéticas (fontes } \\
\text { renováveis - / não-renováveis) }\end{array}$ & Larga \\
\hline
\end{tabular}




\begin{tabular}{|c|c|c|c|c|c|c|c|c|c|c|}
\hline Índia & 4377 & 2011 & Ruchi Soya Industries Limited & $\begin{array}{l}\text { 12.25 MW Bundled Wind Power } \\
\text { Project in India }\end{array}$ & NÃO & $\begin{array}{l}\text { Produção energética - } \\
\text { geradores eólicos }\end{array}$ & NÃO & 1 & $\begin{array}{l}\text { Indústrias energéticas (fontes } \\
\text { renováveis - / não-renováveis) }\end{array}$ & Pequena \\
\hline Índia & 8592 & 2012 & Ruchi Soya Industries Limited & $\begin{array}{l}35.10 \mathrm{MW} \text { Wind Energy Project } \\
\text { by Ruchi Soya Industries } \\
\text { Limited, India }\end{array}$ & NÃO & $\begin{array}{l}\text { Produção energética - } \\
\text { geradores eólicos }\end{array}$ & NÃO & 1 & $\begin{array}{l}\text { Indústrias energéticas (fontes } \\
\text { renováveis - / não-renováveis) }\end{array}$ & Larga \\
\hline Índia & 8818 & 2012 & Ruchi Soya Industries Limited & $\begin{array}{l}\text { Grid Connected Wind Power } \\
\text { Generation Project by Ruchi } \\
\text { Soya Industries Limited in } \\
\text { Madhya Pradesh } \\
\end{array}$ & NÃO & $\begin{array}{l}\text { Produção energética - } \\
\text { geradores eólicos }\end{array}$ & NÃO & 1 & $\begin{array}{l}\text { Indústrias energéticas (fontes } \\
\text { renováveis - / não-renováveis) }\end{array}$ & Larga \\
\hline Índia & 8641 & 2012 & $\begin{array}{l}\text { Rural Electrification Corporation } \\
\text { Limited }\end{array}$ & $\begin{array}{l}\text { Energy efficiency programme in } \\
\text { electricity distribution network } \\
\text { in Chittoor and Madanapalle } \\
\text { operational division of Andhra } \\
\text { Pradesh } \\
\end{array}$ & NÃO & $\begin{array}{l}\text { Eficiência energética - } \\
\text { distribuição e transmissão }\end{array}$ & NÃO & 2 & Distribuição energética & Pequena \\
\hline Índia & 8667 & 2012 & $\begin{array}{l}\text { Rural Electrification Corporation } \\
\text { Limited }\end{array}$ & $\begin{array}{l}\text { Energy efficiency programme in } \\
\text { electricity distribution network } \\
\text { in Tirupati and Puttur } \\
\text { operational division of Andhra } \\
\text { Pradesh } \\
\end{array}$ & NÃO & $\begin{array}{l}\text { Eficiência energética - } \\
\text { distribuiçãao e transmissão }\end{array}$ & NÃO & 2 & Distribuição energética & Pequena \\
\hline Índia & 7441 & 2012 & Sadbhav Engineering Limited & $\begin{array}{l}\text { Wind Power Project in Gujarat } \\
\text { by Sadbhav Engineering Limited }\end{array}$ & NÃO & $\begin{array}{l}\text { Produção energética - } \\
\text { geradores eólicos }\end{array}$ & SIM & 1 & $\begin{array}{l}\text { Indústrias energéticas (fontes } \\
\text { renováveis - / não-renováveis) }\end{array}$ & Pequena \\
\hline Índia & 4411 & 2011 & Sanwaria Agro Oils Limited & $\begin{array}{l}\text { 8.4 MW Wind Energy Project by } \\
\text { Sanwaria Agro Oils Limited, } \\
\text { India }\end{array}$ & NÃO & $\begin{array}{l}\text { Produção energética - } \\
\text { geradores eólicos }\end{array}$ & NÃO & 1 & $\begin{array}{l}\text { Indústrias energéticas (fontes } \\
\text { renováveis - / não-renováveis) }\end{array}$ & Pequena \\
\hline Índia & 5485 & 2011 & Savita Oil Technologies Limited & $\begin{array}{l}\text { Bundled Wind Power generation } \\
\text { project by Savita Oil } \\
\text { Technologies Ltd., India }\end{array}$ & NÃO & $\begin{array}{l}\text { Produção energética - } \\
\text { geradores eólicos }\end{array}$ & NÃO & 1 & $\begin{array}{l}\text { Indústrias energéticas (fontes } \\
\text { renováveis - / não-renováveis) }\end{array}$ & Pequena \\
\hline Índia & 6651 & 2012 & $\begin{array}{l}\text { SEL Manufacturing Company } \\
\text { Limited }\end{array}$ & $\begin{array}{l}10 \text { MW Biomass based Power } \\
\text { plant in Punjab, India }\end{array}$ & NÃO & $\begin{array}{l}\text { Produção energética - casca } \\
\text { de arroz }\end{array}$ & NÃO & 1 & $\begin{array}{l}\text { Indústrias energéticas (fontes } \\
\text { renováveis - / não-renováveis) }\end{array}$ & Pequena \\
\hline Índia & 535 & 2007 & Sesa Goa Limited & $\begin{array}{l}\text { Sesa-Waste Heat Recovery } \\
\text { Based Power Generation }\end{array}$ & SIM & $\begin{array}{l}\text { Produção energética - gases } \\
\text { industriais }\end{array}$ & NÃO & 1 & $\begin{array}{l}\text { Indústrias energéticas (fontes } \\
\text { renováveis - / não-renováveis) }\end{array}$ & Larga \\
\hline Índia & 3926 & 2010 & Shilpa Medicare Limited & $\begin{array}{l}\text { Biomass based steam generation } \\
\text { project at Raichur, India }\end{array}$ & NÃO & $\begin{array}{l}\text { Produção energética - casca } \\
\text { de arroz }\end{array}$ & NÃO & 1 & $\begin{array}{l}\text { Indústrias energéticas (fontes } \\
\text { renováveis - / não-renováveis) }\end{array}$ & Pequena \\
\hline Índia & 802 & 2007 & $\begin{array}{l}\text { Shree Bhawani Paper Mills } \\
\text { Limited }\end{array}$ & $\begin{array}{l}\text { Rice husk based cogeneration } \\
\text { power plant-II at SBPML }\end{array}$ & SIM & $\begin{array}{l}\text { Produção energética - casca } \\
\text { de arroz }\end{array}$ & NÃO & 1 & $\begin{array}{l}\text { Indústrias energéticas (fontes } \\
\text { renováveis - / não-renováveis) }\end{array}$ & Pequena \\
\hline Índia & 183 & 2006 & Shree Cements Limited & $\begin{array}{l}\text { Optimal Utilization of Clinker } \\
\text { project at Shree Cement Limited } \\
\text { (SCL), Beawar, Rajasthan }\end{array}$ & SIM & $\begin{array}{l}\text { Transformação industrial - } \\
\text { substituição de clinker na } \\
\text { produção de cimento }\end{array}$ & NÃO & 4 & Transformação industrial & Larga \\
\hline
\end{tabular}




\begin{tabular}{|c|c|c|c|c|c|c|c|c|c|c|}
\hline Índia & 302 & 2006 & Shree Cements Limited & $\begin{array}{l}\text { Partial replacement of fossil fuel } \\
\text { by biomass as an alternative } \\
\text { fuel, for Pyro-Processing in } \\
\text { cement plant of Shree Cements } \\
\text { Limited at Beawar in Rajasthan, } \\
\text { India }\end{array}$ & NÃO & $\begin{array}{l}\text { Produção energética - outros } \\
\text { resíduos agrícolas }\end{array}$ & NÃO & 4 & Transformação industrial & Larga \\
\hline Índia & 935 & 2007 & Shreyans Industries Limited & $\begin{array}{l}\text { Methane recovery from waste } \\
\text { water generated from wheat } \\
\text { straw wash at Paper } \\
\text { manufacturing unit of Shreyans } \\
\text { Industries Limited (SIL) }\end{array}$ & NÃO & $\begin{array}{l}\text { Tratamento de águas - dejetos } \\
\text { industriais }\end{array}$ & NÃO & 13 e 15 & $\begin{array}{l}\text { Tratamento e eliminação de } \\
\text { resíduos / Agricultura }\end{array}$ & Pequena \\
\hline Índia & 4025 & 2011 & Shreyans Industries Limited & $\begin{array}{l}4.8 \mathrm{MW} \text { biomass based power } \\
\text { plant at Shreyans Industries }\end{array}$ & SIM & $\begin{array}{l}\text { Produção energética - casca } \\
\text { de arroz }\end{array}$ & NÃO & 1 & \begin{tabular}{|l|} 
Indústrias energéticas (fontes \\
renováveis - / não-renováveis)
\end{tabular} & Pequena \\
\hline Índia & 4990 & 2012 & Shriram EPC & $\begin{array}{l}15 \text { MW Wind Power Project by } \\
\text { Shriram Leitwind Ltd }\end{array}$ & SIM & $\begin{array}{l}\text { Produção energética - } \\
\text { geradores eólicos }\end{array}$ & SIM & 1 & $\begin{array}{l}\text { Indústrias energéticas (fontes } \\
\text { renováveis - / não-renováveis) }\end{array}$ & Pequena \\
\hline Índia & 1112 & 2007 & Simbhaoli Sugar Mills Limited & $\begin{array}{l}\text { SSML - Simbhaoli Biomass } \\
\text { Power Project }\end{array}$ & SIM & Produção energética - bagaço & NÃO & 1 & $\begin{array}{l}\text { Indústrias energéticas (fontes } \\
\text { renováveis - / não-renováveis) }\end{array}$ & Larga \\
\hline Índia & 2471 & 2009 & Sintex Industries limited & $\begin{array}{l}\text { Sintex } 7.5 \mathrm{MW} \text { Natural gas } \\
\text { based package cogeneration } \\
\text { project, Gujarat - India }\end{array}$ & NÃO & $\begin{array}{l}\text { Produção energética - } \\
\text { cogeração de gases naturais }\end{array}$ & NÃO & $1 \mathrm{e} 4$ & $\begin{array}{l}\text { Indústrias energéticas (fontes } \\
\text { renováveis - / não-renováveis) } \\
\text { / Transformação industrial }\end{array}$ & Larga \\
\hline Índia & 5175 & 2011 & SPML Infra Limited & $\begin{array}{l}\text { Awa and Binwa Small Hydro } \\
\text { Power Projects in Kangra } \\
\text { District of Himachal Pradesh, } \\
\text { India }\end{array}$ & NÃO & Produção energética - águas & NÃO & 1 & $\begin{array}{l}\text { Indústrias energéticas (fontes } \\
\text { renováveis - / não-renováveis) }\end{array}$ & Pequena \\
\hline Índia & 5099 & 2012 & SPML Infra Limited & $\begin{array}{l}\text { Luni, Iqu and Neogal Small } \\
\text { Hydro Power Projects in Kangra } \\
\text { District of Himachal Pradesh, } \\
\text { India }\end{array}$ & NÃO & Produção energética - águas & NÃO & 1 & $\begin{array}{l}\text { Indústrias energéticas (fontes } \\
\text { renováveis - / não-renováveis) }\end{array}$ & Pequena \\
\hline Índia & 2434 & 2009 & Sree Sakthi Paper Mills Limited & $\begin{array}{l}\text { Methane recovery from } \\
\text { wastewater generated at Paper } \\
\text { manufacturing unit of Sree } \\
\text { Sakthi Paper Mills Ltd., Kerala }\end{array}$ & NÃO & $\begin{array}{l}\text { Tratamento de águas - } \\
\text { celulose e papel }\end{array}$ & NÃO & 13 & $\begin{array}{l}\text { Tratamento e eliminação de } \\
\text { resíduos }\end{array}$ & Pequena \\
\hline Índia & 115 & 2005 & SRF Limited & $\begin{array}{l}\text { GHG emission reduction by } \\
\text { thermal oxidation of HFC } 23 \text { at } \\
\text { refrigerant (HCFC-22) } \\
\text { manufacturing facility of SRF } \\
\text { Ltd }\end{array}$ & SIM & $\begin{array}{l}\text { Transformação industrial - } \\
\text { incineração de fluxos de } \\
\text { resíduos HFC } 23\end{array}$ & NÃO & 11 & \begin{tabular}{|l|} 
Emissões fugitivas da \\
produção e consumo de \\
hidrocarbonetos halogenados \\
e hexafluoreto de enxofre
\end{tabular} & Larga \\
\hline Índia & 2365 & 2009 & SRF Limited & $\begin{array}{l}\text { 13.95 MW grid connected wind } \\
\text { electricity generation by SRF } \\
\text { Limited }\end{array}$ & SIM & $\begin{array}{l}\text { Produção energética - } \\
\text { geradores eólicos }\end{array}$ & NÃO & 1 & $\begin{array}{l}\text { Indústrias energéticas (fontes } \\
\text { renováveis - / não-renováveis) }\end{array}$ & Pequena \\
\hline Índia & 7871 & 2012 & Srinivasa Hatcheries Limited & $\begin{array}{l}\text { Srinivasa Hatcheries Limited } \\
\text { 3MW Wind Project } 2010\end{array}$ & NÃO & $\begin{array}{l}\text { Produção energética - } \\
\text { geradores eólicos }\end{array}$ & SIM & 1 & $\begin{array}{l}\text { Indústrias energéticas (fontes } \\
\text { renováveis - / não-renováveis) }\end{array}$ & Pequena \\
\hline
\end{tabular}




\begin{tabular}{|c|c|c|c|c|c|c|c|c|c|c|}
\hline Índia & 2504 & 2009 & Sterlite Industries India Limited & $\begin{array}{l}\text { Utilization of waste gas heat for } \\
\text { power generation }\end{array}$ & NÃO & $\begin{array}{l}\text { Transformação industrial - } \\
\text { substituição de combustíveis } \\
\text { fósseis }\end{array}$ & NÃO & $1 \mathrm{e} 4$ & $\begin{array}{l}\text { Indústrias energéticas (fontes } \\
\text { renováveis - / não-renováveis) } \\
\text { / Transformação industrial }\end{array}$ & Larga \\
\hline Índia & 3638 & 2012 & Suashish Diamonds Limited & $\begin{array}{l}\text { Wind Power Project in Kutch, } \\
\text { Gujarat by SDL }\end{array}$ & NÃO & $\begin{array}{l}\text { Produção energética - } \\
\text { geradores eólicos }\end{array}$ & NÃO & 1 & $\begin{array}{l}\text { Indústrias energéticas (fontes } \\
\text { renováveis - / não-renováveis) }\end{array}$ & Pequena \\
\hline Índia & 2370 & 2009 & Surana Corporation Limited & $\begin{array}{l}\text { 5.1 MW bundled Wind Power } \\
\text { Project in Tirunelveli (Tamil } \\
\text { Nadu) }\end{array}$ & SIM & $\begin{array}{l}\text { Produção energética - } \\
\text { geradores eólicos }\end{array}$ & NÃO & 1 & $\begin{array}{l}\text { Indústrias energéticas (fontes } \\
\text { renováveis - / não-renováveis) }\end{array}$ & Pequena \\
\hline Índia & 5790 & 2012 & Surana Industries Limited & $\begin{array}{l}12 \mathrm{MW} \text { Wind Electricity } \\
\text { Generation Farm at Radhapuram } \\
\text { by M/s Surana Industries } \\
\text { Limited }\end{array}$ & NÃO & $\begin{array}{l}\text { Produção energética - } \\
\text { geradores eólicos }\end{array}$ & NÃO & 1 & $\begin{array}{l}\text { Indústrias energéticas (fontes } \\
\text { renováveis - / não-renováveis) }\end{array}$ & Pequena \\
\hline Índia & 1199 & 2007 & $\begin{array}{l}\text { Suryachakra Power Corporation } \\
\text { Limited }\end{array}$ & $\begin{array}{l}\text { 9.8 MW Biomass Based Power } \\
\text { Plant At Lahari Power \& Steels } \\
\text { Ltd }\end{array}$ & SIM & $\begin{array}{l}\text { Produção energética - outros } \\
\text { resíduos agrícolas }\end{array}$ & NÃO & 1 & $\begin{array}{l}\text { Indústrias energéticas (fontes } \\
\text { renováveis - / não-renováveis) }\end{array}$ & Pequena \\
\hline Índia & 1110 & 2007 & $\begin{array}{l}\text { Suryachakra Power Corporation } \\
\text { Limited }\end{array}$ & $\begin{array}{l}10 \mathrm{MW} \text { Renewable Energy } \\
\text { Generation For The Grid } \\
\text { Parbhani District Maharashtra }\end{array}$ & SIM & $\begin{array}{l}\text { Produção energética - outros } \\
\text { resíduos agrícolas }\end{array}$ & NÃO & 1 & $\begin{array}{l}\text { Indústrias energéticas (fontes } \\
\text { renováveis - / não-renováveis) }\end{array}$ & Pequena \\
\hline Índia & 1196 & 2007 & $\begin{array}{l}\text { Suryachakra Power Corporation } \\
\text { Limited }\end{array}$ & $\begin{array}{l}10 \mathrm{MW} \text { Biomass Based } \\
\text { Renewable Power Generation } \\
\text { Amaravathi District }\end{array}$ & SIM & $\begin{array}{l}\text { Produção energética - outros } \\
\text { resíduos agrícolas }\end{array}$ & NÃO & 1 & $\begin{array}{l}\text { Indústrias energéticas (fontes } \\
\text { renováveis - / não-renováveis) }\end{array}$ & Pequena \\
\hline Índia & 1049 & 2007 & Suzlon Energy Limited & $\begin{array}{l}15 \text { MW Grid Connected Wind } \\
\text { Energy Project at Sankaneri } \\
\text { Village in Tamil Nadu } \\
\end{array}$ & SIM & $\begin{array}{l}\text { Produção energética - } \\
\text { geradores eólicos }\end{array}$ & NÃO & 1 & $\begin{array}{l}\text { Indústrias energéticas (fontes } \\
\text { renováveis - / não-renováveis) }\end{array}$ & Pequena \\
\hline Índia & 5764 & 2012 & Swan Energy Limited & $\begin{array}{l}\text { Use of agricultural waste instead } \\
\text { of coal in our proposed boiler in } \\
\text { Narol - Vatva Road, } \\
\text { Ahmedabad, Gujarat, India }\end{array}$ & NÃO & $\begin{array}{l}\text { Produção energética - outros } \\
\text { resíduos agrícolas }\end{array}$ & NÃO & 1 & $\begin{array}{l}\text { Indústrias energéticas (fontes } \\
\text { renováveis - / não-renováveis) }\end{array}$ & Pequena \\
\hline Índia & 124 & 2006 & $\begin{array}{l}\text { Tamil Nadu Newsprint \& Papers } \\
\text { Limited }\end{array}$ & $\begin{array}{l}\text { Methane Extraction and Fuel } \\
\text { Conservation Project at Tamil } \\
\text { Nadu Newsprint and Paper } \\
\text { Limited (TNPL), Kagithapuram, } \\
\text { Karur District, Tamil Nadu } \\
\end{array}$ & SIM & $\begin{array}{l}\text { Tratamento de águas - } \\
\text { celulose e papel }\end{array}$ & NÃO & 13 & $\begin{array}{l}\text { Tratamento e eliminação de } \\
\text { resíduos }\end{array}$ & Larga \\
\hline Índia & 4438 & 2011 & $\begin{array}{l}\text { Tamil Nadu Newsprint \& Papers } \\
\text { Limited }\end{array}$ & $\begin{array}{l}\text { Energy Efficiency Improvement } \\
\text { at Tamil Nadu Newsprint and } \\
\text { Papers Limited }\end{array}$ & NÃO & Produção energética - bagaço & NÃO & 1 & $\begin{array}{l}\text { Indústrias energéticas (fontes } \\
\text { renováveis - / não-renováveis) }\end{array}$ & Pequena \\
\hline Índia & 1053 & 2007 & $\begin{array}{l}\text { Tamil Nadu Newsprint \& Papers } \\
\text { Limited }\end{array}$ & $\begin{array}{l}\text { 6.75 MW Small Scale Grid } \\
\text { Connected "Wind Electricity } \\
\text { Generation Project" by Tamil } \\
\text { Nadu Newsprint and Papers } \\
\text { Limited }\end{array}$ & SIM & $\begin{array}{l}\text { Produção energética - } \\
\text { geradores eólicos }\end{array}$ & NÃO & 1 & $\begin{array}{l}\text { Indústrias energéticas (fontes } \\
\text { renováveis - / não-renováveis) }\end{array}$ & Pequena \\
\hline Índia & 5500 & 2012 & $\begin{array}{l}\text { Tamil Nadu Newsprint \& Papers } \\
\text { Limited }\end{array}$ & $\begin{array}{l}\text { 13.75 MW Grid connected } \\
\text { "Wind Electricity generation }\end{array}$ & NẪ & Produção energética - & NÃO & 1 & Indústrias energéticas (fontes & Larga \\
\hline
\end{tabular}




\begin{tabular}{|c|c|c|c|c|c|c|c|c|c|c|}
\hline & & & & $\begin{array}{l}\text { Project by Tamilnadu } \\
\text { Newsprints and Papers Limited" }\end{array}$ & & geradores eólicos & & & renováveis - / não-renováveis) & \\
\hline Índia & 382 & 2006 & Tata Chemicals Limited & $\begin{array}{l}\text { Off gases utilisation from } \mathrm{C}-03 \\
\text { washing tower in Primary } \\
\text { Reformer as fuel }\end{array}$ & SIM & $\begin{array}{l}\text { Transformação industrial - } \\
\text { substituição de combustíveis } \\
\text { fósseis }\end{array}$ & NÃO & 10 e 13 & $\begin{array}{l}\text { Emissões fugitivas de } \\
\text { combustíveis (sólidos, } \\
\text { petróleo e gás) / Tratamento } \\
\text { e eliminação de resíduos }\end{array}$ & Pequena \\
\hline Índia & 587 & 2007 & Tata Chemicals Limited & $\begin{array}{l}\text { Installation of Additional Urea } \\
\text { Trays in Urea Reactors (11/21- } \\
\text { R01) }\end{array}$ & SIM & $\begin{array}{l}\text { Transformação industrial - } \\
\text { substituição de combustíveis } \\
\text { fósseis }\end{array}$ & NÃO & 4 & Transformação industrial & Pequena \\
\hline Índia & 758 & 2007 & Tata Chemicals Limited & $\begin{array}{l}\text { Alternate arrangement for } \\
\text { preheating fuel NG }\end{array}$ & SIM & $\begin{array}{l}\text { Transformação industrial - } \\
\text { substituição de combustíveis } \\
\text { fósseis }\end{array}$ & NÃO & 4 & Transformação industrial & Pequena \\
\hline Índia & 1013 & 2007 & Tata Chemicals Limited & $\begin{array}{l}\text { Supply side energy efficiency } \\
\text { measures at Tata Chemicals } \\
\text { Limited, Mithapur }\end{array}$ & NÃO & $\begin{array}{l}\text { Transformação industrial - } \\
\text { substituição de combustíveis } \\
\text { fósseis }\end{array}$ & NÃO & 1 & $\begin{array}{l}\text { Indústrias energéticas (fontes } \\
\text { renováveis - / não-renováveis) }\end{array}$ & Pequena \\
\hline Índia & 744 & 2007 & Tata Motors Limited & $\begin{array}{l}\text { Bundled Wind Power Projects in } \\
\text { Satara \& Supa (Maharashtra in } \\
\text { India) managed by Tata Motors } \\
\text { Ltd. } \\
\end{array}$ & SIM & $\begin{array}{l}\text { Produção energética - } \\
\text { geradores eólicos }\end{array}$ & NÃO & 1 & $\begin{array}{l}\text { Indústrias energéticas (fontes } \\
\text { renováveis - / não-renováveis) }\end{array}$ & Larga \\
\hline Índia & 2819 & 2010 & Tata Power Company Limited & $\begin{array}{l}\text { 50.4 MW Tata Wind Farm - in } \\
\text { Maharashtra }\end{array}$ & SIM & $\begin{array}{l}\text { Produção energética - } \\
\text { geradores eólicos }\end{array}$ & NÃO & 1 & $\begin{array}{l}\text { Indústrias energéticas (fontes } \\
\text { renováveis - / não-renováveis) }\end{array}$ & Larga \\
\hline Índia & 8442 & 2012 & Tata Power Company Limited & $\begin{array}{l}\text { Tata Power - Wind power } \\
\text { project at Samana in Jamnagar } \\
\text { district, Gujarat }\end{array}$ & NÃO & $\begin{array}{l}\text { Produção energética - } \\
\text { geradores eólicos }\end{array}$ & NÃO & 1 & $\begin{array}{l}\text { Indústrias energéticas (fontes } \\
\text { renováveis - / não-renováveis) }\end{array}$ & Larga \\
\hline Índia & 8102 & 2012 & Tata Power Company Limited & $\begin{array}{l}\text { Wind power project at Gadag } \\
\text { district, Karnataka }\end{array}$ & NÃO & \begin{tabular}{|l} 
Produção energética - \\
geradores eólicos
\end{tabular} & NÃO & 1 & $\begin{array}{l}\text { Indústrias energéticas (fontes } \\
\text { renováveis - / não-renováveis) }\end{array}$ & Larga \\
\hline Índia & 274 & 2006 & Tata Sponge Iron Limited & $\begin{array}{l}\text { TSIL - Waste Heat Recovery } \\
\text { Based Power Project }\end{array}$ & SIM & $\begin{array}{l}\text { Produção energética - gases } \\
\text { industriais }\end{array}$ & NÃO & 1 & $\begin{array}{l}\text { Indústrias energéticas (fontes } \\
\text { renováveis - / não-renováveis) }\end{array}$ & Larga \\
\hline Índia & 1648 & 2009 & Tata Steel Limited & $\begin{array}{l}\text { Top Gas Pressure Recovery } \\
\text { based Power Generation from } \\
\text { 'G' Blast Furnace } \\
\end{array}$ & NÃO & $\begin{array}{l}\text { Produção energética - gases } \\
\text { industriais }\end{array}$ & NÃO & 1 & $\begin{array}{l}\text { Indústrias energéticas (fontes } \\
\text { renováveis - / não-renováveis) }\end{array}$ & Larga \\
\hline Índia & 3884 & 2010 & $\begin{array}{l}\text { Techno Electric \& Engineering } \\
\text { Company Limited }\end{array}$ & $\begin{array}{l}\text { Grid Connected Wind Energy } \\
\text { Project In Tamil Nadu By Super } \\
\text { Wind Project Private }\end{array}$ & NÃO & \begin{tabular}{|l|} 
Produção energética - \\
geradores eólicos
\end{tabular} & SIM & 1 & $\begin{array}{l}\text { Indústrias energéticas (fontes } \\
\text { renováveis - / não-renováveis) }\end{array}$ & Larga \\
\hline Índia & 1116 & 2007 & Torrent Power Limited & $\begin{array}{l}\text { 1147.5 MW Natural gas based } \\
\text { grid connected Combined cycle } \\
\text { power generation project }\end{array}$ & SIM & $\begin{array}{l}\text { Transformação industrial - } \\
\text { substituição de combustíveis } \\
\text { fósseis }\end{array}$ & NÃO & 1 & $\begin{array}{l}\text { Indústrias energéticas (fontes } \\
\text { renováveis - / não-renováveis) }\end{array}$ & Larga \\
\hline Índia & 8048 & 2012 & Torrent Power Limited & $\begin{array}{l}\text { UNOSUGEN Natural gas based } \\
\text { grid connected Combined cycle }\end{array}$ & NÃO & \begin{tabular}{|l|} 
Transformação industrial - \\
substituição de combustíveis
\end{tabular} & NÃO & 1 & Indústrias energéticas (fontes & Larga \\
\hline
\end{tabular}




\begin{tabular}{|c|c|c|c|c|c|c|c|c|c|c|}
\hline & & & & power generation project & & fósseis & & & renováveis - / não-renováveis) & \\
\hline Índia & 267 & 2006 & $\begin{array}{l}\text { Transport Corporation of India } \\
\text { Limited }\end{array}$ & $\begin{array}{l}5 \text { MW Wind Power Project at } \\
\text { Baramsar and Soda Mada, } \\
\text { district Jaisalmer, Rajasthan, } \\
\text { India. } \\
\end{array}$ & SIM & $\begin{array}{l}\text { Produção energética - } \\
\text { geradores eólicos }\end{array}$ & NÃO & 1 & $\begin{array}{l}\text { Indústrias energéticas (fontes } \\
\text { renováveis - / não-renováveis) }\end{array}$ & Pequena \\
\hline Índia & 578 & 2006 & $\begin{array}{l}\text { Triveni Engineering and } \\
\text { Industries Limited }\end{array}$ & $\begin{array}{l}\text { Deoband Bagasse based Co- } \\
\text { generation Power Project }\end{array}$ & SIM & Produção energética - bagaço & NÃO & 1 & $\begin{array}{l}\text { Indústrias energéticas (fontes } \\
\text { renováveis - / não-renováveis) }\end{array}$ & Larga \\
\hline Índia & 826 & 2007 & $\begin{array}{l}\text { Triveni Engineering and } \\
\text { Industries Limited }\end{array}$ & $\begin{array}{l}\text { Bagasse based Co-generation } \\
\text { Power Project at Khatauli }\end{array}$ & SIM & Produção energética - bagaço & NÃO & 1 & $\begin{array}{l}\text { Indústrias energéticas (fontes } \\
\text { renováveis - / não-renováveis) }\end{array}$ & Larga \\
\hline Índia & 7966 & 2012 & Ultramarine \& Pigments Limited & $\begin{array}{l}\text { Wind power project by UPL, } \\
\text { India }\end{array}$ & NÃO & \begin{tabular}{|l|}
$\begin{array}{l}\text { Produção energética - } \\
\text { geradores eólicos }\end{array}$ \\
\end{tabular} & SIM & 1 & $\begin{array}{l}\text { Indústrias energéticas (fontes } \\
\text { renováveis - / não-renováveis) }\end{array}$ & Pequena \\
\hline Índia & 872 & 2007 & UltraTech Cement Limited & $\begin{array}{l}\text { 4.0 MW Power Plant Using } \\
\text { Clinker Cooling Gas Waste Heat }\end{array}$ & SIM & $\begin{array}{l}\text { Produção energética - } \\
\text { indústria de cimento }\end{array}$ & NÃO & 1 & $\begin{array}{l}\text { Indústrias energéticas (fontes } \\
\text { renováveis - / não-renováveis) }\end{array}$ & Larga \\
\hline Índia & 437 & 2006 & United Phosphorus Limited & $\begin{array}{l}\text { Switching of fuel from Naphtha } \\
\text { to Natural gas at United } \\
\text { Phosphorus Limited (UPL) }\end{array}$ & SIM & $\begin{array}{l}\text { Transformação industrial - } \\
\text { substituição de combustíveis } \\
\text { fósseis }\end{array}$ & NÃO & 4 & Transformação industrial & Larga \\
\hline Índia & 8439 & 2012 & United Spirits Limited & $\begin{array}{l}\text { Renewable Biomass based } \\
\text { Energy Generation project in a } \\
\text { Distillery at Uttar Pradesh }\end{array}$ & NÃO & $\begin{array}{l}\text { Produção energética - casca } \\
\text { de arroz }\end{array}$ & NÃO & 1 & $\begin{array}{l}\text { Indústrias energéticas (fontes } \\
\text { renováveis - / não-renováveis) }\end{array}$ & Pequena \\
\hline Índia & 810 & 2007 & $\begin{array}{l}\text { Upper Ganges Sugar \& } \\
\text { Industries Limited }\end{array}$ & $\begin{array}{l}\text { Bagasse based Cogeneration } \\
\text { Plant at Seohara, Uttar Pradesh. }\end{array}$ & NÃO & Produção energética - bagaço & NÃO & 1 & $\begin{array}{l}\text { Indústrias energéticas (fontes } \\
\text { renováveis - / não-renováveis) }\end{array}$ & Larga \\
\hline Índia & 696 & 2006 & Usha Martin Limited & $\begin{array}{l}\text { Usha Martin Limited - Waste } \\
\text { Heat Recovery Based Captive } \\
\text { Power Project activity }\end{array}$ & SIM & $\begin{array}{l}\text { Produção energética - gases } \\
\text { industriais }\end{array}$ & NÃO & 1 & $\begin{array}{l}\text { Indústrias energéticas (fontes } \\
\text { renováveis - / não-renováveis) }\end{array}$ & Larga \\
\hline Índia & 6121 & 2012 & $\begin{array}{l}\text { Ushdev International Pvt } \\
\text { Limited }\end{array}$ & $\begin{array}{l}\text { Wind Power Project by Ushdev } \\
\text { International Limited in Tamil } \\
\text { Nadu }\end{array}$ & NÃO & \begin{tabular}{|l|}
$\begin{array}{l}\text { Produção energética - } \\
\text { geradores eólicos }\end{array}$ \\
\end{tabular} & SIM & 1 & $\begin{array}{l}\text { Indústrias energéticas (fontes } \\
\text { renováveis - / não-renováveis) }\end{array}$ & Pequena \\
\hline Índia & 6237 & 2012 & Varun Industries Limited & $\begin{array}{l}4 \text { MW Wind Power Project by } \\
\text { Varun Industries Ltd. in Tamil } \\
\text { Nadu, India }\end{array}$ & NÃO & $\begin{array}{l}\text { Produção energética - } \\
\text { geradores eólicos }\end{array}$ & NÃO & 1 & $\begin{array}{l}\text { Indústrias energéticas (fontes } \\
\text { renováveis - / não-renováveis) }\end{array}$ & Pequena \\
\hline Índia & 9356 & 2012 & Videocon Industries Limited & $\begin{array}{l}\text { Grid connected solar PV project } \\
\text { by VIL and CPPL }\end{array}$ & NÃO & $\begin{array}{l}\text { Produção energética - } \\
\text { geradores solares }\end{array}$ & SIM & 1 & $\begin{array}{l}\text { Indústrias energéticas (fontes } \\
\text { renováveis - / não-renováveis) }\end{array}$ & Pequena \\
\hline Índia & 1149 & 2007 & Vikash Metal \& Power Limited & $\begin{array}{l}10 \text { MW Waste Heat Recovery } \\
\text { based Captive Power Project at } \\
\text { Vikash Metal and Power } \\
\text { Limited }\end{array}$ & NÃO & $\begin{array}{l}\text { Produção energética - gases } \\
\text { industriais }\end{array}$ & SIM & 1 & $\begin{array}{l}\text { Indústrias energéticas (fontes } \\
\text { renováveis - / não-renováveis) }\end{array}$ & Larga \\
\hline
\end{tabular}




\begin{tabular}{|c|c|c|c|c|c|c|c|c|c|c|}
\hline Índia & 570 & 2006 & Vishal Exports Overseas Limited & $\begin{array}{l}\text { 11.35 MW Grid Connected } \\
\text { Wind Electricity Project At } \\
\text { Pohra Rajasthan }\end{array}$ & SIM & $\begin{array}{l}\text { Produção energética - } \\
\text { geradores eólicos }\end{array}$ & NÃO & 1 & $\begin{array}{l}\text { Indústrias energéticas (fontes } \\
\text { renováveis - / não-renováveis) }\end{array}$ & Pequena \\
\hline Índia & 571 & 2006 & Vishal Exports Overseas Limited & $\begin{array}{l}\text { 10.6 MW Wind Farm At Village } \\
\text { Badabagh District Jaisalmer } \\
\text { Rajasthan }\end{array}$ & NÃO & $\begin{array}{l}\text { Produção energética - } \\
\text { geradores eólicos }\end{array}$ & NÃO & 1 & $\begin{array}{l}\text { Indústrias energéticas (fontes } \\
\text { renováveis - / não-renováveis) }\end{array}$ & Pequena \\
\hline Índia & 1786 & 2008 & Welspun India Limited & $\begin{array}{l}\text { Energy efficiency and fuel } \\
\text { switch project at Welspun India } \\
\text { Limited }\end{array}$ & SIM & $\begin{array}{l}\text { Transformação industrial - } \\
\text { substituição de combustíveis } \\
\text { fósseis }\end{array}$ & NÃO & 4 & Transformação industrial & Pequena \\
\hline Índia & 1025 & 2007 & West Coast Paper Mills Limited & $\begin{array}{l}\text { WCPM Energy Efficiency } \\
\text { Project }\end{array}$ & NÃO & $\begin{array}{l}\text { Produção energética - papel e } \\
\text { celulose }\end{array}$ & NÃO & 1 & $\begin{array}{l}\text { Indústrias energéticas (fontes } \\
\text { renováveis - / não-renováveis) }\end{array}$ & Larga \\
\hline Índia & 827 & 2007 & Yash Papers Limited & $\begin{array}{l}\text { Biomass based Cogeneration } \\
\text { Power Project in Uttar Pradesh }\end{array}$ & SIM & $\begin{array}{l}\text { Produção energética - papel e } \\
\text { celulose }\end{array}$ & SIM & 1 & $\begin{array}{l}\text { Indústrias energéticas (fontes } \\
\text { renováveis - / não-renováveis) }\end{array}$ & Larga \\
\hline Índia & 6389 & 2012 & ZF Steering Gear India Limited & $\begin{array}{l}\text { Wind based power generation by } \\
\text { ZF Steering Gear (India) } \\
\text { Limited in Maharashtra, India }\end{array}$ & NÃO & $\begin{array}{l}\text { Produç̧ão energética - } \\
\text { geradores eólicos }\end{array}$ & NÃO & 1 & $\begin{array}{l}\text { Indústrias energéticas (fontes } \\
\text { renováveis - / não-renováveis) }\end{array}$ & Pequena \\
\hline Índia & 7838 & 2012 & ZF Steering Gear India Limited & $\begin{array}{l}\text { Grid Connected Solar } \\
\text { Photovoltaic Power Project by } \\
\text { M/s. ZF Steering Gear (India) } \\
\text { Ltd }\end{array}$ & NÃO & $\begin{array}{l}\text { Produção energética - } \\
\text { geradores solares }\end{array}$ & SIM & 1 & $\begin{array}{l}\text { Indústrias energéticas (fontes } \\
\text { renováveis - / não-renováveis) }\end{array}$ & Pequena \\
\hline
\end{tabular}

Fonte: Dados da pesquisa (2015). 
APÊNDICE D - Mensuração de RCEs de Projetos de MDLs - Brasil

\begin{tabular}{|c|c|c|c|c|c|c|c|c|c|c|c|c|c|}
\hline $\begin{array}{c}\text { País } \\
\text { hospedeiro }\end{array}$ & $\begin{array}{l}\text { Referência } \\
\text { UNFCCC }\end{array}$ & $\begin{array}{l}\begin{array}{c}\text { Período } \\
\text { vigência } \\
\left(1^{a} \text { fase }\right)\end{array} \\
\end{array}$ & $\begin{array}{c}\text { Estimativa } \\
\text { Total de RE } \\
\left(1^{1} \text { fase }\right) \\
\end{array}$ & $\begin{array}{c}\text { Período } \\
\text { Vigência } \\
\text { (total geral) }\end{array}$ & $\begin{array}{c}\text { Estimativa } \\
\text { total de RE } \\
\text { (geral) }\end{array}$ & $\begin{array}{c}\text { Estimativa } \\
\text { anual de RE }\end{array}$ & $\begin{array}{l}\text { Patrimônio } \\
\text { PL original }\end{array}$ & $\begin{array}{c}\text { Valor } \\
\text { tonelada } \\
\text { de RCEs }\end{array}$ & $\begin{array}{l}\text { Valor total } \\
\text { RE (1 } 1^{\mathbf{a}} \text { fase) }\end{array}$ & $\begin{array}{l}\text { Valor total } \\
\text { RE (geral) }\end{array}$ & $\begin{array}{l}\text { Taxa } \\
\text { Juros } \\
\end{array}$ & $\begin{array}{c}\text { Valor } \\
\text { presente } \\
\left(1^{\mathbf{a}} \text { fase }\right) \\
\end{array}$ & $\begin{array}{c}\text { Valor } \\
\text { Presente } \\
\text { (geral) }\end{array}$ \\
\hline Brasil & 2570 & 7 & 60.438 & 30 & 259.020 & 8.634 & $154.564 .764,04$ & 12,31 & $743.991,78$ & $3.188 .536,20$ & 1,610 & $665.293,04$ & $1.974 .684,93$ \\
\hline Brasil & 3887 & 30 & 4.729 .050 & 30 & 4.729 .050 & 157.635 & $889.539 .570,13$ & 7,03 & $33.245 .221,50$ & $33.245 .221,50$ & 2,008 & $18.310 .586,22$ & $18.310 .586,22$ \\
\hline Brasil & 47 & 10 & 242.770 & 10 & 242.770 & 24.277 & $747.641 .429,68$ & 6,45 & $1.565 .866,50$ & $1.565 .866,50$ & 3,440 & $1.116,527,99$ & $1.116,527,99$ \\
\hline Brasil & 2249 & 10 & 558.240 & 10 & 558.240 & 55.824 & $1.268 .083 .397,48$ & 12,31 & $6.871 .934,40$ & $6.871 .934,40$ & 1,610 & 5.857.529,59 & $5.857 .529,59$ \\
\hline Brasil & 7483 & 7 & 150.738 & 30 & 646.020 & 21.534 & $1.246 .310 .735,14$ & 6,48 & $976.782,24$ & $4.186 .209,60$ & 1,108 & $904.272,07$ & $3.007 .844,47$ \\
\hline Brasil & 7612 & 7 & 288.470 & 30 & 1.236 .300 & 41.210 & $1.246 .310 .735,14$ & 6,48 & $1.869 .285,60$ & $8.011 .224,00$ & 1,108 & $1.730 .521,59$ & $5.756 .165,63$ \\
\hline Brasil & 1410 & 7 & 388.871 & 21 & 1.166 .613 & 55.553 & $38.784 .998,52$ & 15,45 & $6.008 .056,95$ & $18.024 .170,85$ & 4,825 & $4.319 .962,16$ & $6.700 .280,78$ \\
\hline Brasil & 7635 & 7 & 26.726 & 20 & 76.360 & 3.818 & $1.872 .345 .901,64$ & 6,48 & $173.184,48$ & $494.812,80$ & 1,108 & $160.328,35$ & 396945,18 \\
\hline Brasil & 213 & 7 & 46.508 & 25 & 166.100 & 6.644 & $514.538 .162,42$ & 6,45 & $299.976,60$ & $1.071 .345,00$ & 3,440 & $236.737,90$ & $459.956,27$ \\
\hline Brasil & 179 & 7 & 84.210 & 25 & 300.750 & 12.030 & $514.538 .162,42$ & 6,45 & $543.154,50$ & $1.939 .837,50$ & 3,440 & $428.650,96$ & 832822,70 \\
\hline Brasil & 489 & 7 & 156.842 & 30 & 672.180 & 22.406 & $1.740 .947 .372,99$ & 6,45 & $1.011 .630,90$ & 4.335.561,00 & 3,440 & $798.366,86$ & $1.571 .773,44$ \\
\hline Brasil & 6350 & 7 & 480.424 & 20 & 1.372 .640 & 68.632 & 2.918.685.513,24 & 6,48 & $3.113 .147,52$ & $8.894 .707,20$ & 1,108 & $2.882 .047,02$ & $7.135 .448,25$ \\
\hline Brasil & 5495 & 10 & 1.493 .580 & 20 & 2.987 .160 & 149.358 & $2.918 .685 .513,24$ & 6,48 & $9.678 .398,40$ & $19.356 .796,80$ & 1,108 & $8.668 .586,71$ & $15.528 .270,78$ \\
\hline Brasil & 2500 & 7 & 107.912 & 30 & 462.480 & 15.416 & $264.132 .997,26$ & 14,02 & $1.512 .926,24$ & $6.483 .969,60$ & 1,352 & $1.377 .182,49$ & $4.333 .824,06$ \\
\hline Brasil & 1232 & 7 & 353.262 & 28 & 1.413 .048 & 50.466 & $1.503 .921 .593,87$ & 15,45 & $5.457 .897,90$ & $21.831 .591,60$ & 4,825 & $3.924 .382,31$ & $5.835 .378,20$ \\
\hline Brasil & 1317 & 10 & 303.100 & 10 & 303.100 & 30.310 & $1.503 .921 .593,87$ & 15,45 & $4.682 .895,00$ & $4.682 .895,00$ & 4,825 & $2.923 .248,32$ & $2.923 .248,32$ \\
\hline Brasil & 1342 & 7 & 226.408 & 22 & 711.568 & 32.344 & $1.503 .921 .593,87$ & 15,45 & $3.498 .003,60$ & $10.993 .725,60$ & 4,825 & $2.515 .163,11$ & $3.898 .681,25$ \\
\hline Brasil & 2609 & 7 & 302.078 & 10 & 431.540 & 43.154 & $6.688 .425 .261,39$ & 14,02 & $4.235 .133,56$ & $6.050 .190,80$ & 1,352 & $3.855 .146,17$ & $5.289 .880,23$ \\
\hline Brasil & 2610 & 7 & 204.673 & 10 & 292.390 & 29.239 & 6.688.425.261,39 & 14,02 & $2.869 .515,46$ & 4.099.307,80 & 1,352 & 2.612.054,94 & $3.584 .159,25$ \\
\hline Brasil & 429 & 10 & 142.370 & 10 & 142.370 & 14.237 & $814.803 .857,71$ & 6,45 & $918.286,50$ & $918.286,50$ & 3,440 & $654.776,50$ & $654.776,50$ \\
\hline
\end{tabular}




\begin{tabular}{|c|c|c|c|c|c|c|c|c|c|c|c|c|c|}
\hline Brasil & 843 & 7 & 8.939 & 24 & 30.648 & 1.277 & $34.642 .464 .296,44$ & 0,02 & 178,78 & 612,96 & 4,448 & 131,83 & 215,69 \\
\hline Brasil & 1731 & 7 & 401.562 & 25 & 1.434 .150 & 57.366 & 42.684.267.156,91 & 12,31 & $4.943 .228,22$ & $17.654 .386,50$ & 1,610 & $4.420 .338,24$ & $11.842 .444,17$ \\
\hline Brasil & 7597 & 7 & 821.968 & 20 & 2.348 .480 & 117.424 & 267.154.317,58 & 6,48 & $5.326 .352,64$ & $15.218 .150,40$ & 1,108 & $4.930 .957,71$ & $12.208 .195,53$ \\
\hline Brasil & 7769 & 7 & 1.168 .468 & 20 & 3.338 .480 & 166.924 & $267.154 .317,58$ & 6,48 & $7.571 .672,64$ & 21.633.350,40 & 1,108 & 7.009.599,27 & $17.354 .551,29$ \\
\hline Brasil & 268 & 10 & 2.204 .390 & 10 & 2.204 .390 & 220.439 & $981.963 .660,93$ & 6,45 & $14.218 .315,50$ & $14.218 .315,50$ & 3,440 & $10.138 .250,74$ & $10.138 .250,74$ \\
\hline Brasil & 7027 & 7 & 371.028 & 20 & 1.060 .080 & 53.004 & $2.249 .977 .037,60$ & 6,48 & $2.404 .261,44$ & $6.869 .318,40$ & 1,108 & $2.225 .784,19$ & $5.510 .655,37$ \\
\hline Brasil & 7017 & 7 & 321.132 & 20 & 917.520 & 45.876 & $2.249 .977 .037,60$ & 6,48 & $2.080 .935,36$ & $5.945 .529,60$ & 1,108 & $1.926 .459,80$ & $4.769 .580,14$ \\
\hline Brasil & 7021 & 7 & 354.865 & 20 & 1.013 .900 & 50.695 & 2.249.977.037,60 & 6,48 & $2.299 .525,20$ & $6.570 .072,00$ & 1,108 & $2.128 .822,91$ & $5.270 .596,07$ \\
\hline Brasil & 7026 & 7 & 287.602 & 20 & 821.720 & 41.086 & 2.249.977.037,60 & 6,48 & $1.863 .660,96$ & $5.324 .745,60$ & 1,108 & $1.725 .314,49$ & $4.271 .579,25$ \\
\hline Brasil & 7023 & 7 & 268.170 & 20 & 766.200 & 38.310 & $2.249 .977 .037,60$ & 6,48 & $1.737 .741,60$ & 4.964.976,00 & 1,108 & $160.8742,59$ & $3.982 .967,46$ \\
\hline Brasil & 7258 & 17 & 181.322 & 34 & 362.644 & 10.666 & $59.283 .880 .361,60$ & 6,48 & $1.174 .966,56$ & $2.349 .933,12$ & 1,108 & $974.252,82$ & $1.615 .652,03$ \\
\hline
\end{tabular}

Fonte: Dados da pesquisa (2015). 
APÊNDICE E - Mensuração de RCEs de Projetos de MDLs - China

\begin{tabular}{|c|c|c|c|c|c|c|c|c|c|c|c|c|c|}
\hline $\begin{array}{c}\text { País } \\
\text { hospedeiro }\end{array}$ & $\begin{array}{l}\text { Referência } \\
\text { UNFCCC }\end{array}$ & \begin{tabular}{|l|}
$\begin{array}{l}\text { Período } \\
\text { vigência } \\
\left(1^{\mathbf{a}} \text { fase }\right)\end{array}$ \\
\end{tabular} & $\begin{array}{c}\text { Estimativa } \\
\text { Total de RE } \\
\left(1^{1} \text { fase }\right) \\
\end{array}$ & \begin{tabular}{|c|c} 
Período \\
Vigência \\
(total geral)
\end{tabular} & $\begin{array}{c}\text { Estimativa } \\
\text { total de RE } \\
\text { (geral) }\end{array}$ & $\begin{array}{c}\text { Estimativa } \\
\text { anual de RE }\end{array}$ & $\begin{array}{l}\text { Patrimônio } \\
\text { PL original }\end{array}$ & \begin{tabular}{|c|} 
Valor \\
tonelada \\
de RCEs \\
\end{tabular} & $\begin{array}{l}\text { Valor total } \\
\text { RE (1 } 1^{\mathbf{a}} \text { fase) } \\
\end{array}$ & $\begin{array}{l}\text { Valor total } \\
\text { RE (geral) }\end{array}$ & $\begin{array}{l}\text { Taxa } \\
\text { juros }\end{array}$ & $\begin{array}{c}\text { Valor } \\
\text { presente } \\
\left(1^{\mathbf{a}} \text { fase }\right) \\
\end{array}$ & $\begin{array}{c}\begin{array}{c}\text { Valor } \\
\text { Presente } \\
\text { (geral) }\end{array} \\
\end{array}$ \\
\hline China & 898 & 10 & 549.070 & 10 & 549.070 & 54.907 & $685.150 .502,32$ & 0,02 & $10.981,40$ & $10.981,40$ & 4,448 & $7.106,51$ & $7.106,51$ \\
\hline China & 1709 & 10 & 1.147 .100 & 10 & 1.147 .100 & 114.710 & $701.036 .894,84$ & 15,45 & $17.722 .695,00$ & $17.722 .695,00$ & 4,825 & $11.063 .207,37$ & $11.063 .207,37$ \\
\hline China & 2703 & 10 & 1.907 .230 & 10 & 1.907 .230 & 190.723 & $1.068 .537 .712,47$ & 14,02 & $26.739 .364,60$ & $26.739 .364,60$ & 1,352 & $23.379 .103,40$ & $23.379 .103,40$ \\
\hline China & 1402 & 7 & 520.450 & 25 & 1.858 .750 & 74.350 & 805.092.161,94 & 15,45 & $8.040 .952,50$ & $28.717 .687,50$ & 4,825 & $5.781 .671,32$ & $8.841 .535,37$ \\
\hline China & 1628 & 7 & 977.739 & 20 & 2.793 .540 & 139.677 & $116.773 .106,10$ & 15,45 & $15.106 .067,55$ & $43.160 .193,00$ & 4,825 & $10.861 .688,03$ & $16.818 .449,54$ \\
\hline China & 1629 & 7 & 873.558 & 21 & 2.620 .674 & 124.794 & $116.773 .106,10$ & 15,45 & $13.496 .471,10$ & $40.489 .413,30$ & 4,825 & $9.704 .342,85$ & $15.051 .479,49$ \\
\hline China & 1830 & 7 & 973.448 & 20 & 2.781 .280 & 139.064 & $116.773 .106,10$ & 15,45 & $15.039 .771,60$ & $42.970 .776,00$ & 4,825 & $10.814 .019,38$ & $16.744 .638,46$ \\
\hline China & 1869 & 7 & 983.157 & 20 & 2.809 .020 & 140.451 & $116.773 .106,10$ & 15,45 & $15.189 .775,65$ & $43.399 .359,00$ & 4,825 & $10.921 .876,51$ & $16.911 .646,56$ \\
\hline China & 2032 & 7 & 773.472 & 21 & 2.320 .416 & 110.496 & $116.773 .106,10$ & 15,45 & $11.950 .142,40$ & $35.850 .427,20$ & 4,825 & $8.592 .488,96$ & $13.326 .989,10$ \\
\hline China & 2049 & 7 & 755.601 & 21 & 2.266 .803 & 107.943 & $116.773 .106,10$ & 15,45 & $11.674 .035,45$ & $35.022 .106,35$ & 4,825 & $8.393 .960,29$ & $13.019 .070,23$ \\
\hline China & 2886 & 7 & 947.107 & 20 & 2.706 .020 & 135.301 & $297.963 .696,78$ & 12,31 & $11.658 .887,17$ & $33.311 .106,20$ & 1,610 & $10.425 .621,16$ & $24.202 .488,80$ \\
\hline China & 2440 & 7 & 1.083 .397 & 20 & 3.095 .420 & 154.771 & $297.963 .696,78$ & 12,31 & $13.336 .617,07$ & $38.104 \cdot 620,20$ & 1,610 & $11.925 .882,39$ & $27.685 .260,22$ \\
\hline China & 1833 & 7 & 539.021 & 21 & 1.617 .063 & 77.003 & $297.963 .696,78$ & 12,31 & $6.635 .348,51$ & $19.906 .045,53$ & 1,610 & $5.933 .467,65$ & $14.233 .755,92$ \\
\hline China & 2530 & 7 & 723.338 & 21 & 2.170 .014 & 103.334 & $297.963 .696,78$ & 12,31 & $8.904 .290,78$ & $26.712 .872,34$ & 1,610 & $7.962 .403,36$ & $19.100 .956,26$ \\
\hline China & 1815 & 7 & 901.838 & 21 & 2.705 .514 & 128.834 & $297.963 .696,78$ & 12,31 & $11.101 .625,78$ & $33.304 .877,34$ & 1,610 & $9.927 .306,35$ & $23.814 .548,92$ \\
\hline China & 2215 & 7 & 399.056 & 21 & 1.197 .168 & 57.008 & $297.963 .696,78$ & 12,31 & $4.912 .379,36$ & $14.737 .138,08$ & 1,610 & $4.392 .752,54$ & $10.537 .744,73$ \\
\hline China & 2568 & 7 & 1.722 .406 & 26 & 6.397 .508 & 246.058 & $297.963 .696,78$ & 12,31 & $21.202 .817,86$ & $78.753 .323,48$ & 1,610 & $18.960 .003,93$ & $51.990 .160,13$ \\
\hline China & 2441 & 7 & 730.681 & 20 & 2.087 .660 & 104.383 & $297.963 .696,78$ & 12,31 & $8.994 .683,11$ & $25.699 .094,60$ & 1,610 & 8.043.234,08 & $18.671 .912,17$ \\
\hline China & 2615 & 7 & 896.322 & 21 & 2.688 .966 & 128.046 & $393.267 .427,73$ & 14,02 & $12.566 .434,44$ & $37.699 .303,32$ & 1,352 & $11.438 .940,68$ & $28.435 .085,52$ \\
\hline China & 2617 & 7 & 904.190 & 21 & 2.712 .570 & 129.170 & $393.267 .427,73$ & 14,02 & $12.676 .743,80$ & $38.030 .231,40$ & 1,352 & $11.539 .352,79$ & $28.684 .691,41$ \\
\hline
\end{tabular}




\begin{tabular}{|c|c|c|c|c|c|c|c|c|c|c|c|c|c|}
\hline China & 3116 & 7 & 959.882 & 21 & 2.879 .646 & 137.126 & $393.267 .427,73$ & 14,02 & $13.457 .545,64$ & $40.372 .636,92$ & 1,352 & $12.250 .099,03$ & $30.451 .474,75$ \\
\hline China & 3126 & 7 & 937.300 & 21 & 2.811 .900 & 133.900 & $393.267 .427,73$ & 14,02 & $13.140 .946,00$ & $39.422 .838,00$ & 1,352 & $11.961 .905,54$ & $29.735 .079,19$ \\
\hline China & 3105 & 7 & 1.008 .826 & 20 & 2.882 .360 & 144.118 & $393.267 .427,73$ & 14,02 & $14.143 .740,52$ & $40.410 .687,20$ & 1,352 & $12.874 .726,68$ & $30.892 .266,53$ \\
\hline China & 3903 & 7 & 783.650 & 20 & 2.239 .000 & 111.950 & $393.267 .427,73$ & 14,02 & $10.986 .773,00$ & $31.390 .780,00$ & 1,352 & $10.001 .010,65$ & 23.996.927,78 \\
\hline China & 3828 & 7 & 863.667 & 20 & 2.467 .620 & 123.381 & 393.267.427,73 & 14,02 & $12.108 .611,34$ & $34.596 .032,40$ & 1,352 & $11.022 .194,68$ & $26.447 .208,10$ \\
\hline China & 3607 & 7 & 857.766 & 20 & 2.450 .760 & 122.538 & $393.267 .427,73$ & 14,02 & $12.025 .879,32$ & $34.359 .655,20$ & 1,352 & $10.946 .885,60$ & $26.266 .507,69$ \\
\hline China & 3469 & 7 & 1.052 .968 & 20 & 3.008 .480 & 150.424 & $393.267 .427,73$ & 14,02 & $14.762 .611,36$ & $42.178 .889,60$ & 1,352 & $13.438 .070,79$ & $32.243 .982,71$ \\
\hline China & 2892 & 10 & 201.450 & 10 & 201.450 & 20.145 & $393.267 .427,73$ & 14,02 & $2.824 .329,00$ & $2.824 .329,00$ & 1,352 & $2.469 .403,47$ & $2.469 .403,47$ \\
\hline China & 2766 & 7 & 589.295 & 24 & 2.020 .440 & 84.185 & $393.267 .427,73$ & 14,02 & $8.261 .915,90$ & $28.326 .568,80$ & 1,352 & $7.520 .634,94$ & $20.521 .930,68$ \\
\hline China & 3512 & 7 & 3.238 .312 & 23 & 10.640 .168 & 462.616 & $393.267 .427,73$ & 14,02 & $45.401 .134,24$ & $149.175 .155,36$ & 1,352 & 41.327.624,31 & $109.535 .038,86$ \\
\hline China & 2680 & 7 & 743.939 & 20 & 2.125 .540 & 106.277 & $393.267 .427,73$ & 14,02 & $10.430 .024,78$ & $29.800 .070,80$ & 1,352 & $9.494 .215,35$ & $22.780 .897,67$ \\
\hline China & 3804 & 7 & 5.805 .625 & 30 & 24.881 .250 & 829.375 & 393.267.427,73 & 14,02 & $81.394 .862,50$ & $348.835 .125,00$ & 1,352 & $74.091 .900,00$ & $233.158 .103,68$ \\
\hline China & 3060 & 7 & 732.067 & 20 & 2.091 .620 & 104.581 & $393.267 .427,73$ & 14,02 & $10.263 .579,34$ & $29.324 .512,40$ & 1,352 & $9.342 .703,84$ & $22.417 .353,32$ \\
\hline China & 2227 & 7 & 821.856 & 20 & 2.348 .160 & 117.408 & $393.267 .427,73$ & 14,02 & $11.522 .421,12$ & $32.921 .203,20$ & 1,352 & $10.488 .599,00$ & $25.166 .871,79$ \\
\hline China & 4067 & 7 & 395.241 & 20 & 1.129 .260 & 56.463 & $942.575 .244,16$ & 7,03 & $2.778 .544,23$ & 7.938.697,80 & 2,008 & $2.417 .562,36$ & $5.334 .142,52$ \\
\hline China & 3573 & 7 & 707.798 & 20 & 2.022 .280 & 101.114 & $942.575 .244,16$ & 7,03 & $4.975 .819,94$ & $14.216 .628,40$ & 2,008 & $4.329 .373,23$ & $9.552 .388,06$ \\
\hline China & 4341 & 7 & 814.730 & 20 & 2.327 .800 & 116.390 & $942.575 .244,16$ & 7,03 & 5.727.551,90 & $16.364 .434,00$ & 2,008 & $4.983 .441,95$ & $10.995 .534,21$ \\
\hline China & 4093 & 7 & 777.693 & 20 & 2.221 .980 & 111.099 & $942.575 .244,16$ & 7,03 & $5.467 .181,79$ & $15.620 .519,40$ & 2,008 & $4.756 .898,51$ & $1.0495 .685,67$ \\
\hline China & 4112 & 7 & 465.409 & 20 & 1.329 .740 & 66.487 & $942.575 .244,16$ & 7,03 & $3.271 .825,27$ & $9.348 .072,20$ & 2,008 & $2.846 .757,50$ & $6.281 .124,52$ \\
\hline China & 3608 & 7 & 848.120 & 20 & 2.423 .200 & 121.160 & $942.575 .244,16$ & 7,03 & $5.962 .283,60$ & $17.035 .096,00$ & 2,008 & $5.187 .677,87$ & $11.446 .163,11$ \\
\hline China & 4738 & 7 & 909.405 & 20 & 2.598 .300 & 129.915 & $942.575 .244,16$ & 7,03 & $6.393 .117,15$ & $18.266 .049,00$ & 2,008 & $5.562 .538,55$ & $12.273 .260,82$ \\
\hline China & 4912 & 7 & 657.643 & 20 & 1.878 .980 & 93.949 & $942.575 .244,16$ & 7,03 & 4.623.230,29 & $13.209 .229,40$ & 2,008 & $4.022 .591,19$ & $8.875 .499,99$ \\
\hline China & 4781 & 7 & 908.964 & 20 & 2.597 .040 & 129.852 & $942.575 .244,16$ & 7,03 & $6.390 .016,92$ & $18.257 .191,20$ & 2,008 & $5.559 .841,09$ & $12.267 .309,12$ \\
\hline China & 4059 & 7 & 834.099 & 21 & 2.502 .297 & 119.157 & $942.575 .244,16$ & 7,03 & $5.863 .715,97$ & $17.591 .147,91$ & 2,008 & $5.101 .915,91$ & $11.587 .114,35$ \\
\hline
\end{tabular}




\begin{tabular}{|c|c|c|c|c|c|c|c|c|c|c|c|c|c|}
\hline China & 4821 & 7 & 792.323 & 25 & 2.829 .725 & 113.189 & $942.575 .244,16$ & 7,03 & $5.570 .030,69$ & $19.892 .966,75$ & 2,008 & $4.846 .385,53$ & $12.101 .626,32$ \\
\hline China & 5132 & 7 & 663.054 & 20 & 1.894 .440 & 94.722 & $942.575 .244,16$ & 7,03 & 4.661.269,62 & $13.317 .913,20$ & 2,008 & 4.055.688,54 & $8.948 .526,43$ \\
\hline China & 4440 & 7 & 915.180 & 20 & 2.614 .800 & 130.740 & $942.575 .244,16$ & 7,03 & $6.433 .715,40$ & $18.382 .044,00$ & 2,008 & $5.597 .862,37$ & $12.351 .199,78$ \\
\hline China & 5443 & 7 & 850.332 & 20 & 2.429 .520 & 121.476 & $1.112 .366 .813,42$ & 6,48 & $5.510 .151,36$ & $15.743 .289,60$ & 1,108 & $5.101 .112,37$ & $12.629 .468,94$ \\
\hline China & 6678 & 7 & 792.701 & 20 & 2.264 .860 & 113.243 & $1.112 .366 .813,42$ & 6,48 & $5.136 .702,48$ & $14.676 .292,80$ & 1,108 & 4.755.385,99 & $11.773 .510,41$ \\
\hline China & 7091 & 7 & 761.264 & 20 & 2.175 .040 & 108.752 & $1.112 .366 .813,42$ & 6,48 & 4.932.990,72 & $14.094 .259,20$ & 1,108 & 4.566.796,51 & $11.306 .595,59$ \\
\hline China & 5681 & 7 & 746.221 & 20 & 2.132 .060 & 106.603 & $1.112 .366 .813,42$ & 6,48 & 4.835.512,08 & $13.815 .748,80$ & 1,108 & 4.476.554,07 & $11.083 .170,97$ \\
\hline China & 6158 & 7 & 600.201 & 20 & 1.714 .860 & 85.743 & $1.112 .366 .813,42$ & 6,48 & $3.889 .302,48$ & $11.112 .292,80$ & 1,108 & $3.600 .585,12$ & $8.914 .423,88$ \\
\hline China & 6561 & 7 & 822.647 & 21 & 2.467 .941 & 117.521 & $1.112 .366 .813,42$ & 6,48 & $5.330 .752,56$ & $15.992 .257,68$ & 1,108 & 4.935.031,01 & $12.688 .604,59$ \\
\hline China & 5199 & 7 & 469.686 & 20 & 1.341 .960 & 67.098 & $1.112 .366 .813,42$ & 6,48 & $3.043 .565,28$ & $8.695 .900,80$ & 1,108 & $2.817 .630,13$ & $6.975 .963,21$ \\
\hline China & 5733 & 7 & 659.043 & 20 & 1.882 .980 & 94.149 & $1.112 .366 .813,42$ & 6,48 & $4.270 .598,64$ & $12.201 .710,40$ & 1,108 & $3.953 .576,25$ & $9.788 .368,66$ \\
\hline China & 5978 & 7 & 673.295 & 21 & 2.019 .885 & 96.185 & $1.112 .366 .813,42$ & 6,48 & 4.362.951,60 & $13.088 .854,80$ & 1,108 & 4.039.073,51 & $10.384 .981,68$ \\
\hline China & 6415 & 7 & 818.181 & 20 & 2.337 .660 & 116.883 & $1.112 .366 .813,42$ & 6,48 & $5.301 .812,88$ & $15.148 .036,80$ & 1,108 & 4.908.239,63 & $12.151 .949,50$ \\
\hline China & 6670 & 7 & 832.573 & 20 & 2.378 .780 & 118.939 & $1.112 .366 .813,42$ & 6,48 & $5.395 .073,04$ & $15.414 .494,40$ & 1,108 & 4.994.576,74 & $12.365 .705,21$ \\
\hline China & 5688 & 7 & 987.630 & 20 & 2.821 .800 & 141.090 & $1.112 .366 .813,42$ & 6,48 & $6.399 .842,40$ & $18.285 .264,00$ & 1,108 & $5.924 .758,34$ & $14.668 .673,42$ \\
\hline China & 5856 & 7 & 922.537 & 20 & 2.635 .820 & 131.791 & $1.112 .366 .813,42$ & 6,48 & $5.978 .039,76$ & $17.080 .113,60$ & 1,108 & $5.534 .267,68$ & $13.701 .886,30$ \\
\hline China & 7710 & 10 & 693.240 & 10 & 693.240 & 69.324 & $1.112 .366 .813,42$ & 6,48 & $4.492 .195,20$ & $4.492 .195,20$ & 1,108 & $4.023 .494,59$ & 4.023.494,59 \\
\hline China & 5875 & 7 & 262.185 & 20 & 749.100 & 37.455 & $1.112 .366 .813,42$ & 6,48 & $1.698 .958,80$ & $4.854 .168,00$ & 1,108 & $1.572 .838,78$ & $3.894 .075,86$ \\
\hline China & 1172 & 7 & 269.332 & 20 & 769.520 & 38.476 & $190.846 .563,42$ & 0,02 & $5.386,64$ & $15.390,40$ & 4,448 & $3.972,07$ & $6.445,36$ \\
\hline China & 1177 & 7 & 1.630 .734 & 21 & 4.892.202 & 232.962 & $190.846 .563,42$ & 0,02 & $32.614,68$ & $97.844,04$ & 4,448 & $24.049,84$ & $39.231,21$ \\
\hline China & 1487 & 7 & 999.936 & 20 & 2.856 .960 & 142.848 & $268.318 .288,23$ & 15,45 & $15.449 .011,20$ & $44.140 .032,00$ & 4,825 & $11.108 .274,18$ & $17.200 .268,33$ \\
\hline China & 1488 & 7 & 970.095 & 20 & 2.771 .700 & 138.585 & $268.318 .288,23$ & 15,45 & $14.987 .967,75$ & $42.822 .765,00$ & 4,825 & $10.776 .770,95$ & $16.686 .962,27$ \\
\hline China & 2056 & 7 & & 21 & & & & 15,45 & & & 4,825 & & \\
\hline
\end{tabular}




\begin{tabular}{|c|c|c|c|c|c|c|c|c|c|c|c|c|c|}
\hline & & & 411.558 & & 1.234 .674 & 58.794 & $268.318 .288,23$ & & $6.358 .571,10$ & $19.075 .713,30$ & & $4.571 .991,71$ & $7.091 .179,75$ \\
\hline China & 2067 & 7 & 857.115 & 21 & 2.571 .345 & 122.445 & $268.318 .288,23$ & 15,45 & $13.242 .426,75$ & $39.727 .280,25$ & 4,825 & $9.521 .677,81$ & $14.768 .165,19$ \\
\hline China & 1892 & 7 & 831.383 & 20 & 2.375 .380 & 118.769 & $408.604 .654,28$ & 12,31 & $10.234 .324,73$ & $29.240 .927,80$ & 1,610 & $9.151 .747,58$ & $21.245 .263,46$ \\
\hline China & 2140 & 7 & 851.032 & 20 & 2.431 .520 & 121.576 & 408.604.654,28 & 12,31 & $10.476 .203,92$ & 29.932.011,20 & 1,610 & $9.368 .041,02$ & $21.747 .376,43$ \\
\hline China & 2870 & 7 & 945.021 & 20 & 2.700 .060 & 135.003 & $408.604 .654,28$ & 12,31 & 11.633.208,51 & $33.237 .738,60$ & 1,610 & $10.402 .658,77$ & $24.149 .182,90$ \\
\hline China & 2200 & 7 & 719.278 & 20 & 2.055 .080 & 102.754 & $408.604 .654,28$ & 12,31 & $8.854 .312,18$ & $25.298 .034,80$ & 1,610 & 7.917.711,45 & $18.380 .518,50$ \\
\hline China & 2153 & 7 & 3.429 .643 & 23 & 11.268 .827 & 489.949 & $408.604 .654,28$ & 12,31 & $42.218 .905,33$ & $138.719 .260,37$ & 1,610 & $37.753 .029,64$ & $96.072 .343,18$ \\
\hline China & 1621 & 7 & 849.065 & 20 & 2.425 .900 & 121.295 & 408.604.654,28 & 12,31 & $10.451 .990,15$ & $29.862 .829,00$ & 1,610 & $9.346 .388,56$ & $21.697 .111,47$ \\
\hline China & 2857 & 7 & 1.333 .801 & 21 & 4.001 .403 & 190.543 & $408.604 .654,28$ & 12,31 & $16.419 .090,31$ & 49.257.270,93 & 1,610 & $14.682 .294,54$ & $35.221 .258,33$ \\
\hline China & 2035 & 7 & 818.804 & 21 & 2.456 .412 & 116.972 & $408.604 .654,28$ & 12,31 & $10.079 .477,24$ & $30.238 .431,72$ & 1,610 & $9.013 .279,71$ & $21.621 .896,52$ \\
\hline China & 2449 & 7 & 485.604 & 21 & 1.456 .812 & 69.372 & 408.604.654,28 & 12,31 & $5.977 .785,24$ & $17.933 .355,72$ & 1,610 & $5.345 .460,80$ & $12.823 .190,21$ \\
\hline China & 3519 & 7 & 961.667 & 20 & 2.747 .620 & 137.381 & $2.235 .803 .561,06$ & 14,02 & $13.482 .571,34$ & $38.521 .632,40$ & 1,352 & $12.272 .879,35$ & $29.448 .163,78$ \\
\hline China & 3325 & 7 & 1.087 .688 & 20 & 3.107 .680 & 155.384 & $2.235 .803 .561,06$ & 14,02 & $15.249 .385,76$ & $43.569 .673,60$ & 1,352 & $13.881 .170,51$ & $33.307 .178,44$ \\
\hline China & 3439 & 7 & 1.056 .405 & 20 & 3.018 .300 & 150.915 & 2.235.803.561,06 & 14,02 & $14.810 .798,10$ & $42.316 .566,00$ & 1,352 & $13.481 .934,09$ & $32.349 .230,51$ \\
\hline China & 3777 & 7 & 865.893 & 20 & 2.473 .980 & 123.699 & 2.235.803.561,06 & 14,02 & $12.139 .819,86$ & $34.685 .199,60$ & 1,352 & $11.050 .603,09$ & $26.515 .372,66$ \\
\hline China & 3003 & 7 & 846.335 & 20 & 2.418 .100 & 120.905 & 2.235.803.561,06 & 14,02 & $11.865 .616,70$ & $33.901 .762,00$ & 1,352 & $10.801 .002,16$ & $25.916 .467,65$ \\
\hline China & 2604 & 7 & 529.914 & 20 & 1.514 .040 & 75.702 & 2.235.803.561,06 & 14,02 & 7.429.394,28 & $21.226 .840,80$ & 1,352 & $6.762 .809,36$ & $16.227 .024,80$ \\
\hline China & 3093 & 7 & 928.333 & 21 & 2.784 .999 & 132.619 & $2.235 .803 .561,06$ & 14,02 & $13.015 .228,66$ & $39.045 .685,98$ & 1,352 & $11.847 .467,90$ & $29.450 .608,42$ \\
\hline China & 2951 & 7 & 837.144 & 20 & 2.391 .840 & 119.592 & $2.235 .803 .561,06$ & 14,02 & $11.736 .758,88$ & $33.533 .596,80$ & 1,352 & $10.683 .705,81$ & $25.635 .020,88$ \\
\hline China & 3134 & 7 & 892.353 & 20 & 2.549 .580 & 127.479 & $2.235 .803 .561,06$ & 14,02 & $12.510 .789,06$ & $35.745 .111,60$ & 1,352 & $11.388 .287,95$ & $27.325 .630,70$ \\
\hline China & 3447 & 7 & 862.085 & 20 & 2.463 .100 & 123.155 & $2.235 .803 .561,06$ & 14,02 & $12.086 .431,70$ & $34.532 .662,00$ & 1,352 & $11.002 .005,06$ & $26.398 .764,10$ \\
\hline China & 3679 & 7 & 900.249 & 20 & 2.572 .140 & 128.607 & 2.235.803.561,06 & 14,02 & $12.621 .490,98$ & $36.061 .402,80$ & 1,352 & $11.489 .057,40$ & $27.567 .421,98$ \\
\hline China & 3122 & 7 & 828.457 & 20 & 2.367 .020 & 118.351 & 2.235.803.561,06 & 14,02 & $11.614 .967,14$ & $33.185 .620,40$ & 1,352 & $10.572 .841,55$ & $25.369 .007,59$ \\
\hline China & 3153 & 7 & 834.855 & 20 & 2.385 .300 & 119.265 & $2.235 .803 .561,06$ & 14,02 & $11.704 .667,10$ & $33.441 .906,00$ & 1,352 & $10.654 .493,39$ & $25.564 .927,13$ \\
\hline
\end{tabular}




\begin{tabular}{|c|c|c|c|c|c|c|c|c|c|c|c|c|c|}
\hline China & 3799 & 7 & 811.482 & 20 & 2.318 .520 & 115.926 & 2.235.803.561,06 & 14,02 & $11.376 .977,64$ & $32.505 .650,40$ & 1,352 & $10.356 .205,09$ & $24.849 .199,19$ \\
\hline China & 3736 & 7 & 1.349 .481 & 23 & 4.434.009 & 192.783 & $2.235 .803 .561,06$ & 14,02 & $18.919 .723,62$ & $62.164 .806,18$ & 1,352 & $17.222 .195,94$ & $45.645 .834,55$ \\
\hline China & 3258 & 7 & 786.163 & 20 & 2.246 .180 & 112.309 & 2.235.803.561,06 & 14,02 & $11.022 .005,26$ & $31.491 .443,60$ & 1,352 & $10.033 .081,77$ & $24.073 .880,86$ \\
\hline China & 3704 & 7 & 2.313 .647 & 20 & 6.610 .420 & 330.521 & 2.235.803.561,06 & 14,02 & $32.437 .330,94$ & $92.678 .088,40$ & 1,352 & $29.526 .967,75$ & $70.848 .490,99$ \\
\hline China & 3800 & 7 & 393.890 & 20 & 1.125 .400 & 56.270 & 2.235.803.561,06 & 14,02 & $5.522 .337,80$ & $15.778 .108,00$ & 1,352 & $5.026 .859,04$ & $12.061 .698,31$ \\
\hline China & 4001 & 7 & 786.009 & 20 & 2.245 .740 & 112.287 & 2.235.803.561,06 & 14,02 & $11.019 .846,18$ & $31.485 .274,80$ & 1,352 & $10.031 .116,41$ & $24.069 .165,07$ \\
\hline China & 3758 & 7 & 789.453 & 20 & 2.255 .580 & 112.779 & 2.235.803.561,06 & 14,02 & $11.068 .131,06$ & $31.623 .231,60$ & 1,352 & $10.075 .069,05$ & $24.174 .627,23$ \\
\hline China & 3743 & 7 & 784.728 & 20 & 2.242 .080 & 112.104 & 2.235.803.561,06 & 14,02 & $11.001 .886,56$ & $31.433 .961,60$ & 1,352 & $10.014 .768,18$ & $24.029 .938,29$ \\
\hline China & 3470 & 7 & 792.134 & 21 & 2.376 .402 & 113.162 & 2.235.803.561,06 & 14,02 & $11.105 .718,68$ & $33.317 .156,04$ & 1,352 & $10.109 .284,21$ & $25.129 .806,06$ \\
\hline China & 2864 & 7 & 780.528 & 21 & 2.341 .584 & 111.504 & 2.235.803.561,06 & 14,02 & $10.943 .002,56$ & $32.829 .007,68$ & 1,352 & $9.961 .167,41$ & $24.761 .615,16$ \\
\hline China & 1924 & 7 & 850.542 & 20 & 2.430 .120 & 121.506 & 2.235.803.561,06 & 14,02 & $11.924 .598,84$ & $34.070 .282,40$ & 1,352 & $10.854 .692,27$ & $26.045 .294,39$ \\
\hline China & 1965 & 7 & 382.242 & 20 & 1.092 .120 & 54.606 & $2.235 .803 .561,06$ & 14,02 & $5.359 .032,84$ & $15.311 .522,40$ & 1,352 & 4.878.206,23 & $11.705 .013,29$ \\
\hline China & 2123 & 7 & 868.875 & 20 & 2.482 .500 & 124.125 & $2.235 .803 .561,06$ & 14,02 & $12.181 .627,50$ & $34.804 .650,00$ & 1,352 & $11.088 .659,64$ & $26.606 .687,46$ \\
\hline China & 2854 & 7 & 328.972 & 21 & 986.916 & 46.996 & 2.235.803.561,06 & 14,02 & 4.612.187,44 & $13.836 .562,32$ & 1,352 & 4.198.369,78 & $10.436 .368,80$ \\
\hline China & 2817 & 7 & 809.823 & 20 & 2.313 .780 & 115.689 & 2.235.803.561,06 & 14,02 & $11.353 .718,46$ & $32.439 .195,60$ & 1,352 & $10.352 .895,45$ & $24.921 .052,71$ \\
\hline China & 3806 & 7 & 725.004 & 20 & 2.071 .440 & 103.572 & 2.235.803.561,06 & 14,02 & $10.164 .556,08$ & $29.041 .588,80$ & 1,352 & $9.252 .565,20$ & $22.201 .070,16$ \\
\hline China & 3652 & 7 & 672.455 & 20 & 1.921 .300 & 96.065 & $2.235 .803 .561,06$ & 14,02 & $9.427 .819,10$ & $26.936 .626,00$ & 1,352 & $8.581 .930,22$ & $20.591 .914,85$ \\
\hline China & 3792 & 7 & 179.865 & 20 & 513.900 & 25.695 & 2.235.803.561,06 & 14,02 & $2.521 .707,30$ & $7.204 .878,00$ & 1,352 & $2.295 .453,05$ & $5.507 .825,45$ \\
\hline China & 3835 & 7 & 521.584 & 20 & 1.490 .240 & 74.512 & $2.235 .803 .561,06$ & 14,02 & 7.312.607,68 & $20.893 .164,80$ & 1,352 & $6.656 .501,16$ & $15.971 .943,57$ \\
\hline China & 3253 & 7 & 723.884 & 20 & 2.068 .240 & 103.412 & $2.235 .803 .561,06$ & 14,02 & $10.148 .853,68$ & $28.996 .724,80$ & 1,352 & $9.238 .271,67$ & $22.166 .773,52$ \\
\hline China & 4123 & 7 & 756.707 & 20 & 2.162 .020 & 108.101 & $2.632 .775 .386,47$ & 7,03 & $5.319 .650,21$ & $15.199 .000,60$ & 2,008 & 4.628.533,88 & $10.212 .460,21$ \\
\hline China & 4462 & 7 & 4.364 .073 & 20 & 12.468 .780 & 623.439 & 2.632.775.386,47 & 7,03 & $30.679 .433,19$ & $87.655 .523,40$ & 2,008 & 26.693.634,06 & $58.897 .197,81$ \\
\hline China & 5427 & 7 & & 24 & & & & 7,03 & & & 2,008 & & \\
\hline
\end{tabular}




\begin{tabular}{|c|c|c|c|c|c|c|c|c|c|c|c|c|c|}
\hline & & & 685.307 & & 2.349 .624 & 97.901 & $2.632 .775 .386,47$ & & $4.817 .708,21$ & $16.517 .856,72$ & & $4.191 .803,00$ & $10.250 .194,56$ \\
\hline China & 5246 & 7 & 724.857 & 20 & 2.071 .020 & 103.551 & $2.632 .775 .386,47$ & 7,03 & $5.095 .744,71$ & $14.559 .270,60$ & 2,008 & $4.433 .717,65$ & $9.782 .615,03$ \\
\hline China & 5235 & 7 & 484.918 & 21 & 1.454 .754 & 69.274 & 2.632.775.386,47 & 7,03 & 3.408.973,54 & $10.226 .920,62$ & 2,008 & $2.966 .087,79$ & $6.736 .371,00$ \\
\hline China & 5171 & 7 & 843.528 & 20 & 2.410 .080 & 120.504 & 2.632.775.386,47 & 7,03 & $5.930 .001,84$ & $16.942 .862,40$ & 2,008 & $5.159 .590,08$ & $11.384 .189,83$ \\
\hline China & 4203 & 7 & 792.316 & 20 & 2.263 .760 & 113.188 & $2.632 .775 .386,47$ & 7,03 & $5.569 .981,48$ & $15.914 .232,80$ & 2,008 & 4.846.342,71 & $10.693 .036,57$ \\
\hline China & 4689 & 7 & 947.163 & 20 & 2.706 .180 & 135.309 & $2.632 .775 .386,47$ & 7,03 & $6.658 .555,89$ & $19.024 .445,40$ & 2,008 & $5.793 .492,12$ & $12.782 .839,92$ \\
\hline China & 5122 & 7 & 807.982 & 20 & 2.308 .520 & 115.426 & $2.632 .775 .386,47$ & 7,03 & $5.680 .113,46$ & $16.228 .895,60$ & 2,008 & $4.942 .166,60$ & $10.904 .463,71$ \\
\hline China & 4854 & 7 & 800.779 & 21 & 2.402 .337 & 114.397 & 2.632.775.386,47 & 7,03 & 5.629.476,37 & $16.888 .429,11$ & 2,008 & $4.898 .108,16$ & $11.124 .240,45$ \\
\hline China & 4035 & 7 & 801.122 & 20 & 2.288 .920 & 114.446 & 2.632.775.386,47 & 7,03 & $5.631 .887,66$ & $16.091 .107,60$ & 2,008 & $4.900 .206,18$ & $10.811 .881,68$ \\
\hline China & 4038 & 7 & 805.014 & 20 & 2.300 .040 & 115.002 & 2.632.775.386,47 & 7,03 & $5.659 .248,42$ & $16.169 .281,20$ & 2,008 & $4.924 .012,30$ & $10.864 .407,81$ \\
\hline China & 5157 & 7 & 853.118 & 20 & 2.437 .480 & 121.874 & $2.632 .775 .386,47$ & 7,03 & 5.997.419,54 & $17.135 .484,40$ & 2,008 & $5.218 .249,03$ & $11.513 .615,74$ \\
\hline China & 4004 & 7 & 840.637 & 20 & 2.401 .820 & 120.091 & 2.632.775.386,47 & 7,03 & $5.909 .678,11$ & $16.884 .794,60$ & 2,008 & $5.141 .906,76$ & $11.345 .173,11$ \\
\hline China & 5214 & 7 & 1.739 .283 & 20 & 4.969 .380 & 248.469 & $2.632 .775 .386,47$ & 7,03 & $12.227 .159,49$ & $34.934 .741,40$ & 2,008 & $10.638 .635,96$ & $23.473 .231,29$ \\
\hline China & 4797 & 7 & 832.216 & 20 & 2.377 .760 & 118.888 & 2.632.775.386,47 & 7,03 & $5.850 .478,48$ & $16.715 .652,80$ & 2,008 & $5.090 .398,20$ & $11.231 .523,94$ \\
\hline China & 4172 & 7 & 863.590 & 20 & 2.467 .400 & 123.370 & 2.632.775.386,47 & 7,03 & $6.071 .037,70$ & $17.345 .822,00$ & 2,008 & 5.282.302,89 & $11.654 .945,06$ \\
\hline China & 4178 & 7 & 891.583 & 20 & 2.547 .380 & 127.369 & 2.632.775.386,47 & 7,03 & $6.267 .828,49$ & $17.908 .081,40$ & 2,008 & 5.453.527,09 & $12.032 .736,46$ \\
\hline China & 4180 & 7 & 863.877 & 20 & 2.468 .220 & 123.411 & 2.632.775.386,47 & 7,03 & $6.073 .055,31$ & $17.351 .586,60$ & 2,008 & $5.284 .058,38$ & $11.658 .818,39$ \\
\hline China & 4381 & 7 & 164.955 & 20 & 471.300 & 23.565 & $2.632 .775 .386,47$ & 7,03 & $1.159 .633,65$ & $3.313 .239,00$ & 2,008 & $1.008 .976,80$ & $2.226 .220,15$ \\
\hline China & 3803 & 7 & 729.071 & 20 & 2.083 .060 & 104.153 & 2.632.775.386,47 & 7,03 & $5.125 .369,13$ & $14.643 .911,80$ & 2,008 & 4.459.493,34 & $9.839 .486,85$ \\
\hline China & 5388 & 7 & 691.887 & 20 & 1.976 .820 & 98.841 & 2.632.775.386,47 & 7,03 & 4.863.965,61 & $13.897 .044,60$ & 2,008 & $4.232 .050,74$ & $9.337 .654,41$ \\
\hline China & 4573 & 7 & 680.687 & 20 & 1.944 .820 & 97.241 & $2.632 .775 .386,47$ & 7,03 & $4.785 .229,61$ & $13.672 .084,60$ & 2,008 & $4.163 .543,94$ & $9.186 .500,06$ \\
\hline China & 3972 & 7 & 759.920 & 20 & 2.171 .200 & 108.560 & 2.632.775.386,47 & 7,03 & $5.342 .237,60$ & $15.263 .536,00$ & 2,008 & 4.648.186,77 & $10.255 .822,61$ \\
\hline China & 4104 & 7 & 756.952 & 20 & 2.162 .720 & 108.136 & 2.632.775.386,47 & 7,03 & $5.321 .372,56$ & $15.203 .921,60$ & 2,008 & 4.630.032,47 & $10.215 .766,71$ \\
\hline China & 4195 & 7 & 794.437 & 20 & 2.269 .820 & 113.491 & $2.632 .775 .386,47$ & 7,03 & $5.584 .892,11$ & $15.956 .834,60$ & 2,008 & $4.859 .316,19$ & $10.721 .661,42$ \\
\hline
\end{tabular}




\begin{tabular}{|c|c|c|c|c|c|c|c|c|c|c|c|c|c|}
\hline China & 4784 & 7 & 804.202 & 21 & 2.412 .606 & 114.886 & 2.632.775.386,47 & 7,03 & $5.653 .540,06$ & $16.960 .620,18$ & 2,008 & $4.919 .045,56$ & $11.171 .791,99$ \\
\hline China & 5009 & 7 & 748.384 & 20 & 2.138 .240 & 106.912 & $2.632 .775 .386,47$ & 7,03 & $5.261 .139,52$ & $15.031 .827,20$ & 2,008 & $4.577 .624,76$ & $10.100 .133,63$ \\
\hline China & 4842 & 7 & 827.974 & 20 & 2.365 .640 & 118.282 & $2.632 .775 .386,47$ & 7,03 & $5.820 .657,22$ & $16.630 .449,20$ & 2,008 & $5.064 .451,25$ & $11.174 .274,23$ \\
\hline China & 4909 & 7 & 873.005 & 20 & 2.494 .300 & 124.715 & 2.632.775.386,47 & 7,03 & $6.137 .225,15$ & $17.534 .929,00$ & 2,008 & $5.339 .891,43$ & $11.782 .009,18$ \\
\hline China & 4987 & 7 & 746.102 & 21 & 2.238 .306 & 106.586 & 2.632.775.386,47 & 7,03 & $5.245 .097,06$ & $15.735 .291,18$ & 2,008 & $4.563 .666,50$ & $10.364 .679,96$ \\
\hline China & 5147 & 7 & 747.376 & 20 & 2.135 .360 & 106.768 & 2.632.775.386,47 & 7,03 & $5.254 .053,28$ & $15.011 .580,80$ & 2,008 & 4.571.459,15 & $10.086 .529,74$ \\
\hline China & 5587 & 7 & 758.632 & 21 & 2.275 .896 & 108.376 & 2.632.775.386,47 & 7,03 & $5.333 .182,96$ & $15.999 .548,88$ & 2,008 & $4.640 .308,49$ & $10.538 .743,88$ \\
\hline China & 5491 & 7 & 875.210 & 20 & 2.500 .600 & 125.030 & $2.632 .775 .386,47$ & 7,03 & $6.152 .726,30$ & $17.579 .218,00$ & 2,008 & $5.353 .378,71$ & $11.811 .767,70$ \\
\hline China & 5178 & 7 & 838.866 & 20 & 2.396 .760 & 119.838 & $2.632 .775 .386,47$ & 7,03 & $5.897 .227,98$ & $16.849 .222,80$ & 2,008 & $5.131 .074,12$ & $11.321 .271,83$ \\
\hline China & 5382 & 7 & 403.263 & 20 & 1.152 .180 & 57.609 & $2.632 .775 .386,47$ & 7,03 & $2.834 .938,89$ & $8.099 .825,40$ & 2,008 & $2.466 .630,36$ & $5.442 .406,82$ \\
\hline China & 4812 & 7 & 591.199 & 20 & 1.689 .140 & 84.457 & $2.632 .775 .386,47$ & 7,03 & $4.156 .128,97$ & $11.874 .654,20$ & 2,008 & $3.616 .174,56$ & $7.978 .776,81$ \\
\hline China & 4980 & 7 & 644.245 & 20 & 1.840 .700 & 92.035 & $2.632 .775 .386,47$ & 7,03 & 4.529.042,35 & $12.940 .121,00$ & 2,008 & $3.940 .639,92$ & $8.694 .681,60$ \\
\hline China & 5711 & 7 & 864.010 & 20 & 2.468 .600 & 123.430 & $3.119 .766 .707,49$ & 6,48 & $5.598 .784,80$ & $15.996 .528,00$ & 1,108 & $5.183 .166,22$ & $12.832 .620,03$ \\
\hline China & 6265 & 7 & 662.494 & 20 & 1.892 .840 & 94.642 & $3.119 .766 .707,49$ & 6,48 & 4.292.961,12 & $12.265 .603,20$ & 1,108 & $3.974 .278,68$ & $9.839 .624,28$ \\
\hline China & 7129 & 7 & 700.616 & 20 & 2.001 .760 & 100.088 & $3.119 .766 .707,49$ & 6,48 & $4.539 .991,68$ & $12.971 .404,80$ & 1,108 & $4.202 .971,24$ & $10.405 .827,38$ \\
\hline China & 5834 & 7 & 299.418 & 20 & 855.480 & 42.774 & $3.119 .766 .707,49$ & 6,48 & $1.940 .228,64$ & 5.543.510,40 & 1,108 & $1.796 .198,27$ & 4.447.075,18 \\
\hline China & 7425 & 7 & 636.804 & 21 & 1.910 .412 & 90.972 & $3.119 .766 .707,49$ & 6,48 & $4.126 .489,92$ & $12.379 .469,76$ & 1,108 & $3.820 .165,25$ & $9.822 .140,18$ \\
\hline China & 7189 & 7 & 1.503 .649 & 21 & 4.510 .947 & 214.807 & $3.119 .766 .707,49$ & 6,48 & $9.743 .645,52$ & $29.230 .936,56$ & 1,108 & $9.020 .338,54$ & $23.192 .459,95$ \\
\hline China & 6926 & 7 & 698.523 & 21 & 2.095 .569 & 99.789 & $3.119 .766 .707,49$ & 6,48 & 4.526.429,04 & $13.579 .287,12$ & 1,108 & $4.190 .415,41$ & $10.774 .101,34$ \\
\hline China & 6906 & 7 & 705.992 & 21 & 2.117 .976 & 100.856 & $3.119 .766 .707,49$ & 6,48 & $4.574 .828,16$ & $13.724 .484,48$ & 1,108 & 4.235.221,68 & $10.889 .304,07$ \\
\hline China & 6094 & 7 & 378.000 & 20 & 1.080 .000 & 54.000 & $3.119 .766 .707,49$ & 6,48 & $2.449 .440,00$ & $6.998 .400,00$ & 1,108 & $2.267 .608,98$ & 5.614.206,28 \\
\hline China & 1689 & 7 & 2.750 .342 & 21 & 8.251 .026 & 392.906 & $595.188 .488,19$ & 15,45 & $42.492 .783,90$ & $127.478 .351,70$ & 4,825 & $30.553 .508,44$ & $47.388 .629,27$ \\
\hline China & 1499 & 7 & & 25 & & & & 15,45 & & & 4,825 & & \\
\hline
\end{tabular}




\begin{tabular}{|c|c|c|c|c|c|c|c|c|c|c|c|c|c|}
\hline & & & 482.594 & & 1.723 .550 & 68.942 & $584.247 .776,01$ & & $7.456 .077,30$ & $26.628 .847,50$ & & $5.361 .129,58$ & $8.198 .428,13$ \\
\hline China & 1537 & 7 & 209.146 & 20 & 597.560 & 29.878 & $584.247 .776,01$ & 15,45 & $3.231 .305,70$ & $9.232 .302,00$ & 4,825 & $2.323 .399,81$ & $3.597 .597,57$ \\
\hline China & 1539 & 7 & 308.077 & 20 & 880.220 & 44.011 & $584.247 .776,01$ & 15,45 & $4.759 .789,65$ & $13.599 .399,00$ & 4,825 & $3.422 .422,82$ & $5.299 .346,23$ \\
\hline China & 2847 & 7 & 2.052 .127 & 30 & 8.794 .830 & 293.161 & $729.383 .129,11$ & 14,02 & $28.770 .820,54$ & $123.303 .516,60$ & 1,352 & $26.189 .426,37$ & $82.414 .906,20$ \\
\hline China & 2960 & 7 & 1.432 .928 & 30 & 6.141 .120 & 204.704 & $729.383 .129,11$ & 14,02 & $20.089 .650,56$ & $86.098 .502,40$ & 1,352 & $18.287 .153,94$ & $57.547 .426,02$ \\
\hline China & 3968 & 7 & 496.503 & 30 & 2.127 .870 & 70.929 & $729.383 .129,11$ & 14,02 & $6.960 .972,06$ & $29.832 .737,40$ & 1,352 & $6.336 .415,22$ & $19.939 .919,98$ \\
\hline China & 7648 & 7 & 728.616 & 30 & 3.122 .640 & 104.088 & $1.418 .238 .609,51$ & 6,48 & $4.721 .431,68$ & $20.234 .707,20$ & 1,108 & $4.370 .942,28$ & $14.538 .892,70$ \\
\hline China & 1327 & 7 & 645.435 & 25 & 2.305 .125 & 92.205 & 2.752.278.022,29 & 15,45 & $9.971 .970,75$ & $35.614 .181,25$ & 4,825 & $7.170 .127,83$ & $10.964 .811,95$ \\
\hline China & 2223 & 7 & 811.006 & 20 & 2.317 .160 & 115.858 & $2.661 .900 .224,97$ & 14,02 & $11.370 .304,12$ & $32.486 .583,20$ & 1,352 & $10.350 .130,34$ & $24.834 .623,12$ \\
\hline China & 2462 & 7 & 792.456 & 21 & 2.377 .368 & 113.208 & $2.661 .900 .224,97$ & 14,02 & $11.110 .233,12$ & $33.330 .699,36$ & 1,352 & $10.113 .393,60$ & $25.140 .021,25$ \\
\hline China & 2584 & 7 & 708.736 & 20 & 2.024 .960 & 101.248 & $2.661 .900 .224,97$ & 14,02 & $9.936 .478,72$ & $28.389 .939,20$ & 1,352 & $9.044 .951,55$ & $21.702 .911,51$ \\
\hline China & 3092 & 7 & 867.951 & 21 & 2.603 .853 & 123.993 & $2.661 .900 .224,97$ & 14,02 & $12.168 .673,02$ & $36.506 .019,06$ & 1,352 & $11.076 .867,47$ & $27.535 .038,65$ \\
\hline China & 4193 & 7 & 737.639 & 20 & 2.107 .540 & 105.377 & $2.661 .900 .224,97$ & 14,02 & $10.341 .698,78$ & $29.547 .710,80$ & 1,352 & $9.413 .814,19$ & $22.587 .979,09$ \\
\hline China & 3840 & 7 & 726.971 & 21 & 2.180 .913 & 103.853 & $2.661 .900 .224,97$ & 14,02 & $10.192 .133,42$ & $30.576 .400,26$ & 1,352 & $9.277 .668,23$ & 23.062.562,95 \\
\hline China & 3251 & 7 & 912.604 & 20 & 2.607 .440 & 130.372 & $2.661 .900 .224,97$ & 14,02 & $12.794 .708,08$ & $36.556 .308,80$ & 1,352 & $11.646 .733,01$ & $2.7945 .756,75$ \\
\hline China & 3688 & 7 & 832.132 & 20 & 2.377 .520 & 118.876 & $2.661 .900 .224,97$ & 14,02 & $11.666 .490,64$ & $33.332 .830,40$ & 1,352 & $10.619 .742,22$ & $25.481 .543,43$ \\
\hline China & 4182 & 7 & 742.280 & 20 & 2.120 .800 & 106.040 & $3.476 .907 .910,88$ & 7,03 & $5.218 .228,40$ & $14.909 .224,00$ & 2,008 & $4.540 .288,55$ & $10.017 .754,51$ \\
\hline China & 5064 & 7 & 702.499 & 20 & 2.007 .140 & 100.357 & $3.476 .907 .910,88$ & 7,03 & 4.938.567,97 & $14.110 .194,20$ & 2,008 & 4.296.960,94 & $9.480 .873,16$ \\
\hline China & 5706 & 7 & 744.177 & 20 & 2.126 .220 & 106.311 & 4.747.277.337,31 & 6,48 & 4.822.266,96 & $13.777 .905,60$ & 1,108 & $4.464 .292,18$ & $11.052 .812,67$ \\
\hline China & 2763 & 10 & 447.220 & 10 & 447.220 & 44.722 & $149.029 .463,32$ & 14,02 & $6.270 .024,40$ & $6.270 .024,40$ & 1,352 & $5.482 .087,96$ & $5.482 .087,96$ \\
\hline China & 1046 & 10 & 275.850 & 10 & 275.850 & 27.585 & $85.195 .876,49$ & 0,02 & $5.517,00$ & $5.517,00$ & 4,448 & $3.570,28$ & $3.570,28$ \\
\hline China & 2963 & 7 & 868.329 & 20 & 2.480 .940 & 124.047 & 1.601.127.046,86 & 14,02 & $12.173 .972,58$ & $34.782 .778,80$ & 1,352 & $11.081 .691,54$ & $26.589 .967,85$ \\
\hline China & 3727 & 7 & 625.324 & 20 & 1.786 .640 & 89.332 & $303.547 .515,44$ & 14,02 & $8.767 .042,48$ & $25.048 .692,80$ & 1,352 & $7.980 .440,22$ & $19.148 .669,55$ \\
\hline China & 3299 & 7 & 484.085 & 21 & 1.452 .255 & 69.155 & $946.584 .170,98$ & 14,02 & $6.786 .871,70$ & $20.360 .615,10$ & 1,352 & $6.177 .935,61$ & $15.357 .202,40$ \\
\hline
\end{tabular}




\begin{tabular}{|c|c|c|c|c|c|c|c|c|c|c|c|c|c|}
\hline China & 1376 & 7 & 402.612 & 30 & 1.725 .480 & 57.516 & $235.950 .914,28$ & 0,02 & $8.052,24$ & $34.509,60$ & 4,448 & $5.937,66$ & $9.352,68$ \\
\hline China & 8454 & 7 & 1.331 .106 & 20 & 3.803 .160 & 190.158 & $368.251 .603,74$ & 6,48 & $8.625 .566,88$ & $24.644 .476,80$ & 1,108 & 7.985.259,03 & $19.770 .115,53$ \\
\hline China & 4276 & 7 & 1.595 .377 & 31 & 7.065 .241 & 227.911 & $342.188 .591,97$ & 7,03 & $11.215 .500,31$ & $49.668 .644,23$ & 2,008 & $9.758 .409,13$ & $26.817 .672,98$ \\
\hline China & 2946 & 7 & 250.460 & 15 & 536.700 & 35.780 & $287.729 .525,25$ & 12,31 & $3.083 .162,60$ & $6.606 .777,00$ & 1,610 & $2.757 .028,59$ & $5.199 .276,07$ \\
\hline China & 5453 & 7 & 771.211 & 20 & 2.203 .460 & 110.173 & $696.481 .622,92$ & 7,03 & $5.421 .613,33$ & $15.490 .323,80$ & 2,008 & 4.717.250,20 & $10.408 .205,09$ \\
\hline China & 4553 & 7 & 798.154 & 20 & 2.280 .440 & 114.022 & $696.481 .622,92$ & 7,03 & $5.611 .022,62$ & $16.031 .493,20$ & 2,008 & $4.882 .051,88$ & $10.771 .825,77$ \\
\hline China & 4114 & 10 & 740.130 & 10 & 740.130 & 74.013 & $230.941 .710,35$ & 7,03 & $5.203 .113,90$ & $5.203 .113,90$ & 2,008 & $4.265 .019,35$ & 4.265.019,35 \\
\hline China & 4221 & 10 & 19.712 .400 & 10 & 19.712 .400 & 1.971 .240 & $383.299 .700,99$ & 7,03 & $138.578 .172,00$ & $138.578 .172,00$ & 2,008 & $113.593 .243,61$ & $113.593 .243,61$ \\
\hline China & 823 & 7 & 1.846 .600 & 25 & 6.595 .000 & 263.800 & $1.299 .752 .822,53$ & 0,02 & $36.932,00$ & $131.900,00$ & 4,448 & $27.233,40$ & $44.436,68$ \\
\hline China & 1592 & 7 & 657.566 & 20 & 1.878 .760 & 93.938 & $1.342 .413 .521,87$ & 15,45 & $10.159 .394,70$ & $29.026 .842,00$ & 4,825 & $7.304 .890,93$ & $11.311 .035,55$ \\
\hline China & 1480 & 7 & 762.468 & 21 & 2.287 .404 & 108.924 & $1.342 .413 .521,87$ & 15,45 & $11.780 .130,60$ & $35.340 .391,80$ & 4,825 & $8.470 .245,69$ & $13.137 .389,24$ \\
\hline China & 1992 & 7 & 438.760 & 25 & 1.567 .000 & 62.680 & $1.161 .713 .183,74$ & 12,31 & $5.401 .135,60$ & $19.289 .770,00$ & 1,610 & 4.829.808,61 & $12.939 .448,47$ \\
\hline China & 2413 & 7 & 735.294 & 20 & 2.100 .840 & 105.042 & $1.161 .713 .183,74$ & 12,31 & $9.051 .469,14$ & $25.861 .340,40$ & 1,610 & $8.094 .013,33$ & $18.789 .793,34$ \\
\hline China & 2831 & 7 & 582.099 & 20 & 1.663 .140 & 83.157 & 1.601.298.664,16 & 14,02 & $8.161 .027,98$ & $23.317 .222,80$ & 1,352 & 7.428.798,95 & $17.825 .033,71$ \\
\hline China & 3750 & 7 & 792.785 & 20 & 2.265 .100 & 113.255 & 1.601.298.664,16 & 14,02 & $11.114 .845,70$ & $31.756 .702,00$ & 1,352 & $10.117 .592,32$ & $24.276 .659,72$ \\
\hline China & 3091 & 7 & 5.112 .275 & 23 & 16.797.475 & 730.325 & 1.601.298.664,16 & 14,02 & $71.674 .095,50$ & $235.500 .599,50$ & 1,352 & 65.243.305,94 & $172.921 .337,05$ \\
\hline China & 3104 & 7 & 885.549 & 21 & 2.656 .647 & 126.507 & 1.601.298.664,16 & 14,02 & $12.415 .396,98$ & $37.246 .190,94$ & 1,352 & $11.301 .454,70$ & $28.093 .320,86$ \\
\hline China & 4232 & 7 & 699.874 & 20 & 1.999 .640 & 99.982 & $1.601 .298 .664,16$ & 14,02 & $9.812 .233,48$ & $28.034 .952,80$ & 1,352 & $8.931 .853,92$ & $21.431 .539,38$ \\
\hline China & 2887 & 7 & 655.165 & 20 & 1.871 .900 & 93.595 & $1.601 .298 .664,16$ & 14,02 & $9.185 .413,30$ & $26.244 .038,00$ & 1,352 & $8.361 .273,71$ & $20.062 .460,52$ \\
\hline China & 3539 & 7 & 3.302 .621 & 20 & 9.436 .060 & 471.803 & 1.601.298.664,16 & 14,02 & 46.302.746,42 & $132.293 .561,20$ & 1,352 & $42.148 .341,46$ & $101.132 .849,64$ \\
\hline China & 4418 & 7 & 1.572 .984 & 20 & 4.494.240 & 224.712 & $1.801 .599 .629,01$ & 7,03 & $11.058 .077,52$ & $31.594 .507,20$ & 2,008 & $9.621 .438,34$ & $21.228 .872,61$ \\
\hline China & 4783 & 7 & 390.656 & 20 & 1.116 .160 & 55.808 & 1.801.599.629,01 & 7,03 & $2.746 .311,68$ & $7.846 .604,80$ & 2,008 & $2.389 .517,39$ & 5.272.263,71 \\
\hline China & 4808 & 7 & & 20 & & & & 7,03 & & & 2,008 & & \\
\hline
\end{tabular}




\begin{tabular}{|c|c|c|c|c|c|c|c|c|c|c|c|c|c|}
\hline & & & 930.293 & & 2.657 .980 & 132.899 & $1.801 .599 .629,01$ & & $6.539 .959,79$ & $18.685 .599,40$ & & $5.690 .303,74$ & $12.555 .163,68$ \\
\hline China & 4914 & 7 & 159.985 & 20 & 457.100 & 22.855 & $1.801 .599 .629,01$ & 7,03 & $1.124 .694,55$ & $3.213 .413,00$ & 2,008 & $978.576,90$ & $2.159 .145,41$ \\
\hline China & 5102 & 10 & 948.700 & 10 & 948.700 & 94.870 & 1.801.599.629,01 & 7,03 & $6.669 .361,00$ & $6.669 .361,00$ & 2,008 & $5.466 .909,67$ & $5.466 .909,67$ \\
\hline China & 3965 & 7 & 864.129 & 20 & 2.468 .940 & 123.447 & 1.801.599.629,01 & 7,03 & $6.074 .826,87$ & $17.356 .648,20$ & 2,008 & $5.285 .599,78$ & $11.662 .219,36$ \\
\hline China & 6744 & 7 & 576.870 & 20 & 1.648 .200 & 82.410 & $1.971 .017 .395,72$ & 6,48 & $3.738 .117,60$ & $10.680 .336,00$ & 1,108 & $3.460 .623,25$ & $8.567 .902,59$ \\
\hline China & 7239 & 7 & 734.286 & 20 & 2.097 .960 & 104.898 & 1.971.017.395,72 & 6,48 & $4.758 .173,28$ & $13.594 .780,80$ & 1,108 & 4.404.956,41 & $10.905 .907,61$ \\
\hline China & 8332 & 7 & 1.540 .686 & 20 & 4.401 .960 & 220.098 & $1.971 .017 .395,72$ & 6,48 & $9.983 .645,28$ & $28.524 .700,80$ & 1,108 & $9.242 .522,23$ & $22.882 .881,01$ \\
\hline China & 6345 & 7 & 721.742 & 20 & 2.062 .120 & 103.106 & 1.971.017.395,72 & 6,48 & $4.676 .888,16$ & $13.362 .537,60$ & 1,108 & $4.329 .705,39$ & $10.719 .599,13$ \\
\hline China & 8334 & 7 & 652.260 & 20 & 1.863 .600 & 93.180 & $1.971 .017 .395,72$ & 6,48 & $4.226 .644,80$ & $12.076 .128,00$ & 1,108 & $3.912 .885,27$ & $9.687 .624,84$ \\
\hline China & 6060 & 7 & 623.476 & 20 & 1.781 .360 & 89.068 & $1.971 .017 .395,72$ & 6,48 & $4.040 .124,48$ & $11.543 .212,80$ & 1,108 & $3.740 .211,04$ & $9.260 .113,43$ \\
\hline China & 7264 & 7 & 589.176 & 20 & 1.683 .360 & 84.168 & $1.971 .017 .395,72$ & 6,48 & $3.817 .860,48$ & $10.908 .172,80$ & 1,108 & $3.534 .446,52$ & $8.750 .676,19$ \\
\hline China & 7784 & 7 & 586.068 & 20 & 1.674 .480 & 83.724 & $1.971 .017 .395,72$ & 6,48 & $3.797 .720,64$ & $10.850 .630,40$ & 1,108 & $3.515 .801,74$ & $8.704 .514,94$ \\
\hline China & 905 & 7 & 1.398 .460 & 20 & 3.995 .600 & 199.780 & $4.059 .678 .300,07$ & 0,02 & $27.969,20$ & $79.912,00$ & 4,448 & $20.624,30$ & $33.466,43$ \\
\hline China & 2853 & 7 & 805.882 & 20 & 2.302 .520 & 115.126 & 4.187.372.219,25 & 14,02 & $11.298 .465,64$ & $32.281 .330,40$ & 1,352 & $10.284 .737,40$ & $24.677 .716,01$ \\
\hline China & 4736 & 7 & 2.586 .381 & 23 & 8.498 .109 & 369.483 & $5.982 .904 .664,56$ & 7,03 & $18.182 .258,43$ & $59.741 .706,27$ & 2,008 & $15.820 .062,58$ & $37.817 .278,27$ \\
\hline China & 6479 & 7 & 1.274 .945 & 20 & 3.642 .700 & 182.135 & $6.128 .751 .104,55$ & 6,48 & $8.261 .643,60$ & $23.604 .696,00$ & 1,108 & 7.648.351,13 & $18.935 .990,03$ \\
\hline China & 6528 & 7 & 2.819 .054 & 20 & 8.054 .440 & 402.722 & $6.128 .751 .104,55$ & 6,48 & $18.267 .469,92$ & $52.192 .771,20$ & 1,108 & $16.911 .407,81$ & $41.869 .710,80$ \\
\hline China & 4151 & 7 & 734.804 & 21 & 2.204 .412 & 104.972 & $6.128 .751 .104,55$ & 6,48 & 4.761.529,92 & $14.284 .589,76$ & 1,108 & $4.408 .063,88$ & $11.333 .703,77$ \\
\hline China & 2599 & 7 & 962.339 & 20 & 2.749 .540 & 137.477 & $176.535 .437,82$ & 12,31 & $11.846 .393,09$ & $33.846 .837,40$ & 1,610 & $10.593 .292,88$ & $24.591 .729,20$ \\
\hline China & 2598 & 7 & 1.842 .911 & 23 & 6.055 .279 & 263.273 & $263.726 .584,26$ & 14,02 & $25.837 .612,22$ & $84.895 .011,58$ & 1,352 & 23.519.393,26 & $62.335 .972,57$ \\
\hline China & 3078 & 7 & 778.638 & 20 & 2.224 .680 & 111.234 & $263.726 .584,26$ & 14,02 & $10.916 .504,76$ & $31.190 .013,60$ & 1,352 & $9.937 .047,06$ & $23.843 .450,33$ \\
\hline China & 3353 & 7 & 826.035 & 20 & 2.360 .100 & 118.005 & $263.726 .584,26$ & 14,02 & $11.581 .010,70$ & $33.088 .602,00$ & 1,352 & $10.541 .931,77$ & $25.294 .841,11$ \\
\hline China & 3128 & 7 & 519.743 & 20 & 1.484 .980 & 74.249 & $263.726 .584,26$ & 14,02 & $7.286 .796,86$ & $20.819 .419,60$ & 1,352 & $6.633 .006,16$ & $15.915 .568,47$ \\
\hline China & 2911 & 7 & 899.745 & 20 & 2.570 .700 & 128.535 & $263.726 .584,26$ & 14,02 & $12.614 .424,90$ & $36.041 .214,00$ & 1,352 & $11.482 .625,31$ & $27.551 .988,50$ \\
\hline
\end{tabular}




\begin{tabular}{|c|c|c|c|c|c|c|c|c|c|c|c|c|c|}
\hline China & 2918 & 7 & 4.619 .951 & 20 & 13.199 .860 & 659.993 & $263.726 .584,26$ & 14,02 & $64.771 .713,02$ & $185.062 .037,20$ & 1,352 & $58.960 .223,49$ & $141.472 .124,67$ \\
\hline China & 3080 & 7 & 919.072 & 20 & 2.625 .920 & 131.296 & $263.726 .584,26$ & 14,02 & $12.885 .389,44$ & $36.815 .398,40$ & 1,352 & $11.729 .278,19$ & $28.143 .819,83$ \\
\hline China & 3274 & 7 & 986.811 & 20 & 2.819 .460 & 140.973 & $263.726 .584,26$ & 14,02 & $13.835 .090,22$ & $39.528 .829,20$ & 1,352 & $12.593 .769,31$ & $30.218 .123,27$ \\
\hline China & 3344 & 7 & 1.543 .794 & 20 & 4.410 .840 & 220.542 & $263.726 .584,26$ & 14,02 & $21.643 .991,88$ & $61.839 .976,80$ & 1,352 & $19.702 .035,64$ & $47.274 .054,90$ \\
\hline China & 3534 & 7 & 950.607 & 23 & 3.123 .423 & 135.801 & $263.726 .584,26$ & 14,02 & $13.327 .510,14$ & $43.790 .390,46$ & 1,352 & $12.131 .730,65$ & $3.2154 .027,99$ \\
\hline China & 3579 & 7 & 716.373 & 20 & 2.046 .780 & 102.339 & $263.726 .584,26$ & 14,02 & $10.043 .549,46$ & $28.695 .855,60$ & 1,352 & $9.142 .415,62$ & $21.936 .771,70$ \\
\hline China & 3596 & 7 & 852.803 & 20 & 2.436 .580 & 121.829 & $263.726 .584,26$ & 14,02 & $11.956 .298,06$ & $34.160 .851,60$ & 1,352 & $10.883 .547,35$ & $26.114 .530,72$ \\
\hline China & 3603 & 7 & 759.017 & 20 & 2.168 .620 & 108.431 & $263.726 .584,26$ & 14,02 & $10.641 .418,34$ & $30.404 .052,40$ & 1,352 & $9.686 .642,12$ & $2.3242 .616,13$ \\
\hline China & 3718 & 7 & 665.735 & 20 & 1.902 .100 & 95.105 & $263.726 .584,26$ & 14,02 & $9.333 .604,70$ & $26.667 .442,00$ & 1,352 & $8.496 .168,98$ & $20.386 .135,03$ \\
\hline China & 3784 & 7 & 678.244 & 20 & 1.937 .840 & 96.892 & $263.726 .584,26$ & 14,02 & $9.508 .980,88$ & $27.168 .516,80$ & 1,352 & $8.655 .809,95$ & $20.769 .185,59$ \\
\hline China & 3867 & 7 & 1.535 .590 & 20 & 4.387 .400 & 219.370 & $263.726 .584,26$ & 14,02 & $21.528 .971,80$ & $61.511 .348,00$ & 1,352 & $19.597 .335,47$ & $47.022 .832,04$ \\
\hline China & 3891 & 7 & 768.236 & 20 & 2.194 .960 & 109.748 & $263.726 .584,26$ & 14,02 & $10.770 .668,72$ & $30.773 .339,20$ & 1,352 & $9.804 .295,81$ & $23.524 .920,32$ \\
\hline China & 3391 & 7 & 712.355 & 20 & 2.035 .300 & 101.765 & $263.726 .584,26$ & 14,02 & $9.987 .217,10$ & $28.534 .906,00$ & 1,352 & $9.091 .137,55$ & $21.813 .732,52$ \\
\hline China & 3084 & 7 & 867.531 & 20 & 2.478 .660 & 123.933 & $263.726 .584,26$ & 14,02 & $12.162 .784,62$ & $34.750 .813,20$ & 1,352 & $11.071 .507,39$ & $26.565 .531,49$ \\
\hline China & 3124 & 7 & 806.841 & 20 & 2.305 .260 & 115.263 & $263.726 .584,26$ & 14,02 & $11.311 .910,82$ & $32.319 .745,20$ & 1,352 & $10.296 .976,24$ & $24.707 .082,51$ \\
\hline China & 4241 & 7 & 764.932 & 20 & 2.185 .520 & 109.276 & $263.726 .584,26$ & 14,02 & $10.724 .346,64$ & $30.640 .990,40$ & 1,352 & $9.762 .129,87$ & $23.423 .745,24$ \\
\hline China & 4255 & 7 & 782.922 & 20 & 2.236 .920 & 111.846 & $263.726 .584,26$ & 14,02 & $10.976 .566,44$ & $31.361 .618,40$ & 1,352 & $9.991 .719,85$ & 23.974.634,97 \\
\hline China & 4034 & 7 & 693.714 & 20 & 1.982 .040 & 99.102 & $597.697 .629,01$ & 7,03 & $4.876 .809,42$ & $13.933 .741,20$ & 2,008 & $4.243 .225,92$ & $9.362 .311,46$ \\
\hline China & 4204 & 7 & 720.055 & 20 & 2.057 .300 & 102.865 & $597.697 .629,01$ & 7,03 & $5.061 .986,65$ & $14.462 .819,00$ & 2,008 & $4.404 .345,36$ & $9.717 .807,60$ \\
\hline China & 4320 & 7 & 3.811 .598 & 20 & 10.890 .280 & 544.514 & $597.697 .629,01$ & 7,03 & $26.795 .533,94$ & $76.558 .668,40$ & 2,008 & $23.314 .321,78$ & $51.441 .037,16$ \\
\hline China & 4400 & 7 & 568.904 & 20 & 1.625 .440 & 81.272 & 597.697.629,01 & 7,03 & $3.999 .395,12$ & $11.426 .843,20$ & 2,008 & $3.479 .803,20$ & 7.677.885,18 \\
\hline China & 4699 & 7 & 600.222 & 20 & 1.714 .920 & 85.746 & $597.697 .629,01$ & 7,03 & $4.219 .560,66$ & $12.055 .887,60$ & 2,008 & $3.671 .365,36$ & $8.100 .550,53$ \\
\hline China & 4830 & 7 & & 20 & & & & 7,03 & & & 2,008 & & \\
\hline
\end{tabular}




\begin{tabular}{|c|c|c|c|c|c|c|c|c|c|c|c|c|c|}
\hline & & & 651.777 & & 1.862 .220 & 93.111 & $597.697 .629,01$ & & $4.581 .992,31$ & $13.091 .406,60$ & & $3.986 .710,75$ & $8.796 .332,90$ \\
\hline China & 4871 & 7 & 648.291 & 20 & 1.852 .260 & 92.613 & $597.697 .629,01$ & 7,03 & $4.557 .485,73$ & $13.021 .387,80$ & 2,008 & $3.965 .388,00$ & $8.749 .286,11$ \\
\hline China & 4880 & 7 & 734.083 & 20 & 2.097 .380 & 104.869 & $597.697 .629,01$ & 7,03 & $5.160 .603,49$ & $14.744 .581,40$ & 2,008 & $4.490 .150,14$ & $9.907 .128,42$ \\
\hline China & 4917 & 7 & 733.376 & 20 & 2.095 .360 & 104.768 & $597.697 .629,01$ & 7,03 & $5.155 .633,28$ & $14.730 .380,80$ & 2,008 & $4.485 .825,64$ & $9.897 .586,80$ \\
\hline China & 4928 & 7 & 694.134 & 20 & 1.983 .240 & 99.162 & $597.697 .629,01$ & 7,03 & $4.879 .762,02$ & $13.942 .177,20$ & 2,008 & $4.245 .794,92$ & $9.367 .979,75$ \\
\hline China & 4932 & 7 & 731.962 & 20 & 2.091 .320 & 104.566 & $597.697 .629,01$ & 7,03 & $5.145 .692,86$ & $14.701 .979,60$ & 2,008 & $4.477 .176,66$ & $9.878 .503,57$ \\
\hline China & 5081 & 7 & 660.436 & 20 & 1.886 .960 & 94.348 & $597.697 .629,01$ & 7,03 & $4.642 .865,08$ & $13.265 .328,80$ & 2,008 & $4.039 .675,07$ & $8.913 .194,10$ \\
\hline China & 5180 & 7 & 738.465 & 20 & 2.109 .900 & 105.495 & $597.697 .629,01$ & 7,03 & $5.191 .408,95$ & $14.832 .597,00$ & 2,008 & $4.516 .953,42$ & $9.966 .267,56$ \\
\hline China & 5252 & 7 & 625.758 & 20 & 1.787 .880 & 89.394 & $597.697 .629,01$ & 7,03 & $4.399 .078,74$ & $12.568 .796,40$ & 2,008 & $3.827 .560,87$ & $8.445 .182,45$ \\
\hline China & 5269 & 7 & 629.972 & 20 & 1.799 .920 & 89.996 & $597.697 .629,01$ & 7,03 & $4.428 .703,16$ & $12.653 .437,60$ & 2,008 & $3.853 .336,56$ & $8.502 .054,27$ \\
\hline China & 4126 & 7 & 813.785 & 20 & 2.325 .100 & 116.255 & $597.697 .629,01$ & 7,03 & $5.720 .908,55$ & $16.345 .453,00$ & 2,008 & $4.977 .661,69$ & $10.982 .780,56$ \\
\hline China & 4326 & 7 & 810.985 & 20 & 2.317 .100 & 115.855 & $597.697 .629,01$ & 7,03 & $5.701 .224,55$ & $16.289 .213,00$ & 2,008 & $4.960 .534,99$ & $10.944 .991,97$ \\
\hline China & 4900 & 7 & 4.258 .443 & 20 & 12.166 .980 & 608.349 & $597.697 .629,01$ & 7,03 & $29.936 .854,29$ & $85.533 .869,40$ & 2,008 & $26.047 .529,25$ & $57.471 .623,35$ \\
\hline China & 4047 & 7 & 690.893 & 20 & 1.973 .980 & 98.699 & $597.697 .629,01$ & 7,03 & $4.856 .977,79$ & $13.877 .079,40$ & 2,008 & 4.225.970,77 & $9.324 .239,46$ \\
\hline China & 4648 & 7 & 720.069 & 20 & 2.057 .340 & 102.867 & $597.697 .629,01$ & 7,03 & $5.062 .085,07$ & $14.463 .100,20$ & 2,008 & $4.404 .430,99$ & $9.717 .996,54$ \\
\hline China & 6438 & 7 & 556.171 & 20 & 1.589 .060 & 79.453 & $1.386 .873 .568,13$ & 6,48 & $3.603 .988,08$ & $10.297 .108,80$ & 1,108 & $3.336 .450,67$ & $8.260 .472,81$ \\
\hline China & 6752 & 7 & 619.052 & 20 & 1.768 .720 & 88.436 & 1.386.873.568,13 & 6,48 & $4.011 .456,96$ & $11.461 .305,60$ & 1,108 & $3.713 .671,62$ & $9.194 .406,42$ \\
\hline China & 7298 & 7 & 686.609 & 20 & 1.961 .740 & 98.087 & $1.386 .873 .568,13$ & 6,48 & $4.449 .226,32$ & $12.712 .075,20$ & 1,108 & $4.118 .943,73$ & $10.197 .789,85$ \\
\hline China & 7453 & 7 & 649.544 & 20 & 1.855 .840 & 92.792 & $1.386 .873 .568,13$ & 6,48 & $4.209 .045,12$ & $12.025 .843,20$ & 1,108 & $3.896 .592,08$ & $9.647 .285,73$ \\
\hline China & 7517 & 7 & 602.378 & 10 & 860.540 & 86.054 & $1.386 .873 .568,13$ & 6,48 & $3.903 .409,44$ & $5.576 .299,20$ & 1,108 & 3.613.644,87 & 4.994.486,81 \\
\hline China & 7556 & 7 & 653.177 & 20 & 1.866 .220 & 93.311 & $1.386 .873 .568,13$ & 6,48 & $4.232 .586,96$ & $12.093 .105,60$ & 1,108 & $3.918 .386,32$ & $9.701 .244,49$ \\
\hline China & 7749 & 7 & 601.202 & 20 & 1.717 .720 & 85.886 & $1.386 .873 .568,13$ & 6,48 & $3.895 .788,96$ & $11.130 .825,60$ & 1,108 & $3.606 .590,08$ & $8.929 .291,13$ \\
\hline China & 7993 & 7 & 605.927 & 20 & 1.731 .220 & 86.561 & $1.386 .873 .568,13$ & 6,48 & $3.926 .406,96$ & $11.218 .305,60$ & 1,108 & $3.634 .935,20$ & $8.999 .468,71$ \\
\hline China & 8026 & 7 & 610.316 & 20 & 1.743 .760 & 87.188 & $1.386 .873 .568,13$ & 6,48 & $3.954 .847,68$ & $11.299 .564,80$ & 1,108 & $3.661 .264,65$ & $9.064 .655,88$ \\
\hline
\end{tabular}




\begin{tabular}{|c|c|c|c|c|c|c|c|c|c|c|c|c|c|}
\hline China & 8302 & 7 & 628.362 & 20 & 1.795 .320 & 89.766 & $1.386 .873 .5688,13$ & 6,48 & $4.071 .785,76$ & $11.633 .673,60$ & 1,108 & 3.769.521,99 & $9.332 .682,25$ \\
\hline China & 8318 & 7 & 372.267 & 25 & 1.329 .525 & 53.181 & $1.386 .873 .568,13$ & 6,48 & $2.412 .290,16$ & $8.615 .322,00$ & 1,108 & $2.233 .216,91$ & $6.540 .839,91$ \\
\hline China & 8600 & 7 & 573.804 & 21 & 1.721 .412 & 81.972 & $1.386 .873 .568,13$ & 6,48 & $3.718 .249,92$ & $11.154 .749,76$ & 1,108 & $3.442 .230,42$ & $8.850 .420,73$ \\
\hline China & 8626 & 7 & 737.492 & 20 & 2.107 .120 & 105.356 & $1.386 .873 .568,13$ & 6,48 & $4.778 .948,16$ & $13.654 .137,60$ & 1,108 & 4.424.189,10 & $10.953 .524,39$ \\
\hline China & 8682 & 7 & 106.267 & 20 & 303.620 & 15.181 & $1.386 .873 .568,13$ & 6,48 & $688.610,16$ & $1.967 .457,60$ & 1,108 & $637.492,07$ & $1.578 .319,73$ \\
\hline China & 8765 & 7 & 243.040 & 25 & 868.000 & 34.720 & $1.386 .873 .568,13$ & 6,48 & $1.574 .899,20$ & $5.624 .640,00$ & 1,108 & $1.457 .988,59$ & 4.270.283,78 \\
\hline China & 6329 & 7 & 646.898 & 20 & 1.848 .280 & 92.414 & $1.386 .873 .568,13$ & 6,48 & 4.191.899,04 & $11.976 .854,40$ & 1,108 & $3.880 .718,81$ & $9.607 .986,29$ \\
\hline China & 6748 & 7 & 531.230 & 20 & 1.517 .800 & 75.890 & $1.386 .873 .568,13$ & 6,48 & $3.442 .370,40$ & $9.835 .344,00$ & 1,108 & $3.186 .830,47$ & $7.890 .039,16$ \\
\hline China & 6788 & 7 & 616.350 & 20 & 1.761 .000 & 88.050 & $1.386 .873 .568,13$ & 6,48 & 3.993.948,00 & $11.411 .280,00$ & 1,108 & 3.697.462,41 & $9.154 .275,25$ \\
\hline China & 7979 & 7 & 484.386 & 20 & 1.383 .960 & 69.198 & $1.386 .873 .568,13$ & 6,48 & $3.138 .821,28$ & $8.968 .060,80$ & 1,108 & $2.905 .814,92$ & $7.194 .293,45$ \\
\hline China & 4926 & 7 & 211.855 & 20 & 605.300 & 30.265 & $1.386 .873 .568,13$ & 6,48 & $1.372 .820,40$ & $3.922 .344,00$ & 1,108 & $1.270 .910,85$ & 3146554,69 \\
\hline China & 5055 & 7 & 721.350 & 20 & 2.061 .000 & 103.050 & $1.386 .873 .568,13$ & 6,48 & $4.674 .348,00$ & $13.355 .280,00$ & 1,108 & $\begin{array}{r}4.327 .353,79 \\
\end{array}$ & $10.713 .776,99$ \\
\hline China & 5094 & 7 & 732.669 & 20 & 2.093 .340 & 104.667 & $1.386 .873 .568,13$ & 6,48 & $4.747 .695,12$ & $13.564 .843,20$ & 1,108 & $4.395 .256,09$ & $10.881 .891,28$ \\
\hline China & 5277 & 7 & 736.204 & 20 & 2.103 .440 & 105.172 & $1.386 .873 .568,13$ & 6,48 & $4.770 .601,92$ & $13.630 .291,20$ & 1,108 & $4.416 .462,43$ & $10.934 .394,51$ \\
\hline China & 5782 & 7 & 783.454 & 21 & 2.350 .362 & 111.922 & $1.386 .873 .568,13$ & 6,48 & $5.076 .781,92$ & $15.230 .345,76$ & 1,108 & $4.699 .913,55$ & $12.084 .087,12$ \\
\hline China & 5818 & 7 & 791.084 & 21 & 2.373 .252 & 113.012 & $1.386 .873 .568,13$ & 6,48 & $5.126 .224,32$ & $15.378 .672,96$ & 1,108 & $4.745 .685,66$ & $12.201 .773,14$ \\
\hline China & 6288 & 7 & 787.038 & 20 & 2.248 .680 & 112.434 & $1.386 .873 .568,13$ & 6,48 & $5.100 .006,24$ & $14.571 .446,40$ & 1,108 & $4.721 .413,84$ & $11.689 .401,28$ \\
\hline China & 6451 & 7 & 780.304 & 20 & 2.229 .440 & 111.472 & $1.386 .873 .568,13$ & 6,48 & $5.056 .369,92$ & $14.446 .771,20$ & 1,108 & $4.681 .016,81$ & $11.589 .385,24$ \\
\hline China & 8083 & 7 & 607.054 & 20 & 1.734 .440 & 86.722 & $1.386 .873 .568,13$ & 6,48 & 3.933.709,92 & $11.239 .171,20$ & 1,108 & $3.641 .696,03$ & $9.016 .207,36$ \\
\hline China & 8398 & 7 & 602.756 & 20 & 1.722 .160 & 86.108 & $1.386 .873 .568,13$ & 6,48 & $3.905 .858,88$ & $11.159 .596,80$ & 1,108 & $3.615 .912,48$ & $8.952 .371,75$ \\
\hline China & 8691 & 7 & 601.930 & 20 & 1.719 .800 & 85.990 & $1.386 .873 .568,13$ & 6,48 & $3.900 .506,40$ & $11.144 .304,00$ & 1,108 & $3.610 .957,33$ & $8.940 .103,67$ \\
\hline China & 8842 & 7 & 634.081 & 20 & 1.811 .660 & 90.583 & $1.386 .873 .568,13$ & 6,48 & 4.108.844,88 & $11.739 .556,80$ & 1,108 & $3.803 .830,07$ & $9.417 .623,11$ \\
\hline China & 6427 & 7 & & 20 & & & & 6,48 & & & 1,108 & & \\
\hline
\end{tabular}




\begin{tabular}{|c|c|c|c|c|c|c|c|c|c|c|c|c|c|}
\hline & & & 464.940 & & 1.328 .400 & 66.420 & $1.386 .873 .568,13$ & & $3.012 .811,20$ & $8.608 .032,00$ & & $2.789 .159,04$ & $6.905 .473,73$ \\
\hline China & 6454 & 7 & 4.093 .943 & 20 & 11.696 .980 & 584.849 & $1.386 .873 .568,13$ & 6,48 & $26.528 .750,64$ & $75.796 .430,40$ & 1,108 & $24.559 .423,00$ & $60.804 .869,09$ \\
\hline China & 6593 & 7 & 777.574 & 20 & 2.221 .640 & 111.082 & $1.386 .873 .568,13$ & 6,48 & $5.038 .679,52$ & $14.396 .227,20$ & 1,108 & $4.664 .639,63$ & $11.548 .838,19$ \\
\hline China & 6758 & 7 & 1.543 .416 & 20 & 4.409 .760 & 220.488 & $1.386 .873 .568,13$ & 6,48 & $10.001 .335,68$ & $28.575 .244,80$ & 1,108 & $9.258 .899,40$ & $22.923 .428,06$ \\
\hline China & 6759 & 7 & 782.530 & 20 & 2.235 .800 & 111.790 & $1.386 .873 .568,13$ & 6,48 & $5.070 .794,40$ & $14.487 .984,00$ & 1,108 & 4.694.370,51 & $11.622 .446,68$ \\
\hline China & 5789 & 7 & 658.847 & 21 & 1.976 .541 & 94.121 & $1.386 .873 .568,13$ & 6,48 & 4.269.328,56 & $12.807 .985,68$ & 1,108 & $3.952 .400,45$ & $10.162 .134,02$ \\
\hline China & 8550 & 7 & 672.546 & 20 & 1.921 .560 & 96.078 & $1.386 .873 .568,13$ & 6,48 & $4.358 .098,08$ & $12.451 .708,80$ & 1,108 & $4.034 .580,28$ & $9.988 .920,58$ \\
\hline China & 2521 & 10 & 1.101 .240 & 10 & 1.101 .240 & 110.124 & $428.894 .818,67$ & 12,31 & $13.556 .264,40$ & $13.556 .264,40$ & 1,610 & $11.555 .148,12$ & $11.555 .148,12$ \\
\hline China & 2907 & 10 & 421.980 & 10 & 421.980 & 42.198 & $465.024 .797,17$ & 14,02 & $5.916 .159,60$ & $5.916 .159,60$ & 1,352 & $5.172 .692,36$ & $5.172 .692,36$ \\
\hline China & 2522 & 10 & 1.246 .450 & 10 & 1.246 .450 & 124.645 & $465.024 .797,17$ & 14,02 & $17.475 .229,00$ & $17.475 .229,00$ & 1,352 & $15.279 .165,82$ & $15.279 .165,82$ \\
\hline China & 7499 & 7 & 655.410 & 21 & 1.966 .230 & 93.630 & $225.443 .377,16$ & 6,48 & $4.247 .056,80$ & $12.741 .170,40$ & 1,108 & $3.931 .782,01$ & $10.109 .121,33$ \\
\hline China & 2781 & 7 & 222.306 & 21 & 666.918 & 31.758 & $93.554 .093,96$ & 14,02 & $3.116 .730,12$ & $9.350 .190,36$ & 1,352 & $2.837 .088,84$ & $7.052 .476,81$ \\
\hline China & 5204 & 7 & 565.502 & 20 & 1.615 .720 & 80.786 & $968.285 .745,40$ & 7,03 & $3.975 .479,06$ & $11.358 .511,60$ & 2,008 & $3.458 .994,26$ & $7.631 .972,05$ \\
\hline China & 6836 & 7 & 1.037 .022 & 30 & 4.444 .380 & 148.146 & $1.117 .663 .753,43$ & 6,48 & $6.719 .902,56$ & $28.799 .582,40$ & 1,108 & $6.221 .059,25$ & $20.692 .863,71$ \\
\hline China & 7905 & 10 & 440.550 & 10 & 440.550 & 44.055 & $94.370 .125,22$ & 6,48 & $2.854 .764,00$ & $2.854 .764,00$ & 1,108 & $2.556 .907,48$ & $2.556 .907,48$ \\
\hline China & 7233 & 10 & 1.249 .690 & 10 & 1.249 .690 & 124.969 & 1.624.041.557,11 & 6,48 & $8.097 .991,20$ & $8.097 .991,20$ & 1,108 & 7.253.073,91 & 7.253.073,91 \\
\hline China & 2593 & 7 & 930.139 & 24 & 3.189 .048 & 132.877 & $348.434 .883,39$ & 14,02 & $13.040 .548,78$ & $44.710 .452,96$ & 1,352 & $11.870 .516,23$ & $32.391 .668,15$ \\
\hline China & 4020 & 7 & 967.232 & 20 & 2.763 .520 & 138.176 & $461.263 .268,89$ & 7,03 & $6.799 .640,96$ & $19.427 .545,60$ & 2,008 & $5.916 .247,75$ & $13.053 .689,62$ \\
\hline China & 8800 & 7 & 683.172 & 20 & 1.951 .920 & 97.596 & $578.283 .818,96$ & 6,48 & $4.426 .954,56$ & $12.648 .441,60$ & 1,108 & 4.098.325,29 & $10.146 .742,16$ \\
\hline China & 3994 & 10 & 1.128 .080 & 10 & 1.128 .080 & 112.808 & $822.754 .355,52$ & 7,03 & $7.930 .402,40$ & $7.930 .402,40$ & 2,008 & $6.500 .591,82$ & $6.500 .591,82$ \\
\hline China & 3992 & 10 & 1.208 .650 & 10 & 1.208 .650 & 120.865 & $957.043 .066,16$ & 6,48 & $7.832 .052,00$ & $7.832 .052,00$ & 1,108 & 7.014.881,91 & 7.014.881,91 \\
\hline China & 1481 & 7 & 6.312 .950 & 25 & 22.546 .250 & 901.850 & $120.874 .988,29$ & 15,45 & $97.535 .077,50$ & $348.339 .562,50$ & 4,825 & $70.130 .467,80$ & $107.245 .980,75$ \\
\hline China & 1729 & 10 & 1.764 .640 & 10 & 1.764 .640 & 176.464 & $2.154 .599 .775,26$ & 15,45 & $27.263 .688,00$ & $27.263 .688,00$ & 4,825 & $17.019 .072,66$ & $17.019 .072,66$ \\
\hline China & 1726 & 10 & 1.765 .270 & 10 & 1.765 .270 & 176.527 & $2.742 .108 .940,32$ & 12,31 & $21.730 .473,70$ & $21.730 .473,70$ & 1,610 & $18.522 .716,51$ & $18.522 .716,51$ \\
\hline
\end{tabular}




\begin{tabular}{|c|c|c|c|c|c|c|c|c|c|c|c|c|c|}
\hline China & 2469 & 10 & 1.056 .810 & 10 & 1.056 .810 & 105.681 & $460.049 .253,82$ & 12,31 & 13.009.331,10 & 13.009.331,10 & 1,610 & $11.088 .950,72$ & $11.088 .950,72$ \\
\hline China & 1238 & 7 & 70.120 .645 & 21 & 210.361 .935 & 10.017 .235 & $52.609 .451 .817,88$ & 0,02 & $1.402 .412,90$ & 4.207.238,70 & 4,448 & $1.034 .129,67$ & $1.686 .919,88$ \\
\hline China & 1368 & 7 & 2.044 .112 & 20 & 5.840 .320 & 292.016 & $63.429 .815 .525,80$ & 15,45 & $31.581 .530,40$ & $90.232 .944,00$ & 4,825 & $22.708 .009,85$ & $35.161 .525,24$ \\
\hline China & 5361 & 7 & 1.611 .750 & 25 & 5.756 .250 & 230.250 & $106.221 .779 .698,24$ & 7,03 & $11.330 .602,50$ & $40.466 .437,50$ & 2,008 & $9.858 .557,52$ & $24.617 .228,34$ \\
\hline China & 5362 & 7 & 885.423 & 18 & 2.276 .802 & 126.489 & $106.221 .779 .698,24$ & 7,03 & $6.224 .523,69$ & $16.005 .918,06$ & 2,008 & $5.415 .848,35$ & $11.190 .884,15$ \\
\hline China & 2309 & 7 & 4.027.212 & 21 & 12.081 .636 & 575.316 & $100.179 .352,20$ & 12,31 & 49.574.979,72 & $148.724 .939,16$ & 1,610 & $44.330 .985,47$ & $106.345 .305,03$ \\
\hline China & 7673 & 7 & 1.484 .602 & 25 & 5.302 .150 & 212.086 & $149.839 .199,31$ & 6,48 & $9.620 .220,96$ & $34.357 .932,00$ & 1,108 & 8.906.076,24 & $26.084 .890,72$ \\
\hline China & 1711 & 10 & 1.030 .250 & 10 & 1.030 .250 & 103.025 & 1.583.176.982,86 & 15,45 & 15.917.362,50 & $15.917 .362,50$ & 4,825 & $9.936 .247,40$ & $9.936 .247,40$ \\
\hline China & 1823 & 7 & 832.342 & 20 & 2.378 .120 & 118.906 & $325.973 .312,11$ & 15,45 & $12.859 .683,90$ & $36.741 .954,00$ & 4,825 & $9.246 .474,92$ & $14.317 .422,06$ \\
\hline China & 2027 & 7 & 805.553 & 20 & 2.301 .580 & 115.079 & $325.973 .312,11$ & 15,45 & $12.445 .793,85$ & $35.559 .411,00$ & 4,825 & $8.948 .876,31$ & $13.856 .614,58$ \\
\hline China & 3288 & 7 & 2.140 .481 & 20 & 6.115 .660 & 305.783 & $2.002 .738 .741,52$ & 14,02 & $30.009 .543,62$ & $85.741 .553,20$ & 1,352 & $27.317 .007,94$ & $65.545 .802,30$ \\
\hline China & 3477 & 7 & 7.154 .525 & 20 & 20.441 .500 & 1.022 .075 & $1.558 .473 .108,87$ & 7,03 & $50.296 .310,75$ & $143.703 .745,00$ & 2,008 & $43.761 .933,46$ & $96.556 .926,09$ \\
\hline China & 5233 & 7 & 4.071 .102 & 23 & 13.376 .478 & 581.586 & $1.558 .473 .108,87$ & 7,03 & $28.619 .847,06$ & $94.036 .640,34$ & 2,008 & $24.901 .624,47$ & $59.526 .418,27$ \\
\hline China & 5736 & 7 & 339.234 & 20 & 969.240 & 48.462 & $1.775 .233 .895,53$ & 6,48 & $2.198 .236,32$ & $6.280 .675,20$ & 1,108 & $2.035 .053,08$ & $5.038 .438,24$ \\
\hline China & 1781 & 7 & 2.608 .284 & 21 & 7.824 .852 & 372.612 & $156.810 .375,50$ & 15,45 & $40.297 .987,80$ & $120.893 .963,40$ & 4,825 & $28.975 .388,22$ & $44.940 .957,71$ \\
\hline China & 2321 & 7 & 1.346 .331 & 21 & 4.038 .993 & 192.333 & $255.055 .204,55$ & 12,31 & $16.573 .334,61$ & $49.720 .003,83$ & 1,610 & $14.820 .223,02$ & $35.552 .134,05$ \\
\hline China & 2323 & 7 & 962.437 & 21 & 2.887 .311 & 137.491 & $255.055 .204,55$ & 12,31 & $11.847 .599,47$ & $35.542 .798,41$ & 1,610 & $10.594 .371,65$ & $25.414 .767,42$ \\
\hline China & 2071 & 7 & 313.411 & 30 & 1.343 .190 & 44.773 & $58.429 .406,23$ & 12,31 & $3.858 .089,41$ & $16.534 .668,90$ & 1,610 & $3.449 .984,38$ & $1.0240 .047,28$ \\
\hline China & 3058 & 7 & 410.361 & 20 & 1.172 .460 & 58.623 & $1.001 .721 .158,19$ & 14,02 & $5.753 .261,22$ & $16.437 .889,20$ & 1,352 & $5.237 .063,40$ & $12.566 .073,22$ \\
\hline China & 3917 & 7 & 799.484 & 20 & 2.284 .240 & 114.212 & 1.001.721.158,19 & 14,02 & $11.208 .765,68$ & $32.025 .044,80$ & 1,352 & $10.203 .085,56$ & $24.481 .796,48$ \\
\hline China & 4849 & 7 & 203.721 & 20 & 582.060 & 29.103 & $1.219 .983 .284,01$ & 7,03 & $1.432 .158,63$ & $4.091 .881,80$ & 2,008 & $1.246 .095,98$ & $2.749 .403,15$ \\
\hline China & 3306 & 7 & 2.877 .546 & 21 & 8.632 .638 & 411.078 & 1.219.983.284,01 & 7,03 & $20.229 .148,38$ & $60.687 .445,14$ & 2,008 & $17.601 .025,44$ & $39.974 .217,13$ \\
\hline China & 2701 & 10 & & 10 & & & & 12,31 & & & 1,610 & & \\
\hline
\end{tabular}




\begin{tabular}{|c|c|c|c|c|c|c|c|c|c|c|c|c|c|}
\hline & & & 670.540 & & 670.540 & 67.054 & $624.757 .988,19$ & & $8.254 .347,40$ & $8.254 .347,40$ & & $7.035 .876,85$ & $7.035 .876,85$ \\
\hline China & 1695 & 10 & 167.380 & 10 & 167.380 & 16.738 & 2.916.627.782,23 & 12,31 & $2.060 .447,80$ & $2.060 .447,80$ & 1,610 & $1.756 .293,54$ & $1.756 .293,54$ \\
\hline China & 3166 & 10 & 21.946 .940 & 10 & 21.946 .940 & 2.194 .694 & 2.784.303.075,05 & 14,02 & $307.696 .098,80$ & $307.696 .098,80$ & 1,352 & $269.028 .790,18$ & $269.028 .790,18$ \\
\hline China & 3328 & 10 & 5.166 .220 & 10 & 5.166 .220 & 516.622 & 2.784.303.075,05 & 14,02 & $72.430 .404,40$ & $72.430 .404,40$ & 1,352 & $63.328 .277,95$ & $63.328 .277,95$ \\
\hline China & 6774 & 10 & 2.427 .740 & 10 & 2.427 .740 & 242.774 & 4.395.018.290,94 & 6,48 & $15.731 .755,20$ & $15.731 .755,20$ & 1,108 & $14.090 .356,52$ & $14.090 .356,52$ \\
\hline China & 3044 & 7 & 819.826 & 20 & 2.342 .360 & 117.118 & $171.232 .209,27$ & 14,02 & $11.493 .960,52$ & $32.839 .887,20$ & 1,352 & $10.462 .691,96$ & $25.104 .709,14$ \\
\hline China & 3055 & 7 & 800.415 & 20 & 2.286 .900 & 114.345 & $171.232 .209,27$ & 14,02 & $11.221 .818,30$ & $32.062 .338,00$ & 1,352 & $10.214 .967,06$ & $24.510 .305,56$ \\
\hline China & 3072 & 7 & 1.388 .436 & 20 & 3.966 .960 & 198.348 & $171.232 .209,27$ & 14,02 & $19.465 .872,72$ & $55.616 .779,20$ & 1,352 & $17.719 .343,10$ & $42.516 .682,73$ \\
\hline China & 3065 & 7 & 1.339 .548 & 20 & 3.827 .280 & 191.364 & $171.232 .209,27$ & 14,02 & $18.780 .462,96$ & $53.658 .465,60$ & 1,352 & $17.095 .430,11$ & $41.019 .634,55$ \\
\hline China & 4069 & 7 & 958.741 & 20 & 2.739 .260 & 136.963 & $222.049 .945,07$ & 7,03 & $6.739 .949,23$ & $19.256 .997,80$ & 2,008 & $5.864 .311,03$ & $12.939 .095,73$ \\
\hline China & 3056 & 7 & 1.152 .858 & 20 & 3.293 .880 & 164.694 & $222.049 .945,07$ & 7,03 & $8.104 .591,74$ & $23.155 .976,40$ & 2,008 & $7.051 .662,42$ & $15.558 .884,02$ \\
\hline China & 3057 & 7 & 819.826 & 20 & 2.342 .360 & 117.118 & $222.049 .945,07$ & 7,03 & $5.763 .376,78$ & $16.466 .790,80$ & 2,008 & $5.014 .612,55$ & $11.064 .309,44$ \\
\hline China & 3066 & 7 & 1.331 .988 & 20 & 3.805 .680 & 190.284 & $222.049 .945,07$ & 7,03 & $9.363 .875,64$ & $26.753 .930,40$ & 2,008 & $8.147 .343,15$ & $17.976 .408,90$ \\
\hline China & 3068 & 7 & 707.588 & 20 & 2.021 .680 & 101.084 & $222.049 .945,07$ & 7,03 & $4.974 .343,64$ & $14.212 .410,40$ & 2,008 & $4.328 .088,72$ & $9.549 .553,91$ \\
\hline China & 3061 & 7 & 746.011 & 20 & 2.131 .460 & 106.573 & $222.049 .945,07$ & 7,03 & $5.244 .457,33$ & $14.984 .163,80$ & 2,008 & $4.563 .109,88$ & $10.068 .107,80$ \\
\hline China & 3069 & 7 & 736.400 & 20 & 2.104 .000 & 105.200 & $222.049 .945,07$ & 7,03 & $5.176 .892,00$ & $14.791 .120,00$ & 2,008 & $4.504 .322,48$ & $9.938 .398,48$ \\
\hline China & 3071 & 7 & 810.320 & 20 & 2.315 .200 & 115.760 & $222.049 .945,07$ & 7,03 & $5.696 .549,60$ & $16.275 .856,00$ & 2,008 & $4.956 .467,40$ & $10.936 .017,19$ \\
\hline China & 3064 & 7 & 745.913 & 20 & 2.131 .180 & 106.559 & $222.049 .945,07$ & 7,03 & $5.243 .768,39$ & $14.982 .195,40$ & 2,008 & $4.562 .510,45$ & $10.066 .785,20$ \\
\hline China & 7869 & 7 & 85.694 & 25 & 306.050 & 12.242 & $308.493 .149,80$ & 6,48 & $555.297,12$ & $1.983 .204,00$ & 1,108 & $514.075,35$ & $1.505 .668,61$ \\
\hline China & 8327 & 7 & 94.864 & 25 & 338.800 & 13.552 & $308.493 .149,80$ & 6,48 & $614.718,72$ & $2.195 .424,00$ & 1,108 & $569.085,87$ & $1.666 .788,18$ \\
\hline China & 3282 & 7 & 819.091 & 20 & 2.340 .260 & 117.013 & $530.988 .219,49$ & 14,02 & $11.483 .655,82$ & $32.810 .445,20$ & 1,352 & $10.453 .311,82$ & 25.082.201,97 \\
\hline China & 4369 & 7 & 736.022 & 20 & 2.102 .920 & 105.146 & $1.503 .211 .178,30$ & 7,03 & $5.174 .234,66$ & $14.783 .527,60$ & 2,008 & $4.502 .010,38$ & $9.933 .297,02$ \\
\hline China & 2374 & 7 & 112.455 & 18 & 289.170 & 16.065 & $101.327 .776,47$ & 12,31 & $1.384 .321,05$ & $3.559 .682,70$ & 1,610 & $1.237 .888,88$ & $2.670 .269,92$ \\
\hline China & 5358 & 10 & 2.536 .120 & 10 & 2.536 .120 & 253.612 & $1.430 .306 .449,49$ & 7,03 & $17.828 .923,60$ & $17.828 .923,60$ & 2,008 & $14.614 .460,80$ & $14.614 .460,80$ \\
\hline
\end{tabular}




\begin{tabular}{|c|c|c|c|c|c|c|c|c|c|c|c|c|c|}
\hline China & 892 & 7 & 14.953 .218 & 25 & 53.404 .350 & 2.136 .174 & $302.521 .326,83$ & 0,02 & $299.064,36$ & $1.068 .087,00$ & 4,448 & $220.528,01$ & $359.835,01$ \\
\hline China & 902 & 7 & 6.753 .425 & 25 & 24.119 .375 & 964.775 & $302.521 .326,83$ & 0,02 & $135.068,50$ & $482.387,50$ & 4,448 & $99.598,59$ & $162.514,77$ \\
\hline China & 1630 & 7 & 1.005 .018 & 21 & 3.015 .054 & 143.574 & $310.943 .440,40$ & 15,45 & $15.527 .528,10$ & $46.582 .584,30$ & 4,825 & $11.164 .730,04$ & $17.316 .546,60$ \\
\hline China & 4662 & 10 & 1.708 .100 & 10 & 1.708 .100 & 170.810 & $523.091 .800,67$ & 7,03 & $12.007 .943,00$ & $12.007 .943,00$ & 2,008 & $9.842 .972,92$ & $9.842 .972,92$ \\
\hline China & 5768 & 7 & 680.764 & 21 & 2.042 .292 & 97.252 & 281.915.340,97 & 6,48 & $4.411 .350,72$ & $13.234 .052,16$ & 1,108 & $4.083 .879,78$ & $10.500 .184,42$ \\
\hline China & 7868 & 7 & 434.371 & 30 & 1.861 .590 & 62.053 & $281.915 .340,97$ & 6,48 & $2.814 .724,08$ & $12.063 .103,20$ & 1,108 & $2.605 .776,66$ & 8.667.492,01 \\
\hline China & 8333 & 7 & 679.231 & 30 & 2.910 .990 & 97.033 & $281.915 .340,97$ & 6,48 & $4.401 .416,88$ & $18.863 .215,20$ & 1,108 & 4.074.683,37 & $13.553 .458,38$ \\
\hline China & 5042 & 10 & 605.770 & 10 & 605.770 & 60.577 & $207.887 .084,47$ & 7,03 & $4.258 .563,10$ & $4.258 .563,10$ & 2,008 & $3.490 .766,18$ & $3.490 .766,18$ \\
\hline China & 193 & 7 & 40.527 .774 & 21 & 121.583 .322 & 5.789 .682 & $169.502 .594,93$ & 6,45 & $261.404 .142,30$ & $784.212 .426,90$ & 3,440 & 206.296.985,62 & $385.456 .142,36$ \\
\hline China & 868 & 7 & 33.667 .417 & 21 & 101.002 .251 & 4.809 .631 & $169.094 .945,69$ & 0,02 & $673.348,34$ & $2.020 .045,02$ & 4,448 & $496.522,46$ & $809.950,27$ \\
\hline China & 1343 & 7 & 6.559 .469 & 21 & 19.678 .407 & 937.067 & $1.071 .267 .534,41$ & 15,45 & $101.343 .796,05$ & $304.031 .388,15$ & 4,825 & $72.869 .043,71$ & $113.020 .215,18$ \\
\hline China & 1603 & 10 & 3.820 .190 & 10 & 3.820 .190 & 382.019 & $138.291 .693,98$ & 15,45 & $59.021 .935,50$ & $59.021 .935,50$ & 4,825 & $36.843 .827,17$ & $36.843 .827,17$ \\
\hline China & 4903 & 7 & 154.266 & 23 & 506.874 & 22.038 & $3.060 .823 .661,38$ & 6,48 & $999.643,68$ & $3.284 .543,52$ & 1,108 & $925.436,42$ & $2.549 .224,40$ \\
\hline
\end{tabular}

Fonte: Dados da pesquisa (2015). 
APÊNDICE F - Mensuração de RCEs de Projetos de MDLs - Índia

\begin{tabular}{|c|c|c|c|c|c|c|c|c|c|c|c|c|c|}
\hline $\begin{array}{c}\text { País } \\
\text { hospedeiro }\end{array}$ & $\begin{array}{l}\text { Referência } \\
\text { UNFCCC }\end{array}$ & $\begin{array}{l}\text { Período } \\
\text { vigência } \\
\left(1^{\mathbf{a}} \text { fase }\right)\end{array}$ & $\begin{array}{c}\text { Estimativa } \\
\text { Total de RE } \\
\left(\mathbf{1}^{\mathbf{a}} \text { fase }\right)\end{array}$ & $\begin{array}{c}\text { Período } \\
\text { Vigência } \\
\text { (total } \\
\text { geral) } \\
\end{array}$ & $\begin{array}{c}\text { Estimativa } \\
\text { total de RE } \\
\text { (geral) }\end{array}$ & $\begin{array}{r}\text { Estimativa } \\
\text { anual de RE }\end{array}$ & $\begin{array}{l}\text { Patrimônio } \\
\text { PL original }\end{array}$ & $\begin{array}{c}\text { Valor } \\
\text { tonelada } \\
\text { de RCEs }\end{array}$ & $\begin{array}{l}\text { Valor total } \\
\left.\text { RE ( } 1^{\text {a }} \text { fase }\right)\end{array}$ & $\begin{array}{l}\text { Valor total } \\
\text { RE (geral) }\end{array}$ & $\begin{array}{l}\text { Taxa } \\
\text { juros }\end{array}$ & $\begin{array}{c}\text { Valor } \\
\text { presente } \\
\left(1^{\mathbf{a}} \text { fase }\right)\end{array}$ & $\begin{array}{c}\text { Valor } \\
\text { Presente } \\
\text { (geral) }\end{array}$ \\
\hline Índia & 5728 & 10 & 670.600 & 10 & 670.600 & 67.060 & $163.420 .253,79$ & 6,48 & $4.345 .488,00$ & $4.345 .488,00$ & 1,108 & $3.892 .094,33$ & $3.892 .094,33$ \\
\hline Índia & 5980 & 10 & 706.840 & 10 & 706.840 & 70.684 & $163.420 .253,79$ & 6,48 & $4.580 .323,20$ & $4.580 .323,20$ & 1,108 & $4.102 .427,61$ & 4.102.427,61 \\
\hline Índia & 6072 & 10 & 706.840 & 10 & 706.840 & 70.684 & $163.420 .253,79$ & 6,48 & $4.580 .323,20$ & $4.580 .323,20$ & 1,108 & $4.102 .427,61$ & 4.102.427,61 \\
\hline Índia & 2679 & 10 & 231.210 & 10 & 231.210 & 23.121 & $712.348 .300,30$ & 12,31 & $2.846 .195,10$ & $2.846 .195,10$ & 1,108 & $2.426 .052,27$ & 2.426.052,27 \\
\hline Índia & 6700 & 10 & 118.930 & 10 & 118.930 & 11.893 & $1.012 .362 .542,20$ & 6,48 & $770.666,40$ & $770.666,40$ & 1,108 & $690.257,65$ & $690.257,65$ \\
\hline Índia & 5928 & 7 & 435.519 & 25 & 1.555 .425 & 62.217 & $2.872 .762 .431,21$ & 6,48 & $2.822 .163,12$ & $10.079 .154,00$ & 1,108 & $2.612 .663,47$ & $7.652 .196,02$ \\
\hline Índia & 2716 & 10 & 18.395 .160 & 10 & 18.395 .160 & 1.839 .516 & $339.061 .537,83$ & 12,31 & $226.444 .419,60$ & $226.444 .419,60$ & 1,610 & 193.017.687,86 & 193.017.687,86 \\
\hline Índia & 3225 & 10 & 11.930 .170 & 10 & 11.930 .170 & 1.193 .017 & $951.153 .461,83$ & 14,02 & $167.260 .983,40$ & $167.260 .983,40$ & 1,352 & $146.241 .763,17$ & $146.241 .763,17$ \\
\hline Índia & 1456 & 10 & 89.690 & 10 & 89.690 & 8.969 & $53.697 .323,78$ & 15,45 & $1.385 .710,50$ & $1.385 .710,50$ & 4,825 & $865.015,32$ & $865.015,32$ \\
\hline Índia & 1047 & 7 & 170.016 & 20 & 485.760 & 24.288 & 4.379.101,44 & 0,02 & $3.400,32$ & $9.715,20$ & 4,448 & $2.507,37$ & $4.068,64$ \\
\hline Índia & 9410 & 7 & 62.811 & 20 & 179.460 & 8.973 & $6.707 .236,05$ & 6,48 & $407.015,28$ & $1.162 .900,80$ & 1,108 & $376.801,02$ & $932.893,94$ \\
\hline Índia & 109 & 10 & 259.370 & 10 & 259.370 & 25.937 & $456.174 .741,34$ & 21,1 & $5.472 .707,00$ & $5.472 .707,00$ & 2,335 & $4.344 .704,65$ & $4.344 .704,65$ \\
\hline Índia & 932 & 10 & 28.770 & 10 & 28.770 & 2.877 & $66.554 .847,78$ & 0,02 & 575,40 & 575,40 & 4,448 & 372,36 & 372,36 \\
\hline Índia & 1403 & 10 & 341.480 & 10 & 341.480 & 34.148 & $65.505 .011,13$ & 15,45 & $5.275 .866,00$ & $5.275 .866,00$ & 4,825 & $3.293 .404,28$ & $3.293 .404,28$ \\
\hline Índia & 112 & 7 & 88.746 & 18 & 228.204 & 12.678 & $34.104 .378,41$ & 7,03 & $623.884,38$ & $1.604 .274,12$ & 2,008 & $542.830,80$ & $1.121 .662,98$ \\
\hline Índia & 2546 & 10 & 216.990 & 10 & 216.990 & 21.699 & $178.613 .048,77$ & 12,31 & $2.671 .146,90$ & $2.671 .146,90$ & 1,610 & $2.276 .843,91$ & $2.276 .843,91$ \\
\hline Índia & 389 & 10 & 234.290 & 10 & 234.290 & 23.429 & $117.557 .195,63$ & 6,45 & $1.511 .170,50$ & $1.511 .170,50$ & 3,440 & 1.077.527,46 & $1.077 .527,46$ \\
\hline Índia & 471 & 7 & 329.686 & 25 & 1.177 .450 & 47.098 & $261.903 .206,11$ & 6,45 & $2.126 .474,70$ & 7.594.552,50 & 3,440 & $1.678 .188,10$ & $3.260 .538,94$ \\
\hline Índia & 2947 & 10 & 205.880 & 10 & 205.880 & 20.588 & $603.936 .278,00$ & 14,02 & $2.886 .437,60$ & $2.886 .437,60$ & 3,440 & $2.523 .707,06$ & $2.523 .707,06$ \\
\hline Índia & 8415 & 10 & 381.270 & 10 & 381.270 & 38.127 & $2.057 .899,62$ & 6,48 & $2.470 .629,60$ & $2.470 .629,60$ & 1,108 & $2.212 .852,38$ & $2.212 .852,38$ \\
\hline Índia & 7770 & 10 & 137.920 & 10 & 137.920 & 13.792 & $62.771 .591,27$ & 6,48 & $893.721,60$ & $893.721,60$ & 1,108 & $800.473,68$ & $800.473,68$ \\
\hline
\end{tabular}




\begin{tabular}{|c|c|c|c|c|c|c|c|c|c|c|c|c|c|}
\hline Índia & 4343 & 10 & 88.990 & 10 & 88.990 & 8.899 & $23.675 .783,33$ & 7,03 & $625.599,70$ & $625.599,70$ & 2,008 & $512.807,31$ & $512.807,31$ \\
\hline Índia & 991 & 10 & 6.866 .970 & 10 & 6.866 .970 & 686.697 & $28.480 .682,47$ & 0,02 & $137.339,40$ & $137.339,40$ & 4,448 & $88.877,92$ & $88.877,92$ \\
\hline Índia & 4877 & 10 & 213.290 & 10 & 213.290 & 21.329 & $32.823 .561,19$ & 7,03 & $1.499 .428,70$ & $1.499 .428,70$ & 2,008 & $1.229 .089,45$ & $1.229 .089,45$ \\
\hline Índia & 7968 & 10 & 160.920 & 10 & 160.920 & 16.092 & $28.204 .214,72$ & 6,48 & $1.042 .761,60$ & $1.042 .761,60$ & 1,108 & $933.963,35$ & $933.963,35$ \\
\hline Índia & 1236 & 10 & 192.690 & 10 & 192.690 & 19.269 & $75.291 .912,87$ & 0,02 & $3.853,80$ & $3.853,80$ & 4,448 & $2.493,95$ & $2.493,95$ \\
\hline Índia & 1574 & 10 & 721.580 & 10 & 721.580 & 72.158 & $73.641 .106,08$ & 15,45 & $11.148 .411,00$ & $11.148 .411,00$ & 4,825 & $6.959 .279,20$ & $6.959 .279,20$ \\
\hline Índia & 3822 & 10 & 803.850 & 10 & 803.850 & 80.385 & $112.671 .634,20$ & 14,02 & $11.269 .977,00$ & $11.269 .977,00$ & 1,352 & $9.853 .710,49$ & $9.853 .710,49$ \\
\hline Índia & 792 & 7 & 158.039 & 20 & 451.540 & 22.577 & $112.041 .433,34$ & 0,02 & $3.160,78$ & $9.030,80$ & 4,448 & $2.330,74$ & $3.782,02$ \\
\hline Índia & 7558 & 10 & 227.320 & 10 & 227.320 & 22.732 & $31.906 .445,49$ & 6,48 & $1.473 .033,60$ & $1.473 .033,60$ & 1,108 & $1.319 .342,21$ & $1.319 .342,21$ \\
\hline Índia & 1216 & 10 & 53.600 & 10 & 53.600 & 5.360 & $461.445 .101,06$ & 0,02 & $1.072,00$ & $1.072,00$ & 4,448 & 693,73 & 693,73 \\
\hline Índia & 4997 & 10 & 62.500 & 10 & 62.500 & 6.250 & $811.027 .471,04$ & 7,03 & $439.375,00$ & $439.375,00$ & 2,008 & $360.157,96$ & $360.157,96$ \\
\hline Índia & 800 & 7 & 57.638 & 20 & 164.680 & 8.234 & $257.489 .809,83$ & 0,02 & $1.152,76$ & $3.293,60$ & 4,448 & 850,04 & $1.379,33$ \\
\hline Índia & 2036 & 10 & 97.690 & 10 & 97.690 & 9.769 & 1.976.106.592,49 & 12,31 & $1.202 .563,90$ & $1.202 .563,90$ & 1,610 & 1.025.046,69 & $1.025 .046,69$ \\
\hline Índia & 8801 & 10 & 41.610 & 10 & 41.610 & 4.161 & $1.172 .660 .940,20$ & 6,48 & $269.632,80$ & $269.632,80$ & 1,108 & $241.500,22$ & $241.500,22$ \\
\hline Índia & 314 & 10 & 264.150 & 10 & 264.150 & 26.415 & $71.326 .135,06$ & 6,45 & $1.703 .767,50$ & $1.703 .767,50$ & 3,440 & $1.214 .857,14$ & $1.214 .857,14$ \\
\hline Índia & 568 & 10 & 26.450 & 10 & 26.450 & 2.645 & $71.326 .135,06$ & 6,45 & $170.602,50$ & $170.602,50$ & 3,440 & $121.646,68$ & $121.646,68$ \\
\hline Índia & 4543 & 10 & 216.270 & 10 & 216.270 & 21.627 & $109.314 .700,90$ & 7,03 & $1.520 .378,10$ & $1.520 .378,10$ & 2,008 & $1.246 .261,78$ & $1.246 .261,78$ \\
\hline Índia & 8417 & 7 & 195.153 & 20 & 557.580 & 27.879 & $127.136 .217,80$ & 6,48 & $1.264 .591,44$ & $3.613 .118,40$ & 1,108 & $1.170 .716,12$ & $2.898 .489,94$ \\
\hline Índia & 8121 & 10 & 155.950 & 10 & 155.950 & 15.595 & $99.878 .846,07$ & 6,48 & $1.010 .556,00$ & $1.010 .556,00$ & 1,108 & $905.117,97$ & $905.117,97$ \\
\hline Índia & 548 & 10 & 1.530 .780 & 10 & 1.530 .780 & 153.078 & 157.553.232,00 & 6,45 & $9.873 .531,00$ & $9.873 .531,00$ & 3,440 & $7.040 .238,56$ & $7.040 .238,56$ \\
\hline Índia & 479 & 10 & 38.410 & 10 & 38.410 & 3.841 & $684.805 .570,68$ & 6,45 & $247.744,50$ & $247.744,50$ & 3,440 & $176.652,14$ & $176.652,14$ \\
\hline Índia & 987 & 10 & 318.780 & 10 & 318.780 & 31.878 & 659.395.529,90 & 0,02 & $6.375,60$ & $6.375,60$ & 4,448 & $4.125,91$ & $4.125,91$ \\
\hline Índia & 1807 & 10 & & 10 & & & & 15,45 & & & 4,825 & & \\
\hline
\end{tabular}




\begin{tabular}{|c|c|c|c|c|c|c|c|c|c|c|c|c|c|}
\hline & & & 40.460 & & 40.460 & 4.046 & $713.558 .158,43$ & & $625.107,00$ & $625.107,00$ & & $390.216,52$ & $390.216,52$ \\
\hline Índia & 3115 & 10 & 341.860 & 10 & 341.860 & 34.186 & $569.914 .694,51$ & 14,02 & $4.792 .877,20$ & $4.792 .877,20$ & 1,352 & $4.190 .569,72$ & $4.190 .569,72$ \\
\hline Índia & 1852 & 10 & 682.950 & 10 & 682.950 & 68.295 & 77.451.054,94 & 12,31 & $8.407 .114,50$ & $8.407 .114,50$ & 1,610 & $7.166 .093,14$ & $7.166 .093,14$ \\
\hline Índia & 1003 & 10 & 466.800 & 10 & 466.800 & 46.680 & $184.270 .959,93$ & 15,45 & $7.212 .060,00$ & $7.212 .060,00$ & 4,825 & $4.502 .053,18$ & $4.502 .053,18$ \\
\hline Índia & 4332 & 10 & 345.810 & 10 & 345.810 & 34.581 & 495.635.989,38 & 7,03 & $2.431 .044,30$ & $2.431 .044,30$ & 2,008 & $1.992 .739,57$ & $1.992 .739,57$ \\
\hline Índia & 4608 & 10 & 327.950 & 10 & 327.950 & 32.795 & $495.635 .989,38$ & 7,03 & $2.305 .488,50$ & $2.305 .488,50$ & 2,008 & $1.889 .820,84$ & $1.889 .820,84$ \\
\hline Índia & 332 & 10 & 403.920 & 10 & 403.920 & 40.392 & $97.446 .068,58$ & 6,45 & $2.605 .284,00$ & $2.605 .284,00$ & 3,440 & $1.857 .675,93$ & $1.857 .675,93$ \\
\hline Índia & 982 & 10 & 570.340 & 10 & 570.340 & 57.034 & $95.759 .573,21$ & 0,02 & $11.406,80$ & $11.406,80$ & 4,448 & $7.381,80$ & $7.381,80$ \\
\hline Índia & 6522 & 10 & 333.920 & 10 & 333.920 & 33.392 & $62.868 .063,38$ & 6,48 & $2.163 .801,60$ & $2.163 .801,60$ & 1,108 & $1.938 .037,78$ & $1.938 .037,78$ \\
\hline Índia & 2540 & 10 & 143.130 & 10 & 143.130 & 14.313 & $120.285 .287,42$ & 12,31 & $1.761 .930,30$ & $1.761 .930,30$ & 1,610 & $1.501 .841,88$ & $1.501 .841,88$ \\
\hline Índia & 2943 & 10 & 2.216 .740 & 10 & 2.216 .740 & 221.674 & $152.099 .668,01$ & 14,02 & $31.078 .694,80$ & $31.078 .694,80$ & 1,352 & $27.173 .122,10$ & $27.173 .122,10$ \\
\hline Índia & 2997 & 10 & 1.320 .330 & 10 & 1.320 .330 & 132.033 & $152.099 .668,01$ & 14,02 & $18.511 .026,60$ & $18.511 .026,60$ & 1,352 & $16.184 .797,63$ & $16.184 .797,63$ \\
\hline Índia & 8595 & 10 & 1.272 .720 & 10 & 1.272 .720 & 127.272 & $178.860 .536,93$ & 6,48 & $8.247 .225,60$ & $8.247 .225,60$ & 1,108 & 7.386.737,69 & $7.386 .737,69$ \\
\hline Índia & 8729 & 10 & 509.080 & 10 & 509.080 & 50.908 & $178.860 .536,93$ & 6,48 & $3.298 .838,40$ & $3.298 .838,40$ & 1,108 & $2.954 .648,64$ & $2.954 .648,64$ \\
\hline Índia & 8731 & 10 & 819.100 & 10 & 819.100 & 81.910 & $178.860 .536,93$ & 6,48 & $5.307 .768,00$ & $5.307 .768,00$ & 1,108 & $4.753 .973,25$ & $4.753 .973,25$ \\
\hline Índia & 1461 & 10 & 265.720 & 10 & 265.720 & 26.572 & $8.509 .067,26$ & 15,45 & $4.105 .374,00$ & $4.105 .374,00$ & 4,825 & $2.562 .736,87$ & $2.562 .736,87$ \\
\hline Índia & 2347 & 7 & 2.196 .285 & 20 & 6.275 .100 & 313.755 & $3.585 .735 .807,33$ & 12,31 & $27.036 .268,35$ & $77.246 .481,00$ & 1,610 & $24.176 .397,57$ & $56.124 .137,09$ \\
\hline Índia & 2474 & 7 & 164.409 & 20 & 469.740 & 23.487 & $3.585 .735 .807,33$ & 12,31 & $2.023 .874,79$ & $5.782 .499,40$ & 1,610 & $1.809 .791,24$ & $4.201 .327,81$ \\
\hline Índia & 3642 & 7 & 991.319 & 20 & 2.832 .340 & 141.617 & $4.160 .889 .019,92$ & 7,03 & $6.968 .972,57$ & $19.911 .350,20$ & 2,008 & $6.063 .580,20$ & $13.378 .765,94$ \\
\hline Índia & 1257 & 10 & 412.840 & 10 & 412.840 & 41.284 & $27.752 .069,10$ & 0,02 & $8.256,80$ & $8.256,80$ & 4,448 & $5.343,31$ & $5.343,31$ \\
\hline Índia & 1339 & 10 & 610.070 & 10 & 610.070 & 61.007 & $21.130 .360,29$ & 15,45 & $9.425 .581,50$ & $9.425 .581,50$ & 4,825 & $5.883 .820,87$ & $5.883 .820,87$ \\
\hline Índia & 3191 & 7 & 65.856 & 25 & 235.200 & 9.408 & $24.359 .968,49$ & 14,02 & $923.301,12$ & $3.297 .504,00$ & 1,352 & $840.460,10$ & $2.357 .095,90$ \\
\hline Índia & 1139 & 10 & 866.230 & 10 & 866.230 & 86.623 & $160.961 .809,46$ & 0,02 & $17.324,60$ & $17.324,60$ & 4,448 & $11.211,45$ & $11.211,45$ \\
\hline Índia & 556 & 10 & 783.800 & 10 & 783.800 & 78.380 & $141.047 .978,48$ & 6,45 & $5.055 .510,00$ & $5.055 .510,00$ & 3,440 & $3.604 .789,05$ & $3.604 .789,05$ \\
\hline
\end{tabular}




\begin{tabular}{|c|c|c|c|c|c|c|c|c|c|c|c|c|c|}
\hline Índia & 6712 & 10 & 361.750 & 10 & 361.750 & 36.175 & $2.745 .649,25$ & 6,48 & $2.344 .140,00$ & $2.344 .140,00$ & 1,108 & $2.099 .560,28$ & $2.099 .560,28$ \\
\hline Índia & 5767 & 10 & 146.100 & 10 & 146.100 & 14.610 & $75.500 .278,62$ & 6,48 & $946.728,00$ & $946.728,00$ & 1,108 & $847.949,57$ & $847.949,57$ \\
\hline Índia & 7819 & 7 & 52.241 & 25 & 186.575 & 7.463 & $75.500 .278,62$ & 6,48 & $338.521,68$ & $1.209 .006,00$ & 1,108 & $313.391,96$ & $917.889,63$ \\
\hline Índia & 1548 & 7 & 192.969 & 25 & 689.175 & 27.567 & $38.106 .677,25$ & 15,45 & 2.981.371,05 & $10.647 .753,75$ & 4,825 & $2.143 .689,76$ & $3.278 .205,86$ \\
\hline Índia & 3594 & 10 & 51.540 & 10 & 51.540 & 5.154 & $20.105 .476,22$ & 14,02 & $722.590,80$ & $722.590,80$ & 1,352 & $631.784,83$ & $631.784,83$ \\
\hline Índia & 2937 & 10 & 219.490 & 10 & 219.490 & 21.949 & $20.105 .476,22$ & 14,02 & $3.077 .249,80$ & $3.077 .249,80$ & 1,352 & $2.690 .540,42$ & $2.690 .540,42$ \\
\hline Índia & 832 & 10 & 1.357 .780 & 10 & 1.357 .780 & 135.778 & $517.665 .139,46$ & 0,02 & $27.155,60$ & $27.155,60$ & 4,448 & $17.573,49$ & $17.573,49$ \\
\hline Índia & 3182 & 7 & 91.637 & 25 & 327.275 & 13.091 & $29.245 .579,53$ & 14,02 & $1.284 .750,74$ & $4.588 .395,50$ & 1,352 & $1.169 .479,50$ & $3.279 .840,82$ \\
\hline Índia & 5384 & 10 & 162.470 & 10 & 162.470 & 16.247 & $74.965 .436,80$ & 7,03 & $1.142 .164,10$ & $1.142 .164,10$ & 2,008 & $936.237,81$ & $936.237,81$ \\
\hline Índia & 4898 & 10 & 82.740 & 10 & 82.740 & 8.274 & $40.081 .620,87$ & 7,03 & $581.662,20$ & $581.662,20$ & 2,008 & $476.791,51$ & $476.791,51$ \\
\hline Índia & 4886 & 10 & 350.440 & 10 & 350.440 & 35.044 & $33.313 .011,97$ & 7,03 & $2.463 .593,20$ & $2.463 .593,20$ & 2,008 & $2.019 .420,08$ & $2.019 .420,08$ \\
\hline Índia & 264 & 10 & 178.280 & 10 & 178.280 & 17.828 & $18.630 .717,43$ & 6,45 & $1.149 .906,00$ & $1.149 .906,00$ & 3,440 & $819.930,84$ & $819.930,84$ \\
\hline Índia & 772 & 10 & 506.200 & 10 & 506.200 & 50.620 & $35.854 .264,66$ & 0,02 & $10.124,00$ & $10.124,00$ & 4,448 & $6.551,65$ & $6.551,65$ \\
\hline Índia & 1719 & 10 & 1.599 .260 & 10 & 1.599 .260 & 159.926 & $62.065 .454,33$ & 15,45 & $24.708 .567,00$ & $24.708 .567,00$ & 4,825 & $15.424 .065,04$ & $15.424 .065,04$ \\
\hline Índia & 531 & 10 & 164.470 & 10 & 164.470 & 16.447 & 78.619.802,61 & 6,45 & $1.060 .831,50$ & $1.060 .831,50$ & 3,440 & $756.417,01$ & $756.417,01$ \\
\hline Índia & 4062 & 10 & 95.480 & 10 & 95.480 & 9.548 & $71.522 .666,48$ & 7,03 & $671.224,40$ & $671.224,40$ & 2,008 & $550.206,11$ & $550.206,11$ \\
\hline Índia & 662 & 10 & 27.840 & 10 & 27.840 & 2.784 & $88.356 .195,17$ & 6,45 & $179.568,00$ & $179.568,00$ & 3,440 & $128.039,46$ & $128.039,46$ \\
\hline Índia & 339 & 10 & 519.320 & 10 & 519.320 & 51.932 & $897.005 .218,44$ & 6,45 & $3.349 .614,00$ & $3.349 .614,00$ & 3,440 & $2.388 .414,20$ & $2.388 .414,20$ \\
\hline Índia & 858 & 10 & 151.570 & 10 & 151.570 & 15.157 & $1.147 .611 .208,70$ & 0,02 & $3.031,40$ & $3.031,40$ & 4,448 & $1.961,74$ & $1.961,74$ \\
\hline Índia & 3602 & 10 & 215.090 & 10 & 215.090 & 21.509 & $2.302 .823 .438,26$ & 7,03 & $1.512 .082,70$ & $1.512 .082,70$ & 2,008 & $1.239 .462,00$ & $1.239 .462,00$ \\
\hline Índia & 949 & 10 & 174.750 & 10 & 174.750 & 17.475 & $18.798 .897,90$ & 0,02 & $3.495,00$ & $3.495,00$ & 4,448 & $2.261,76$ & $2.261,76$ \\
\hline Índia & 494 & 10 & 994.620 & 10 & 994.620 & 99.462 & $134.075 .428,85$ & 6,45 & $6.415 .299,00$ & $6.415 .299,00$ & 3,440 & $4.574 .375,20$ & $4.574 .375,20$ \\
\hline Índia & 500 & 10 & & 10 & & & & 0,02 & & & 4,448 & & \\
\hline
\end{tabular}




\begin{tabular}{|c|c|c|c|c|c|c|c|c|c|c|c|c|c|}
\hline & & & 46.310 & & 46.310 & 4.631 & $153.560 .435,30$ & & 926,20 & 926,20 & & 599,38 & 599,38 \\
\hline Índia & 940 & 10 & 89.540 & 10 & 89.540 & 8.954 & $153.560 .435,30$ & 0,02 & $1.790,80$ & $1.790,80$ & 4,448 & $1.158,90$ & $1.158,90$ \\
\hline Índia & 7092 & 10 & 715.660 & 10 & 715.660 & 71.566 & $236.984 .693,22$ & 6,48 & 4.637.476,80 & 4.637.476,80 & 1,108 & 4.153.617,99 & 4.153.617,99 \\
\hline Índia & 7248 & 10 & 390.320 & 10 & 390.320 & 39.032 & $236.984 .693,22$ & 6,48 & $2.529 .273,60$ & $2.529 .273,60$ & 1,108 & $2.265 .377,66$ & 2.265.377,66 \\
\hline Índia & 1 & 10 & 30.000 .000 & 10 & 30.000 .000 & 3.000 .000 & $70.559 .273,41$ & 21,1 & $633.000 .000,00$ & $633.000 .000,00$ & 2,335 & $502.529 .742,74$ & $502.529 .742,74$ \\
\hline Índia & 1615 & 7 & 361.326 & 20 & 1.032 .360 & 51.618 & $176.313 .134,88$ & 15,45 & $5.582 .486,70$ & $15.949 .962,00$ & 4,825 & $4.013 .965,17$ & $6.215 .301,93$ \\
\hline Índia & 7724 & 7 & 124.530 & 20 & 355.800 & 17.790 & $400.634 .961,86$ & 6,48 & $806.954,40$ & $2.305 .584,00$ & 1,108 & $747.051,18$ & $1.849 .569,07$ \\
\hline Índia & 2948 & 10 & 162.000 & 10 & 162.000 & 16.200 & $116.781 .231,15$ & 14,02 & $2.271 .240,00$ & $2.271 .240,00$ & 1,352 & $1.985 .819,62$ & $1.985 .819,62$ \\
\hline Índia & 1540 & 10 & 50.820 & 10 & 50.820 & 5.082 & $1.543 .238,81$ & 15,45 & $785.169,00$ & $785.169,00$ & 4,825 & $490.133,55$ & $490.133,55$ \\
\hline Índia & 5141 & 7 & 277.312 & 20 & 792.320 & 39.616 & $263.850 .102,15$ & 7,03 & $1.949 .503,36$ & $5.570 .009,60$ & 2,008 & $1.696 .228,51$ & $3.742 .581,69$ \\
\hline Índia & 7720 & 10 & 755.190 & 10 & 755.190 & 75.519 & $301.530 .929,04$ & 6,48 & $4.893 .631,20$ & $4.893 .631,20$ & 1,108 & $4.383 .046,10$ & $4.383 .046,10$ \\
\hline Índia & 2550 & 10 & 3.329 .470 & 10 & 3.329 .470 & 332.947 & $299.004 .020,73$ & 12,31 & $40.985 .775,70$ & $40.985 .775,70$ & 1,610 & $34.935 .635,31$ & $34.935 .635,31$ \\
\hline Índia & 5087 & 10 & 918.750 & 10 & 918.750 & 91.875 & $230.915 .455,43$ & 6,48 & $5.953 .500,00$ & $5.953 .500,00$ & 1,108 & $5.332 .331,74$ & $5.332 .331,74$ \\
\hline Índia & 1727 & 10 & 8.660 & 10 & 8.660 & 866 & $286.735 .082,28$ & 12,31 & $106.604,60$ & $106.604,60$ & 1,610 & $90.868,10$ & $90.868,10$ \\
\hline Índia & 3372 & 10 & 165.560 & 10 & 165.560 & 16.556 & $352.956 .734,62$ & 14,02 & $2.321 .151,20$ & $2.321 .151,20$ & 1,352 & $2.029 .458,62$ & 2.029.458,62 \\
\hline Índia & 6551 & 10 & 211.590 & 10 & 211.590 & 21.159 & $518.363 .358,46$ & 6,48 & $1.371 .103,20$ & $1.371 .103,20$ & 1,108 & $1.228 .046,88$ & $1.228 .046,88$ \\
\hline Índia & 8020 & 10 & 318.650 & 10 & 318.650 & 31.865 & $518.363 .358,46$ & 6,48 & $2.064 .852,00$ & $2.064 .852,00$ & 1,108 & $1.849 .412,25$ & $1.849 .412,25$ \\
\hline Índia & 8172 & 10 & 556.200 & 10 & 556.200 & 55.620 & $518.363 .358,46$ & 6,48 & $3.604 .176,00$ & $3.604 .176,00$ & 1,108 & $3.228 .128,34$ & $3.228 .128,34$ \\
\hline Índia & 7397 & 10 & 937.180 & 10 & 937.180 & 93.718 & $377.480 .668,91$ & 6,48 & $6.072 .926,40$ & $6.072 .926,40$ & 1,108 & 5.439.297,59 & $5.439 .297,59$ \\
\hline Índia & 855 & 10 & 516.090 & 10 & 516.090 & 51.609 & $1.318 .227 .615,69$ & 0,02 & $10.321,80$ & $10.321,80$ & 4,448 & $6.679,66$ & $6.679,66$ \\
\hline Índia & 1824 & 7 & 455.252 & 20 & 1.300 .720 & 65.036 & $2.131 .443 .135,21$ & 12,31 & $5.604 .152,12$ & $16.011 .863,20$ & 1,610 & $5.011 .350,23$ & $11.633 .565,62$ \\
\hline Índia & 1856 & 7 & 1.106 .889 & 20 & 3.162 .540 & 158.127 & $2.131 .443 .135,21$ & 12,31 & $13.625 .803,59$ & $38.930 .867,40$ & 1,610 & $12.184 .479,03$ & $28.285 .577,68$ \\
\hline Índia & 7873 & 7 & 312.389 & 20 & 892.540 & 44.627 & $3.962 .248 .674,13$ & 6,48 & $2.024 .280,72$ & $5.783 .659,20$ & 1,108 & $1.874 .010,85$ & $4.639 .725,63$ \\
\hline Índia & 7895 & 7 & 601.041 & 20 & 1.717 .260 & 85.863 & $3.962 .248 .674,13$ & 6,48 & $3.894 .745,68$ & $11.127 .844,80$ & 1,108 & $3.605 .624,25$ & $8.926 .899,89$ \\
\hline
\end{tabular}




\begin{tabular}{|c|c|c|c|c|c|c|c|c|c|c|c|c|c|}
\hline Índia & 7981 & 7 & 300.384 & 20 & 858.240 & 42.912 & $3.962 .248 .674,13$ & 6,48 & $1.946 .488,32$ & $5.561 .395,20$ & 1,108 & $1.801 .993,27$ & 4.461.422,59 \\
\hline Índia & 8198 & 7 & 294.917 & 20 & 842.620 & 42.131 & $3.962 .248 .674,13$ & 6,48 & $1.911 .062,16$ & $5.460 .177,60$ & 1,108 & $1.769 .196,92$ & $4.380 .224,54$ \\
\hline Índia & 8303 & 7 & 223.125 & 20 & 637.500 & 31.875 & $3.962 .248 .674,13$ & 6,48 & $1.445 .850,00$ & $4.131 .000,00$ & 1,108 & $1.338 .519,19$ & $3.313 .941,21$ \\
\hline Índia & 3964 & 10 & 226.360 & 10 & 226.360 & 22.636 & $133.545 .325,29$ & 7,03 & $1.591 .310,80$ & $1.591 .310,80$ & 2,008 & $1.304 .405,68$ & $1.304 .405,68$ \\
\hline Índia & 717 & 10 & 515.270 & 10 & 515.270 & 51.527 & $373.679 .261,51$ & 0,02 & $10.305,40$ & $10.305,40$ & 4,448 & $6.669,04$ & $6.669,04$ \\
\hline Índia & 3763 & 10 & 1.101 .570 & 10 & 1.101 .570 & 110.157 & $63.446 .857,85$ & 14,02 & $15.444 .011,40$ & $15.444 .011,40$ & 1,352 & 13.503.205,66 & $13.503 .205,66$ \\
\hline Índia & 348 & 10 & 474.630 & 10 & 474.630 & 47.463 & $21.779 .793,77$ & 0,02 & $9.492,60$ & $9.492,60$ & 4,448 & $6.143,05$ & $6.143,05$ \\
\hline Índia & 793 & 10 & 106.270 & 10 & 106.270 & 10.627 & $5.796 .889,29$ & 0,02 & $2.125,40$ & $2.125,40$ & 4,448 & $1.375,43$ & $1.375,43$ \\
\hline Índia & 277 & 7 & 100.912 & 25 & 360.400 & 14.416 & $9.739 .990,71$ & 6,45 & $650.882,40$ & $2.324 .580,00$ & 3,440 & $513.668,51$ & $998.002,66$ \\
\hline Índia & 4740 & 7 & 273.553 & 20 & 781.580 & 39.079 & $22.359 .027,31$ & 7,03 & $1.923 .077,59$ & $5.494 .507,40$ & 2,008 & $1.673 .235,91$ & $3.691 .850,51$ \\
\hline Índia & 686 & 10 & 29.870 & 10 & 29.870 & 2.987 & $1.709 .883 .400,71$ & 6,45 & $192.661,50$ & $192.661,50$ & 3,440 & $137.375,67$ & $137.375,67$ \\
\hline Índia & 677 & 10 & 225.870 & 10 & 225.870 & 22.587 & $1.709 .883 .400,71$ & 6,45 & $1.456 .861,50$ & $1.456 .861,50$ & 3,440 & $1.038 .802,89$ & $1.038 .802,89$ \\
\hline Índia & 745 & 10 & 81.950 & 10 & 81.950 & 8.195 & $1.709 .883 .400,71$ & 6,45 & $528.577,50$ & $528.577,50$ & 3,440 & $376.897,76$ & $376.897,76$ \\
\hline Índia & 679 & 10 & 522.470 & 10 & 522.470 & 52.247 & $1.840 .108 .215,84$ & 0,02 & $10.449,40$ & $10.449,40$ & 4,448 & $6.762,23$ & $6.762,23$ \\
\hline Índia & 821 & 10 & 39.500 & 10 & 39.500 & 3.950 & $1.840 .108 .215,84$ & 0,02 & 790,00 & 790,00 & 4,448 & 511,24 & 511,24 \\
\hline Índia & 806 & 10 & 215.050 & 10 & 215.050 & 21.505 & $1.840 .108 .215,84$ & 0,02 & $4.301,00$ & $4.301,00$ & 4,448 & $2.783,35$ & $2.783,35$ \\
\hline Índia & 890 & 10 & 431.610 & 10 & 431.610 & 43.161 & $1.840 .108 .215,84$ & 0,02 & $8.632,20$ & $8.632,20$ & 4,448 & $5.586,25$ & $5.586,25$ \\
\hline Índia & 2241 & 30 & 1.733 .760 & 30 & 1.733 .760 & 57.792 & $2.082 .539 .350,76$ & 12,31 & $21.342 .585,60$ & $21.342 .585,60$ & 1,610 & $13.217 .626,97$ & $13.217 .626,97$ \\
\hline Índia & 3035 & 7 & 253.274 & 20 & 723.640 & 36.182 & $2.380 .069 .137,73$ & 14,02 & $3.550 .901,48$ & $10.145 .432,80$ & 1,352 & $3.232 .305,20$ & $7.755 .755,61$ \\
\hline Índia & 3890 & 10 & 746.500 & 10 & 746.500 & 74.650 & $2.601 .264 .812,58$ & 7,03 & $5.247 .895,00$ & $5.247 .895,00$ & 2,008 & $4.301 .726,65$ & $4.301 .726,65$ \\
\hline Índia & 433 & 10 & 463.870 & 10 & 463.870 & 46.387 & $11.996 .344,77$ & 6,45 & $2.991 .961,50$ & $2.991 .961,50$ & 3,440 & $2.133 .393,08$ & $2.133 .393,08$ \\
\hline Índia & 7186 & 10 & 83.830 & 10 & 83.830 & 8.383 & $258.487 .315,91$ & 6,48 & $543.218,40$ & $543.218,40$ & 1,108 & $486.540,81$ & $486.540,81$ \\
\hline Índia & 8079 & 10 & & 10 & & & & 6,48 & & & 1,108 & & \\
\hline
\end{tabular}




\begin{tabular}{|c|c|c|c|c|c|c|c|c|c|c|c|c|c|}
\hline & & & 279.920 & & 279.920 & 27.992 & $258.487 .315,91$ & & $1.813 .881,60$ & $1.813 .881,60$ & & $1.624 .627,27$ & $1.624 .627,27$ \\
\hline Índia & 8464 & 7 & 92.701 & 25 & 331.075 & 13.243 & $258.487 .315,91$ & 6,48 & $600.702,48$ & $2.145 .366,00$ & 1,108 & $556.110,10$ & $1.628 .783,64$ \\
\hline Índia & 8958 & 10 & 52.400 & 10 & 52.400 & 5.240 & $258.487 .315,91$ & 6,48 & $339.552,00$ & $339.552,00$ & 1,108 & $304.124,28$ & $304.124,28$ \\
\hline Índia & 510 & 10 & 403.080 & 10 & 403.080 & 40.308 & $483.180 .674,69$ & 6,45 & $2.599 .866,00$ & $2.599 .866,00$ & 3,440 & $1.853 .812,67$ & $1.853 .812,67$ \\
\hline Índia & 3683 & 10 & 370.750 & 10 & 370.750 & 37.075 & $97.576 .956,21$ & 14,02 & $5.197 .915,00$ & $5.197 .915,00$ & 1,352 & $4.544 .707,55$ & $4.544 .707,55$ \\
\hline Índia & 1287 & 10 & 700.900 & 10 & 700.900 & 70.090 & $165.556 .262,08$ & 0,02 & $14.018,00$ & $14.018,00$ & 4,448 & $9.071,62$ & $9.071,62$ \\
\hline Índia & 1324 & 10 & 751.870 & 10 & 751.870 & 75.187 & $290.194 .239,79$ & 15,45 & $11.616 .391,50$ & $11.616 .391,50$ & 4,825 & 7.251.411,14 & $7.251 .411,14$ \\
\hline Índia & 351 & 10 & 3.876 .430 & 10 & 3.876 .430 & 387.643 & $353.020 .184,70$ & 6,45 & $25.002 .973,50$ & $25.002 .973,50$ & 3,440 & $17.828 .160,77$ & $17.828 .160,77$ \\
\hline Índia & 5864 & 10 & 384.590 & 10 & 384.590 & 38.459 & 2.669.543.092,93 & 6,48 & $2.492 .143,20$ & $2.492 .143,20$ & 1,108 & $2.232 .121,32$ & $2.232 .121,32$ \\
\hline Índia & 2562 & 7 & 240.905 & 20 & 688.300 & 34.415 & $13.159 .030,83$ & 12,31 & $2.965 .540,55$ & $8.472 .973,00$ & 1,610 & $2.651 .848,49$ & $6.156 .116,01$ \\
\hline Índia & 350 & 10 & 8.115 .660 & 10 & 8.115 .660 & 811.566 & $193.593 .519,49$ & 0,02 & $162.313,20$ & $162.313,20$ & 4,448 & $105.039,48$ & $105.039,48$ \\
\hline Índia & 8009 & 10 & 8.647 .160 & 10 & 8.647 .160 & 864.716 & $840.179 .917,16$ & 6,48 & $56.033 .596,80$ & $56.033 .596,80$ & 1,108 & $50.187 .238,88$ & $50.187 .238,88$ \\
\hline Índia & 325 & 10 & 7.673 .250 & 10 & 7.673 .250 & 767.325 & $978.045 .642,26$ & 0,02 & $153.465,00$ & $153.465,00$ & 4,448 & $99.313,45$ & $99.313,45$ \\
\hline Índia & 915 & 10 & 595.020 & 10 & 595.020 & 59.502 & $7.308 .809,89$ & 0,02 & $11.900,40$ & $11.900,40$ & 4,448 & $7.701,23$ & $7.701,23$ \\
\hline Índia & 4540 & 10 & 444.990 & 10 & 444.990 & 44.499 & $94.233 .225,80$ & 7,03 & $3.128 .279,70$ & $3.128 .279,70$ & 2,008 & $2.564 .267,03$ & $2.564 .267,03$ \\
\hline Índia & 2266 & 10 & 166.700 & 10 & 166.700 & 16.670 & $135.768 .793,86$ & 12,31 & $2.052 .077,00$ & $2.052 .077,00$ & 1,610 & $1.749 .158,40$ & $1.749 .158,40$ \\
\hline Índia & 2958 & 7 & 89.747 & 20 & 256.420 & 12.821 & $237.422 .362,36$ & 14,02 & $1.258 .252,94$ & $3.595 .008,40$ & 1,352 & $1.145 .359,16$ & $2.748 .232,35$ \\
\hline Índia & 3946 & 10 & 133.210 & 10 & 133.210 & 13.321 & $172.121 .073,50$ & 7,03 & $936.466,30$ & $936.466,30$ & 2,008 & $767.626,26$ & $767.626,26$ \\
\hline Índia & 4578 & 10 & 260.880 & 10 & 260.880 & 26.088 & $172.121 .073,50$ & 7,03 & $1.833 .986,40$ & $1.833 .986,40$ & 2,008 & $1.503 .328,13$ & $1.503 .328,13$ \\
\hline Índia & 6930 & 10 & 101.720 & 10 & 101.720 & 10.172 & $172.121 .073,50$ & 6,48 & $659.145,60$ & $659.145,60$ & 1,108 & $590.372,55$ & $590.372,55$ \\
\hline Índia & 427 & 10 & 629.580 & 10 & 629.580 & 62.958 & $68.211 .413,60$ & 6,45 & $4.060 .791,00$ & $4.060 .791,00$ & 3,440 & $2.895 .513,00$ & 2.895.513,00 \\
\hline Índia & 7620 & 7 & 80.010 & 20 & 228.600 & 11.430 & $11.771 .668,14$ & 6,48 & $518.464,80$ & $1.481 .328,00$ & 1,108 & $479.977,23$ & $1.188 .340,33$ \\
\hline Índia & 1472 & 10 & 162.170 & 10 & 162.170 & 16.217 & $24.921 .198,19$ & 15,45 & $2.505 .526,50$ & $2.505 .526,50$ & 4,825 & $1.564 .048,77$ & $1.564 .048,77$ \\
\hline Índia & 1571 & 10 & 36.480 & 10 & 36.480 & 3.648 & $24.921 .198,19$ & 15,45 & $563.616,00$ & $563.616,00$ & 4,825 & $351.831,41$ & $351.831,41$ \\
\hline
\end{tabular}




\begin{tabular}{|c|c|c|c|c|c|c|c|c|c|c|c|c|c|}
\hline Índia & 262 & 10 & 45.850 & 10 & 45.850 & 4.585 & $77.145 .808,67$ & 6,45 & $295.732,50$ & $295.732,50$ & 3,440 & $210.869,58$ & $210.869,58$ \\
\hline Índia & 1690 & 10 & 52.000 & 10 & 52.000 & 5.200 & $5.640 .161,26$ & 12,31 & $640.120,00$ & $640.120,00$ & 1,610 & $545.628,29$ & $545.628,29$ \\
\hline Índia & 9398 & 10 & 31.650 & 10 & 31.650 & 3.165 & $9.293 .320,82$ & 6,48 & $205.092,00$ & $205.092,00$ & 1,108 & $183.693,39$ & $183.693,39$ \\
\hline Índia & 1551 & 10 & 177.810 & 10 & 177.810 & 17.781 & $56.756 .069,14$ & 15,45 & $2.747 .164,50$ & $2.747 .164,50$ & 4,825 & $1.714 .888,76$ & $1.714 .888,76$ \\
\hline Índia & 2894 & 10 & 196.440 & 10 & 196.440 & 19.644 & $62.711 .328,57$ & 12,31 & $2.418 .176,40$ & $2.418 .176,40$ & 1,610 & $2.061 .215,81$ & $2.061 .215,81$ \\
\hline Índia & 9250 & 10 & 90.560 & 10 & 90.560 & 9.056 & $105.708 .267,03$ & 6,48 & $586.828,80$ & $586.828,80$ & 1,108 & $525.601,05$ & $525.601,05$ \\
\hline Índia & 1308 & 10 & 48.230 & 10 & 48.230 & 4.823 & $261.065 .260,22$ & 0,02 & 964,60 & 964,60 & 4,448 & 624,23 & 624,23 \\
\hline Índia & 960 & 10 & 367.230 & 10 & 367.230 & 36.723 & $261.065 .260,22$ & 0,02 & $7.344,60$ & $7.344,60$ & 4,448 & $4.752,99$ & $4.752,99$ \\
\hline Índia & 1573 & 7 & 160.419 & 25 & 572.925 & 22.917 & $288.387 .159,00$ & 15,45 & $2.478 .473,55$ & $8.851 .691,25$ & 4,825 & $1.782 .092,29$ & $2.725 .238,28$ \\
\hline Índia & 8689 & 7 & 159.754 & 25 & 570.550 & 22.822 & $693.663 .330,33$ & 6,48 & $1.035 .205,92$ & $3.697 .164,00$ & 1,108 & $958.358,74$ & $2.806 .924,44$ \\
\hline Índia & 9403 & 7 & 65.597 & 25 & 234.275 & 9.371 & $15.705 .924,13$ & 6,48 & $425.068,56$ & $1.518 .102,00$ & 1,108 & $393.514,14$ & $1.152 .558,45$ \\
\hline Índia & 7647 & 10 & 1.562 .880 & 10 & 1.562 .880 & 156.288 & $302.222 .270,70$ & 6,48 & $10.127 .462,40$ & $10.127 .462,40$ & 1,108 & $9.070 .796,88$ & $9.070 .796,88$ \\
\hline Índia & 3973 & 10 & 69.560 & 10 & 69.560 & 6.956 & $77.100 .964,77$ & 14,02 & $975.231,20$ & $975.231,20$ & 1,352 & $852.676,62$ & $852.676,62$ \\
\hline Índia & 4879 & 10 & 217.650 & 10 & 217.650 & 21.765 & $115.609 .230,66$ & 7,03 & $1.530 .079,50$ & $1.530 .079,50$ & 2,008 & $1.254 .214,07$ & $1.254 .214,07$ \\
\hline Índia & 1579 & 7 & 243.810 & 25 & 870.750 & 34.830 & $1.292 .075,35$ & 15,45 & $3.766 .864,50$ & $13.453 .087,50$ & 4,825 & $2.708 .481,67$ & 4.141.905,54 \\
\hline Índia & 8792 & 10 & 148.180 & 10 & 148.180 & 14.818 & $5.943 .680,19$ & 6,48 & $960.206,40$ & $960.206,40$ & 1,108 & $860.021,68$ & $860.021,68$ \\
\hline Índia & 1568 & 10 & 735.820 & 10 & 735.820 & 73.582 & $6.833 .464,67$ & 15,45 & $11.368 .419,00$ & $11.368 .419,00$ & 4,825 & 7.096.616,90 & 7.096.616,90 \\
\hline Índia & 5184 & 10 & 121.160 & 10 & 121.160 & 12.116 & $78.212 .187,82$ & 7,03 & $851.754,80$ & $851.754,80$ & 2,008 & $698.187,81$ & $698.187,81$ \\
\hline Índia & 4481 & 10 & 102.050 & 10 & 102.050 & 10.205 & $62.372 .474,30$ & 7,03 & $717.411,50$ & $717.411,50$ & 2,008 & $588.065,91$ & $588.065,91$ \\
\hline Índia & 5576 & 10 & 127.400 & 10 & 127.400 & 12.740 & $62.372 .474,30$ & 7,03 & $895.622,00$ & $895.622,00$ & 2,008 & $734.145,98$ & $734.145,98$ \\
\hline Índia & 5016 & 30 & 4.409 .940 & 30 & 4.409 .940 & 146.998 & $3.022 .764,19$ & 7,03 & $31.001 .878,20$ & $31.001 .878,20$ & 2,008 & $17.075 .012,23$ & $17.075 .012,23$ \\
\hline Índia & 4066 & 10 & 230.010 & 10 & 230.010 & 23.001 & 2.261.017.185,00 & 7,03 & $1.616 .970,30$ & $1.616 .970,30$ & 2,008 & $1.325 .438,91$ & $1.325 .438,91$ \\
\hline Índia & 6011 & 10 & & 10 & & & & 6,48 & & & 1,108 & & \\
\hline
\end{tabular}




\begin{tabular}{|c|c|c|c|c|c|c|c|c|c|c|c|c|c|}
\hline & & & 412.110 & & 412.110 & 41.211 & $2.310 .392 .698,96$ & & $2.670 .472,80$ & $2.670 .472,80$ & & $2.391 .844,61$ & $2.391 .844,61$ \\
\hline Índia & 803 & 10 & 217.040 & 10 & 217.040 & 21.704 & $33.158 .703,11$ & 0,02 & $4.340,80$ & $4.340,80$ & 4,448 & $2.809,11$ & $2.809,11$ \\
\hline Índia & 804 & 10 & 654.930 & 10 & 654.930 & 65.493 & $33.158 .703,11$ & 0,02 & $13.098,60$ & $13.098,60$ & 4,448 & $8.476,64$ & $8.476,64$ \\
\hline Índia & 805 & 10 & 602.670 & 10 & 602.670 & 60.267 & $33.158 .703,11$ & 0,02 & $12.053,40$ & $12.053,40$ & 4,448 & $7.800,25$ & $7.800,25$ \\
\hline Índia & 813 & 10 & 263.210 & 10 & 263.210 & 26.321 & $33.158 .703,11$ & 0,02 & $5.264,20$ & $5.264,20$ & 4,448 & $3.406,68$ & $3.406,68$ \\
\hline Índia & 1233 & 10 & 165.440 & 10 & 165.440 & 16.544 & $42.227 .765,90$ & 15,45 & $2.556 .048,00$ & $2.556 .048,00$ & 4,825 & $1.595 .586,28$ & $1.595 .586,28$ \\
\hline Índia & 1797 & 10 & 219.270 & 10 & 219.270 & 21.927 & $205.265 .551,91$ & 12,31 & $2.699 .213,70$ & $2.699 .213,70$ & 1,610 & $2.300 .767,62$ & $2.300 .767,62$ \\
\hline Índia & 394 & 10 & 1.183 .830 & 10 & 1.183 .830 & 118.383 & $76.028 .367,26$ & 6,45 & 7.635.703,50 & $7.635 .703,50$ & 3,440 & $5.444 .574,41$ & $5.444 .574,41$ \\
\hline Índia & 818 & 10 & 590.970 & 10 & 590.970 & 59.097 & $14.379 .577,61$ & 0,02 & $11.819,40$ & $11.819,40$ & 4,448 & $7.648,81$ & $7.648,81$ \\
\hline Índia & 4249 & 10 & 715.810 & 10 & 715.810 & 71.581 & $337.792 .535,33$ & 7,03 & $5.032 .144,30$ & $5.032 .144,30$ & 2,008 & $4.124 .874,68$ & 4.124.874,68 \\
\hline Índia & 5096 & 10 & 117.330 & 10 & 117.330 & 11.733 & $32.022 .363,32$ & 7,03 & $824.829,90$ & $824.829,90$ & 2,008 & $676.117,33$ & $676.117,33$ \\
\hline Índia & 1130 & 10 & 448.200 & 10 & 448.200 & 44.820 & $93.743 .255,63$ & 0,02 & $8.964,00$ & $8.964,00$ & 4,448 & $5.800,97$ & $5.800,97$ \\
\hline Índia & 117 & 10 & 222.670 & 10 & 222.670 & 22.267 & $101.549 .627,86$ & 21,1 & $4.698 .337,00$ & $4.698 .337,00$ & 2,335 & $3.729 .943,26$ & $3.729 .943,26$ \\
\hline Índia & 4518 & 10 & 136.020 & 10 & 136.020 & 13.602 & $44.612 .004,08$ & 7,03 & $956.220,60$ & $956.220,60$ & 2,008 & $783.818,97$ & $783.818,97$ \\
\hline Índia & 1288 & 7 & 109.704 & 25 & 391.800 & 15.672 & $130.303 .218,97$ & 15,45 & $1.694 .926,80$ & $6.053 .310,00$ & 4,825 & $1.218 .700,11$ & $1.863 .679,12$ \\
\hline Índia & 838 & 10 & 28.021 .500 & 10 & 28.021 .500 & 2.802 .150 & $33.467 .508,50$ & 0,02 & $560.430,00$ & $560.430,00$ & 4,448 & $362.677,06$ & $362.677,06$ \\
\hline Índia & 2023 & 7 & 1.315 .251 & 35 & 6.576 .255 & 187.893 & 2.908.646.923,05 & 12,31 & $16.190 .739,81$ & $80.953 .699,05$ & 1,610 & $14.478 .098,74$ & 46.287.198,92 \\
\hline Índia & 2025 & 7 & 1.167 .817 & 35 & 5.839 .085 & 166.831 & $2.908 .646 .923,05$ & 12,31 & $14.375 .827,27$ & $71.879 .136,35$ & 1,610 & $12.855 .165,92$ & 41.098.602,31 \\
\hline Índia & 5558 & 10 & 237.410 & 10 & 237.410 & 23.741 & 3.597.452.930,05 & 6,48 & $1.538 .416,80$ & $1.538 .416,80$ & 1,108 & $1.377 .903,54$ & $1.377 .903,54$ \\
\hline Índia & 9392 & 7 & 46.998 & 25 & 167.850 & 6.714 & $10.966 .835 .484,25$ & 6,48 & $304.547,04$ & $1.087 .668,00$ & 1,108 & $281.939,38$ & $825.768,55$ \\
\hline Índia & 473 & 10 & 125.540 & 10 & 125.540 & 12.554 & $41.773 .792,51$ & 6,45 & $809.733,00$ & $809.733,00$ & 3,440 & $577.373,33$ & $577.373,33$ \\
\hline Índia & 579 & 10 & 423.460 & 10 & 423.460 & 42.346 & $41.773 .792,51$ & 6,45 & $2.731 .317,00$ & $2.731 .317,00$ & 3,440 & $1.947 .542,70$ & $1.947 .542,70$ \\
\hline Índia & 814 & 10 & 53.200 & 10 & 53.200 & 5.320 & $11.530 .481 .678,17$ & 0,02 & $1.064,00$ & $1.064,00$ & 4,448 & 688,56 & 688,56 \\
\hline Índia & 847 & 10 & 78.020 & 10 & 78.020 & 7.802 & $11.530 .481 .678,17$ & 0,02 & $1.560,40$ & $1.560,40$ & 4,448 & $1.009,80$ & $1.009,80$ \\
\hline
\end{tabular}




\begin{tabular}{|c|c|c|c|c|c|c|c|c|c|c|c|c|c|}
\hline Índia & 1220 & 10 & 977.410 & 10 & 977.410 & 97.741 & $11.530 .481 .678,17$ & 0,02 & $19.548,20$ & $19.548,20$ & 4,448 & $12.650,44$ & $12.650,44$ \\
\hline Índia & 1354 & 10 & 87.930 & 10 & 87.930 & 8.793 & 12.283.149.204,47 & 15,45 & $1.358 .518,50$ & $1.358 .518,50$ & 4,825 & $848.040,99$ & $848.040,99$ \\
\hline Índia & 2648 & 10 & 40.430 & 10 & 40.430 & 4.043 & $13.690 .966 .442,82$ & 12,31 & $497.693,30$ & $497.693,30$ & 1,610 & $424.226,00$ & $424.226,00$ \\
\hline Índia & 2856 & 7 & 600.334 & 20 & 1.715 .240 & 85.762 & $16.693 .155 .465,97$ & 14,02 & $8.416 .682,68$ & $24.047 .664,80$ & 1,352 & 7.661.515,63 & $18.383 .425,82$ \\
\hline Índia & 6888 & 10 & 16.125 .060 & 10 & 16.125 .060 & 1.612 .506 & $20.110 .878 .803,40$ & 6,48 & \begin{tabular}{|l}
$104.490 .388,80$ \\
\end{tabular} & $104.490 .388,80$ & 1,108 & $93.588 .211,42$ & $93.588 .211,42$ \\
\hline Índia & 7578 & 7 & 3.808 & 21 & 11.424 & 544 & $20.110 .878 .803,40$ & 6,48 & $24.675,84$ & $74.027,52$ & 1,108 & $22.844,06$ & $58.735,04$ \\
\hline Índia & 7634 & 7 & 5.145 & 21 & 15.435 & 735 & $20.110 .878 .803,40$ & 6,48 & $33.339,60$ & $100.018,80$ & 1,108 & $30.864,68$ & $79.357,09$ \\
\hline Índia & 8286 & 10 & 658.110 & 10 & 658.110 & 65.811 & $20.110 .878 .803,40$ & 6,48 & $4.264 .552,80$ & $4.264 .552,80$ & 1,108 & $3.819 .603,64$ & $3.819 .603,64$ \\
\hline Índia & 2126 & 10 & 530.820 & 10 & 530.820 & 53.082 & 1.385.229.088,59 & 12,31 & $6.534 .394,20$ & $6.534 .394,20$ & 1,610 & $5.569 .815,60$ & $5.569 .815,60$ \\
\hline Índia & 5480 & 7 & 56.826 & 20 & 162.360 & 8.118 & $19.416 .452,10$ & 6,48 & $368.232,48$ & $1.052 .092,80$ & 1,108 & $340.897,22$ & $844.002,34$ \\
\hline Índia & 8984 & 7 & 311.920 & 20 & 891.200 & 44.560 & 175.214.309,06 & 6,48 & $2.021 .241,60$ & $5.774 .976,00$ & 1,108 & $1.871 .197,33$ & 4.632.759,85 \\
\hline Índia & 5313 & 7 & 328.881 & 25 & 1.174 .575 & 46.983 & $175.214 .309,06$ & 6,48 & $2.131 .148,88$ & $7.611 .246,00$ & 1,108 & $1.972 .945,79$ & $5.778 .535,22$ \\
\hline Índia & 5328 & 10 & 529.800 & 10 & 529.800 & 52.980 & $175.214 .309,06$ & 6,48 & $3.433 .104,00$ & $3.433 .104,00$ & 1,108 & $3.074 .905,42$ & $3.074 .905,42$ \\
\hline Índia & 1294 & 7 & 91.714 & 21 & 275.142 & 13.102 & $16.818 .615,54$ & 15,45 & $1.416 .981,30$ & $4.250 .943,90$ & 4,825 & $1.018 .849,46$ & $1.580 .240,11$ \\
\hline Índia & 2026 & 10 & 129.750 & 10 & 129.750 & 12.975 & 7.969.496,83 & 15,45 & $2.004 .637,50$ & $2.004 .637,50$ & 4,825 & $1.251 .374,04$ & $1.251 .374,04$ \\
\hline Índia & 309 & 10 & 457.210 & 10 & 457.210 & 45.721 & $17.467 .939,76$ & 6,45 & $2.949 .004,50$ & $2.949 .004,50$ & 3,440 & $2.102 .762,95$ & $2.102 .762,95$ \\
\hline Índia & 327 & 10 & 253.470 & 10 & 253.470 & 25.347 & $63.406 .660,27$ & 6,45 & $1.634 .881,50$ & $1.634 .881,50$ & 3,440 & $1.165 .738,56$ & $1.165 .738,56$ \\
\hline Índia & 329 & 10 & 212.920 & 10 & 212.920 & 21.292 & $63.406 .660,27$ & 6,45 & $1.373 .334,00$ & $1.373 .334,00$ & 3,440 & $979.244,30$ & $979.244,30$ \\
\hline Índia & 328 & 10 & 210.260 & 10 & 210.260 & 21.026 & $63.406 .660,27$ & 6,45 & $1.356 .177,00$ & $1.356 .177,00$ & 3,440 & $967.010,65$ & $967.010,65$ \\
\hline Índia & 4856 & 10 & 235.270 & 10 & 235.270 & 23.527 & $253.816 .671,37$ & 7,03 & $1.653 .948,10$ & $1.653 .948,10$ & 2,008 & $1.355 .749,80$ & $1.355 .749,80$ \\
\hline Índia & 2233 & 10 & 224.450 & 10 & 224.450 & 22.445 & $4.925 .636,32$ & 12,31 & $2.762 .979,50$ & $2.762 .979,50$ & 1,610 & $2.355 .120,59$ & $2.355 .120,59$ \\
\hline Índia & 1181 & 7 & 172.480 & 25 & 616.000 & 24.640 & $5.912 .353,69$ & 15,45 & $2.664 .816,00$ & $9.517 .200,00$ & 4,825 & $1.916 .077,76$ & $2.930 .133,58$ \\
\hline Índia & 2792 & 7 & & 21 & & & & 12,31 & & & 1,610 & & \\
\hline
\end{tabular}




\begin{tabular}{|c|c|c|c|c|c|c|c|c|c|c|c|c|c|}
\hline & & & 3.131 .135 & & 9.393 .405 & 447.305 & $248.227 .308,33$ & & $38.544 .271,85$ & $115.632 .815,55$ & & $34.467 .095,40$ & $82.682 .885,00$ \\
\hline Índia & 2801 & 7 & 6.313 .776 & 21 & 18.941 .328 & 901.968 & $248.227 .308,33$ & 12,31 & $77.722 .582,56$ & $233.167 .747,68$ & 1,610 & $69.501 .161,62$ & $166.725 .872,55$ \\
\hline Índia & 2247 & 10 & 239.600 & 10 & 239.600 & 23.960 & $42.784 .739,62$ & 12,31 & $2.949 .476,00$ & $2.949 .476,00$ & 1,610 & $2.514 .087,29$ & $2.514 .087,29$ \\
\hline Índia & 564 & 10 & 107.490 & 10 & 107.490 & 10.749 & $60.435 .067,87$ & 6,45 & $693.310,50$ & $693.310,50$ & 3,440 & $494.359,24$ & $494.359,24$ \\
\hline Índia & 3710 & 10 & 156.100 & 10 & 156.100 & 15.610 & $148.408 .261,57$ & 14,02 & $2.188 .522,00$ & $2.188 .522,00$ & 1,352 & $1.913 .496,56$ & $1.913 .496,56$ \\
\hline Índia & 4475 & 10 & 170.960 & 10 & 170.960 & 17.096 & $373.104 .379,38$ & 7,03 & $1.201 .848,80$ & $1.201 .848,80$ & 2,008 & $985.161,67$ & $985.161,67$ \\
\hline Índia & 4301 & 10 & 311.960 & 10 & 311.960 & 31.196 & $403.467 .120,22$ & 6,48 & $2.021 .500,80$ & $2.021 .500,80$ & 1,108 & $1.810 .584,17$ & $1.810 .584,17$ \\
\hline Índia & 8988 & 10 & 186.150 & 10 & 186.150 & 18.615 & $403.467 .120,22$ & 6,48 & $1.206 .252,00$ & $1.206 .252,00$ & 1,108 & $1.080 .395,70$ & $1.080 .395,70$ \\
\hline Índia & 5228 & 10 & 102.720 & 10 & 102.720 & 10.272 & $21.272 .520,28$ & 7,03 & $722.121,60$ & $722.121,60$ & 2,008 & $591.926,81$ & $591.926,81$ \\
\hline Índia & 261 & 10 & 233.910 & 10 & 233.910 & 23.391 & $9.461 .840 .258,24$ & 6,45 & $1.508 .719,50$ & $1.508 .719,50$ & 3,440 & $1.075 .779,80$ & $1.075 .779,80$ \\
\hline Índia & 340 & 10 & 348.070 & 10 & 348.070 & 34.807 & $9.461 .840 .258,24$ & 6,45 & $2.245 .051,50$ & $2.245 .051,50$ & 3,440 & $1.600 .815,16$ & $1.600 .815,16$ \\
\hline Índia & 445 & 10 & 105.720 & 10 & 105.720 & 10.572 & $9.461 .840 .258,24$ & 6,45 & $681.894,00$ & $681.894,00$ & 3,440 & $486.218,80$ & $486.218,80$ \\
\hline Índia & 946 & 10 & 54.910 & 10 & 54.910 & 5.491 & $11.790 .686 .735,53$ & 0,02 & $1.098,20$ & $1.098,20$ & 4,448 & 710,69 & 710,69 \\
\hline Índia & 956 & 10 & 122.160 & 10 & 122.160 & 12.216 & $11.790 .686 .735,53$ & 0,02 & $2.443,20$ & $2.443,20$ & 4,448 & $1.581,09$ & $1.581,09$ \\
\hline Índia & 3772 & 10 & 211.570 & 10 & 211.570 & 21.157 & 24.349.096.767,97 & 7,03 & $1.487 .337,10$ & $1.487 .337,10$ & 2,008 & $1.219 .177,91$ & 1.219.177,91 \\
\hline Índia & 4239 & 10 & 210.190 & 10 & 210.190 & 21.019 & $24.349 .096 .767,97$ & 7,03 & $1.477 .635,70$ & $1.477 .635,70$ & 2,008 & $1.211 .225,62$ & $1.211 .225,62$ \\
\hline Índia & 5129 & 7 & 50.288 & 25 & 179.600 & 7.184 & $24.349 .096 .767,97$ & 7,03 & $353.524,64$ & $1.262 .588,00$ & 2,008 & $307.595,56$ & $768.078,91$ \\
\hline Índia & 9380 & 10 & 645.430 & 10 & 645.430 & 64.543 & $148.907 .385,23$ & 6,48 & $4.182 .386,40$ & $4.182 .386,40$ & 1,108 & $3.746 .010,20$ & $3.746 .010,20$ \\
\hline Índia & 3818 & 10 & 200.330 & 10 & 200.330 & 20.033 & $33.149 .398,06$ & 14,02 & $2.808 .626,60$ & $2.808 .626,60$ & 1,352 & $2.455 .674,35$ & $2.455 .674,35$ \\
\hline Índia & 3996 & 10 & 458.510 & 10 & 458.510 & 45.851 & $349.124 .262,73$ & 7,03 & $3.223 .325,30$ & $3.223 .325,30$ & 2,008 & $2.642 .176,40$ & $2.642 .176,40$ \\
\hline Índia & 4377 & 10 & 237.160 & 10 & 237.160 & 23.716 & $349.124 .262,73$ & 7,03 & $1.667 .234,80$ & $1.667 .234,80$ & 2,008 & $1.366 .640,98$ & $1.366 .640,98$ \\
\hline Índia & 8592 & 10 & 686.060 & 10 & 686.060 & 68.606 & $327.809 .046,25$ & 6,48 & $4.445 .668,80$ & $4.445 .668,80$ & 1,108 & $3.981 .822,60$ & $3.981 .822,60$ \\
\hline Índia & 8818 & 10 & 211.270 & 10 & 211.270 & 21.127 & $327.809 .046,25$ & 6,48 & $1.369 .029,60$ & $1.369 .029,60$ & 1,108 & $1.226 .189,63$ & $1.226 .189,63$ \\
\hline Índia & 8641 & 10 & 309.300 & 10 & 309.300 & 30.930 & $2.182 .359 .695,91$ & 6,48 & $2.004 .264,00$ & $2.004 .264,00$ & 1,108 & $1.795 .145,80$ & $1.795 .145,80$ \\
\hline
\end{tabular}




\begin{tabular}{|c|c|c|c|c|c|c|c|c|c|c|c|c|c|}
\hline Índia & 8667 & 10 & 291.070 & 10 & 291.070 & 29.107 & 2.182.359.695,91 & 6,48 & $1.886 .133,60$ & $1.886 .133,60$ & 1,108 & $1.689 .340,73$ & $1.689 .340,73$ \\
\hline Índia & 7441 & 7 & 141.764 & 20 & 405.040 & 20.252 & $172.940 .318,70$ & 6,48 & $918.630,72$ & $2.624 .659,20$ & 1,108 & $850.437,35$ & $2.105 .535,29$ \\
\hline Índia & 4411 & 10 & 131.510 & 10 & 131.510 & 13.151 & $34.434 .683,68$ & 7,03 & $924.515,30$ & $924.515,30$ & 2,008 & $757.829,97$ & $757.829,97$ \\
\hline Índia & 5485 & 10 & 152.680 & 10 & 152.680 & 15.268 & $62.441 .385,01$ & 7,03 & $1.073 .340,40$ & $1.073 .340,40$ & 2,008 & $879.822,67$ & $879.822,67$ \\
\hline Índia & 6651 & 10 & 582.210 & 10 & 582.210 & 58.221 & $161.299 .942,24$ & 6,48 & $3.772 .720,80$ & $3.772 .720,80$ & 1,108 & $3.379 .087,74$ & $3.379 .087,74$ \\
\hline Índia & 535 & 10 & 1.123 .570 & 10 & 1.123 .570 & 112.357 & $278.109 .651,93$ & 0,02 & $22.471,40$ & $22.471,40$ & 4,448 & $14.542,16$ & $14.542,16$ \\
\hline Índia & 3926 & 10 & 351.880 & 10 & 351.880 & 35.188 & $16.671 .415,78$ & 14,02 & 4.933.357,60 & 4.933.357,60 & 1,352 & 4.313.396,34 & $4.313 .396,34$ \\
\hline Índia & 802 & 10 & 139.930 & 10 & 139.930 & 13.993 & $5.059 .900,94$ & 0,02 & $2.798,60$ & $2.798,60$ & 4,448 & $1.811,09$ & $1.811,09$ \\
\hline Índia & 183 & 10 & 680.150 & 10 & 680.150 & 68.015 & $65.081 .709,84$ & 6,45 & 4.386.967,50 & $4.386 .967,50$ & 3,440 & $3.128 .090,42$ & $3.128 .090,42$ \\
\hline Índia & 302 & 10 & 1.070 .740 & 10 & 1.070 .740 & 107.074 & $65.081 .709,84$ & 6,45 & $6.906 .273,00$ & $6.906 .273,00$ & 3,440 & $4.924 .460,10$ & $4.924 .460,10$ \\
\hline Índia & 935 & 10 & 125.780 & 10 & 125.780 & 12.578 & 4.817.913,79 & 0,02 & $2.515,60$ & $2.515,60$ & 4,448 & $1.627,95$ & $1.627,95$ \\
\hline Índia & 4025 & 10 & 182.820 & 10 & 182.820 & 18.282 & $10.445 .305,89$ & 7,03 & $1.285 .224,60$ & $1.285 .224,60$ & 2,008 & $1.053 .505,25$ & $1.053 .505,25$ \\
\hline Índia & 4990 & 7 & 227.633 & 20 & 650.380 & 32.519 & $107.669 .797,72$ & 6,48 & $1.475 .061,84$ & 4.214.462,40 & 1,108 & $1.365 .562,52$ & $3.380 .895,82$ \\
\hline Índia & 1112 & 10 & 446.820 & 10 & 446.820 & 44.682 & $17.525 .798,52$ & 0,02 & $8.936,40$ & $8.936,40$ & 4,448 & $5.783,11$ & $5.783,11$ \\
\hline Índia & 2471 & 10 & 251.220 & 10 & 251.220 & 25.122 & $253.102 .544,45$ & 12,31 & $3.092 .518,20$ & $3.092 .518,20$ & 1,610 & $2.636 .014,23$ & $2.636 .014,23$ \\
\hline Índia & 5175 & 10 & 302.010 & 10 & 302.010 & 30.201 & $69.368 .234,47$ & 7,03 & $2.123 .130,30$ & $2.123 .130,30$ & 2,008 & $1.740 .340,88$ & $1.740 .340,88$ \\
\hline Índia & 5099 & 10 & 455.510 & 10 & 455.510 & 45.551 & $73.146 .848,19$ & 6,48 & $2.951 .704,80$ & $2.951 .704,80$ & 1,108 & $2.643 .733,80$ & $2.643 .733,80$ \\
\hline Índia & 2434 & 10 & 39.230 & 10 & 39.230 & 3.923 & $5.243 .298,63$ & 12,31 & $482.921,30$ & $482.921,30$ & 1,610 & $411.634,58$ & $411.634,58$ \\
\hline Índia & 115 & 10 & 38.335 .660 & 10 & 38.335 .660 & 3.833 .566 & $79.629 .245,42$ & 21,1 & $808.882 .426,00$ & $808.882 .426,00$ & 2,335 & $642.160 .311,92$ & $642.160 .311,92$ \\
\hline Índia & 2365 & 10 & 348.860 & 10 & 348.860 & 34.886 & $144.780 .602,50$ & 12,31 & 4.294.466,60 & 4.294.466,60 & 1,610 & $3.660 .536,28$ & $3.660 .536,28$ \\
\hline Índia & 7871 & 7 & 37.667 & 20 & 107.620 & 5.381 & $13.442 .846,25$ & 6,48 & $244.082,16$ & $697.377,60$ & 1,108 & $225.963,04$ & $559.445,26$ \\
\hline Índia & 2504 & 10 & 180.820 & 10 & 180.820 & 18.082 & $3.802 .381 .324,22$ & 12,31 & $2.225 .894,20$ & $2.225 .894,20$ & 1,610 & 1.897.317,46 & $1.897 .317,46$ \\
\hline Índia & 3638 & 10 & & 10 & & & & 6,48 & & & 1,108 & & \\
\hline
\end{tabular}




\begin{tabular}{|c|c|c|c|c|c|c|c|c|c|c|c|c|c|}
\hline & & & 29.940 & & 29.940 & 2.994 & $107.725 .945,67$ & & $194.011,20$ & $194.011,20$ & & $173.768,72$ & $173.768,72$ \\
\hline Índia & 2370 & 10 & 117.000 & 10 & 117.000 & 11.700 & $20.287 .736,91$ & 12,31 & $1.440 .270,00$ & $1.440 .270,00$ & 1,610 & $1.227 .663,66$ & $1.227 .663,66$ \\
\hline Índia & 5790 & 10 & 267.960 & 10 & 267.960 & 26.796 & $114.378 .203,23$ & 6,48 & $1.736 .380,80$ & $1.736 .380,80$ & 1,108 & $1.555 .212,64$ & $1.555 .212,64$ \\
\hline Índia & 1199 & 10 & 379.470 & 10 & 379.470 & 37.947 & $11.012 .981,77$ & 0,02 & $7.589,40$ & $7.589,40$ & 4,448 & $4.911,41$ & $4.911,41$ \\
\hline Índia & 1110 & 10 & 425.240 & 10 & 425.240 & 42.524 & $11.012 .981,77$ & 0,02 & $8.504,80$ & $8.504,80$ & 4,448 & $5.503,80$ & $5.503,80$ \\
\hline Índia & 1196 & 10 & 433.450 & 10 & 433.450 & 43.345 & $11.012 .981,77$ & 0,02 & $8.669,00$ & $8.669,00$ & 4,448 & $5.610,06$ & $5.610,06$ \\
\hline Índia & 1049 & 10 & 371.440 & 10 & 371.440 & 37.144 & $607.271 .764,74$ & 0,02 & $7.428,80$ & $7.428,80$ & 4,448 & $4.807,48$ & $4.807,48$ \\
\hline Índia & 5764 & 10 & 263.920 & 10 & 263.920 & 26.392 & $27.706 .965,65$ & 6,48 & $1.710 .201,60$ & $1.710 .201,60$ & 1,108 & $1.531 .764,89$ & $1.531 .764,89$ \\
\hline Índia & 124 & 10 & 358.600 & 10 & 358.600 & 35.860 & $96.887 .588,92$ & 6,45 & $2.312 .970,00$ & $2.312 .970,00$ & 3,440 & $1.649 .243,88$ & $1.649 .243,88$ \\
\hline Índia & 4438 & 10 & 1.326 .320 & 10 & 1.326 .320 & 132.632 & $144.709 .397,87$ & 7,03 & $9.324 .029,60$ & $9.324 .029,60$ & 2,008 & $7.642 .955,24$ & $7.642 .955,24$ \\
\hline Índia & 1053 & 10 & 144.310 & 10 & 144.310 & 14.431 & $99.639 .819,22$ & 0,02 & $2.886,20$ & $2.886,20$ & 4,448 & $1.867,78$ & $1.867,78$ \\
\hline Índia & 5500 & 10 & 284.780 & 10 & 284.780 & 28.478 & $143.077 .389,42$ & 6,48 & $1.845 .374,40$ & $1.845 .374,40$ & 1,108 & $1.652 .834,21$ & $1.652 .834,21$ \\
\hline Índia & 382 & 10 & 72.260 & 10 & 72.260 & 7.226 & $411.521 .573,09$ & 6,45 & $466.077,00$ & $466.077,00$ & 3,440 & $332.332,30$ & $332.332,30$ \\
\hline Índia & 587 & 10 & 28.270 & 10 & 28.270 & 2.827 & $444.502 .094,72$ & 0,02 & 565,40 & 565,40 & 4,448 & 365,89 & 365,89 \\
\hline Índia & 758 & 10 & 18.450 & 10 & 18.450 & 1.845 & $444.502 .094,72$ & 0,02 & 369,00 & 369,00 & 4,448 & 238,79 & 238,79 \\
\hline Índia & 1013 & 10 & 94.290 & 10 & 94.290 & 9.429 & $444.502 .094,72$ & 0,02 & $1.885,80$ & $1.885,80$ & 4,448 & $1.220,38$ & $1.220,38$ \\
\hline Índia & 744 & 10 & 324.330 & 10 & 324.330 & 32.433 & $1.334 .579 .593,35$ & 0,02 & $6.486,60$ & $6.486,60$ & 4,448 & $4.197,74$ & $4.197,74$ \\
\hline Índia & 2819 & 10 & 830.220 & 10 & 830.220 & 83.022 & $2.026 .077 .248,33$ & 14,02 & $11.639 .684,40$ & $11.639 .684,40$ & 1,352 & $10.176 .957,80$ & $10.176 .957,80$ \\
\hline Índia & 8442 & 10 & 968.210 & 10 & 968.210 & 96.821 & 1.829.133.234,61 & 6,48 & $6.274 .000,80$ & $6.274 .000,80$ & 1,108 & $5.619 .392,56$ & $5.619 .392,56$ \\
\hline Índia & 8102 & 10 & 991.000 & 10 & 991.000 & 99.100 & $1.829 .133 .234,61$ & 6,48 & $6.421 .680,00$ & $6.421 .680,00$ & 1,108 & $5.751 .663,41$ & $5.751 .663,41$ \\
\hline Índia & 274 & 10 & 317.620 & 10 & 317.620 & 31.762 & $27.273 .551,23$ & 6,45 & $2.048 .649,00$ & $2.048 .649,00$ & 3,440 & $1.460 .772,01$ & $1.460 .772,01$ \\
\hline Índia & 1648 & 10 & 608.110 & 10 & 608.110 & 60.811 & 4.114.301.424,98 & 12,31 & $7.485 .834,10$ & $7.485 .834,10$ & 1,610 & $6.380 .808,11$ & $6.380 .808,11$ \\
\hline Índia & 3884 & 7 & 560.609 & 20 & 1.601 .740 & 80.087 & $76.158 .083,84$ & 14,02 & 7.859.738,18 & $22.456 .394,80$ & 1,352 & 7.154.541,67 & $17.166 .967,00$ \\
\hline Índia & 1116 & 10 & 31.897 .040 & 10 & 31.897 .040 & 3.189 .704 & $467.586 .434,44$ & 0,02 & $637.940,80$ & $637.940,80$ & 4,448 & $412.837,46$ & $412.837,46$ \\
\hline
\end{tabular}




\begin{tabular}{|c|c|c|c|c|c|c|c|c|c|c|c|c|c|}
\hline Índia & 8048 & 10 & 12.705 .970 & 10 & 12.705 .970 & 1.270 .597 & $849.088 .662,88$ & 6,48 & $82.334 .685,60$ & $82.334 .685,60$ & 1,108 & $73.744 .160,12$ & $73.744 .160,12$ \\
\hline Índia & 267 & 10 & 58.050 & 10 & 58.050 & 5.805 & $30.044 .811,14$ & 6,45 & $374.422,50$ & $374.422,50$ & 3,440 & $266.978,83$ & $266.978,83$ \\
\hline Índia & 578 & 10 & 854.700 & 10 & 854.700 & 85.470 & $102.423 .785,76$ & 6,45 & $5.512 .815,00$ & $5.512 .815,00$ & 3,440 & $3.930 .866,55$ & $3.930 .866,55$ \\
\hline Índia & 826 & 10 & 868.080 & 10 & 868.080 & 86.808 & $124.874 .305,50$ & 0,02 & $17.361,60$ & $17.361,60$ & 4,448 & $11.235,40$ & $11.235,40$ \\
\hline Índia & 7966 & 7 & 24.745 & 20 & 70.700 & 3.535 & $12.068 .928,10$ & 6,48 & $160.347,60$ & $458.136,00$ & 1,108 & $148.444,40$ & $367.522,58$ \\
\hline Índia & 872 & 10 & 168.710 & 10 & 168.710 & 16.871 & $305.609 .665,11$ & 0,02 & $3.374,20$ & $3.374,20$ & 4,448 & $2.183,58$ & $2.183,58$ \\
\hline Índia & 437 & 10 & 557.830 & 10 & 557.830 & 55.783 & $236.872 .214,28$ & 6,45 & $3.598 .003,50$ & $3.598 .003,50$ & 3,440 & $2.565 .526,25$ & $2.565 .526,25$ \\
\hline Índia & 8439 & 10 & 64.050 & 10 & 64.050 & 6.405 & $687.136 .067,46$ & 6,48 & $415.044,00$ & $415.044,00$ & 1,108 & $371.739,70$ & $371.739,70$ \\
\hline Índia & 810 & 10 & 797.230 & 10 & 797.230 & 79.723 & $28.161 .271,32$ & 0,02 & $15.944,60$ & $15.944,60$ & 4,448 & $10.318,40$ & $10.318,40$ \\
\hline Índia & 696 & 10 & 543.400 & 10 & 543.400 & 54.340 & $113.147 .173,70$ & 6,45 & $3.504 .930,00$ & $3.504 .930,00$ & 3,440 & $2.499 .160,97$ & $2.499 .160,97$ \\
\hline Índia & 6121 & 7 & 152.642 & 20 & 436.120 & 21.806 & $76.372 .507,32$ & 6,48 & $989.120,16$ & $2.826 .057,60$ & 1,108 & $915.694,10$ & 2.267.099,67 \\
\hline Índia & 6237 & 10 & 87.950 & 10 & 87.950 & 8.795 & $44.787 .068,23$ & 6,48 & $569.916,00$ & $569.916,00$ & 1,108 & $510.452,87$ & $510.452,87$ \\
\hline Índia & 9356 & 7 & 119.791 & 25 & 427.825 & 17.113 & 1.134.907.431,94 & 6,48 & $776.245,68$ & $2.772 .306,00$ & 1,108 & $718.622,08$ & $2.104 .762,85$ \\
\hline Índia & 1149 & 7 & 385.917 & 21 & 1.157 .751 & 55.131 & $12.832 .042,06$ & 0,02 & $7.718,34$ & $23.155,02$ & 4,448 & $5.691,45$ & $9.284,16$ \\
\hline Índia & 570 & 10 & 138.210 & 10 & 138.210 & 13.821 & $37.479 .123,07$ & 6,45 & $891.454,50$ & $891.454,50$ & 3,440 & $635.644,16$ & $635.644,16$ \\
\hline Índia & 571 & 10 & 160.590 & 10 & 160.590 & 16.059 & $37.479 .123,07$ & 6,45 & $1.035 .805,50$ & $1.035 .805,50$ & 3,440 & $738.572,43$ & $738.572,43$ \\
\hline Índia & 1786 & 10 & 351.310 & 10 & 351.310 & 35.131 & $83.072 .548,25$ & 15,45 & $5.427 .739,50$ & $5.427 .739,50$ & 4,825 & $3.388 .209,73$ & $3.388 .209,73$ \\
\hline Índia & 1025 & 10 & 356.930 & 10 & 356.930 & 35.693 & $40.128 .662,29$ & 0,02 & $7.138,60$ & $7.138,60$ & 4,448 & $4.619,68$ & $4.619,68$ \\
\hline Índia & 827 & 7 & 233.954 & 30 & 1.002 .660 & 33.422 & $6.540 .186,14$ & 0,02 & $4.679,08$ & $20.053,20$ & 4,448 & $3.450,32$ & $5.434,75$ \\
\hline Índia & 6389 & 10 & 80.000 & 10 & 80.000 & 8.000 & $29.748 .636,73$ & 6,48 & $518.400,00$ & $518.400,00$ & 1,108 & 464311,88 & $464.311,88$ \\
\hline Índia & 7838 & 7 & 56.784 & 25 & 202.800 & 8.112 & $29.748 .636,73$ & 6,48 & $367.960,32$ & $1.314 .144,00$ & 1,108 & $340.645,26$ & $997.711,46$ \\
\hline
\end{tabular}

Fonte: Dados da pesquisa (2015). 